Jelenkortörténeti és Összehasonlító Történettudományi

Doktori Program

\title{
Történelem és emlékezet a Mequinensa mítoszban
}

Jesús Moncada A folyók városa címü regényének történelemképe (1870-1970)

Doktori (PhD-) értekezés

Szerző: NEMES KRISZTINA

Témavezető: PROF. DR. MAJOROS ISTVÁN, professor emeritus, ELTE BTK, Új- és Jelenkori

Egyetemes Történeti Tanszék

Szeged

2018 


\section{Tartalomjegyzék}

I. Bevezetés 5

1. Regénybe zárt történelem 6

2. Emlékezet 8

3. Az irodalom mint történelmi reprezentáció 10

4. Historiográfiai háttér 13

5. Módszer és felhasznált források $\quad 27$

6. Száz év Spanyolországban, történelmi vázlat 31

II. Jesús Moncada és Mequinensa $\quad 40$

1. Az író és a kor $\quad 40$

1.1. Az író életútja $\quad 40$

1.2. Az író kora 51

1.2.1. Nyelv, irodalom és társadalom Katalóniában 51

1.2.2. La Franja de Ponent 58

2. Genius loci - Mequinensa $\quad 64$

2.1. Mequinensa száz éve 64

2.2. Víztározók és vízerőmüvek Spanyolországban a 20. században 66

2.3. Helytörténeti monográfia 72

2.4. Restauráció, Primo de Rivera diktatúra, II. Köztársaság,

2.5. A vörös város 92

III. Camí de sirga - A folyók városa 95

1. Mequinensa emlékezetföldrajza - Tér és idő összefonódása

1.1. A regény címe $\quad 95$

1.2. „Mert a város valójában te vagy...” 96

1.3. A regény nyitánya: bevezetés a városba és Moncada
történelemfilozófiájába

1.4. A regény témája és szerkezete 101

1.5. A regény időszerkezete 103

1.6. A regény tere és a katalán emlékezeti tér kapcsolata 106

$\begin{array}{ll}\text { 1.7. A regény által kirajzolt földrajzi univerzum } & 107\end{array}$

$\begin{array}{ll}\text { 1.7.1. Folyók } & 107\end{array}$

1.7.2. A folyók halála, a vízerőmü építkezés irodalmi, társadalmi
és történeti emlékezete

$\begin{array}{ll}\text { 1.7.3. Városok, kereskedelem, legendák } & 118\end{array}$ 
2. Mequinensa történelmi emlékezete 124

2.1. A polgárháború regényben tükröződő emlékezete 124

2.2. Memoria mortuorum Mequinensában 128

2.3. Mequinensa emlékezete, a spanyolországi emlékezetháború kontextusában 137

3. Gazdaság, társadalom és ideológia Mequinensában a regény tükrében $\quad 140$

$\begin{array}{ll}\text { 3.1. Az erőszak } & 140\end{array}$

3.2. Írás-olvasás, műveltség Mequinensában 144

3.3. A bányászsztrájk irodalmi kronológiája 147

3.4. A társadalmi szakadék 149

3.5. A Kaszinó 151

3.6. A Kávéház 155

3.7. A kávéházi emlékezet 160

3.8. Mequinensa és az egyház 163

4. Irodalmi halál 169

IV. Összefoglalás: történelem az irodalomban 176

1. Sikeres katalán emlékezetregények az 1980-as években 176

2. Absztrakt történelmi téridő, versus érintettséget előidéző irodalmi téridő 178

3. A megteremtett táj 181

4. A szemtanú irodalmi emlékezethelyet alkot 182

5. Történelmi megértés azonosulás útján, az egyedi és az általános viszonya 183

6. Mequinensa kollektív emlékezete mint irodalmi mítosz és identitásképző tényező 186

7. Kisnemzeti irodalom és nemzeti identitás Spanyolországban 189

Felhasznált források $\quad 196$

Moncada Családi Levéltár anyaga 196

$\begin{array}{ll}\text { Moncada Családi Levéltár digitalizált anyaga } & 207\end{array}$

$\begin{array}{ll}\text { Felhasznált irodalom } & 233\end{array}$

Bibliográfia $\quad 233$

A szerző témához kapcsolódó publikációi 252

Folyóirat-, újság- és online cikkek, weboldalak 253

Mellékletek $\quad \mathbf{2 6 0}$

$\begin{array}{ll}\text { Lexikon } & 260\end{array}$

$\begin{array}{ll}\text { Képek, térképek } & 271\end{array}$ 


\section{Köszönetnyilvánítás}

Ennek a dolgozatnak az elkészülését rengeteg szakmai, családi és baráti segítség tette lehetővé, melyekért nagyon hálás vagyok mindenkinek. Próbálom időrendi sorba rendezve kifejezni ezt a hálát, ami segít felidézni, hogy milyen gyökerekből táplálkozik ez a munka.

Köszönöm Eloi Castelló i Gassolnak, az ELTE egykori katalán lektorának, kedves jó barátomnak, hogy mesélt nekem az elsüllyedt város irodalmi mítoszáról, és megajándékozott Jesús Moncada könyveivel. Köszönöm Faluba Kálmán tanár úrnak, hogy a Katalán Könyvtár sorozatba két Moncada müvet is beletervezett, melyeket én fordíthattam, s mindig készséggel válaszolt kérdéseimre, segített könyvek beszerzésében katalán tudományos és könyvtári kapcsolatainak mozgósításával. Köszönöm, hogy az Institució de les Lletres Catalanes meghívására, a többi fordítóval együtt eljuthattam Mequinensába, a regények színhelyére. Köszönöm az Institut Ramon Llull-nak, hogy ösztöndíjakkal támogatta müfordítói munkámat, melyek segítségével több hónapon át használhattam az Universitat Autònoma de Barcelona könyvtárát.

Köszönöm Anderle Ádám tanár úrnak, hogy a doktori kurzus elvégzésére biztatott, munkám során mindig bátorított, könyvekkel, folyóiratokkal látott el, s hogy a Moncada regények univerzumát, e folyami hajós és bányász világ irodalmi emlékezetének történelmi szempontú elemzését ajánlotta témául. Köszönöm Majoros István tanár úrnak, hogy elvállalta a konzulens feladatát a nagy késéssel felbukkanó régi tanítvány mellett, s végigkísért az írás kanyargós útjain, tartva az irányt, mikor eltévedtem.

Köszönöm Rosa Maria Moncadának, Jesús Moncada húgának, hogy bizalmába és otthonába fogadott, s nem csak a családi levéltár feldolgozásában, értelmezésében segített, hanem megajándékozott a barátságával, s megismertetett mequinensaiakkal és Moncada tisztelőivel, müvének gondozóival. Ez úton köszönöm a rengeteg segítséget, amit Hèctor Moret (költő), Andrés Coso (helytörténész), Jordi Estruga (szerkesztő), Carles-Jordi Guardiola (kiadó), Mercè Biosca (nyelvész), Xavier Iglesias (irodalmár, Moncada kutató) nyújtott. Andrés, Hèctor és Jordi ajándékaképpen jutottam hozzá a Mequinensa helytörténetét és a Franja történelmét feldolgozó, nyomtatásban megjelent szakirodalomhoz, Mercè küldte a Moncada specifikus nyelvészeti szakmunkákat. Mindannyian segítségemre voltak személyes interjúk és levelezés során feltett kérdések megválaszolásával. Köszönettel tartozom Agustí Alcoberro történész professzornak, a Museu d'Història de Catalunya egykori igazgatójának a sok értékes ajándék könyvért és információért, s feleségének, Anna Grau szerkesztőnek, vendégszeretetükért.

Köszönöm a Szegedi Egyetem Hispanisztika Tanszékének, s a hozzá tartozó szellemi mühelynek a magas szakmai színvonalú és mindig melegszívű, jóindulatú támogatását, s Harsányi Iván tanár úrnak külön köszönöm a lakáskönyvtárból kölcsönadott könyveket.

Köszönöm édesanyámnak és a barátaimnak, hogy biztattak az úton, s Demeter Csilla szerkesztőnek a szöveg formai gondozását. Nagy hálával tartozom férjemnek, aki türelmesen, és sok áldozatot vállalva segített végig ezekben az években, és köszönöm a három gyereknek, akik kibírták, és közben nagyobbra nőttek, mint a szüleik. 


\title{
I. Bevezetés
}

\author{
Al que vingui a enderrocar-la \\ (per a escriure a la porta de ca meva) \\ Enruna-la si cal, \\ però sense escarnir-la \\ El que els teus ulls prendran per argamassa i pedra \\ és dolorida pell d'uns altres dies; \\ allí on sentiràs sinó el silenci \\ nosaltres hi escoltem les antigues paraules ${ }^{1}$
}

JESÚS MONCADA

Jesús Moncada (Mequinensa, 1941-Barcelona, 2005) a kortárs katalán irodalom egyik legjelentősebb alkotója. Neve egyet jelent az általa teremtett irodalmi mítosszal szülővárosának, az aragóniai katalán területen fekvő, s az ország modernizációja során egy víztározó mélyére süllyesztett Mequinensának a mítikus krónikájával. ${ }^{2}$

Dolgozatomban Jesús Moncada fő müvének, a magyar fordításban is megjelent $A$ folyók városa (Camí de sirga) címü regénynek a történelmi szempontú elemzésére teszek kísérletet. Az írói életmü három novelláskötetet, három és fél regényt és egy publicisztikai gyüjteményt tartalmaz, melyek a megjelenés idejének sorrendjében a következők:

- Històries de la mà esquerra i altres narracions, Barcelona, La Magrana, 1981. (Magyar fordítás: Balkézről jött történetek, Budapest, l’Harmattan Kiadó, 2012.)

- El Cafè de la Granota, Barcelona, La Magrana, 1985.

- Camí de sirga, Barcelona, La Magrana, 1988. (Magyar fordítás: A folyók városa, Budapest, Íbisz Kiadó, 2004; második kiadás: l’Harmattan Kiadó, 2013.)

- La galeria de les estàtues (Szoborgaléria), Barcelona, La Magrana, 1992.

- Estremida memòria (Megrázkódott emlékezet), Barcelona, La Magrana, 1997.

\footnotetext{
${ }^{1}$ MCSL Moncada Családi Levéltár. (A továbbiakban a dolgozat során hivatkozott, a családi levéltárból származó forrásokra a MCSL rövidített jelölést alkalmazom). Búcsúvers, melyet Jesús Moncada az asztalfióknak írt szülővárosa lerombolásának idején. Soha nem jelent meg, csak a halála után került elő a hagyatékból: „Annak, aki jön, hogy lerombolja (írják fel a házunk ajtajára) Rombold le, ha ezt kell tenned, / de ne üzz csúfot belőle / Amit te habarcsnak és kőnek vélsz / az régi idők fájó burka; / Ahol te csak a csendet hallod / ott hozzánk a régi szavak szólnak.” A várost földig rombolták, mind a parton maradó, mind pedig a víz alá süllyesztett épületeket.

${ }^{2}$ A regények és a mítosz színhelye, Mequinensa, valamint a dolgozatban szereplő többi helységnév a katalán írásformát követi, a regény eredeti szövegéhez igazodva. Kivételt képeznek a spanyol nyelvú bibliográfiai hivatkozásokban szereplő helységnevek, és Saragossa neve, amikor a regény magyar fordításából idézek, ahol a spanyol Zaragoza forma szerepel.
} 
- Calaveres atònites (Álmélkodó koponyák), Barcelona, La Magrana, 1999.

- Cabòries estivals i altres proses volanderes (Egynyári töprengések, s egyéb röpke írások), Calaceit-Fraga, Quaderns de les Cadolles, 2003.; Barcelona, Edicions 62, 2005.

- Dante S.A. (Dante Rt.) az író halála miatt befejezetlen és publikálatlan regény, kéziratban MCSL.

Bár az irodalom közvetlen eszközként történő felhasználása a valóság tényeinek megismeréséhez nem problémamentes mủvelet, korlátaira Dominick LaCapra hívja fel a figyelmet, mikor az ezt szorgalmazó gyakorlatot az irodalmi szöveg dokumentarista redukcionalizmusának ${ }^{3}$ nevezi (levonjuk az irodalmat, megmarad a tény). A történelmet ugyanakkor a közmegegyezés szerint ugyanezen tények hiteles tolmácsolójaként tartjuk számon.

\section{Regénybe zárt történelem}

A történettudományban is lezajlott „nyelvi fordulat” óta ${ }^{4}$ irodalom és történelem rokonsága sokat tárgyalt témává vált. Ennek az episztemológiai és morális kérdések felmerülése nyomán kialakult fordulatnak a következtében történelem és irodalom kapcsolatát leginkább abból a szempontból közelítették meg, hogy megmutassák, mennyiben tekinthető irodalmi alkotásnak a történelem. Én ebben a munkában ennek fordítottjára teszek kísérletet, s irodalmi alkotások történelmi szempontból értékes alkotóelemein keresztül próbálom megmutatni, mennyiben lehet történelem az irodalom. Kiváló történészek gyakran hivatkoznak az irodalomra, és anekdotaként, illusztrációként fel is használják műveikben. Jaume Vicens Vives (1910-1960) a nemzetközi hírnevü katalán történész a következőt vallja e kérdésben: „Önmagunk megismerésének nagy feladatához szükségünk van a költők és a regényírók közremüködésére, akik nem dokumentumok átvizsgálásából, hanem a néplélek legmélyén zajló mozgások érzékeléséből merítenek. Egy zseniális strófa [...] egy pillanat alatt megvilágíthat olyan rejtett görbületeket, ahová a legjobban beállított dokumentum- mikroszkóp sem volna képes soha betekinteni.” ${ }^{5}$ Korának újító szellemü történésze ezzel a kijelentéssel nemcsak azt állítja, hogy az irodalom komplementer tudást jelent a történeti ismeret számára, hanem azt is, hogy a történészi hivatás célja hozzásegíteni a közösséget, s annak tagjait a

\footnotetext{
${ }^{3}$ Gyáni Gábor, „Történelem és regény: a történelmi regény”, http://www.lib.jgytf.u-szeged.hu/folyoiratok/ tiszataj/04-04/gyani.pdf, letöltés 2017. ápr. 6.

${ }^{4}$ Gelléri Gábor, „Az emlékezet fenomenológiától az emlékezetpolitikáig. Paul Ricoeur új könyvéről”, Korall, 2001 Ösz-Tél. 253-263. o. http://epa.oszk.hu/00400/00414/00004/pdf/12recenziok.pdf, letöltés 2017. ápr. 11.

${ }^{5}$ Vicens Vives, Jaume, Noticia de Cataluña, Barcelona, Destino, 1954. 12. o.
} 
nemzeti önismerethez, vagyis identitásuk megalapozásához, amihez az irodalom is fontos segítséget ad. Az írók maguk gyakran hangsúlyozzák, hogy a történelmet örökítik meg müveikben, azaz, úgy próbálják megjeleníteni korukat és világukat fikciós formában, hogy annak a valósághoz és az igazsághoz leginkább hủ rajzát tárhassák olvasóik elé. Az irodalmi alkotások sok esetben bevallottan koruk krónikái kívánnak lenni, Camilo José Cela egyenesen azt állítja, hogy Méhkas (La colmena) címủ müve a korszak történelmének igazi krónikája. $^{6}$

Jesús Moncada esetében azt láthatjuk, hogy amint kortárs klasszikusként bekerült a katalán irodalmi tantervbe, több didaktikai kiadvány is felhívta a figyelmet arra, hogy az életmü irodalmi és nyelvi értékei mellett, a diákok számára hasznossá tehető a Moncada művek történelmi olvasata is. ${ }^{7}$ Emellett, az íróval készített interjúk és munkásságával foglalkozó újságcikkek, tanulmányok is gyakran utalnak arra, hogy a müvek nagyon gazdagok történeti vonatkozásokban. $^{8}$

Jesús Moncada életmüvét hazájában nyelvészek, irodalmárok és kritikusok méltatják és elemzik, történészi szemszögböl azonban még nem született müveivel kapcsolatos tanulmány. Nekem az adott bátorságot ehhez a vállalkozáshoz, hogy ennek a víztározó mélyére süllyesztett, katalán nyelvü, aragóniai településnek az irodalmi mítoszát, az író főművének tartott Camí de sirgát én fordítottam magyarra, amit azóta is műfordítói munkám legszebb és legérdekesebb darabjának tartok. ${ }^{9}$ Történelem szakon végzett egyetemi tanulmányaim és az irodalom iránti érdeklődésem között félúton mindig az ilyen típusú regények felé

\footnotetext{
${ }^{6}$ Cela, Camilo José, La Colmena, Barcelona, Club Bruguera, 1982. A regény látlelet Madrid polgárháború utáni társadalmáról. A negyedik kiadás előszavában mondja művéről, hogy „ez egy történelemkönyv, nem egy regény.” A dolgozatban megjelenő regények címét elöször magyarul adom meg, ha léteznek magyar fordításban, majd zárójelben közlöm a mű eredeti címét. Amennyiben a münek nincs magyar fordítása, úgy elöször az eredeti címet adom meg, majd zárójelben jelzem a jelentését.

${ }^{7}$ Sasot Escuer, Mario, „Jesús Moncada, A la recerca de la infància segrestada”, in Sasot Escuer, Mario (dir.), Així s'escriu a la Franja (Antologia i guia didàctica d'autors de l'Aragó catalanòfon), Zaragoza, Gobierno de Aragon, Departamento de Educación y Cultura, 1992. 103-129. o. Bayo, Emili - Biosca, Mercè, Guia de lectura de Jesús Moncada, Barcelona, La Magrana, 1992; Chavarría, Joan - Dolç, Jordi - Pont, Màrius, „La Mequinensa de Jesús Moncada”, in El gust per la lectura, Generalitat de Catalunya, Departament d'Ensenyament Seminari 2000-2001.

${ }^{8}$ Ennek alátámasztására két cikkből idézek a MCSL digitalizált cikkgyüjteményéből, melyek A folyók városa kiadása után jelentek meg a katalán és a spanyol nyelvü sajtóban. A cikkek sajátos jelzete a MCSL kronológiai sorrendje szerinti klasszifikációt követi. L. később a Módszer és felhasznált források alfejezetben. 1989-12-02 Inventario „a könyvben elbeszélt események (Mequinensa) utolsó száz évének történelmi eseményeinek felszíni szövetére épülnek, még akkor is, ha az író nem kifejezetten történelmet akart írni.” 1995-12-24 Heraldo de Aragón „,nem történész vagyok, hanem író, a Camí de sirga történelmi tényei mind valóságos tények, melyeket irodalmi alapanyagként használok."

${ }^{9}$ A magyarul A folyók városa címmel megjelent regény Magyarországon két kiadást ért meg, melyeket követte Moncada első novelláskötetének fordítása is, a Balkézröl jött történetek, Budapest, l'Harmattan, 2012.
} 
vonzódtam, melyek szereplöik sorsán keresztül bevezetnek egy másik nép kultúrájába, történelmébe, s megmutatják koruk vallási, társadalmi, filozófiai állapotát.

A folyók városa - a Moncada életmü legfontosabb, huszonegy nyelvre lefordított regénye - előhangja kifejezetten a regénynek a történelemmel való szoros kapcsolatára hívta fel a figyelmemet: „Bár a regény anyagát a régi Mequinensa elmúlt száz esztendejének eseményei alkotják, s főként azok, amelyek sorsát az 1957-es esztendőtől kezdve visszafordíthatatlanul meghatározták, az író szeretné leszögezni, hogy nem a korszak klasszikus értelemben vett, történelmi krónikájának megírására vállalkozott.” ${ }^{10}$ Az író fikciós formában akarta megörökíteni az övéi múltját, és ehhez az emlékezetet választotta közvetítő elemnek, ennek szürőjén eresztette át az eltünt város és lakóinak történeteit.

\section{Emlékezet}

Moncada hiteles krónikával kívánt szolgálni, de forrásként nem elsősorban a városi levéltárban megőrzött iratokhoz fordult, hanem a még élő elbeszélő hagyomány iránt érdeklődött az antropológus, a néprajztudós, a történész kíváncsiságával. Kisgyerekkorától fogva jegyezte fel magának az öreg hajósok, bányászok történeteit, melyekre a kávéházban, a tömegkommunikáció előtti kor (az író gyermek- és ifjúkora) általános hírfórumán tett szert, ahová beérkezett, ahol megrostálódott, és ahonnan újra útjára indult minden korabeli információ. ${ }^{11}$ Ezt a szóbeli kultúrát, az élő emlékezetet, s annak hordozóját, a történetek formáját kialakító, gazdag nyelvi kifejezésmódot Ebro-parti Homéroszként öntötte írott formába. Az egyik interjúban úgy nyilatkozott, hogy a modernitás korában a nyelv nem egyszerüen csak változik, hanem leegyszerüsödik, uniformizálódik, mivel az emberek a modern technológiák (rádió, televízió, majd a telefon és az internet,) korában sokkal kevesebbet beszélnek ${ }^{12}$, kevésbé lakják be nyelvi emlékezetük tájait, következésképpen megszünik a történetmondói közeg. Jesús Moncada rendelkezett a mesélők, történetmondók, a közösségi emlékezet fenn-

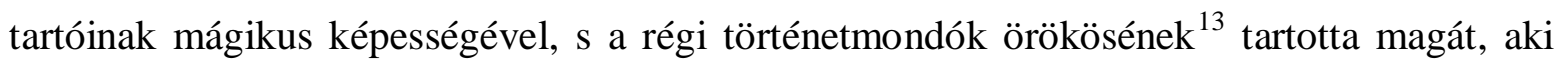

\footnotetext{
${ }^{10}$ AFV 5. o. A továbbiakban A folyók városa című regényből vett magyar nyelvü idézetek a l'Harmattan kiadó által megjelentetett 2. kiadás szövegéből származnak, AFV rövidítéssel és az oldalszám jelölésével.

${ }^{11}$ A Moncada Családi Levéltárban több olyan, Moncada által kézírással, majd később számítógéppel rögzített dokumentumot találtam, amelyekben az író tényszerü, szociográfiai, történelmi vagy néprajzi érdeklődését tükröző megfigyeléseit örökíti meg.

12 1989-02-01 Serra d'Or 351 - Aproximación a la obra de Jesús Moncada, Mercè Biosca.

13 1989-10-22 El Día de Aragón - Imán- Sólo soy un contador de historias, Anton Castro; 1997-10-01 Regió7 - Sempre he estat un narrador nat - Drama i ironia, Josep Gras. R. G. Collingwood, oxfordi történész és filozófia professzor meghatározásában a történész elsősorban történetmondó, s történeti érzéke az a képesség,
} 
beleszületett ebbe a történetmondói hagyományba, s megtapasztalta az eltűnését is. Moncada valójában ugyanazt a változást regisztrálja, amit Pierre Nora francia történész: a közösségekben megszünt az élő hagyomány által fenntartott emlékezet (megszűnnek a les milieux de mémoire - azok a közegek, amelyekben az emlékezés aktív hatóerő és a mindennapi tapasztalat része -, s marad helyettük a les lieux de mémoire - a helyek, amelyek körül a történelem kikristályosítja a társadalom mozdulatlan emlékezetét, azaz tudománnyá válik). ${ }^{14} \mathrm{~A}$ Moncada által észlelt nyelvi emlékezetvesztés ugyanehhez a folyamathoz tartozik, amit a nyelv „legmagasabb” regiszterét, poétikai funkcióját használó müvész nyilván világosan érzékelt.

Az írói életmünek az emlékezettel való szoros kapcsolatát jelzik már a korai novelláskötetek kapcsán keletkezett újságcikkek, sajtóban megjelent tanulmányok, interjúk is. ${ }^{15}$ Ezek egyikében Jesús Moncada maga is úgy határozza meg A folyók városát mint „emlékezetgyakorlatot”. A regényben leírt rombolás első napján születik az író ethoszát jellemző mondat: „Lehetséges, hogy az utcák, a terek, a házak s a két folyó ontották magukból kétségbeesetten az emlékeket, hogy valaki összegyüjtse őket az elkerülhetetlenül bekövetkező leromboltatás és szétszórattatás előtt." ${ }^{16}$ Minden háznak megvan a maga története, melyet a halál elleni védekezésképpen elmesél, a felelősségét érző írástudó pedig összegyűjti, és lejegyzi őket, hogy városát megmentse a feledéstől. Ezt a regényt tehát műfaját tekintve, mint emlékezetregényt határozhatjuk meg, amely az író szándéka szerint történelmi, de nem történészi alkotás.

Az életmű másik két és fél regényét szintén emlékezet-regénynek tekinthetjük, amit az 1997-ben született regény címe is egyértelmüvé tesz: Estremida memòria (Reszketeg emlékezet). Az első és a harmadik regény földrajzilag ugyanabban a térben játszódik, Mequinensa mikrokozmoszában, ám A folyók városa (Camí de sirga) horizontja tágabb csakúgy, mint az általa átfogott időintervallum is. Az Estremida memòria (Reszketeg emlékezet) témája egyetlen esemény, egy 1877-es rablógyilkosság, melynek elkövetői mequinensaiak voltak. Moncada, mint minden mequinensai ismerte a legendát, s regényében arra keresi a választ, miért maradt meg különböző, néha egymásnak ellentmondó válto-

amely segítségére van abban, hogy az események tömegéből értelmezhető történetet tud alkotni. Idézi White, Hayden, A történelem terhe, Budapest, Osiris, 1997. 73. o.

${ }^{14}$ Nora, Pierre (dir.), Emlékezet és történelem között, Budapest, Napvilág Kiadó, 2010. 13. o.

15 1985-04-16 El Correo Catalán - El café de la granota - Novela aplazada, Pilar Rahola „...visszaszerzi a modern katalán irodalomban elfelejtett terület emlékezetét.”; 1985-04-23 El País - De tot i més en la novel.la „ezek olyan regények (köztük a Camí de sirga), melyek vissza akarják szerezni és újra akarják értelmezni az irodalom számára a kollektív történelem egy részét.”

${ }^{16}$ AFV 33. o. 
zatokban, súlyos teherként a közösség emlékezetében. Az emlékezetnek a jelennel való szoros kapcsolata végig hangsúlyos a regényben, mely erőteljes áthallásokat tartalmaz az írás idejének emlékezeti problémáival kapcsolatban is.

A második regény, a La galeria de les estàtues (Szoborgaléria) az emlékezet nyomasztó hiányának és szükségszerü újraindulásának története, amely megmutatja, mennyire létfontosságú az emlékezet az identitását meghatározni akaró új nemzedék számára. Itt a cél egyértelmüen a köztudatból hiányzó köztársasági emlékezet ívének felrajzolása, s annak bizonyítására, hogy az író ezt sikerrel oldotta meg, egy történész olvasói levelébő1 ${ }^{17}$ idézek: „A regény a polgárháború általam ismert legjobb elemzése és paradigmája, ami ezentúl még szívhez szóló és tisztán érthető is. [...] A regény szövege megdöbbentő, kemény és elevenünkbe vágó, de miért ne nevezhetnénk egyenest alapvetően szükséges, katartikus olvasmánynak, amely elengedhetetlenül fontos ahhoz, hogy ezekről az eseményekről beszélni tudjunk, hogy meghallhassuk mások hangját, s hogy más megközelítésben ismerhessük meg a történelmi tényeket, melyek máig hatóan meghatározzák, hogy kik is vagyunk”.

A másik két regényben az író saját közössége, az aragóniai kisváros kollektív emlékezetének müködési mechanizmusait tárja fel. Ezeken keresztül mutatja meg, milyen nehéz eljutni az igazsághoz, vagy akár csak megközelíteni is azt, s hogy az emlékezet mennyire törékeny, bizonytalan, hogyan igyekszik teljesíteni a narratív igazság feltételeit a hiátusok kitöltésével, hogyan léptet életbe romantikus önigazoló vagy önvédelmi sémákat.

A befejezetlenül maradt utolsó regény, a Dante S.A. (Dante Rt.) a 60-as évek Barcelonájának kiadói világát mutatja be az első regény narrációs technikájához hasonló emlékezetmozaik felépítésén keresztül.

Dolgozatom tárgyát terjedelmi okokból csak a Mequinensa száz évének történetét felölelő, magyar fordításban is megjelent $A$ folyók városa (Camí de sirga) című regényre korlátoztam. A továbbiakban a regény címét csak magyarul jelzem mind az elemző, mind a leíró fejezetekben.

\section{Az irodalom mint történelmi reprezentáció}

A Moncada regények mindegyike az emlékezetregény kategóriájába illeszthető, mely mủfaj a spanyolországi és a katalán irodalomban egyaránt fontos áramlat. Ez a műfaji megjelölés azokra a regényekre vonatkozik, amelyek a polgárháború témáját dolgozzák fel, de

${ }^{17}$ MCSL Juan Antonio Resina Navas középkortörténész olvasói levele. 
már nem a traumát átélő nemzedék mesél, hanem a háborút és a kemény diktatúrát közvetlenül meg nem tapasztaló második vagy harmadik generációs írók mondják el a maguk traumáját, emléknyomokból, apró emlékszigetekből összeállítva szüleik, nagyszüleik történetét. Valójában, minden jelentős spanyol író megírta a maga polgárháborús regényét. ${ }^{18} \mathrm{~A}$ téma máig élő és feldolgozatlan trauma jellegére utal az, hogy a demokratikus átmenet idején sem csökkent részaránya a spanyol regényirodalomban. Gómez López-Quiñones irodalomtörténeti elemző kötetének címe La Guerra persistente (Az el nem múló háború) is a téma töretlen népszerüségére utal, s a polgárháborús témájú regényeket külön alműfajnak tekinti a spanyol irodalomban. ${ }^{19} \mathrm{Az}$ emlékezetregényeket a tényregényektől megkülönböztető fontos vonás, hogy nem kortársak és szemtanúk által rögzített emlékekről van szó, hanem az emlékezeti lánc következő nemzedékei szólalnak meg. Ök árnyaltabban, s az emlékezeti mechanizmusok müködésének finomságait is figyelembe véve ábrázolják az eseményeket, de érintettségük nyilvánvaló, hiszen az assmanni fogalomrendszerben kommunikatív emlékezetnek ${ }^{20}$ nevezett tartományban járunk, az unokák közvetlen traumák nélkül, de a nagyszülők emlékezeti vonalához kötődve láttatják a múltat. ${ }^{21} \mathrm{Ez}$ az almüfaj tehát értelmezhető úgy is, mint a példaszerü demokratikus átmenet óta diktatórikus múltjának feldolgozásával küszködő ország társadalomlélektani, generációs jelensége.

Fontos megemlítenünk ugyanakkor a katalán irodalom Franco halála utáni korszakának egy vonását: több író jelentkezik történelmi témájú regénnyel, melyeknek célja, amint azt Josep Lozano kijelentett, hogy „megmutassa a valóban történt történelmet, és mítoszt faragjon”. ${ }^{22}$ Ezek a regények a katalán történelem addig meg nem jelenített századaiba vagy eseményeibe vezetik be az olvasót, kutatásra és levéltári dokumentációra támaszkodva raj-

\footnotetext{
${ }^{18}$ Csikós Zsuzsanna, „A spanyol polgárháború traumája a kortárs spanyol szépprózában”, Mediterrán Világ, 2017/39-40. 78-89. o.

${ }^{19}$ Gómez López-Quiñones, Antonio, La guerra persistente, Memoria, violencia y utopía: representaciones contemporáneas de la guerra civil española, Madrid, Iberoamericana Vervuert, 2006. 12. o.

${ }^{20}$ Assmann, Jan, A kulturális emlékezet, Budapest, Atlantisz Kiadó, 2013. 49-57. o. Assmann ezt 3-4 nemzedéki időben, azaz kb. 80-100 évben határozza meg az ősi kultúrák és az oral history vizsgálatok tapasztalatai alapján. Moncada Estremida memòria (Reszketeg emlékezet) c. regénye az aragóniai kis közösség, Mequinensa esetében ennél hosszabb, kb. 120 évre visszamenő érintettséget mutat ki.

${ }^{21}$ Néhány példa az alműfaj jeles alkotásaiból a spanyol irodalomban: Javier Cercas, Szalamiszi katonák (Los soldados de Salamina) (2001), Almudena Grandes, Dermedt szív (Corazón helado)(2007), vagy Javier Marías, Rossz kezdet (Así empieza lo mal) (2014); s a katalán irodalomban: Jesús Moncada, La galeria de les estàtues (Szoborgaléria) (1998), Jaume Cabré, A Pamano zúgása (Les veus del Pamano) (2004), Carme Riera, La meitat de l'ànima (A lelkem egyik fele) (2004).

${ }^{22}$ Alcoberro, Agusti, Arxiu de ficcions, Barcelona, Cruïlla, 1991.
} 
zolnak hiteles történelmi hátteret. ${ }^{23}$ Céljuk a diktatúra történelemképéből hiányzó kisnemzeti emlékezet irodalmi formában történő kiépítése.

A folyók városa ábrázolástechnikájánál fogva egyértelmüen, témájánál fogva pedig részben az emlékezetregény kategóriába sorolható, és beleilleszthető a katalán történeti témájú regények közé, ezért úgy tekintek rá, mint egy irodalmi formában megnyilvánuló történeti reprezentációra. Kisantal Tamás Az irodalmi alkotás mint történelmi szöveg, címü cikkében azt mondja, hogy ha ilyen reprezentációnak tekintett, „modern eseményeket megjelenítő alkotást vizsgálunk, [...] az talán hozzásegíthet az irodalmi szövegek történeti szempontú olvasási módszereinek, stratégiáinak kidolgozásához”. ${ }^{24}$

A történettudomány alapanyaga a múlt, mely teljességében nem áll a kutató rendelkezésére, csak akaratlagosan hagyományozott dokumentumok és véletlenszerüen fennmaradt nyomok $^{25}$ segítségével rekonstruálható. Ezekből kell felépítenie a történésznek a történet egészét, vagyis fikciós formát alkotni, melynek során azonban a történész szakma tudományos követelményei miatt nem élhet a fikció szabadságával. A nyomok egységes történetté rendezése során azonban a történész, jó detektív módjára, kénytelen az „alkotó képzelethez” ${ }^{26}$ folyamodni, s így a rekonstruált múlt más-más történész tollából egészen különböző hangsúlyokat és értelmet kaphat aszerint, hogy a hiátusokat ki milyen magyarázattal tölti ki, s a tényeket milyen formában cselekményesíti. ${ }^{27}$ A szakma szabályai alapján eljáró, tudo-

\footnotetext{
${ }^{23}$ Ilyen típusú alkotás pl: Josep Lozano, Crim de Germania (Valencia 16. sz.), Maria Aurèlia Capmany, Un lloc entre els morts (Katalónia 18. sz..), Jaume Cabré, Senyoría (Barcelona, 1799), Joan Francesc Mira, Cucs de seda (Valencia 19. sz.), Papa Borja (Valencia15. sz.).

${ }^{24}$ Kisantal Tamás, „Az irodalmi alkotás mint történelmi szöveg”, Tiszatáj LVIII. évf. 11. sz. http://epa.niif.hu/00700/00713/00159/pdf/tiszataj_EPA00713_2004_11_075-101.pdf, letöltés 2017. ápr. 12.

${ }^{25}$ Jakob Burckhardt kultúrtörténeti koncepciójában kifejti, hogy a szövegek egy kor kódolt üzenetei, tudatos kifejezésformái, minden ehhez kapcsolódó tendenciózus (ön)megtévesztéssel együtt. A nyomokban ezzel szemben a kor szándékolatlan, cenzúra és torzítás nélküli emlékezetét véli felfedezni, melyeknek nagyobb igazságtartalmat tulajdonít. L. Aleida Assmann, „Beszélgetés a holtakkal: a szöveg mint a kulturális emlékezet médiuma” in: Kisantal Tamás (szerk.), Narratívák 8. Jesús Moncada független író volt. Nem tartozott politikai párthoz, sem pedig a 70-es évek politikailag harcos, katalanista írói csoportosulásához, amelyhez születési ideje alapján sorolnunk kéne. Saját művészi szándékain, céljain kívül más követelményeknek nem kívánt megfelelni. Ezért úgy gondolom, hogy alkotásai történelmi szempontból tekinthetők ilyen burckhardt-i értelemben vett nyomoknak.

${ }^{26}$ Ez a kifejezés szintén R. G. Collingwood tollából származik, aki azonban a posztmodern többértelműségével szemben feltételezte az események halmazában a priori módon létező történeteket, melyeket a történész képessége hoz felszínre, aki képes megérezni az igazi történetet. Idézi White, Hayden, id. mü 73-74. o.

${ }^{27}$ Amikor fordítóként dolgoztam Jesús Moncada Camí de sirga magyar változatán, felmerült bennem, hogy a fordítói munka nagyon sokban hasonlít a történészéhez. Ahogyan a történészi etika a valóság tényeihez való hűséget írja elö, ugyanúgy kötelez a fordítói etika az eredeti szöveg értelméhez, formájához való ragaszkodásra. A fordítás múvelete azonban csak az értelmezés után kezdődik, s hatalmas szabadság áll rendelkezésünkre a szavak konnotációs mezőjének tágassága és saját anyanyelvi tudásunk függvényében. Majdnem mindig többféle változat lehetséges, s hogy melyik a legjobb, azt tudásunk mellett stílusérzékünk, nemzeti vagy társadalmi érzékenységünk, ideológiai beállítottságunk és sokszor még a hangulatunk is meghatározza. Így jár el a tényeket tiszteletben tartó történész is, amikor a valóságot annak kulturálisan meghatározott, szimbolikus értelmezésébe, vagyis szövegbe kódolja.
} 
mányos alapossággal dolgozó, elméletét bizonyítékokkal alátámasztó történész tehát, a valóság végtelenül gazdag szövedékének csak egyik lehetséges történetét mondja el.

A regények szerzője ugyanabból a valóságból indul ki, mint a korszakot leíró történész, de másfajta összefüggésbe állítja az anyagot, ami így a tudomány szigora és logikája helyett/mellett az érzelmek és a fikció kötőanyagával rajzol ki történeti ívet, és annak a periférikus és nem nemzeti történelemnek a megírására törekszik, ami a történelemkönyvekből kimaradt. A Moncada hagyatékban találtam egy felkérést, melyben Carlo Forcadell Alvarez $^{28}$, a Zaragozai Egyetem Legújabb Kori Történeti Tanszékének professzora arra kérte Moncadát, hogy egy készülő kiadványba írja meg a Mequinensa környéki, és az Ebro alsó folyása menti területen végbement háborús pusztítások krónikáját. ${ }^{29} \mathrm{Ez}$ a szaktörténésztől érkezett felkérés véleményem szerint azt bizonyítja, hogy a Moncada regényekben ábrázolt, a mequinensai öregektől oral history formájában gyüjtött és összeállított múltkép történészi szemmel is hiteles, és hiánypótló forrásként tételeződik. Úgy gondolom, hogy az írói szándék, valamint a családi levéltárban található, élénk történeti, néprajzi, helytörténeti, és szociológiai érdeklődésről tanúskodó jegyzetanyag, a lelkes olvasói levelek és cikkek, alátámasztják ennek az olvasatnak a legitim voltát a valóság és a narratív konstrukció különbségei ellenére is, hiszen a történelem szintén retorikai alakzatok és narratív konstrukciók segítségével tudja csak leképezni a valóságot, s ebben az értelemben Hayden White óta szintén problematikus.

\section{Historiográfiai háttér}

A történeti szempontú elemzés előtt a regény értelmezési kereteként kínálkozó különböző historiográfiai területek feldolgozását végeztem el, melyek a következők: irodalom és történelem, valamint történelem és emlékezet egymáshoz való viszonyát vizsgáló szakirodalom, Spanyolország politika-, gazdaság- és eszmetörténete, Katalónia politika- és kultúrtörténete, ezen belül elsősorban a könyvkiadás és az irodalom, valamint az emlékezetpolitika és a történelmi emlékezet kérdéseit tárgyaló szakirodalom, Mequinensa helytörténetét feldolgozó monográfiák és helytörténeti szakirodalom, a tágabb geopolitikai keret, a Franja de Ponent története, a Jesús Moncada korszakára vonatkozó spanyol és a katalán irodalomtörténet, katalán szociolingvisztika. Az érintett historiográfiai területek ismertetése:

\footnotetext{
${ }^{28}$ www.enciclopedia-aragonesa.com/voz.asp?voz id=5770\&tipo busqueda=1\&nombre=carlos\%20forcadell \&categoria id=\&subcategoria id=\&conImagenes=, letöltés 2018. jan. 17.

${ }^{29}$ MCSL 3. Baráti levelek, olvasói gratulációk, vélemények, felkérések, meghívók, köszönetek 2005. április 23. Carlo Forcadell Alvarez levele.
} 
A 18. században még szépirodalmi müfajként létező történelem igyekezett elhatárolni magát a mủvészetben gyökerező múltjától, és a természettudományokhoz hasonlóan önmagát tudományos kutatásként meghatározni. Egyúttal igyekezett megszabadulni a metafizikai előfeltevésektől és a „valójában megtörtént” dimenzióját jelölte ki maga számára, mint az igazságszerzés területét, ahol a forráskritika és az objektív tárgyilagosság, a sine ira et studio elve alapján építette ki vizsgálódási területét és nyelvezetét. A történettudományban végbement nyelvi fordulat ${ }^{30}$ a történeti kutatásban elötérbe helyezte a narrativitást és a történelemfilozófiát. Paul Ricoeur és Hayden White egyetértettek abban, hogy a narratív nyelv meghatározó a történeti mező konstitúciójában. Reinhardt Koselleck, a fogalomtörténeti iskola alapítója megfogalmazásában minden történelmi tény a tényleges fikciójából származik, miközben a valóságos már elmúlt. Ez azonban nem azt jelenti, hogy a tény önkényes konstrukció, hiszen a történészi forráskritika ezt megakadályozza azáltal, hogy leszükíti a lehetséges állítások körét. ${ }^{31}$ Maguk a történelmi tények azonban csakis a rendszerező történész választása nyomán lesznek azzá az adatgyüjtés, és értékelés fázisában, a cselekményesítés $^{32}$ tekintetében pedig nyilvánvaló a történelem és az irodalom rokonsága, hiszen mondanivalója közvetítése érdekében mindkettő a ,jó történet” (jó, érthető, hatásos, ami tanít és szórakoztat) megteremtésére törekszik. Ebben a fázisban egyértelműen regényírói műveletet végez a történész, ő dönti el, hogy milyen cselekményszerkezet keretében (tragikus, komikus, romantikus, ironikus) tárja fel a történetet, s ezek a civilizáció által belénk kódolt történetsémák a szavak tartalmi jelentésén túli értelmet is kölcsönöznek a tényeknek. Collingwood megállapítását idézi Hayden White, miszerint egy tragikus eseményt nem lehet megértetni egy olyan emberrel, aki nem ismeri azokat a helyzeteket, amelyeket a mi kultúránkban tragikusnak neveznek. ${ }^{33}$ Ezek a különböző cselekményszerkezetek a kultúránk olyan inherens részei, melyek önmagukban is a tények bizonyos értelmezését adják. Northop Frye szerint az irodalmi müfajok közül külön tudománnyá váló történelem hiába próbál értéksemleges, tudományos nyelvezetet kialakítani, a művészetekben gyökerező múltjától nem tud elszakadni, nem retorikátlanítható. ${ }^{34}$

\footnotetext{
${ }^{30}$ White, Hayden, Metahistory: The Historical Imagination in Nineteenth Century Europe, Johns Hopkins University Press, 1973, valamint Paul Ricoeur, Temps et récit I-III Paris, Seuil,1983-1985. Ricoeur müvéről öt évvel a megjelenése után folytatott vitát az Annales kör, s hatására olyan kritikai fordulatot hirdetett

31 Gyáni Gábor, „A történetírás fogalmi alapjairól”, http://www.tankonyvtar.hu/hu/tartalom/tamop425/ 20110001 520 bevezetes_a tarsadalomtortenetbe/ch01.html\#id476444, letöltés 2018. ápr. 2.

${ }^{32}$ White, Hayden, A történelem terhe, Osiris Kiadó, Budapest, 1997, 251-279. o. és 68-103. o.

${ }^{33}$ Uo. 76. o.

${ }^{34}$ Paul Ricoeur hermeneutikai eszközökkel kimutatta, hogy maga is hiábavalóan kísérelte meg elvetni a cselekményességen és a cselekményszövésen alapuló történeti okfejtést, mert a történeti szövegek mindenképpen hordoznak egyfajta cselekményességet, nélküle szociológiává válnának. Szimbólumértékü vállalkozása
} 
A regényirodalomban a 20. század elejétől fogva megindultak a klasszikus realista regény megújítását célzó kísérletek (James Joyce, Marcel Proust, John dos Passos, William Faulkner), a történelem megmaradt a 19. századi regényekre jellemző szerkezetnél, és a mindentudó narrátor szerepében tárgyalta továbbra is az eseményeket. A narratív fordulat óta, azonban a múlt század 70-es, 80-as éveitől fogva folyamatban van a történettudományi diskurzus megújulása, e területen is új történetírói müfajok keletkeznek. Ide sorolhatjuk a mikrotörténelmi müfajt megteremtő klasszikus müvet, az 1976-ban megjelent Carlo Ginzburg, A sajt és a kukacokat ${ }^{35}$, De fontos említeni a mikrotörténelem előfutárának tekintett, a történetírás lépték- és szemléletváltását jelző müvet, Georges Duby 1973-ban kiadott Le dimanche de Bouvines címü müvét. Ebben az Annales iskolához kapcsolt szerző a long durée és a struktúrák vizsgálata helyett egyetlen napot, az 1214-es bouvines-i csata napját írja le, amikor a franciák első mítikus győzelmüket aratták Fülöp Ágost zászlaja alatt a németeken. A szerző ennek az egy napnak az apropóján ad betekintést a 13. századi társadalmi, hadászati, gazdasági és szellemi viszonyaiba. Az Annales iskola másik kiemelkedő történésze, Emmanuel Le Roy Ladurie szintén ebben az időszakban jelentkezett egy antropológiai szemléletü mentalitástörténeti munkával, a Montaillou-val, amely egy az inkvizíció által elpusztított kathar hitủ okszitán falu vallási hiedelmeinek, világképének rekonstruálására tett kísérlet az inkvizíció aktái alapján. ${ }^{36}$ A müben megszólaltatott falusiak több hangja párbeszédet folytat a történésszel, aki értelmezi e hangokat. Ezeknek a müveknek a megjelenése kapcsán a brit társadalomtörténész, Lawrence Stone 1979-ben megjelent írásában megállapította, hogy a strukturalizmus kimerült, újra előtérbe került a mentalitás kérdése, s a korábbi leíró-elemző munkák helyett ismét a narratív forma megjelenésének lehetünk tanúi a történetírásban, amely folyamatot „az elbeszélés visszatérésének” keresztelték. ${ }^{37}$ Kisantal Tamás A történetírásban újabban meghonosodott fordulatokról címü írásában összefoglaló-

keretében Braudel Mediterráneumát elemezte, s mutatta ki a totális történelem és a struktúrák nagy mesterének könyvében a cselekményességet. L: Gelléri Gábor, Az emlékezet fenomenológiától az emlékezetpolitikáig. Paul Ricoeur új könyvéröl, Korall, 2001 Ösz-Tél.

${ }^{35}$ Ginzburg, Carlo, A sajt és a kukacok, Budapest, Európa, 2011. A könyv megírása során alkalmazott módszer a nyolcvanas években “mikrotörténelem” néven vált önálló müfajjá. A szerző egy inkvizíciós peranyag alapján rekonstruálja egy apró friuli falucska XVI. században élt molnárának világképét. A történész az ő sorsa, vélekedései, és történetei tükrében tesz kísérletet egy eldugott falucska társadalomtörténetének ábrázolására, ahová a peranyag tanúsága alapján eljutottak a reformáció eszméi. A könyv újítása a léptékből adódó szemléletében, a félreeső hely és a „nem történelmi” főszereplö legitim forrássá avatásában keresendő.

${ }^{36}$ Le Roy Ladurie, Emmanuel, Montaillou, village occitan de 1294 à 1324, Paris, Gallimard, 1975. A mü a történeti antropológia és a mentalitástörténet müfajába tartozik, melynek megjelenését az Annales iskola egyik alapítójának, Marc Blochnak az 1924-ben megjelent Les rois thaumaturges (Gyógyító királyok, 2005) címü müvéhez köthetjük.

${ }^{37}$ Idézi Kisantal Tamás, „A történetírásban újabban meghonosodott fordulatokról”, in Kisantal Tamás (szerk.), Narratívák 8, 9-35. o. 
an megállapítja: „A kor történetírásában egyre inkább egyfajta visszakanyarodás figyelhető meg a globálistól a lokális, a struktúrától az esemény, a felülnézetitől az alulnézeti és [...] a leírástól az elbeszélés felé.” ${ }^{38}$ Az elbeszélés visszatérése mellett megfigyelhetjük a formai újításokat célzó munkák megjelenését is, mint Norman Davies, Európa szíve (1984) című, érdekes kronológiai újítással visszafelé megírt Lengyelország története, amelyben a szerző „Lengyelország jelenének múltját” akarja megérteni, és végig nagy hangsúlyt fektet arra, hogy az előzmények ismerete nélkül egyik fejezet sem érthető. A több nézőpontúságra jó példa Richard Price eddig egyedülálló, kísérleti müve, az Alabi’s World (Alabi világa) (1990), mely a 18. századi Surinam történetét beszéli el, négy különböző szemszögből: a néger rabszolgákéból, a holland hivatalnokokéból, a német-morva misszionáriusokéból és végül magáéból az elbeszélő történészéből. Simon Schama, Dead Certainities. Unwarranted Speculations (Holt bizonyosságok, jogtalan spekulációk)(1992) című könyvében pedig a történelmi elbeszélést teljes mértékben fiktív beszámolók tarkítják). ${ }^{39}$ Natalie Zemon Davis, az Új Történelem (New History) jeles képviselője fontos müvet jelentetett meg 1987-ben Fiction in the Archives (Levéltári fikciók) címmel, melyben kijelentette, hogy történészként más úton szeretne járni, mint amire tanították, hogy a történeti dokumentumok fiktív komponenseit leválasztva próbáljon elérni a valódi tényekig. ${ }^{40}$

Az új müfajokat meghonosítani igyekvő történészek bevallottan használnak müveikben fiktív elemeket, annak illusztrációjaképpen, hogy a történész, bár adatokkal, forrásokkal, dokumentumokkal dolgozik, tudása közvetett, és részben feltételezéseken alapul, s mert a rendelkezésre álló dokumentumokból nem állítható össze hiánytalanul a „jó történet”. A narratív fordulat a történelmet az elbeszélő próza egyik fajtájaként a tudományelmélet és az ismeretelmélet helyett visszautalta a retorika és a poétika hatáskörébe, ahová korábban, a 19. századi tudományos fordulat előtt tartozott. Az író-történész szerző a művészet létmódjában teremti meg művét. Mindkettő láttatni akar, ezért kiemel, elhagy, felnagyít, hogy átélhetővé, s ezáltal megérthetővé tegye a történetét. Paul Ricoeur, La mémoire, l’histoire et l’oubli (2000) címü müvében szükségesnek látta kiemelni a történelmi mező referencialitását a White féle dinamikus strukturalista szemlélettel szemben, mert úgy vélte, hogy a narratív formáknak nem inherens része a referencialitásra törekvés, a conditio historica,

\footnotetext{
${ }^{38}$ Uo.

${ }^{39}$ Peter Burke, „Az eseménytörténet és az elbeszélés felélesztése”, in Thomka Beáta (szerk.), Narratívák 4. A történelem poétikája, Budapest, Kijárat Kiadó, 2000. 37-52. o.

40 Szélpál Lívia, „A történelem jövője: Bevezetés egy nem hagyományos történetírás (unconventional history) elméletébe”, Aetas, 135-146. o. http://acta.bibl.u-szeged.hu/41312/1/aetas_2007_001_135-146.pdf, letöltés 2018. ápr. 15.
} 
vagyis a történelemmel ontológiai viszonyban levő ember számára azonban, igen. ${ }^{41}$ A történelemben élés, a saját tapasztalat, $\mathrm{s}$ az azt feldolgozó - a freudi pszichoanalízisből vett gyász/emlékmunka fogalom segítségével - emlékezet kapcsolja össze a történelemtudós tárgyát az élettel. Az emlékezet képes nemcsak a múlthoz való viszonyának megőrzésére, hanem világosan látni engedi a tapasztalattér és az elvárás-horizont dinamikáját is. Ricoeur számára a tanú kulcsfigura a történelemben, hiszen ő a hitelesítő kapocs a jelen és a múlt közt, akinek emlékezete maga a történelem tárgya, a történész szerepe pedig az, hogy eredetük alapján elválassza egymástól a különböző tanúságtételeket, és „megmagyarázza, miért nem lehet globális történelmet írni, amely megsemmisítené a különböző perspektívák közti feloldhatatlan ellentmondásokat.”42

A formai újítások és a mikrohistória léptékváltása mellett az új műfajok közt találjuk az oral historyt, és az emlékezetkutatást is. A hiteles szemtanúkat megszólaltató oral history a 60-as években vált elfogadott kutatási módszerré az USA-ban. Jellemzően a traumatikus tapasztalatok egyéni emlékezetbe zárt képeinek rekonstruálására törekszik az interjúalanyokkal való empatikus és értő beszélgetés során. A módszer a spanyol történetírásban a demokratikus átmenet idején honosodott meg, amikor már nemcsak az angolszász és az emigrációban élő történészek tehették közre kutatási eredményeiket, hanem lehetett beszélni a diktatúra büneiről, s ekkor kaptak szerepet a hosszú csend paktum után megszólaló túlélők, az addig meg nem jelenített történelem szereplői. ${ }^{43}$ A történettudomány az emlékezet felöli sebezhetőségét és a szubjektivitás vádját is felvállalta, amikor forrásai között megjelennek a közelmúlt tragikus történelmét megszólaltató tanúk.

A 70-es években tehát a tudományos történetírás területére visszatért a narráció az egyedi esemény, a mentalitás iránti érdeklődés, és az antropológiai szemlélet. A kísérleti műfajok újításai jelzik, hogy a posztmodern szerzők által társadalmunk problémájának tartott megrendült folytonosságérzet és megsokszorozódott időbeliség nyomot hagy nemcsak az irodalomban, hanem a történetírásban is. A mikrotörténelem a történelem fösodrából hiányzó, korábban ismeretlen területeket vont be a történettudományi vizsgálatba, a történelmi müvekben addig főszerephez nem jutott helyek és társadalmi csoportok képviselői köré szövi

\footnotetext{
41 Tengelyi László, „A történelmi tapasztalat védelmében. Paul Ricoeur vitája Hayden White-tal”, http://real.mtak.hu/34197/1/Tengelyi_Laszlo_A tortenelmi_tapasztalat_vedelmeben_u.pdf, letöltés 2018. ápr. 17.

${ }^{42}$ Ricoeur, Paul, La mémoire, l'histoire, l'oublie, Paris, Édition du Seuil, 2000. 334-335. o. Ezt a kijelentést Ricoeur a holokauszt áldozatai és hóhérai tanúságtételének kontextusában teszi.

${ }^{43}$ A megszólalás nehézségét Manuel Vázquez Montalbán így fogalmazza meg: „...fiatalok és öregek koptatták régi rettegésüket, ami bennük rekedt azon a napon, amelyen a diktátor meghalt. Agyukban, szívükben öröm, de a szájuk néma.” L. A menedzser magányossága, Budapest, Zrínyi Katonai Kiadó, 1985. 150. o.
} 
elbeszélő bemutatását, s igyekszik emberközpontúan megközelíteni a témát Mindez alapján arra következtethetünk, hogy a nyelvi fordulat utáni történetírás nyíltabban felvállalja tudomány és müvészet közti félúton állásának problémáját. Frank Ankersmith A sajt és a kukacok kapcsán így ír: „mint a modern festészetben, itt sem az a cél már, hogy a történelmi mü egy, a reprezentáció mögötti valóságra utaljon, hanem az, hogy a valóság felszívódjon magában a reprezentációban”. ${ }^{44}$ Ez a kijelentés egyértelműen a műalkotások létmódjába utalja a történelem megjelenítési módját, eltávolítva ezzel az objektív a bíró szerepében, harmadik félként ítélkező tudomány képzetétől. A mikrotörténetírással az igazságkeresés terepe szélesebbé vált, mellékesnek, véletlenszerünek, felejthetőnek tünő témákkal bővült, formája megváltozott és az irodalom felé mozdul el. Ugyanakkor szembetűnő, hogy a posztmodern történetírói elméletek nagy számával szemben igen kevés a posztmodern szemléletű történeti munka a gyakorlatban. ${ }^{45}$

Az érintettség, és annak felvállalása az egyik fontos eleme annak az unconventional historynak nevezett új történetírói irányzatnak, melynek programadó cikke a History and Theory címü folyóirat 2002/41. számában jelent meg. ${ }^{46}$ Ennek bevezető cikkében Brian Fay úgy jellemzi a „nem konvencionális történetírást”, mint az akadémikus történelem ellentétét, s helyénvalónak látja irodalom és történelem közelítését, valamint az érzelmek és az empátia rehabilitálását a történelemben. Ennek a „nem hagyományos történetírásnak” az előzménye az Annales-iskola 1980-as években meghirdetett, az interdiszciplináris módszertan bevezetését célzó felhívásnak az amerikai történetírásra gyakorolt hatásában keresendő. A magát Új Történelemnek nevező irányzat (Natalie Zeman Davies, Peter Burke, Frank Ankersmith), nem állítja a történelemről, hogy objektív, és vizsgálati tárgynak tartja hétköznapi emberek magán történeteit, a vizuális vagy a populáris kultúrát is. Forrásai közé számítja az irodalmi mủveket, melyeket nemcsak történeti kontextusuk kedvéért vizsgál, hanem történelmi dokumentumként tekint rájuk. ${ }^{47}$ A nem hagyományos történetírás lehetőséget nyújt a múlt többszólamú és alternatív nézőpontból történő megközelítésére, s a posztmodern történetírás gyakorlati megvalósulásához. ${ }^{48}$ Fontos, és magam számára követendő irányzatnak tartom a szintén hermeneutikai alapvetésü Practice (as) Research kutatási módszert, mely-

${ }^{44}$ Idézi Kisantal Tamás, „A történetírásban újabban meghonosodott fordulatokról” in Kisantal Tamás (szerk), Narratívák 8. 9-35. o.

45 Szélpál Lívia, im.

${ }^{46}$ Fay, Brian, „Unconventional History”, History and Theory 2002. 41. 6. o. https://www.jstor.org/stable/ 3590664, letöltés 2017. nov. 27.

${ }^{47}$ Szélpál Lívia, „A történelem jövője: Bevezetés egy nem hagyományos történetírás (unconventional history) elméletébe”, Aetas 135-146. o. http://acta.bibl.u-szeged.hu/41312/1/aetas_2007_001_135-146.pdf, letöltés 2018. ápr. 15.

${ }^{48}$ Uo. 
nek lényege abban áll, hogy egy müvészeti ág gyakorlása által jutunk tudáshoz, új kérdésekhez vagy új nézőpontokhoz. ${ }^{49}$ Az objektív, és a hipotézisek verifikációjára épülő módszertani eljárások helyett a husserli fenomenológia alapcélkitűzése értelmében visszatér a megélt tapasztalathoz. Kutatási módszere az előfeltevések nélküli, step by step módszer, ami a gyakorlatban előzetesen megszerzett személyes tapasztalatra építi később az elméletet.

A léttől elválasztott tiszta tudás hermeneutikai értelemben nem elképzelhető. A conditio historica ontológiai kötöttséget feltétezelő ricoeuri gondolata, vagy Koselleck tapasztalattér kifejezése, vagy a Practice Research által használt - a magyar származású tudománytörténész, Michel Polanyi által megalkotott - embodied knowledge fogalom mind arra utal, hogy a történész kutató egyszerre alanya és tárgya is vizsgálódásainak, hiszen maga is egy erkölcsi, történeti közösség és hagyomány része, és csak úgy tud ismerethez jutni, ha a hagyományban állva teszi fel a maga kérdéseit. „A történész számára az erkölcsi hatalmak jelentik azt, amit a természetismeret számára a törvények. A hagyományt szüntelenül kutatva sikerül végül újból és újból a megértés.” ${ }^{50} \mathrm{Ez}$ a hagyományhoz való kapcsolódás, ez a megújítva megőrzés és elkerülhetetlen benne állás - ami még tagadás formáját is öltheti -, teszi tehát lehetővé a humán tudományok számára a megértést, mely egyben értelmezés is, mely a megértés nyelvi alakban létrejövő explicit formája. Ennek során az interpretáló saját belső valóságának jelenéhez igazítva magyarázza az adott szöveget. Arisztotelész a tudást Platónhoz hasonlóan az erkölcsi lét lényegi mozzanatának tartja, és megkülönbözteti egymástól a phronészisz erkölcsi tudását és az episztémé elméleti tudását. „Az erkölcsi tudás, ahogyan azt Arisztotelész leírja [...] nem tárgyi tudás [...], melyet csupán megállapít, hanem az, amit megismer, őt magát közvetlenül érinti. Valami olyasmi, amit tennie kell [...] nem olyan ismeret, mint a tudományoké. Az ilyen elméleti tudománnyal szemben a szellemtudományok inkább az erkölcsi tudományokkal tartoznak szorosan össze. Moráltudományok. Tárgyuk az ember, s az, amit az ember magáról tud.”51

Az igazságkeresés és a szövegértelmezés problémája valójában már az ókortól fogva tárgyalt filozófiai probléma. Ennek a kérdéskörnek a feldolgozásában a történettudomány történetét általánosságban tárgyaló, összefoglaló munkák, Ernst Breisach, Historiográfia, és Gérard Noirel, A történetírás „válsága” címü müve mellett Marc Blochnak a történész mesterségéről írt elmélkedése volt segítségemre, és fontosnak tartottam Arisztotelész, Poétika és

\footnotetext{
${ }^{49}$ Schroeder, Franziska, „Bringing practice closer to research - seeking integrity, sincerity and authenticity” https://www.academia.edu/11404281/Bringing_practice_closer_to research__seeking_integrity_sincerity and authenticity, letöltés 2018. ápr. 19.

${ }^{50}$ Gadamer, Hans-Georg, Igazság és módszer, Budapest, Gondolat Kiadó 1984. 161. 0.

${ }^{51}$ Gadamer, i.m. 222. o. L. még Ancsel Éva, Éthosz és történelem, Budapest, Kossuth, 1984.
} 
Platón, Phaidrosz című művét is, mint a témakör eredetét jelző írásokat. A történetírás narratív fordulatának kérdéseit Hayden White, A történelem terhe, és Paul Ricoeur, teljességében egyelőre csak franciául olvasható, La mémoire, l'histoire, l'oublie címü könyvén valamint H. G. Gadamer hermeneutikai alapmüvén, az Igazság és módszeren keresztül közelítettem meg. A téma magyar szakirodalmában nagyon fontos, hiánypótló, interdiszciplináris tanulmánykötet-sorozat a Narratívák, mely a Pécsi Egyetemen müködő, Thomka Beáta által vezetett narratív kutatócsoport gondozásában és szerkesztésében jelenik meg 1998-tól. Ezek közül a Narratívák 2. Történet és fikció, Thomka Beáta (szerk.), a Narratívák 3. A kultúra narratívái, N. Kovács Tímea és Thomka Beáta (szerk.), a Narratívák 4. A történelem poétikája, Thomka Beáta (szerk.), a Narratívák 5. Narratív pszichológia, László János és Thomka Beáta (szerk.), valamint a Kisantal Tamás által szerkesztett Narratívák 8. Elbeszélés, kultúra, történelem címü kötetek engedtek széles spektrumú betekintést az elbeszélés elmélet nemzetközi szakirodalmába a történelem, az antropológia, és a pszichológia területén. A válogatásokban szereplő szerzők a téma nemzetközileg elismert szakértői, többek között: Roger Chartier, Paul Ricoeur, Frank R. Ankersmith, Aleida Assmann, Peter Burke, Carlo Ginzburg, vagy Stephen Bann. A modern történelemelmélet kérdéseit járják körül a Kisantal Tamás által szerkesztett Tudomány és müvészet között című tanulmánykötet szerzői, és szintén e téma köré szerveződik Rákai Orsolya - Z. Kovács Zoltán (szerk.), A narratív identitás kérdései a társadalomtudományokban címü kötet, melyben a témában publikáló magyar szerzők, többek között Gyáni Gábor, László János és Dávidházi Péter írásainak gyüjteménye. A historiográfia új áramlatait mutatja be Gyáni Gábor, „A történetírás fogalmi alapjairól” írott fejezete Bódy Zsombor - Ö. Kovács József (szerk.), Bevezetés a társadalomtörténetbe, és Kisantal Tamás nyitó tanulmánya, „A történetírásban újabban meghonosodott fordulatokról” a Narratívák 8. című kötetben, s ehhez szolgál információval Ewa Domańska interjúkötete is.

Az emlékezet tanulmányozása Pierre Nora a francia emlékezethelyek feltérképezését célzó, iskolateremtő vállalkozása után lett a történelemkutatás egyik speciális, a nyugati társadalmakban központi jelentőségü ágazata. A francia történész, az általa vezetett kutatócsoport tizennégy éves kutatómunkájának összesítéseként száz, főként történész szerző, százharmincnégy tanulmányát adta közre hét kötetben, 1984 és 1993 között Les lieux de mémoire címen. A magyar változat egy egykötetes válogatás, mely 2010-ben jelent meg Emlékezet és történelem között címen. Különösen nagy erejü, és a politika, valamint a közélet és a kultúra minden területére kiterjedő ez az emlékezetkonjunktúra a rendszerváltáson 
átesett, vagy az új nemzetállami keretek közé került népek esetében. Ezekben az esetekben a legnyilvánvalóbb, hogy felbomlottak a korábbi monopolizáltan irányított azonosulási keretek, s helyettük a múltbéli emlékezetekből válogatva új vezérfonalat kellett felépíteni. ${ }^{52}$ Jan Assmann A kulturális emlékezet címủ müvében megkülönbözteti a kommunikatív és a kulturális emlékezet fogalmát, ahol az előbbi a még élő, személyes, és átadott emlékekből álló hagyományozást, az utóbbi pedig a már rögzült, csoportemlékezettől nem befolyásolt, történelmi területen álló emlékezetet jelent. Aleida Assman, Rossz közérzet az emlékezetkultúrában, és Tzvetan Todorov, A rossz emlékezete, a jó kísértése címü munkák a traumatikus múlt, a holokauszt eseménye szempontjából járják körül az emlékezet és a társadalmi magatartás kérdését. Paul Ricoeur, La mémoire, l’histoire, l'oublie című, 2000-ben megjelent monumentális történetfilozófiai munkája, a történettudomány és az emlékezet egymáshoz való viszonyának kidolgozása, s bár a kérdéskör egyik alapművének számít, még nem olvasható magyarul. A kollektív emlékezet fogalmát a két világháború között megalkotó Maurice Halbwachs francia szociológus alapmüvei, a Les cadres sociaux de la mémoire, s a La mémoire collective interneten elérhetők francia nyelven, de az 1925-ben megjelent elöbbi münek létezik egy 1971-ben született, Az emlékezet társadalmi keretei címmel készült fordítása is. Halbwachs kollektív emlékezet fogalma sokat hivatkozott terminus, mellyel teljesen egybecsengenek a francia müveltséggel rendelkező Jesús Moncada közösségi emlékezettel kapcsolatos gondolatai. Halbwachs úgy tekint a kollektív emlékezetre, mint a csoport tagjai által közösen birtokolt tudásra, mely nyelvi kommunikáció révén alakul ki, mindig helyhez és időhöz kötött, és a csoport önazonosságát jelöli. Megállapítja, hogy az emlékezet nem csupán egy statikus és akkumulatív tárház, hanem egy aktív rekonstruktív erő, mely maga választja, konstruálja a tényeit, s a tovahaladó időben mindig változó vonatkoztatási keretek alapján rajzolja meg a múlt képét. A köznapi emlékezés és az emlékezet munkája közti megkülönböztetést megtaláljuk a klasszikus görög filozófia mneme és ananmnesis fogalompárjában is. Az „alkotó emlékezet” tehát egy olyan újrarendező és strukturáló képesség, amely nem csupán a megélt tapasztalat rögzítésére szolgál. A kognitív pszichológia mai

\footnotetext{
52 Példaként említhetjük a Bosznia-Hercegovinában állami és külföldi segítséggel egyre erőteljesebbé váló muszlim identitást, a Romániában, Ukrajnában és Oroszországban, stb. egyre erősödő pravoszláv építkezést, Magyarországon a Wass Albertért zajló harcot, melynek célja, hogy az író elfoglalhassa helyét a Magyar Írók Panteonjában, a meggyalázott Kádár sírt, a fel nem állított Hóman szobrot, a felállított „A német megszállás áldozatainak emlékművét” a szabadság téren, Spanyolországban pedig a Történelmi Emlékezet törvényét, annak katalán párját, s a Katalóniában Ricard Vinyes történész kezdeményezésére gyakorlatban is megvalósult Memorial Democràtic katalán kormánytól függő közintézményt.
} 
álláspontja szerint az emlékezet tényleges funkciója az ember által megélt dolgok feldolgozása, fogalmak és kategóriák segítségével reprezentáció készítése. Az emlékezetnek ezt a feldolgozó, s az időben haladó tapasztalattér tükrében újraíró képességét kapcsolta be Ricoeur a White-féle dinamikus strukturalizmus igazság relativizálásával fenyegető rendszerébe a történelmi mező referencialitásának védelmében. Szent Ágoston az emlékezet tanulmányozásának szenteli a Vallomások X. könyvét, és a XVI. fejezetben felhívja a figyelmet arra, hogy a feledésnek is van emlékezete, vagyis a feledést nem tekinthetjük az emlékező tevékenység hiányosságának, hanem e tevékenység egyik funkciójának/feladatának, ugyanúgy aktív képességünk, csak kevésbé tanulmányozták, mint az emlékezetet. Épp ezért a kihagyott, elfelejtett, eltitkolt dolgok is ugyanannyira részét képezik a társadalmak mindenkori ko/órtörténetének. A felejtéssel foglalkozó általános szakirodalom Weinrich, Harald, Léthé. A felejtés müvészete és kritikája, vagy a spanyol-katalán filozófus, Rogelio Moreno, La farmacia del olvido címü munkája.

Spanyolországban a történelmi emlékezetnek több könyvtárnyi irodalma és saját tanszéke van a madridi Complutense egyetemen, s Európában egyedülálló módon jogi formát is öltött. 2007-ben ugyanis megszületett a Törvény a Történelmi Emlékezetről, amit nem csak történészi körökben, hanem parlamenti-politikai és morális síkon is máig vitatnak. ${ }^{53} \mathrm{Ez}$ jól mutatja, hogy emlékezet szempontjából mennyire megosztott a spanyol társadalom, s ezen belül a katalán is. Katalóniában az autonóm parlament szintén törvényi szinten szabályozza a kérdést, és a törvény örve alatt határozott elmozdulás körvonalazódik az önálló katalán identitás megteremtése irányába. Az emlékezet kutatása Spanyolországban a polgárháború és a Franco diktatúra valamint a demokratikus átmenet, vagyis a spanyol közelmúlt traumatikus eseményeire irányul, az 1977-es Amnesztia törvény teremtette „csend paktum” hatálya alatt. A téma feldolgozásában segítségemre volt az UAB könyvtára, ahol több hónapig kutathattam, s áttekintettem a vonatkozó alapmunkákat. Ezek közül, a 2007-es törvény előkészítésének időszakában született mérvadó tanulmánykötetek a következők: Julio Aróstegui François Godicheau (dir.), Guerra civil, mito y memoria (2006), Josefina Cuesta (dir.), Memorias históricas de España (2006), Santos Juliá (dir.), Memoria de la Guerra Civil y del Franquismo (2007), Ulrich Winter, (dir.) Lugares de memoria de la guerra civil y el franquismo. Representaciones literarias y visuales (2006), Ángeles Egido (dir.), Memoria de la Segunda República. Mito y Realidad (2006). Szerzőik kimerítően tárgyalják

\footnotetext{
${ }^{53}$ Rengel, Carmen, 10 años de la Ley de Memoria Histórica: ni verdad, ni justícia, ni reparación https://www.huffingtonpost.es/2017/12/26/10-anos-de-la-ley-de-memoria-historica-ni-verdad-ni-justicia-nireparacion_a_23316863/, letöltés 2017. dec. 30.
} 
az emlékezeti konfliktus társadalmi, politikai, pszichológiai, valamint a művészeti ágakra gyakorolt hatását. Valamivel későbbi a szintén interdiszciplináris tematikájú, katalán, lokális témákat is feldolgozó Ricard Vinyes, El estado y la memoria: gobiernos y ciudadanos frente a los traumas de la historia (2009), s Jaume Sobrequés (dir.), Les presons de Franco (2004). Az emlékezet témájának monografikus feldolgozása Luís Castro, Héroes y caídos, Políticas de la memoria en la España contemporánea (2008) című munkája, mely egyértelmủen harcos álláspontot képvisel az átmenet morálisan nem kielégítő megoldásával szemben az elmaradt igazságszolgáltatás kérdésében, míg Treglown, Jeremy, Franco's Crypt: Spanish Culture and Memory Since 1936 (2013) inkább revizionista álláspontot képvisel, s a spanyol baloldal politikai tőkeszerzésének láttatja a 2007-es törvényt. Felhasználtam még az Alicantei Egyetem Pasado y Memoria, valamint a Salamancai Egyetem La Guerra Civil, Studia Historica címü kortárs történelmi folyóiratainak vonatkozó számait, és az interneten elérhető cikkeket, publikációkat, a téma aktualitásával kapcsolatban. A spanyol irodalomban tükröződő a történelmi emlékezet kérdéskörét többek közt Fernando Larraz, Ulrich Winter, William J. Nickols, Claudia Jünke, Anthony Nuckols cikkei, José Maria Izquierdo, Memoria y literatura en la narrativa española contemporanea címü esszéje és Gómez López-Quiñones, Antonio, La guerra persistente címü kötete elemzi. Kiváló monográfia a téma általános és filozófiai vonatkozásairól María Inés Mudrovcic, Historia, narración y memoria és David K. Herzberger, Narrating the Past, Fiction and Historiography in Postwar Spain című könyve, amely már 1995-ben felfigyelt a két terület összefüggéseire. Magyarul a spanyol holocaustdrámák kiváló elemzését találjuk Katona Eszter, „Egy elfelejtett tragédia: spanyolok a mauthauseni lágerben” című cikkében, a törvényi szinten elrendelt emlékezet spanyolországi problémájáról Anderle Ádám írt „Spanyol törvény a történelmi emlékezetről” címmel közvetlenül a törvény megjelenése után. A példaszerü átmenet árnyoldalairól és a katalán emlékezetpolitika társadalmi identitásképző erejéről szól Nemes Krisztina, „Törvénybe foglalt emlékezet”című cikke, míg Ferwagner Péter Ákos, általános ismertetést ad a spanyol emlékezet megosztottságáról „Történelem és politika; emlékezetpolitika” címú cikkében.

A Spanyolország történetét magyarul tárgyaló szakirodalomból Anderle Ádám, Megosztott Hispánia, és Spanyolország története címü munkáira valamint Spanyol mozaik és Történelmi minták és utak címü cikkgyüjteményeire, valamint a másik kiváló magyar hispanista, Harsányi Iván, Spanyol dilemmák, spanyol megoldások és A félperifériától a centrum felé, és a szerző nemzetközileg is elismert kiváló Franco életrajzára támaszkodtam. 
Pierre Vilar, Spanyolország története nemcsak gazdaság- és politikatörténeti értelmezései, hanem a különböző hispán identitásokat megvilágító aspektusai miatt is fontos munka. Átfogó képet ad a korszakról García de Cortázar - González Vesga, Spanyolország története csakúgy, mint Sheelagh Ellwood Franco monográfiája a diktátor személyére koncentrálva. A spanyol nyelvű történeti munkák közül Jaume Vicens Vives, Aproximación a la historia de España, Pedro Voltes, Nueva historia de España, Ramon Tamames, La república, La era de Franco, Juan Pablo Fusi, Un siglo de España, La cultura címü munkáit tanulmányoztam. Aragónia történelméhez szintén Juan Pablo Fusi munkáját használtam, mely a demokratikus átmenetet követően alakult autonómiák történészek általi elemzését tartalmazza España, Autonomías címmel. A korszak spanyol egyháztörténetét vizsgálja a montserrati bencés szerző Hilari Raguer, La pólvora y el incienso, La Iglesia Española y la Guerra Civil Española (1936-1939) alaposan dokumentált, az egyház alapvető köztársaság ellenes beállítódását bíráló, munkája, s szintén ő jegyzi a Divendres de passió, vida i mort de Manuel Carrasco i Formiguera címü monográfiát. A spanyol történettudomány, politika és oktatás összefüggéseit vizsgálják a Juan Sisinio Pérez Garzón által szerkesztett kötet La gestión de la memoria, La Historia de España al servicio del poder tanulmányai. A spanyol irodalom új szempontú, társadalomtörténeti beágyazottságú feldolgozását találjuk az aragón JoséCarlos Mainer, Tramas, libros, nombres, Para entender la literatura española 1944-2000 címü irodalomtörténetében. A korszak vázlatos áttekintését magyarul biztosítják Csikós Zsuzsanna Tiszatájban és a Mediterrán Világban megjelent cikkei, melyek a spanyol irodalmat bemutató, munkafázisban levő könyvének kutatási eredményeit tartalmazzák, és Juan Goytisolo, Problemas de la novela címü irodalomelméleti esszéi az 50-es évek társadalmi elkötelezettségü irodalmának kérdéseit elemzik.

A Jaume Vicens Vives tanítványai köréböl a hatvanas években alakult, újító szellemü barcelonai iskola a nyolcvanas évek közepén történészvitát indított, melynek fö kérdése az volt, mi a történész szerepe az ország (értsd: Katalónia) történeti tudatának kialakításában. A katalán történésztársadalom az Avenç folyóirat hasábjain 1982-1984-ben vitatta meg a kérdést, hogy az autonóm intézményrendszer biztosította nemzeti építkezési lehetőség vajon nem áll-e ellentétben a történész objektivitást feltételező és részrehajlást nem türő etikájával. A kérdés felmerülése jelzi a történészek munkájának társadalmi felelősségét a demokratikus átmenet korszakában. A történetírás a 19. századi nemzetállami átalakulás során átvette az eposz közösséglélektani és ideológiai funkcióját, s a közösség narratív identitásának újfajta megerősítését szolgálta. A történészvita megállapította, hogy nem léteznek nemzetek 
referenciapontok és szimbólumok nélkül, s hogy a spanyol történelem mítoszai (reconquista, katolikus királyok, Amerika meghódítása) mélyen gyökeret vertek a köztudatban, míg a katalán mítosz elemei (Guifré el Pelòs, Jaume I el Conqueridor, 1714. szeptember 11.) még meg sem honosodtak. Ezért a mítoszoktól, mint tudománytalan képződményektől való megszabadulás mást jelent egy már létező és mást egy kiépítendő nemzet identitása számára. A vita során Okszitánia említésével megfogalmazódik a nemzetféltés gondolata is.

2002-ben az oktatás- és az emlékezetpolitika kapcsán felmerülő kérdéssel kapcsolatban Ricard Vinyes a Barcelonai Egyetem professzora s az ő javaslatára később létrejött közintézmény, a Memorial Democràtic igazgatója így fogalmazott: „Nekünk történészeknek erkölcsi kötelességünk egy civil mozgalmat teremteni, amely az emlékezet megerősítését követeli [...] vannak pillanatok, amelyekben a történeti kutatásnak szüksége van politikai támogatásra." ${ }^{54}$ A kijelentés az emlékezetpolitikai harcok hevében hangzott el, s megvilágítja, milyen történészi erőfeszítést igényel egy új emlékezetpolitika mentén egy új identitást kiépíteni. Katalónia történelmével kapcsolatos átfogó történeti munkák: Az 1954-ben megjelent Jaume Vicens Vives, Noticia de Cataluña, mely a diktatúra idején először adott hírt Katalóniáról, s a katalán idioszinkrázia jellemzőiről. Albert Balcells, Cataluña contemporanea, La història de Catalunya a debat, valamint a Pierre Nora mintájára a katalán emlékezethelyek gondolata köré szervezett, Els llocs de memòria dels catalans címü müvei. Ferran Soldevila, Síntesis de historia de Cataluña klasszikusnak számító munkáját. Tömör, és a függetlenség irányába haladó ívet rajzol Agustí Alcoberro, 100 històries clau de la Història de Catalunya címü munkája. Manuel Castells, Az identitás hatalma müvében külön fejezetet szentel Katalónia esetének. A „Katalánföld” koncepció történetének alapos feldolgozása: Gonzàlez Vilalta, Arnau, La nació imaginada Els fonaments dels Països Catalans, ezen a témakörön belül a katalán nacionalizmust Jordi Vila Foruny, El nacionalisme català, aportacions a un debat, Jaume Fabre, Quienes somos los Catalanes, Észak-Katalónia helyzetét Alà Baylac-Ferrer, Catalunya Nord, Societat i identitat, Valencia helyzetét Joan Fuster alapmüve a Nosaltres els valencians, valamint Joan Francesc Mira, Crítica de la nació pura, sobre els símbols, les fronteres i altres assaigs impetiosos, Sobre la nació dels valencians müveiből ismerhetjük meg. A „katalán kulturális genocídium” (Josep Benet) kísérletének összefoglalója, Josep María Solé i Sabater, Cronología de la repressió de la llengua i la

\footnotetext{
${ }^{54}$ Scagliola, A., „Cambio en las políticas públicas de la memoria en Cataluña: El pasado como problema” Entelequia, Revista interdisciplinar, 2008. http://www.eumed.net/entelequia/pdf/2008/e07a18.pdf, letöltés 2014. nov. 10.
} 
cultura catalanes 1936-1975 címü munkája. Josep María Castellet, Qüestions de la literatura, política i societat és Francesc Vallverdú, El fet lingüístic com a fet social, és L'Escriptor català i el problema de la llengua címü könyvei szociolingvisztikai elemzések csakúgy, mint Joan Solà, Plantem cara című esszégyüjteménye.

A Franja de Ponent történetét főként a jelen szociológiai, demográfiai, kulturális és nyelvészeti kérdéseire koncentrálva találjuk Josep Espluga, Hèctor Moret, Mario Sasot Escuer, Ramon Sistac, és Artur Quintana bibliográfiában felsorolt munkáiban. Mequinensa két, átfogó történeti kutatásokat tartalmazó helytörténeti monográfiával rendelkezik: José Ramon Marcuello Calvín, Siempre Mequinenza (2007) és Jordi Estruga Estruga, Mequinenza a través de la historia (2010). Marcuello Calvín alaposan dokumentált könyve a spanyolországi vízierőmüépítkezések történetéhez szolgáltat nagyon fontos ismereteket, lévén a szerző a hidroelektrika témájának szakújságírója.

Jesús Moncada munkásságáról és nyelvéről Mercè Biosca, a Lleidai Egyetem nyelvésze, Hèctor Moret, Kathryn Crameri és Ramon Acín szerkesztett tanulmányköteteket. Mercè Bioscával szerkesztett A 2015-ben megjelent Moncada frazeológiai szótár. A katalán irodalom álfogó történetét találjuk Parcerisas, Francesc (dir.), Entre dos mons, Visions de la literatura catalana a l'inici del segle XX. 1906-2006, Ferran Carbó - Vicent Simbor, Literatura catalana del siglo XX, Triadú, Joan, La novella catalana de postguerra Joan Fuster, Literatura catalana contemporània címủ munkáiban. A katalán könyvkiadók egyesülete három kötetben adta ki a katalán kiadók történetét, az ide vonatkozó kötet: Manuel Llanas, L'edició a Catalunya: el segle XX (1939-1975), Stewart King, „Un problema de identidad? La cultura catalana de expresión castellana” címü könyvfejezete a kortárs spanyol nyelvü katalán irodalmat elemzi, az Àlex Broch és szerzőtársai, 70-80-90 Literatura, Oriol Pi de Cabanyes, La generació literària dels 70, és Manuel Llanas - Jordi Chumillas, Edicions Magrana (1976-2000) az átmenet és a demokrácia kezdetének katalán írói és kiadói nemzedékét vizsgálja.

$\mathrm{Az}$ áttekintett szakirodalomban nem találtam kifejezetten katalán irodalmi művek történeti szempontú elemzésével foglalkozó tanulmányt, csak néhány munka célkitűzése hasonló: Carme Gregori „Identitat, memòria, literatura: les novelles de Carme Riera”, címü cikke emlékezet és identitás összefüggéseit elemzi Carme Riera regényeiben, Barbara Luczak, Espacio y memoria, Barcelona en la novela catalana contemporánea címü kötete térpoétikai keretben vizsgálja a kortárs katalán regények különböző Barcelona ábrázolásait. Josep Massot i Muntaner, a mallorcai származású bencés szerzetes és történész Tres 
escriptors davant la Guerra Civil, George Bernanos, Joan Estelrich, Llorenç Villalonga címü kötetében három mallorcai vonatkozású író spanyol polgárháborúhoz való viszonyulását tekinti át. A Jaume Sobrequés által szerkesztett, a Franco-korszak börtönvilágát feltérképező kötet, a nehezen megközelíthető levéltárak mellett, a történészi gyüjtőmunka forrásai közé sorolja az irodalmi művekben található tanúságtételeket, Agustí Alcoberro, Arxiu de ficcions címü tanulmánykötete a szerző által reprezentatívnak tartott katalán regények történelmi elemeit emeli ki.

\section{Módszer és felhasznált források}

A folyók városa mind tartalmi mind müfaji sajátosságai, mind pedig recepciója okán alkalmas a történeti elemzésre, mert a benne megfogalmazódó kérdések: a történelememlékezet, az igazság-fikció viszonya, rímelnek a megújuló történettudomány által tárgyalt kérdésekre, melyek az esztétika, az objektív valóság és a jelentés körül kristályosodnak ki. ${ }^{55}$ A regények, a helytörténet és a nemzeti narratíva viszonyáról Gyáni Gábor egy helytörténeti konferencián a következőképp fogalmazott: „,a nagytörténet, a nemzet historikumának történelmi fogalma többnyire elnyomja, majd pedig a feledés, netán az irodalmi megnyilatkozás zárványába számüzi a helyi történelmi tudást és érzékenységet." "56 Úgy vélem, hogy A folyók városa épp ilyen tudásnak a lenyomata, s mint a recepciója bizonyítja, a választott forma sokkal kevésbé zárványszerü, mint a város később megjelent helytörténeti monográfiái. ${ }^{57}$ A dolgozat kiindulópontja és fókusza A folyók városa, és az általa közvetített történelemkép. A regényvalóság adatait a szaktörténészek és helytörténészek által készített történeti monográfiák és a Moncada hagyatékban található, valamint az általam készített oral history interjúk adataival tudtam összevetni, s ehhez a regényen kívül elsődleges források három csoportját használtam fel:

1. A Moncada Családi Levéltár anyaga, melyet az író húga, Rosa Maria Moncada bocsátott rendelkezésemre 2012 őszén, 2013 májusában és 2015 őszén. Az írói hagyaték 2017

\footnotetext{
${ }^{55}$ Domańska, Ewa, Encounters. Philosophy of History after postmodernism, Charlottesville and London, University Press of Virginia, 1998. A Stanford University nagy történész tekintélyeivel (Hayden White, Frank Ankersmith, Steven Bann, Peter Burke) készített interjúkötet összegzéseképpen a lengyel történész kutató megállapítja, hogy bár a történészek eltérö véleményeket képviselnek, abban azonban egyetértenek, hogy melyek ma a történettudomány fö kérdései.

56 Gyáni Gábor, „Identitás, emlékezés, lokalitás”, 2000, 2008/6. ketezer.hu/2008/06/identitas-emlekezeslokalitas/, letöltés 2017. dec. 12.

${ }^{57}$ Uo. Gyáni szerint a helytörténeti ismeretek terjesztése korlátozott lehetőségekkel bír az intézményi háttér hiánya miatt, s mert a szubnacionális tehát alsóbbrendünek tekintett történelem nem tarthat igényt széleskörü ismertségre.
} 
őszén került a Barcelonai Autonóm Egyetem Humán Tudományok Könyvtárába ${ }^{58}$, így könnyebben hozzáférhetővé válik a kutatók számára. A hagyaték történészek számára érdekes része három csoportra bontható:

a) az író édesapja, José Moncada Moncada által megőrzött újságcikkek, eredeti dokumentumok, és személyes iratok alkotta csoport;

b) az író rajzait, jegyzeteit, mequinensai öregekkel készített interjúit, fordítóival, olvasóival folytatott levelezését, és az Estremida memòria (Reszketeg emlékezet) címü regény alapanyagául szolgáló levéltári irat másolatát, s a regényhez gyüjtött más korabeli dokumentumokat tartalmazza;

c) spanyol, katalán és nemzetközi sajtóban megjelent Moncada témájú cikkek és sajtóközlemények, egyéb kiadványok, beszédek, hirdetmények és az író végrendelete. Az ebbe a csoportba sorolt dokumentumok azért képeznek külön egységet, mert a hagyaték többi, rendezetlen részével ellentétben, ezeket a család 2015-ben már digitalizált formában őrizte a hagyatékban. Ez a digitalizált adattár rengeteg információt biztosított számomra, mivel a helyi betekintés rövid idejével ellentétben, ezt az adatbázist hazahozhattam elektronikus formában. A felhasznált források jelölésénél az első két csoporthoz tartozó dokumentumokat a Moncada Családi Levéltár anyaga fejezetben sorolom fel, a helyszíni feldolgozás során magam által alkotott kategóriákra bontva. Az író és édesapja által készített fotókat és az író festményeinek reprodukcióit csak megtekintettem, de feldolgozni nem volt módomban. A harmadik csoportba tartozó 714 tétel a Moncada Családi Levéltár digitalizált anyaga címü fejezetben található. Ez utóbbi esetben a hagyaték rendezőjének kronologikus rend alapján felállított klasszifikációját követtem, melyben elsőként szerepel a megjelenés időpontja, majd dőlt betűvel a sajtótermék neve, aztán a cikk címe, s végül vesszővel elválasztva a szerző neve, amennyiben azt a cikk jelzi. 714 tétel között találhatók újságmellékletek is, melyek esetenként négy vagy öt cikket is tartalmaznak. A lista végére azok a cikkek kerültek, amelyeknek dátumát a hagyaték rendezője nem jelezte, s én sem tudtam megállapítani.

2. Oral history: személyes beszélgetések, levelezés Jesús Moncada húgával, Rosa Maria Moncadával, barátjával, Hèctor Morettel, első kiadójával, Carles-Jordi Guardiolával, Magda Godià-val, Mequinensa polgármesterével és Jordi Estrugával, a Mequinensa monográfia szerkesztőjével és Andrés Coso helytörténésszel, a monográfia egyik szerzőjével. Az Oral history, mint forrásanyag használata a kortárs történeti kutatások elengedhetetlen eleme,

\footnotetext{
${ }^{58}$ A hagyaték közgyüjteménybe helyezéséröl tudósít az UAB oldala www.uab.cat/web/detall-de-noticia/elllegat-de-jesus-moncada-a-la-biblioteca-d-8217-humanitats-1345697212743.html?noticiaid=1345734555798, letöltés 2017. dec. 20.
} 
hiszen a közelmúlt eseményeinek szemtanúi még életben vannak, s az általuk elbeszélt történetek biztosítják a kutatási téma több szempontú ismeretét. Ebbe a kategóriába sorolom a saját magam által készített interjúkon kívül az íróval készített rádiós és televíziós interjúkat is, melyek gyüjteménye megtekinthető az Espais literaris de Jesús Moncada (Jesús Moncada irodalmi terei) című weblapon, valamint az író által a mequinensai öregekkel készített, s a hagyatékban fellelt életútinterjúkat. Előbbiek az író, utóbbiak pedig a regény korára vonatkozó értékes források.

3. Jesús Moncada egyéb müvei, kortárs katalán és spanyol irodalom müvei.

A kultúra-, eszme- és mentalitástörténet talán nem lehet soha olyan objektív, mint a gazdaság vagy politikatörténet, melyek forrásanyaga konkrétabban lehatárolható, klasszikus történelmi mezőt alkot. Én a kultúra minden megnyilvánulására úgy tekintek, mint az adott társadalom gondolkodásmódjának lenyomatára, vagyis, társadalmi tényként kezelem. Az irodalmi müvek a kor szellemének lenyomatai és az értelmezés alakzatai tehát ilyen értelemben a vizsgálódás forrásaiként kínálkoznak A folyók városa csakúgy, mint a Moncadaéletmü többi alkotása egy különleges helyzetben levő nyelv és kultúra irodalmának terméke, s így elemzése során egy állam nélküli nemzet identitásáról alkothatunk fogalmat, méghozzá abból a ritkán felvett nézőpontból, amit az aragóniai katalán kettős identitás képes közvetíteni. Ebből kiindulva végzem el a dolgozat II. fejezetében a regény külső elemzését, melynek során a mü és szerzője társadalmi térbe illeszkedését vizsgálom. Az irodalmat a katalán virtuális tér kitágításaként értelmezem, egy olyan területként, ahol a nyelvi, nemzeti különállás érzékletesen jelenik meg, és a politika számára presztízsértékkel bír. A valenciai író és kritikus, Josep Iborra irodalom-történelem-emlékezet összefüggése kapcsán megállapítja: „az irodalom még mindig társadalmi dokumentum [...] a mi regényirodalmunk [...], s kultúránk csak akkor lesz valósággá, ha képesek vagyunk megtenni a kellő erőfeszítést a feledés ellen." 59

A folyók városa alávethető egy belső elemzésnek is. Kisantal Tamás fent idézett cikkében óva int bennünket ,a leegyszerüsített mimézisfogalommal” bíró, direkt történeti vizsgálattól,

\footnotetext{
${ }^{59}$ Enric Valor i Vives, Sense la terra promesa, Cicle de Cassana, Tàndem Edicions, València 1991, Előszó: Josep Iborra. Valenciában a valenciai (a katalán nyelvi változat) beszélö közösség nyelvi létében sokkal inkább fenyegetett, mint a katalóniai. Ha a nyelv csak egy helyi közösség keretein belül használható, szóbeli kommunikációs eszköz, melynek se kulturális, se gazdasági, se hivatalos téren nincs többletértéke, feleslegessé válik. Az adott nyelven születő jelentős irodalmi alkotások, mint Valor Cassana ciklusa (egy mítikus valencia településen játszódó többgenerációs családregény, a belső valenciai emberi és természeti táj ábrázolása) nagy jelentőséggel bírnak az anyanyelvi kultúra számára, mert az egyedülálló kombinációban létező nyelv, tartalom és forma teszi, hogy a mü más nyelven megírhatatlan.
} 
melyben a valóság problémátlanul meghatározhatónak tűnik. Az elemzés során nem a tényeknek az irodalmi szövegből történő kiszürésére, s a levéltári adatokkal való összevetésére törekszem, mivel ennek feltételei nem katalán és nem mequinensai kutató lévén, csak igen korlátozott mértékben állnak rendelkezésemre, s mivel a regényre nem kizárólag úgy tekintek, mint adatőrző médiumra. Marc Bloch azt állítja a tényekkel kapcsolatban, hogy a történelemnek nem volna igazán szellemi jelentősége, ha teljesítménye csupán abból állna, hogy bizonyossággal megállapítja, hogy mely események történtek meg valójában. ${ }^{60} \mathrm{~A}$ Mequinensa-mítosz, vagyis az irodalmi Mequinensa párhuzamba állítható a város helytörténeti nagymonográfiájával ${ }^{61}$ és a Moncada által készített oral history interjúkban, s a mai mequinensaiak visszaemlékezéseiben megőrzött emlékekkel, így néhány konkrét esetben lehetővé válik igazság, tény, emlékezet és fikció viszonyának többoldalú vizsgálata. Ezen kívül a regényben szereplő történelmi tények, hangsúlyok és ábrázolásmód összevethetők a helytörténeti monográfia tényeivel és ábrázolásmódjával, ami megmutatja, hogy mely tények hol kapnak nagyobb hangsúlyt, és hol hiányoznak, holott más forrásból bizonyosan tudunk róluk. Ebböl következtethetünk a különböző közegek által indukált, és különböző elváráshorizontokra fókuszáló emlékmunkák eredményeire.

A regény szövegére gyakorló műfordítóként úgy tekintek, mint az elsődleges jelentésre koncentráló szemantikai olvasatra, amint Umberto Eco mondja, a naiv olvasatra. ${ }^{62}$ Az írói szándék tükrében Moncada valóságmegjelenítési módját igazság-intenció által vezérelt tevékenységként tételezem. Bár a fikción nem kérhető számon valóságreferencia, de az író által birtokolt nyelvi tudás, hagyományban élés, phronészisz azaz erkölcsi tudás, valamint regényírás=emlékmunka alaphelyzet véleményem szerint elegendö alapot teremt a belsö elemzéshez. A naiv olvasat a konkrét ténymegfeleltetésen túl jelenti még az ábrázolt történeti univerzum feltérképezését a következő kérdések alapján: Mely tények, személyek, történelmi események, földrajzi és néprajzi vonatkozású motívumok jelennek meg a regényben? Mit tartott megörökítésre méltónak az író? A regény terében ábrázolt személyeket, eseményeket, helyeket milyen szemszögből láttatja? E. H. Carr állítása szerint a történelmi tény a történész alkotása. Amennyiben a történész társadalom úgy ítéli meg, hogy egy kiemelt esemény hitelesen mutat meg fontos összefüggéseket, úgy az a későbbiek során törté-

\footnotetext{
${ }^{60}$ Bloch, Marc, A történész mestersége. Történetelméleti írások, Budapest, Osiris, 1996. 76. o.

${ }^{61}$ Estruga Estruga, Jordi (dir.), Mequinenza a través de la historia, Mequinenza, Ayuntamiento de Mequinenza, 2010. Ennek elkészítésébe a szerkesztő igyekezett bevonni Jesús Moncadát, az akkor már híres írót is, aki azonban nemet mondott a felkérésre, mert nem kívánt más grémium más szabályai alapján alkotni. A nagymonográfia szerkesztőjének, Jordi Estruga Estrugának személyes közlése alapján.

${ }^{62}$ Umberto Eco, Az értelmezés határai, Budapest, Európa Kiadó, 2013. 42-48. o.
} 
nelmi ténnyé válik. ${ }^{63}$ A Mequinensa száz évének történetét megrajzoló író esetében szintén érdemes nyomon követni, milyen tényeket validál a közösségi emlékezet megörökítőjeként, mert ez kirajzolhatja egy periférikus terület központi történelemtől eltérő sajátos vonatkoztatási pontjait. Arra a kérdésre is választ kaphatunk, hogy mennyivel járul hozzá Jesús Moncada műve a szükebb és tágabb katalán közösség önképének alakításához, szerepet játszik-e az életmü az ismeretlen vagy elhallgatott történelmek köztudatban való artikulálásában, s tekinthetők-e a Moncada regények a történelmi emlékezet helyreigazítóinak, kiegészítőinek. Megfigyelhetjük az író által kialakított történeti-emlékezeti kép jellemzőit: Milyen álláspontot közvetít a regény morális és érzelmi univerzuma? A klasszikus vagy középponti történelemhez képest milyen az aragóniai katalán nézőpontú, kisvárosi szemléletű, a barcelonai „metropolisztól” és a fejlettebb tengerparti régiótól távoli, a polgárháborúban a vesztesekhez tartozó elbeszélő történelemképe? Milyen mechanizmusok segítségével alakítja ki egy kisvárosi közösség az önképét?

A Moncada regények áttételesen tükrözik az írás idejének (1971-2005), társadalomtörténeti és politikai kontextusát is, mint az egyértelmüen kimutatható az Estremida memòria esetén, s kevésbé A folyók városa esetében is. A regényíró legitim módon írhatja mindig saját élettörténetét, $\mathrm{s}$ a müvében fellelhető prezentizmus korának társadalmi problémáit világíthatja meg. Munkám során igyekeztem figyelemmel lenni a Hans Kellner ${ }^{64}$ által crooked, azaz megcsavart olvasásként jellemzett lehetőségre is, ami azt figyeli, hogy milyen retorikai mechanizmus jeleníti meg az író a mondandóját, mit közöl velünk a forma, és nem a tartalom által.

\section{Száz év Spanyolországban, történelmi vázlat}

A folyók városa által ábrázolt korszak, a város pusztulását megelőző száz év történelmi főszereplői és eseményei felbukkannak a Mequinensa mítosz történetében is. Spanyolország történelme, mint közös emlékezeti háttér tájékozódási pontot kínál az olvasóknak, ezért a kor föbb vonásait egy rövid történeti vázlatban ismertetem. Ennek elkészítésében a historiográfiai bevezetőben jelzett spanyol és katalán történeti munkákra támaszkodtam.

A Bourbon Ház Restaurációjának ideológusa Cánovas de Castillo 1874-ben formailag az angol parlamentáris rendszerhez hasonló, két párt (liberális és konzervatív) váltógazdaságán

\footnotetext{
${ }^{63}$ Carr, E. H., Mi a történelem?, Budapest, Századvég Kiadó, 1993. 11-12. o.

${ }^{64}$ Hans Kellner, „A Valóság legmélyebb tisztelete”, in Kisantal Tamás (szerk.), Tudomány és müvészet között. A modern történelemelmélet problémái, Budapest, L’Harmattan, 2003. 211-232. o.
} 
alapuló rendszert hozott létre, mely arra volt hivatott, hogy véget vessen a politikai instabilitásnak, melyet a dicsőséges forradalmat (1868) követő kantonális lázadások, a harmadik karlista háború (1872-1876), s a hadseregnek a politikai életbe történő állandó beavatkozása okozott. Ez a demokratikus szabályokat látszatra betartó, ám királyi rendeletekkel irányított parlamenti váltógazdaság valóban stabilizálta a politikai teret $-\mathrm{s}$ benne a Bourbon monarchia helyzetét - az 1923-as diktatúráig, majd annak segítségével még 1931-ig, a II. Köztársaság kikiáltásáig. Ez a felső szinten parlamentáris demokráciának tűnő rendszer azonban egy politikailag éretlen vidéki társadalomra épült, melyet a kacikizmus rendszere müködtetett. A kacikizmus azt jelentette, hogy a falvakban és a kisvárosokban, a helyi hatalmasságok a személyes függések és helyi érdekeltségek olyan szövedékét alakították ki, amelyben mindenki a fennálló rend foglya maradt. Ezek a helyi hatalmasságok érdekeiket a helyi választások manipulálásán keresztül érvényesítették. A 19. század végi regeneracionismo egyik legjelentősebb jogász-politikus-írója, Joaquín Costa úgy fogalmazott, hogy „létezik egy majdnem európai színvonalú Spanyolország, és egy másik, amelyik szinte törzsi szinten él, annyira elmaradott. Az első kategória az, amelyik a történészeket foglalkoztatta és foglalkoztatja, míg a másik, a kicsikből álló nagy Spanyolország hallgat, és nem látszik". ${ }^{65}$ Gazdasági fejlettség tekintetében az ország területenként is nagyon eltérő jegyeket mutatott. Mindössze három régió rendelkezett számottevő iparral: Baszkföld - vaskohászat, Asztúria - szénbányászat és Katalónia - textilipar. Ezen kívül Madrid az ipari fellendülés egyik centruma, és a citrusféléket termelő Valencia ápol gyümölcsöző kereskedelmi kapcsolatokat Európa többi részével. A peremterületek és Madrid fejlettségétől nagyon elmaradt az ország döntően mezőgazdaságból élő többi része. A vasúthálózat kiépítése rendkívüli jelentőséggel bírt a spanyolországi belső piac megteremtése szempontjából. A 19. századi liberális törekvések az ország ipari és mezőgazdasági beruházásaihoz szükséges tőkét a holtkézi birtokok megszüntetése és áruba bocsátása (Mendizábal, 1836) révén kívánták előteremteni. Ennek második ütemében, a Pasqual Madoz nevéhez köthető, a közösségi földek kisajátítását célzó rendelet (1855) nyomán befolyt összegeket az államadósság törlesztése mellett a közművek és a vasúthálózat kiépítésének céljaira szánták. ${ }^{66}$ A vasútépítkezések valóban megindultak, az államilag finanszírozott hálózatnak azonban nagy hátránya volt, hogy tervezésekor nem az országban valóban létező és müködő áruforgalmi relációkat vették alapul, hanem egy su-

\footnotetext{
${ }^{65}$ Joaquín Costa, El problema de la ignorancia del derecho y sus relaciones: el status individual, el referéndum y la costrumbre , székfoglaló beszéd a Moráltudományok Királyi Akadémiájára való belépésekor. \%. http://e-archivo.uc3m.es/bitstream/handle/10016/2708/TEMA\%202.pdf;jsessionid=EBAA4596FA9 DE7AFA080B415707223AF?sequence=1 letöltés 2017. máj. 10.

${ }^{66}$ García de Cortázar-González Vesga, Spanyolország története, Budapest, Osiris Kiadó, 2001, 332. o.
} 
garas hálózatot kívántak építeni Madrid központtal. Sok vonalról az üzembe helyezés után derült ki, hogy egyáltalán nem gazdaságos. Ekkor egy vasúti liberalizációs törvénnyel lehetővé tették, hogy a társaságok saját érdekeik szerint jelöljenek ki útvonalakat, majd az 1866os vasúti csőd véget vetett a finanszírozási konjunktúrának. ${ }^{67}$ Addig mintegy 7000 km vasút épült meg, ami döntőnek bizonyult a spanyol piaci integráció kiépülése szempontjából. Ebben a korszakban épült ki többek között a Madrid-Saragossa, Saragossa-Barcelona szakasz is.

A 19. század végén és a 20. század elején kezdtek megalakulni a politikában helyet kérő, addig képviselettel nem rendelkező munkások pártjai, érdekképviseletei, melyek kezdettől fogva megoszlottak Marx és Bakunyin tanainak követői közt (Spanyol Szocialista Munkáspárt - PSOE (1879), és szakszervezete - UGT (1888) Madrid; anarchoszindikalista szakszervezet - CNT (1911) Barcelona; Spanyol Kommunista Párt PCE 1921). Az első világháború során bár a háború kínálta piac miatt a termelés nagyon felfutott, de a munkások fizetésének értéke csökkent, mert a beáramló tőke inflációt okozott. Ez 1917-től kezdődően sztrájkokhoz vezetett. A gyárosok nem fektettek be a termelés technikai modernizációjába, csupán kihasználták a konjunktúrát, s az olcsó munkaerőt. A háború utáni óriási termelés visszaesés miatt tömeges elbocsájtások következtek, s a munkanélküliség miatt a politikai helyzet ingataggá vált, amihez a nagy sztrájkhullámok is hozzájárultak. Az I. világháború végétől kezdődően, a 20-as években Barcelonában szinte állandósultak a merényletek, melyeket az anarchisták követtek el gyárosok és politikusok ellen, s ennek válaszcsapásaként, a patronátus felbérelt pistolerók által elkövetett merényletek útján próbált megszabadulni az anarchistáktól, ami egy kvázi polgárháborús helyzetet eredményezett.

Katalóniában 1913-ban megalakult a négy katalán provincia federációja, a Mancomunitat de Catalunya, ami a felvilágosult elvek alapján 1833-ban kirajzolt egységes közigazgatási rendszerbe visszasatírozta a Principátus történelmi tartományának egykori körvonalait. Eduardo Dato miniszterelnök 1882-es törvénye tette lehetővé a spanyol provinciák szövetkezését, amit egyedül a Lliga Regionalista politikusai (Prat de la Riba, Puig i Cadafalch) használtak ki, s hoztak létre egy infrastrukturális (vízierőművek, utak, hírközlés), oktatási és kulturális fejlesztéseket favorizáló katalán intézményi teret, „mini államot”.

Kuba elvesztése (1898) hatalmas csapást jelentett a spanyol nemzeti büszkeségre, mert ezzel a hajdani birodalom elvesztette utolsó gyarmatát is. A birodalmi helyzetre méretezett

${ }^{67}$ Uo. 341-2. o. L. még Alcoberro, Agustí, 100 episodis clau de la història de Catalunya, Valls, Cossetània Edicions, 138. o. 
hadsereg, s benne az aránytalanul nagy létszámú tisztikar azonban megmaradt. E hatalmas összegeket felemésztő katonai és bürokratikus szervezet számára egyedül a marokkói spanyol mandátumterületeken nyílott lehetőség a hadierények bizonyítására a spanyol üzleti magánérdekeltségek védelmében. Az 1921-es szégyenletes annuali vereség, a király és a hadsereg felelősségének elkenése, a parlamenti vizsgálóbizottság eredményeinek nyilvánosságra nem hozatala szintén hozzájárult a helyzet destabilizálódásához, ami 1923-ban katonai diktatúra bevezetését eredményezte.

Primo de Rivera tábornok, Barcelona katonai főparancsnoka a király beleegyezésével katonai puccsot hajtott végre, hogy a szokásos spanyol módszerrel, a pronunciamientóval megmentse az országot az anarchiától. Felfüggesztette az alkotmányt, cenzúrát vezetett be, egységpártot hozott létre, s bár ideológiai és társadalompolitikai alapokat nem sikerült kiépítenie, de 1926-ban pacifikálta a rif törzseket, és jelentős közmunkaprogramot indított el. Ennek keretében állami beavatkozással (eladósodás árán) javult az úthálózat, víztározók épültek, megkezdődött az elmaradt területek villamosítása, s az ország gazdasági korszerüsítésére a rendszer technokratái tíz éves tervet dolgoztak ki. Az ő kormányzása alatt jöttek létre vízügyi konfederációk (Confederacions Hidrogràfiques), mely szervezetek voltaképpen napjainkig ugyanazzal a célkitűzéssel müködnek. Feladatuk a spanyol folyók vízgyüjtő területeinek tudományos feltérképezése, és nemzetgazdasági szintű hasznosítási tervek kidolgozása. A nemzeti egységtörekvések jegyében a tábornok megszüntette a katalán Mancomunitat intézményét (1925), és a liberális eszmék korlátozására szigorú cenzúrát vezetett be.

A konjunktúra éveit követő világgazdasági válság és a társadalmi bázis hiánya elsöpörte Primo de Rivera diktatúráját, s vele együtt a Bourbon monarchia intézményét is, amely az ország strukturális problémáit (államszerkezet, politikum, agrárium, hadsereg modernizációja) nem tudta megoldani. Ez az 1931 április 14-én kikiáltott második köztársaságra maradt. Az ország modernizációs késedelme egyrészt az egyház ideológiai és oktatási monopóliumában, a középkori mezőgazdasági szerkezet és technika fennmaradásában, a munkástömegek politikából kirekesztett és rossz szociális helyzetében, valamint a hadsereg bizonyos fokú törvényen felüliségében mutatkozott meg.

A köztársasági rendszer alapproblémája volt, hogy a republikánus párt által képviselt polgári liberális társadalmi átalakulás annak a közép és kispolgárságnak az érdekeit képviselte, melynek jelenléte a spanyol társadalomban igen csekély súlyú volt. Az óvatos agrárreform például sértette a hatalmat kezében tartó nagyarisztokrácia és finánctőke érdekeit, vi- 
szont igen kevésnek bizonyult a nincstelen agrártömegek számára. Megoldatlanok maradtak a világgazdasági válság következtében munkanélküliséggel sújtott munkásság problémái is. A II. Köztársaság leginkább a munkaügyi szabályozás terén zárkóztatta fel az országot a nyugat-európai modellhez ( 8 órás munkaidő az agrárszektorban is, beteg- és balesetbiztosítás, munkanélküli segély), és a szekularizált oktatás terén ért el nagy eredményeket (megközelítőleg tizenkét ezer új iskola építése, új szemlélet az oktatásban). A hadseregreform szintén korszerü és időszerü volt, ám hatalmas ellenfeleket szerzett a köztársaságnak a katonai kaszt konzervatív gondolkodású rétegeiben. Az 1931-es alkotmány megadta a polgári szabadságjogokat, eltörölte a nemesi kiváltságokat, lehetőséget teremtett az autonómiák megteremtésére, elválasztotta egymástól az egyházat és az államot, s lehetővé tette a polgári házasságot. A korszerüsítő intézkedések sokszor elsietett végrehajtása (a szükséges és jó oktatási reform során bezárták az egyházi iskolákat, mikor még nem nyitották meg a világi intézményeket) a hagyományosan mélyen katolikus szellemű társadalom egy részét, és az európai kontinens legkonzervatívabb - a reconquista, majd a zsidók és mórok kiüzésével megteremtett, állam és hit egységét hirdető - egyházát szembefordították a köztársasággal. Elkobozták az egyház vagyonát, a jezsuita rendet feloszlatták, betiltották a miséket, az egyházi temetéseket, az egyházi oktatást, szekularizálták a temetőket, s ezzel a türelmetlen egyházpolitikával nem találták meg a liberális és katolikus szellem összeegyeztetését lehetővé tevő középutat, mely szélsőségek közti békés utat jelenthette volna. A széles köztársasági tábor egy részének túl lassú, a másik részének túl radikális törvényhozás, a szélsőséges forradalmi vagy a visszarendeződést kívánó tendenciákat erősítette meg a centrum helyett. A polgári köztársasági kormány csendőrsége fellépett az anarchisták és a falangisták ellen is. Az 1933-35-ös jobboldali visszarendeződés kormányai visszavonták a megadott katalán autonómiát, az autonóm kormány börtönbe került, Asztúriában pedig a bányászok vívtak sikertelen háborút szerzett jogaik megtartásáért. 1936 februárjában népfrontkormány alakult, s a választási térkép alapján megállapítható, hogy ehhez leginkább az ország periférikus területei, Katalónia, Valencia, Baszkföld, Andalúzia szavazói járultak hozzá, az ország központi részének, Ó- és Új Kasztíliának, valamint Leónnak a földbirtokos arisztokrácia, az Egyház és a kacikák által ellenőrzött lakossága inkább a visszarendeződést támogatta.

A fokozódó anarchia és politikai gyilkosságok légkörében konzervatív katonatisztek lázadást robbantottak ki július 18-án Marokkóban, s ezzel nemcsak politikai, hanem katonai tekintetben is kettészakadt az ország, s megkezdődött a második világháború bevezető fejezetének tekintett spanyol polgárháború. A lázadók által képviselt ideológia az egyház és a 
hadsereg korporatív érdekeit (Isten és Haza) valamint a nagybirtokos arisztokrácia és a fináncoligarchia számára előnyös társadalmi berendezkedést védte, melyhez Hitler és Mussolini támogatását élvezte. A köztársasági oldal viszont Anglia és Franciaország be nem avatkozási politikája miatt csak a sztálini Szovjetuniótól kapott segítséget, ami amellett, hogy hadászati szempontból létfontosságú volt, kiélezte a „polgárháború a polgárháborúban” helyzetet. Az anarchisták, a katalán POUM, a trockisták, a radikális szocialisták úgy vélték, hogy a győzelemhez vezető út a társadalmi forradalmon át vezet, melynek elsőbbséget kell adni. A kommunisták és szovjet támogatóik szerint azonban előbb a háborút kell megnyerni, és csak utána jöhetnek a társadalmi reform kérdései. Míg a lázadók által ellenőrzött területeken a caudillo egy kézben összpontosította a katonai, gazdasági és politikai hatalmat, a köztársaság területein az ipar és a mezőgazdaság kollektivizálása, a különböző baloldali pártok egymás ellen harcoló, a központi kormányzatnak sem engedelmeskedő milíciái nem tették lehetővé a hatékony és egységes fellépést. Ramon Tamames szellemes megfogalmazásában „a Köztársaságot a monarchisták hozták el, és a republikánusok veszejtették el.”68 A Spanyolország megmentése érdekében a „marxista hordák” ellen keresztes hadjáratot folytató nemzetiek fegyvereit megáldotta az egyház, s a polgárháború első évében sikeresen megvalósult hatalomkoncentráció (Franco államfö, kormányfö, hadsereg parancsnok, s a FET y JONS nemzeti egységpárt vezetője) a béke éveiben sem látszott lazulni.

A polgárháború Franco tábornok és a nemzeti oldal győzelmével végződött 1939. április 1-én, s a köztársaság politikai berendezkedését a tábornok egyszemélyi diktatúrája váltotta fel. A teljhatalmú caudillo „csak Isten és a Történelem színe előtt tartozott felelősséggel”, s rendszerének három alappillérére - a hadsereg, a katolikus egyház és az időközben Movimiento Nacionalra keresztelt párt - támaszkodva vezette az országot. Az Una, Grande y Libre jelmondat jegyében felszámolta a köztársaság alatt életbe lépett autonómiákat. A megtorlás elől köztársaságpártiak százezrei menekültek emigrációba, az országban maradt legyőzöttek ellen pedig a béke idején is tovább folytatódott az egyház ideológiájával támogatott keresztes háború. Csak 1969-ben, vagyis 30 évvel a polgárháború befejezése után évültek el a háború alatt elkövetett „,bűntettek”. Így ítélte halálra a hadbíróság 1963-ban Julián Grimaut, az illegális kommunista mozgalom egyik vezetőjét, „folytatólagos katonai lázadás vádjával”, a polgárháború ideje alatt a hátországban elkövetett büncselekmények miatt. ${ }^{69}$ A katonai bíróságokat, melyek a Franco-rendszer alapvető tartozékaként működtek

\footnotetext{
${ }^{68}$ Ramón Tamames, La República, La era de Franco, Alianza Editorial Alfaguara, 1986, Madrid, 17. 0.

69 Risques, Manuel, „Dictadura i rebellió militar, 1936-1968”, in Sobrequés, Jaume (dir.), Les presons de Franco, Barcelona, Museu d’Història de Catalunya, 2004. 16. o.
} 
az állam bírósági szervei mellett, a Burgosi Nemzeti Védelmi Junta állította fel 1936. július 28-án. A közrend, azaz a Haza békéjének megzavarása kategóriájába esett minden, korábban állampolgári jognak számító gyülekezés, szervezkedés, sztrájk is, amiért a rendszer éveiben börtönbüntetés járt. A megtorlások mértékéről a történészek közt még ma is vita folyik, megközelítően 2-3 millió ember számít valamilyen módon érintettnek, s 1944-ben a spanyol igazságügyminiszter által hivatalosan közölt adat szerint körülbelül 195 ezerre tehető az 1939-44 között büntető intézményekben kivégzettek száma. ${ }^{70}$ Spanyolország nem volt hadviselő fél a II. világháborúban, de nem volt semleges sem, hiszen mikor Hitler megtámadta a Szovjetuniót, Franco a segítségére küldött egy hadosztályt (División Azul), hogy a kommunizmus elleni harcot támogassa, ugyanakkor a volt köztársasági sereg katonái közül több ezren harcoltak Franciaország felszabadításáért. ${ }^{71}$

A polgárháború után az ország romokban hevert, s a lakosság nagy részének nélkülözés és nyomor jutott osztályrészül egészen az ötvenes évekig. A caudillo gazdaságfilozófiája és az ország II. világháború utáni elszigetelődése folytán létrejött autarkiás gazdasági berendezkedés lassította a helyreállítást, és nem tette lehetővé a gazdasági fellendülést. A jegyrendszer (s vele együtt az estraperlo rendszere) 1952-ig érvényben maradt. Közben az állami intervencionizmus a nagytőke érdekeit képviselte, az erőltetett ütemü nehézipari fejlesztésbe fektetett állami tőke a fináncoligarchia pozícióit erősítette $\mathrm{s}$ a mezőgazdaság égető gondjai megoldatlanok maradtak. Ennek következtében az ötvenes években felgyorsult az elvándorlás, és a hatvanas-hetvenes évekre a vidék elnéptelenedése figyelhető meg.

Az ország lakosságát vertikális, hivatásrendi szakszervezetekbe tömörítették, melyek iparáganként egyesítették a vezetőket és a beosztottakat, s ebben az utópikusan ideális korporatív rendben a munkás érdeke nem állt szemben a tőkésével. Az ország fejlődésének lehetőségeit teljesen beszükítő autarkia a csőd szélére juttatta az országot, s ekkor Franco kénytelen volt teret engedni az Opus Dei technokratái által irányított gazdasági nyitásnak. 1959-ben új gazdasági új szabályozást vezettek be Stabilizációs Terv néven, lebontották a külföldi tőke beáramlását és a külföldi tulajdonlást korlátozó jogszabályokat, csökkent az állami beavatkozás és ellenőrzés mértéke, s elindult a gazdasági liberalizálódás. Ennek nyomán megvalósult a „spanyol gazdasági csoda”, s míg a politikai felszín változatlan maradt, az országban társadalmi, gazdasági és természetesen nemzedéki átalakulás zajlott. Franco

\footnotetext{
${ }^{70}$ Harsányi Iván, Franco in Ormos Mária - Harsányi Iván, Mussolini - Franco, Budapest, Pannonica, 2001. 266-270. o.

${ }^{71}$ Kb. Hétezer a francia hadseregben, s háromezer az idegenlégióban. L. Izquierdo, José María, Maquis: Guerrilla antifranquista https://www.uv.es/cerverab/Izquierdo.pdf, letöltés 2018. ápr. 18.
} 
csak 1967-ben a Ley Orgánica del Estado útján próbált jogállami külsőt kölcsönözni a diktatúrának, melyet organikus demokrácia névre keresztelt. Ekkor választották el egymástól az államföi és a kormányföi tisztet, ismerték el a vallásszabadságot ${ }^{72}, \mathrm{~s}$ az addig törvény felett álló fegyveres erőket is akkor foglalták bele az alaptörvénybe. A 70-es években a gazdasági válság és a nemzedéki váltás következtében erősödött az illegális ellenzéki tevékenység, melynek egyértelmű jele volt a sok diáklázadás és munkássztrájk. 1971-ben megalakult az Assemblea de Catalunya, a katalán nemzetgyülés civil szervezete, a II. Vatikáni Zsinat szellemében gondolkodó spanyol egyház pedig kiadott egy nem hivatalos nyilatkozatot, melyben bocsánatot kért, hogy a polgárháború után nem tudta az egykori ellenfelek közötti megbékélés ügyét szolgálni.

A Franco diktatúra a caudillo halálával ért véget 1975-ben, s a király nélküli monarchia két nappal a diktátor halála után, az ő végakaratának megfelelően, jelöltjének királlyá koronázásával, visszatért a királlyal rendelkező monarchiák sorába. Juan Carlos király 1976-ban az UCD politikusát, Adolfo Suárezt tette miniszterelnökké, ami által sikerült az átmenet folyamatát a politikai közép medrében tartani, és elkerülni a szélsőségek veszélyeit. Az Assemblea de Catalunya hatalmas tömeggyülései hármas jelszó: Llibertat, Amnistia, Estatut d’Autonomia alatt vonultak Barcelona utcáin 1976-ban és 1977-ben. A demokratikus átmenet éveiben a politikai élet szereplői a do ut des reálpolitikai elv jegyében kölcsönösen lemondtak az erőszakról (Moncloa paktumok), ami eredményeképp 1977-ben megszületett az Amnesztia Törvény, a gyülekezés szabadságát és a népszavazás intézményét garantáló törvény, valamint a Politikai Reform törvény, mely a Cortes önfeloszlatásával és az alaptörvények módosításával az átmenet jogfolytonosságát biztosította. Megnyíltak a börtönkapuk a politikai elítéltek előtt, de ugyanakkor kínzóik és rabtartóik is teljes büntetlenséget nyertek, s a két szembenálló politikai család leszármazottai, a polgárháborúban egykor egymással szembenálló két Spanyolország együtt építette a demokráciát. 1978. december 27-én megszületett az új spanyol alkotmány, mely kimondta a vallásszabadságot, egyház és állam szétválasztását, s elismerte a nemzetiségek és régiók autonómiáját. A katalán parlament már 1978. szeptember 28-án jóváhagyta és továbbította Madridba a Katalán Autonómia Statútumot, ennek ellenére az alkotmányozó atyák úgy döntöttek, hogy nem részesítik külön eljárásban a katalánokat, hanem a történelmi jogokkal és korábbi autonómiával rendelkező

\footnotetext{
${ }^{72}$ 1967-ben a Fuero de los Españoles módosítása során hirdették ki az 1967/44-es törvényt, mely lefektette az állampolgárok jogát a vallásszabadsághoz. Ez azonban nem jelentett toleranciát, a „confesiones disidentes” létét csak a privát szférában engedélyezte, a katolikus vallást, „mely a spanyol nemzet vallása” előbbre sorolta. www.elolivo.net/HISTORIA/Resena\%20historico-social\%20del\%20Protestantismo\%20EspanolBlazquez.pdf, letöltés 2017. dec. 2.
} 
baszkokkal és gallegókkal együtt, lehetővé tették számukra, hogy gyorsított eljárásban juthattak belső életüket szabályozó autonómia statútumhoz (café para todos).

A spanyol nemzet kortárs traumája, a polgárháború totális háború volt, mely kiterjedt az ország egészére, mert katonai, társadalmi, ideológiai, kulturális, vallási és etnikai vetületei révén nem volt senki, aki valamely fent említett közösséghez való tartozása révén kimaradt volna belőle. A demokratikus átmenet korszakában azonban mind törvényhozási, mind reálpolitikai szinten érinthetetlen kérdésnek számított, ami abban a történelmi pillanatban legbölcsebb megoldásnak látszott. A törvényileg elrendelt felejtés, az Amnesztia Törvény (1977), azonban nem jelentett morálisan kielégítő megoldást a polgárháború veszteseihez tartozó oldal számára, ezért 40 évvel később megszületett a Történelmi Emlékezet Törvénye (2007), mely igyekezett jogi eszközökkel rendezni a kérdést, mely ez által sem jutott nyugvópontra. 


\section{Jesús Moncada és Mequinensa}

\section{Az író és a kor}

Jesús Moncada véleménye szerint, egy író minden regényében a saját - s az övéi önéletrajzát írja meg, csak nem kronológiai sorrendben. ${ }^{1}$ Másutt pedig azt vallja, hogy „az író egész műve fikciós formában megírt önéletrajz”. ${ }^{2}$ Alejo Carpentier, a latin-amerikai próza nagymestere - akinek a Fény százada címü müve Moncada egyik kedvenc regénye - úgy tartja, hogy a regényíró szerepe az, hogy „meghatározza, rögzítse, bírálja, és megmutassa azt a világot, amelyben élnie adatott”. 3 Vagyis a regényeket bizonyos értelemben tekinthetjük korrajznak is, és ugyanez a helyzet az írók kronológiai sorrendben elbeszélt életútjával is, ami szintén egyfajta kultúr-korrajz, mely láttatni engedi, milyen tere nyílik, milyen szerepe van a társadalom közéletében egy alkotónak és müvének. Mivel a fikciós formában megírt közösségi életrajz, azaz a Mequinensa-mítosz ${ }^{4}$ Moncada bevallása szerint szorosan kötődik az írói életúthoz, ezért dolgozatom első fejezete az írói életpálya bemutatását foglalja magában. Erről Katalóniában még nem született összefoglaló munka, s csak e dolgozat írása közben jutott tudomásomra, hogy 2017 őszén megjelent az első, Jesús Moncada életútját összegző katalán monográfia. ${ }^{5}$

\subsection{Az író életútja}

Jesús Moncada 1941-ben, a polgárháború utáni korszak nélkülözéssel teli második esztendejében született az aragóniai régi Mequinensában - mely város 1971-től már csak a riba-rojai víztározó fenekén létezik -, a tartomány katalánul beszélő keleti övezetében. Az író szülővárosa, mint az a szerzővel készített interjúkból egyértelműen kiderül, a polgárhá-

\footnotetext{
${ }^{1}$ 1994-01-02 El Periódico - Mequinenza ya no existe y no volverá a existir, Miguel Á. „Az írás az te magad vagy, s az emlékeid mindig megjelennek az írásaidban [...]. Beleírod a saját világnézetedet, életszemléletedet, azt a világot, melyet megélned adatott."

2 2001-11-12 Avui - 20 anys de contes de Jesús Moncada, Ada Castells.

${ }^{3}$ Carpentier, Alejo, Irodalom és poltikai tudat Latin-Amerikában, Budapest, Gondolat, 1979.

4 1992-02-14 Diari de Barcelona - No m'interesso gens a mi mateix com a personatge, Carles Singla „Mint a kisvárosi-falusi közegben felnőtt emberek általában, én is ahhoz vagyok hozzászokva, hogy a közösség, nem pedig az individuum szempontjából tekintsek az életre [...] Mequinensa a gyerekkorom világa [...] az író már ott lakik benned gyermekként is, és lehetséges, hogy nem tesz mást, minthogy megírja az önéletrajzát.”

${ }^{5}$ Biosca i Llahí, Marc, Jesús Moncada, mosaic de vida, Lleida, Pagès Editors, 2017.
} 
ború veszteseihez tartozott, lévén republikánus és baloldali hagyományokkal rendelkező bányászváros. ${ }^{6}$

Ebben az aragóniai kisvárosban az emberek máig 95\%-ban katalán nyelvüek annak ellenére, hogy semmiféle anyanyelvi nyelvhasználati joggal nem rendelkeznek. Moncada anyanyelve ez a sajátos, eredeti tisztaságú, nyugati katalán dialektus. ${ }^{7}$ Ezen nőtt fel, ezen hallgatta a folyó mítikus lényeinek, a hajósoknak a történeteit, legendáit, humorral átitatott anekdotáit. Úgy emlékszik vissza magára, mint egy „kávéháztöltelékre”8, aki gyermekkorától fogva szeretett a vidéki társasági élet központjában, a kávéházban időzni, amely intézményt a kisváros tömegkommunikáció előtti agórájának, alapvető kulturális fórumának tartja. A történetmondói hagyomány folytatása feltételezi az alapvető hordozó, az anyanyelv használatát és megőrzését, ami Moncada számára a hitelesség kérdését veti fel. Erről így vall egy interjúban: „A világot a folyón, a folyó szavain át ismertem meg, mikor leírtam, le kellett fordítanom spanyolra, s az nem volt hiteles."9

A Franco korszakban a rendszer iskoláiban azonban egyszerüen csak xapurreo névvel illették a nyelvet, ami az ügyetlen, kevert, rossz beszéd jelölésére szolgál. ${ }^{10}$ A diákoknak tilos volt ezt a fejletlen, kultúrálatlan nyelvet alkalmazni egymás közt is. Jesús Moncada, aki a középiskolai tanulmányait Saragossában egy bentlakásos iskolában végezte, önkéntelenül lázadt a szabály ellen, és mequinensai társaival az osztálytermen kívül anyanyelvén beszélgetett. Arról azonban fogalma sem volt, hogy ez az anyanyelv létezik írott formában is, és európai mércével mérve is jelentős irodalmi hagyományokkal bír. Már tanítóként dolgozott a szülővárosában, amikor a hatvanas évek elején egy lleidai utazás alkalmával egy antikváriumban felfedezett egy polcnyi katalán könyvet, a Selecta kiadó műveit, köztük Paul Valéry verseinek katalán fordítását. ${ }^{11}$ A meglepetéstől szólni se tudott, nem értette, mit lát, a rendszer iskoláiban tanultak alapján, egy nem létező dologgal találta szembe magát. ${ }^{12}$ Pedig Moncada különleges iskolákba járt.

\footnotetext{
${ }^{6}$ 2005-06-25 La Vanguardia - Jesús Moncada, Oriol Pi de Cabanyes; 2004-02-01 l'Avenç - La memoria d'un món negat, Josep M. Muñoz.

${ }^{7}$ 2001-11-12 Avui - 20 anys de contes de Jesús Moncada, Ada Castells.

8 1988-06-01 Llibrería 122 (Gremi de 1libreters) - Entrevista a Jesús Moncada, alquimista del temps, Joan Peña.

${ }^{9}$ 1989-10-22 El Día de Aragón - Ficción y leyenda de una ciudad sumergida, Anton Castro.

${ }^{10}$ Muñoz, Josep M. „La memòria d’un món negat”, in Acín, Ramón (dir.), Jesús Moncada, Su universo literario, Gobierno de Aragón, Ayuntamiento de Mequinenza, Zaragoza, 2005. 47-61. o.

${ }^{11}$ Moret, Xavier, „Jesús Moncada, La passió per escriure”, in Retrats, Associació d'Escriptors en Llengua Catalana, Barcelona, 2005.

${ }^{12}$ TVE SA. Barcelona 1992 Literal címü irodalmi müsorában Raimon, a népszerü dalszerző és énekes, a középkori valenciai irodalom megzenésítője, a demokrácia és a szabadság jegyében a 60-as években megszólaló katalanista művészeti mozgalom, a Nova Cançó emblematikus alakja, ugyanerről a tökéletes
} 
Az érettségi első két évére (1950-51; 1951-52) Mequinensában készült magántanulóként, több társával együtt egy volt republikánus tanító felkészítésével, aki a Francorendszer iskoláiban nem taníthatott ${ }^{13}$, de akinek a városka mégis munkát adott, s akiről az író nagy tisztelettel emlékezik meg az idézett interjúban. A vizsgákat a Mequinensához legközelebb eső provinciaszékhelyen, Lleidában kellett letenniük. A felsőbb gimnáziumi tanulmányok kérdésében azonban a meggyőződéses republikánus és baloldali érzelmű apa, José Moncada Moncada úgy döntött, hogy a katalán püspöki székhely, Lleida helyett, ahol csak egyházi intézmények kínáltak továbbtanulási lehetőséget, a jó eszű gyereket a jóval távolabbi Saragossába küldi, egy akkoriban igen ritka, laikus, nyitott és liberális szellemü középiskolába. Ennek az iskolának az igazgatója a híres szürrealista költő, Miguel Labordeta $^{14}$, akinek testvére is itt tanított, a költő-dalszerző, Juan Antonio Labordeta ${ }^{15}$, aki később a demokratikus Spanyolország parlamentjének aragón nemzeti képviselője lesz. A költő-tanár, aki szerette tehetséges tanítványát, el is látogatott Mequinensába a Moncada családhoz, és egy iskolai pályázat alkalmával, irodalmi díjjal tüntette ki (ajándékkönyv Santiago Ramón y Cajal, Memorias. Mi infancia y juventud) egy mequinensai legendát spanyolul feldolgozó elbeszélése jutalmául. A Labordeta család által müködtetett Buen Pastor utcai iskolában nem volt kápolna, a diákok a San Cayetano templomba jártak misére, amely az egész város legrövidebb miséje volt. ${ }^{16} \mathrm{Ez}$ az iskola egy nyitott szellemiségü, különleges kis sziget volt a Franco korszak szürke, indoktrinációs módszerekkel ideológiát sulykoló intézményei között. Jesús Moncada büszke volt rá, hogy a Colegio Santo Tomasba járt, mert megmenekült attól, hogy rátelepedjen a kor néhány komplexusa, és mert irodalmi érdeklődése kiteljesedhetett egy olyan korszakban, amelyben az emberek nem olvastak. ${ }^{17}$ Aztán, mivel a család nem engedhette meg magának, hogy egyetemi tanulmányokat finanszírozzon, Jesús Moncada a Saragossai Tanítóképzőt végezte el az érettségi utolsó két évével párhuzamosan.

tudatlanságról számol be, s jelzi, hogy ő első éves történelem szakos egyetemista korában találkozott elöször katalán nyelvü irodalmi alkotással.

${ }^{13}$ 1988-02-01 Resso de Ponent - Guardeu-vos de caure en mans de periodistes afeccionades, Mercè Biosca.

14 Miquel Labordeta Subías (Zaragoza, 1921-Zaragoza, 1969) http://www.enciclopedia-aragonesa.com/ voz.asp?voz id=7561, letöltés 2017. máj. 15. L. melléklet Lexikon 1.

${ }_{15}$ Juan Antonio Labordeta Subías (Zaragoza, 1935-Zaragoza, 2010) http://www.enciclopedia-aragonesa.com/ voz.asp?voz_id=7559, letöltés 2017. máj. 17. L. melléklet Lexikon 2.

${ }^{16}$ Amikor Moncada Saragossában bemutatta A folyók városa spanyol fordítását (Camino de sirga, Barcelona, Anagrama, 1989; és 2. kiadás Zaragoza, Heraldo de Aragón, 2010.), egy idős úr a közönségböl megkérdezte tőle, hogy hova járt iskolába, $\mathrm{s}$ a válasz hallatán rémülten felkiáltott „B... ! A vörösökhöz!” L. 2004-02-01 l'Avenç - La memòria d'un món negat, Josep M. Muñoz.

${ }^{17}$ 1988-02-01 Resso de Ponent - Guardeu-vos de caure en mans de periodistes afeccionades, Mercè Biosca; 1991-12-06 La Vanguardia - Jesús Moncada crea un nuevo universo literario en La Galeria de les estàtues, Mario Sasot; 1997-10-01 Regió7 - Sempre he estat un narrador nat - Drama i ironia, Josep Gras. 
1953 és 1958 között folytatott tanulmányai befejeztével hazatért Mequinensába. Kérvényezte, hogy elfoglalhassa a betöltetlen tanítói állást, de nem kapta meg hozzá az engedélyt, mivel még nem töltötte be a tizennyolcadik életévét, a munkát azonban elvégezhette, mint kisegítő munkaerő, kevesebb fizetésért. ${ }^{18}$ A katonai szolgálat éveit szintén Saragossában töltötte a légvédelmi alakulatnál, s mikor leszerelt, újra visszatért Mequinensába tanítani. ${ }^{19}$ Ekkor ismerkedett meg egy ebrói hajókiránduláson a szintén mequinensai születésű történész, újságíró és fordító, Edmond Vallès-szel ${ }^{20}$ is, aki Barcelonából gyakran hazajárt látogatóba Mequinensába. Ö biztatta Jesús Moncadát arra, hogy írjon katalánul, amit az ifjú akkor még hitetlenkedve hallgatott. Számára, mint nemzedékének sok más írója és költője számára, akik Spanyolországnak azon a részein nőttek fel, ahol nem a spanyol nyelv volt a lakosság anyanyelve, ez kivitelezhetetlen vállalkozásnak tünt.

A Moncada családnak, mint az interjúkból tudjuk, sok könyve volt, olvasott az apa és az anya is, míg a nagymamák írástudatlanok voltak. Jesús Moncada egy Franciaországban élő unokatestvére, mikor már hazajárhatott Mequinensába nyaralni, francia nyelvü könyveket, főként irodalmi alkotásokat vitt ajándékba Moncadának, aki így olvasta elöször Albert Camus, Pestis címủ könyvét, vagy Sartre müveit. ${ }^{21}$ Edmon Vallès szintén könyveket küldött neki, a Vergara kiadó Isard sorozatából, amit talán a „Világkönyvtár Katalánul” névvel lehetne legjobban jellemezni. ${ }^{22}$ Ennek a sorozatnak érdeme és jelentősége, hogy a világirodalom nagyjainak katalánul való megszólaltatása által bizonyította a nyelv egyenrangúságát a spanyollal, a magaskultúra addigi egyedüli közvetítőjével, emelve ezáltal a katalán presztízsét.

Az ifjú tanár közben igyekezett összegyüjteni és lejegyezni a már épülő víztározók fenyegetésének árnyékában azt, ami a régi várost, a régi életmódot, az ő gyermek és ifjú korának Mequinensáját jellemezte. Tizennégy éves volt, amikor elkezdtek szállingózni a

\footnotetext{
${ }^{18}$ Maria Estruga, Jesús Moncada édesanyja úgy emlékszik vissza a tanítójára, mint aki katalánul beszélt hozzájuk az iskolában. L. Quintana, Artur (dir.), Epistolari de Desideri Lombarte (1981-89), Calaceit, Lo Trill (8), Associació Cultural de Matarranya, 2002. 86. o. Moncada egyik volt tanítványa, Andrés Coso visszaemlékezése szerint Moncada a 60-as évek elején a tanteremben kizárólag csak spanyolul szólalt meg, de az iskolán kívül katalánul beszélt a gyerekekkel. Ebböl arra következtethetünk, hogy a Franco diktatúra a korábbi rendszereknél szigorúbban szabályozta a nyelvhasználat kérdését.

${ }^{19}$ A saragossai kamasz és ifjúkori emlékek a Galeria de les Estatues (1992) alapanyagát szolgáltatták.

${ }^{20}$ Edmon Vallès i Perdrix (Mequinensa, 1920-Barcelona, 1980). L. melléklet Lexikon 3. http://www.mequinenza.com/eminencia/Edmon\%20Vall\%C3\%A9s, letöltés 2017. máj. 15. L. még 1999-0502 El Periódico - La realidad es muy literaria, Antón Castro.

${ }^{21}$ 2004-02-01 l'Avenç - La memòria d'un món negat, Josep M. Muñoz.

${ }^{22}$ Edmon Vallès maga is dolgozott a Vergara Kiadónak és fordított is ebben a világirodalom modern klasszikusait (Greene, Orwell, Exupéry, Camus, stb.) katalánra átültető sorozatban, amely „elkényeztette a fordítókat” (Joan Fuster, Joan Vinyes, stb.). L. https://negritasycursivas.wordpress.com/2014/10/17/lacoleccion-quemimaba-a-los-traductores-isard-1962-1971/, letöltés 2017. máj. 14.
} 
víztározók építésével kapcsolatos első hírek ${ }^{23}$, tizenhat, amikor 1957 farsangján - mint azt A folyók városa is megörökíti - az ENHER (Empresa Nacional Hidroeléctrica del Ribagorzana) munkásai megkezdték a munkálatokat, s tizenhét, amikor elkezdett tanítani a városban. Sok adatot rögzített az öregek emlékezetén keresztül a városról, annak szokásairól, iparáról, kereskedelméről, társadalmi életéről ünnepeiről és közszájon forgó történeteiről. A Moncada hagyaték dokumentumai közt több olyan feljegyzést találtam, amelyben hajóácsok, bányászok, hajóskapitányok életét, mesterségük fogásait és az azzal kapcsolatos szókincset örökíti meg. ${ }^{24}$ Mint a bevezetőben az író ethoszával kapcsolatban idézett mondat jelzi, az emlékek összegyüjtésére a közelgő pusztulás víziója ösztönözte, mert érezte, hogy gyerekkora hőseinek világa eltünőfélben van. A lignit helyett a tisztább, olcsóbb gáz és olaj, az élő víz útja helyett a tározókba gyüjtött víz által termelt energia kapott elsőbbséget. A bányákat a tulajdonosok eladták, egyik a másik után zárt be, a folyók hajózhatóságának lehetősége pedig a riba-rojai tározó megépítésével végleg megszünt a torkolat felé is.

Edmon Vallès hívására, aki szerint Mequinensában lehetetlen kibontakoztatni az ifjú írói és festői tehetségét, Jesús Moncada 1966 szeptemberében Barcelonába költözött. Ott először festőként próbálta megkeresni a kenyerét, társulva egy rokonához, a barcelonai hangulatokat sikerrel megörökítő Santiago Estrugához. Bevételeiből alig tudta fenntartani magát, s az éhhalál küszöbén ${ }^{25}$, Edmon Vallès beajánlotta a Montaner y Simón Kiadóhoz. ${ }^{26}$ Ezt a patinás kiadóvállalatot, az ország egyik legkorábbi (1861) alapítású könyvkiadóját, 1952-ben vásárolta meg a mexikói UTEHA ${ }^{27}$ legendás alapítója, González Porto (1895-1975). Amikor Jesús Moncada ismeretlen vidéki ifjúként a vállalathoz került, nagy szerencséjére Pere Calders ${ }^{28}$ keze alatt kezdett dolgozni, aki a katalán irodalom már polgárháború előtt is alkotó nemzedékének jelentős írója volt, és 1962-ben tért vissza Barcelonába mexikói száműze-

\footnotetext{
${ }^{23}$ 2005-06-16 El País (Quadern) - Última sirga, Homenatge a Jesús Moncada: Afluents, Agustí Fancelli; Un paseig per Mequinensa, Xavier Moret.

${ }^{24}$ Interjú az öreg Raiettel (1889), Interjú Joaquim Patriciet bácsival (1892), Interjú az „Admirálissal” (1899. nov. 31.), Interjú Garinnal (1920), Interjú Quicóval stb.) A szintén ezen írások között talált, Cronica del tio Rayet címet viselö írás egy spanyol nyelvü elbeszélés, mely az öreg alakját örökíti meg, s mutatja, azt az interjúk során is többször említett tényt, hogy Moncada elöször spanyolul kezdett írni.

${ }^{25}$ Ezt ironikus hangvételü, önéletrajzi ihletésü regénye, a barcelonai éveket feldolgozó, töredékes Dante S.A. örökíti meg. L. még 1994-01-02 El Periódico - Mequinenza ya no existe y no volverá a existir, Miguel Á Royo.

${ }^{26}$ Montaner y Simón Kiadóvállalat https://www.fundaciotapies.org/site/spip.php?rubrique969, letöltés 2017. máj. 10. L. melléklet Lexikon 4.

${ }^{27}$ Unión Tipográfica Editorial Hispano América Kiadó. L. melléklet Lexikon 5. https://negritasycursivas. wordpress.com/2017/04/14/gonzalez-porto-y-la-edicion-culturalmente-ambiciosa/, letöltés 2017. máj. 14.

${ }^{28}$ Pere Calders (Barcelona, 1912-Barcelona, 1994) katalán író, grafikus. L. melléklet Lexikon 6. http://www.escriptors.cat/autors/caldersp/pagina.php?id_sec=491, letöltés 2017. máj. 12.
} 
téséből. González Porto rábízta a Montaner y Simón irodalmi osztályát, melynek dolgozóit a kiadó munkatársai csak úgy nevezték „los catalanes”. Az ifjú Moncada itt ismerkedett meg kora jeles katalán értelmiségi elitjének íróival. Köztük volt Xavier Benguerel, Felix Cucurull, Avellí Artis Gener „Tísner”, akiknek, mint Calders baráti köréhez tartozó személyeknek, bejárásuk volt az osztályra. ${ }^{29}$ Itt dolgozott Josep Soler i Vidal ${ }^{30}$, a Katalán Kommunista Párt egyik alapítója is, aki szintén a mexikói emigrációhoz tartozott, s akinek alakját Moncada az Història d’un jersey gris (Egy szürke pulóver története) ${ }^{31}$ címü elbeszélésében örökíti meg, s aki szintén élénk kapcsolatot ápolt a mexikói emigrációból hazatértekkel. Moncada ebben a közegben ismerte meg az emigráció világát, amit a saját családja körében - bár ott is voltak emigrációba kényszerültek - sürü csönd övezett. ${ }^{32}$ Calders, akit Edmon Vallès tájékoztatott az ifjú irodalmi ambícióiról, megkérte, hogy mutasson neki valamit az írásai közül. Ekkor, 1971-ben írta a Fejcsere (Jocs de caps) című elbeszélést ${ }^{33}$, három hónapnyi kemény munkával, mert addig katalán nyelven még nem próbálkozott papírra vetni semmit. Caldersnak nagyon tetszett a kis írás, folytatásra biztatta az ifjút, és beavatta a katalán helyesírás rejtelmeibe. Munka után mindennap a barcelonai Atheneumban írtak, és beszélgettek. Moncada a mesterének tekintette Calderst, ami első elbeszélés kötetének stílusán érződik is. Bár két teljesen eltérö közegből érkeztek (barcelonai polgári értelmiségi és vidéki munkásváros kiskereskedői család), ironikus látásmódjuk és az abszurd iránti érzékenységük rokonítja írásaikat. Pere Calders nemcsak az írás folytatásra ösztökélte Moncadát, hanem arra is, hogy örizze meg az Ebro-vidéki nyelv sajátos zamatát, kifejezéseit, fordulatait. ${ }^{34}$ Az irodalmi díjakon túl az első kézzelfogható eredmény az 1981-ben megjelent Balkézről jött történetek (Històries de la mà esquerra) című elbeszéléskötet, amelyhez Pere Calders írt előszót. Ebben az általa nagyra tartott tanítványt a katalán irodalom igen jelentős, és személyes hangú alkotójaként mutatja be, akinek írásművészete igen távol áll a népies, hagyományőrző, romantikus, s a kiveszőfélben levő ízes, dialektális fordulatok megörökítésére törekvő irodalomtól. „Ö teljes tudatossággal törekszik az ország, a nyelv, a történelmi

\footnotetext{
${ }^{29}$ 1996-06-01 Serra d'Or - Jesús Moncada novellar l'absència, Marta Nadal.

30 Josep Soler i Vidal (Barcelona, 1908-Gavà, 1999) L. melléklet Lexikon 7. http://irla.cat/wp-content/ uploads/2015/11/homenatge_josep_soler.pdf, letöltés 2017. máj. 11.

${ }^{31}$ Moncada, Jesús, „Història d’un jersey gris”, in Cabòries estivals, Calaceit-Fraga, Quaderns de les Cadolles, 2003. L. melléklet Lexikon 7.

32 1992-02-24 El Temps - Moncada contraataca, Assumpció Maresma.

33 Jesús Moncada, Balkézröl jött történetek, Budapest, l’Harmattan, 2012. 5-13. o.

${ }^{34}$ MCSL Pere Calders levele 1983. nov. 10. „Igen figyelemreméltó nyelvi gazdagsággal rendelkeztél, amikor kezdted az írást, de azt még tovább fejlesztetted, és úgy gondolom, sikerült megtalálnod a megfelelő arányt, ahol a (nyelvet oly gazdaggá tévő) dialektális fordulatok összhangban vannak a más területről származó olvasók érthetőség iránti igényével. Ezt elérni sokkal nagyobb munka, mint az ember gondolná, s te nagyszerü megoldást dolgoztál ki.”
} 
korszakfordulók, és az általuk megsebzett emberek ábrázolására.” ${ }^{35}$ Az irodalmi nyelv alatti xapurreo, a kezdetleges, barbár dadogás helyes ortográfiával, normatív rendbe szedve nézett vissza a papírról alkotójára, aki úgy érezte, hogy az eredmény sokszorosan kárpótolja a három hónapnyi irodalmi túlóráért. „Végre saját szavaimat láttam, és nem kellett egy idegen nyelvi kódexet használnom ahhoz, hogy írjak.” ${ }^{36}$ Korábban „hiányzott a gyengéd, bensőséges kötődés a munkaeszközömhöz... véglegesen eldőlt a sorsom, mikor kiderült, hogy lehetséges az anyanyelvemen írni.”37 Az ecset és a toll közti választás tehát annak hatására született meg, hogy a nyelvi emlékezet és az írói képzelet alkotta képek mondatokba rendeződve rajzolhatták ki a hiteles történeteket, míg a saját anyanyelvi közeg irodalmi regiszterének megtalálása előtt ezek a képek festmények formájában születtek meg. ${ }^{38}$

A kritika gyakran kiemeli a szerző azon érdemét, hogy bár egy Isten háta mögötti, ismeretlen hely ábrázolására vállalkozott, mégsem esik a folklorizmus és a lokalizmus csapdájába. Sok kifejezést, fordulatot, frazeologizmust használ, amelyek a nyugati katalánban és annak is a mequinensai változatában élnek, de sosem a nyomtatás általi megőrzés vágyától indíttatva, hanem tökéletes stílusérzékkel úgy kontextusba helyezve, hogy azt az olvasó megérti és örömét leli egy általa addig ismeretlen nyelvi kincstár felfedezésében. ${ }^{39}$ Amikor egy riporter az általa alkalmazott gazdag szókinccsel kapcsolatban faggatja, s lelkesen megvallja, hogy könyvei olvastán az az érzése, hogy a katalánok nem ismerik eléggé a nyelvüket, Jesús Moncada szerényen csak annyit mond, hogy neki sosem volt célja nyelvészeti ásatásokat végezni vagy valamiféle archaikus katalánt a holtaiból feltámasztani, s nem az ő hibája, hogy Mequinensában még használják ezeket a kifejezéseket. ${ }^{40}$

Az író életműve kitüntetések hosszú sorát nyerte el. Ezek közül az első négy pályázati sikert jelez: Brugués (1970), Joan Santamaria (1971), Crida dels escriptors joves de la revista Serra d’Or (1971), valamint a Jacme March (1980). Miután e sikerek nyomán Moncada talált magának kiadót, a Magranát (Històries de la mà esquerra, 1981), többé nem adta be müveit pályázatokra, minden további, általa elnyert díj a már kiadott műveknek

\footnotetext{
${ }^{35}$ Calders, Pere, Pròleg, Jesús Moncada, Històries de la mà esquerra, Barcelona, Edicions 62, 2004. 8. 0.

${ }^{36}$ Xavier Moret, Jesús Moncada, La passió per escriure, Retrats, Barcelona, Associació d’Escriptors en Llengua Catalana, 2005. 23. o.

${ }^{37}$ Biosca, Mercè, „El riu de la memòria”, in Acín, Ramón (dir.), Jesús Moncada, Su universo literario, Zaragoza, Gobierno de Aragón, Ayuntamiento de Mequinenza, 2005. 27-39. o.

${ }^{38}$ Ezzel a döntéssel, úgy vélem, a katalán irodalom nagyon nagyot nyert, a katalán képzőművészet viszont nem veszített olyan sokat. Moncada festményei egy sajátos, Dalí stílusára emlékeztető Ebro-parti univerzumot ábrázolnak. Ebben a gyötrődések és félelmek sokkal nagyobb súllyal vannak jelen, mint a humor, mely inkább a kisgrafikai ábrázolásait és karikatúráit jellemzi. A regényekben viszont valóban létrejön a Moncada-féle „,totális regény”, egy csakis rá jellemző, különböző idődimenziókat és látásmódokat ötvöző egyedi stílusban.

${ }^{39}$ Estanislau Vidal-Folch, „Ocupeu una cadira al Cafè de la Granota”, El País, 1985. március 26. 4. o.

${ }^{40}$ Capital Humà TVE2 http://www.jesusmoncada.cat/?page_id=155, letöltés 2017. máj. 22.
} 
szólt. Az 1988-ban megjelent A folyók városa hatalmas sikert aratott mind a kritika, mind a közönség körében, az addig szűk körben ismert író müvéröl egy csapásra úgy kezdtek beszélni, mint az utóbbi tíz, húsz vagy akár negyven év katalán irodalmának legjobb művéről. ${ }^{41}$ A regény elnyerte a Barcelonai Atheneu által alapított Joan Crexells (1988) díjat, a Premi Lletres de la Fundació d'Amics de les Arts i de les Lletres de Sabadell díjat (1988), a Premi Nacional de la Crítica (1988) díjat, melyet a legjobb nem spanyol nyelvű spanyolországi mü kaphat, a rangos irodalmi, kritikai folyóirat, a Serra d’Or (1989) kritikai nagydíját, a Barcelona város által adományozott irodalmi díjat (1989), és döntőbe jutott a Premio Nacional de Literatura, a Spanyol Kulturális Minisztérium által az esztendő legjobb könyvének ajándékozható díj 1989-es versenyében, melyet végül Bernardo Atxaga (1951) Obabakoak címü, baszk nyelven írott novelláskötete nyert el. Az Estremida memòria címü regénnyel másodszorra is elnyerte a Joan Crexells Díjat (1997) és a Serra d’Or Kritikai Nagydíját (1998), valamint az Humbert Torres díjat. Pályatársai és írótársai neki ajándékozták először a 2001-ben alapított Premi Jaume Fuster dels Escriptors en Llengua Catalana díjat, melyet később a Premi dels Escriptors Catalans (Katalán Írók Díja) névre kereszteltek. Ugyanebben az évben kapott díjat Aragóniában és Katalóniában is, a Generalitat de Catalunya Szent György Kereszttel, Saragossa provincia pedig Santa Isabel de Portugal Éremmel tüntette ki. Végül pedig, 2004-ben az Aragón tartományi gyűlés Jesús Moncadának ítélte a Premio de Honor de las Letras Aragonesast, vagyis az Aragón Irodalmi Nagydíjat, melyet személyében először, s mindezidáig utoljára kapott katalán nyelven alkotó szerző. Közben tönkrement a Montaner y Simón Kiadó (1981), Jesús Moncada egy rövid ideig dolgozott a La Gran Enciclopèdia Catalana szerkesztőségében, majd műveinek kiadójánál a Magrana Kiadónál, mint francia müfordító. ${ }^{42}$ Ezzel a maga számára engedélyezett egyetlen pénzszerző tevékenységgel, mint mondta, időt vásárolt magának az íráshoz, mert a katalán irodalomban csak nagyon keveseknek jutott és jut osztályrészül az a luxus, hogy kizárólag irodalmi tevékenységből éljenek. Jesús Moncada ezt már befutott íróként, $A$ folyók városa 125000 eladott példányszámával is csak időről időre tudta megtenni.

Mủveit a világ 21 nyelvére fordították le, és Mercè Rodoreda, a legismertebb (27 nyelvre lefordított) katalán regény a Diamant tér szerzője után Jesús Moncada a legtöbb nyelvre lefordított katalán szerző. A Franja de Ponent területéről Jesús Moncada az első katalán

\footnotetext{
${ }^{41}$ 1988-03-29 Diari de Barcelona - Mequinensa al costat de les grans obres. Camí de sirga, Pere Marcet; 1988-06-01 Llibrería 122 - Entrevista a Jesús Moncada, alquimista del temps, Joan Peña; 1993-04-23 El País - Entrevista y fotos, Xavier Moret.

${ }^{42}$ Mủfordítóként ő jegyzi például Jules Verne regényeit, és Alexandre Dumas, Monte Cristo grófját.
} 
nyelven alkotó író. A róla szóló cikkek és tudósítások, s még a kortárs irodalomtörténet is kiemeli, hogy „Rendkívül maximalista [...], csakis az irodalmi alkotómunkának él. Ezt a tevékenységet nem hajlandó mással ötvözni, csak a fordítással, viszont ugyanakkor lemondott arról, hogy szerepet vállaljon a tömegkommunikációban, a média világában, ami általánosan gyakorolt kiegészítő tevékenység a katalán írók esetében."43 Moncada tudta, s többször hangoztatta is, hogy írni, egyféle szolgálat az országnak (értsd Katalóniának), s ezzel az indoklással maradt távol civil kezdeményezésektől, közvetlen politikai vagy közéleti megmozdulásoktól, melyekbe be akarták volna vonni. ${ }^{44}$ A cikkek tanúsága alapján mind a

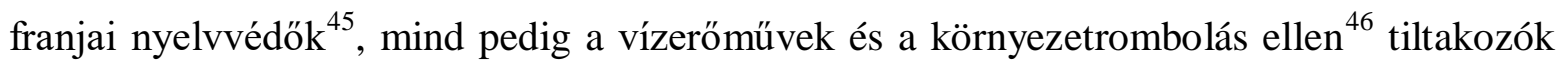
is a zászlajukra tűzték Moncadát, idézték, és érvelésük alapjává tették szavait.

A Moncada hagyatékban több levelet is találtam Jordi Pujol katalán kormányfő tollából, melyekben gratulál az írónak, méltatja $A$ folyók városa sikerét ${ }^{47}$, vagy kondoleál Maria Estrugának, az édesanyának ${ }^{48}$ Moncada halálakor. Az író húga említette azt is, hogy a katalán kormány vezetője (1980-2003) ajánlott Jesús Moncadának egy szerződést, melynek értelmében anyagi támogatás fejében egy évig csak az írásnak szentelhette volna az idejét. Ezt a hipotetikus szerződést azonban Moncada nem fogadta el, mert nem akart határidőre írni, a saját tempójában akart dolgozni, s megadni a müveknek a megszületésükhöz szükséges időt, még ha ennek anyagi fedezetét nem is volt könnyü fordításból előteremteni. A családi levéltár egyik dokumentuma arról is tanúskodik, hogy a Svéd Akadémia kérésére a katalán kormány Moncada müveit is elküldte a Nobel Könyvtárba. ${ }^{49}$ A cikkgyüjteményből az derül ki, hogy a Nobel-bizottság spanyol irodalomért felelös irodalomkritikusa, A folyók

\footnotetext{
${ }^{43}$ Carbó, Ferran - Simbor, Vicent, Literatura catalana del siglo XX., Madrid, Sintesis, 2005. 277-280. o.

${ }^{44}$ Sistac, Ramon, „Territori, llengua i identitat en l'obra de Jesús Moncada”, in Moret, Hèctor (dir.), Cròniques de la cerç i la garbinada, Recepció i projecció de l'obra de Jesús Moncada, Lleida, Pagès, 2006. 64-69. o.

${ }^{45}$ 2005-07-01 Temps de Franja - A reveure, Jesús, Mario Sasot; 1989-10-26 La Comarca - Camí de sirga. La recreació d'un món amb nom propi, Hèctor Moret; 1995-12-24 Heraldo de Aragón - El fin de la Mequinenza vieja me afectó mucho, Genoveva Crespo. A riporternő azt kérdezi, miért nem írta alá a dokumentumot, mely a katalán hivatalossá tételét követeli Aragónia katalánul beszélő részén. Moncada válasza: „Én hozzáteszem, amit tudok azzal, hogy katalánul írom a könyveimet.”

${ }^{46}$ MCSL Vicién Mañé, Enrique, „Astérix en Mequinenza, Jesús Moncada, un aragonés que escribe en catalán”, Trébede Itt elmondja, hogy meghívták egy televíziós műsorba és felkérték cikkírásra is a Rialbivíztározó kapcsán, de ő visszautasította, mert nem áll szándékában semmilyen ügy bajnokává válni.

${ }^{47}$ Ezt újságcikkek is hangoztatták, Jordi Pujol a Frankfurti könyvvásáron A folyók városa érdemeit ecseteli, vagy a Camí de sirga gallego fordítását ajándékozza az 1999-es Katalán Könyvnapokon 1991-11-25 El Temps - Jesús Moncada ja té títol per a la seva pròxima novella; 1999-05-02 El Periódico - La realidad es muy literaria, Antón Castro.

${ }^{48}$ MCSL 2005 június 14. Jordi Pujol magánlevélben kondoleál Jesús Moncada édesanyjának: „Ön szeretett fiát veszítette el, mi katalánok pedig elveszítettük az utóbbi évtizedek egyik kétségkívül legkiválóbb, legnagyszerübb katalán nyelvü íróját [...] müvei közül kiváltképp a híres A folyók városa tett rám nagy hatást”.

49 1989. május 5-én Oriol Pi de Cabanyes az Institució de les Lletres Catalanes nevében értesíti az írót, hogy A folyók városa címü regénye az elküldött müvek között van.
} 
városát katalánból svédre fordító, Kjell Johansson komoly esélyesnek tartotta az írót a Svéd Akadémia díjára. Ezt a korabeli katalán sajtó büszkén hangoztatta ${ }^{50}$, sőt találtam olyan cikket is, mely a következőképp fogalmaz: ,,a katalán kultúra számára a nemzetközi elismertséghez oly szükséges a Nobel-díj, mint a mindennapi betevő falat [...] s Jesús Moncada a díj egyik várományosa.” ${ }^{51}$. Ezeknek a cikkeknek a tükrében érthetőbb a felajánlás, melyet Generalitat feje tett az író felé, hiszen a katalán nacionalista kormányfő véleménye szerint „Katalónia esete különleges: megvan a saját nyelvünk és kultúránk, nemzetet alkotunk állam nélkül...”52, amit egy kivételes minőségü, nemzetközi jelentőségű irodalmi alkotás ékesen bizonyíthatna. A Franco korszakban szocializálódott nacionalisták számára óriási presztízsértékkel bírt az irodalom, hiszen abban látták nyelvük és kultúrájuk átmentésének zálogát. Ennek az irodalomnak, az „átmentett szavaknak” nemzetközi elismertsége pedig a nemzetek közti virtuális térben való honfoglalással egyenértékű eredmény.

Óriási várakozás előzte meg tehát mind a kiadó, a kritika, az olvasóközönség és a politika részéről is a Dante S.A. című regényt, melynek színhelye Barcelona, amit Jesús Moncada a Montaner y Simón Kiadó történetén keresztül kívánt bemutatni. ${ }^{53}$ 2005-ben bekövetkezett, korai halála azonban nem adott elég időt arra, hogy megszülessen a város, a katalán irodalom, és a kiadói világ történetét különböző szereplök emlékeiből összefüző regény. Ez a téma 2000 után vált elmesélhető múlttá, akkorra érett írói témává, mikor Jesús Moncada már majd negyven éve Barcelona polgára volt. Jan Assmann A kulturális emlékezet címü könyvében sajátos jelentőséget tulajdonít a negyven évnyi időtartamnak. Szerinte ez az a kritikus idő, amelynek elteltével egy bizonyos korszakot, eseményt felnőtt fejjel megélő nemzedék kiválik a jövőre irányuló létből, elkezd hátratekinteni, emlékezni, s emlékeit szeretné rögzíteni, továbbadni. ${ }^{54} \mathrm{Az}$ emlékek érését biztosító, majd negyven barcelonai év után Moncadának arra már nem adatott elég idő, hogy emlékeit regénybe írja.

\footnotetext{
50 1995-12-05 La Vanguardia - Para ganar el Nobel mejor no ir a Estocolmo, Margarita Rivière; 1995-12-18 El Temps - Jesús Moncada, Ramón Barnils; 1998-12-25 El Punt - El nom i el personatge no tenen res a veure, Carina Filella; 1999-09-29 El Triangle - Moncada, ara en castellá; 2001-11-12 El Triangle - El mèrit del contista.

${ }^{51}$ 1998-11-19 Segre - Pura dinamita, Vidal Vidal

${ }^{52}$ Castells, Manuel, Az identitás hatalma, Budapest, Gondolat Kiadó, 2005. 74. o.

${ }^{53}$ A kiadó egykori székháza ma is áll Barcelonában az Eixample-n, bejárata felett Dante Alighieri arcképének dombormüve látható, ez adta az írónak az ötletet a regénybeli kiadó névhez (az író húgának közlése alapján). http://www.fundaciotapies.org/site/spip.php?rubrique65, letöltés 2017. máj. 11.

${ }^{54}$ Assmann, Jan, A kulturális emlékezet, Budapest, Atlantisz Könyvkiadó, 2013. 52. o.
} 
Az Aragón Irodalmi Nagydíjat már súlyos betegen, a kemoterápia következtében a felismerhetetlenségig megváltozott külsővel vette át 2005. áprilisában. A díjátadásra Terolban került sor, ahová a mequinensaiak több bérelt busszal érkeztek. Az egyik újságcikk megörökíti a pillanat erejét: barátja kérdésére „Miért nem fordultál meg? Az egész terem állva tapsolt.” Moncada azt válaszolta: „Mert elsírtam volna magam.” ${ }^{55}$. Egy lleidai újság nekrológjában megfogalmazódik, hogy Jesús Moncada tudatában volt annak, milyen példaértékü elismerés az Aragón Irodalmi Nagydíj egy katalánul alkotó szerző számára, hiszen a tartomány katalán anyanyelvű polgárai továbbra is csak spanyol nyelven folytathatnak iskolai tanulmányokat, anyanyelvük használatát a törvény semmilyen területen nem biztosítja. ${ }^{56}$ Jesús Moncada tehát elment nagybetegen, és átvette a díjat Terolban, mert tudta, hogy ezzel előmozdítja a katalán nyelv elfogadását célzó, sokat ígérgetett törvényt, s ez a saját eszközeivel történő küzdelmet jelentette. Azt vallotta, hogy Aragóniával meg kell értetni, hogy a katalán beletartozik gazdag kulturális örökségébe. Az Aragón Irodalmi Nagydíj a nyelvi különbségek és hagyományos ellentétek ellenére annak elismerése volt, hogy Ramon J. Sender, Crónica del alba (A hajnal krónikája) (1942) című regénye óta nem született olyan magas irodalmi színvonalú irodalmi alkotás, mint A folyók városa melynek színhelye Aragónia, és szerzője aragón. ${ }^{57}$

A barcelonai tanatóriumban tartott búcsúztatón és a mequinensai temetésen készült fényképeken katalán és aragón politikusokat, írókat és közéleti szereplőket egyaránt láthatunk. ${ }^{58}$ A nekrológok többsége kiemeli Jesús Moncada szerénységét, s úgy jellemzi, mint az irodalomcsinálás közéleti mechanizmusaitól távol maradó, szinte szerzetesi megszállottsággal az irodalmi alkotásnak élö, barátaihoz, családjához, városához hüséges, minden müvészi allürtől mentes, szeretetre méltó embert, akinek halála hatalmas veszteség az irodalom számára.

\footnotetext{
55 2005-06-14 El País - Fallece Jesús Moncada, el gran escritor del Ebro, Fallece Jesús Moncada, cronista del Ebro, Xavier Moret; Un clásico en vida, Xavier Moret; La magia de la memòria, Pau Vidal.

56 2005-06-21 El Temps - La Franja perd el seu referent, Anna Sáez.

57 2005-07-01 Temps de Franja - A reveure, Jesús, Mario Sasot. A cikk az Heraldo de Aragón, aragóniai lapban megjelent, elfogultsággal nem vádolható irodalmi kritikára hivatkozik.

58 2005-06-16 Avui - Que hi feu aquí - Només sóc un escriptor, Ada Castells. A fotón látható három baloldali, (PSC, ERC) politikus, Pasqual Maragall, Josep Bargalló, és Josep-Maria Carod-Rovira.
} 


\subsection{Az író kora}

Jesús Moncada életének meghatározó pontjait már az életrajz első mondata is kijelöli: a Franja de Ponent területéről származó katalán anyanyelvü aragóniai író. A katalán esetében a nyelv és az irodalom modern kori története és helyzete egyfajta politikai-kulturális látlelet is, mely által képet kaphatunk egy ország nélküli nemzet társadalmában létező identitásokról. Ennek megmutatásában az irodalomnak, mint egy olyan virtuális térnek, amelyben kultúrák, nem pedig politikai entitások versengenek egymással, kitüntetett szerep jut. A Moncada müvek kritikusai leggyakrabban az író rendkívül gazdag, sokszínü, veretes, nyelvét emelik ki, mert megmutatja, mire képes a katalán nyelv mint irodalmi kifejezőeszköz. Így válik a Franja és a Principátus nyelvvédői körében a „Moncada nyelve” kifejezés a katalán védelmére irányuló politikai törekvések mottójává. ${ }^{59}$ A nyelvféltő, nyelvvédő, nyelvápoló kommentárok gyakorisága ${ }^{60}$ a Nora-féle megkülönböztetés helyénvalóságát támasztja alá a katalán nyelv kontextusában: az emlékezés milieux-i helyett az emlékezés lieux-i maradnak. Ebben az értelemben a katalánnak, mint állam nélküli kis nyelvnek az anyanyelvi emlékezete a kollektív emlékezet egyik fajtája, az irodalom, pedig annak emlékezethelye. Moncada a mequinensai használat gazdag, élő nyelvét, a katalán irodalmi hagyománnyal ötvözve hozta létre müveit, s ily módon épített nyelvi és irodalmi emlékezethelyet. Ennek a nyelvi és irodalmi téren kibővített Moncada kontextusnak - mely bizonyos értelemben egy ország nélküli nép megmaradni akarásának krónikája is, hiszen a katalán nacionalizmus alapvetően nyelvi alapokra épül - szentelem a következő két alfejezetet.

\subsubsection{Nyelv, irodalom és társadalom Katalóniában}

Franco tábornok győzelmével a II. Köztársaság alatt nemzeti autonómia statútumot kivívott kisnemzetek elvesztették nemcsak politikai, hanem irodalmi és kulturális intézményeiket is, mely nyelvi és kulturális különállásukat biztosította. A Franco rendszer 1966-ig érvényben lévő cenzúra törvénye (Ley de la Censura de 29 de abril 1938) a polgárháború

\footnotetext{
59 Puigvert, Antoni, „Envenenar la llengua de Moncada”, La Vanguardia http://www.caffereggio.net/ 2013/05/13/envenenar-la-lengua-de-moncada-de-antoni-puigverd-en-la-vanguardia/, letöltés 2013. máj. 13.

60 Katalóniában a nyelvvesztéstől való félelem különösen élessé teszi ezt a kérdést, ami indokolja az interjúkban nyelvvel, nyelvhasználattal, nyelvjárással, nyelvpolitikával kapcsolatost kérdések túlsúlyát is, ami az írót arra a keserủ megjegyzésre ragadtatta, hogy Katalóniában, az irodalmi művek kapcsán is mindig csak a nyelvvel kapcsolatban faggatják.
} 
idején született, és a háborús időkhöz illő szigorúsággal tiltott minden, a nacionál-katolikus ideológiához nem illeszkedő gondolatot és kifejezésmódot. Maria Josepa Gallofré katalán történész, a francói cenzúra kutatója megállapította, hogy a katalán könyvkiadás és sajtó esetében alkalmazott tiltások sokkal durvábbak voltak, mint a spanyol kiadás esetében, mert míg ott a cél csak bizonyos szerzők és müvek betiltása volt, a katalán kiadás esetében a katalán olvasóközönség és könyvkiadás teljes egészében történő megsemmisítésére törekedtek. $^{61}$ A katalán könyvkiadás állapotát 1939 és 1946 között Josep Pla szavai érzékeltetik a legjobban: „1946-ban nem létezett a piacon egyetlen katalán nyelvű könyv sem, amelyet ne legalább 10 évvel korábban adtak volna ki.” ${ }^{62}$ Az engedélyezett facsimile kiadások az 1932-es Normes de Castelló előtti régies formában jelenhettek csak meg, ezzel is érzékeltetve, hogy a katalán kulturálisan alacsonyabb szinten álló nyelv, mint az ország hivatalos nyelve, a spanyol. ${ }^{63}$ A II. világháború befejezése után, a nyugati demokráciák győzelme által teremtett helyzethez alkalmazkodva a diktatúra megtette első engedményeit a katalán nyelvü kiadás teljes tiltásának feloldásával. 1946-1951 között 200 könyv jelenhetett meg katalánul, de a háború előtti mennyiség, (1936-ban 865 kiadvány) eléréséig a katalán társadalomnak 1977-ig kellett várnia. A 60-as évekig, a megjelenő könyvek többsége a hagyományőrző, népies, 19. századi, vallásos, vagy a klasszikusnak számító katalán irodalom képviselője volt, melyek közül igen kevés nyújthatott szellemi táplálékot az újdonságok és a táguló világ kínálta ismeretek után áhítozó olvasók számára. Teljesen tiltott kategória maradt a hatvanas évekig a történelem témája, a katalán nyelvü esszéirodalom és a világirodalom jeles műveinek katalánra fordítása. Így talán jobban érthető a Vergara Kiadó Isard sorozatának jelentősége, s az a kultúrmissziós szerep, amit ez, s a hozzá hasonlóan a hatvanas években induló, vállalkozások betöltöttek a katalán irodalomban. A polgárháború végétől a hatvanas évekig tehát a katalán könyvkiadás és kultúra elkerülhetetlenül a folklorizálódás irányába mozdult el, hiszen egyedül a hagyományőrzés terepét engedélyezték számára, s kizárták az autokton modernizációból. Ez a tény érthetővé teszi a Moncada vidékinek, archaikusnak tartott nyelvezetével, kifejezésmódjával kapcsolatos polémiát is, s hogy méltatói miért emelik ki oly gyakran, hogy esetében nem lokalista, hagyományőrző irodalomról van szó, amely kategória

\footnotetext{
${ }^{61}$ Francesc Vallverdú, „La meva experiència a Edicions 62”, A Barcelonai Autonóm Egyetem „Fordítás és Cenzúra” című konferenciájának nyitóbeszéde Jornades sobre „Traducció i censura”, Càtedra Jordi Arbonès, UAB, 17/18 octubre 2012. Az előadás szövegét a szerző bocsátotta rendelkezésemre.

${ }^{62}$ Llanas, Manuel, L'edició a Catalunya: el segle XX (1939-1975), Barcelona, Gremi d’Editors de Catalunya, 2006. 23. o.

${ }^{63}$ Ezzel kapcsolatban 1. Anderle Ádám, Megosztott Hispánia, Budapest, Kossuth Kiadó 1985. 168. o-n a „A spanyol hazafiság katekizmusa” egy dialógusát: L. melléklet Lexikon 8.
} 
visszalépést jelentett a gazdasági-társadalmi fejlődés és modernitás spanyolországi élvonalában levő, s ennek az irodalom terén is hangot adni kívánó katalán olvasótábor számára. A kétnyelvü katalánok számára engedélyezett kultúraközvetítő nyelv csak a spanyol lehetett, a rendszer iskoláiban írni-olvasni, csak ezen a nyelven tanulhattak. Mint Joan Margarit (1938-), a híres kétnyelvű költő, a Premio Nacional 2008 díjazottja mondta: „Jómagam spanyolul kezdtem írni, mert ez volt az egyetlen módja annak, hogy írjak, semmi más nyelven nem rendelkeztem kultúrával”. ${ }^{64}$ Mint fentebb láttuk Moncadánál, a más nyelven való rögzítés kényszere hitelességi problémákat vetett fel, „le kellett fordítanom maga-

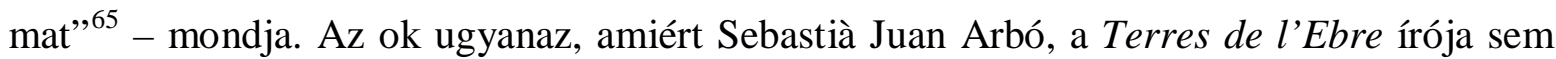
érezte hitelesnek az ebrói hajósok szavait spanyol fordításban. ${ }^{66}$ Arbó egyik kritikusa azt tanácsolta az írónak, hogy maradjon a vidéki témáknál (értsd: írjon katalánul), az jobban illik hozzá, mint a városi, azaz spanyol nyelvű alkotás. ${ }^{67}$ A katalán irodalom berkein belül mutatkozó ellentét városi (fejlettség, modernség záloga) és vidéki (elmaradottság, alacsonyabb kulturális színvonal) között, ebben a kontextusban nyelvi színezetet is kap, melynek üzenete egyértelmủen az, hogy az ország kultúrnyelve a spanyol, mert egyedül ez alkalmas magas színvonalú, modern, tudományos és összetett gondolatok megfogalmazására, amire a katalán nem. ${ }^{68}$ Valószínűleg ez a Franco korban gyökerező, ám máig ható szociolingvisztikai beidegződés magyarázza a spanyol anyanyelvü többség érdeklődésének a hiányát a katalán irodalom felé, amit periférikusnak, érdektelennek, kevésbé értékesnek, kisebbségi kultúrának lát, szemben a spanyol világnyelvi távlatokat átfogó nyelvi kultúrájával. Ebben nem kizárólag a spanyol és a katalán kultúrnacionalizmus szembenállását kell látnunk, hanem azt a tényt, amit Szerb Antal a világirodalom történetéről írott müvének bevezetöjében leszögez, hogy a világirodalom elsősorban a nagy nemzetek, illetve nyelvek története. Szerb Antal, mint magyar író, ezt kiküszöbölhetetlen igazságtalanságnak tartja ${ }^{69}$, mivel ez nem azt jelenti, hogy a nagy nyelvek irodalma magasabb színvonalú lenne, csak azt, hogy a közös

\footnotetext{
${ }^{64}$ Margarit, Joan, Pregó Les Festes de la Mercè 2010 Barcelona, a város védőszentjének ünnepén mondott nyitóbeszéd https://es.slideshare.net/silviamartinez/preg-de-la-merc-2001-margarit, letöltés 2016. szept. 14.

${ }^{65}$ Muñoz, Josep M., „La memòria d’un món negat”, in Ramón Acín (dir), Jesús Moncada, Su universo literario, Zaragoza, Gobierno de Aragón, Ayuntamiento de Mequinenza, 2005. 52. o.

${ }^{66} \mathrm{~S}$. J. Arbó azt vallotta, hogy valószínúleg sosem lett volna belőle kétnyelvủ író, ha nincs a polgárháború. Katalánul kezdett írni a 30-as években, majd a háború után áttért a spanyolra. Sajnálattal állapítja meg, hogy a spanyol egyáltalán nem illik az ebrói hajósok párbeszédeinek hangulatához, amit ő megörökíteni igyekezett. idézi Vallverdú,Francesc, L’Escriptor català i el problema de la llengua, Barcelona, Edicions 62, 1968, 59. o. ${ }^{67}$ Uo.

68 Jól példázza ezt a király által a demokratikus átmenet irányítására kinevezett kormány vezetőjének, a katalánokkal általában szimpatizáló Adolfo Suáreznek az a megállapítása, hogy a katalán nyelv alkalmatlan arra, hogy közvetítésével az atomfizika kérdéseit tanulmányozhassák. L. Vila Foruny, Jordi, El nacionalisme català, aportacions a un debat, Barcelona, Barcanova, 1992. 13. o.

${ }^{69}$ Szerb Antal, A világirodalom története, Budapest, Magvető Kiadó, 1989. 8. o.
} 
irodalmi tudatba a kis nyelven írott müvek nem kerülnek be. Ugyanebből a városi=modern, vidéki=elmaradott szembeállításból fakad az a Moncadával foglalkozó cikkekben gyakran visszatérő kérdés, hogy mikor helyezi regényei színterét Barcelonába, valamint az a gyakran hangoztatott vélemény, hogy a katalán irodalom modernitását az bizonyítaná leginkább, ha a nyüzsgő nagyvárost, a spanyol fejlődés élvonalát képviselő Barcelonát jelenítené meg. ${ }^{70} \mathrm{Ez}$ egyértelműen egy nemzeti alsóbbrendűségi komplexusból táplálkozó vágyálom, melynek abszurditását az írótársadalom javarészt felismerte ${ }^{71}$, de még a demokratikus átmenet utáni korszakban is kísértett a katalán kultúrpolitikában. A Barcelona, mint regényhelyszín kérdés gyakorisága az interjúkban azt jelzi, hogy a gazdasági-társadalmi fejlettségre alapozó katalán nemzettudat nagyon szívesen látná, ha irodalma is megénekelné a dinamikusan fejlődő, gazdag fővárost, „Katalónia városállamot” (Catalunya ciutat). Katalán nyelven azonban mind a mai napig nem írták meg azt a regényt, melynek föszereplője Barcelona. Ez annál inkább is hiányosságnak tünhet, mivel a spanyol nyelvü katalóniai szerzők tollából viszont világhírủ művek és bestsellerek születtek a városról. ${ }^{72}$ Jesús Moncada mindig tiltakozott e vidéki-városi megkülönböztetésre alapozó irodalmi kategorizálás ellen, amely neki, témaválasztása miatt a vidéki jelzőt juttatta. Egy mérvadó katalán irodalmi folyóirat kritikusa szerint ez a típusú osztályozás nem képes megmutatni, mennyire rokon az egyértelműen nagyvárosi írók közé sorolt Pere Calders és a „vidéki” Jesús Moncada látás- és kifejezésmódja, s Maria Barbal - a par excellence vidéki író - hangja mennyire leginkább a Barcelonához kötődő Mercè Rodoreda mủveiben találja meg az előképét. ${ }^{73}$

A francói nyelvpolitika tehát a Renaixança, a Mancomunitat és a II. Köztársaság idején az önálló kultúra és nyelv irányába nagy sikerrel építkező Katalóniát, a regionalizáció útjára terelte át, mely állapotot a szociolingvisztika a diglosszia kifejezéssel írja le. Ez azt jelenti, hogy a Franco-korszakban, sőt még a 80-as években is a katalánok többsége csak az otthon falai közt használta az anyanyelvét. A formális és írott regiszterekben csakis az

\footnotetext{
70 1991-01-01 Els Marges - Al marge. Rurales y urbanos, Víctor Martinez Gil; 1992-02-24 El Temps Moncada contraataca; 1991-09-18 La Vanguardia - Jesús Moncada entrega al editor su segunda novela; $1993-$ 11-25 Segre - Jesús Moncada hace un retrato esperpéntico de la Barcelona de los 50, E.R.; 2001-11-12 Avui 20 anys de contes de Jesús Moncada, Ada Castells.

${ }^{71}$ 1990-11-03 Avui - Les tardors, Montserrat Roig; Sergi Pàmies ironikus hangvételü novelláskötetének a provokatív La gran novel·la sobre Barcelona (Nagyregény Barcelonáról) címet adta.

${ }^{72}$ Eduardo Mendoza, A csodák városa; Manuel Vázquez Montalbán Carvalho-ciklusa, melyet „nuevos episodios nacionales montalbanianos” néven is emleget az irodalomkritika; Juan Marsé, Utolsó délutánok Teresával; Ildefonso Falcones, La catedral del mar; Carlos Ruiz Zafón, A szél árnyéka.

73 1991-01-01 Els Marges - Al marge. Rurales y urbanos, Víctor Martinez Gil.
} 
engedélyezett kultúrnyelv, a spanyol használatára nyílt lehetősége, miáltal ezekben a regiszterekben jobban is tudta magát kifejezni spanyolul ${ }^{74}$.

Amikor a Fraga Iribarne minisztersége idején, a cenzúra szabályait lazító 1966-os törvény (Ley de Prensa y Imprenta) következményeképp kitágultak a katalán kultúra számára kínálkozó törvényi keretek, a gombamódra szaporodó katalán nyelvű kiadók terjeszkedése óriási akadályba ütközött: a katalánul olvasni tudó olvasóközönség hiányába. A katalanista jellegü kulturális vállalkozások, mint a Serra d’Or, a montserrati bencések által müködtetett katalán nyelvü irodalmi, kulturális, közéleti folyóirat ${ }^{75}$, az Edicions 62,vagy az Enciclopèdia Catalana kiadók vagy később a $\operatorname{PSAN}^{76}$ (Partit Socialista d'Alliberament Nacional dels Països Catalans) aktivistáinak köréből, politikai könyvek kiadásával indító Magrana ${ }^{77}$ kiadó, Moncada későbbi kiadója, vagy a lemezkiadó Edigsa, az illegalitásban indult, patrióta lelkesedésből táplálkozó nyelvmüvelők csoportjaira építő kisés középpolgárságból kiindulva kezdték kultúraépítő vállalkozásukat a 60-as, 70-es években. A katalán nagypolgárság „nemzeti” identitása kulturális tekintetben már nem volt katalán, létezett azonban egy az intézményes kereteken kívül és mellett kiépült erős civil társadalom, mely kulturális országépítő igénnyel lépett fel, és kulcsszerepet vállalt Franco halála után, a demokratikus átmenet idején megvalósuló katalán újrarendezésben. ${ }^{78}$ Ebben az időszakban Katalónia kulturális infrastruktúrája, identitása és azonosulási mintája túlnyomó részben spanyol volt, de a civil társadalmi kezdeményezések megragadták az autonómia kínálta lehetőségeket, és újra kiépült a katalán kulturális intézményrendszer, mely a katalán identitás megerősítését tűzte ki célul. 1978-ban 70 taggal megalakult a Katalán Kiadók Szövetsége Associació d'Editors en Llengua Catalana ${ }^{79}$ a nyolcvanas évek elején az iskolákban bevezették a katalán oktatást, majd a nyelvi normalizáció törvényével (Ley de la

\footnotetext{
${ }^{74}$ Ortega y Gasset tanítványának, Julián Maríasnak a nyelvészeti elmélete értelmében a katalánok „nyelvi otthona” egy kétemeletes építmény, melynek földszintjén élik hétköznapi és családi életüket, ahonnan azonban gyakran feljárnak az emeletre, a spanyol szintjére, s ott is, továbbra is otthon vannak. A nyelvi ház szintjeinek elhelyezkedése a nyelvek hierarchiáját is jelzi. L. Vallverdú, i.m. 39. o.

${ }^{75}$ http://www.lluisvives.com/hemeroteca/serrador/, letöltés 2017. ápr. 12. http://www.pamsa.cat/pamsa/revista/sdo.html, letöltés 2017. ápr. 12.

${ }^{76}$ PSAN https://www.psan.cat/, letöltés 2017. jún. 3. A Katalánföld nemzeti felszabadításáért küzdő szocialista párt, melynek földalatti gyülésein a 70-es években részt vett Jesús Moncada és leendő kiadója, Carles-Jordi Guardiola is, a Magrana Kiadó későbbi alapítója.

${ }^{77}$ Llanas, Manuel - Chumillas, Jordi, Edicions Magrana (1976-2000) Política, Literatura i escola, Barcelona, Publicacions de l'Abadia de Montserrat, 2012; Guardiola, Carles-Jordi, Ofici d'editar, Barcelona, Magrana, 1996.

${ }^{78}$ Tresserres, Joan Manuel, „Catalunya i la mundialització, Llengua i cultura: nous reptes”, in Albareda i Salvadó, Joaquim (dir.), Catalunya, Nació d'Europa, Barcelona, Enciclopèdia Catalana, 2014, 222-235. o.

${ }^{79} \mathrm{Az}$ adatok Guardiola, Carles-Jordi, Ofici d'editar c. könyvéből származnak. L. még AELLC http://editors.cat/lassociacio/qui-som/, letöltés 2017. jún. 17.
} 
Normalización lingüística (1983), s a nyelvi bemerítés (immersió lingüística) módszerének fokozatos általánossá tételével az 1983-84-es tanévtől, sikerült elérni, hogy a Katalán autonóm tartomány területén törvényileg biztosított módon a katalán lett az iskoláztatás és a társadalmi kohézió nyelve. ${ }^{80} 1984$ januárjában elindult az első katalán nyelvű televízió, a TV3. Már a Katalán Kulturális Kongresszus első találkozóján (1975-1977) megalakult az AELC (Associació d'Escriptors en Llengua Catalana), a Katalánul Alkotó Írók Szövetsége, mely azokat az intellektuelleket fogta össze, akik irodalmi alkotásuk nyelvéül a katalánt választották. Erre a körültekintő és bonyolult megfogalmazásra azért volt szükség mert a katalán nyelv és az előbb említett nyelvi szabályozás hatálya alá eső Katalán Autonómia határai nem esnek egybe. Míg Katalónián (Principátus) belül létezik egy spanyol nyelvü katalán irodalom is ${ }^{81}$, addig a tartomány határain kívül eső területek, Valencia, a Baleáriszigetek, Aragónia katalánul beszélő keleti övezete, Llenguadoc-Roselló Francia országban (Észak-Katalónia), Andorra és a szardíniai Alguer városa, vagyis a Països Catalans ${ }^{82}$ (Katalánföld) ${ }^{83}$ minden területe jeles írókkal képviselteti magát az AELC-ben. ${ }^{84}$

A Països Catalans, azaz a pánkatalán gondolat egy utópikus, idealista elképzelés, mely ugyan reálisan létező nyelvi, etnikai, kulturális alapokra épül, ám ellentétben áll a nemzeti lojalitás egy másik, igen fontos elemével, a politikai, adminisztratív tér realitásával. A fentebb felsorolt területeknek még a nyelvi egységesítése sem jöhetett létre a kidolgozott közös nyelvi norma ellenére, s a közös nyelvnek sincs egyezményes, közös neve. A reneszánsz kortól külön politikai egységekben élő katalánok mallorcaivá és valenciaivá lettek az idők során, és bár ugyanazt a nyelvet használták, másként nevezték. A nyelv csak

\footnotetext{
${ }^{80}$ A törvény és a módszer bevezetéséröl, az ellene Werth miniszter által indított ellentámadás (2014) és annak előzményei kapcsán l. http://www.vilaweb.cat/noticia/4176888/20140306/immersio-linguistica-modeldexit.html, letöltés 2014. dec. 3. A katalóniai nyelvi viszonyokról árnyaltabb képet kapunk az EULP 2013 (l’Enquesta d’Usos Lingüístics de la Població) statisztikájából: http://www20.gencat.cat/docs/Llengcat/ Documents/Publicacions/Altres/Arxius/EULP2013 fullet.pdf, letöltés 2014. febr. 13. Ennek eredményei azt erősítik, hogy Katalóniában a többség nyelve minden kritérium alapján továbbra is a spanyol. Európa többi kisebbségi vagy regionális nyelvével ellentétben ugyan a katalánt 600000 más anyanyelvü tartja az identifikáció nyelvének, vagyis tényleges vonzerővel bír, ám semmiképpen sem szoríthatja ki a használatból a spanyolt, a katalán autonóm tartományi lakosság 55\%-ának anyanyelvét.

${ }^{81}$ Pl. Eduardo Mendoza, Juan Marsé, Manuel Vázquez Montalbán, Juan Goytisolo, Augustín Goytisolo stb.

${ }^{82}$ L. Katalánföld különböző ábrázolásait az első, 1881-ből származó térképtől a jövő vízióit ábrázoló terképekig l. http://blocs.mesvilaweb.cat/vicent/?p=268581, letöltés 2017. júl. 20.

${ }^{83}$ A Països Catalans szó szerinti fordítása „Katalán Országok” jobban érzékelteti a széttagoltságot. Katalánföld, viszont azt jelzi, hogy nem politikai egységröl, hanem nyelvi alapú összetartozástudatról van szó. Joan Fuster, valenciai író 1962-ben kiadott, Nosaltres, els valencians (Mi, valenciaiak) címü könyvében dolgozza ki ennek a nyelvi-kulturális alapokon nyugvó összetartozásnak vagy nemzetgondolatnak az elméletét, ezért őt szokás a pánkatalanizmus atyjának tekinteni.

${ }^{84}$ Amikor ezt a nyelvet katalánnak nevezem, akkor az egész nyelvterület közös nyelvére utalok, mellőzve a sikertelen egységtörekvések során létrejött közvetítő terminusokat, mint bacavès, levantí vagy llimosí, valamint a katalán, valenciai és mallorcai jelzők felsorolását. Hivatalosan a katalán csak Katalónia nyelve, nyelvészetileg azonban igazolt tény, hogy egy és ugyanazon nyelvről van szó.
} 
Katalóniában tett szert magas társadalmi presztízsre, és lett a nemzeti fejlődés egyik fő szimbóluma, ott ugyanis a 19. századi, romantikus nemzeti megújhodási mozgalomhoz társult még egy rendkívül fontos elem, az ipari forradalom, melynek eredményeképp létrejött egy erős középosztály, amely a katalánt, a centrum ellenében a sajátjának kiáltotta ki, s így a nyelv az ipari haladás presztízsét tudhatta magáénak. A többi katalán nyelvü területen azonban ez a folyamat nem zajlott le, a nép katalánul, a magasabb társadalmi rétegek, a hatalom képviselői pedig kasztíliai nyelven beszéltek ${ }^{85}$, a katalán testvéri szövetkezés ügyét pedig csak értelmiségiek elszigetelt csoportjai képviselték. Bár politikai téren egyértelmüen olyan kísérletek tanúi lehetünk, amelyek ezeknek a katalánul beszélő területeknek a szétválasztására irányulnak ${ }^{86}$, kulturális téren azonban léteznek ezt kiegyensúlyozni próbáló tevékenységek is. ${ }^{87}$ Jó példa erre a Katalóniában a 70 -esek nemzedékének nevezett írók ${ }^{88}$, akik egy kollektív mozgalom keretében úgy tekintettek a kulturális tevékenységre, mint a politikai akciókban használható fegyverre. ${ }^{89}$ A Katalán Nyelvű Írók Szövetségének utazó kiállítása „A könyv, mint a nép újra kialakításának eszköze” címet viselte ${ }^{90}$. A pánkatalán politikai platformon álló Carles-Jordi Guardiola, a Magrana Kiadó igazgatója és a Katalán Kiadók Szövetségének első elnöke ezzel kapcsolatban a következőképp fogalmazott: „a könyv döntő eszköz lehet a katalanizáció folyamatában, $\mathrm{s}$ a katalán társadalom identitásszimbólumainak visszaszerzésében. Mi a könyv mellé tesszük le a voksunkat, mely a legalkalmasabb arra, hogy a nemzeti és demokratikus újraépítkezés folyamatát vezérelje."91

\footnotetext{
${ }^{85}$ Raimon a Nova Cançó egyik emblematikus dalává vált versében, a „Jo vinc d’un silenci”-ben ezt így fogalmazza meg: „Egy régi és nagyon hosszú csöndből jövök, olyan emberek közül, akik az idők mélyéről bukkannak fel, s akiket alárendelt osztályoknak neveznek.”

${ }^{86}$ Valenciában a demokratikus átmenet időszakában, a nyelvi partikularizmus képviselöi politikai platformot alakítottak (blaverizmus), és a valenciait teljesen önáló, autokton nyelvként védelmezik. Amikor a 2013-as Aragón nyelvtörvény a katalánt, a keleti területek saját/őshonos aragóniai nyelvének nevezte, a Spanyol Nyelvészeti és Történettudományi Akadémia tizenkilenc tagja személyes alapon, levélben tiltakozott a tudomány politikai célokra való felhasználása ellen. Leszögezik, hogy a nyelvtudomány állásfoglalása alapján a principátusbeli, a valenciai, a baleári, a rosselói az andorrai és a Franja területén beszélt nyelv a katalán és annak nyelvi változatai. http://www.ascuma.org/wordpress/wp-content/uploads/2009/11/la-lengua-de-losvalencianos.pdf, letöltés 2014. nov. 10.

${ }^{87}$ Észak Katalóniában az Escola de Bressol, Valenciában az Escola valenciana katalán nyelvủ iskolarendszer, Aragóniában a heti két katalán óra, melyből egyet már franciára változtatott a törvényi szabályozás. Iskolai kirándulások szervezése a Principátusból a többi katalán nyelvü területre.

${ }^{88}$ Moncada nem azonosult a 70-es években megszólaló katalán írónemzedék nemzeti követeléseket zászlajára tűző, harcos, politikai állásfoglalásával. Joan Orja irodalomkritikus Moncadát (Aragónia), Maria Barbalt (Katalónia Pallars de Noguera) és Ferran Torrentet (Valencia) egyértelmüen nem a fó sodorba tartozóknak nyilvánítja. L. Orja, Joan, Fahrenheit 212, Barcelona, Magrana, 1989. 107. o.

${ }^{89}$ Broch, Àlex - Calafat,Francesc - Izquierdo, Oriol - Lluró, Josep M. - Sala-Valldaura, Josep M., 70-80-90 Literatura, València, Quaderns Tres i Quatre, 1992. 17-63. o.

${ }^{90}$ 20é aniversari AELC, (1996) Az Írószövetség jubileumi kiadványa a megalakulás 20. évfordulóján.

${ }^{91}$ Guardiola, Carles Jordi, i.m. 59-72. o.
} 
A nyelv összetartó ereje az irodalmi alkotás területén nagyobbra rajzolja „Katalánföld” határát, amit kiválóan érzékeltet a 2007-es Frankfurti Könyvvásár díszvendégeként érkező „Katalán Kultúra.”92 A díszvendégnek szóló meghívás korábban mindig csak országoknak, azaz politikai egységeknek járt. A katalán szellemi tér, szellemi haza tehát a politikai tér minden realitása ellenére létezett, és létezik, ezért nyilatkozhatott a nyolcvanas években Jesús Moncada a következőképpen: „Én Mequinensában született katalán írónak tartom magam. Mint ahogy léteznek Barcelonában vagy Gironában született katalán írók. Az én szememben a Franja nem az ország többi részétől elválasztott terület."93 Ez az ország pedig nem lehet más, mint a Països Catalans, a nyelvi, szellemi, kulturális közös tér, a „képzelt nemzet”.

\subsubsection{La Franja de Ponent}

A Països Catalans területileg és lélekszám tekintetében is egyik legkisebb része a Franja, területileg Aragóniához tartozik, lakói azonban katalánul beszélnek. Az Aragónia és Katalónia határán észak-déli irányban mintegy 210 km hosszúságú, kelet-nyugati irányban pedig körülbelül 5-30 km szélességü, nyelvi hovatartozás alapján kirajzolódó határsáv eredete sok száz éves múltra tekint vissza. A Marca Hispanica területeiből a Frank Birodalom gyengülésével megalakult két független ország, az Aragón Királyság és a Katalán hercegség feudális szerződések útján állapította meg határait, melyek a 14. századra szilárdultak meg.

Spanyolország modern állammá szerveződése során, 1833-ban, francia mintára provinciákra osztotta területét, az új közigazgatási egységeket azonban a középkori országok területi határai mentén alakították meg. A Franco-korszak után újjáalakuló Autonómiák országa szintén megtartotta ezeket a középkori eredetủ egységeket. Egyházi adminisztratív beosztás alapján azonban a Franja települései csak 1955, 1995 és 1998 folyamán, három lépésben kerültek át a Lleidai (Katalónia) Püspökségtől az aragóniai Barbastre-Montsói püspökséghez. Ezzel kapcsolatban Moncada így vall egy interjúban: „Engem még a lleidai

\footnotetext{
${ }^{92}$ Bargalló Valls, Josep, Què fem a Frankfurt? http://es.slideshare.net/JosepBargallo/que-fem-fkt-catala, letöltés 2015. okt. 11. Az IRLL igazgatója címü írásában méltatja a katalán, valenciai és baleár összefogással megvalósult sokszínű bemutatkozást, melynek keretében nem a politikai, hanem a kulturális egység képviseltette magát. Bár a katalán egyetlen kis államnak, a 77000 lakosú Andorrának a hivatalos nyelve, a katalánul beszélő területeken összesen 13,5 millióan élnek, s ebből 9,5 millió érti, 7,5 millió pedig beszéli a nyelvet. Nem létezik azoban egyetlen olyan terület sem, ahol az emberek csak katalánul beszélnének, minden katalánul beszélő ember kétnyelvü.

${ }^{93}$ 1989-04-21 La Veu de l'Anoia - Jesús Moncada, Camí de premis, Francesc Rossell i Farré.
} 
püspök bérmált [...] A pap, aki a polgárháborút követően a leghosszabb időn át volt Mequinensa plébánosa, korábban montserrati bencés szerzetes volt. Katalánul beszélt, mint mi, és ha kellett, bizonyos esetekben felemelte a szavát. Ez teljesen megváltozott, mikor Mequinensa átkerült a Saragossai Érsekséghez, s kaptunk egy urat, aki amellett, hogy politikailag megbízható volt, nem beszélte a hívek nyelvét.”94

Az aragóniai katalánok, az észak-dél irányban sorakozó települések 45000 lakója, Aragónia lakosságának mintegy 4\%-a ${ }^{95}$ tehát sosem tartozott a Katalán Hercegség fennhatósága alá. A terület ma használatos neve a Franja de Ponent, azaz a Nyugati Övezet a múlt század hetvenes éveiben született Barcelonában, a Centre Comarcal Lleidetà szombat esti asztaltársaságának körében, a katalán főváros aragóniai származású intellektueljei és az aragóniai katalán kisebbség lelkes nyelvvédő civil aktivistái körében. ${ }^{96}$

Katalónia Aragóniánál előbb fedezte fel ezt a Saragossától és Barcelonától egyaránt távol eső határmenti sávot, először is annak nyelvi sajátosságait, melyeket elsőként a híres nyelvész, a mallorcai pap, Antoni M. Alcover ${ }^{97}$ írt le a múlt század elején magna opusában, a Diccionari català-valencià-balear-ban. Ez az 1926 és 1962 között tíz kötetben megjelenő etimológiai nagyszótár tartalmazza az Alcover eredeti gyüjtéseiből származó, aragóniai katalán kifejezések bőséges tárházát. ${ }^{98}$ A tömegkommunikáció korszaka előtti időkben éppen ez a határszél jelleg, a dinamikusan fejlődő központi területektől való távolság és elzártság tette nyelvészeti szempontból különösen vonzóvá ezt a területet. Aragón és katalán nyelvészek mellett a romanisztika francia és német szakértői is kutatták a Franja különböző nyelvjárásait. ${ }^{99}$ Egy 1934-ben született nyelvészeti tanulmány a folyami hajózás, mint ősi mesterség szakszavait gyüjtötte össze Mequinensában, a katalán nyelvterület egyik ritka folyami kikötőjében.

A II. Köztársaság idején a ’31-es Katalán (Núriai) Statútum 4. cikkelye csak általánosságban beszél a katalán nyelvű területek lehetséges federációjáról, melyhez, mint megállapítja, az szükséges, hogy az érintett területek lakosságának 3/4-e ezt kérvényezze, népszavazással döntsenek róla, és jóváhagyja a katalán és az összspanyol parlament is. A madridi

${ }^{94}$ 1999-10-22 Avui -Jesús Moncada: „Els contes que semblen més fantàstics són els més reals”, Jordi Capdevila.

${ }^{95}$ http://www.uoc.edu/euromosaic/web/document/catala/ca/i4/i4.html, letöltés 2015. okt. 5.

${ }^{96}$ Hèctor Moret, Indagacions sobre llengua i literatura catalanes a Aragó, Calaceit, Associació Cultural del Matarranya, Institut d'estudis del Baix Cinca, 1998. 12. o.

${ }^{97}$ http://alcover.iec.cat/, letöltés 2015. szept. 25.; Hèctor Moret, i.m. 30-34. o.

98 Hèctor Moret, Lèxic de l'Aragó catalanòfon al Diccionari Aguiló i al Diccionari Català/Valencià/Balear, Alazet Revista de Filología ISSN 0214-76025, 1993. 91-126. o.

99 „L’Aragó catalonòfon entre el Primer Congrés (1906) i el Segon (1986)”, Estudis Baleàrics 82/83, Separata, Institut d'Estudis Baleàrics. 
parlament azonban ezt a cikkelyt teljes egészében kivette a statútum végleges, 1932 szeptember 9-én jóváhagyott változatából ${ }^{100}$, s elvetette a federáció elvi lehetőségét is ${ }^{101}$, melyet a Núriai Statútum még becikkelyezett. Érdekes megfigyelni, hogy a demokratizálódási lehetőségek megnyílásának korszakaiban a Katalóniai politikában mindig újra felvetődik a szélesebb katalán összetartozás gondolata, ami esetlegesen a térkép megváltoztatását is maga után vonhatná. ${ }^{102}$ A demokratikus átmenet idején, az aragóniai katalánok is Katalónia felé fordultak, mert onnan irányult rájuk nagyobb figyelem, s megindultak a civil nyelvvédő és kultúraápoló mozgalmak. Ennek egyik nyilvánvaló jele a Mequinensai Nyilatkozat, melyet 17 katalán nyelvü aragóniai település polgármestere írt alá 1984. február 1-én az aragón kormány kulturális miniszterével, José Bada Paniellóval együtt. Ez alapot biztosított a katalán választható tárgyként való tanításához a települések iskoláiban. ${ }^{103} 1978$ júniusában létrejött egy katalán és aragón parlamenti képviselök részvételével zajló találkozó Alcanyísban (Franja d'Aragó), ahol az aragón képviselők nyilvánvalóvá tették, hogy aragón történelmi területek semmi szín alatt sem kerülhetnek katalán fennhatóság alá. ${ }^{104}$

Az aragón autonómia politikai építkezése során teljesen figyelmen kívül hagyta ezt a hatalmi központjától, Saragossától távol eső, a tartomány keleti perifériáján elhelyezkedő sávot, amelynek a nyelvi összetartozás tényén kívül valójában nincsen semmilyen közös iden-

\footnotetext{
${ }^{100}$ http://blocs.xtec.cat/historia2nbat/files/2013/02/estatut-1932-1931-BLOG.pdf, letöltés 2017. márc. 21. Ez az oldal a két statútum szövegét hasonlítja össze.

${ }^{101}$ Gonzàlez Vilalta, Arnau, La nació imaginada Els fonaments dels Països Catalans Editorial Afers, 2006, Barcelona 143-146.o.

${ }^{102}$ A Katalán Autonómia Statútumot 1978. szeptember 29-én hagyta jóvá a Katalán Parlament, s azon nyomban továbbküldte Madridba. Ennek teljes, még megnyirbálatlan szövegében szerepel az a követelés is, hogy „legyen lehetséges Valencia, a Baleári szigetek és a Principátus autonóm kormányai számára az összefogás, és amennyiben mindhárom kisnemzet egyaránt úgy kívánja, hadd alkossanak federatív közösséget. Fabre, Jaume, Quienes somos los Catalanes y porque así somos pedimos la autonomia, Barcelona, Edición Epidauro, 1979.

José Moncada Moncada hagyatékában találtam egy újságkivágást, az Avui 1976. december 17-i számának Països Catalans mellékletéböl: Ll. Sole Sabaris, Les terres desmembrades del Principat. Írója tájékoztat, hogy a Katalán Kultúra Kongresszusán az egyik szekció feladata az, hogy a katalánok tudatában kirajzolja az egység képét. A leválasztott területek közt említi az aragón területeket is, és a visszaszerzés stratégiájaként a kulturális vonzerő megteremtését jelöli ki. A katalán politikai egység perifériáján erős kulturális, irodalmi vonzerejü központokat kell kiépíteni, melyek a politikai csatlakozásig felerősítik a magterület és a határ túloldalán levő terület közti kommunikációt, gazdasági és társadalmi kapcsolatokat, s oktatás útján megismertetik e területek lakosságával $a$ valódi történetüket. Az író édesapja, aki a köztársasági hadseregben harcolt, és a családi fotóalbum általa készített képei közt szerepel egy közeli kép Lluís Companysról (egy lleidai gyülés alkalmából a köztársaság idején készült - az író húga közlése) feltehetőleg szimpatizált a cikkíró véleményével.

${ }^{103}$ A Mequinenzai Nyilatkozat https://www.elnacional.cat/es/efemerides/marc-pons-declaracion-mequinensacatalan-aragon_134967_102.html, letöltés 2017. jún. 25.

${ }^{104}$ Espluga, Josep \& Moret, Hèctor, „Sobre la Transició a la Llitera (1976-1979): el tímid despertament de la identitat sociocultural d'una comarca perifèrica” in Espluga, Josep, Com embolicar la Franja amb una fulla de pi, Calaceit, Quaderns del Cingle, 2008. 55-79. o.
} 
titástudata. ${ }^{105}$ Lakóinak mindennapi gazdasági, kereskedelmi, infrastrukturális kapcsolatai kelet-nyugat irányúak függetlenül attól, hogy a környezetükben fekvő szomszédos települések milyen nyelvüek. Nyelvüket nem katalánnak nevezik, hanem annak a helységnek a nevéből származtatják, ahol beszélik (Tamaritban a tamarità-t beszélik, Fragában a fragatí-t, Mequinensában a mequinensà-t). Az aragóniai katalánok és a szomszédos katalóniai települések polgárai jól megértik egymást a nyelvészek által a katalán nyugati nyelvjárási változataként definiált nyelven. A határnak azonban óriási identitás meghatározó szerepe van, mert a határ menti katalóniai megkérdezettek, akik napi kapcsolataik során gyakran találkoznak az aragóniai katalánokkal, egyértelmüen aragónnak tartják őket. Megkülönböztetik őket maguktól a belső-aragóniai terület lakosai is, akik viszont katalánnak tartják őket. ${ }^{106}$ A Moncada hagyatékban találtam egy José Moncada, által megőrzött cikket, amely a Calatorao (Saragossa provincia) és a Mequinenza csapata közti futballmeccs körüli vitáról tudósít. A cikkíró egyértemüen kijelenti, hogy a mequinensaiak nem nemeslelkü aragónok, amit az is mutat, hogy a pályán egymás közt valami érthetetlen, zagyva beszédet használnak. A katalánok gúnyneve, a „polacos”, mellyel a franjai katalánokat gyakran gúnyolták(ják), szintén arra utal, hogy más nyelvet használnak. ${ }^{107}$ A Franja lakosai adott helyzettől függően hol katalánnak, hol aragónnak tartják magukat, hisz mindkettő halmazba tartoznak, de egyiknek sem „rendes” tagjai. A mindennapi kommunikáció során standardizálatlan nyelvet használnak, s bizonyos csoportjaik a helyi sajtóban is kifejezetten spanyolos helyesírást használnak a helyi nyelv átírására, hogy annak a katalán nyelvi normáktól eltérő jellegét hangsúlyozzák. Desideri Lombarte, pena rojai író és nyelvvédő ezt „ostoba büszkeség, ostoba regionalizmus” jelzővel illeti, és sajnálja, hogy az emberek csak azért nem tanulják meg a normát, hogy ne érvényesüljön a katalanista kulturális befolyás. Szomorú tényként állapítja meg azonban, hogy a katalánok „Fabrával” (nyelvi normák) a hónuk alatt és zászlóval a kezükben érkeznek ${ }^{108}$, vagyis „térítő” szándékkal. A Franja lakosai valójában há-

${ }^{105}$ Ez a katalán oktatás elterjedésével és rendszeressé válásával, valamint a katalán tömegkommunikációs eszközök, elsősorban a TV3 által sugárzott információ hatására kezd megváltozni, s a mindössze pár évtizedes múltra visszatekintő elnevezés, a Franja kezd alakot ölteni és identitásképző jelentőségre szert tenni.

${ }^{106}$ Két szociolingvisztikai kutatás, az Euromozaik nevet viselő, az Európai Unió által finanszírozott 1993-as, valamint a Katalán Szociolingvisztikai Kutatóintézet által finanszírozott 1994-es, a Franja lakóinak nyelvhasználati szokásait és identitását vizsgáló kutatás eredményeinek összefoglaló közlése: Espluga J., „La imatge de l'altre: aragonesos i catalans fronterers que s’observen mútuament” in Ripacurtia, núm. 1.

${ }^{107}$ Ez a katalánokra általában használt gúnynév adja a TV3 aktuálpolitikai paródia sorozatának címét is: Polònia.

${ }^{108}$ Quintana, Artur, (dir.), Epistolari de Desideri Lombarte (1981-89), Calaceit, Lo Trill (8) Associació Cultural de Matarranya, 2002. 290-291. o. A levélgyüjteményben gyakran szó esik a nyelvészeti normák elfogadásának szükségességéről, kritizálja azokat, akik a regionalista büszkeség jegyében xapurreo pártiak, azaz a dialektus megörzése mellett állnak ki. 
romnyelvüek, létezik egy családi, baráti közegben használt, a standard katalántól lexikailag és szintaxis tekintetében is eltérő helyi nyelv, egy a katalánokkal való érintkezés során használt, a katalán standardhoz lexikailag jobban közelítő, de intonációjában jellegzetesen helyi nyelv, és a kasztíliai, melyet a nyugati szomszédokkal, és minden hivatalos érintkezés során használnak. ${ }^{109}$

Az 1978-as Spanyol Alkotmány értelmében „az állam hivatalos spanyol nyelve a kasztíliai”, s e mellett a többi spanyol nyelv is hivatalos azokban a tartományokban, ahol beszélik, amint azt az autonómia statútumokban rögzítették. Az 1982-ben elfogadott Aragón Autonómia Statútum azonban nem nevezi meg a tartomány nyelveit, s így nem biztosít semmiféle jogot a nyelvhasználat, és az iskoláztatás terén e nyelvek beszélőinek. ${ }^{110}$ Ezért az aragón $^{111}$ és a katalán nyelv védelmére a civil szektorból indultak kezdeményezések ${ }^{112}$, melynek első példája a fent említett Mequinensai Nyilatkozat. Ennek hatására kezdődtek meg az 1984-85-ös tanévben az első anyanyelvi katalán kurzusok azon diákok számára, akiknek szülei ezt igényelték. Ők a kötelező spanyol nyelven folyó oktatáson túl, heti két alkalommal tanulhattak írni-olvasni az anyanyelvükön. Miközben ma Katalóniában az általános és a középiskolai oktatás teljes egészében katalán nyelvü, az aragóniai katalánok számára, az anyanyelven folyó oktatás kérdése fel sem merül, marad a heti két nyelvóra, civil nyelvmüvelő és kulturális egyesületek, katalán nyelvü könyvkiadás, valamint az irodalmi díj. ${ }^{113}$

Az itt élők azonban, mint láttuk, alkalmazkodtak ehhez a sajátos határhelyzethez, identitásuk kettős, és bonyolultabb sémákat követ, mint egynyelvü honfitársaiké. Az irodalmi díj és a könyvkiadás nagy presztízsértékkel bíró fegyvertények, de nem oldják meg az irodalomhoz feltétlenül szükséges olvasóközönség kérdését, melynek híján bajosan születhetnek

\footnotetext{
${ }^{109}$ Espluga, Josep, Planeta Franja, El trencaclosques del català a l'Aragó, Lleida, Pagès editors, 2005.

110 Aragónia 1982-es autonómia statútuma a tartomány nyelveire, mint történelmi öröksége részére utal, melyek „muzeális” értéküknél fogva védendők. http://noticias.juridicas.com/base datos/Admin/lo52007.tp.html\#a7, letöltés 2017. jan. 17.

${ }^{111}$ Az iberoromán nyelvcsaládba tartozó aragón nyelv kihalófélben van, mára mindössze tízezer beszélője maradt a Pireneusok kis falvaiban. A középkorban az Aragón Korona kancelláriájának nyelve a latin az aragón és a katalán. A Trastamara dinasztia uralkodásától kezdve a kasztíliai lett a hivatalos nyelv, s az aragón nem vált önálló, irodalmi, standard nyelvvé Aragóniában.

${ }^{112} \mathrm{Az}$ aragón alaptörvénnyel szemben több kritika is megfogalmazódik, hiszen az 1978-as Spanyol Alkotmány 3.2 -ben foglaltak értelmében a kasztíliai nyelven kívül létező más spanyol nyelvek is hivatalossá tehetők a kasztíliai, mellett azokban az autonóm tartományokban, ahol annak a nyelvnek a beszélői élnek. Az aragóniai döntéshozók azonban nem kívánták biztosítani e jogokat a nyelvi kisebbség számára. L. Moret, Hèctor, i.m. Indagacions 1998.

${ }^{113}$ A Guillem Nicolau díjat Aragónia Kulturális Minisztériuma ítéli oda a legjobb aragóniai katalán nyelvủ irodalmi alkotásnak. A nyolcvanas évek közepén hirdettek meg elöször, majd a PAR kormány alatt megszüntették. 1995-től 2012-ig minden évben meghirdették, ám egy ideje újratervezés alatt áll, nem írnak ki pályázatot. http://masdebringue.wordpress.com/2013/01/16/descovocats-els-premis-guillem-nicolau-i-arnal-cavero/, letöltés 2016. febr. 17.
} 
nagyszerű irodalmi alkotások, hiszen mint Jesús Moncada megállapítja: „Az irodalom csakis az olvasóknak szólni akarásból fakadhat.”114 Mequinensában tett látogatásaim, és mequinensaiakkal folytatott beszélgetéseim és levelezésem alapján azt állapíthattam meg, hogy a nyelv kérdése Mequinensában ma is ellentmondásos és nehézségekkel terhelt kérdés szociológiai, identitásbeli és politikai szempontból egyaránt, s nem jutott nyugvópontra még a mequinensaiak közösségén belül sem. Létezik nyelvjárás párti álláspont, mely a helyi dialektust preferálja a standard katalánnal szemben a sajtó nyelveként is, ami elzárja a közösséget a szélesebb katalán kultúrkörtől. A közösségen kívüli idegenekhez nem szívesen szólnak dialektusban, mert általános tapasztalat és beidegződés, hogy a spanyol a közvetítőnyelv. A katalán standard pártján állók nyelvmüvelő, kultúraterjesztő aktivitása kevés embert mozgat meg, a kiadványok, előadások munkatársai, résztvevői szük körre korlátozódnak. A Moncadával kapcsolatos cikkgyüjtemény nagyon nagy mennyiségben tartalmaz a katalán nyelvre, és az író identitására vonatkozó kérdéseket, ${ }^{115}$ ami azt mutatja, hogy az a jelenség, amit író és müve képvisel, középpontba állítja ezeket a kérdéseket. Moncada számára az anyanyelven írás hitelességi kérdést vet fel. A franjai lakosság összetett identitásából fakadó kérdésekre az általa adott válasz az, hogy a standard irodalmi nyelvet kell gazdagítani a dialektus szavaival, kifejezéseivel, be kell tartani a megállapodás szerinti normatívát, mert ez a nyelv megmaradásának egyetlen esélye. A helyi nyelvjárások kevés kiművelt beszélője nem képes egy magas színvonalú irodalmi kultúra létrehozására, erre csak a többi katalánul beszélő területtel megosztott, közös kulturális térben nyílik lehetőség.

\footnotetext{
114 1999-10-22 Avui - Els contes que semblen més fantàstics són els més reals, Jordi Capdevila.

115 Néhány példa az első Moncada írások publikálásakor született cikkekből, melyek fóként azt emelik ki, honnan jött, és miért katalánul ír 1971-05-26 - Premi Joan de Santamaría; 1971-05-26 El Correo Catalán - La 'Ma esquerra' de Jesús Moncada; 1971-05-26 La Vanguardia Española - Premi Joan de Santamaría; 1971-0527 Diario de Barcelona - Jesús Moncada premi Santamaría; 1971-05-27 Tele-eXpres - El premio es la única forma posible por ahora, Josep M. Soria; A katalán nyelv állapota, változásai, egészsége, veszélyben forgó léte a másik nagy téma: 1982-10-15 El Món - Propostes per la narrativa catalana actual, Francesc Parcerisas; 198804-19 Punt Diari de Girona - Sirgant tartera, Jordi Vendrell; 1988-04-20 Punt Diari - Aires de Mequinensa, Emmanuel Cuyàs; 1990-10-06 Avui - El grau de compromís dels escriptors amb la normativa, Ricard Fité; 1991-12-03 Heraldo de Aragón - Un mequinenzano escritor de un río y de sus gentes, Mario Sasot; 1992-0210 El Observador - Podría escribir cien mil novelas con Mequinenza como escenario, Santiago del Rey; Az író identitásával kapcsolatban, mikor meg kellett válaszolnia, hogy aragón-e vagy katalán : 1984-06-14 La Vanguardia - Donde paces, más que de donde naces; 1989-04-12 El Dia de Aragón - El pueblo inundado de Mequinenza, Anton Castro; 1989-04-21 La Veu de l'Anoia - Jesús Moncada camí de premis, Francesc Rossell i Farré; 1989-10-26 La Comarca - Camí de sirga. La recreació d'un món amb nom propi, Hèctor Moret.
} 


\section{Genius loci - Mequinensa}

Ez az alfejezet az író művei főszereplőjének és nyelvészeti szempontból valamint kollektív emlékezet tekintetében „társzerzőjének”, Mequinensának az adatolt, azaz történelmi történetét vázolja fel abban a korszakban, amelyet az író fikcionális formában megörökített, különös tekintettel a végzetére, azaz a vízerőmü építkezésekre. Ez a végzet a Francokorszak erőltetett ütemü iparosítása következtében elsüllyesztett sok száz más településével rokonítja a „katalán Atlantisz” ${ }^{116}$ sorsát. A vízerőmű építkezésnek szentelt alfejezet kitekintés a kérdés spanyolországi dimenziójára. A város történetének megrajzolásához a helytörténeti monográfiák, s kiemelten a Mequinenza a través de la historia (2010) volt segítségemre, mely a paleolítikumtól a város pusztulásáig, s az új-Mequinensa születéséig, körülbelül 1973-ig követi nyomon a város múltját. Másrészt forrásul használtam a családi levéltárban fennmaradt és a mequinensai „legendárium” személyes ismerőseim által őrzött elemeit.

\subsection{Mequinensa száz éve}

Moncada A folyók városa bevezetőjében jelzi, hogy regénye témáját az általa a „világegyetem középpontjának”" ${ }^{117}$ tekintett „régi Mequinensa elmúlt száz esztendejének eseményei alkotják”, s úgy véli, hogy a kritika épp emiatt a száz éves időhatár miatt próbálta oly sokszor rokonítani művét Gárcia Márquez, Száz év magány című regényével és a mágikus realizmussal. ${ }^{118}$ Ezt a száz éves időhatárt, a kollektív emlékezetre forrásként támaszkodó szerző számára a szóbeli, élő emlékezet akciórádiusza jelöli ki, mely a gyermekekhez a nagyszülők közvetítésével jut el, akiknek emlékezetében még él saját nagyszüleik emlékezete. Az Estremida memòria című regény egy 1877-es bűntényt dolgoz fel 120 évvel később a mequinensai közösségi emlékezetre támaszkodva, s leleplezve annak a jelenkorig ható hárító, ferdítő mechanizmusait. Moncada gyakran hangsúlyozza, hogy úgy tekint önmagára, mint aki maga is szerves része a város kollektív emlékezetének, és íróként kivitelezhetetlen vállalkozásnak tartja, ha valaki olyasvalamit akar megírni, amit nem ismer elég alaposan. Egy cikkben elmondja, azért nem Barcelona a regényei színtere: „mert nem szándékozom

\footnotetext{
116 Zelei Dávid, „A Katalán Atlantisz” Élet és Irodalom LVII. évfolyam, 22. szám, 2013. május 31. 117 Jesús Moncada, Calaveres atònites Pròleg. L. Mellékletek. Képek, térképek, 11. A folyók városa. 118 1988-09-01 El Urogallo - El auge de la narración escrito en catalán; 1989-04-09 Heraldo de Aragón - Los premios de la crítica literaria; 1988-06-01 Lletra de Canvi - Entrevista amb Jesús Moncada, Josep Maria Ripoll.
} 
egy olyan város múltjáról írni, amely történetének csak az utolsó 24 évét ismerem”"119, vagyis csak egy generációnyi élő emlékezete tartozik szervesen az övéhez.

A regényben elbeszélt 1870-1970-es korszak eseményeit a száz évre visszamenően aktívan müködő közösségi emlékezet és elbeszélői hagyomány hálója fogja össze. A száz éves emlékhatáron túl elhelyezkedő, s a város emlékezetében mégis helyet kérő eseményeket tárgyak közvetítik, melyek túlélik az embereket. Ezek olyan fordulópontokhoz kötik a városka történelmét, amelyek az ország és az európai történelem szempontjából is nagy jelentőségüek, s az írott és tanított történelem jeles eseményeihez való kapcsolódás ad súlyt a helyi történelemnek. Ilyen esemény például Mequinensa részvétele és szerepe a Napóleonnal vívott háborúban, ami térképekkel és haditudósításokkal dokumentálva, 14 oldal terjedelemben szerepel a Mequinenza a través de la historia címü, 385 oldalas monográfiában, a regényben pedig egy zsákmányolt rézlátcső emlékeztet rá. A város ostromára és Suchet marsall seregének sikerére Moncada egy francia lap vele készített interjújában is utal. ${ }^{120}$ Ily módon, majd kétszáz évvel az események után a város hősi szerepe a napóleoni háborúkban, intellektuális tájékozódási pontul szolgál a szomszéd ország világtörténelmi jelentőségü személyiségén keresztül az ismeretlen kis hely történelméhez. ${ }^{121}$ A Moncada hagyatékban találtam olyan helytörténész által készített leírást ${ }^{122}$, amely részletesen ismerteti a város hősi ellenállását az 1808-1809-es ostrom során, majd az 1810-es francia támadás sikerét, melynek következményeképpen Mequinensa neve felkerült a napóleoni győzelmeket megörökítő párizsi Arc de Triomphe de l'Étoile oszlopára. A mequinensaiak azonban másképpen is kivették részüket a napóleoni háborúkból, hiszen csapatokat küldtek Saragossa védelmére. Ezt a történelmileg hiteles tényt megerősíti egy irodalmi forrás is, hiszen Benito Pérez Galdós,

\footnotetext{
${ }^{119}$ MCSL Kronológiai jelzet nélküli cikkek: No hago novela rural, Rosa Ma Piñol.

120 1992-07-01 Nuit Blanche - Jesús Moncada, écrivain par entêtement, Anik Lapointe.

${ }^{121}$ Uo. említi Moncada azt a tényt, hogy az első világháború idején menekültek érkeztek Franciaországból Mequinensába, ahol a kontinensen zajló háború addig nem látott mértékü fellendülést okozott a bányászatban, s munkát adott sok új jövevénynek is. A Nagy Háború említése is egy olyan közös európai emlékezettartamhoz kapcsolja a beszélgetést, amelyen keresztül a francia riporter képes lesz saját történelmi emlékezetéhez kötni Mequinensát.

122 MCSL 1. Jesús Moncada jegyzetei, vázlatai... Mario Arbiol, Sitio de Mequinenza en la Guerra de la Independencia. A sürün gépelt lapokon az író édesapjának jóbarátja részletesen megörökíti a három mequinensai ostrom és a város bevételének hadtörténeti és politikatörténeti aspektusait, s azt a tényt is, hogy Mequinensa küldött egy zászlóaljat Saragossa védelmére, ami által, Arbiol véleménye szerint, Mequinensa eleget tett a haza függetlenségéhez való hozzájárulás kötelességének. A Moncada hagyatékban találtam egy olyan regénytervezetet is, amely a Guerra de Francèstöl indította volna a cselekményét, s föszereplöje egy a napóleoni seregből Mequinensában maradt tiszt lett volna. L. uo. Ezek arra utaló jelek, hogy a múlt e távoli de kitüntetett pontja, a hely révén való kapcsolat miatt mégis foglalkoztatja az utókort.
} 
Zaragoza ostroma ${ }^{123}$ címü, történelmi regényének egyik hős városvédő főszereplője, Don José Montoria, mequinensai.

A családi levéltár egy cikkének tanúsága szerint ${ }^{124}$ a „nemeslelkű aragón” jellem készteti a mequinensaiakat arra, hogy hős elődeikhez hasonlóan - akik Pleyan de Porta ${ }^{125}$ leírása alapján, 1808-ban egész kis hadseregként érkeztek az aragón főváros védelmére - feláldozzák a köz javáért városuk földjét. Mint látjuk, a „nemeslelkű aragón” jelző ebben az esetben kijárt a városlakóknak, nem úgy, mint a fent említett futballmeccs esetében, ahol győzelmüket épp annak tudták be, hogy híján vannak e tulajdonságnak. Az 1965-ös cikk írója szerint a hős mequinensaiakat hosszú századok edzették az ily mértékü áldozathozatalra, s az ország energiatermelése oltárán hozott patrióta áldozatot összekapcsolja a 19. század eleji ostromok során a város által tanúsított hősi ellenállással. Ez nem más, mint a hősöket gyártó, romantikus történelemszemlélet hazugsága. Úgy vélem, hogy a városban senki nem volt híve e nézetnek. Erről ékesen tanúskodik a város pusztulásáról szóló Moncada regény csakúgy, mint a történeti nagymonográfia, ezek azonban a Franco-korszak után keletkeztek (1988, 2010). A Franco-rendszer történetírása és hírszolgáltatása azonban kedvelte a hösi sémákat, ahol a Jó (ez esetben az országot megváltó modernizáció) győzedelmeskedik a Rossz (energiahiányban szenvedő ipar, az áramkorlátozások között sötétségben élő lakosság) fölött, amihez az emberek büszkén és öntudatosan asszisztálnak. Ez jól illusztrálja a rendszer dichotómiáját, mely a bukásához is vezetett: elfogadta a kikerülhetetlenné váló gazdasági modernizációt, melynek eredményei azonban túlmutattak azon a manicheista szemléletű hősi mítoszon, amelynek ideológiai keretei közé megpróbálták beszorítani a spanyol társadalmat.

\subsection{Víztározók, vízerőmüvek Spanyolországban a 20. században}

Jesús Moncada születésének évében, 1941-ben, a Franco rendszer autarkhiája idején jött létre az INI (Instituto Nacional de Industria) ${ }^{126}$, a polgárháború során hatalmas veszte-

123 Pérez Galdós, Benito, (Las Palmas de Gran Canaria, 1843-Madrid, 1920) Történelmi epizódok c. sok kötetes regénysorozatában örökíti meg a 19. századi spanyol történelem jeles eseményeit, köztük Saragossa ostromát, ami a spanyol ifjúság egyik legkedvesebb klasszikus olvasmánya volt, s kulturális referenciaponttá vált.

124 MCSL 5. José Moncada Moncada archívuma: Castillo Genzor, Adolfo, „Sigilografia y Heraldica Municipal, Escudos de los pueblos, villas y ciudades de Aragón, Armas de la villa de Mequinenza”, El Noticiero, 1965.

${ }^{125}$ Josep Pleyan de Porta (1841-1891) katalanista költő, tanár, történész, a lleidai Renaixença kulcsfigurája.

126 INI Nemzeti Ipari Intézet http://www.enciclopedia-aragonesa.com/voz.asp?voz_id=7148, letöltés 2017. ápr. 2. L. Lexikon 24. 
ségeket szenvedett spanyol ipari termelés állami befektetés útján való helyreállítása és fellendítése céljából. Az INI 1944-ben hozta létre az ENDESA-t (Empresa Nacional de Electricidad, S.A.) azzal a céllal, hogy egy állami nagyvállalaton keresztül ellenőrizni tudja a stratégiai fontosságúnak tekintett energia szektort. Ez a nagyvállalat 1957-ben az író regényciklusában megörökített régi Mequinensa mellé tervezte az akkori idők Spanyolországának legnagyobb vízerőművét. Ezzel együtt, a 20 folyamkilométerrel távolabb fekvő Ribarojába telepített egy másikat, amelynek víztározója elnyelte a várost. ${ }^{127}$ Az római időktől fogva létező kisváros, (Octogesa), a berber Miknasa-al-Zaytún ${ }^{128}$, a három folyó (Ebro, Segre és Cinca) összefolyásánál fekvő folyami kikötő, a Hispán-félsziget belsejébe vivő természetes utak egykor fontos állomása eltűnt, mint lakott település. Megmaradt viszont a Mequinensa név az ország tíz legnagyobb vízerőmüvét megjelenítő térképen. ${ }^{129} \mathrm{E}$ kisváros tragikus sorsa azonban korántsem egyedülálló a spanyol történelemben, ezért ipartörténeti szempontból is tekinthetünk úgy rá, mint egy norai értelemben vett emlékezethelyre. ${ }^{130} \mathrm{~A}$ „Mequinensa mítosz” egy veszteségtörténet emlékhelye, a spanyol gazdaságtörténet sikeres vízerőmü építési projektjének tekintett érem másik oldala.

„Spanyolországban az elektromos áram igazi katalán találmány”131, Barcelonában már 1875-ben létezett egy dinamótelep ${ }^{132}$, mely a városközpont közvilágításához szükséges áramot biztosította. Ezt tíz évvel korábban telepítették, mint hogy egy királyi rendelet 1885-ben előírta, hogy az országban elektromos berendezéseket kell létesíteni. ${ }^{133}$ Spanyolország a kezdetben gázmotorral, majd hőerőmüvekkel termelt áram helyett a 20. század elején tért át a vízerőművekre. Egy kanadai mérnök, Frederick Stark Pearson 1911 szeptemberében ${ }^{134}$ megalapította a Barcelona Traction, Light and Power Company Limited nevü

\footnotetext{
${ }^{127}$ Interjú Victoriano Muñoz Oms mérnökkel, aki részt vett a tervezésben. Készítette Joan Tort i Donada és Pere Tobaruela i Martínez http://www.ub.edu/geocrit/b3w-339.htm, letöltés 2017. ápr. 2.

${ }_{128}$ Balaña i Abadía, Pere, Les arrels islàmiques de Mequinensa Barcelona Rafael Dalmau, Editor 1994.

129 http://elperiodicodelaenergia.com/las-10-mayores-centrales-hidroelectricas-de-espana/, letöltés 2017. ápr. 2.

${ }^{130}$ A loci memoriae - a nemzeti történelem számára meghatározó helyek, események, történetek emlékezetét magában foglalni képes dolgok, melyeket az emlékezetpolitikát gyakorló hatalom jelöli ki egy bizonyos fejlődési ív illusztrálásaképpen. Ezeknek a pontoknak azonban mindig megvan a „veszteségtörténete” is, mint ahogy egy csata emlékmüve is csak az egyik hadsereg számára jelenthet győzelmet. L. Mellékletek. Képek, térképek, 12. Az érem másik oldala.

${ }^{131}$ García de Cortázar - González Vesga, Spanyolország története, Budapest, Osiris Kiadó, 2001. 359. o.

${ }^{132} \mathrm{Az}$ első közcélú áramfejlesztő telepek és hálózatok az 1880-as években jönnek létre. New Yorkban Edison 1882-ben épít erőművet, az európai nagyvárosok adatai a következők: Milánó 1883, Berlin 1885, Párizs 1888, Bécs 1889.

${ }^{133}$ A vízienergia története Spanyolországban címü weblap http://www.energiaysociedad.es/manenergia/1-2historia-de-la-electricidad-en-espana/, letöltés 2017. ápr. 3.

134 A La Vanguardia újság Hemerotecájából származó tudósítás http://www.lavanguardia.com/hemeroteca/ 19110912/54214299775/se-funda-la-canadiense.html, letöltés 2017. ápr. 3.
} 
céget, közismertebb nevén a La Canadiense-t ${ }^{135}$, azzal a céllal, hogy biztosítsa Katalónia áramellátását. A Tibidabo tetejéről a századeleji Barcelonát szemlélő Pearson óriási üzleti haszonnal kecsegtető, szüz terepet fedezett fel, s nem késlekedett azt kiaknázni. ${ }^{136}$ A vállalat az első víztározókat s a hozzájuk kapcsolódó vízerőműveket a Noguera-Pallaresa folyón, Tremp és Camarasa települések közelében kezdte építeni 1912-től. A kanadai tőkéjű vállalat biztosította az áram szállítását biztosító rendszer kiépítésének anyagi hátterét is.

Az ipari villamosítás a századelőtől kezdve az ország minden területére kiterjedve folyamatosan haladt előre, a kormányváltások, és az egymást váltó államformák ellenére. Jól példázzák ezt az erőművek építési és üzembe helyezési dátumai, például a ma létező legnagyobb kapacitású spanyol vízerőmü az Aldeadávila I, II, mely a Duero folyón épült, két ütemben, 1956 és 1986 között. A folyó áramtermelő képességét kiaknázni kívánó vállalatot, a Saltos del Duerót 1918 júliusában alapították Bilbaóban. A spanyol kormány 1926 augusztusában adott teljes koncessziót a vállalatnak a Duero és mellékfolyói vízenergiatermelő kapacitásának kihasználására. Az erőmürendszer első tagja, a Salto de Ricobayo építkezése 1929-ben kezdődött és 1935-ben fejeződött be. Története tehát a Restaurációtól a Primo de Rivera diktatúrán át a Köztársaságig tart, és egy politikai rendszerek fölötti érdeket képviselt: az ország villamosítását, s ezáltal modernizációját. A váltakozó vízhozamú spanyol folyók vizének tározókba gyüjtése, s ezáltal az öntözéses mezőgazdaság szükségleteinek kiegyensúlyozott biztosítása, a rómaiak és az arabok idején is fontos szempont volt, és égető szükségletként jelentkezett Joaquín Costa idejében, a 19. sz. végi regeneracionismo gondolatkörében. ${ }^{137}$

A víztározó és vízerőmü építkezések a Franco korszakban, az 1950-es években vettek hatalmas lendületet, s a 70-es években mutatták a legnagyobb eredményeket. ${ }^{138}$ Amikor Fran-

\footnotetext{
${ }^{135}$ Ez a nagyvállalat Spanyolország társadalomtörténetébe is beleírta a nevét, a munkásai által indított, és róla elnevezett La Canadiense sztrájkkal, mely 1919-ben 44 napig tartott, félmillió munkás részvételével, s eredményeképpen 8 órára csökkentették a napi munka időtartamát. L. Vilar, Pierre, Spanyolország története, Budapest, Gondolat, 1984. 96. o.; Balcells, Albert, Cataluña contemporánea II. 1900-1939, Madrid, España Editores, 1984.

${ }^{136} \mathrm{~A}$ La Canadiense villamosenergia ipari vállalat történetéről szóló dokumentumfilm a TV3 archívumából http://www.rtve.es/alacarta/videos/otros-documentales/otros-documentales-gran-aventura-canadiensecanadiense-nacimiento-sueno/4021758/, letöltés 2017. ápr. 4.

${ }_{137}$ Joaquín Costa, Colectivismo Agrario en España, 1898, Política hidráulica (alcím Misión social de los riegos en España, Az öntözéses földmüvelés társadalmi küldetése Spanyolországban). Madrid, Biblioteca Joaquín Costa, 1911. A mü Aragónia és más mezögazdasági területek öntözéses vízgazdálkodásának tervét tartalmazza, s a víz feletti ellenőrzés és tulajdonlás különböző formáit taglalja. A régi Mequinensában az arab kultúra technikai eszköze, a víz összegyüjtésére, átemelésére, tárolására és szétosztására szolgáló vízkerék biztosította az öntözést (noria-anafora).

${ }^{138} \mathrm{http}$ :/hispagua.cedex.es/datos/energia\#ENERGIA_ESPA\%C3\%91A, letöltés 2017. ápr. 4.
} 
co átvette a hatalmat, a spanyol víztározók összkapacitása mindössze $3930 \mathrm{Hm}^{3}$ volt, halálakor pedig ez a tározókapacitás elérte a 40264 Hm³, azaz, több mint tízszeresére növekedett. ${ }^{139}$ Ez azt jelenti, hogy Franco kormányzásának 36 éve alatt épült ki az ország jelenlegi víztározókapacitásának 65\%-a. A demokratikus átmenet utáni időkben 1987-ig az építkezések nagy része a diktatúra alatt megkezdett építkezések vagy tervek megvalósítását jelentette $\mathrm{e}^{140}$, tehát az építkezések a demokratikus korszakban is megtartották rendszereken átívelő jellegüket.

Julio Llamazares (Vegamián, 1955-), leóni író maga is egy elsüllyesztett falu szülötte, melyet a Porma, majd később a tervezőjéről, Juan Benet ${ }^{141}$ víztározónak nevezett létesítmény nyelt el hét másik településsel együtt. Az író az El País oldalain keményen kritizálta a Felipe González kormány döntését, melynek értelmében a szocialista kormányzat 1982-től folytatta a Riaño víztározó 1965-ben megkezdett építkezését. A tározót csak erőszakkal, katonai erők bevetésével és kényszerkilakoltatással sikerült üzembe helyezni 1987. december 31-én, egy nappal az előtt, hogy életbe lépett volna az ilyen tározók létesítését tiltó Európa uniós szabályozás. Llamazares véleménye szerint lesújtó, hogy akik korábban kritizálták Francót a „fáraói” építkezéseknek nevezett óriás-beruházások miatt, hatalomra kerülésük után nem tudtak ellentmondani a környezeti és társadalmi károkat generáló, ám más szempontból szükségesnek tekinthető építkezéseknek, s még nagyobb érzéketlenséggel kezelték a témát, mint korábban a diktatúra. ${ }^{142}$

A víz tározókba gyüjtése Spanyolországban napjainkban is nemzetgazdasági jelentőségü kérdés, s ez továbbra is így marad, hiszen a World Resources Institute 2015-ös, a klímaváltozás következményeinek elörejelzéseit tartalmazó jelentése azt mutatja, hogy a közel-keleti országok után Spanyolország és Görögország is ott van a 2040-re vízhiánnyal küzdő orszá-

Franco egyik gúnyneve volt a „Paquito el Rano”, aki egyik víztározót avatta a másik után. A vízenergia felhasználás megoldást jelentett a súlyos energiahiányra, s teljesíthető lett a francói ígéret-jelmondat: Fényt minden spanyol otthonába, kenyeret minden spanyol asztalára -Ni un hogar sin lumbre ni un español sin pan.

${ }^{139}$ Los pantanos de Franco http://foros.periodistadigital.com/viewtopic.php?t=37198, letöltés 2017. ápr. 4.

A Fundación de Francisco Franco weboldala ismerteti Franco zászlóshajó programjait: víztározóépítés, az öntözéssel müvelt területek megnövelése, kolonizáció, és erdő újratelepítések. http://www.fnff.es/Obra_senera_de_Franco_embalses_regadios_colonizacion_y_repoblacion_forestal_Parte_1 1113 c.htm, letöltés 2017. ápr. 4.

$\overline{140}$ http://foros.periodistadigital.com/viewtopic.php?t=37198, letöltés 2017. ápr. 4.

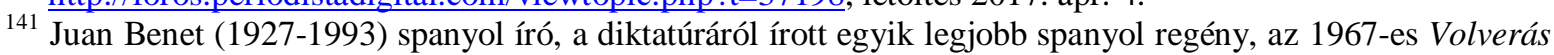
a Región szerzője. Stílusa radikálisan szakít a korban uralkodó realizmussal, Región egy képzeletbeli terület, a kritikusok a Porma víztározó környezetével azonosítják, amelynek Benet tervező mérnöke volt. http://www.escritores.org/biografias/923-benet-juan, letöltés 2018. máj. 1.

${ }^{142}$ Karina Sainz Borgo, Volverás a Vegamián, Llamazares rescata el pueblo que Benet sepultó bajo un pantano http://www.vozpopuli.com/cultura/Literatura-Novelas-Ficcion-Novela-Julio_Llamazares-Vegamian_0 779922050.html; http://elpais.com/diario/2007/06/24/eps/1182665761_850215.html, letöltés 2017. ápr. 4. 
gok listáján. ${ }^{143}$ Ezt kivédendő, Spanyolország változó vízhozamú mediterrán folyóin hatalmas víztározó rendszert épített ki száz év alatt, s ezzel negyedik a világ legtöbb, nagy víztározóval rendelkező országainak sorában. A spanyol folyók hozama 106000 Hm³ amelyből víztározók nélkül csak $9000 \mathrm{Hm}^{3-}$ t tudnának hasznosítani. A tározókban felfogott víz 80\%át a mezőgazdaság szükségleteire használják fel, a lakossági fogyasztás 8-10\%-ot, míg az ipari 12-15\%-ot tesz ki. Jelenleg 1312 vízerőmü létesítmény működik az országban ${ }^{144}$, melyek a spanyol villamos energia termelés 20\%-ának előállításáról gondoskodnak. A kormány weboldalán, ahol minden vízenergia felhasználással kapcsolatos adat megtalálható, jelzik a megújuló energiaforrások közé tartozó vízenergia hasznosítás hátulütőit is, köztük a társadalmi és demográfiai problémákat. ${ }^{145}$

Bár a kormányoldal, a víztározók és vízerőmüvek valamint a különböző nagyvállalatok honlapjai ${ }^{146}$ készségesen szolgálnak információval az erőművek teljesítményéről, a tározók vízkapacitásáról, az energiaárakról és a jövőbeli fejlesztési tervekről, arról azonban nem találtam hivatalos, összspanyolországi adatot, hogy hány település esett áldozatul a vízerőmủ építkezés száz éve tartó folyamatának. Egyes becslések megközelítőleg ötszáz településről beszélnek spanyolországi viszonylatban. ${ }^{147} \mathrm{Ez}$ a szám azonban jóval nagyobb is lehet, hiszen egy-egy víztározó, esetenként 3-4 települést is elnyelt, ${ }^{148}$ a Riaño víztározó például kilenc, a Porma víztározó nyolc kitelepített és lerombolt település hullámsírja. ${ }^{149}$ Vannak azonban olyan tározók is, mint a folyásirányban a régi-Mequinensa fölött elhelyezkedő mequinensai tározó, amelyek helyén nem voltak lakott települések. Mivel a víz alá süllyesztett települések szárazság idején újra előbukkannak, a helyi turizmus kiaknázza ezt a lehetőséget, s egyes régiók ezért közölnek adatokat a területükön található elsüllyedt tele-

\footnotetext{
${ }^{143}$ Global Water Risk Assessment http://www.wri.org/our-work/project/aqueduct, letöltés 2017. ápr. 5.

${ }^{144}$ http://hispagua.cedex.es/datos/energia\#ENERGIA_ESPA\%C3\%91A, letöltés 2017. ápr. 5.

${ }_{145} \mathrm{http://hispagua.cedex.es/datos/energia \# ENERGIA} \mathrm{ESPA \% C3 \% 91A,} \mathrm{letöltés} \mathrm{2017.} \mathrm{ápr.} 5$.

${ }_{146}$ Ezen az oldalon megtalálható az összes spanyolországi víztározóval kapcsolatos müszaki és gazdasági adat http://www.embalses.net/pantano-133-porma-juan-benet.html, letöltés 2017. ápr. 5.

147 http://www.traveler.es/viajes/al-natural/articulos/lo-que-el-embalse-se-llevo-pueblos-espanolessumergidos-bajo-el-agua/6189; http://pueblos-desiertos.blogspot.hu/2016/11/aceredo-orense.html, letöltés 2017. ápr. 5. Eugenio Bartolomé listája a különféle okok miatt elhagyott spanyolországi településekről. Köztük megtalálhatjuk a víztározók mélyére került települések leírását is. A Mequinenza a través del tiempo utolsó, a víztározó építkezésnek és a város megmaradásáért folytatott küzdelemnek szentelt fejezet szerzője, a mequinensai Andrés Coso Catalán maga is az ENHER dolgozója volt (1964-2002). Kérdésemre elmondta, hogy ő sem talált ezzel kapcsolatban hivatalos adatokat.

${ }^{148}$ https://pueblosdelolvido.wordpress.com/2016/01/17/trago-de-noguera-lleida/, letöltés 2017. ápr. 4.

149 https://es.wikipedia.org/wiki/Embalse_de_Ria\%C3\%B1o, letöltés 2017. ápr. 4.
} 
pülésekről. ${ }^{150}$ Leleményes vállalkozók magas vízszint idején is izgalmas sportlehetőséget kínálnak, a turisták víz alatti templomokat látogathatnak búvárfelszereléssel. ${ }^{151}$

A világ jelenleg létező legnagyobb vízenergia termelő erőműve a Kínában található Három Szurdok erőmü a Jangcén, melynek megépítéséhez a felvíz által elöntött területről 1,3 millió embert kellett kiköltöztetni: 13 várost, 140 kisvárost, és 1350 falut. ${ }^{152}$ A vízerőművek áramtermelésében világelső Kína adatai mellett a spanyol számok jelentéktelennek tünnek, a fejlődés logikája pedig megkérdőjelezhetetlenné teszi a közösségek számára nagyobb jót ígérő haladás érdekében hozott áldozatokat. Az érem másik oldalán ott találjuk azonban az ipari termelés és modernitás szolgálatára átalakított természetet, mely folyamat szélsőséges formái ellen a természetvédők és a zöld politikai pártok tiltakoznak. Bennünket a víztározó építkezések során elpusztított emberi kultúra lenyomatai érdekelnek ${ }^{153}$, mint az egyik legjobb kortárs katalán regénynek tartott régi Mequinensa krónikája. Az író kora tehát, a vízerőmű építések kora is, melynek negatív következményei a természetvédőkön kívül csak az érintett területek kiköltöztetett lakossága számára váltak nyilvánvalóvá. Az ő tragédiájukat dokumentarista céllal megörökítő írások mellett néhány irodalmi alkotásban is felbukkan ez a téma. ${ }^{154}$ Julio Llamazares egy interjúban úgy fogalmazott, hogy a víztározó építkezések miatt kitelepített lakosság története a zsidók kiűzésének 20. századi változata, rokonítja őket a szefárd kulcs legendája, hisz a víztározók száműzöttjei is magukkal vitték a házuk kulcsát, pedig tudták, hogy nem térhetnek vissza elárasztott otthonaikba. ${ }^{155}$

A víztározók kérdését azért igyekeztem részletesebben, és a Franco-korszakénál tágabb időben tárgyalni, mert úgy vélem, hogy országos és százados távlatban tekintve Mequinensa tragikus pusztulása nem különleges és kivételes esemény. Beleilleszkedik a Franco rendszer által is folytatott modernizálási folyamatokba, s bár bizonyos kérdésekben lehetett szerepe annak, hogy „vörös” város volt, és katalánok lakták, amint azt lakói az interjúkban megfo-

\footnotetext{
${ }^{150}$ http://www.turismoreinodeleon.com/embalses/pueblos-anegados/, letöltés 2017. ápr. 4.

${ }^{151}$ http://www.traveler.es/viajes/al-natural/articulos/lo-que-el-embalse-se-llevo-pueblos-espanolessumergidos-bajo-el-agua/6189, letöltés 2017. ápr. 5.

152 http://www.vizinform.hu/pic/kepek/vizenergia.pdf, letöltés 2017. ápr. 5.

153 Aragónia víztározó építkezés során elpusztult településeinek nyomát „,új népdalok”, habanerák, rondák, bolerók is örzik. L. https://www.letras.com/la-ronda-de-boltaa/457977/; https://www.letras.com/la-ronda-deboltaa/457978/, letöltés 2017. ápr. 10. Témájuk a szülőföldjükről elmenni kényszerülő emberek fájdalma és emlékei. Köszönet egy franjai diáknak, aki felhívta rájuk a figyelmemet egy Moncada előadás után az UAB-on.

${ }^{154}$ Teresa Viejo, La memoria del agua (Szent Izabella Királyi Gyógyfürdő, Kasztília); Ana Maria Matute, El río (Mansilla, La Rioja), Julio Llamazares, Distintas formas de mirar el agua (Vegamián, León).

${ }^{155} \mathrm{http} / / / \mathrm{www}$.vozpopuli.com/cultura/Literatura-Novelas-Ficcion-Novela-Julio_Llamazares-Vegamian 0 779922050.html, letöltés 2017. ápr. 5. Ugyanez a motívum megjelenik a regényben is. Llamazares, Julio, Distintas formas de mirar el agua, Barcelona, Pinguin Random House, 2016. 28-9. o. Az egyik föszereplő emlékezetében az otthonuk után rájuk váró átmeneti szállásnak szánt barakkok képe a náci koncentrációs táborokét idézi, mert akaratuk ellenére terelték őket oda, s nem volt emberi élethez méltó hely.
} 
galmazták, s amint a szájhagyomány tartja ${ }^{156}$, és Moncada is jelzi A folyók városa oldalain, de az elpusztítására irányuló döntést nem ezek a motívumok irányították elsősorban. Kivételesnek tekinthető azonban a város közösségének a megmaradásáért folytatott eredményes harca, és a város történetének irodalmi mítosz formájában való fennmaradása.

\subsection{Helytörténeti monográfia}

A Mequinenza a través de la historia ${ }^{157}$ c. történeti nagymonográfia egy kis aragóniai katalán közösség története, mely természetesen spanyolul íródott. Szerkesztője, Jordi Estruga $^{158}$ a bevezetőben utal a Mequinensával foglalkozó főbb publikációkra. Ezek közül elsőként Jesús Moncada műveit említi, melyeket - mint mondja - nem kíván bővebben ismertetni, mivel ezt az irodalomtudomány müvelői már megtették. Megállapítja, hogy a városkával foglalkozó művek bibliográfiája nem túl terjedelmes. A város történelmével három általános tematikájú kiadvány valamint tizenegy helytörténeti és nyelvészeti témájú monográfia foglalkozik. A nagymonográfia szerzői, akik egyrészt a Barcelonai Egyetem történészei, s adott korszak szakértői, másrészt pedig helytörténészek vagy autodidakta helytörténészek különböző levéltárakban (Városi Levéltár Fraga, Lleida, Mequinensa, Saragossa; Aragón Korona Levéltára Barcelona; Medinacelli Herceg Levéltára, Sevilla; Saragossa Provincia Levéltára; Jordi Estruga magánlevéltára, Barcelona; Nemzeti Történeti Levéltár, Madrid; Katalán Nemzeti Könyvtár, Barcelona) végeztek a város történetével kapcsolatos kutatásokat. Vizsgálódásunk körébe csak a Jesús Moncada regények által feldolgozott száz esztendő történeti bemutatása tartozik.

A Restauráció 1875-1931, a Primo de Rivera diktatúra (1923-1931), azaz a 7. fejezet, valamint a II. Köztársaság (1931-1939), a polgárháború (1936-1939) és az 1949-ig tárgyalt Franco korszak, azaz a 8. fejezet szerzője David Tormo Benavent, a történettudomány dok-

\footnotetext{
${ }^{156}$ Idézek a Mequinenza a través de la historia társszerzőjével, a mequinensai származású Andrés Cosóval folytatott magánlevelezésemből: „Mindig azt hallottam a mequinensai öregektől, hogy a mi városunkra igencsak görbén néztek a fövárosban, Saragossában (teli Franco párthíveivel, hadi létesítményekkel, katonatisztekkel és egyházi intézményekkel, mint Torrelloba a Galeria de les Estàtues című regényben), s ennek két fö oka volt: az Els fets de Vallcomuna, (azaz a mequinensaiak által a 19. század végén elkövetett rablógyilkosság) és az, hogy Saragossa provinciában a polgárháború idején Mequinensa volt az egyetlen város, amely kitartott a Köztársaság oldalán. Én még hozzátenném a bányászsztrájkokat és azt, hogy a város katalánul beszél.”

157 Estruga Estruga, Jordi (dir.), Mequinenza a través de la historia, Mequinenza, Ayuntamiento de Mequinenza, 2010.

${ }_{158}$ Jordi Estruga mequinensai gyökerủ, Barcelonában élő műszaki értelmiségi, aki egyben a katalán antik könyvgyüjtők szövetségének elnöke. Hatalmas házi könyvtárában/levéltárában ritka ősnyomtatványok, kódexek, eredeti történeti dokumentumok ezreit őrzi.
} 
tora. A régi Mequinensa pusztulásához vezető, 1957-1973-ig tartó periódus krónikája, a monográfia utolsó, 9. fejezete, Andrés Coso Catalán munkája, aki egy mequinensai százmazású autodidakta helytörténész, az ENHER egykori dolgozója. Ennek a megközelítőleg száz évnek a történetét a nagymonográfia 110 oldalnyi terjedelemben tárgyalja, melynek körülbelül fele foglalkozik az 1875-1957-ig tartó hetvenkét év eseményeivel, a másik fele az 1957-1973-ig tartó tizenhat év történetét dolgozza fel. Az évek és az oldalak száma közötti aránytalanság annak köszönhető, hogy a város életének legnagyobb történelmi eseménye erre az utolsó tizenhat esztendőre esett, melynek során elpusztult a régi Mequinensa, és felépült az új. A történeti monográfia tehát hasonló hangsúllyal ábrázolja az időt, mint a regény, melynek „anyagát a régi Mequinensa elmúlt száz esztendejének eseményei alkotják, s főként azok, amelyek sorsát az 1957-es esztendőtől kezdve visszaordíthatatlanul meghatározták”.

A nagymonográfia az ország történelmének általános keretére építi rá a lokális szempontból fontos eseményeket, melyeknek csak így tud kontinuitást biztosítani, hiszen a helyi levéltár egy tűzvész következtében 1870-ben megsemmisült ${ }^{159}$, s a benne később felhalmozódott anyag sem szolgál bőséges adatokkal a teljes várostörténet kirajzolásához. Megállapítja, hogy bár a liberális állam 1850-től arra kötelezte a községeket, hogy saját politikai életükről készítsenek hivatalos feljegyzéseket, a Mequinensai Levéltárban csak 1919-től kezdve találunk adatokat. ${ }^{160}$ A több forrásból összeszedett gazdaság- és politikatörténeti anyag korántsem fedi le a száz évnyi történelmi időt, a hiátusokat az ország, valamint Aragónia és Katalónia történelmének központi korpusza alapján valószínűsíti a történész szerző.

\subsection{Restauráció, Primo de Rivera diktatúra, II. Köztársaság, Polgárháború,} Franco korszak Mequinensa történeti monográfiájában

A Restauráció korának első, történeti hitelességü eseménye a vallcomunai gyilkosság esete 1877-ben, melyet irodalmi formában Jesús Moncada Estremida memòria című regé-

\footnotetext{
159 Jesús Moncada, Estremida memòria 118. o. A regényben annak indoklásaképp örökíti meg a Városi Levéltár megsemmisülését, hogy nem tudja pontosan megállapítani, mikori eredetű a Borbó személynév Mequinensában. Andrés Coso, aki helytörténeti és családtörténeti kutatásokat végzett a levéltárban, szintén említi egy levelében, hogy csak az 1874-ben született anyai nagyapjának találta meg a születési anyakönyvi kivonatát, a nála pár évvel idősebb apai nagyapjáét azonban már nem, mert a levéltár leégett (nincs pontos évszám, hogy mikor).

${ }^{160}$ Estruga, J. (dir.), 243. o. Lehetséges, hogy ezt a szájhagyományon kívül más hiteles történeti adat nem támasztja alá.
} 
nye dolgoz fel. A monográfia a regényre és a Moncada által is felhasznált dokumentumokra hivatkozva mutatja be a történteket. ${ }^{161}$

A következő téma, melyet a monográfia tárgyal, a szénkitermelés felfutása. Ezt a szerző az I. világháború okozta konjunktúrával hozza összefüggésbe, s megállapítja, hogy az első nagy iparvállalat, mely a mequinensai lignitre építette energiaellátását, a flixi Elektrokémiai Üzem volt, amely már 1904-től kezdett kitermelési jogot vásárolni a környéken saját szükségleteinek ellátására. Az I. világháború előtt csak a helyi ipar (édesgyökér-kivonat gyár, olajütő, cementgyártás, mészégető kemencék) számára termelö mequinensai bányák száma megsokszorozódott, s az adatok tanúsága szerint a nemzeti széntermelésnek addig alig 7\%át biztosító szénmedence a háború alatt az össztermelés 30\%-át adta. ${ }^{162}$ A monográfia a rendelkezésére álló adatok alapján - bár felteszi, de - nem tudja hiteles történeti dokumentumokra támaszkodva megválaszolni a kérdést, hogy a bányák számának növekedése milyen munkásszervezeteket alakított ki a városban. Ebben az időszakban nincsenek adatok munkaügyi konfliktusról vagy sztrájkról a szénmedencében ${ }^{163}$ annak ellenére, hogy a bányászok hagyományosan a munkásosztály legszervezettebb és legharciasabb rétegét alkották. Az aragóniai anarchista és szocialista munkásszervezetek történetét feldolgozó monográfiák sem említik, hogy Mequinensában léteztek volna szakszervezetek vagy munkásmegmozdulások. Regisztrálja viszont a szerző az első világháború utáni bányabezárásokat és a lakosság 20\%-os csökkenését, s jelzi, hogy az elvándorlás iránya általában Barcelona.

A következő témacsoport a választások: A Primo de Rivera diktatúráig tartó időszakban két választási ciklus volt, amelyben a mequinensaiak nem gyakorolták választójogukat, mert az 1907-es választási törvény 29-es cikkelye lehetővé tette, hogy automatikusan iktassák be a jelölteket, ha azok épp annyian vannak, mint a képviselői helyek száma. Ebből a tényből a szerző arra következtet, hogy a mequinensai politikai élet irányítása a dinasztikus pártok kezében volt, s ellenzéki pártok (republikánus, karlista, szocialista) nem léteztek a városban. A szerző szerint az, hogy ebből az időszakból nincs adat se politikai se társadalmi se munkaügyi konfliktustól, azt jelenti, hogy Mequinensa élete nyugodt volt, s politikai életét a szabályoknak megfelelően a helyi kacika irányította. Az Estremida memòria címü regényben Moncada által ábrázolt 19. század végi városkép alátámasztja a történész feltételezését.

A Primo de Rivera diktatúra idején a monográfia szerzője által feldolgozott városi akták főként a modernizálás tényét erősítik meg. A korszak fejlesztései a következők: a városi

\footnotetext{
${ }^{161}$ Estruga, J. (dir.), 238-41. o. MCSL 4. Az Estremida memòria című regény eredeti dokumentumai.

${ }^{162}$ Estruga, J. (dir.), 242. o.

${ }^{163}$ Uo.
} 
közvilágítás és az ivóvízhálózat bevezetése, egy új, országos szinten is korszerünek számító iskolaépület, az Ebrón átvezető híd megépítése, valamint csendőrőrs és posta/távíró állomás létesítése a városban. ${ }^{164}$ A korszakban a városban jelzett iparágak a következők: malomipar, oliva olajgyártás (olasz és francia exportra), szappangyártás, tíz müködő bánya, (szállítás csak vízen, nincs vasút), édesgyökérkivonat gyártása gyógyszeripari célokra.

A Köztársaság éveinek ábrázolásához a történész a Mequinensai Városi Levéltár jegyzőkönyveit dolgozta fel. (Ugyanezeket a dokumentumokat tanulmányozta és jegyzetelte ki Jesús Moncada is, a Moncada hagyatékban talált kéziratos jegyzetek tanúsága alapján. ${ }^{165}$ ) A köztársaság idejéből közli az egymást követő városvezetőségek tisztviselőinek listáit, és a korszak fö konfliktusai között tárgyalja az elektromos ellátást biztosító céggel zajló árvitát, a munkanélküliség megfékezésére tett önkormányzati javaslatokat és erőfeszítéseket, a központi kormány javaslatát a telefon bevezetésére, amelyet a testület forráshiány miatt leszavazott. Az 1934. november 7-i ülés jegyzőkönyve rögzíti, hogy a város vezetősége (a történész nem rendelkezik pontos adatokkal, de azt valószínüsíti, hogy a Lerroux-féle radikálisok, de mindenképpen a köztársasági jobboldal hívei) elítéli az asztúriai és a katalóniai eseményeket, és üdvözli a kormány és a hadsereg által a rend helyreállítására hozott intézkedéseket, melyek finanszírozására pénzügyi támogatást is megszavaz. Vitákat váltott ki a testületen belül a Primo de Rivera idején a városba helyezett csendőrosztag lakhatásának anyagi fedezete, amit a köztársasági balszárnyhoz tartozó tanácstagok nem akartak támogatni.

A városi aktákból kiderül, hogy a vezetőség sok esetben tárgyalt a vallás tárgykörébe tartozó ügyekről ${ }^{166}$, ami azt mutatja, hogy a kisváros mindennapjait átszövő vallásos jellegü események megszokott rituáléi a köztársasági törvénykezés fényében új megvilágítást kaptak. Tekinthető-e például vallásos demonstrációnak egy katolikus temetés, melyben a menet élén pap halad, s magasra emelik a keresztet? Engedélyezzék-e a szokásos éves búcsút, mely a város védőszentjének ünnepe, tehát vallásos tartalommal bír? Azaña 1933. június 2-i törvénye a vallásokról és a vallási gyülekezetekről lehetővé tette, hogy a polgármester maga döntsön a kérdésben. Ő azonban, a jegyzőkönyvek tanúsága szerint, hogy biztos legyen döntése helyességében, a Civil kormányzósághoz fordult, ahonnan azt válaszolják, hogy 1933.

\footnotetext{
${ }^{164}$ Estruga, J. (dir.), 244-258. o.

165 Ezek kézzel írott jegyzetek, melyeket Jesús Moncada a városi levéltárban készített. Az első kijegyzetelt jegyzőkönyv 1931. május 24-i ülésről, az utolsó pedig az 1936 június 20-i ülésről készült. Érdekességük, hogy katalán nyelvüek, pedig a városi levéltár iratai spanyol nyelvüek, hisz Mequinensában a közigazgatás nyelve spanyol. Úgy gondolom, hogy ez a jegyzetelési mód is a spanyolul tökéletesen tudó Jesús Moncada katalán nyelv iránti elkötelezettségét tanúsítja.

${ }^{166}$ Estruga, J. (dir.), 274-6, 279-80. o. A monográfiában feldolgozott, vallással kapcsolatos kérdések mindegyikéről készített jegyzetet Jesús Moncada.
} 
szeptember hónapjában engedélyezik a hagyományos formában megtartott katolikus temetéseket. Az aktákból kiderül, hogy ez ellen tiltakozott a városvezetőség egyik tagja, Vidallet ${ }^{167}$, aki kifogásolta, hogy ugyanakkor az UGT helyi szervezete által május elsejére tervezett demonstráció nem kapott engedélyt. Az akták alapján a városvezetőség ebben az időszakban általánosságban nem tanúsított harcos antiklerikális álláspontot, s az is látszik, hogy igyekszik elhatárolódni a szélsőségektől, melyek közé az 1933. szeptember 13-i általános közgyülés jegyzőkönyve szerint odaszámította az UGT május elsejei felvonulását is. ${ }^{168}$

A katalán történelemmel foglalkozó történész számára nagyon érdekes annak az 1932. május 15-i ülésnek a jegyzőkönyve, amelyben Mequinensa városvezetősége Catalayud városának javaslatát tárgyalja. Ez felszólítja Mequinensát, hogy csatlakozzon a corteshez benyújtandó kérvényükhöz, amelyben tiltakoznak a Katalán Statútum elfogadása ellen. Mequinensa elöljárói kijelentik, hogy ellenzik a katalán autonómiát, mert az lerombolná Spanyolország területi egységét, valamint a spanyol nép és a spanyol államhatalom egységét. Emellett határozottan tiltakoznak a katalán statútum 4-es cikkelyéből fakadó lehetséges következmények ellen, melyek az olyan településekre vonatkoznak, mint Mequinensa, ahol az emberek katalánul beszélnek, ám - fogalmaz a jegyzőkönyv - a katalán javaslat nem veszi figyelembe „az ilyen települések érzelmileg aragón beállítottságát, hisz ezek inkább választanák a megsemmisülést, minthogy olyanokhoz csatlakozzanak, akik soha el nem mulasztják kinyilvánítani az Anyanemzet és a Haza iránti ellenszenvüket”. ${ }^{169}$ E kijelentés szerint az akkori vezetés nemzeti érzelmei teljesen kompatibilisek voltak a spanyol nacionalizmus haza fogalmával, a katalánok Pi i Margall gondolatáig visszamenő federalizmusával azonban nem. A történész szerző valószínűsíti, hogy a polgári köztársasági jobboldal véleményével van dolgunk, mely nem szimpatizált sem az asztúriai bányászsztrájkkal, sem a katalán függetlenség kikiáltásával, sem pedig a federatív elképzelésekkel. A városvezetőség változása következtében azonban 1936 májusában Mequinensa már követeket küldött az Aragón Statútum tervezet kidolgozását előkészítő gyülésre Caspba.

Az 1936 februári országos választásokon Mequinensában elsöprő győzelmet arattak a népfront jelöltjei (1182 népfront és 151 CEDA konzervatív koalíció szavazat). Az 1931 áprilisában megválasztott, valószínűleg a Lerroux-féle radikálisokhoz tartozó helyi vezetősé-

\footnotetext{
${ }^{167}$ Vidallet neve megjelenik a Moncada családi levéltárban található jegyzetekben is, amelyekben Jesús Moncada a törzsközönség politikai pártállása szerint feltérképezi a város kávéházainak törzsközönségét. Itt a következőt olvashatjuk Alejandro kávéházáról: „a város baloldali szervezeteinek (ERC és a szocialista párt) törzshelye. Ez a városban létező egyetlen politikailag tudatos, párt formájában szervezett erő. Oda járt Torrent bácsi, Castelló bácsi, az apja, Jacinto, Manolo Canero és a többi ERC tag, meg a szocialista Vidalletek”.

${ }^{168}$ Estruga, J. (dir.), 275. o.

${ }^{169}$ Estruga, J. (dir.), 272. o.
} 
get a mequinensai népfront képviselői lemondásra szólították fel, s később korrupcióval vádolták. A történész által nyomon követett események továbbra is az addig felmerült vitás kérdések megoldatlanságát jelzik: 1. éleződő harcok az egyre szélsőségesebbé váló köztársasági bal és jobb oldal között; 2. munkanélküliség csökkentésére közmunka javaslatok: útépítés Mequinensa és Faió közt, mely vasúti összeköttetést biztosított volna a városnak, tanárlakás építés, erdősítési terv, mosóház építés terve; 3. egyház és vallás kérdésében a balra tolódott önkormányzat a temetési menetek és a harangszó betiltását tárgyalja, mely antiklerikális intézkedések a helyi katolicizmust az otthonok falai közé szorították, s kiélezték az ellentéteket; 4. bányászsztrájk: az 1936. április 11-i gyülésen a bányászok sztrájkbizottsága a városvezetőség közbenjárását kéri az alacsony bérek és a rossz munkakörülmények miatti helyzet javítására. A május 23-i ülésen a polgármester egy távirat üzenetét közvetíti a bizottságnak, mely Saragossába hívja a mequinensai sztrájkolókat. ${ }^{170}$ A szerző kiemeli, hogy levéltárban található dokumentumok alapján egészen eddig az esetig nem bizonyítható, hogy Mequinensa fejlett bányászata ellenére sztrájkok vagy egyéb munkaügyi konfliktusok színhelye lett volna. ${ }^{171}$ Erre az adatra, mint látni fogjuk, A folyók városa által rögzített emlékezet rácáfol. A monográfia a szervezett munkásság jelenlétének igazolására sem talál hitelt érdemlő adatokat 1932 februárjáig, amikor a szocialista Vida Nueva lap közölte, milyen tagsággal rendelkezett az UGT Saragossa provinciában. Mequinensában a szakszervezet 359 tagot számlált, mellyel első volt a caspi körzet települései közt. ${ }^{172}$

A polgárháború tárgyalásakor a szerző felvázolja az általános aragóniai képletet: a felkelők oldalán állók a terület legnagyobb részén elsöprő győzelmet arattak, ami lehetetlenné tette a köztársasági ellenállást. ${ }^{173}$ Cabanellas tábornok, a Saragossában állomásozó 5. hadosztály élén a számottevő munkásság ellenállása ellenére már július 19-ére elfoglalta az aragón fövárost, és rendkívüli állapotot hirdetett. A mequinensai eseményekről nincs adat, az utolsó, II. Köztársaság idejéből származó jegyzőkönyv 1936. június 20-án kelt, s ez az utolsó, Moncada által kijegyzetelt esemény dátuma is. A városi levéltárban nem találhatók a polgárháború idejéből származó dokumentumok. A Felkelés Mequinensában, az Elnyomás és terror a köztársasági hátországban, avagy a forradalmi igazságszolgáltatás, A kollektivizáció és Az Aragón Tanács című alfejezetek mindegyike aragóniai történeti monográfiák-

\footnotetext{
${ }^{170}$ Estruga, J. (dir.), 280. o.

${ }^{171}$ Uo.

172 Luis G. Germán, Historia del socialismo en Aragón PSOE-UGT (1879-1936), Zaragoza, Facultad de Ciencias Empresaliales y Económicas de Zaragoza, 1979. 138. o. és Estruga, J. (dir), 270. o.

${ }^{173}$ José Luis Ledesma, Los dias de llamas de la revolución. Violencia y política en la retaguardia republicana de Zaragoza durante la guerra civil. Zaragoza, Institución Fernando el Católico, 2003, 48. idézi Estruga, J. (dir.), 281. o.
} 
ból ${ }^{174}$ vett adatokra támaszkodva igyekszik megrajzolni a mequinensai események képét. E müvelet során a helyspecifikus adatok hiánya miatt a monográfia szerzője a mequinensai szóbeli emlékezetre támaszkodik a konkrét események ismertetésekor, ezért gyakran találkozunk „úgy tünik”, „mint mesélik”, „bár nehéz összeállítani a kaotikus események kronológiáját” fordulattal kezdődő mondatokkal. A mequinensaiak, „mint mondják”, a felkelésről a rádióból értesültek, s alakult egy helyi bizottság „nem tudjuk pontosan” milyen összetételü és mikor, s ennek egyik legfontosabb feladata a vérontás megakadályozása volt. Ezért a helyi jobboldal kiemelkedő személyiségeinek azt javasolták, hogy maradjanak otthon, és ne mutatkozzanak az utcán. Közben Katalóniából milicista osztagok érkeztek Aragóniába és visszavették a felkelőktől Casp városát, és ott rendezték be az Aragónia Védelmének Regionális Tanácsa, irányító szervezet székhelyét. ${ }^{175} \mathrm{~A}$ szerző megállapítja, hogy „bár nem rendelkezünk semmiféle összefoglaló tanulmánnyal az aragón republikánus zóna hátországában elkövetett kivégzések számát illetően”, az áldozatok száma 3000-re tehető. ${ }^{176}$ Megtudjuk, hogy Mequinensába gyakran érkeztek anarchista osztagok Fragából ${ }^{177}$, de még inkább Caspból, Aragónia anarchista irányítás alatt álló területének fővárosából. „Úgy tünik”, hogy a tisztogatást leginkább a Caspból érkező osztagok sürgették, amelyek többször fordultak a Mequinensát irányító bizottsághoz egy nyolcvan fős listával, követelvén az ott szereplő jobboldaliak kivégzését. „Úgy tünik”, hogy a helyi bizottság válasza mindannyiszor ugyanaz volt: saját ügyeiket maguk kívánják elrendezni. Ezek a gyakran szereplő mondatkezdetek azt mutatják, hogy a helyiek emlékezetére támaszkodó történész, David Tormo Benavent akinek kutatási munkássága a republikánus zóna hátországában végbement erőszakcselekmények feltérképezésére irányul, s a fejezetben általa idézett forrásmunkák között egy az anarchista vérengzéseket bemutató munka is szerepe ${ }^{178}$-, bár kénytelen a helyi emlékezetre támaszkodni, azt mégsem tekinti teljesen megbízható forrásnak.

\footnotetext{
${ }^{174}$ Ezeket a konkrét hivatkozásoknál jelzem.

${ }^{175}$ Ezek az adatok szintén a Ledesma könyvböl származnak, Mequinensából nincs adat. A libertárius kommunizmus hátországbeli tevékenységét a Ledesma könyv mellett mükedvelő helytörténészek és hagyományőrző egyesületek kiadványaira támaszkodva vázolja fel a szerző.

${ }^{176}$ Estruga, J. (dir.), 284. o. Az adat a SBHAC (Sociedad Benéfica de Historiadores Aficionados y Creadores) amatőr történészek társasága adatbázisából való www.sbhac.net, letöltés 2019. április 29. A köztársasági emlékezetet örző oldal azonban Saragossa provinciában 6546 azonosított áldozatot jelöl 2005-ben, az 1999-es, Santos Julià által végzett kutatások eredményeképp pedig 6029-et. Ezek egyike sem egyezik a monográfia adataival, mely forrásként hivatkozik az oldalra http://www.sbhac.net/Republica/Victimas/WinAux02.htm, letöltés 2019. április 29.

177 MCSL Entrevista amb Joaquim del Patriciet a jegyzet így szól: „A fragaiakkal az a probléma 1937-ben volt."

${ }^{178}$ Toni Oresanz, L’òmnibus de la mort: parada Falset, Badalona, Ara Llibres, 2008. Ez a munka a Halálbrigád útját követi nyomon, amely Katalónia nyugati szélén és a Franja településein (köztük Mequinensában) hajtott végre forradalmi ítéleteket.
} 
Ledesma könyve, és a mequinensai helytörténészek csoportja által kiadott visszaemlékezések könyve ${ }^{179}$ két kivégzést tart számon. Az egyik áldozat Mequinensa papja, a 83 éves Juan Aixalá Verdes, akit 1936 július 28-án végeztek ki, mert „mint a szóbeli hagyományból megtudjuk" hiába figyelmeztették többször is, hogy meneküljön, ő inkább a maradást és a halált választotta. ${ }^{180}$ A szerző Ledesmát idézi, akinek az a hipotézise, hogy a pap kivégzése „súlyos morális teherként nehezedik majd a város kollektív emlékezetére”. ${ }^{181}$ A monográfia szerzője kiemeli, hogy Caspban az anarchisták csak július 25-én vették át a hatalmat, vagyis a pap halálába igen hamar beleegyezett a közösség, amire hatással lehetett az 1936 során egyre erősödő egyházellenes hangulat is. „Ezen a ponton nem tudunk egyetérteni azzal, hogy a helyi bizottság aktív ellenállást fejtett ki a caspi osztagok követeléseivel szemben, bár értékeljük, hogy a mequinensai döntésnek két ember halála árán 78 ember megmenekülését sikerült elérnie” - mondja a történész szerző, aki az összeredményt pozitívként könyveli el, de nem enged teret a szóbeli hagyomány heroizálási kísérletének. A pap kivégzésének időpontja, három nappal a caspi anarchista hatalomátvétel után, azt valószínüsíti, hogy a közhangulat és az események logikája értelmében ő volt a leginkább „,beáldozható” személy, akinek megmentésén nemigen fáradoztak.

A másik áldozat, José Moré Matienzo gazdag kereskedő volt, a helyi jobboldal egyik legkiemelkedőbb képviselője, akit egy hónappal a pap után, 1936. augusztus 28-án végeztek ki. A szerző itt újra Ledesmát idézi, aki szerint a kereskedő kiválasztásában „szerepet játszhatott az is, hogy a városban az ő nevéhez kapcsolták egy szindikalista meggyilkolását a diktatúra idején, de ezzel kapcsolatban nem sikerült más anyagot, adatot, dokumentumot fellelni. Sokak számára az ő kivégzése erkölcsi igazságszolgáltatást jelentett.”182 Ennek az erkölcsi motívumnak a jogosságát emeli ki Moncada A folyók városában. A nagymonográfia kétszer is nyomatékosan hangsúlyozza ${ }^{183}$, hogy a republikánus zóna hátországában elkövetett anarchista vérengzések tükrében „Mequinensa dicséretes kivételnek szá-

\footnotetext{
${ }^{179}$ Estiu ardent. Acción del alto de los Auts, Huesca Grupo de Investigación Coses del Poble, 1996. 151. o.

180 Estruga, J. (dir.), 284-285. o. Ugyanígy mesélte el a pap halálát Hèctor Moret, mikor az eseményről kérdeztem: a pap a többszöri figyelmeztetés és menekítési kísérletek ellenére mindig visszatért a parókiára. ${ }^{181}$ Uo. 285. o.

182 Uo. Ez a megfogalmazás „szerepet játszhatott” szintén arra utal, hogy egy a kollektív emlékezetben megörzött és szájhagyomány útján terjedő értelmezéssel van dolgunk. Ezt a két esemény közötti oksági kapcsolatot, melyet a mequinensai szájhagyomány fenntartott, ugyanebben a formában megerősítette nekem levélben Hèctor Moret költő, nyelvész és Andrés Coso mérnök, autodidakta helytörténész is, mindketten mequinensai származásúak. A szindikalista halála szerepel a Moncada hagyaték interjúiban, l. MCSL Entrevista amb l'oncle Joaquim del Patriciet. Ez a szindikalista Blanco halálát a Fostigueres polgármester által kiadott parancsnak tulajdonítja. Ezt a nevet sehol sem találtam a monográfiában közölt városvezetőségeket jelölő listákon (1920-31).

${ }^{183}$ Uo. 284-285. o.
} 
mít”, s hogy a két kivégzés „a körzet más településein történtekhez viszonyítva igen alacsony számnak tekinthető”. Ennek hangsúlyozása a regény lapjain is fontos szerepet kap.

Ledesma könyvéből származó adat a nagymonográfiában, hogy a forradalmat követő általános ikonoklaszta lázban égő nép, közcélokat szolgáló helyiséggé alakította át a templomot. Mequinensában köztársasági garázzsá és autószerelő mühellyé, s a többi köztársaságpárti aragóniai településhez hasonlóan a szobrokat és a kegytárgyakat itt is nyilvánosan elégették. A templom-garázs motívum szerepel A folyók városában is. A Jesús Moncada által feljegyzett anekdoták, között találtam egy erre a történeti adatra teljesen rímelő feljegyzést $^{184}$ Joaquima la Faionáról, aki a mequinensaiak által eltartott koldusasszony volt, s akit mindenki nagyon szeretett. „Július 18-án - pontosabban inkább 19-én vagy 20-án amikor a Zaragoza utcai kápolnából kidobták a Szent Balázs szobrot, Joaquima épp arra járt, s nekiadták, mert fából volt, hogy tüzelje el, s ö így is tett.” - mondja a történet.

Szintén Ledesma könyvének adatait felhasználva állapítja meg a monográfia szerzője, hogy Mequinensában a földeket nem kollektivizálták, a bányákat pedig pszeudokollektivizálták, mert megosztott irányításuk a dolgozók és a helyi városvezetés kezébe került. Ez szintén mérsékelt forradalmi magatartásról tanúskodik, s azt engedi sejteni, hogy Mequinensában nem torkollottak anarchiába az események, a helyi vezetés elég erös volt ahhoz, hogy a maga módján szervezze meg a társadalmi átalakulás során a termelés kontrollját. A regény által kirajzolt kép is ezt erősíti. A helyi összefogás és a létező saját álláspont meglétét bizonyítja egy a Ledesma könyvben dokumentált és a monográfiában is átvett esemény: 1936 novemberében egy 40 tagú milicista különítmény érkezett Fragából, hogy végrehajtassa a kollektivizációt. Elfoglalta a távirati irodát, de a helyi lakosoknak sikerült elkergetni őket. ${ }^{185} \mathrm{Ez}$ az esemény szerepel az egyik Jesús Moncada riportban is, ahol az anarchistákat elkergető mequinensai nők történetének hitelességét az író a vox populi vox dei elvvel bizonyítja. ${ }^{186}$ A monográfia szerzője nem a mequinensai nők hősies győzelmeként könyveli el az eseményt, mint az anekdota. A történész az anarchisták sikertelenségét

\footnotetext{
${ }^{184}$ MCSL Història de Joaquima la Faiona captaire de Mequinensa.

${ }^{185}$ Erről az eseményről is Ledesma könyve tudósít, idézi Estruga, J. (dir.), 286. o. Ez az esemény (vagy az anarchista látogatások közül egy másik) ismert és bizonyos családokban, például a Moncada családban újra és újra elmesélt történet.

186 „Egyszer, a polgárháború alatt állig felfegyverzett anarchista különítmény érkezett, hogy átvegye a hatalmat nálunk, és likvidálja a burzsujokat, akiknek a hajuk szála sem görbült; az asszonyok vették észre, hogy az anarchisták elfoglalták a főbb stratégiai pontokat, odamentek, jól felpofozták, és lefegyverezték őket. Még jó, hogy közbeléptek a férfiak, különben mindet bedobálták volna a folyóba. Ez egy valóban megtörtént eset, nagyon fontos, amiről mindenkinek tudomása van, s jól mutatja, hogy milyenek voltak a mequinensai nők." (meg azt is, hogy milyenek voltak az anarchisták). 1996-06-01 Serra d'Or - Jesús Moncada, novellar l'absència, Marta Nadal.
} 
annak a ténynek tulajdonítja, hogy Mequinensában a háború elején az UGT taglétszáma 359 volt, a CNT, vagyis az anarchista szakszervezet taglétszáma pedig mindössze $20 .{ }^{187}$ A városban valószínűleg többségben levő szocialisták védték a kistulajdonosok jogát a földjükhöz, és nem értettek egyet az erőszakos kollektivizációval sem. A monográfiában gyakran használt „Nem tudjuk”, „Keveset tudunk arról” kezdetű mondatok jelzik, hogy az aragóniai eseményeket feldolgozó történeti munkákra és a szájhagyományra támaszkodó történetíró milyen nehézségekkel küzd a történtek rekonstruálása során.

A háborús eseményekből a monográfia csak a város közvetlen közelében zajló Ebrói csatát tárgyalja, amelynek során 1938. július 25-től kezdődően a város négy hónapon át a frontvonalban helyezkedett el, s július 25. és augusztus 6. között a Mequinensa-Faió térség a háború legfontosabb eseményeinek színtere lett. Az Ebrói csata és a háború vége címü alfejezet a monográfiában már a Franco korszak fejezetébe tartozik, hiszen az 1938. március 9én az aragóniai fronton 300 km hosszúságban indított nemzeti offenzíva a város térségében is elsöpörte a köztársasági hadállásokat. Vicente Rojo tábornok mindenütt visszavonulást rendelt el, melynek során 1938. március 27-én az utolsó köztársasági katonák is elhagyták Mequinensát, miután felrobbantották a hidat, ami azonban nem tudta megakadályozni Franco csapatainak bevonulását a városba. „Keveset tudunk arról” - mondja a monográfia - milyenek voltak a mequinensaiak hétköznapjai ez alatt a négy hónap alatt. Ennek irodalmi rekonstruálására JesúsMoncada vállalkozott a La galeria de les estàtues és A folyók városa lapjain. A monográfia két dokumentumot közöl, melyek az ebrói csatával kapcsolatos információt tartalmaznak, a városi levéltárban nem található erre vonatkozóan több adat. Ezek a szokásos francói frazeológiával tudatják velünk, hogy „a marxista horda a várossal szemben foglalt állást”[...] a város „teljes egyetértéssel, ünnepélyesen a Caudillo és dicsőséges hadserege oldalára áll”, majd később „,dokumentumban lefekteti, mennyire boldog és elégedett a nép, mert az Ebro jobb partja felszabadult”. ${ }^{188}$ A regények tanúsága ezen a ponton teljességgel ellentmond a levéltári adatok alapján felrajzolható történeti képnek.

A monográfia a Franco korszakot 1949-ig bezárólag tárgyalja a Köztársaság, polgárháború és Franco korszak (1931-1949) című fejezetcím alatt. Közli még az 1938 és 1954 között egymást váltó négy városi vezetőség (1938-45; 1945-46; 1946-49; 1949-54) neveit tartalmazó listákat is. Külön alfejezetet szentel a város újjáépítésének, ennek kezdő mondata a következő: „Semmiféle dokumentum nem áll rendelkezésünkre, mely alapján megállapít-

\footnotetext{
187 Ezt az adatot a monográfia szerzője Julián Casanova, Anarquismo y revolución en la sociedad rural aragonesa 1936-38, Madrid, Ediciones Siglo XXI, 1985 címủ müvéből vette.

${ }^{188}$ Estruga, J. (dir.), 292-293. o.
} 
ható lenne, milyen károkat okozott a front átvonulása a városon.” ${ }^{189}$ Külön fejezet foglalkozik a háború utáni gazdasági helyreállítás néhány aspektusával, valamint a háború által követelt emberéletek megközelítő meghatározásával. Itt a monográfia (2010) leszögezi, hogy a fronton elesettek és a számüzetésbe kényszerültek számának meghatározásához kutatásokat kell végezni, majd számba veszi mindkét oldalon a dokumentált áldozatokat. Megállapítja, hogy a Franco korszak megtorlásai következtében két bányász vesztette életét, a köztársasági megtorlás fentebb már tárgyalt két áldozatának listája pedig - amelyet a városvezetőség 1940 szeptemberében helyezett el kőbe vésve (Caídos por Dios y por España) a templom homlokzatán -, még három személlyel bővült. Ezek közül az egyikröl semmit nem lehet tudni, a másodikat egy eltévedt golyó ölte meg, miközben az utcán biciklizett, a harmadik pedig nem mequinensai volt, hanem a város jótevőjének, a Primo de Rivera diktatúra idején a város számára iskolaépületet és hidat kijáró Maria Quintanának az unokája, akit egy a Baleári szigeteknél állomásozó cirkálón szolgálva ért a halál, s akiről 1940-ben újrakeresztelték a Zaragoza utcát. ${ }^{190}$

Mequinensa történeti monográfiájának zárófejezete, A régitöl az új Mequinensáig. Hoszszú és nehéz átmenet, a vízerőmű építését, a régi város lerombolását, és az új felépítéséhez vezető, sok bizonytalansággal és félelemmel teli év történetét írja le, A folyók városa címü regény nyitómondatát választotta mottóul. A fejezetet, Andrés Coso Catalán jegyzi, aki maga is mequinensai, s a társszerzői felkérést azért kapta, mert az ENHER dolgozójaként első kézből ismerte a történetet. Az ENHER-t az a Victoriano Muñoz Oms, lleidai mérnök alapította 1946-ban, akit a II. Köztársaság nevezett ki 1935-ben a Katalónia területén zajló közmunkák tervezésének élére, mely pozíciója során a fiatal mérnök kidolgozta a Noguera Ribagorçana folyó teljes vízügyi hasznosítási tervét. Ennek kivitelezésére alapította meg az ENHER-t, mely vállalat később részt vett az Ebro vízenergiája hasznosítására kiírt pályázaton, s azt el is nyerte a Grupo March csoport ellenében. ${ }^{191}$ Victoriano Muñoz személye ebben az esetben is az össztársadalmi és gazdasági érdekeket szem előtt tartó iparosítás rendszereken és korokon átívelő jellegét mutatja meg.

\footnotetext{
${ }^{189}$ Estruga, J. (dir.), 296. o.

190 Estruga, J. (dir.), 299-300 o.

191 1955-ben a Közmunkaügyi Minisztérium úgy döntött, hogy az Ebro Escatrón és Flix közötti szakaszát vízenergia fejlesztési-szabályozási célokkal teljes koncesszióba adja az ENHER-nek, szemben a szintén pályázó, a Franco rendszer bankárjának tartott Juan March érdekeltségébe tartozó FECSA-val, a mallorcai milliárdos által felvásárolt Barcelona Traction utódjával. Estruga, J. (dir.), 301-302. o. Franco nem szerette, ha éreztették vele, hogy lekötelezettje valakinek. L. Harsányi Iván, Franco - Ormos Mária, Mussolini, Budapest, Pannonica, 2001. 255. o.
} 
Ez az állami óriásvállalat, az ENHER 1956-ban tűnt fel először Mequinensában, nem tárgyalt az önkormányzattal, nem értesítette a provincia civil kormányzóját sem, hanem egyenesen azokkal a földtulajdonosokkal vette fel a kapcsolatot, akiktől a tervezett építkezés céljaira szánt földterületeket fel akarta vásárolni. 1957 márciusában megkezdődtek az építkezések, s az akkor 4500 lakosú, virágzó település lakosságának fogalma sem volt róla, hogy velük mi a terve a vállalatnak. José Moncada Moncada, az író édesapja, az akkori polgármester, már 1956-ban levélben fordult Victoriano Muñozhoz, az ENHER igazgatójához, hogy a lakosság megnyugtatása érdekében adjon tájékoztatást a folyamatban levő munkálatokról, a válasz mindössze annyit közölt, hogy ne nyugtalankodjanak, a vállalat figyelembe fogja venni a város érdekeit. ${ }^{192}$ A nyugtalanság azonban ezzel nem szünt meg, hiszen a tervezett mequinensai és a riba-rojai tározók közé szorított település, létének minden alapját készült elveszíteni:

1. A riba-rojai tározó vízszintje alá kerül az épületállomány 55,5\%-a, ezek közül a folyóparthoz közelebb eső területen elhelyezkedő középület állomány 96,4\%-a.

2. A lakosság nagy része a bányákban (12) dolgozott, melyeket vagy elönt majd a víz (7), vagy kisajátítás fenyegeti (5).

3. A szénszállítás, valamint a folyó hajózhatóságának megszünte miatt az összes többi, vitorlással történő áruszállítás is lehetetlenné válik. ${ }^{193}$

4. A város elveszíti öntözéssel művelhető földterületeinek 100\%-át (200H). ${ }^{194}$

A problémájára megoldást kereső közösséget a távoli jövőre vonatkozó üres ígéretek nem elégítették ki. A polgármester levélben fordult az INI-hez, az Ebro vízügyi társulásához, a provincia civil kormányzatához, és táviratban kérte Francót, hogy függessze fel a települést létében fenyegető, hivatalos bejelentés nélkül megkezdett munkálatokat. ${ }^{195} 1957-$ 1958 során nemcsak a város vezetője, de maguk a polgárok is táviratokkal árasztották el a caudillót és az ENHER vezetőségét. ${ }^{196} 1958$ nyarán az ENHER végre úgy döntött, hogy

\footnotetext{
192 Estruga, J. (dir.), 303. o.

193 Pinilla Navarro, Vicente (dir.), Gestión y usos del agua en la cuenca del Ebro en el siglo XX., Zaragoza, Prensas Universitarias de Zaragoza, 2008, 306. o. Az ebrói gőzhajózás meghonosítására tett kísérlet bukását a Saragossa-Lleida-Barcelona útvonalon 1862-ben kiépült vasút sikerének tulajdonítja. Az Ebrón nem terjedt el a gőzhajózás, a Saragossa és Tortosa közti szakasz kereskedelmi forgalmát a 70-es évekig vitorlásokkal bonyolították. A mü településenként megadja ezeknek a vitorlásoknak a számát: 16 Mequinensában, 35 Faióban, 26 Flixben, 4 Ascóban, 4 Mora d'Ebre-ban, azaz összesen 85 hajó.

${ }^{194}$ Estruga, J. (dir.), 310. o.

195 A Francónak címzett távirat a Moncada hagyatékban található, s fényképe szerepel a Mequinenza monográfia 306. oldalán. Ugyanilyen tónusban íródott a vízügyi társulásnak írott levél is, melyben a város mindenféleképpen sérülö érdekei feletti őrködésre kérik a szakmai szervezetet u.o. 305. o.

${ }^{196}$ MCSL, Cirac, Sebastián, Apelación en Defensa del Ebro 1959, Barcelona, Estudios Caspenses, Riegos y Electricidad del Ebro, 338. o. A város kitartó harcát írja le, s a mequinensaiak és Granja d’Escarp lakossága
} 
nyilvánosságra hozza a végleges terveket, s kiderült, hogy Mequinensa a folyásirányban következő szomszédos településsel, Faióval együtt el fog tünni a térképről. José Moncada, Mequinensa polgármestere összehívta az építkezések miatt érintett települések (Faió, Torrent de Cinca, Granja d’Escarp, Massalcoreig és Almatret) polgármestereit, s közösen megfogalmaztak egy tiltakozást, melyet elküldtek a kérdésben érintett különböző minisztériumokhoz. Ezt követően, 1958 szeptemberében összehívta a mequinensai családfők gyűlését, és felvilágosította őket az előttük álló jövőről, ami miatt a provincia civil kormányzója táviratilag, azonnal felmentette polgármesteri tisztségéből. ${ }^{197}$ Ez a magatartás a kor politikai berendezkedését és erőviszonyait figyelembe véve meglepően merész kezdeményezés a polgármester részéről. A helyiek véleményére nyilvánvalóan nem voltak kíváncsiak a döntéshozók, érdekegyeztetésről szó sem lehetett.

Az építkezések tovább folytatódtak az érintett önkormányzatokkal való tárgyalás és megegyezés nélkül. 1959. június 29-30-án Franco Mequinensába látogatott, ahol a nép meglepetésére - nagy lelkesedéssel köszöntötte, tiszteletbeli polgármesterré választotta, és eljuttatott hozzá egy fogalmazványt, mely három kérést tartalmazott: település, öntözött földek, ipar. Bíztak benne, hogy e közvetlen módon átnyújtott kérés meghallgatásra talál, s annyit el is értek, hogy a meglepett államfö, elégedettségét kifejezendő, arra utasította az ENHER képviselöit, hogy vigyázzanak ezekre a „jó” mequinensai emberekre.

A hivatalos állami közlönyben BOE (Boletín Oficial del Estado) azonban csak három évvel később, 1962. május 20-án jelent meg a Dirección de Obras Públicas (központi közmunka hivatal) döntése, amelynek értelmében az ENHER megkapta a riba-rojai erőmű építésének koncesszióját. Ennek a hivatalos közleménynek a 21. pontja tartalmazta azokat a feltételeket, amelyek teljesítésére a vállalat kötelezte magát. A szövegben, amelyre a mequinensaiak oly sokszor hivatkoztak, a következő állt: „A koncessziót elnyerő cég, a jelen koncesszió dátumától számított három hónapon belül bemutatja új-Mequinensa és újFaió településeinek építési tervét, az öntözéses földművelést [...] lehetővé tevő területek rendezési tervét, és az új iparágak telepítési tervét azzal a céllal, hogy megoldással szolgáljon a települések, termőföldek és bányák elárasztása által okozott társadalmi problémára."198 Az ENHER 1962 végén elő is áll a tervekkel, de Mequinensa, miután lakossági gyüléseken

által hivatalos helyekre küldött táviratok számát kétezerre becsüli. Leírja továbbá, hogy az 1958-ban tisztségéből eltávolított José Moncada helyett a mequinensaiak egy olyan polgármestert választottak, akit korábban már szintén eltávolítottak egyszer a tisztéböl. A választást megörökítő irat elismeri a letett polgármester érdemeit, és az újjal kapcsolatban jelzi, hogy „,ugyanúgy fog eljárni, mint elődje Mequinensa, az Ebro és Spanyolország védelmében”.

${ }^{197}$ Ennek az 1958. szeptember 8-i táviratnak az eredetije is a Moncada hagyatékban található.

${ }^{198}$ Estruga, J. (dir.), 309. o. 
ezeket megvitatta, elutasító közleménnyel fordult a vállalat felé, melyben utalt többek között, Ribadelago katasztrófájára, ahol 144 ember vesztette életét, miután a Vega de Tera víztározó szakszerütlenül megépített gátja átszakadt, és a kiáramló 8 millió $\mathrm{m}^{3}$ víz elmosta a zamorai települést. ${ }^{199} \mathrm{~A}$ mequinensaiak annak a véleményüknek adtak hangot, hogy nem biztonságos egy majd ötezer lakosú települést a víztározó lábához építeni, s javasolják az áttelepítést az Ebro bal partjáról a Segre jobb partjára, egy védettebb helyre. Kifogásolták, hogy az ENHER terve nem oldja meg a bányák bezárása (500 munkahely megszünése) által okozott társadalmi, gazdasági problémát. S kifogásolták azt is, hogy a vállalat nem akart kárpótlást fizetni azok számára, akiknek a háza nem kerül víz alá, mert a település felső részének lakói. Úgy érveltek, hogy a ház ugyan megmarad, de infrastruktúra és közintézmények nélkül, a lakók egy életképtelen épületegyüttes tulajdonosai lesznek, nem pedig egy müködőképes város-közösség tagjai. Kárpótlást azonban csak azok kaphattak, akiknek a háza víz alá kerül. ${ }^{200}$

1964-ben, „a Béke 25. évében” Mequinensába látogatott a munkálatok megtekintésére a közmunkaügyi és az ipari miniszter, valamint a Kolonizációs Intézet vezetője, aki szintén terveket ígért a polgármesternek a város problémájának kezelésére. Ezt az 500 hektár öntözéses gazdálkodásba vont földre vonatkozó tervet azonban a Minisztertanács 1964 júliusában elutasította, mert nem találta gazdaságosnak. Megalakult viszont egy tárcaközi bizottság (Ipari Minisztérium, Vízerőmü Építkezések Központi Igazgatósága, a Helyi Közigazgatás Központi Igazgatósága, a Nemzeti Kolonizációs Intézet, az ENHER, valamint Mequinensa és Faió polgármesterei részvételével), amely a két város problémáira kereste a megoldást különleges és előzmények nélküli módon. A két városnak azt a javaslatát, hogy a vízszintet csökkentsék 12 méterrel, a vállalat elutasította ${ }^{201}$, mert az sokkal nagyobb termeléskiesést okozott volna, mint amennyibe a települések kényszerkisajátítása került. Mequinensa viszont a félbevágott és megosztott, két különböző módon kárpótolt település megoldásba nem akart belemenni, és a létfeltételeit biztosító ipar és mezőgazdaság megteremtését köve-

\footnotetext{
${ }^{199}$ Lera, José, El País 1999 január 10 http://elpais.com/diario/1999/01/10/espana/915922818 850215.html, letöltés 2017. ápr. 6. El Mundo Kasztília és León internetes kiadás http://www.elmundo.es/ elmundo/2009/01/02/castillayleon/1230902542.html, letöltés 2017. ápr. 06. A Franco rendszer vízerömüépítéseinek ez volt az első, sok emberéletet követelő katasztrófája, amelyről alig írtak a sajtóban, s amikor megtették inkább azt hangsúlyozták, hogy bár Spanyolország a világon a második ország a 30 m-nél magasabb gátak építésében, most történt először tragédia. Franco adoptálta a túlélőket (kb. 500 lakost), és az elsodort falu helyett felépíttette nekik a Ribadelago de Franco nevü települést. A 15 évnél fiatalabb áldozatokért 25ezer, a felnőttekért 75ezer pezeta kárpótlásban részesítette a hozzátartozókat. A tározó első feltöltése alkalmával átszakadt gát ma is ott áll mementóként, turistalátványosságként, a vízerőmüvet nem használják, a felelősöket nem büntették meg, a település később Ribadelago Nuevo-ra keresztelte magát.

${ }^{200}$ A válaszközlemény szövegét l.: Estruga, J. (dir.), 310-313. o.

${ }^{201}$ Estruga, J. (dir.), 313-314. o.
} 
telte. ${ }^{202}$ Mequinensa városának lakosai müködő közösségként akartak megmaradni, s ezért még hosszú éveken át tartó küzdelmet folytattak, ami a korszakban egyedülálló, s amit a város történetéről írt regény nem győz hangsúlyozni.

A hivatalos helyekre küldött táviratok, a madridi látogatások, kérvényezések után végül 1966. október 17-én Mequinensa és az ENHER egyezséget kötött, melyet a mequinensai lakosok 85\%-a megszavazott még az aláírás előtt összehívott tájékoztatás alkalmával. Az egymást váltó mequinensai polgármesterek mindegyikénél megfigyelhetjük ezt a demokratikus vonást, hogy az érintettekkel való közvetlen konzultáció útján kívánnak megalapozott döntéseket hozni. Jesús Moncada nagyon sok interjúban utal Mequinensa különleges társadalmi összetételére és haladó szellemü gondolkodására. ${ }^{203}$ A történeti monográfia szerzője a várost jellemző demokratikus vonások, és a jogosnak vélt követelések melletti kiállás hangsúlyozására Jesús Moncadát idézi, aki szerint a város nyitottabb és társadalmi rétegződés tekintetében sokkal előrehaladottabb mint a környezetében található többi település. ${ }^{204}$

1967 márciusában a vízzáró gát falán észlelt szivárgások rémületet keltettek a lakosságban, és megerősödött a települést áthelyezni kívánók hangja. A munkálatok szakszerütlenségét leleplező mérnököt, Manuel Sánchez del Corralt elbocsátották az ENHER-től, de bejelentése következtében megalakult egy különleges bizottság, amely szorosan ellenőrizte az építkezés munkálatait, és több megerősítést is végzett. A szivárgásokról és az építkezés szakszerütlenségéről szóló hírek hatására 1967. április 7-én Mequinensában tüntetés zajlott csak nők és gyermekek részvételével. ${ }^{205}$ Ennek egyszerü oka volt, a mequinenzai tüntetés

\footnotetext{
202 Estruga, J. (dir.), 314-315. o.

203 1999-05-02 El Periódico - La realidad es muy literaria, Antón Castro; 1992-02-14 Diari de Barcelona - No m'interesso gens a mi mateix com a personatge, Carles Singla. Több Moncadával készített interjúban találkozunk azzal a jellemzéssel, hogy Mequinensa a Franco korszak alatt is republikánus érzelmủ város volt, mert a polgárháború befejezése után megválasztható Franco párthívek száma nem volt több féltucatnyinál, s a városvezetőségben megüresedő helyekre kénytelenek voltak a mérsékelt republikánusok közül tisztségviselőket választani. 1999 -10-24 Presència - Calaveres Atónites, Pere Puig; 1999-10-22 Avui - Els contes que semblen més fantàstics són els més reals; 2003-05-05 Diari de Sabadell - M'interessen les repercussions individuals de la història.

${ }^{204}$ Estruga, J. (dir.), 303. o.

${ }^{205}$ Még a polgárháború idején 1938-ban született a „Munka Törvénykönyve”, mely szerint a sztrájk súlyos büncselekménynek számított, mivel veszélyezteti a termelést. A Büntető Törvénykönyv 1944-ben a sztrájkot, mint a lázadás büncselekményét tételezte. Az 1960-ban a társadalmi rendről hozott törvény lehetővé tette a sztrájkok szervezőinek „,katonai lázadás” címén történő felelősségre vonását. L. Harsányi, i.m. 317. o. A Franco-rendszer törvényeit 1977-ben törölte el egy törvényhatározat. L: http://losojosdehipatia.com. es/cultura/historia/breve-historia-del-derecho-de-huelga-en-espana/, letöltés 2017. máj. 06. A törvényi szabályozás ellenére voltak sztrájkok a Franco korszakban. Az elsők éppen a bányász szektorban már az ötvenes években. L. Francisco Palacios az 1962-es, 2 hónapon át tartó asztúriai bányássztrájkról: http://www.lne.es/cuencas/2012/04/09/primavera-62/1225151.html, letöltés 2017. máj. 6. Jorge Muñiz Sánchez megemlékezése a sztrájk 50. évfordulóján, melyben a demokratikus változások egyik elindítójának nevezi és ’34-es elődjéhez kapcsolja a gazdasági liberalizáció nyomán fellépő drágulás miatt kitört sztrájkot: http://web.archive.org/web/20120505122421/ http://www.lavozdeasturias.es:80/suplementos/as-7/sacrificio-
} 
pénteki munkanapra esett, és a bányatulajdonosok elbocsájtással fenyegették a dolgozókat. A férfiak végül csak az előkészületekben, feliratok fogalmazásában vettek részt, de törvényt nem bontottak, aznap elmentek dolgozni. Az 1967-es mequinensai tüntetés - asszonyok és gyermekek a vízzáró gát fenyegetése árnyékában, a demonstráció feliratai a biztonsághoz való jogot hirdették - széles visszhangot kapott a korabeli sajtóban ${ }^{206}$, ami igen furcsa a rendszer politikai berendezkedésének ismeretében. A provincia civil kormányzója kétszáz csendőrt és rohamkocsikat rendelt a helyszínre, s két embert letartóztattak. A mequinensaival körülbelül egy időben zajló, ám hat hónapon át tartó, bilbaói sztrájk kezdetén a csendőrség egy 180 tagú osztagot rendelt a helyszín biztosítására. A Mequinensába küldött rendőri erők száma azt mutatja, hogy a hatalom igen nagy jelentőséget tulajdonított ennek a demonstrációnak. ${ }^{207}$ A monográfia arról tudósít, hogy egy asszonyokból álló küldöttség meglátogatta a polgármestert, aki megmutatta nekik a kormányzóhoz írt táviratát, melyben tudósított a tüntetésről, az emberek félelméről, és kérte, hogy biztosítsák a település áthelyezését. Ezt a táviratot kiszegezték a városháza kapujára, s az emberek némileg megnyugodtak, bár a település jövőjéről még mindig nem lehetett tudni semmi biztosat. Annyi azonban kiderült a kor intellektueljeivel folytatott jogi konzultációk ${ }^{208}$ és a jogi úton történő érdekérvényesítő próbálkozások során, hogy a város által hivatkozási alapnak tekintett 21-es pontban tett ígéreteknek semmiféle jogilag kötelező, a vállalaton behajtható érvénye nincs, a város esetére egyedül a kényszerkisajátításokat szabályozó törvény vonatkozik, ami azonban a megállapított vízszint magassága miatt csak a település egyik felének nyúj-

lanzo-transicion_0 674332650.html, letöltés 2017. máj. 6. A Franco korszak leghosszabb, hat hónapon át tartó sztrájkja (1966. nov. 30. -1967. máj. 20.) Baszkföldön tört ki prémium-megvonások miatt a Laminación de Bandas en Frío de Echevarri Müvekben amelynek megoldására Franco rendkívüli állapotot hirdetett, elbocsátásokkal, börtönbüntetéssel és a munkások más provinciákba telepítésével oldotta meg a helyzetet. http://www.abc.es/20120328/archivo/abci-bandas-huelga-franquismo-echevarri-201203271431.html, letöltés 2017. máj. 6.

${ }^{206}$ A monográfia szerzője nem közölte hipotézisét, vajon hogyan kaphatott széles nyilvánosságával tüntetés, mert - mint mondta - történelmi hitelességü bizonyítékkal nem tudta alátámasztani a birtokába jutott szóbeli információt, miszerint az INI és az Ipari Minisztérium között folyó hatalmi vetélkedésnek volt köszönhető. A Minisztérium az INI elleni propagandájában az intézmény szakszerütlenségét, alkalmatlanságát kritizálta, ennek alátámasztására használta fel a mequinensai tüntetést, ami a minisztérium embereinek segítségével mehetett végbe békésen, s kaphatott nagy nyilvánosságot a sajtóban. Támogatja a hipotézist, hogy a 480/1968 márciusi kormányrendelet értelmében az INI -t az Ipari Minisztérium alá rendelték, melynek fó irányvonala a magántőke bevonása és a magánkezdeményezések favorizálása volt, szemben az INI autarkhiás filozófiájával. Abban azonban, hogy a Mequinensa monográfiában ez a hipotézis nem szerepelt, talán az is közrejátszott, hogy a „mequinensaiak - ENHER” Dávid és Góliát harcának sémájú történetis veszített volna erejéből ezáltal. 207 Estruga, J. (dir.), 320-321. o. l. még http://www.abc.es/20120328/archivo/abci-bandas-huelga-franquismoechevarri-201203271431.html, letöltés 2017. máj. 7.

${ }^{208}$ Az egyik ilyen híres személyiség, akinek a véleményét kikérték José María Gil Robles volt, aki 1968-ban született válaszában azt válaszolta a mequinensaiak megkeresésére, hogy a 21-es cikkely szerint az ENHERnek csak a terveket kell bemutatnia, és nem tartozik nagyobb kárpótlást fizetni Mequinensának és polgárainak, mint amit a kényszerkisajátítással kapcsolatos törvény elöír. Gil Robles a 60-as évektől kezdve már munkásvezetők és rendszer ellenes papok védelmét látta el. L. Harsányi, i.m. 354. o. 
tott kárpótlást, és nem kötelezte a vállalatot új település építésére. 1968-ban a város helyzete a 11 éve tartó harc ellenére kétségbeejtő volt. Az ENHER elkezdte építeni a megosztott lakosság egyik felének járó épületeket, a bányák kezdtek bezárni, s az ENHER azonnal kisajátította őket, akár víz alá kerültek, akár nem. A víztározó és az erőmű munkálatai szinte teljesen befejeződtek, a munkásokat szélnek eresztették. A munka nélkül maradt emberek kénytelenek voltak elvándorolni, hogy megélhetésüket biztosítani tudják. ${ }^{209}$ Ezen kívül ott volt előttük a szomszédos település, Faió példája, amelyet 1967-ben, egy 3 napos, mesterségesen előidézett árvízzel lakoltattak ki úgy, hogy egyszerüen megnyitották a zsilipeket, s ezzel megtörték az életüket futással mentő lakók ellenállását. ${ }^{210}$

Mequinensában 1968-ban megalakult egy vegyes bizottság, melyben a polgármester, a város vezetősége és 30 városi választott bizottsági tag igyekezett kidolgozni a város problémájának lehetséges megoldásait és a vállalattal való megegyezés lehetőségeit. Az ENHER számára is fontos volt a megegyezés, mert amíg a város a helyén volt, nem tudta feltölteni a víztározót a megfelelő szintig, s csak félgőzzel tudott müködni, ami óriási haszonkiesést jelentett, de már megkapta az engedélyt a Dirección General de Obras Hidraulicas hivatalától, hogy sürgősségi intézkedéssel kilakoltassa a lakosságot a számára szükséges szintig épült házakból. ${ }^{211}$

Mequinensa lakossága 1969. február 1-jén 72\%-ban megszavazta az eredeti terv módosítását, lemondott jogos követeléseinek egy részéről, hogy sikerüljön békés megegyezésre jutni az állami nagyvállalattal. Sikerként könyvelhették viszont el, hogy a víz alá nem kerülő házak tulajdonosai számára is kiharcolták a családtagonként 50 ezer pezeta kártérítést, házukat pedig becsült értéken átvette tőlük az ENHER. A vállalat által már megkezdett építkezések mellett tehát megkezdődhetett város többi, helyben maradni kívánó, lakosa számára történő lakásépítkezés is, mégpedig szövetkezeti vállalkozás formában. Ezek a mequinensaiak 1969 júniusában 448 taggal megalapították a Santa Agatòclia Lakásszövetkezetet, s ugyanezen év novemberében megkezdődtek az építkezések. Kilenc különböző típusú, nagyságú, komfortfokozatú és árú lakástípus között lehetett választani, melyeket típusonként sorsolással osztottak el maguk között az építkezők. A lakásszövetkezet elnöke

\footnotetext{
${ }^{209}$ Mequinensa az építkezés megkezdésétől számított egy évtized alatt elvesztette lakosságának kb. felét. Az elvándorlás fő célpontja Katalónia. L.: http://www.mequinenza.com/historia, letöltés 2017. máj. 10.

${ }^{210}$ Fayón, El embalse de discordia A film bemutatja a régi Faió tragédiáját, az ENHER által épített új települést, s az ott megvalósított gazdasági fejlesztéseket a régi megélhetés (bányák, hajózás) helyettesítésére. Mequinensa és Faió története sokban hasonlít, ám Faiónak nem sikerült lakásszövetkezetben összefogni a közösség érdekeit, s gazdaságilag is megalapozni a jövőjét. A korábban kb. 1500 lelket számláló, a partvidék legnagyobb flottájával rendelkező településnek ma már csak kb. 400 lakosa van. https://www.youtube.com /watch?v=1JAUqxUU7Gg, letöltés 2017. máj. 10.

${ }^{211}$ Estruga, J. (dir.), 333. o.
} 
José Moncada volt, az író édesapja, aki a számára fontos iratok között megőrzött néhányat e sorsoló cédulák közül. ${ }^{212}$ Az új Mequinensában végül 651 lakás épült, melyből 203-at az ENHER, 448-at pedig a lakásszövetkezet épített fel. A városi infrastruktúra kiépítéséhez hiányzó pénzt az ENHER-rel aláírt végszámla rendezés útján teremtették elő, amikor a város és a vízerőmű vállalat elszámolt egymással, és az ENHER kifizette amivel még a városnak tartozott. Így született meg 1974-re, (mire minden lakója átköltözött a régi városból) az új város, mely valószínüleg egyedülálló volt Spanyolországban abban a tekintetben, hogy körülbelül 3000 lakosból álló közösségének minden családja saját tulajdonú lakással rendelkezett. $^{213}$

Egy különös epilógus zárja a történeti monográfiában a víztározó és új Mequinensa felépítésének krónikáját, mely Az egyház szerepe és a régi Mequinensa utolsó házai címet viseli. Ebben arról értesülünk, hogy Mequinensa papja, Eduardo Royo Tejedor, a régi településen maradt 36 lakó érdekeinek védelmében megtagadta a kiköltözést a paplakból, s 1973. január 28-i homíliájában a gyengék védelmére kelt a hatalmas vállalattal szemben, amit mint mondja - evangéliumi kötelessége volt megtenni. Saragossa érseke, Pedro Cantero Cuadrado $^{214}$ azonban a nemzet java érdekében felszólította a papot, hogy haladéktalanul költözzön át az új településre. Szavait az Heraldo de Aragón 1973. február 17-i száma közli, majd ugyanitt, a március 1-i számban jelenik meg a pap válasza, akit ellenállásában támogatnak a környékbeli települések Favara, Maella és Nonasp plébánosai is. Jelzi, hogy addig nem kíván távozni, amíg az ENHER és Mequinensa között meg nem indul a párbeszéd, ami szerinte, az érsekség és az ENHER között aláírt szerződés ellenére nem jött létre. Az eset végül a parókián összegyült papok hatósági kilakoltatásával végződött. A csendőrök feltörték a parókia ajtaját, a bútorokat átszállították az új településre, és az épületet lakhatatlanná tették, amiről több korabeli sajtóorgánum is tudósított. ${ }^{215}$ A fejezet szerzője nem füzött semmiféle kommentárt ezekhez az eseményekhez, csak a tényközlésre szorítkozott, majd zárásképpen megadta az új településen épült templom felszentelésének idejét: 1973. szeptember 16. Közzétette a szentelési ünnepségre szóló meghívót, amely felsorolta a résztvevők

\footnotetext{
212 Rosa María Moncada tulajdonában, aki büszkén mutatta nekem a cédulákat, mint az édesapja által követett demokratikus eljárás bizonyítékát, melynek eredményeképp nekik egy nem túl szerencsés fekvésü sorházi lakás jutott.

${ }^{213}$ A Santa Agatòclia Lakásszövetkezet zárógyülésének dokumentumában a szövetkezet elnöke büszkén említi, hogy „az általuk végzett társadalmi munka eredményeképp olyan település született, amilyen a világon talán még nem is létezik, ahol mindenki tulajdonosa a házának”. A mequinensaiak tehát tudatában voltak az általuk elért eredmény nagyságának. Estruga, J. (dir.), 342. o.

${ }^{214}$ http://www.enciclopedia-aragonesa.com/voz.asp?voz_id=3071\&voz_id_origen=4220, letöltés 2017. ápr. 7.

215 Amanecer 1973 április 11; Aragón Express 1973 április 11. Estruga, J. (dir.), 345-6. o.
} 
nevét: az ünnepséget celebráló érsek, a provincia civil kormányzója, és a provincia küldöttgyülésének elnöke.

Eduardo Royo, a pap további sorsáról teljesen más forrásokból értesültünk. ${ }^{216}$ Ezek tanúsága szerint a plébánost a templom felszentelésének napján áthelyezték, majd később papi tisztségétől megfosztották csakúgy, mint társát, Favara papját, Wirberto Delsót, aki az aragón alsópapság rendszerkritikus, a nemzetikatolikus irányvonalat elutasító részének vezéralakja volt. Ö több konfliktust felvállalt a politikai életben is aktív, keményvonalas érsekkel. $^{217} \mathrm{Az}$ ide vonatkozó újságcikkek tanúsága alapján az érsek kiegyezett az ENHERrel, mely így mentesült attól a kényszertől, hogy az egész települést kötelező legyen felvásárolnia. A templom és a paplak képezték ugyanis azt az épületállományt, amely átbillentette volna a víz alá kerülő épületállományt a település több mint 50\%-ába. A pap kényszerkilakoltatása után nem volt már akadálya az elárasztásnak, aminek az árát nem kellett megfizetni, hiszen az érsek „átengedte” az épületeket a vállalat tulajdonába. A mequinensai kollektív emlékezetben örzött verzió szerint, mikor megkezdődtek a tárgyalások az érintett felek és a vízerőmü vállalat között, a saragossai érsek elégedetlen volt az ENHER ajánlatával, felbiztatta a papot, hogy tanúsítson ellenállást, s ezért indult meg a „gyengék pártját fogó” keresztény ellenállás a hosszú tárgyalásos folyamat végén, 1973ban. Majd mikor az érsek és az ENHER megkötötte „az Egyház számára nagyon előnyös egyezségét (új templom építése és sok pénz - nem tudom, pontosan mennyi, de egyesek szerint rengeteg)”218, az érsek kihátrált az egyházi ellenállás támogatásából ${ }^{219}$, ám a felettese által magára hagyott Eduardo Royo megmakacsolta magát. A régi városban maradt, és az ENHER-rel sajátos magánérdekeik miatt megállapodni nem tudó 36 család képviseletével veszélyeztette az új településre átköltözni kívánó 730 család érdekeit. A

\footnotetext{
${ }^{216}$ Egyrészt az Andalán 1977 és a Primera Plana 1977. nov. 10-16. 1. évf. 37. szám. Ezeket kivágott újságcikk formában találtam José Moncada hagyatékában, másrészt pedig egy tanulmányból, mely a lázadó vidéki alsópapság késő Franco kori történetét dolgozta fel Aragóniában: Zuriaga, María José Esteban, Curas contestatarios en el campo aragonés durante el tardofranquismo http://www.academia.edu /12466061/Curas_contestatarios_en_el_campo_aragon\%C3\%A9s_durante_el_tardofranquismo, letöltés 2017. máj. 8. Az esetet jegyzi az Aragón Enciklopédia is http://www.enciclopedia-aragonesa.com/voz. asp?voz id=4220, letöltés 2017. máj. 8., valamint egy Eduardo Royo Tejedorral, Xavier López Coma által, érettségi kutatómunkájához készített riport, melyet a monográfia szerzőjének leadott kézirata tartalmazott, nyomtatásban azonban nem jelent meg. A kéziratos változatot a szerző, Andrés Coso küldte el nekem. Ebben a pap azzal indokolja ellenállását, hogy kezdték lerombolni a víztározó szintje fölötti házakat is. (Ma az egykori város helyén csak romok vannak, csak három lakóház áll még, s a távolabb épült iskola.)

${ }^{217}$ Pedro Quantero Quadrado érsek 1964-77-ig töltötte be Saragossa érseke tisztét, 1967-ben Franco közvetlenül beválasztotta a Cortes-be procuradornak, és tanácsadónak, s a királyi Régenstanács tagjának. Ebben a minőségében Franco halála után két napig töltötte be a régens tisztét, míg Juan Carlost ki nem kiáltották királlyá.

${ }^{218}$ Andrés Coso magánvéleménye.

219 „A mequinensai papot csak felhasználta a püspökség” Rosa Maria Moncada magánvéleménye.
} 
mequinensaiak szerint a város és az ENHER akkor már 16 éve tartó harcában kissé későn jött a gyengék pártját fogó keresztény megszólalás. ${ }^{220}$ Az Egyház szerepét negatívan értékeli a Mea Culpa színtársulat El darrer dia del Cafè de la Granota (A Békához címzett Kávéház utolsó napja) című darabja is, melynek forrása a Moncada novellák mellett szintén a város kollektív emlékezete, mely a kisajátításba, rombolásba pénzért beleegyező érsek képét őrzi. ${ }^{221}$ A város verziója, miszerint a saragossai érsek akkor hátrált ki az általa gerjesztett papi tiltakozás mögül, mikor megígérték neki az új templomot és egy szép kis összeget, bizonyosan hamis legalábbis részben, hiszen a pap ellenállása az 1973. január 28-i homíliával kezdődik, márciusban lakoltatják ki, és szeptemberben már felszentelik az új település templomát, melynek felépítése nem lehetett csupán néhány hónap műve. Az 1977ben megjelent cikkekben adott értelmezés szerint a mequinensaiaknak nem sikerült jó egyezséget kötniük az ENHER-rel, és egyértelmüen vesztesen kerültek ki a nagyvállalattal folytatott harcból, míg a monográfia szerzői azt hangsúlyozzák, hogy Mequinensa képes volt sok különféle harcmodort alkalmazó kitartó küzdelemre, s arra is, hogy taktikát váltson, s ezzel biztosítsa a közösség megmaradásának (730 család alkotta közösség) feltételeit. Mequinensa büszke arra, hogy a körülményekhez képest a legtöbbet sikerült kiharcolnia, és hogy saját közösségén belül demokratikus módszerekkel járt el. A város honlapja is a város történelmének fontos jellemzőjeként említi, hogy olyan Spanyolországban egyedülálló települést hoztak létre, ahol mindenki tulajdonosa a házának. ${ }^{222}$ A különböző értelmezések, vélemények, dokumentált és szóban őrzött verziók (1. E. Royo az ügy mártírja, 2. E. Royót felültették, 3. E. Royo akadályozta a demokratikus úton hozott döntés kivitelezését, az ENHER-rel kötött szerződés a közösség érdekeit szolgálta, 4. Mequinensa veszített) azt mutatják, hogy a város közössége különböző érdekek mentén megosztott volt, de az egyház szerepét, még a nemzetikatolikus egyházi hierarchia ellen lázadó plébánosét is negatívan értékelte.

\footnotetext{
${ }^{220}$ Andrés Coso ezt a tájékoztatást adta levélben a mequinensaiak papról alkotott véleményéről.

${ }^{221}$ A dramaturg, s egyben föszereplő színésznő Mari-Àngels Largo a helyiekkel folytatott beszélgetések alapján írta meg a darab kerettörténetét, melyben a föszereplő azon kesereg, miért kellett felrobbantani, elpusztítani a házakat, ha úgyis víz alá süllyesztik őket, s külön fájlalja, hogy miért kellett lerombolni a templomot, mikor az magasabban volt, mint az elárasztandó terület, s azt a következtetést vonja le, hogy nyilvánvalóan szép kis summát kaphatott érte cserébe az egyház https://vimeo.com/153133635, letöltés 2017 jan. 16. (5. perc „per la butxaca del bisbe”). Talán furcsának tünhet a város baloldaliságának sokszoros hangoztatása, s a polgárháború ikonoklaszta vonásainak felidézése után, hogy az emberek fájlalták a templom lerombolását. Érthető azonban, ha figyelembe vesszük, hogy Mequinensa közösségi és családi ünnepeit (húsvét, keresztelö, bérmálkozás, esküvő, búcsú, karácsony stb.) a templomhoz kötődő vallásos események alkották, így a templom szorosan hozzátartozott a város életéhez.

${ }^{222}$ http://www.mequinenza.com/historia, letöltés 2017. szept. 5.
} 


\subsection{A vörös város}

Az író a vele készített interjúk során gyakran beszél szülővárosa sajátos jellegéről, mely elüt a földrajzi környezetében található települések többségétől. Arra a kérdésre, hogyhogy az ő kávéházaiban ülő figurák olyan sokat sakkoznak ahelyett, hogy kártyáznának, Moncada azt válaszolja, hogy Mequinensában a lakosság fő megélhetési forrását a lignitbányák és a lignit szállítását biztosító folyami hajózás jelentette, ami a környékbeli mezőgazdasággal foglalkozó településekétől igen különböző társadalom szerkezetet hozott létre. ${ }^{223}$ „Mequinensa minden szempontból különös hely volt. Ipari település, melynek lakói élénk társadalmi és politikai életet éltek, ami az első bányafeltárásokkal vette kezdetét az 1860-as években." 224

A bányák alkalmazásában álló munkások fizetése a gazdasági válságok kivételével rendszeres és biztos volt, ezért a parasztcsaládok is igyekeztek úgy intézni, hogy a családnak legalább egy tagja a bányába kerüljön dolgozni. ${ }^{225}$ A dokumentum, amelyben Mequinensa választ ad az ENHER 1962-es gazdasági és szociális helyzet rendezésére tett ajánlatára, szintén kiemeli a bányászok jó körülményeit. „Ebben a szénmedencében a bányászok fizetése magas, ami jó életszínvonalat biztosít Mequinensa lakosságának. Az itt müködő társadalom és balesetbiztosítási rendszer egészen különleges, egy sor olyan juttatást tartalmaz [...] mint például az 55 éves nyugdíjkorhatár, és a havi 250 kg ingyen szénhez való jog, mely életük végéig megilleti őket."226

A szájhagyomány azonban fenntartotta a korábbi idők emlékezetét is, mely szerint 1914ig kevés munka akadt a bányában, csak akkor dolgoztak, ha volt megrendelés, különben szélnek eresztették őket. Nem volt biztonság, s elég nagy volt a nyomor. A háború kitörésekor azonban nagy szükség lett a munkáskézre, a környék településeiről mindenki felcsapott bányásznak, a Canota bányában még két francia is dolgozott. Egy öreg bányász egyenesen háborús bányáknak nevezi a mequinensai bányákat, és a helyi bányászat első fellendülését a kubai háborúval (1898) hozza összefüggésbe. ${ }^{227}$ A 19. század végén működő bányák Mequinensában főleg a lakossági igényeket, és a helyi ipar (édesgyökérkivonat gyár és malom) szükségleteit elégítették ki, később a német tőkéjü Flixi Vegyipari Kombinátnak szállí-

\footnotetext{
223 1995-12-24 Heraldo de Aragón - El fin de la Mequinenza vieja me afectó mucho, Genoveva Crespo.

224 1992-02-14 Diari de Barcelona - No m'interesso gens a mi mateix com a personatge, Carles Singla.

225 1992-07-01 Nuit Blanche - Jesús Moncada, écrivain par entêtement, Anik Lapointe; 1989-12-09 Diario16 - Moncada. La novela rural, Carles Mengual.

${ }^{226}$ Estruga, J. (dir.), 311. o.

${ }^{227}$ MCSL Entrevista amb l’oncle Joaquim del Patriciet bányász (1892-).
} 
tották a gyenge minőségű lignitet. ${ }^{228}$ Moncada öreg bányászokkal készített interjúiból kiderül, hogy a bányák nyáron gyakran bezártak, mivel a folyó vízszintje olyan alacsony volt, hogy hat tonnánál nagyobb terhelést nem engedhettek meg maguknak a hajók, a szén a bányaudvarokon halmozódott fel. A háztartási kereslet is alacsonyabb volt ilyenkor. A bányászok nyáron Lleida és Balaguer (Katalónia) körzetében mezőgazdasági idénymunkával (aratás, szüret) egészítették ki keresetüket. Fizetést csak akkor kaptak a bányától, ha a szenet a tulajdonosok már értékesítették. ${ }^{229}$ Hosszú volt tehát az út a '62-es ENHER ajánlatra küldött válaszban jelzett magas életszínvonalig. A lakosság többségét alkotó bányász és hajóstársadalom egyértelmüen baloldali kötődésü volt, és életszínvonalát, müveltségét mélységes szakadék választotta el a városi társadalmi ranglétra csúcsán álló gazdag tulajdonos rétegtől. ${ }^{230}$

Mequinensában az a mondás járta, hogy „itt még a jobboldaliak is balos gondolkodásúak”231, s amellett, hogy a mequinensai nyilatkozók egyértelműen vörösnek látják a várost $^{232}$, mind a történeti monográfia mind pedig Jesús Moncada megörökíti azt a tényt, hogy a polgármester vagy a békebíró ${ }^{233}$ még a Franco korszak idején is republikánus múltú vagy érzelmű volt. Jó példa erre Jesús Moncada édesapja, aki 1954-1958 között a város megválasztott polgármestere volt annak ellenére, hogy a republikánus hadseregben harcolt. A demokratikus átmenet idejétől, az 1979-es helyhatósági választásoktól napjainkig a város vezetése továbbra is mindig a PSA-PSOE vagy az IU választói többségből alakul (aragóniai szocialista, spanyol szocialista vagy spanyol egyesült baloldal párt). ${ }^{234}$ Moncada, aki mindig visszautasította a müveivel kapcsolatban hangoztatott mágikus realizmus jelzőt, egy interjúban egy megkérdőjelezhetetlen ténnyel próbálta érzékeltetni Mequinensa az abszurditásig vörös valóságát: „Mequinensa polgármestere az Izquierda Unida (spanyol egyesült baloldal) tagja, családneve Borbó ${ }^{235}$, aki összehívott egy 150 polgármesterből álló gyülést a franjai

\footnotetext{
${ }^{228}$ Estruga, J. (dir.), 235. o.

${ }^{229}$ MCSL Entrevistes Oncle Calafat, oncle Patriciet, tiet Vidallet, Manolo Jordi.

230 Andrés Coso magánlevél.

231 2005-06-23 El Periódico (Libros) - Territorio Moncada Viaje al escernario y a la memoria literaria del autor de 'Camí de sirga' El autor que tiró siempre de la sirga.

232 2005-06-23 El Periódico (Libros) - Territorio Moncada Viaje al escernario y a la memoria literaria del autor de 'Camí de sirga'.

233 Crònides Vallbadó békebíró a Calaveres atònites egyik föszereplöje a történet szerint megjárta a francói börtönt. Manuel Sanjuán Mequinensa polgármestere 1959-ben Franco látogatása idején megtagadja, hogy a rendszerellenes múlttal rendelkező elemeket az államfö Mequinensában tartózkodásának idejére becsukják vagy eltávolítsák a városból, mert akkor - mint mondja - vele magával kéne kezdeni a letartóztatások sorát. Estruga, J. (dir.), 308-309. o.

234 2001-09-01 L'Hiperbòlic - Entrevista Escriure es una qüestió de resistència.

${ }^{235}$ A királyi család nevét viselö, baloldali politikus, Jaime Borbón Oliver két ciklusban állt Mequinensa élén (1995-1999) és (1999-2003).
} 
katalán hivatalos elismertetésének akadályoztatása ellen”, azaz királyi névvel, baloldali politikusként, katalán nyelvvédő politikát folytat.

Az élénkebb társadalmi és politikai élet alapjait ez a fizetésből élő életmód és a közösségi erőfeszítéseket, összetartást, szolidaritást igénylő munka (bányász brigádok, hajók legénységei) biztosította. A mozgalmas társadalmi élet irányába hatott az is, hogy a három folyó összefolyásánál épült város vitorlásai az Ebro torkolatáig tartó szakaszon hajóztak, néha egészen a tengerig, s ez a tömegkommunikáció előtti korban a mezőgazdasági települések elzártságával ellentétben információgazdagságot és nyitottságot jelentett.

Nem állt módomban más víztározó építkezés miatt elsüllyesztett település további sorsának tanulmányozása, de a rendelkezésemre álló példák azt mutatják, hogy a Mequinensa által elért eredmény nagyszerűnek és különlegesnek mondható. A Mequinensával azonos okokból víz alá került Faióban a közösségi összefogás, és a közös jövőkép hiánya azt eredményezte, hogy az ENHER által tetszőleges helyen felépített új település napjainkra lakosságának több mint 2/3-át veszítette el. Julio Llamazares ${ }^{236}$ 2016-ban megjelent irodalmi alkotásából megtudhatjuk, hogy Vegamián lakosainak egy részét, akik továbbra is a mezőgazdaságban akartak dolgozni, egy lecsapolt mocsaras terület közepére telepítették barakkokba, együtt más területekről (Guadalajarából vagy Zamorából) származó, szintén víztározó építkezések miatt hontalanná váló családokkal. A barakk átmeneti szállásként szolgált arra az időre, amíg felépítik az új saját házukat, amit a régiért kényszerkisajátításként kapott összeg messze nem fedezett, ezért hitelt kellett felvenniük. A papírokat a vízerőmü vállalat intézte. A kapott összeg a megélhetésüket biztosító föld megvásárlására volt csak elég, amit be is fizettek a terület tulajdonosának, a márkinőnek, akit az új telepesek közül soha senki nem látott. A Llamazares regény olyan hegyi gazdálkodásból élő kistelepülés sorsát mutatja be, amelynek lakói nem lázadtak, elfogadták a fejük felett hozott döntést, és nem igyekeztek sorsukat közösségi összefogással másképp alakítani. A víztározó építkezések során áttelepített lakosság általában gazdaságilag nagyobb prosperitás lehetőségét kínáló területekre került, s a hegyvidék elnéptelenedése ma is zajló folyamat Spanyolország minden területén. A kényszerkitelepítettek azonban mind fájdalommal emlékeznek az elveszített szülöföldre, s első generációjuk komoly beilleszkedési nehézségekkel, az emigráns lét minden szimptómájával éli meg a modernizáció diktálta váltást.

${ }^{236}$ Llamazares, J. i.m. 


\section{Camí de sirga - A folyók városa}

\section{Mequinensa emlékezetföldrajza - Tér és idö összefonódása az irodalmi emlékezetben}

\subsection{A regény címe}

„A folyók és a hajózás szinte varázslatos világa volt a régi Mequinensa. Az Ebrót már Saragossában sem értettem, más volt, nem hajózták.”1 A regény címe magyarul $A$ folyók városa, ami igyekszik visszaadni a folyók ritmusában élő, erejüket tisztelő Mequinensa ideáját, mivel az eredeti cím szó szerinti fordításától: A vontatókötél útja/A vontatóút, a fordító visszariadt. Azok a katalánok, akik nem olvasták Jesús Moncadát, nem tudják mit jelent a camí de sirga, mint ahogy a spanyolok sem ismerik a camino de sirga jelentését. ${ }^{2}$ A Magrana Kiadó igazgatója is furcsán nézett az elkészült regény címére 1988-ban, mert sose hallotta ezt a folyami hajózás szakszókincsébe tartozó terminust. ${ }^{3}$ A vontatóút a folyóval párhuzamosan haladt, vonalvezetését tiszteletben kellett tartani mindenkinek, az akadályokat el kellett távolítani róla, szent és sérthetetlen volt, mert kedvezőtlen széljárás esetén ez biztosította az árral szemben haladó hajók mozgását. Kezdetben emberi, majd az I. világháború idejétől kezdődően állati erővel történt a vontatás egy igen erős, nehéz kötél, a sirga segítségével. ${ }^{4}$ Ennek a kötélnek a nevéből képzett ige jelentése katalánul: fáradtságos, kemény munkát végezni. ${ }^{5}$ Jesús Moncada első regényének címe kockázatos kísérlet volt, mely visszaépítette a katalán nyelvi emlékezet egy mozaikdarabkáját. A vontatás nehéz munkája pedig kiválóan jellemzi azt az irodalmi motivációból született emlékmunka vagy emlékterápia alkotói folyamatot is, amelyből a regény született. ${ }^{6}$

\footnotetext{
1 1989-02-01 Serra d'Or 351 - Aproximació a la obra de Jesús Moncada, Mercè Biosca.

${ }^{2}$ Manuel José de Lara Ródenas professzor az Huelvai Egyetem történésze magánlevelében azt írta, „mikor megláttam a camino de sirga kifejezést, meg se fordult a fejemben, hogy köze lehet a folyókhoz”. Megpróbálta kivenni a könyvtárból a regényt, s nagy meglepetéssel látta, hogy egy huelvai költő is írt ezen a címen egy háromszáz oldalas verseskötetet: José Luis Vázquez de Zafra, Camino de sirga, Madrid, 1952, második kiadás Huelva 1964. Erről, a hosszú évek óta Huelva hely- és kultúrtörténetét kutató professzornak egyáltalán nem volt tudomása. Az előszóban a kötetet ismertető kritikus, Federico Carlos Sainz de Robles a címválasztással kapcsolatban kétszer is megjegyzi, hogy nem tetszik neki. L. még a Vanguardia beküldhető rejtvényfeladványát: Mi a sirga? 2005-12-07 La Vanguardia - Concurso Què és una sirga?

${ }^{3}$ Személyes interjú Carles-Jordi Guardiolával 2015. májusában Barcelonában Jordi Estruga közvetítésével.

4 1992-11-15 Presència - El llagut o l'origen del camí de sirga, Jordi Gamero. A Sirga ma egy Kortárs Zenei Fesztivál http://www.sirga-festival.com/, letöltés 2017. aug. 10. neve Tortosában, mely a Terres de l'Ebre városainak összefogásával indult 2015-ben, ami a szó poétikai regiszterben történő meghonosodására utal.

5 1989-04-12 El Dia de Aragón - El pueblo inundado de Mequinenza, Anton Castro.

${ }^{6}$ Jesús Moncada megbízott a fordítóiban, és szabad kezet adott nekik még a cím fordításakor is. Véleménye szerint „A pedáns fordító kártékonyabb, mint a jégeső, az ilyet le kéne csukni, mint hamisítót”. L. 2004-02-01 l'Avenç La memòria d'un món negat, Josep M. Muñoz. A hasonló folyami kultúrával nem rendelkező nyelvek
} 
1.2. „Mert a város valójában te vagy...” Tér és idő összefonódása az emlékezetben

„A tér legfontosabb eleme az idő.” „Nem elegendő csak nézni, emlékezni kell rá, az időt a legnehezebb látni.”” Ezek a kortárs spanyol szerző holokauszt témájú drámájából vett sorok a helyekben rejlö emlékezet titkaira, erejére hívják fel a figyelmet. A város, mint életünk burka, identitásunk fontos őrzője, megfogalmazódik a katalán költészetre és irodalomra Carles Riba fordításán keresztül nagy hatást gyakorló ${ }^{8}$ Konstantinos Kavafis költészetében is, akit Joan Margarit idéz: „Barcelona, a városom kezd a múltam városává válni [...] Az utcák belülről néptelenednek el. A város azt bizonyítja, hogy a felszín csak azt jeleníti meg, ami a mélyben van [...] Ezért mondja Kavafis, hogy bárhová mégy, a város veled megy. Mert a város valójában te vagy.”" Ezzel a tér és ember között fennálló szoros összefüggéssel a modern társadalomtudomány térpoétikai ága is foglalkozik: „A város maga a történelem letéteményese, egy város architektúrája szorosan kapcsolódik a társadalom-, a politika- és a kultúrtörténethez [...] A város maga az emberek kollektív emlékezete [...]”10

Ugyanezt az emlékezet - tér - identitás közötti szoros kapcsolatot fejezik ki a mequinensaiak visszaemlékezései ${ }^{11}$ a régi város lerombolására. A megfogalmazásbeli hasonlóságok alátámasztására néhány példát idézek: „életünk egy darabját vették el tőlünk [...] elszakítottak bennünket a múltunktól. Ha visszamehetnénk a régi városba, ott kézzelfogható formában találnánk meg az emlékeinket, melyeket itt, fizikai referenciák hiányában sokkal nehezebb felidéznünk. Mert elvágták a köldökzsinórt, mely a múltunkhoz köt bennünket.”12 „Mintha kilakoltattak volna. Mintha megint számüzetésbe kellett volna mennünk, mint a háború idején [...] szorongás, tehetetlenség, kétségbeesés [...] a városunk

fordítói közül többen más képet közvetítenek a címben, köztük a legkifejezőbb a szlovén fordító, Simona Skrabec, Proti toku (Ár ellen) verziója.

${ }^{7}$ Mayorga, Juan, El cartógrafo, http://muestrateatro.com/archivos/22Cartografo.pdf, letöltés 2017. dec. 7.

${ }^{8}$ http://www.vilaweb.cat/noticies/carles-jordi-guardiola-carles-riba-actua-com-a-pal-de-paller-vertebradordaquesta-generacio-destrossada-per-la-guerra-civil-i-lexili/, letöltés 2017. júl. 20. Interjú Carles-Jordi Guardiolával, a Magrana Kiadó volt igazgatójával, Carles Riba életmüvének irodalomtörténeti feldolgozójával.

9 Margarit, Joan, Pregó a la Mercé de Barcelona 2010 http://www.vilaweb.cat/media/continguts/000/015/ 162/162.pdf, letöltés 2017. júl. 21. Kavafis versét, La ciutat fordította Carles Riba 1910-ben „La ciutat, on tu vagis anirà" https://www.researchgate.net/publication/283487014_Nuestro_Cavafis_El_nostre_Kavafis 63, letöltés 2017. júl. 21.

${ }^{10}$ Rossi, Aldo, La architectura de la ciudad, Barcelona, Gustavo Gili, 1995, 222. o. idézi Luczak, Barbara, Espacio y memoria, Barcelona en la novela catalana contemporánea, Poznań, Uniwersytet i.m. Adama Mickiewicza w Poznaniu, Seria Filologia Romańska, 2011. 25-35. o.

${ }^{11}$ Cubero, Carlos - Estruga, Batiste, Mequinenza „Lo Poble”. El triste final de un pasado, la esperanza de un futuro 1956-73, Zaragoza, Diputación de Zaragoza, 2016.

${ }^{12}$ I.m. Cubero-Estruga, 57. o. Ricardo Orús Rodes visszaemlékezése. 
olyan volt nekünk, mint egy családtag, s látni a halálát, ahogy napról napra pusztulnak el a házai, melyek annyi emléket őriznek [...]”13 „Felkavaró érzés. Hogy a város, ahol születtél apránként eltünik [...] s vele az emlékeid, a kamaszkorod. Még ma is, ha otthon beszélünk valakiről, de nem jövök rá, hogy ki az, azt kérdezem, hol lakott a régi városban?”, „[...] ha a pozitív oldalát akarom nézni, akkor azt mondhatjuk, hogy a házak lerombolása, és annak fájdalma az új Mequinensa lakóinak közös emléke, mely összeköt bennünket.”15 Moncada nem csak a pusztulás fájdalmát, a mequinensai kollektív emlékezet e leglényegesebb összekötő elemét akarta megírni, hogy „a könyv ne legyen elviselhetetlen rémálom”. A romos város utolsó évébe mindig visszafutó időszerkezet jelzi az elkerülhetetlen véget ${ }^{16}$, de a humorral és szeretettel megírt történetek emlékezeti hálóba fonják a régi egységet. A regény formája tehát ugyanolyan lényegi része a mítikus Mequinensa történetének, mint a benne foglalt történetek jelentése. Moncada véleménye szerint minden narráció megköveteli a maga formáját, s úgy lehet elrontani egy a történetet, ha az író rossz formát választ az elmeséléséhez. ${ }^{17}$ A folyók városának szerkezete megmutatja a város egészét az idő egészében, amennyire az író prizmája képes volt azt magába gyüjteni és visszaadni. Olvasásakor Mequinensa halotti torán veszünk részt, mely magába süríti az elmúlás fájdalmát, és érezteti az élők összetartozását, s a közös ünnep örömét.

\subsection{A regény nyitánya: bevezetés a városba és Moncada történelemfilozófiájába}

A regény nyitómondata, melyet a Mequinenza a través de la historia c. helytörténeti monográfia szerzője a régi város elpusztításának $\mathrm{s}$ az új felépítésének szentelt fejezet mottójául választott, így hangzik: „Az oszlopok és a főfalak hirtelen megrepedtek, s a meredek Patkó utcán fülsiketítő robaj zúgott végig, amelyben eggyé olvadt a mestergerendák és a keresztgerendák recsegése, a lépcsők, födémek, közfalak, a beomló boltívek döreje, az üvegtáblák csörömpölése meg az összetöredező téglák, cserepek és

\footnotetext{
${ }^{13}$ Uo. 66-7. o. Marieta Roca (del Moliner) visszaemlékezése.

${ }^{14}$ Uo. 105. o. Rafael Navarro Candel visszaemlékezése.

${ }^{15}$ Uo. 132. o. Geri Nicolau Ordoñez visszaemlékezése.

${ }^{16}$ Nagy hálával tartozunk az írónak, aki nem eltemette, hanem feltámasztotta a régi várost. Julio Llamazares, aki szintén egy víztározó mélyére süllyesztett település, Vegamián szülötte, 2016-ban jelentette meg életrajzi vonatkozású regényét, Distintas formas de mirar el agua ( $A$ víz szemlélésének különbözö módjai) címmel. Ebben nosztalgiával teli, elégikus hangnemben elsiratja a nagyszülők tragédiáját, a szülők és az unokák gondolatain át idézi meg az eltünt völgyet, a régi életmódot. Ezzel szemben A folyók városa egy sokarcú, életteli „totális” városportré. A különbségért egyrészt az írók stílusa és lelki alkata felelős, de szerepet játszhat benne az emlékező közösség nagy részének otthoni tájban maradása Mequinensa esetében, és a teljes szétszóródás Vegamián esetében.

17 1989-11-26 El Punt - El mite de l'Ebre, Miquel Pairolí.
} 
csempék ropogása, a ház pedig egyszer s mindenkorra összedőlt. Az omlást követően porfelleg emelkedett a városka fölé, az első azok közül, amelyek az akkor megkezdődött hosszú haláltusát végigkísérték.”18 Ennek a mondatnak a fordítását tizenkét nyelven köztük magyarul is ${ }^{19}$ - hangfájlban közli az író müveinek és életének szentelt weboldal, az Espais literaris de Jesús Moncada. Az irodalmi alkotás esetében szokatlan helyszín képe in medias res állítja az olvasót a város lerombolásának színhelyére és idejébe. A történeti monográfia mequinensai szerzője, aki maga is átélte a rombolást, fontosnak tartotta, hogy olvasóival érzékeltesse annak brutalitását, s a mottóval az érintettséget próbálta megidézni. A weboldalt készítő irodalmárok és nyelvészek a mondatot olyan nyelvi bravúrként érzékelték, amelynek fordítására és fonetikájára idegen nyelveken is kíváncsiak voltak. A nyitómondat, mely a rombolás nyitányát örökíti meg, a regény idejét 1970. április 12-éhez köti, amikor a módszeres pusztítás fizikailag megkezdődött. Az ENHER a lakosság demoralizálásával igyekezett felgyorsítani az erőmü üzembe helyezését, ezért azonnal lerombolta a házat, melynek tulajdonosaival megegyezésre jutott a kiköltözésről. A mequinensaiak ezért, ki hosszabb, ki rövidebb ideig, állandó porfelhöben és romok között éltek, amelyek eltakarításáról a vállalat látványosan nem gondoskodott. ${ }^{20} \mathrm{~A}$ regény ideje csillagtúra módjára mindig a város felszámolásának keserü végnapjaiba tér vissza, az innen kiinduló, száz évnyi távolságba tett kirándulások mind itt találják meg végpontjukat.

A könyv nyitánya az első ház lerombolásában összesűrített képen túl tartalmaz még egy nagyon fontos történelemfilozófiai eszmefuttatást is, melyben az író az események és azok „városi krónikája” (közbeszédben megőrzött legendárium) közti meg nem felelést hangsúlyozza. Humorral érzékelteti a tanúvallomások drámaiságát, miszerint, az első ház lerombolása előtti éjszakán megállt a templomtorony órája, ami „kérlelhetetlenül hirdette, hogy a régi idők véget értek”. ${ }^{21}$ A „városi krónika” felvonultat még jó pár költői és drámai képet, mint a hátborzongató szorongás, a viharos alkony, vagy a zsigerekbe költözött félelem, s ezeket az író alteregója, a patikus, a rombolás egyetlen valóságos szemtanúja mind megcáfolja. Ironikus kommentárjai arra hívják fel a figyelmet, hogy a városka akkor már hosszú ideje, tizenhárom éve, szüntelenül rettegett és feszültségben élt, ez nem a rombolás megkezdése előtti éjszaka különlegessége volt. Az első ház lerombolásának

\footnotetext{
${ }^{18}$ AFV 9. o.

${ }^{19}$ http://www.jesusmoncada.cat/?p=919\&page=8, letöltés 2017. aug. 16. A felvétel az író müveinek fordítói számára szervezett Moncada szemináriumon készült Mequinensában 2008 szeptemberében, ezért az első magyar kiadás szövege szerepel. Jesús Moncada, A folyók városa, Budapest, Íbisz, 2004.

${ }^{20}$ L. Mellékletek. Képek, térképek, 12. Az érem másik oldala.

${ }^{21}$ AFV 9. 0.
} 
hangja rövidke dördülés volt csupán „egy olyan városban, amely úgy hozzászokott már a robbantásokhoz, hogy föl se kapta rá a fejét”. ${ }^{22}$ Ez a szikár, egyszerű mondat, a törvényszerűen bekövetkezett pusztulás jelzésére több fájdalmat sürít magába, mint a „krónika” dagályos és patetikus megfogalmazása. A patikus szerint a „krónikában” összegyüjtött tanúvallomások állításával ellentétben, a mindennapi dolguk után loholó emberek észre sem vették az első ház lerombolását, s csak évekkel később kezdték a koholt tanúvallomások gyártását, hogy enyhítsék lelkiismeret furdalásukat és igazolják magukat a történelem színe előtt. „A városka lakói becsapták magukat azzal, hogy oly makacsul ragaszkodtak az 1970. április 12-i dátumhoz, mint kollektív drámájuk legfontosabb időpontjához. S tévedtek akkor is, amikor bünösnek érezték magukat, mert nem voltak jelen az eseménynél.”23

A regény irodalmi müélvezet tekintetében legnehézkesebb és legszárazabb része ez a nyitó magyarázat. Ezzel Moncada megpróbálja érzékeltetni, hogy: 1. Az események valóságához legközelebbi ábrázolásnak nincs feltétlenül köze a tudományosság követelményeit teljesíteni igyekvő kronológiai pontossághoz („,a bürokratikus véletlen épp ezt a napot jelölte ki”24). 2. A tragikus-romantikus megjelenítés nem tud közelebb vinni annak a lényegi jelentéséhez, ami történt. 3. Hosszú, csendes, fájdalommal teli folyamatok múlnak el jeltelenül, melyek érzékeltetésére a krónika típusú megjelenítés nem alkalmas, pedig az emberek életét sokkal nagyobb részben határozzák meg, mint a jeles napok. Rámutat, hogy a kollektív emlékezet (kulturális és kommunikatív egyaránt) hogyan ruház fel szimbolikus jelentőséggel egy-egy dátumot, mert az események időbe való belehorgonyzása megnyugtató magyarázatként szolgál az időbe vetett ember számára. Az annalesek, a történetírás legkorábbi formái megelégedtek azzal, hogy kronologikus keretbe illesztették az eseményeket, amivel kijelölték helyüket a parttalan időben. Az emberi életút két legfontosabb eseménye a születés és a halál, a temetőkben egyedül a befejezett életutak sírkőbe vésett dátumai jelzik számunkra az emberek világban egykor elfoglalt helyét. A mequinensaiak bűntudata abból fakadt, hogy ennél az utólag rendkívüli fontossággal felruházott, szimbolikus eseménynél nem voltak jelen, ami a kisvárosi mentalitásból fakadóan olyan, mint ha valaki nem menne el egy földije temetésre. Ezt a Történelem színe elötti mulasztást igyekeztek pótolni a hamis tanúvallomások romantikus túlzásai. Ez a furcsa nyitány egyben

\footnotetext{
${ }^{22}$ AFV 12. 0.

${ }^{23}$ AFV 13. o.

${ }^{24}$ Uo.
} 
írói szándéknyilatkozat is arra, hogy nem kronologikusan és nem romantikusan akarja ábrázolni a város megsemmisülését.

A moncadai „totális regény” a mequinensaiak individuális emlékezetének az író által összeállított mozaikja. Ezeknek a megjelenését ő is a „bürokratikus véletlen” által kijelölt naphoz, a pusztulás kezdetéhez köti: „az emlékek szokatlanul heves megjelenése talán (annak köszönhető, amit) [...] a Patkó utcában álló ház lerombolása [...] keltett a városka emlékeiben. Lehetséges, hogy az utcák, a terek, a házak s a két folyó ontották magukból (az emlékeket) [...], hogy valaki összegyüjtse öket az elkerülhetetlenül bekövetkező leromboltatás és szétszórattatás előtt”. ${ }^{25}$ A fikció tehát nem lép ki a történelmi időből, melynek e pillanatát maga is mérföldkőként használja, de jelzi, hogy más idősíkokat is megmozgat. Az emlékezés egyértelműen a halálhoz kötődik, Moncada ezzel az emlékmunkával ad halálon túli életet szülővárosának, amely az írói alteregó, a patikus szerint: „nyilvánvalóan nem ugyanazon a napon halt meg mindenki számára. A gyötrelem hosszú évei alatt, mindenki más-más pillanatban érezte, hogy elérkezett a vég, s az öreg Nelson számára ez a pillanat valószínűleg Júlia távozása volt." ${ }^{26}$ A szeretetszálak által összefüzött város a kényszerü számüzetések ritmusában, apránként hal meg. A rövidke dörrenések közepette leomló házaknak nincs történelmi jelentőségük, mint ahogyan a falaik közt eltelt életeknek sem. A történelmi horderejü esemény, a város lerombolása azonban felszínre hozza a bennük rejtőző emlékezeteket, s ezek önmagukban értéktelen darabkáit összeillesztve az író, egy egyedülálló művészi korrajzot, egy Moncada trencadíst hoz létre.

Ebben a nyitó részben megjelenik még a patikus alakja, a város sorsában osztozó írói alteregó, aki „a fájdalomtól moccanni sem bírt”, amikor végignézte az első ház lerombolását. Az ő ironikus kommentárjaiban halljuk megfogalmazódni Moncada racionális kritikáját a város legendaképző mechanizmusaival, babonáival és tudatlanságával szemben, s az ő szeretettel teli humora aranyozza be a késő Franco korszak szürke, erkölcscsősz világát. A város történetét romantikus túlzásokkal ábrázoló „krónikák”, a patikus ironikus kritikája, a szereplők egyéni emlékfolyamai, és a különböző narrációk valóságértékének szembeállítása, reflektáltsága azt jelenti, hogy Moncada jóval árnyaltabban nyúl a diskurzus és annak tárgya közötti megfelelés kérdéséhez, mint nagy realista példaképe, Balzac, aki azt vallotta: „A történetíró a francia társadalom lesz, nekem csak az a dolgom, hogy az írnoka legyek.”²7

\footnotetext{
${ }^{25}$ AFV 32-33. o.

${ }^{26}$ AFV 120. o.

27 Balzac, Honoré de, Emberi színjáték, Bevezető http://enciklopedia.fazekas.hu/palyakep/vilag/Balzac.htm , letöltés 2017. júl. 20.
} 


\subsection{A regény témája és szerkezete}

Az érintettség előidézésére szolgáló sorokat és a szerző történelemfilozófiai álláspontjának alapvetéseit tartalmazó bevezető fejezetet követően a regény négy fejezetre és egy epilógusra tagolódik.

Az első rész, Az Éden napjai által ábrázolt idő az I. világháború utáni válsággal zárul, és paradicsomi, boldog békeidőként ábrázolja a századelő és a háborús konjunktúra éveit. Az egyik igen fontos szereplő, a mítikus erővel felruházott „párjanincs” hajóskapitány, az 1840es születésű Arquimedes Quintana emlékei nyomán visszajutunk egészen a tetuáni csatáig (1860), melynek történetét a kisvárosi kávéház közönsége gyakran elmesélteti az öreg veteránnal. Legendák, babonák, hiedelmek tarkítják a történeteket, és megismerjük a két főszereplő néhány vonással felrajzolt gyerekkorát. A regény jellegzetes figurákon keresztül megjeleníti egész Mequinensát, s valójában maga a város a föszereplő, de létezik két különösen fontos figura, akik egyidősek, s két különböző emlékezeti fonadék fő szálát képviselik. Az egyikük, Robert Ibars, alias Nelson, Arquimedes Quintana tanítványa, maga is legendás hajóskapitány, amint az a városkában rövid ideig tartózkodó angol geológus által neki adományozott névből is kitűnik. ${ }^{28}$ Ö a hajósok, bányászok, hajóácsok, s egyéb mesteremberek és segédmunkások, vagyis a város plebejus emlékezetének őrzője. A másik főszereplő Carlota de Torres i Camps kisasszony, (a Dagadt Carlota), a földek, bányák, gyárak, házak tulajdonosainak emlékeit őrzi a magáéba olvasztva. Mindketten a századelőn születtek, s életük a város lerombolásáig szorosan összefonódik Mequinensa életével. Az ő emlékezetük asszociációs lánca minden fejezetben megjelenik, s kiegészül más melléktörténetekkel. A kiindulópont minden esetben a regény jelenideje, az egymás után sorra következő házak lerombolása, s az ezekből kiinduló emlékezetfolyamok.

A második rész, A tizenhárom szent szigete szintén a rombolások idejéből indít. Először a különböző lerombolandó házakból a kiürítés során előkerülő tárgyak történetén keresztül eleveníti fel a múltat, amelynek szálai elérnek egészen a napóleoni (függetlenségi) háborúig, amikor 1808-ban Mequinensát elfoglalták Suchet tábornok csapatai, vagy az első karlista háborúig, amikor Cabrera tábornok seregei támadták a várost 1834-ben. Ez a rész mutatja be a város történetét az 1920-as években, a köztársasági években és a polgárháború idején.

\footnotetext{
${ }^{28}$ Az angol geológus - valószínűleg teljesen fiktív figura, semmilyen más, általam ismert forrás nem említi -, a regényben a köztársaságpárti emlékezeti vonalhoz tartozik. Az általa adományozott név az író beszélö neveinek egyike, hisz a trafalgari győző (1805) neve a dicső katonai-birodalmi spanyol gondolatkörrel való szembenállást hangsúlyozza.
} 
Az utolsó jelenet 1938. március 27-én játszódik, a város kiürítésének napján, mely a regény jelenében az apácazárda épületének lerombolásával áll asszociációs párban. Ennek az épületnek a falait díszítették Aleix de Segarra, a liberális bohém nemes festményei, aki az Éden mulató boldog napjait ábrázoló freskókra ráfestette a polgárháborúval a várost elborító félelmet és szorongást, s a győztesek bevonulásának vízióját.

A harmadik rész A hamuvá lett naptár a révész emlékeivel indít, aki a város módszeres elpusztításának második évében, a kikötő épületeinek lerombolásakor visszaemlékezik arra, hogyan kezdte újra ösei mesterségét 1939-ben, a híd nélkül maradt városban. A hidat a köztársaságiak robbantották fel a város evakuálásakor, a lázadók által felállított ideiglenes pontonhidat pedig Franco csapatainak távozása után felszedték. Ez a fejezet a kompon érkező visszatérők emlékeit gyüjti össze, melyekben a háború alatti megpróbáltatások, veszteségek, és a háború utáni éhezés, koncentrációs táborok, eltünt hozzátartozók képe jelenik meg. Nelsonnak sikerül a háborúból megmentenie a hajóját, így ennek története is csatlakozik a Barcelonából visszatért kormányosáéhoz. Carlota de Torres Valladolidból, a nacionalista országrészből érkezik vissza a háború végén, elfoglalja helyét a Dísz téri ház erkélyén, ahonnan újra „felügyeli és uralja az embereket és a tárgyakat”, és megállapítja, hogy „végérvényesen visszatért a dolgok örök rendje az 1936-os felfordulás után”. ${ }^{29}$ A háború utáni autarkiás gazdasági berendezkedés, a csendőri önkény, a korai Franco-korszak ideje ez, mely Mequinensában paradox módon a II. világháború által generált ipari fellendüléssel párosul. A zárójelenetben Carlota apjának 1950-es pompás, ámde botrányosra sikeredett temetését idézi fel a városi emlékezet, mely az évforduló alkalmából mondatott gyászmise apropóján lép elő az emlékezetből. Ekkorra már, „a rombolások második évében, a temetési menet egykori útvonala, amely majd ezer évig a város ütőereként szolgált, már mindenütt tele volt sebekkel. A Móló Kávéház törzsvendégeinek emlékei gyakran elvesztek a romok között.”30

A negyedik rész, A fekete szél a víztározóépítés korszakát öleli fel. Ennek fő helyszínei szintén a Móló Kávéház és annak hajósnépekből és bányászokból álló törzsközönsége, valamint Carlota de Torres Dísz téri otthona. A cselekmény idővázát a patikus öt és fél letartóztatásának krónikája adja, melyek mindegyike a Franco-rendszer ironikus karikatúráját adja. A letartóztatások oka többek között a közszemérem elleni vétség, a megrendelésre működő isteni csodák kigúnyolása, az emlékezet nélkül maradt köztársasági

\footnotetext{
${ }^{29}$ AFV 203. o.

${ }^{30}$ AFV 233. 0.
} 
halottakra való emlékeztetés, a jeltelenül, tömegsírba temetett katonák elgyászolatlan, végtisztesség nélküli halálának motívuma, ami egyfajta rendszerkritikaként is olvasható, mely a humor segítségével vonja ki a fájdalmat az elszenvedett sérelmekből, s mutatja meg mégis a rendszer igazságtalan és képmutató jellegét.

Az Epilógus a Végleges számüzetés alcímet viseli. Ez a mindössze hét és fél oldalas zárszó elégikus búcsú a régi várostól, egy régi kortól, melynek elmúlását drasztikusan felgyorsította a vízerőmü építése. Az epilógus sorai kísérik utolsó útjára Carlota de Torrest, a régi város utolsó halottját, $\mathrm{s}$ a horizonton megpillantjuk az új várost is, melyről Nelson azt mondja: „A város lakói közti mindennapi kapcsolatok bonyolult hálója bizonyosan újrafonódik majd, és az élet, amelyben a folyók már nem számítanak a város ütőereinek, más alapokon fog újraszerveződni. A régit azonban csak a legfiatalabbak, a csecsemők felejtik el teljesen, a többiek emlékezetének egy része ottmarad, s gyökérként kapaszkodik az Ebro és a Segre vize alatt [...] Ö, a hajó nélküli hajós, a visszatérés minden reményétől megfosztott számüzött már ahhoz a végtelen éjszakához tartozik, amelyben apja, kislánya, [...] és annyi más, szívének kedves árny hajózik csendesen a feledés felé.»31

\subsection{A regény idöszerkezete}

Jesús Moncada ezt a regényét érdektelennek és hatástalannak érezte volna, ha időrendi sorrendben építi fel a cselekményét. Az általa választott flash-back technika arra szolgál, hogy összekösse az idő szálait, hogy megteremtse azt a helyet, ahol egyszerre létezik a jelen és a múlt, hiszen a rombolás az emberek múltjukhoz való viszonyát érintette, valójában azt rombolta le. Az idő nyitva maradt a jövő, az új város felé, ám megszünt a begyökerezettség, amely a jelen pontban állva egy személy identitásának az egyensúlyát adhatja. A romokból visszakígyózó emlékezetek rengeteg apró történetet, részletet, szokást, szót, arcélet őriztek meg, s ezek mindegyike jelen van a regény lapjain a bonyolult időépítménynek köszönhetően.

Moncadának igaza van abban, hogy a kronológiai sorrend valóban nem képes érzékeltetni a múlt jelenlevőségét, s felszámolásának fájdalmát, ám számára is rendszerező elvet kínál a történet felépítéséhez, hiszen a rombolás ideje (1970-1973), csakúgy, mint a felidézett múlt (Tetuáni csata, Tragikus hét, I. világháború, Spanyol polgárháború, második világháború, Franco-korszak), időrendben halad a város megsemmisülése felé. Moncada

${ }^{31}$ AFV 297-8. 0. 
történelmi dátumai pontosak, és a regény felépítményében fontos szerepet játszanak, mert megnevezésükkel az író azt érzékelteti, hogy a világméretben is jelentős események hatása elér Mequinensába. Jó példa erre az I. világháború, amelyben Spanyolország nem volt hadviselő fél, de iparára nagyon fontos hatást gyakorolt a konfliktus: „Néhány hónappal később, novemberben, a legyőzött Németország fegyverszüneti egyezményt kötött Compiègne-ben, s a város bányáiban kitermelt szén iránti kereslet, mely addig kielégíthetetlennek tűnt, hirtelen megcsappant.”32 Vagy: „Lelöttek egy trónörökös herceget valami Szarajevónak nevezett távoli helyen, a városban pedig valaki, nem tudni, hogy ki, rálőtt Jaume de Torres úrra.”33. Moncada gyakran alkalmazza regényeiben ezt a „kronológia technikát”, a helyi eseményeket, az országos vagy az európai politika fordulópontjaihoz köti, így az olvasó könnyebben el tudja helyezni a regény idejét a történelmi időben. Fordított irányban is jól müködik ez a regénytechnikai eszköz, mely a történelemben járatlan olvasó számára megkönnyíti, hogy a regénybeli történethez kötött évszámok segítségével jobban eligazodhasson az ország vagy a világ történelmét meghatározó jelentős dátumok között. A szarajevói merénylet például általánosan ismert szinonimája az első világháború kitörésének, ami a müvelt átlagolvasóban felvillantja az 1914-es dátumot. A compiègne-i fegyverszünet már kevésbé pontos támpontot ad a laikusok számára, a kontextusból azonban egyértelműen kiderül, hogy az első világháborút lezáró francia-német egyezményről van szó. Egy születésnapi ünnepségen, ahol látens ellentét feszül az antantbarát és németbarát vendégek közt, a háború hadszíntereiről folyik a beszélgetés, melyből kiderül, hogy a háborún gazdagodó mequinensai vállalkozóknak fogalmuk sincs az események földrajzi vagy történelmi összefüggéseiröl, és szívük mélyén egyikük sem kívánja a háború végét. Az eseményeknek a sorában Moncada egyetlen nevet említ: „Joffre tábornok hasztalan áttörési kísérletei a Vogézekben”, s így az első világháború kapcsán belecsempészi a regénybe a katalán híres emberek panteonjába tartozó, magas rangú francia tábornok emlékezetét. $^{34}$ A II. világháború eseményei közül megjelenik Lengyelország lerohanása, és 1940 júniusa, amikor a németek bevonultak Párizsba, amit a kaszinóbeli németbarát úri középosztály örömmel üdvözöl. Megjelenik még Hitler és Mussolini neve

\footnotetext{
${ }^{32}$ AFV 73. o.

${ }^{33}$ AFV 40. o.

${ }^{34}$ Joseph Joffre ( 1852-1931) a marne-i győző. L. melléklet Lexikon 9. http://www.historyofwar.org/articles/ people_joffre.html, letöltés 2017. szept. 23. és https://www.racocatala.cat/forums/fil/189857/militar-catalames-important-historia-va-ser?pag=1, letöltés 2017. szept. 23.
} 
mint a spanyol birodalmi ékesszólás fő hivatkozási pontjai ${ }^{35}$, valamint Hitler legyőzése és a japán fegyverletétel, amelyhez a regény idejében a Mequinensa-környéki partizántevékenység megélénkülése kapcsolódik. A partizánokat, s az őket segítő városlakókat Moncada szimpátiával ábrázolja, de nem heroizálja, inkább az ideáljaik kiharcolására választott módszer tragikus lehetetlenségét hangsúlyozza, s ebben rokon a pár évvel korábban megjelent Farkasok ideje (Luna de lobos) címü Llamatzares regény szemléletével. ${ }^{36}$ A Franco-korszak irodalmának partizánábrázolásai minden politikai, eszmei és emberi érték híján lévő, törvényen kívüli rablóknak láttatják ezeket a köztársaságpárti gerillákat, akiknek harca 1963-ig tartott. A partizánok, mint az elveszett történelmi emlékezet egyik témája a 90-es évek regényirodalmában jelenik meg gyakrabban témaként Spanyolországban. ${ }^{37}$

A regényben ábrázolt idők egyike az örök ismétlődésekkel jellemzett „vidéki idő”: Carlota de Torres szobalányaiból például mindig három van, csak a nevük változik, de ezt a három nevet az író minden esetben felsorolja. Az úri szalon uzsonnájára hivatalos „édesszájú hárpiák” (középosztálybeli dámák) csapata a görög drámák kórusához hasonlóan kommentálja a kisvárosi eseményeket mindig ugyanabban a sorrendben, mindig ugyanolyan jelentéktelen, hétköznapi rosszindulattal. Erről az időről a szerző így nyilatkozott: ,,a vidéki élet nagy veszélye, hogy az idő nemigen számít [...] hajlamos vagy rá, hogy másnapra hagyd a dolgodat, s ez a másnap eltarthat száz évig is.”38

Ebbe a vidéki időbe tartoznak a Mequinensa mítosz történetei is. A rengeteg fö és mellékszereplő egymást kiegészítő, magyarázó történetei, melyek színtere a város. Ugyanazok az utcák, ugyanaz az időpont, és két teljesen különböző történet. Ahogy az emberek útja keresztezi egymást a jelenben, úgy ütköznek egymásba az emlékezetek a regényben. Carlota de Torres szobalánya arra emlékszik, hogy nagyon félt, amikor kisurrant a házból, hogy úrnője üzenetét titokban elvigye a szeretőjének, mert az utcán nagy felfordulást, verekedést talált. Az „öreg Nelson nem vette észre, hogy Carmela emlékein bandukol keresztül, amelyek a városnak éppen arra a pontjára vetültek, ahol 1925-ben a

\footnotetext{
35 Ezzel Moncada kiemeli a Franco-rendszer ideológiai alapjait, melyeket a fasiszta retorikától és szimbolikától távolodó, magát szalonképessé tenni igyekvő organikus demokrácia nem hangsúlyoz.

${ }^{36}$ Llamazares, Julio, Luna de lobos, Barcelona, Seix Barral, 1985. A katalán irodalomban a téma fontos ábrázolása Jaume Cabré, Les veus del Pamano, Barcelona, Proa, 2004.

${ }^{37}$ Izquierdo, José María, „Maquis: Guerrilla antifranquista. Un tema en la literatura de la memoria española” https://www.uv.es/cerverab/Izquierdo.pdf, letöltés 2018. ápr. 18. . . Quico Sabaté 1980. Colectivo Penta. Documental sobre el guerrillero catalán https:/www.youtube.com/watch?v=Dqne1wyftPY, letöltés 2017. ápr. 18.

38 1988-02-01 Resso de Ponent - Guardeu-vos de caure en mans de periodistes afeccionades, Mercè Biosca.
} 
csendőrosztag megrohamozta a tüntetőket.”39 A felidézett történetekben a két szereplő csak villanásnyi időre pillantja meg egymást, nincsen semmi közük egymáshoz, a közös tér és idő nem köti őket egy emlékezeti csoporthoz. Az író így érzékelteti, hogy a tapasztalattér és az elváráshorizont különbsége mentén ugyanabban a városban az emlékezetnek különböző „országai” élnek.

Az emlékezéssel meghosszabbított rövidke emberi idő, $\mathrm{s}$ a történelmi idő is eltörpül a természet nagy idejéhez képest. A polgárháborús világégés után Nelson így gondolkodik: „[...], a folyó mégsem változott semmit [...] a csata emlékét nem őrizte meg. Az emlékezés az emberek sajátja, és az Ebróban rejlő erő érzéketlen azoknak a teremtményeknek az erőfeszítései iránt, akik kihalásszák belőle a halat, hajóikkal a hullámait hasítják, vagy holtan fekszenek sáros, hideg fenekén." ${ }^{40}$ Egy tájnak a térképét tehát mi teremtjük meg azáltal, hogy melyik pontjára emlékezünk, mint ahogy a történelmünket is mi írjuk azokkal a szereplőkkel, akik a szívünknek kedvesek, vagy akikre azért emlékezünk, mert gyülöletesek, s árulkodó a csönd is, mellyel kiejtjük emlékezetünkből bizonyos események és szereplők nyomát.

\subsection{A regény tere és a katalán emlékezeti tér kapcsolata}

Mequinensa helyét megrajzolni az olvasók szellemi térképén nagy kihívásnak számított a nyolcvanas években, amikor a katalán irodalomkritika Barcelonát preferálta, mint regény helyszínt, s mint a nemzetközi siker zálogát. Katalónia világhírü metropolisza mellett találunk azonban más regényes városrajzot is a katalán irodalomban: Maria Aurèlia Capmany, Betúlia (Badalona), Miquel Llor, Laura a la ciutat dels sants (Vic), Jaume Cabré, El llibre de Feixes (Terrassa), Joan Frances Mira, Els treballs perduts, El Purgatori, (València); Baltasar Porcel mítikus regényhelyszíne, Andratx vagy Jesús Moncada irodalmi Mequinensája. Az ismeretlen kis települések csakis krónikásuknak köszönhetően kerülnek be egy nemzet kulturális kánonába. Mequinensa képét Moncada regényei rajzolták bele a katalán köztudatba. Először 1971-ben irányította a figyelmet a kisváros hamarosan bekövetkező tragédiájára, amikor a montserrati bencések által müködtetett katalán nyelvü irodalmi, kulturális, közéleti folyóirat, a Serra d’Or, 1971 márciusában megjelentette az akkor még teljesen ismeretlen, ifjú írónak az újság irodalmi pályázatára beküldött novelláját

\footnotetext{
${ }^{39}$ AFV 109. o.

${ }^{40}$ AFV 190. o.
} 
Az utolsó rum krónikája ${ }^{41}$ címmel. A Serra d’Or, a Franco-korszak legrégibb és egyik legtekintélyesebb katalán orgánuma ${ }^{42}$ volt, s már az is egy jutalommal ért fel, hogy ha egy írást itt közöltek. A novellához mellékelt fényképek a régi várost, a meredek hegyfalakat, és a mequinensai embereket ábrázolják, s egy rövid definíció eligazítja a katalán olvasókat, hogy hol keressék a kérdéses helyet: „Mequinensa, a katalán-aragón határon fekvő, katalán nyelvü város a Segre és az Ebro folyók összefolyásánál található, és közigazgatásilag Saragossához tartozik". ${ }^{43}$ Erre a rövid, tájékoztató jellegü közlésre azért volt szükség, hogy a teljes ismeretlenségből előlépő hely koordinátáit meghatározza a katalán szellemi térben.

A folyók városának neve a regényben különös módon egyedül az előszóban jelenik meg, amikor az író jelzi, hogy „a regény anyagát a régi Mequinensa elmúlt száz esztendejének eseményei alkotják”, attól kezdve a város csakis, mint vila ${ }^{44}$ szerepel az eredeti szövegben, ellentétben a mequinensaiak városukra alkalmazott lo poble megnevezéssel. Az író döntése kitágítja a város fogalmát, mely így egy mindenkit befogadó várossá válik. A lo poble csak a helyi lakosok számára utal Mequinensára, a vila az irodalmi város megnevezése, melynek polgárai az olvasók is.

\subsection{A regény által kirajzolt földrajzi univerzum ${ }^{45}$}

\subsubsection{Folyók}

A folyók városának emlékezet-földrajzi univerzumát egyrészt úgy határozhatjuk meg, hogy összegezzük a szereplők emlékeiben felbukkanó városok, települések által felrajzolt térképet. A város az Ebro és a Segre összefolyásánál található, aminek ma már nincs stratégiai jelentősége, de az út- és a vasúthálózat kiépülése előtti időben ez rendkívüli fontosságot biztosított a településnek és erődítményének katonai és közlekedési

\footnotetext{
${ }^{41}$ Cabòries estivals, Barcelona, Edicions 62, 2004. 17-29. o. A szerző publicisztikáját tartalmazó kötet.

${ }^{42}$ http://www.lluisvives.com/hemeroteca/serrador/, letöltés 2017. jún. 11. L. még http://www.pamsa.cat/ pamsa/revista/sdo.html, letöltés 2017. jún. 11. Publicacions de l’Abadía de Montserrat S.A.

${ }^{43}$ 1971-03-01 Serra d'Or Crònica del darrer rom - Escriptors joves, Jesús Moncada.

${ }^{44}$ Mequinensát IV. Ramon Berenguer IV aragón-katalán seregei 1149-ben vették be, miután egy évvel korábban elfoglalták a régió legfontosabb andalúz fơvárosát, Tortosát. Pere Balaña, Mequinensa mór korszaka kutatójának véleménye szerint a moriszkó lakosság a maradás mellett döntött, s a betelepülés során Katalóniából érkeztek új lakosok. Mivel azonban a várost az aragón nemesség csapatai foglalták el, Saragossa városi jogát kapta. IV. Ramon Berenguer a móroktól visszahódított földek ötödrészét a templomos lovagoknak adta segítségükért cserébe, így került az Ebro mente Mequinensától (castrum és vila) Benifalletig 1153-ban a templomosok nagymesterének joghatósága alá (Maestrat) Estruga, Jordi (dir.), Mequinenza a través de la historia, Mequinenza, Ayuntamiento de Mequinenza, 2010, 90-103. o.

${ }^{45}$ L. Mellékletek. Képek, térképek, 1 . Térképek.
} 
szempontból egyaránt. A Segre Lleidán át a katalán Pireneusok felé nyitott víziutat (265 $\mathrm{km})$, melyen az ottani erdők fáját úsztatták a tengerig, az Ebro pedig Saragossa és az általa képviselt Aragónia számára biztosította az olyannyira áhított kijáratot a tengerig. A regény középkori városmagról és régi mór piactérről beszél, melynek labirintusán túl az új városrészt a 18. században kerítették újabb városfallal, de a történeti monográfia utal olyan hipotézisre is, mely szerint Mequinensa azonos a Római Birodalom Octogesa nevü

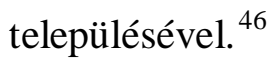

A regényben legtöbbet szereplö földrajzi nevek a folyók nevei. Első helyen áll az Ebro, mely 158-szor jelenik meg, ezzel szemben a Segre csak 27-szer. Ennek a különbségnek az oka abban rejlik, hogy bár a Segre áradásai szintén fenyegették a várost, a partján ugyanúgy mostak az asszonyok és játszottak a gyerekek, mint az Ebróén, ám a mequinensai hajósok az Ebrót hajózták. Az Ebro Spanyolország legnagyobb vízhozamú folyója, mely a Földközitengerbe ömlik. A 900 km hosszú folyó a Cantábriai hegység déli oldalán ered, Rioján és Aragónián folyik keresztül, ahonnan Riba-rojánál lép át Katalóniába, majd Tortosa alatt széles és termékeny deltát alkotva éri el a tengert.

Mequinensától folyásirányban az első település Faió, mely szintén a riba-rojai tározó vize alatt pihen, mint a régi Mequinensa. Faió neve 31-szer szerepel a regényben. Ezen a településen haladt át a Barcelona-Saragossa vasútvonal, ennek a vasútállomására érkeztek a Mequinensába tartó utasok, akik innen hajóval (szénszállító vitorlással) vagy gyalog folytathatták útjukat a városig. A Faióig közlekedő vitorlásokról rakták át a szenet a tehervonatokra ${ }^{47}$, így a település mind közlekedés, mind pedig kereskedelem szempontjából fontos része volt Mequinensa életének. Ennek a Faiót érintő vasútvonalnak a kiépülése lett az igazi vetélytársa az ebrói hajózásnak, melyet hiába próbáltak modernizálni menetrendszerü gőzhajó közlekedéssel, ez képtelen volt állni a versenyt a gyorsabb vasúttal majd később az aszfaltozott úthálózattal.

Az ebrói vitorlások másik időhöz tartozó közlekedési eszközök, ám, mint a regény is dokumentálja, a két rendszer egészen 1970-ig, párhuzamosan müködött a térség természeti kincseinek piacra juttatásában. Az átlagban húsz tonna lignitet szállító vitorláshajók ${ }^{48}$,

\footnotetext{
${ }^{46}$ Estruga, J. (dir.), 52-60. o.

${ }^{47}$ MCSL Entrevista amb Quico. A hajóskapitány elmondja, hogy a Faióba tartó hajók hajnali 4-kor futottak ki, és este kilencre értek vissza a városba.

48 L. Mellékletek. Képek, térképek, 2. Szénszállító hajók. MCSL Entrevista amb el vell Raiet(1889-) A hajóács a nagy teherbírású vitorlásokat 30 tonnásoknak mondja. Ő maga vagy 70-et készített. Egy ilyen hajó elkészítésén a mequinensai hajógyárban egy hajóács és két segédmunkás egy hónapon át dolgozott. MCSL Entrevista amb Quico: elmondja, hogy a legtöbb hajó Tortosában, Faióban vagy Morában készült.
} 
az úgynevezett latin vitorlával ${ }^{49}$ szelték az Ebro vizét, kedvezőtlen széljárás esetén pedig emberi, később állati erővel vontatták őket árral szemben. ${ }^{50}$ A vontatás modernizálását a regény az első világháború idejére, pontosabban 1916-ra teszi, s a Moncada hagyatékban talált feljegyzések azt mutatják, hogy ez a megkérdezett interjúalanyok által megjelölt időpontok közti kompromisszum. ${ }^{51}$ Moncada mindent el akar mondani a folyókról, amit az öregek tudtak róla, akik hajózták. Legendákat, babonákat, anekdotákat, gazdasági és kronológiai adatokat egyaránt gyüjt, első regényének talán ezért van jelentős etnográfiai tartalma is. A gyüjtés folyamatát a következőképpen ábrázolja a regényben: „Időközben Honorat (írói alteregó) állandó kibic lett a kártyapartikban. [...] figyelt, hallgatott, s mohón szívta magába nemcsak a játék titkait [...], hanem valami rejtettebb dolgot is, a város szellemét, amely öreg volt, mint a folyók, és csak úgy áradt a kártyázás ürügyével az asztalhoz telepedett emberekből." 52 Az öregeket kérdezte a gőzhajózás megindulásáról is, melyet a válaszok 1918-ra tesznek, és egy Cíclop (Küklopsz) nevü hajóhoz kötnek. ${ }^{53}$ A regényben Polüphémosz névre keresztelt hajó próbaútja Moncada sajátos datálási rendjébe ágyazva jelenik meg: „özvegy Salleresné hajójával kapcsolatos várakozás még az 1918 márciusának végén indított nagyerejü német offenzíváról érkező híradásokat is elhomályosította, amelynek során a németek majdnem elfoglalták Párizst”54.

A regényben szereplő kísérleti gőzhajó neve nemcsak a valóban létezett hajó emlékéhez kötődik, hanem Jesús Moncada kedvenc mediterrán mítoszához az Odüsszeiához is, melynek hőse csakúgy, mint az ő gyermekkorának, egy hajós. ${ }^{55}$

A folyami hajózás válságát, J. R. Marcuello szavaival „elöre bejelentett halálának krónikáját" már jó ideje írta a technikai fejlődés, melyet a vitorlásokkal szemben a gőzhajtású energia ${ }^{56}$, majd az első világháború után elterjedő, nagy távolságokra is szállítható elektromos áram, és a közúti közlekedést forradalmasító belső égésű motorok képviseltek.

${ }^{49}$ L. Mellékletek. Képek, térképek, 3. Latin vitorla.

${ }^{50}$ L. Mellékletek. Képek, térképek, 4. Vontatás - Camí de sirga.

${ }^{51}$ MCSL Entrevista amb l’Almirant (1899-), aki az eseményt 1915 tájára teszi; 2a entrevista amb Quico (kb. 1920-), aki szerint Cerero el Vell próbálta ki elöször, 1918-20 táján; Entrevista amb Jorget a vontató öszvér intelligenciáját dicséri. Ez a motívum megjelenik a regényben is.

${ }^{52}$ AFV 239. 0.

${ }^{53}$ MCSL Entrevista amb Jorget, a folyószükületeknél a gőzhajó nem tudott jól haladni, felrobbant. Entrevista amb l’Almirant hajóskapitány (1899-). Szerinte 1918-ban tették vízre.

${ }^{54}$ AFV 65. o.

${ }^{55}$ 2005-06-14 Avui - Mor Jesús Moncada, La voluntad de la perfecció, Carles-Jordi Guardiola. Moncada többször említi a vele készült interjúkban, hogy ízig-vérig mediterrán emberként, Homérosz Odüsszeiája az egyik kedvenc olvasmánya, ez volt vele az utolsó napokban a kórházban is. Anton Castro egy interjúban Homérosz leszármazottjának mondja az írót: 1989-10-22 El Día de Aragón Imán - Sólo soy un contador de historias, Los senderos se bifurcan a Mequinensa, Anton Castro.

${ }^{56} \mathrm{Az}$ első spanyol gőzhajót egy katalán tengeri kereskedelmi társaság bocsátja útjára 1834-ben. L. García de Cortázar-Gonzales Vesga, i.m. 354. o. 
Spanyolországban a 20. század elejétől jelentkeztek a vízenergia segítségével elektromos áramot termelő, elsősorban külföldi cégek. Ezek közül az első, mint arra már utaltunk az Író és kora/Vízerőmüvek fejezetben, az észak-amerikai energiatermelő lobby, a La Canadiense vízenergiatermelő ágazata a Barcelona Traction, Light and Power Company. Ez a multinacionális óriáscég be akart szállni az Ebro vízenergiatermelő kapacitásának kihasználására indult versenybe is, s ezzel a céllal alapította meg a Riegos y Fuerzas del Ebro S.A-t. Mint a társaság neve is mutatja, a folyóra települő energiagyárak tározóinak kettős célja volt, az öntözéssel müvelhető területek kiterjesztése (Riegos) és az energiatermelés (Fuerzas). Ebben versenytársa a századelőn Flix-ben (Katalónia, Tarragona provincia) létesült spanyol-német elektrokémiai nagyvállalat, a Sociedad Electroquímica Flix, amely már 1898-ban megvásárolta egy spekulánstól a koncessziót az Ebro első vízerőművének létesítésére. Ez Flix-ben, 1904-re meg is épült. ${ }^{57} \mathrm{~A}$ vízenergia kiaknázásában rejlő lehetőségek megnyílása elindította a korrupciót is, és a jó információval rendelkező spekulánsok sorra vásárolták fel az Ebro különböző szakaszait érintő koncessziókat, melyeket aztán tőkeerős külföldi vagy spanyol-külföldi vegyesvállalatoknak adtak tovább busás haszonnal. A flixi elektrokémiai vállalat ugyanakkor bányakitermelési jogokat is szerzett Mequinensa területén, ami mutatja, hogy a századelőn még korántsem ért véget a lignit, mint energiahordozó felhasználása az energiaszektorban. Az Ebro vízenergiájának kitermeléséért indult versenyben szerepelt egy francia tőkéjü vállalat is, az EISA (Energías y Indústrias Aragonesas), melynek alapítója a Compañía Catalana de Productos Químicos en Badalona S.A., mely a világon Japán után először gyártott ammóniát. A La Canadiense 1914-ben kért koncessziót egy Faió területén építendő vízerőműhöz, amelyet a folyó vízhozamát szabályozó átalakításokkal és a folyami hajózás lehetőségének fenntartásával együtt terveztetett meg. A vállalat 1917-ben kért koncessziója már a folyó Xerta, Mora, Ascó, Flix és Riba-rojáig tartó szakaszára vonatkozott. A La Canadiense híres 1919-es sztrájkja azonban annyira meggyengítette a vállalatot, hogy terveit nem tudta valóra váltani. ${ }^{58}$ A francia tőkéjű EIASA a polgárháború után szintén egy olyan Ebro szabályozási tervet készített a folyó Saragossától a tengerig tartó szakaszára, amely sikerrel egyeztette össze a vízenergia-termelés követelményeit a meglévő értékekkel, megőrizve a településeket, az öntözött területeket és a hajózás ezeréves intézményét. Franco azonban annak dacára, hogy az ország energiahiánnyal küzdött és ipari létesítményeiben

\footnotetext{
${ }^{57}$ Marcuello Calvín, José Ramón, Siempre Mequinenza, Mequinenza, Ayuntamiento de Mequinenza, 2007. 295-7. o.

${ }^{58}$ Uo. 299. o.
} 
óriási károkat szenvedett, elutasította az EIASA tervét. Az autarkia korszakának különleges körülményei még egy ideig lehetővé tették a szénszállító vitorlások közlekedését, hogy aztán annál végérvényesebben szüntessék meg. Az interjúkban az egyik öreg hajós azt kifogásolja, hogy még sport céljából sem őrizték meg ezt a lehetőséget. ${ }^{59}$ 1953-ban a La Canadiense energiaszektorát felvásárló FECSA (Fuerzas Eléctricas de Cataluña S. A.), Juan March érdekeltsége, igényt nyújtott be a Faió, Mequinensa, Riba-roja szakasz vízenergiakitermelésének megszerzésére. 1954-ben az EIASA nyújtotta be az Escatrón (Saragossa provincia) és Flix közti szakaszra készített terveit, melyek Lorenzo Pardónak, az Ebro természeti értékeit védő nagyszerű vízmérnöknek a szellemében dolgoztak ki. ${ }^{60}$ Manuel Lorenzo Pardo, Joaquín Costa elgondolásai alapján alapította a Confederación Hidrográfica del Ebrót (1926. március 5.), s ez volt az egyetlen, Primo de Rivera kormány alatt létrejött vízügyi társulás Spanyolországban, amely érdembeli munkát végzett, és kiváló terveket készített. $^{61}$ A Franco kormány azonban mindkét vállalat kérelmét elutasította, és az energiakitermelés jogát az INI, vagyis az Állami Ipari Intézet irányítása alatt működő ENHER nagyvállalatnak adta 1955-ben. A sürgető energiagondok megoldására a vállalatot arra kötelezték, hogy 8 hónapon belül mutassa be terveit. Ezek el is készültek, s az országban addig még soha nem látott méretű és kapacitású erőműveket irányoztak elő. Egyet Mequinensában, s egy másikat Riba-roja felett, s ez utóbbi tározója okozta a régi Mequinensa elárasztását. Ugyanez a rendelet a következőképp fogalmazott: „az általános érdek megköveteli az egyes érdekek feláldozását.”62

A fentebb ismertetett tények és tervek ismeretében ez korántsem tünik megkérdőjelezhetetlen szükségszerüségnek, de a szakmai és természetvédelmi szempontokat egyaránt kielégítő ám megvalósulatlan tervek létezése mindössze ahhoz a szomorú elégtételhez

\footnotetext{
${ }^{59}$ MCSL Carta de Mariano Sanjuán Sagarra. A kalligrafikus spanyol nyelvü levél 1904-ben született szerzője, Mariano Sanjuán hajóskapitány részletesen ismerteti az íróval a vitorlások számát, teherbírását, szállítmányait, s a maga hajós életének fontosabb állomásait. Külön bekezdést nyit a következő címmel: „Az idők megváltoztak. Az Ebro szomorú lett a hajósai nélkül. Már csak a riba-roja-i és mequinensai gát hiányzott, hogy megadják neki a kegyelemdöfést. Én, aki világéletemben hajóztam, nem tudom felfogni, hogyan engedhették meg azt, hogy semmiféle átjárót sem hagyva vágják el a folyót. Véleményem szerint ezzel megadták a kegyelemdöfést a mi nagy folyónknak. Mert ha másért nem is, de legalább a sportolás céljaira meg kellett volna hagyni egy átjárót, hogy ezzel megadják a tiszteletet a folyónak.”

${ }^{60}$ Marcuello Calvín, i.m. 300-305. o.

${ }^{61}$ Vilar, Pierre, Spanyolország története, Budapest, Gondolat, 1984, 98-99. o.

62 Marcuello Calvín, i.m. 306. o. L. még II. fejezet 2.1. Mequinensa száz éve. Az „aragón tenger” névvel illetett óriási tározó La Pobla de Massaluca és Riba-roja (Katalónia) területeinek részleges, Mequinensa és Faió (Aragónia) települések teljes elárasztását jelentette.
} 
elegendő Mequinensa számára, hogy megcáfoljon egy képmutatóan hősi kijelentést. ${ }^{63}$ A lakosoknak - az író visszaemlékezései alapján - nagyon kevés információt adtak, azt is a korszak triumfalista megfogalmazásában: „ez lesz Európa legnagyobb erőműve, a leghatalmasabb vízerőmü, amely valaha is épült.”64 Az Ebro a rá települt vízerőművekkel, ma Spanyolország egyik „energiagyára”. Aragóniai területén 138 vízerőmű található, ebből 74 Osca, 30 Saragossa és 34 Terol provinciában. ${ }^{65}$

1.7.2. A folyók halála, a vízerőmü építkezés irodalmi, társadalmi és történeti emlékezete

A regény utolsó része, a Fekete szél dolgozza fel a vízerőmű építésének 16 évét a kisváros szemszögéből. Kezdetben kósza hírek érkeznek, melyek annyira hihetetlenek, hogy senki nem veszi őket komolyan. Aztán 1957 farsangján hirtelen megindul az invázió. ${ }^{66} \mathrm{Az}$ író így jellemzi az előzetes figyelmeztetés és egyezség nélküli támadást: „gépek és emberek törtek be a tanyákba engedély nélkül, müszerekkel megpakolt földmérők árasztották el a várost és környékét [...], a munkások előregyártott fabarakkokat állítottak fel maguknak az Ebro partján, miközben a lakosság megpróbált védekezni a durva erőszakkal szemben, melynek szándékolt célja volt elbátortalanítani az embereket, hogy elejét vegyék bármiféle ellenszegülésnek.”67 Bizonyossággá vált, hogy a szóbeszéd nem alaptalan: „átvágják az Ebrót, és két hatalmas víztározót építenek rajta. Az egyiket a várostól kicsit feljebb, a másikat pedig lejjebb, Riba-rojánál. Ez a második hullámsírba süllyeszti majd Faiót és a várost.”, ${ }^{98}$ A mequinensaiak törvénytelenségnek tartják a rájuk eröltetett döntést, s próbálják megállítani a szörnyü gépezetet, de azzal a tudattal teszik ezt, hogy ,a várost úgyis eltapossák. A víztározókat építő vállalat annak az államnak a tulajdonában volt, amely a döntéseket hozta. A döntéshozók pedig [...] azok voltak, akik 1936-ban fellázadtak a köztársaság ellen, a háborús vérontás felelősei [...] Ki mert itt a törvényességre hivatkozni? [...] a félelmek: kisajátítják a földeket, a bányákat, a házakat; el fogják árasztani a várost

\footnotetext{
${ }^{63}$ Szembetűnő a többség és a közjó érdekét hangoztató hatalom érzéketlensége a kisebbség sorsa iránt, ennek irodalmi párhuzamaként l. Espriu, Salvador, La pell de brau. www.epdlp.com/texto.php?id2=486, letöltés 2017. dec. 11. L. melléklet Lexikon 10. Mequinensától ugyanezt az önfelszámoló áldozatot várta el a hatalom, s mint a történet mutatja, választási lehetösége sem adódott.

${ }^{64}$ 1988-06-20 Avui - Jesús Moncada en el camí de la vida, Anna Cabeza.

${ }^{65}$ Perelló Capdevila, Joan, La navegació fluvial al riu Ebre http://wwwa.urv.cat/ogovern/consellsocial/ PSecundaria/DVD\%20Premis\%202007-09/material/09cap08/09cap08.pdf, letöltés 2017. aug. 10.

${ }^{66}$ AFV 250. o. Llamazares ugyanezt a nyitányt rögzíti regényében (Distintas formas de mirar el agua), a terjedő pletykát, majd a hirtelen bizonyosságot hozó, megindult munkálatokat.

${ }^{67}$ AFV 251. 0.

${ }^{68}$ AFV 251. o.
} 
[...] Aztán rögtön jött a kérdés: milyen jövő vár rájuk? Hová menjenek? [...] a megyei kormányzó úr szó szerint az mondta, hogy tele van a töke annak a vörös bandának a tiltakozásával, és ha nem hagyják abba [...], puskával kergeti fel őket a teherautókra, és északra viteti őket, hogy az asztúriai bányákban dolgozzanak." ${ }^{69}$ Jesús Moncadának város megmentése érdekében különböző hivatalokban kilincselő édesapja révén első kézből származó információja volt a mequinensai tiltakozások fogadtatásával kapcsolatban, ami nem szerepel a történelemkönyvek lapjain, ahol csak az egyezmények, határozatok és jegyzőkönyvek elég érdemesek arra, hogy jelezzék az események alakulásának útját. Az események regénybeli interpretációja egyértelművé teszi, hogy a túlhatalommal rendelkező autoriter döntéshozó erőszakkal érte el, amit akart. Az organikus demokrácia döntéshozóinak a látszatra sem kellett ügyelniük, a közjó érdekében hozott döntés kivitelezése során. A mequinensaiak összefogása és tiltakozása először csak elutasítást és megfélemlítő akciókat váltott ki a központi hatalomból.

„A város közben megtelt idegenekkel [...] A többség szánalomra méltó, szegény emberekből állt, akik az ország minden részéböl érkeztek, hogy itt összekaparjanak egy kis pénzt, és hazaküldjék a családjuknak [...] Minden háznál nyílt egy bolt, egy kocsma [...] csalóka gazdagság volt ez, tiszavirág életü fellendülés." ${ }^{70}$ A város először ellenszenvvel fogadta a pantanerókat ${ }^{71}$, de mint a Moncada idézet is mutatja, az emberek felismerték a szegény munkástömeg övékhez hasonló sorsát, kiszolgáltatottságát. A „magát foggalkörömmel védő város” nem sejtette, „hogy a legtöbbjüket öregkoráig, sokukat pedig egészen haláláig elkíséri ez a lelket mardosó félelem.”72 Az emberek általános vélekedése szerint az építtetők ,szándékosan választották ezt a lassú, zsibbasztó módszert [...] így akarták elemészteni, megosztani és megsemmisíteni azokat az embereket, akik makacsul védték az érdekeiket és azt a jogukat, hogy mint közösség is fennmaradhassanak. Tizenhárom éven át rágta őket a bizonytalanság, felörölve az idegeiket [...] embertelen nyomás nehezedett rájuk, amit a diktatúra szájkosara is súlyosbított. Lehet, hogy igaza volt Rumos Honoratnak, mikor azt mondta, a rendszer kihasználta az alkalmat, hogy megfizettesse velük, méghozzá jó drágán, hogy a polgárháború idején hủek maradtak a köztársasághoz. Ezek az évek

\footnotetext{
${ }^{69}$ AFV 252. o. L. még II. fejezet 2.4. 202-es lábjegyzet az 1966-os bilbaói sztrájkról.

70 AFV 252-3. o.

${ }^{71}$ Coso, Andrés magánlevél. A pantanerók Kasztíliából, Katalóniából, Murciából, de leginkább Andalúziából jöttek dolgozni az erőmüvek építésén, közülük később többen megtelepedtek Mequinensában. Mikor a vállalat továbbállt, felajánlotta megvételre a lakóknak a Colònia de l'ENHER házait, ahol addig laktak, s ahol iskolát és templomot is építettek számukra a munkálatok idején.

${ }^{72}$ AFV 253. 0.
} 
nagyon mély sebeket ejtettek és megosztották a városlakókat [...]”73 A 2010-es monográfiában közölt beszéd, melyet a Santa Agatòclia Lakásépítő Szövetség elnöke, az író édesapja, José Moncada mondott az 1972. június 15-i közgyülésen, megindoklandó az ENHER-rel kötött, sokak által kifogásolt végszámla rendezési egyezség szükségességét, szintén utal ezekre a sebekre. „Sokat kellett szenvednünk az érdekeitekért, a Szövetkezetünkért, mert elvesztettünk számunkra nagyon fontos barátokat [...] azért, hogy emelt fővel mondhassuk, elvégeztük a feladatot, amellyel megbíztatok bennünket.”74

A közösség tehát megszenvedte a regényben kiemelt tizenhárom évnyi bizonytalanságot és félelmet, mely meghatározó volt az egyéni életekre nézve, a város történetét kívülröl szemlélő történész számára azonban ez nem említésre méltó. Ezt az új város alapításával járó sok szakadást és ellentétet, nem érzékelik a kívülállók, vagy ha mégis, nem jegyzik le, hanem a tények és az eredmények megörökítésére koncentrálnak. Érdekesen példázza ezt a város két történeti monográfiájának története: Mequinensa 2007-ben megbízást adott az életrajzíró, publicista, újságíró José Ramón Marcuello Calvínnak, a vízenergia-gazdálkodás elismert szakértőjének, hogy készítse el a város monográfiáját. A kérésnek a szerző eleget is tett, és egy igen alapos, jól dokumentált munkában megírta a város történelmét, melynek különösen a spanyolországi víz- és vízenergia-gazdálkodás kontextusába illesztett fejezetei tartalmaznak igen részletes és adatgazdag elemzéseket. 2010-ben Mequinensa önkormányzata újabb történeti monográfia elkészítésére adott megbízást, ezúttal egy Jordi Estruga által összefogott szerzőgárdának, melyben több mequinensai kötődésű szerző is helyet kapott. Ez a monográfia a vízerőmü építkezés korát a város küzdelmének bemutatásával együtt ábrázolja, amihez támaszkodik a város emlékezetére is. Végigkísérhetjük az egyezmények, tüntetések, kérvények, kilincselések történetét, az objektív krónikát anekdoták, visszaemlékezések teszik érzékletesebbé, s a fejezet mottójául A folyók városa nyitó sorai szolgálnak.

Az emlékekbe beleivódott félelem az egyéni élet léptékéhez tartozik, így kimarad a vízerőmü építkezések történeti krónikájából is, nyomait csak a Moncada regény lapjain találjuk. Amikor az első víztározó elkészült, a munkásokat átszállították a második munkálataihoz, s a regény szavaival a városban csak a csend és a szorongás maradt. „Lassan kifutottak az időből, de a fekete csontvázhoz ragaszkodó emberek nem engedtek a követelésükből, míg el nem érték a kárpótlást, amit utolsó mentsvárként fogalmaztak meg, amikor nyilvánvalóvá vált, hogy a házak megóvásáért folytatott harc teljesen

\footnotetext{
73 AFV 265. o. A megosztottság legékesebb példája a régi városban maradó 35 család.

${ }^{74}$ Estruga, J. (dir), 342. o.
} 
reménytelen.”75 „Ha ezt elérik, az új várost alapításához nem lesz szükségük a kormányra, amelyik nem törődik velük, és csak a városi vezetök üldözésében és elnyomásában buzgólkodik, elhallgattatja az aggodalmaskodókat, vagy rendőröket és csendőröket küld a városban állomásozó helyőrség megerősítésére, amikor a feszültség tüntetésben robban ki, mert ez veszélyezteti a diktatúra szent és sérthetetlen társadalmi rendjét. Amikor a riba-rojai víztározó munkálatainak befejezése már a küszöbön állt, és a vízerőmü-vállalat, látva, hogy a városlakók nem engednek, úgy döntött, hogy teljesíti a követeléseiket [...] A harcból egy elcsigázott és szétforgácsolódott város került ki, minden eddiginél bizonytalanabb jövővel, amely azonban a végsőkig ragaszkodott emberi közösségként való létezéséhez [...] hátra volt még a feketeleves: míg ott éltek a régi városban, végig kellett szenvedniük a rombolás szükségtelen és kegyetlen folyamatát [...]"76 Az állami vállalat a meg nem szünő tiltakozás hatására, s mivel végletesen diktatórikus módszerekhez nem akart nyúlni, végül tárgyalóasztalhoz ült, s a két fél megegyezett. A regény azt emeli ki, mennyire idegőrlő és hosszú harc eredményeképp született meg az eredmény, az új város. A monográfia szerzője sokkal inkább az eredmény pozitívumai felöl közelít, hogy a városlakók elérték a kitüzött (kitűzhető) célt, s létrehoztak egy új, modern várost. Ez a fiatalok és az átköltözők szemlélete. A regény terepe a régi város, a történetek és emlékek nélküli újé nem tartozik az író által ábrázolt valósághoz. Moncada tekintete az öregek, az emlékezők régi Mequinensája felé fordul, a másik város egy másik kor, egy másik történet.

Miközben a regény egyik főszereplője Nelson, a híres kormányos azon búsul, hogy meg kellett érnie a szülővárosa és a mestersége halálát, eszébe jut, amint ennek először hírét vette. A kávéházban a tulaj bejelentette, hogy eladták a folyót, és „felolvasta azoknak a szállítóknak és kereskedőknek a nevét, akik lemondtak az Ebrón való hajózás jogáról, és hogy melyikük hány milliót vágott zsebre annak fejében, hogy a vízerőmü-vállalatot felmentsék a riba-roja-i tározón keresztül vezető hajózó útvonal biztosításának kötelezettsége alól.” „A Segrén és az Ebrón nemcsak az ő apjuk, nagyapjuk és dédapjuk hajózott [...] Hogyan lehetséges hát, hogy örökre elvágják? Ki adott rá engedélyt? Miféle urak azok, akik el merészelik adni a folyót?”77 A fentebb idézett Mariano Sanjuán levél kiválóan érzékelteti az ősi természeti erővel együtt élő, küzdelmes életek mély tiszteletét az élő víz iránt, mely általános volt az idős hajósok gondolkodásában. A regény megmutatja, hogyan vitatja meg a folyók halálát a monográfiában szereplő Közös Bizottság városi polgárokból

\footnotetext{
${ }^{75}$ AFV 267. o.

${ }^{76}$ AFV 267-8. 0.

${ }^{77}$ AFV 270. o.
} 
szerveződött része, mely a Benjamí bárban szokta tartani az üléseit. Itt érzékeljük igazán az állam túlhatalmát, s a modernizáció által eltűnésre ítélt világ szereplőinek tehetetlenségét, érvényre nem juttatható igazságának tragédiáját s a felháborító korrupciót. A történeti monográfia a tények és a város által elért eredmények rögzítésére koncentrál, melyekhez nem füz értékítéletet. Bár láttatja a város és az ENHER közti harcot, ezt szigorúan tényközlő tónusban teszi, s a dráma érzékeltetésére a regényből idéz.

A bőséges idézetmennyiséggel azt szerettem volna ábrázolni, hogy a regény mennyire hüen követi nemcsak a város harcának és tragédiájának pszichológiáját, hanem annak gazdasági, társadalmi vonatkozásait is. A fikció kiemel és elhagy, azt láttatja, amit Walter Benjamin sírfelirata névtelen lények emléké-nek nevez, amit a történetírásnak fel kell vállalnia, mivel ők nem képesek hallatni a hangjukat. A regényben a víztározó építkezés tömör krónikáját kapjuk azok szemszögéböl, akik elszenvedték, Moncada szavai az ő történelmüket örökítik meg. A regény 298 oldalából alig valamivel több mint három oldal foglalkozik konkrétan a tározók építésével és a város tragédiájával, miközben az egész regény ennek az idejében, ebbe beleágyazódva, s ennek kifejezésére íródik.

Az író megfogalmazza a város hipotézisét is, amely Mequinensa elpusztítását Franco számlájára írja, aki a vörös szeparatistákat, azaz a köztársaságpárti katalán várost így akarta eltörölni a térképről. Igaz, hogy a riba-rojai tároló szintjének megállapításakor az INIENHER egy gyors, és minden más érdeket (környező települések öntözéses művelésű földjei, Madrid-Barcelona vasútvonal megváltoztatása, új híd építésének kötelezettsége az elárasztott mequinensai helyett, stb.) figyelmen kívül hagyó döntést hozott. S tény az is, hogy nem létezik sehol olyan okirat, amely indokolja, hogy a második erőmühöz szükséges tározó szintje miért nem állt meg 60 méternél, miért volt szükséges a minden más természeti és épített értéket elpusztító 80 méteres szint előirányzása. ${ }^{78}$ Ez valószínűsíti, hogy a döntésben szerepe lehetett a mequinensaiak által fö oknak tartott „,vörös-szeparatista” okegyüttesnek is. Moncada azonban, bár egy írói alteregó véleményeként tünteti fel a hipotézist, a filozófiai töprengéseket megfogalmazó főszereplő hangján mondja ki, aki nem teljes meggyőződéssel állítja. A regény tehát csak valószínűsíti a lehetőséget. Míg a város kollektív emlékezete a mequinensaellenesség okai közt felsorolja a mequinensaiak által a 19. század végén elkövetett rablógyilkosságot, a Köztársasághoz való hűséget, a bányászsztrájkokat és azt is, hogy a város katalánul beszél ${ }^{79}$, a regény csak a köztársasághűséget

\footnotetext{
${ }^{78}$ Marcuello Calvín, i.m. 316-8. o.

${ }^{79}$ L. II. fejezet 156. lábjegyzet.
} 
veti fel, a többire okra nem is céloz. Érdekes megfigyelni a kollektív emlékezet hajlamát arra, hogy a várost pozitív hősként, heroikus pózban tüntesse fel, mint az idézett Andrés Coso levél mondja, „én mindig azt hallottam az öregektől, hogy Saragossa provinciában a polgárháború idején Mequinensa volt az egyetlen város, amely kitartott a Köztársaság oldalán”. Pedig ezek az öregek nyilvánvalóan tudták, hogy Casp, az egyik város, ahonnan az anarchista különítmények érkeztek Mequinensába, szintén az ő provinciájukhoz tartozik, s tudták azt is, hogy a front Lleida felé haladt, és a Mequinensával határos, de már Osca tartományban levő, katalán nyelvű Fraga, az aragóniai anarchisták másik székhelye, később lett Francói terület, mint Mequinensa. Az öregek vélekedésére tekinthetnük úgy, mint a város önmagáról alkotott képére. Bizonyos értelemben ez egy a mequinensaiak identitásmeghatározó jegyeivel kibővített áldozati narratíva. Mint a II. fejezet vízerőmő-építkezéseket tárgyaló részében láttuk, a döntéshozók a többség érdekére hivatkozva nem tartották túl nagy áldozatnak a fejlődés útjában álló települések eltűnését akkor sem, ha nem köztársasághü és spanyolajkú településekről volt szó. A mequinensaiak „vörös” és nyelvükhöz ragaszkodó identitása a közbeszédben fontos elemként adódik hozzá a modernizáció útjában álló kis település önképéhez, mely ezáltal ideológiai megerősítést kap. Nem csupán egy jelentéktelen, eltörölhető pontocska, hanem többszörösen hátrányból induló, megbélyegzett, de eszméiért küzdő, jogtalanul eltaposott, különleges hely. Ez a kollektív emlékezetben őrzött vád teljesen hiányzik a monográfiából, de részben megjelenik a regényben („vörös banda”, „megfizetteti”). Moncada nem hallgatja el, mivel az emberek így éreztek, s ő maga, mint a város mitológiájának részese, s egyben kritikusa is, fontos motívumnak érzi.

Úgy gondolom, hogy a regény többi eleme azt a hipotézist támogatja, hogy a város történetét Lampedusához és Villalongához hasonlóan, egy letünt kor elégiájaként megmutató író, a nagy idő távlatában látta városát, s nem a francóisták bosszújának tulajdonította eltűnését, bár többi földijének vélekedése, és apja küzdelmének végigkövetése nyilván hatott ítéletére. Moncada nem az okok pontos kinyomozására törekedett, hanem a következmények rögzítésére, s ezáltal egy valóban unconventional history született. Juan Mayorga öreg térképészének metaforája a következőképp fogalmaz: „Itt jön elő a lépték kérdése. A fontos dolgokat csakis a kisléptékü térképeken lehet látni. Könnyü ábrázolni két sereget, amint épp összecsapni készül [...] De hogyan mutatod meg, hogy melyik katona miért hal meg, milyen bátor vagy mennyire fél?” ${ }^{80}$ A történetírás történetében a

\footnotetext{
${ }^{80}$ Mayorga, Juan, El cartógrafo http://muestrateatro.com/archivos/22Cartografo.pdf, letöltés 2017. aug. 26.
} 
mikrohistória megjelenése is egy ilyen léptékváltást jelzett, mely közelebb vitte a történelemábrázolást az egyszerü, hétköznapi emberek világának bemutatásához az addig uralkodó felülnézeti történelem kiegészítőjeként. Moncada Mequinensa emléktérképét szerkesztette meg, s az általa „nem klasszikusnak” nevezett történelem megírásához oral history forrásokra támaszkodott. Az interjúk elkészítéséhez és az értelmezés kialakításához sokban hozzátesz a saját érintettsége és hagyományban állása, ami tanúságtevő íróvá avatja.

A Mequinensáról készített monográfiák közös jellemzője, hogy a Restauráció korszakánál hivatkoznak a mequinensai rablógyilkosságot feldolgozó Moncada regényre. Andrés Coso a 2010-es monográfiában A folyók városából származó idézeteket használ a régi-Mequinensa utolsó éveiben zaljó események értelmezéséhez, Marcuello Calvín pedig az általa írt monográfia ajánlásában így fogalmaz: „Jesús Moncadának, s rajta keresztül minden mequinensainak, akik voltak, vannak és lesznek”. Ez az ajánlás, és hivatkozás annak köszönhető, hogy a város irodalmi krónikáját minden helytörténészi és történészi vállalkozásnál korábban megalkotó író müve megkerülhetetlen hivatkozási alappá vált.

\subsubsection{Városok, kereskedelem, legendák}

Az Ebro menti települések, mint a hajózási útvonal fontos állomásai megjelennek a regényben is: Tortosa (14), Miravet (10), Amposta (2), Flix (3), Benissanet (2) Ascó (13), Riba-roja (7), Arenal (2). A kontextus tájékoztatja az olvasót a kor kereskedelmi viszonyairól. Amikor „Benissanetben berakták a cserépedényeket, még nehezebb dolga volt (az öszvérnek), mert nem ugyanaz ám felvontatni egy üres vitorlást, mint egy olyat, amelyik tele van korsókkal, virágcserepekkel, agyagfigurákkal meg tálakkal.” 81 „A Neptunus súlyos rizs- és agyagedény-rakománnyal jött visszafelé Tortosából, és már közel járt a városhoz.”82 Szintén egy tortosai út során „[...] a téglagyárban lerakott lignit helyett a hajóra hordott rizseszsákok”83 alkotják a rakományt. Képet kapunk tehát a folyó mentén zajló cserekereskedelemről, megismerjük az ascói várat, a folyószigeteket, az örvényeket, zátonyokat, áradásokat, folyószükületeket, a vontatóút mentén a legénységek rendelkezésére álló menedékeket, a terep nehézségeit. A mequinensai hajóskapitányok és hajóácsok emlékezetére

\footnotetext{
${ }^{81}$ AFV 63. 0.

${ }^{82}$ AFV 142. 0.

${ }^{83}$ AFV 211. 0.
} 
támaszkodó regény kiváló kalauz az egykori élő folyó világához. ${ }^{84}$ Az interjúk egyike rögzíti, hogy Flix-nél, az Ebro első vízerőmüve biztosította az átjárást a vitorlásoknak, csak elöre szólni kellett, hogy jöjjön a hajóért a csónak és bevezesse az „alagútba”. ${ }^{5}$ Megtudjuk azt is, hogy Mequinensától Tortosáig 150 km a távolság, ${ }^{86}$ s hogy Tortosától a tengerig csak rendszámtáblával ellátott hajók és érvényes kapitányi képesítéssel rendelkező kapitányok hajózhattak. $^{87}$

Több interjú is őrzi egy a regényben is megörökített baleset történetét, amely élénken él a helyiek emlékezetében. „1914. június 12-én, dél körül a Torres i Camps ház lisztet szállító vitorlása, a Fürge a lliberolai folyószükületnél az Ebróba veszett [...] Révészek, halászok és hajósok kémlelték fáradhatatlanul a vizet, a folyó egész partvidékét fellármázták, a várostól le egészen a tengerig, de az Ebro ez egyszer nem engedte el a zsákmányát, s a hajótörésben eltüntek nyomára sosem bukkant rá senki.” ${ }^{88}$ Az adatközlők száma, az életkoruk közti különbség, s a balesetnek a regényben elfoglalt fontos helye (a föszereplő Nelson azért jut korai árvaságra, mert édesapja ebben a balesetben eltünt) mutatja, hogy a közösség nagy jelentőséget tulajdonított a kollektív emlékezetben sokáig fennmaradt történetnek. A regényben az esemény még nagyobbra nő az által, hogy Moncada köréje építve ad ízelítőt az Ebro legendáinak világából is: „a kapitány, mint általában azok a halottak, akiknek nem adatik meg a koporsó nyugalma, hazajáró lélekké változott [...] Találkoztak az elveszett hajóval a Canota völgyének egyik egyenes szakaszán [...] jártak az evezői, pedig nem húzta őket senki [...] Főleg télen, ködös időben [...] sötétedés után a Fürge kiköt a városka kikötőjében, és a halott kapitány [...] körbejár a kávéházakban [...], és felhajtja a bárpultra [...] letett italokat.” ${ }^{89}$ A kávéházakban mesélt helyi jelentőségű események beépülnek az új nemzedékek emlékezetébe, és közös legendakinccsé válnak, melynek ugyanúgy része a gyermekkorban megtapasztalt titokzatos folyó, s a hozzá kapcsolódó félelmek, mint a köznapi vagy a történelmi események.

A folyó menti településeken kívül a következő városok jelennek meg a regényben: Lleida (19), Barcelona (17), Párizs (14), Madrid (11), Saragossa (6), Casp (2), Fraga (2), s a polgárháború eseményföldrajzához kötve Valladolid (5), Terol (3), Carrascal (2), Brunete (2).

\footnotetext{
${ }^{84}$ A Moncada által öregekkel készített interjúk visszatérő kérdései a hajók teherbíró kapacitására és az általuk szállított árukra vonatkozik. Ezekből megtudjuk, hogy a fent felsorolt árukon kívül többek közt tüzifát, trágyát és szalmát is, stb. szállítottak L. MCSL Entrevista amb el vell Raiet (1889-)

${ }^{85}$ MCSL Entrevista amb l’Almirant hajóskapitány (1899-). L. Mellékletek. Képek, térképek, 5. Zsilipelés.

${ }^{86}$ Uo.

${ }^{87}$ MCSL Entrevista amb Jorget.

${ }^{88}$ AFV 23-24. o. MCSL Oncle Calafat, oncle Patriciet, tiet Vidallet, Manolo Jordi; Entrevista amb l'Almirant hajóskapitány (1899); Entrevista amb Garin hajós (1920-).

${ }^{89}$ AFV 24. o.
} 
Lleida a legközelebbi nagyváros, katalán provinciaszékhely, és egyházmegyei központ, melyhez a múlt század 90-es éveiig több aragóniai településsel együtt Mequinensa is tartozott. ${ }^{90}$ Lleida a regényben is legtöbbször egyházi kontextusban jelenik meg: a lleidai püspök, a lleidai katedrális, a lleidai kanonok iskola, a lleidai zarándoklat, de megjelenik egy lleidai faszobrász is, jelezvén, hogy komolyabb művészi értéket képviselő alkotások elkészítéséhez a mequinensaiak Lleidában találtak mestert. Moncada nem hagyja említés nélkül a provinciaszékhely ezoterikus nevezetességét, a lleidai boszorkányt, sem pedig a klerikális város mequinensaiak által szintén előszeretettel látogatott intézményét, a bordélyt, ami valószínüleg nem szerepel sem a helytörténeti sem pedig a katalán történelmi irodalomban, csak szigorúan magánemlékezetekbe zárva, vagy emlékezetregények lapjain. A legtöbbször felbukkanó szókapcsolat a lleidai országút, mely a Cinca völgyén át, Fraga érintésével vezet Lleidába, s onnan tovább Barcelonába. Az író életrajzából láttuk, édesapja nem akarta, hogy fia a mequinensaiak számára természetes központként (vásárlás, orvos) müködő város egyházi intézményei egyikében tanuljon tovább. Így került a gimnazista korú gyermek a megközelítőleg háromszor akkora távolságra ${ }^{91}$ található Saragossába, egy országos viszonylatban is igen ritka, liberális intézménybe, ahol viszont anyanyelve a használatától volt elzárva. A választható lehetőségek köre jelzi, hogy egy baloldali gondolkodású és katalánul, ráadásul dialektusban beszélő diák számára nem létezett a korban jó opció. ${ }^{92}$

Saragossa szintén egyházi központ, a Hispániai-félsziget egyik legkorábbi keresztény kultuszhelye, hiszen itt található a Nuestra Señora del Pilar székesegyházában ${ }^{93}$ az az oszlop, melyet a hagyomány szerint a Szüzanya, egy Mária-jelenés során adományozott az erejében és hitében kételkedni kezdő idősebb Szent Jakab apostolnak, aki Cesaraugustában (Saragossa) térített i. sz. 40-ben. ${ }^{94}$ A saragossai Szüzanya amellett, hogy Saragossa, Aragónia, Spanyolország és az egész Hispanidad patrónája, még a fegyveres erők több ágának, a Csendőrségnek és a Haditengerészetnek is a védőszentje. Az aragón főváros katonai $^{95}$ jellegét a La galeria de les estàtues címü Moncada regény rajzolja meg. A folyók

\footnotetext{
${ }^{90}$ L. II. fejezet/La Franja de Ponent.

${ }^{91}$ Mequinensa-Lleida távolsága légvonalban $38 \mathrm{~km}$, ma országúton $50 \mathrm{~km}$, ami kb. 40 perces autóút http://www.distanciasentreciudades.com/distancia-lerida-a-mequinenza, letöltés 2017. aug. 10., míg a Mequinensa-Saragossa távolság 104 km légvonalban, országúton pedig 133 km, ami kb. másfél órás autóút.

${ }^{92}$ Ez a helyzet ma ugyanúgy fennáll a Franja területén, de az egymást kizáró nacionalizmusok egymásnak feszülése idején a Principátus területén is.

93 http://www.basilicadelpilar.es/inicio.htm, letöltés 2017. aug. 12.

94 A kultusz történetéről az Aragón Enciklopédia http://www.enciclopedia-aragonesa.com/voz.asp? voz_id=10191\&tipo_busqueda=1\&nombre=Pilar\&categoria_id=\&subcategoria_id=\&conImagenes=\#Punto_3, letöltés 2017. aug. 12.

${ }^{95}$ Saragossában található a Primo de Rivera idején alapított híres Katonai Akadémia, amelynek 1928-tól Franco tábornok volt az igazgatója. Manuel Azaña első intézkedéseinek egyikeként a hadsereg tiszti
} 
városában a jezsuiták saragossai gimnáziumát említi, ahová a mequinensai társadalom felső rétegének képviselője, Carlota de Torres a fiait tanulni küldi. Megjelenik Saragossa a Valladolidból hazafelé tartó Torres család utazásának térképén, innen kezdve a Cincavölgyéig a Monegres sivatagos táján haladnak. A város másik három említése a polgárháborús eseményt érint, az aragón főváros közelében, Gelsában a köztársaságiak egy pontonhidat építenek hajókból, amelyhez felhasználják a Mequinensában rekvirált vitorlásokat (2), s a háború után ott végeznek ki egy mequinensai testvérpárt (1).

Mivel a regény Mequinensa történetének 100 évét ábrázolja emlékezetregény formában, megállapíthatjuk, hogy a mequinensaiak emlékeiben, sokkal inkább jelen van a hozzájuk földrajzi, közlekedési és nyelvi szempontból közelebb található katalán provincia székhely, mint a saját, aragóniai provincia székhelyük, melyhez közigazgatásilag tartoznak. Ez az emlékezetföldrajzi adat összecseng a Franja területén az ezredfordulón végzett szociológiai kutatásokkal. A Franja lakosai több határokon átnyúló szerveződés tagjai, melyek közül a legfontosabb az ACTEL (Agrupació de Cooperatives de les Terres de Lleida), a több mint ötven gyümölcstermelö szövetkezetet összefogó szervezet, melyhez a határ mindkét oldaláról csatlakoznak a gazdák, értékesítési esélyeiket növelendő. Az aragóniai Franja kis és közepes területen gazdálkodó gyümölcstermelő gazdái hasonló termelői szerkezetben dolgoznak, mint katalán társaik, a központ, és a fö piac egyértelműen Lleida. ${ }^{96}$ A hatalmas aragóniai latifundiumoktól nagyon különböző gazdasági és birtokszerkezet szintén olyan identitásképző elem, amely a terület lakosait Katalóniához köti. A régi mequinensai gazdag földbirtokos családoknak nagy édesgyökér ültetvényeik voltak a Segre partján a Lleida provinciához tartozó Granja d’Escarp területén Mequinensától 8 km-re északra. ${ }^{97}$

Fővárosok tekintetében is Katalónia javára billen el a mérleg, hiszen Barcelona 37-szer jelenik meg a regényben, míg Madrid 11-szer. Ha megvizsgáljuk a kontextust, amelyben ezek a városok felbukkannak, láthatjuk, hogy Madrid úgy jelenik meg, mint: don José de Canalejas miniszterelnök meggyilkolásának színhelye (1); a mequinensai ókonzervatív,

állományának csökkentése érdekében bezáratta. A Franco-korszakban újra megnyitották, s az ország egyik legtekintélyesebb akadémiájaként tovább müködött. Harsányi Iván, „Az elrabolt füzetek” http://www.c3.hu/ klio/klio992/klio119.html, letöltés 2017. aug. 12. Saragossában egy nagy amerikai katonai légitámaszpont is létesült az 1953-as kétoldalú egyezmény eredményeképp, Jesús Moncada itt töltötte katonai szolgálatát a légvédelmi alakulatnál.

${ }_{96}$ Espluga, Josep, Planeta Franja, El trencaclosques del català a l’Aragó, Lleida, Pagès editors, 2005, 64-65. o. Ezek a megállapítások csak két franjai járásra, Lliterára és Baix Cincára (Mequinensa itt található) vonatkoznak, ahol a „zöld forradalom” óta fellendülő termelési ággá vált a gyümölcstermesztés. A pireneiusi járásban a Ribagorçanában a hegyi gazdálkodás az uralkodó, a legdélibb járás, Matarranya pedig inkább aragóniai területekkel tart fenn gazdasági, kereskedelmi kapcsolatokat.

${ }^{97}$ Coso, Andrés magánlevél, melyben a Justribó-Fornos családdal kapcsolatos kutatásait jegyzi le, a készülő családi életrajz vázlataképp (sokan a regény Torres i Camps családjával azonosítják). 
a kemény kéz politikáját követelő család gyermeke ügyvédi tanulmányainak, majd életének színhelye (4); a gazdag mequinensai bánya-, gyár-, és földtulajdonos család gyermekei ott helyezkednek el a közigazgatás gépezetében (4); a gazdag vállalkozó réteg képviselői ügyintézés céljából utaznak oda (1), egy Mequinensából elszármazott hölgy madridi jó kapcsolatainak köszönhetően infrastukturális beruházásokhoz jutott a város Primo de Rivera korszakában (1). Az említések tematikája tehát Madridhoz országos jelentőségű politikai eseményeket, helyi következményekkel bíró politikai döntéseket, közigazgatási gépezetet, és jobboldali ideológiához illeszkedő karrierlehetőséget köt. A Barcelonához kötődő események és tények a következők: az 1909-es Tragikus Hét (4); egy iparmágnás anarchisták általi meggyilkolása (1); a Barcelonai Operaházban történt robbantás 1) ${ }^{98}$; a gazdag bánya és gyártulajdonos üzleti utazásai (1); barcelonai arisztokrata feleség, aki a szerzett vagyonhoz nemesi címet biztosít (1); a barcelonai vonat, mely a párizsi nászutas házaspárt hozza haza a faiói állomásig, vagy a párizsi száműzetésből visszatérőket hozza (2); a barcelonai gyáraknak szállított lignit (3); a jól felismerhető barcelonai kiejtés (1); barcelonai kikötő és sörgyár, ahol a munkanélkülivé vált mequinensaiak a válság után munkát találnak, elvándorlási célpont általánosságban ${ }^{99}$ (4); a város evakuálása utáni menedék, átmeneti munkahely (3); a posguerra ínséges ideje (1), barcelonai kórházi kezelés a városka gazdag, liberális gondolkodású bányatulajdonosa számára (1); barcelonai rokonok a gazdag Torres családban, a bohém, liberális Segarrák családjában (3); Grácia negyed Barcelonában, ahová a mequinensaiak általában költöznek ${ }^{100}$ (4); Barcelona, mint a magasabb művészeti, tudományos képzés színhelye (2); barcelonai áruk a mequinensai boltokban (1); a gazdag mequinensaiak a vízerőmü vállalattól kapott kisajátítási összeg felvétele után Barcelonába költöznek (3); ahonnan a Lumière testvérek találmánya, a mozi Mequinensába érkezik (1). Barcelona tehát sokkal több szálon (emigráció, szórakozás,

\footnotetext{
${ }^{98}$ Barcelona és Katalónia emlékeiben élénken él az anarchista merénylethullám egyik első, húsz ember életét követelő bombamerénylete, melyet 1893. november 7-én követtek el a Liceuban. A Barcelonai Városi Történeti Múzeum örzi az egyik, a merényletben fel nem robbant Orsini bomba mását. L. Rubio Velasco, Albert, „Atentado anarquista en el Liceu”, La Vanguardia, 2013. november 7. http://www.lavanguardia.com/ hemeroteca/20131107/54392762387/liceu-bomba-atentado-anarquismo-santiago-salvador.html , letöltés 2017. aug. 28. L. még http://www.ccma.cat/324/el-centre-de-colleccions-del-muhba-un-viatge-per-la-historia-debarcelona/noticia/2672726/, letöltés 2017. aug. 28. Català, Víctor, „A bomba”, in Faluba Kálmán (dir.), A Gondviselés szeszélye, Mai katalán elbeszélők, Budapest, Íbisz Kiadó, 1998.

99 A Baix Cinca járás - melyhez Mequinensa is tartozik - elvándorlási adatai: 1900-1970 közt 6 ezer; 1970 1990 közt 10000 elvándorló. Ennek 60\%-a Katalóniába (31\% Lleida, 29\% Barcelona); 20\% Saragossa, 3\% Madrid. Zapater, Ismael, La Ribera Baix del Cinca: una comarca frontera, Fraga, Institut d’Estudis del Baix Cinca, Instituto de Estudios Altoaragonesos, la Gabella, 1992. 124-5. o.

${ }^{100}$ Itt élt Jesús Moncada, 1966-2005-ig.
} 
tudomány, nyelvjárás, sztrájkhullám, sorozás, menedék a polgárháborúban) kötődik Mequinensa minden társadalmi rétegének életéhez.

A főváros szó 22-szer jelenik meg a regényben. Ebböl többször tartományi főváros értelemben (Saragossa, Valladolid), máskor idegen ország fővárosa (Párizs), néha Madrid szinomájaként, de nyolc esetben egyértelműen Barcelona jelzésére szolgál, támogatva ezzel Juan Pablo Fusi állítását, mely szerint Spanyolországnak valójában két fővárosa - azaz két hatalmas, gazdasági és kulturális szempontból egyenértékünek tekinthető metropolisza van, Madrid és Barcelona. ${ }^{101}$ Megállapíthatjuk, hogy Mequinensa emlékezettérképén Barcelona van jelen nagyobb súllyal, az itteniek sorsa jóval gyakrabban és erősebben kötődik Spanyolország mediterrán fővárosához.

A regény szövegében 14-szer megjelenő Párizs egyértelműen a fény, a szórakozás, a divat, a kultúra, az erkölcstelen nőszemélyek és a kicsapongások városa. Megjelenik a regény lapjain a Plaçe de l’Étoile téri diadalív, melyen szerepel Mequinensa neve. ${ }^{102}$ Párizs, mint a város gazdag nászutasainak, a város bohémjainak, valamint az inkognitóban kicsapongó papságnak az úticélja, a köztársasági menekültek egyik célpontja, ahová 1940 júniusában bevonultak a németek.

A francia városok közül megjelenik még az „okszitániai Toulouse” ${ }^{103}$, mint a köztársasági emigráció egyik célpontja, és Marseille, ahová a mequinensai édesgyökér kivonatot szállították gyógyszeripari feldolgozás céljából. ${ }^{104}$ Moncada az okszitániai Toulouse-hoz hasonlóan Párizshoz is hozzáteszi a „franciaországi Párizs” pontosítást. Ez a szókapcsolat háromszor fordul elő ${ }^{105}$ a regényben, mindig olyan kontextusban, amikor helyi emberek beszélnek az ő világegyetemüktől fényévnyi távolságra levő, világhírü helyről, amelyet csak kósza hírekből, információfoszlányokból ismernek. Két esetben a köznép nyilatkozik így, az egyik esetben azonban Moncada az úri társaság kulturális és politikai tájékozatlanságát, sznobságát jelzi általa. Ebben a kontextusban a helyi előkelők egy ünnepi lakoma alkalmával az első világháború okozta gazdasági fellendülésnek örvendeznek, s nem győzik eléggé

\footnotetext{
${ }^{101}$ Fusi, Juan Pablo, Un siglo de España, La cultura, Madrid, Marcial Pons, 1999, 41-2. o. Fusi a következőképp fogalmaz: „Kulturális tekintetben 1900 és 1933 között csak Katalónia jelentett problémát. Prat de la Ribának igaza volt: Spanyolországban két nemzeti gondolat, két kultúra és két fóváros létezett, Madrid és Barcelona."

${ }^{102}$ L. Mellékletek. Képek, térképek, 6. Mequinenza felirat a diadalíven Párizsban.

${ }^{103}$ AFV 218. o. Toulouse a köztársasági és katalán köztársasági emigráció fő székhelye Franciaországban a Franco korszak alatt. l. http://www.tour.toulouserepublicana.com/ca/, letöltés 2017. aug. 30.

${ }^{104}$ Edmon Vallès Perdrix életrajzából tudjuk, hogy a polgárháború után marseilles-i rokonainál keresett menedéket. Ö annak a gazdag mequinensai (aragón-katalán-francia) családnak a leszármazottja, akik az egyik mequinensai édesgyökérkivonat gyárat tulajdonolták.

${ }^{105}$ AFV 47. o.; AFV 71. o.; AFV 77. o.
} 
hangsúlyozni, hogy a hadviselő felek egyikéhez sem kötődnek semmilyen módon. Hiszen a franciák „nem elég, hogy lenyakaztak egy királyt, 1808-ban eljöttek egészen idáig [...] kemény ostrommal bevették a várost, majd borzalmas vérfürdőt rendeztek, ami a dicső [...] napóleoni győzelmek közt szerepel az Étoile téri diadalíven a franciaországi Párizsban.”106 De nem különb a „hitszegő Albion (sem), ahogy Sàssola bárója nevezte, mielőtt belebonyolódott volna a Gibraltárral és más sérelmekkel kapcsolatos, keserü filippikába.”107 S „nem azt mondta a plébános úr, hogy a németség pogány protestáns banda?” ${ }^{108}$ A groteszk ábrázolás kiemeli az önző gazdasági érdek és nyereségvágy alátámasztására szolgáló hazug, üres retorikát, melyben megjelennek az ellenségképek: a katolikus értékek felmagasztalása a protestantizmussal szemben, a birodalmi nagyságot méltánytalanul csorbító gibraltári helyzet.

Az okszitániai Toulouse ${ }^{109}$ és a vele grammatikailag egyenértékü franciaországi Párizs megnevezés az államnélküli kisnemzethez tartozó író fricskája, mellyel Okszitániát (a kulturális óriást és politikai törpét), a Katalóniával rokon történelmü, kultúrájú és nyelvi entitást nyelvtanilag egyenértéküvé teszi Franciaországgal. Moncadának voltak rokonai (apja unokatestvére és családja), akik Okszitániában, a Toulouse-tól 50 km-re északra található Montauban-ban (Montalbà) találtak új otthonra. Ez a város szintén a köztársasági emigráció fontos központja volt, itt halt meg 1940-ben Manuel Azaña, ${ }^{110}$ a II. Köztársaság államelnöke.

\section{Mequinensa történelmi emlékezete}

\subsection{A polgárháború regényben tükrözödö emlékezete}

A polgárháború eseményföldrajzának a regényben megjelenő települései a következők: Valladolid(5), Terol (3), Carrascal (2), Brunete (2). Valladolid egyetlen egy kontextusban szerepel, a város tulajdonosi rétegének leggazdagabb családja, a Torres i Camps tagjai „egy

\footnotetext{
106 AFV 47. o.

${ }^{107}$ Uo. Gibraltár, a spanyol-angol diplomácia ütközőpontja, 1713-ban, a spanyol örökösödési háborút lezáró utrechti szerződéssel került brit fennhatóság alá. A vagyonát elherdáló báró az ország katonai dicsőségére alapozó spanyol birodalmi gondolat üres szavait hangoztatja, Moncada groteszk ábrázolásában.

${ }^{108}$ Uo. A Hitlerrel később szövetséget kereső, álszent katolicizmus frappáns ábrázolása. Spanyolországban a protestáns gyülekezetek müködését a Franco-korszak végéig korlátozták az 1967-es törvény ellenére.

${ }^{109}$ Katalánul a hajdan független toulousi grófság székhely neve Tolosa de Llenguadoc. http://www.enciclopedia.cat/EC-GEC-0066325.xml, letöltés 2018. ápr. 20.

110 http://www.enciclopedia.cat/EC-GEC-0006389.xml, letöltés 2017. aug. 30. L. még Harsányi Iván, „Manuel Azaña literátor, a harcoló Spanyol Köztársaság elnöke”, in A félperifériáról a centrum felé, Pécs, Publikon Kiadó, 2011. 109-119. o.
} 
hosszú esztendőt töltöttek Valladolidban [...] ahová az után mentek, hogy Franco csapatai bevonultak a városba, hogy ott várják ki a háború végét.”111 Kasztília-León tartományban, s Valladolidban elsőként győzedelmeskedett a katonai felkelés 1936. július 19-ére, a rohamrendőrség hathatós segítséget kapott a falangistáktól és a monarchista csoportoktól. A város a nacionalista zóna középpontjában helyezkedett el, sosem volt müveleti terület, csak a köztársasági bombázások okoztak kárt emberéletben és épületállományban. Logikus célja lehetett tehát egy a nemzetiekkel szimpatizáló, a harcokat is megszenvedő „vörös” Mequinensából menedékre vágyó jobboldali család számára.

Carrascal egy aragóniai kistelepülés Osca provinciában, amelyet egy köztársasági filmhíradó tanúsága szerint a proletárhadsereg a szabadság és az igazság terjesztésének missziójával 1936-ban elfoglalt. ${ }^{112}$ Erről a csatáról nem találtam említést más forrásokban.

Brunete Madridtól keletre található, itt a köztársaságiak által indított, 1937. július 6-26. között tartó hadmüvelet célja az volt, hogy a lázadók északi fronton kibontakozó támadásától haderőket vonjanak el, s felszámolják a Madridtól nyugat-délnyugatra állomásozó nacionalista csapatokat. Ez a csata volt a polgárháború egyik legkegyetlenebb csatája, melyben a Köztársaság 23 ezer, a nacionalisták pedig 13 ezer embert veszítettek, s az eredményt mindkét fél győzelemként könyvelte el. A köztársaságiak azonban nem tudták felszámolni Varela tábornok Madridot fenyegető csapatait, és teljes kimerülésüket követően Franco csapatai pár hónap késéssel a megelőző csapás „sikere” ellenére likvidálták az északi frontot. ${ }^{113}$

Az aragóniai Terol a polgárháború igen fontos csatájának színhelye. Terolban szintén győzedelmeskedett a katonai felkelés, mint Aragóniában a legtöbb helyen, a Katalóniából érkező milicisták azonban visszafoglalták a város körüli terület nagy részét a Köztársaság számára. A nacionalista kézen maradt város ellen 1937. december 15-én indult köztársasági offenzíva, az addigi legnagyobb, 100000 ember Hernández Sarabia tábornok vezetésével, akik elfoglalták a Rey d'Harcourt ezredes által alig több mint 5000 emberrel védett települést. Az északi front likvidálása (1937. október 21.) után a Madrid elszigetelésére a Guadalajara felé indítandó nacionalista offenzívát ez a köztársasági hadmüvelet megakadályozta. A nacionalisták ellentámadása azonban rövid időn belül megindult, december 29-én a Kondor Légió és az olasz nehéztüzérségi egységek bevetésével. Az extrém időjárási körülmények között, mínusz $18{ }^{\circ} \mathrm{C}$-os téli hidegben elkeseredett harc folyt a straté-

\footnotetext{
111 AFV 176. o.

${ }^{112}$ La conquista de Carrascal del Chimillas https://www.youtube.com/watch?v=ZpOqxCbH2Xs, letöltés 2017. aug. 30.

${ }^{113}$ Tamames, Ramón, La República, La era de Franco, Madrid, Alianza Editorial Alfaguara, 284-285. o.
} 
giailag jelentéktelen, ám nagy presztízsértékü városért. Ez 1938. február 17-én a köztársaságiak vereségével és visszavonulásával ért véget. A teroli siker kihasználására Franco azonnal elrendelte az offenzívát az aragóniai fronton, mely 1938. március 9-én meg is indult. Ez a sikerrel kibontakozó offenzíva tette lehetővé a nacionalisták számára a köztársasági terület kettévágását. Napokon belül elestek a Katalónia védelmét biztosító fontos köztársasági városok (Belchite, Casp és Fraga) ${ }^{114}$, s a front végül A Segre és az Ebro alsó folyása mentén stabilizálódott. Franco csapatai ennek a 300 km-en egyszerre kibontakozó offenzívának a keretében foglalták el Mequinensát 1938. március 27-én, s összeomlott a sokáig állóháborúra berendezkedett aragóniai front. ${ }^{115}$ Az első katalóniai provinciaszékhely, Lleida elfoglalására 1938. április 3-án került sor, s amint a háború átlépett katalán területre, Franco Burgosban hivatalosan eltörölte a katalán autonómiát 1938. április 5-én. ${ }^{116}$

Moncada nem a történész pontosságával rajzolja meg a csaták földrajzát és kronológiáját, s csak részben közelít a gyász és a veszteség felöl. A hétköznapi életben üresen maradt helyeket, s az elveszett értékeket egy fájdalmat szublimáló, humoros közvetítő elem, a Folyóparti Harmónia zenekar segítségével mutatja be. Ennek sorsán keresztül távolságtartással, a polgárháború utáni idők zenekarszervezőjének gondjain keresztül mutatja be a város veszteségeit. „A régi zenekar [...] meglehetősen szétzilálódott a szénmedence 1918-as válsága idején, a polgárháború pedig szinte megsemmisítő csapást mért rá: sem a sajnálatos halálesetek (egy trombita Terolnál, a basszustuba Carrascalnál, egy klarinét az ebrói csatában) sem pedig a helikon mexikói számüzetése miatti üresedést nem sikerült feltölteni.”117

A másik szövegrész, melyben a városka polgárháborús halottait veszi számba, szintén egy közvetítő elem, egy freskó beiktatásával tárja elénk a veszteségeket, melyet Aleix de Segarra, a republikánus bohém fest a család tulajdonában levő kolostor falára. Itt már jóval komorabb tablót tárul a szemünk elé. A freskó először az Ebro-parti boldog békeidőt ábrázolja, barátokról és városlakókról mintázott faunok és nimfák nyüzsögnek vidáman a tájban. Később ezeket az idilli képeket festi át, s a békét a képeken is elsöpri a polgárháború festő által ábrázolt tragédiája: „Aleix egyik unokaöccse, a Carrascalnál elesett Lluís holtteste, mellette pedig a néhai Arquimedes Quintana két idősebb fia, akiket Zaragozában

\footnotetext{
114 Tamames, R. 288-291. o.

${ }^{115}$ Estruga, J. (dir), 288. o.

116 Tamames, R. 290. o.

${ }^{117}$ AFV 227. 0.
} 
lőttek agyon, ahol a katonai felkelés érte őket. [...] a Kolumbusz Kristóf legénységét ábrázolta, akiket lekaszált az ellenséges légierő géppuskája; a holttestek közt, a megfeneklett hajó orrában, a golyószaggatta oldalú, haldokló Szenes öszvér kétségbeesve tátja ki vérző száját."118 Fontos elem, hogy a freskón a köztársasági halottak mellett megjelenik „Sadurní Romaguera pisztolygolyóktól lyuggatott teste” ${ }^{119}$ is. Ö annak a bizonyos José Moré Matienzónak a regénybeli alakja, akit a mequinensaiak a pap mellett átengedtek az anarchista különítményesek jobboldaliakat likvidálni kívánó dühének. Ez a második ábrázolásmód a humor minden árnyalatát nélkülözve, az emberrel együtt szenvedő állat picassói motívumát is alkalmazva vezeti be az olvasót a háború okozta fájdalomba.

A harmadik, háborús veszteségeket bemutató jelenetben pedig közvetítés nélkül, egyenesen vall a gyászról: „,...eszébe jutott a Bruneténél elesett, jeltelen gödörben elföldelt, elsőszülött fia, akinek az emléke még mindig fájt”, „... mert a bátyám elvesztését sosem hevertük ki.” ${ }^{120}$ Ezek a szavak egy maróan gúnyos jelenet közepén hangzanak el, mely nevetségessé teszi a késő-francói kor pocakos, Ebro-parti Hamlet módjára egy koponyát vádlón a kezében tartó csendőrőrmesterét, aki ürügyet keres a patikus letartóztatására, az 1971-es város romjai alól előásott bizonyítékkal. Ez a jelenet a polgárháború halottai miatt érzett fájdalmat egyrészt azzal igyekszik enyhíteni, hogy kíméletlenül kifigurázza a bosszúért lihegő csendőrt, másrészt pedig azzal, hogy a város általános pusztulásának közepén játszódik. A polgárháború emlékeit elnyeli a város 1971-es pusztulásának tragédiája: „A katona porladó csontváza, a koponya, amelyben még nem csendesült el a csatazaj, azon a határvonalon túl helyezkedett el, ahonnan nem akarták, hogy bármi is beszüremkedjen a világukba. Otthagyták a múltat a romok között, hadd hordja szét az északi szél a város leülepedett porával együtt.” ${ }^{121} \mathrm{Ez}$ a mondat jelzi, hogy az új és aktuális fájdalom felülírja a régit, nem lehet akkumulálni a fájdalmakat, a felejtés szükséges a túléléshez, hisz emlékezet nélkül lehet élni, de felejtés nélkül nem. ${ }^{122}$ A zenekar sorsa, a festmény és a komikus keretbe ágyazott történet arra szolgál, hogy elmesélhetővé tegyen nagy emberi tragédiákat a művészet és a humor segítségével. Ez nem a tagadó, hanem a feldolgozó felejtés, ami a szavak által helyet biztosít az emléknek, s így a megbékélés irányába hat.

\footnotetext{
${ }^{118}$ AFV 159. o. L. Mellékletek. Képek, térképek, 7. Cavall mort sencer.

${ }^{119}$ Uo.

${ }^{120}$ AFV 286. o.

${ }^{121}$ AFV 287. o.

${ }^{122}$ Moreno, Rogelio, La farmacia del olvido, Barcelona, RBA; a szerző Nietzschét idézi, akivel egyetért: „Lehetséges tehát csaknem emlékezet nélkül élni, sőt boldogan élni, amint az állat tanúsítja; az azonban teljességgel lehetetlen, hogy felejtés nélkül egyáltalán éljünk.”... „A történeti és a történetietlen egyaránt szükséges valamely egyén, nép, vagy kultúra egészségéhez.” Nietzsche, Friedrich, A történelem hasznáról és káráról, Budapest, Akadémiai Kiadó, 1989. 31-2. o.
} 


\subsection{Memoria mortuorum Mequinensában}

A mequinensaiak több halottat is találtak a városhoz tartozó területen, mely az aragóniai frontáttörés és az ebrói csata során is müveleti terület volt, de a regény nem ábrázol egyetlen polgárháborús csatajelenetet sem, csak azok emlékezetét. A fent említett koponyához tartozó csontváz mellett egy bőriszákban az ismeretlen köztársasági katona iratait is megtalálta a Castells család, akik úgy döntöttek, megörzik a csontokat, és felveszik a kapcsolatot a katona családjával, hogy alkalomadtán hazaküldhessék, s a család méltón eltemethesse. A levelet az írástudatlan apa helyett a lánya írja meg, ám válasz soha nem érkezett. Abban reménykedtek, hogy ha ők ezt megteszik, cserében majd így tesz valaki az ő fiuk földi maradványaival is.

Moncada regényeiben és novelláiban fontos és gyakran megjelenő motívum a halál és annak rítusai. ${ }^{123} \mathrm{Az}$ öregekkel való beszélgetések és anekdoták, valamint saját megfigyelései alapján a transzcendentálissal való kapcsolat általános emberi igényét ábrázolja. Ezt jól példázza egyik novellája, mely leírja, hogyan alakítja ki sebtében a II. Köztársaság által egycsapásra laikussá tett társadalom a temetés új szertartásait, hogy a holtakat méltón kísérhessék utolsó útjukra, s azok így nyugalmat leljenek a túlvilágon. ${ }^{124} \mathrm{~A}$ hazajáró lelkekkel kapcsolatos korábban idézett legenda is a koporsó nyugalmát biztosító szertartás fontosságát hangsúlyozza. A regény első fejezetének keretéül szolgáló, 1970. április 12-i temetési menetet Moncada megnyugtatóan beágyazza a város életébe: „a városkának rendelkezésére álltak azok a világi rítusok, amelyek megkönnyítik elviselni még a halál jelenlétét is.” ${ }^{125}$ A kávéházban, melynek törzsközönségéhez az elhunyt tartozott „egy darabig az élet törékenységéről filozofáltak, majd a halott szerencsés csillagzatát emlegették [...] Miután ily módon elhárult a veszély, amely abból származhatott volna, ha nem csillapítják a lehető legnagyobb mértékben azt a titokzatos erőt, amivé Pasqual de Serafí időközben már talán át is változott, a beszélgetés elkerülhetetlenül átterelődött a

\footnotetext{
${ }^{123}$ Nemes Krisztina, 'Mort a Mequinensa' in Catalanística a Hongria 1971/72 - 2011/12. Budapest, Universitat Eötvös Loránd de Budapest, 2013, 149-155. o.

${ }^{124}$ Moncada, Jesús, Balkézről jött történetek, Budapest, L’Harmattan 2013 „Adj, Uram, örök nyugodalmat nekik" c. novellában a főszereplő öreg a köztársasági idők első elhunytja. Mivel nem akart egyházi temetést, nem ravatalozzák fel a templomban, de a háza túl közel esik a temetőhöz, így a menet egykettőre odaér. A történet lejegyzését megtaláltam a Moncada családi levéltárban. Itt csak annyit füz hozzá a tényekhez, hogy nagyon szegényes lett így a temetés. A novellában az öreg kikel a koporsóból, és megmondja a magáét: ő is megérdemli, hogy végigvigyék a városka utcáin, hogy méltón kísérjék utolsó útjára, s ne úgy kaparják el, mint egy kutyát. Vagyis a gyászmenet, ha nincs is pap kereszttel az élén, szükséges a halott békés távozásához. ${ }^{125}$ AFV 11. 0.
} 
futballbajnokság legutóbbi versenynapja eseményeinek taglalásába.” ${ }^{126}$ A halál tehát az élet része, a szertartáson való részvétel a világ ősi rendje szerint kötelező, s mint a regény és a novellák bemutatják, ilyenkor kiürültek a kocsmák, a kávézók, mindenki beállt a holtat utolsó útjára kísérők közé. A végtisztesség megadása összefogta az élőket, és megnyugvást hozott számukra, s ez a vörös városban sem mellőzető funkció. Az idézett példák nevetséges színben tüntetik fel a halállal kapcsolatos babonákat, ám a humor itt épp annak hangsúlyozására szolgál, hogy mennyire mélyen gyökerező a közösség (élők és holtak is) összetartozása, mely ebben a rítusban mutatkozik meg. Az író maga is ahhoz a kávéházi törzsközönséghez tartozott, mely tovább éltette a társadalmi kohézió e fontos elemét. A modern társadalmak eltávolítják a halál gondolatát és szertartásait, de az emberiség történetével egyidős halotti és emlékezeti kultuszt őrzik a hagyományos életformához közel álló, vidéki kis társadalmak, melyek közé Mequinensát is sorolhatjuk. Julio Llamazares regényéből megtudhatjuk, hogy az ő szülőfalujának, a leóni Vegamiánnak a lakosai közül, akik megtehették, kihantoltatták a halottaikat az elárasztandó temetőből, s magukkal vitték a csontokat új lakhelyükre. ${ }^{127}$

A regényt 1988-ban adták ki először, ekkor még nem indultak meg Spanyolországban a feltáratlan tömegsírokban elveszett hozzátartozókat kereső mozgalmak. Ebben a folyamatban a fordulat évének egyértelmüen 2000 tekinthető, az ARMH (Asociación para la Recuperación de la Memoria Histórica) civil szervezet megalakulásának éve, mely Emilio Silva eltűnt nagyapja utáni nyomozásból nőtt ki. Több mint százötven tömegsír feltárását köszönhetjük nekik, ezek közt az első a Priaranza del Bierzo-i jeltelen tömegsír, amely 13 republikánus földi maradványait tartalmazta, köztük Emilio nagyapjáét. ${ }^{128}$ A regénybeli Castells család által talált csontváz sorsát megörökítő sorok arról vallanak, hogy Mequinensában a temetetlen halottakhoz nem csak az ebrói folklór tárgykörébe tartozó legendák kapcsolódnak, hanem nagyon sok élő és elgyászolatlan fájdalom is, melyet nem enyhíthetett a város „rendelkezésére álló” ősi hagyomány, a modern, laicizálódott társada-

\footnotetext{
${ }^{126}$ AFV 30. o.

${ }^{127}$ Llamazares, J., Distinctas formas de mirar el agua, 14. o. Ugyanez a motívum található García Márquez Száz év magány című regényében is, amikor a befogadó Buendía családhoz megérkezik az elárvult gyerek, aki egy vászontarisznyában magával hozza a szülei csontjait. A falu kevéssel korábban telepedett máshová, s „Mivel akkortájt nem volt temető Macondóban, mert addig még nem halt meg senki, a tarisznyában hozott csontokat otthon tartották, hogy majd csak akad méltó sír a számukra”.

${ }^{128}$ Treglown, Jeremy, Franco's Crypt: Spanish Culture and Memory Since 1936, Farrar, Straus and Giroux, 2013. 27-30. o. l. még http://www.memoriahistorica.org.es/joomla/index.php/quienes-somos, letöltés 2017. szept. 10. A szervezet 2007 és 2011 között évi 45-60 000 Eurót kapott a polgárháború áldozatainak exhumálására, majd 2012-től ezt a juttatást a Rajoy kormány megszüntette. Az állami szubvenció nullára apadásáról l. még Elena Cabrera cikkét: http://www.eldiario.es/sociedad/Segundo-enterramiento-Memoriahistorica_0_110239847.html, letöltés 2017. szept. 10.
} 
lomban is fontos rite de passage, a temetés. 2007-ben José Luís Rodríguez Zapatero szocialista kormánya 2007-ben törvényt hozott a történelmi emlékezetről, amely elismeri minden állampolgár és család jogát az egyéni emlékezethez. A törvény úgy fogalmaz, hogy „,helyet ad annak a „nagyon jogos követelésnek, mely nem kevés olyan állampolgártól érkezik, akinek nincs tudomása hozzátartozói fellelhetőségének helyéről, akik közül többen még tömegsírokban hevernek, intézkedéseket és eszközöket dolgoz ki annak érdekében, hogy a közigazgatási szervek megkönnyíthessék a kérelmezők számára a lokalizálás és az esetleges azonosítás feladatát.”129 Ezt a törvényben kitűzött célt máig nem sikerült elérni, s talán éppen ezért a világhálón ma rengeteg olyan szervezet, egyesület létezik, amely a tömegsírokban jeltelenül eltünt hozzátartozók keresését, azonosítását igyekszik megkönnyíteni, s legalább ennyi internetes fórum vitatja az exhumálások szükségességét vagy időszerűségét. ${ }^{130}$ A regénybeli csontváz végül ottmarad a lassan teljesen rommá váló Mequinensa törmeléke alá temetve, ami azt sugallja, hogy az új trauma átveszi a régebbi helyét, a regény jelene a város elvesztését gyászolja, s ennek fájdalma felülírja a korábbi tragédiáét.

A temetés, a méltó temetés, és az újratemetés kérdése Spanyolországban fontos, megoldatlan, élő kérdés. ${ }^{131}$ Ennek bizonyára vannak politikai okai is, hiszen a diktatúra megtorlásként és békeidőben elkövetett gyilkosságainak következményei, a feltáratlan tömegsírok erkölcsi-politikai tőkét jelentenek a spanyolországi baloldalnak a büntetlenül maradt gyilkosok örököseiként láttatott jobboldallal szemben. ${ }^{132}$ Az aktuálpolitikai okok azonban felszínre hozzák a demokratikus átmenet során a politikai realitásokkal számoló Amnesztia Törvény nyomán kialakult helyzet igazságtalanságát. Az idegen földben elkapart, a kegyeleti tisztességtől megfosztott, „temetetlenül maradt holtak” ma is kísértenek a spanyol társadalomban, s különösen, annak az ateista, köztársaságpárti részében. Nyilván azért, mert az ő halottaikról van szó, s mert a nyíltan vallott antiklerikális beállítottság nem jelenti azt, hogy

\footnotetext{
${ }^{129}$ Történelmi emlékezet törvénye http://www.boe.es/boe/dias/2007/12/27/pdfs/A53410-53416.pdf, letöltés 2017. aug. 31.

${ }^{130}$ Néhány példa: https://lamemoriaviva.wordpress.com/2009/01/30/consulta-listados-de-queralt-sole/, letöltés 2017. aug. 31.; https://aricomemoriaaragonesa.wordpress.com/2010/09/26/\%C2\%BFdonde-esta-mi-abuelo/, letöltés 2017. aug. 31.; https://www.meneame.net/m/actualidad/c/21356942, letöltés 2017. aug. 31.

${ }^{131}$ A halottak azonosítására, és hazai földbe temetésére való törekvés nem spanyol különlegesség, hanem egyetemes emberi törekvés. Városlődön (Veszprém megye) a felső (frank) temetőben egy nagy tömegsírban temették el a II. világháború során a város melletti csatában elesett német katonákat. 2016-ban a sírt felnyitották a sírt megtaláló hozzátartozók kérésére, akik hazavitették halottaik maradványait. Magyar egyesület gondozza a katonatemetőket Ukrajnában, s igyekszik azonosítani a lövészárkokban jeltelenül elföldelt magyar katonákat. L. www.karpataljalap.net letöltés 2017. aug. 31. A hírhedt Bleiburg repatriation és halálmenet következtében Szlovéniában található tömegsírok feltárását szintén az egykori polgárháborús helyzet akadályozza. L." Mitja Ferenc, "Secret World War Two mass graves in Slovenia", in Jambrek, Peter, Crimes Committed by Totalitarian Regimes, Ljubljana: Slovenian Presidency of the Council of the European Union, 2008.

${ }^{132}$ Nemes Krisztina, Törvénybe foglalt emlékezet, Létünk 2015/2 129-145. o.
} 
a halottaknak a tiszteletet ne kívánnák megadni ősi szokás szerint, mint azt a fentebb idézett, Adj, Uram, örök nyugodalmat nekik címü Moncada novella is szemlélteti. A furcsa inkább az, hogy a magát kereszténynek valló jobboldal szemében ez nem érthető törekvés.

Pablo de Greiff, különleges referens jelentést készített az ENSZ Emberi Jogok Bizottságának 2014. január-februárban tett spanyolországi látogatásának tapasztalatairól, melynek célja az volt, hogy megállapítsa, milyen intézkedéseket hoztak a spanyol hatóságok az igazság, az igazságszolgáltatás a helyrehozatal és a meg nem ismétlődés garanciája érdekében a polgárháború és a Franco diktatúra által az emberi és a nemzetközi jogok ellen elkövetett sérelmek kérdésében. A Greiff jelentés az igazságszolgáltatás nagy hiányosságait állapította meg, mire a spanyol ENSZ nagykövet kijelentette, hogy a spanyol állam eltérő véleménnyel van megfigyeléseivel kapcsolatban. ${ }^{133}$ A referens jelentését az a számtalan kérelem teszi érthetővé, amelyek sikertelenül próbálják a köztársasági legitimitás talaján álló, s ezért kivégzett rokonokat, hozzátartozókat legalább az utókor számára rehabilitáltatni. A jelenlegi törvényi szabályozás alapján Spanyolországban ez nem lehetséges, hiszen a Történelmi Emlékezet spanyol törvénye nem mondja ki, hogy 1936. július 18-a egy törvényes hatalom elleni puccs volt, a kormány oldalán harcolók a jog oldalán harcoltak, a Franco-rezsim diktatórikus elnyomást jelentett, amelynek áldozatai voltak. Ezt a helyzetet példázza a katalán emlékezetpolitikában egyre markánsabban megjelenő mártír miniszterelnök, Lluís Companys ${ }^{134}$, a jobboldali, katalanista republikánus politikus Manuel Carrasco Formiguera, akit mély katolikus hite sem mentett meg a kivégzéstől 1938-ban ${ }^{135}$, s a kommunista költő, Miguel Hernández esete is. Az ő családja által 2010-ben a Legfelsőbb Bírósághoz benyújtott rehabilitációs kérelmet elutasították. A család az Alkotmánybírósághoz fellebbezett, amely 2012ben azzal az indoklással utasította el a költő elítélésének érvénytelenítésére történt kísérletet, hogy nem létezik olyan alapjog, amelyet az ítélet sértett volna. ${ }^{136}$

A folyók városa még egy helyen érinti a polgárháborúban életüket vesztett katonák megkülönböztetésének kérdését: amikor „a városka templomának homlokzatán márványtáblát helyeztek el annak a tucatnyi lakosnak a nevével, akik Franco oldalán harcolva estek el a polgárháborúban, a birodalmi beszédekkel, zászlókkal és hazafias zenével ünnepelt

\footnotetext{
${ }^{133}$ http://memorialdemocratic.gencat.cat/ca/detalls/Noticia/20140915_Pablo-de-Greiff, letöltés 2015. jan. 7.

134 L. melléklet Lexikon 17.

${ }^{135}$ L. melléklet Lexikon 18.

${ }^{136}$ Escudero Alday, Rafael, Los tribunales españoles ante la memoria histórica: el caso de Miguel Hernández http:/hispanianova.rediris.es/11/ensayos/11e001.pdf, letöltés 2015. jan. 7. Megállapítják, hogy a Történelmi Emlékezet Törvénye értelmében "igazságtalan és illegitim" ítélet született, de nem érvénytelenítik, s nem fogadják el a család által, a költő ártatlanságának bizonyítására összegyüjtött bizonyítékokat. https://elpais.com/elpais/2011/02/16/actualidad/1297847848 850215.html, letöltés 2017. nov. 19.
} 
avató másnapján a városháza kapuján megjelent egy lista, rajta vagy nyolcvan névvel, a köztársaságpárti halottakéval.” ${ }^{137}$ Mint láttuk, a helytörténeti krónika is megörökíti ezt a táblaavatást, és elmondja, hogy a város lelkiismeretét terhelő két halott listáját a márványtábla még három személlyel bővítette, ők azonban vagy nem voltak mequinensaiak, vagy tisztázatlan okokból érte őket a halál. Itt a két közölt adat nem egyezik, a regény tucatnyi, a monográfia pedig öt halottról beszél, a tábla pedig a templom lerombolásával együtt megsemmisült. A köztársaság oldalán elesett halottak számáról a történeti monográfia nem közöl becsléseket, arra hivatkozva, hogy a veszteségek megállapításához további kutatások szükségesek. Ez azt jelenti, hogy a hátországi megtorlások történetével foglalkozó szaktörténész, David Tormo Benavent nem támaszkodhatott hitelt érdemlő levéltári, hivatalos vagy statisztikai adatokra. A Francói megtorlás áldozataiként két bányászt sorol fel. A regény ezzel szemben körülbelül nyolcvan före teszi a köztársasági oldalon elesettek számát. Mint látjuk, a számok itt sem egyeznek, ami a téma feldolgozatlanságára, megoldatlanságára utal, s megerősíti az amerikai hispanista, Stanley G. Payne megállapítását, miszerint egyfajta számháború zajlik még mindig a jobb- és baloldali áldozatok kérdésében. ${ }^{138}$ Úgy vélem, a regény és a monográfia tükrében, hogy a sok esetben hiányzó dokumentumok pótlására a történész csak az oral history tanúságtévőire támaszkodhat, mert a térben összekapcsolt egyéni emlékezetek regisztere őrzi a halottak nyomát, erről tanúskodik a regényben közölt jóval magasabb szám.

Megjelenik a regényben az emigráció, melyből nincs visszatérés, és egy Franciaországból, a partizánok közvetítésével 1950-ben hazajuttatott rövid üzenet tudósít Aleix de Segarra mauthauseni haláláról. A köztársaságiak kálváriájának Mauthausenben (El campo de los españoles) elérkező végpontjának felidézésével a regény megidézi annak a közel kilencezer, menekültnek a tragédiáját, akiket az 1940 nyarán megszállt Franciaországból Pétain kormánya átadott Németországnak, mert sem Franco, sem Sztálin nem tartott rájuk igényt. A deportáltak többsége, 7200 ember Mauthausenbe került, ahol 4800-an életüket vesztették. ${ }^{139}$ A náci koncentrációs táborok köztársasági áldozatairól 1968-ig a spanyol

\footnotetext{
${ }^{137}$ AFV 243-244. o.

138 idézi Anderle Ádám, „Vörösterror Spanyolországban”, in Spanyol mozaik, Pécs, Kronosz Kiadó, 2015. 215222. o. José Javier Esparza, El terror rojo en España. Epílogo: el terror blanco, Madrid, Altera, 2007.

139 Españoles en los campos nazis http://www.lavanguardia.com/internacional/20160508/401639794161/ espanoles-en-los-campos-nazis.html, letöltés 2016. dec. 12.
} 
közvéleményt egyáltalán nem tájékoztatták, a Mauthausenben tartott éves megemlékezéseken 2005-ben vett részt először spanyol kormányfö. ${ }^{140}$

A regény által megörökített kollektív emlékezet arra is ad magyarázatot, hogy miért olyan alacsony Mequinensában a francói megtorlás áldozatainak száma. Ennek oka az, hogy a kontinensen megkezdődött a II. világháború: „Kellett a szén, és hajók is kellettek a szállításhoz, de hajó nem volt ${ }^{141} \ldots$ Mindenütt lázas tevékenység folyt... A tulajdonosok valósággal versenyeztek a hajósokért és a bányászokért, akiket a köztársaság és a háború idején tanúsított magatartásuk miatt éhezésre ítéltek. A kormányosok és a legénység felfogadásakor szabályos veszekedések törtek ki. „Ha a burzsujnak szüksége van rád, hogy meggazdagodjon, ne félj, megkeres, még akkor is, ha te kötötted fel az apját.” ${ }^{142}$ A regény mindezt 1940 júniusához, a németek Párizsba való bevonulásához köti, mely esemény következtében „kezdtek mutatkozni a város számára jól ismert történet forgatókönyvének első jelenetei: emelkedett a lignit iránti kereslet..."143 A helyzet azonban nem volt ilyen egyszerü, még ha a kemény fizikai munka mentesíthetett is a kivégzés, száműzetés vagy koncentrációs táborokba hurcolás alól. A regény kifejezetten durva megtorlást ábrázol, ahol a táborokból hazatérők elöször nem kaptak munkát, lépten-nyomon megalázták és vörös söpredéknek titulálták őket, a város éhezett, az asszonyok közbenjárásért könyörögtek, kilincseltek a gazdagoknál, s „a kíméletlen győztesek fapuskával, trombitaszóval és dobpergéssel háborúsdit játszattak a rosszul táplált, tetves gyereksereggel.”144

A egyik interjúban Joaquim del Patriciet, az 1892-ben született bányász meséli el élete történetét Moncadának. Ö, korára való tekintettel nem volt katona, az evakuáció idején elmenekült a városból, amikor visszatért bilincsbe verve vitték Saragossába és húsz év börtönbüntetést kapott, amit közbenjárók szavára két évre mérsékeltek. Moncada feljegyzi, hogy a kihallgatás során a csendőrtiszt azt mondta neki: „nagy kár, hogy a városkában nem követtek el több disznóságot a háború alatt, amire hivatkozva likvidálhatnám mindegyiküket”145 A regény ezt a párbeszédet felhasználja annak alátámasztására, hogy a II. Köz-

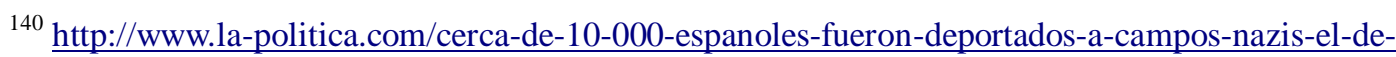
mauthausen-era-conocido-como-el-campo-de-los-espanoles/, letöltés 2018. ápr. 22. Erröl magyarul Ripoll, Laia, El convoy de los 927, drámája http://szinhaz.net/wp-content/uploads/2016/03/927-spanyol-utja.pdf, letöltés 2018. ápr. 14. Mauthausenről a katalán emlékezeti térben L. melléklet Lexikon 11. https://www.ara.cat/cultura/catalans-camps-nazis-torna-llibreries_0_1862813822.html, letöltés 2017. nov. 7.

${ }^{141}$ A mequinensai öregek interjúi között az egyik így fogalmaz: „A háború után [...] bármi megfelelt, lehetett akár egy láda is, csak gyorsan elkészüljön, fennmaradjon a vízen, és képes legyen szenet szállítani.” MCSL Entrevista amb Jorget.

142 AFV 202. 0.

143 AFV 201. 0.

144 AFV 171. 0.

${ }^{145}$ MCSL Entrevista amb l'oncle Joaquim del Patriciet.
} 
társaság idején városka elöljárói és a nép erkölcsileg magasabb rendü viselkedést tanúsítottak, mint a Franco rendszer igazságszolgáltatása. Ezt erősíti egy háború utáni jelenet is, melyben a munkásaival jó viszonyt ápoló bányatulajdonos megbékélésre szólít, mondván, ti sem bántottatok minket a köztársaság idején, hát fogjunk össze, kell a szén. Mequinensa történeti monográfiája szintén azt hangsúlyozza, milyen példamutatóan alacsony volt a mequinensai jobboldali áldozatok száma az aragóniai köztársasági hátországban elkövetett vérengzések áldozatainak számához képest. A regényben szavaival: „... ez a csendőr egy vérengző fenevad: nyíltan megmondta, mennyire sajnálja, hogy a helybeliek nem kegyetlenkedtek az urakkal és a jobboldaliakkal, és így nem állhat bosszút rajtuk, halomra lövetve a bányászcsőcseléket, akik szerinte éppen olyan veszélyesek, mint asztúriai társaik. ${ }^{146} \mathrm{Ez}$ volt a vesszőparipája akkor is, amikor a munkatáborokból és a börtönökböl hazatérteket vallatta, és nagyon dühbe gurult, ha nem talált senkit, akin kiélhette volna vérszomjas hajlamát. Nem a gyilkosokra vadászott, hanem annak a háborúnak a vesztes katonáira, amelyet a másik fél kezdett, s amelyben sokan

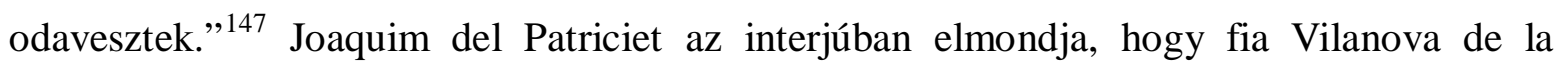
Barcánál halt meg egy mórokkal vívott csatában, ahol nem voltak se sebesültek se foglyok, de a feleségének csak annyit mondott, hogy a fiú eltünt. Majd így fogalmaz: „azokat a könnyek, amiket nem sírtam el akkor, hogy ne búsítsam jobban az anyját, most sírom el, öregemberként. Nem tudom megbocsátani nekik, amit a háború után csináltak, a posguerrát nem nyerték meg.” ${ }^{448}$ A regény az oral history tanúságtételekre építve kiemeli a Francorendszer megtorlás jellegü igazságszolgáltatását, melynek célja az elrettentés és a megfélemlítés volt. A háború halottairól rendelkezésünkre álló adatok tükrében azt látjuk, hogy Mequinensának a márványtáblán jelzett öt (monográfia) vagy tizenkettő (regény) nemzeti oldalhoz köthető halottjával szemben, körülbelül nyolcvan, a közösségi emlékezet által őrzött köztársasági halottja van, ami teljességgel igazolja „vörös” város jellegét.

Mint a helytörténeti monográfiából tudjuk, a városnak két, dokumentált, történészek és helytörténészek által is lejegyzett jobboldali kivégzésével kell elszámolnia. A regényben ez

\footnotetext{
${ }^{146}$ Manolo Comas Cabistany (L. melléklet Lexikon 12.) emlékirataiban találjuk meg a leírását annak az asztúriai sztrájknak, (időpontját nem jelöli) melynek hatására a mequinensai bányászok is szolidaritássztrájkot hirdettek. Ennek büntetéseképp az emlékiratok szerzője apjának egy társával együtt még két év katonai szolgálatot kellett letöltenie. Társa annak az Andrés Cosónak a nagyapja, aki a Mequinensa történeti monográfia 9. fejezetének szerzője. Ö, nagyapja története alapján, megerösíti az emlékiratok szerzőjének tanúságtételét. A bányásztársadalomban tehát létezett szolidaritás, és a mequinensaiak figyeltek Asztúriára. Asztúriai volt az a bányászvezető is, aki a regényben politikai tudatosságra nevelte a munkásokat. Az ö identitását Moncada a regényben megváltoztatja, s barcelonait csinál belőle.

147 AFV 190-191. 0.

${ }^{148}$ MCSL Entrevista amb l’oncle Joaquim del Patriciet.
} 
az elszámolás a bohém, republikánus festő szerelmének, Malenának az emlékein keresztül történik meg. Az idős asszony a lerombolásra váró kolostor freskói előtt állva csak a szépre szeretne emlékezni, de „az emlékek nem álltak meg, vitték tovább a megrázó krónika minden egyes állomására. Romaguera halálánál a képekhez hozzákapcsolta az emlékezés a felesége és a lányai kétségbeesett sikoltozását aznap éjjel, amikor elvitték. Így fizetett meg Arnau Terrer meggyilkolásáért. A környék településeit vérbe borító események közepette itt ez volt az egyetlen gyilkosság, no meg a plébánosé, akinek pedig megengedték, hogy elhagyja a várost, sőt még civil ruhát is adtak neki, ő mégis visszatért, és a jelenléte meg az esztelen megjegyzései tarthatatlan helyzetbe hozták a burzsoák kivégzését követelő idegen csapatok előtt."149

A város idős plébánosának a halálát ugyanolyan gyakorlatias, szikár szenvtelenséggel közli a regény, mint ahogyan az általam e témában megkérdezett mequinensaiak nyilatkoztak róla. ${ }^{150} \mathrm{Az}$ öregekkel készített interjúk egyike sem tartalmaz utalást a pap halálára, s Moncada sem áldoz rá többet, mint fél mondatot a regény 298 oldalából. Ebböl a fél mondatból azt tudhatjuk meg, hogy a pap elmenekülhetett volna, ha akar, a vörös város még álruhát is biztosított neki, ám a pap maga kereste a bajt, rosszul mérte fel helyzetét, és saját döntésének köszönheti halálát. Súlyosbító körülményként említi a pap esztelen megjegyzéseit, melyek döntőnek bizonyultak a kivégzés kiprovokálásában. Mivel más adattal nem rendelkezünk, s a helytörténeti monográfia adatai is a szóbeli hagyományozásra támaszkodnak, s ugyanezt a verziót támogatják, mindössze annyit állapíthatunk meg, hogy a történész szerző véleménye, miszerint a 83 éves, öreg plébános kivégzése „súlyos morális teherként nehezedik majd a város kollektív emlékezetére» ${ }^{151}$, a regényben egyáltalán nem igazolódik. Az író közli az eseményt, mert megtörtént, s az igazsághoz hü Mequinensa történelem ezt nem hallgathatja el. Az eseményhez azonban nem füződik semmiféle érzelmi viszonyulás, szép emlék, katarzisra vagy bocsánat elnyerésére törekvő mondat, szó vagy stilisztikai eszköz általi jelzés. Ha a regényre úgy tekintünk, mint Mequinensa száz évének emléktérképére, azt mondhatjuk, hogy a papnak egyetlen tűszúrásnyi nyoma maradt, a halálára szánt fél mondat, mely igazolja és felmenti a várost az abban való bűnrészesség vádja alól.

A gazdag kereskedő, José Moré Matienzo halálát a regény Romaguera történetében dolgozza fel. Az események ismertetésekor az író ugyan felidézi a család tragédiáját, amivel

\footnotetext{
149 AFV 159. 0.

${ }^{150}$ Hèctor Moret költő és nyelvész, Rosa-Maria Moncada, az író húga.

${ }^{151}$ Estruga, J. (dir.), 285. o.
} 
érzékelteti a hozzátartozók fájdalmát, s így emberibbé, egyedibbé teszi a politikai indíttatású kivégzést, de egyértelmüen kijelenti, hogy volt erkölcsi alapja: így fizetett meg a munkásvezető általa elrendelt és elhazudott haláláért. Arnau Terrer-t tőrbe csalták és meggyilkolták a város vezetői, mert öntudatra ébresztette a városka bányászait, írni-olvasni tanította őket, és megismertette velük az összefogásban, szervezettségben rejlő erőt. A nyomozás megállapította, hogy baleset történt, a vizsgálatot az igazságszolgáltatás képviseletében Romaguera polgármester rokonai, lekötelezettjei és üzletfelei végezték. A nyomozati eredmény elleni tiltakozásnak nem volt eredménye, s „az ügy látszólag feledésbe merült, de az a másik város, melyet Carlota de Torres semmibe vett vagy megvetett, hosszú éveken át megtartotta az emlékezetében.” ${ }^{\text {152 }}$ Ezt jelzi a történet során újra meg újra, összesen háromszor felbukkanó felkiáltó mondat: Ne felejtsétek Arnau Terrer-t! A Moncada által készített interjúk közt az idős bányász, Joaquim del Patriciet történetei közt Blanco története néven megtaláljuk a regénybeli Romaguera-Terrer konfliktus eredetijét: „Blanco a bányában dolgozott. A ca Ralet nevü kocsma egy szobájában lakott, ott tanította írni-olvasni az embereket. Egy Canero nevü csendőr ölte meg Fostigueres polgármester parancsára. A haláleset Fraga területén történt, ahol a mequinensai polgármester testvére volt a törvényszéki orvos, és ő eltussolta a dolgot. Valaki látta, hogyan ölték meg Blancót, de aztán az nem mondott semmit.” ${ }^{153}$ A regényben tükröződő kollektív emlékezet - a város plebejus emlékezete - ezt a fortélyosan elkövetett igazságtalan politikai gyilkosságot őrizte meg. Ennek továbbéléséröl a regényben Carlota de Torres ad számot, amikor a II. Köztársaság kikiáltásakor nyilvánvalóvá lesz számára, hogy „az állítólag semmivé foszlott kísértet új életre kelt az utcákon, megrepesztve az idő páncélját”. A Torres ház körül lélegző város, az a világ, melyet Carlota de Torres sosem kívánt sem megismerni, sem megérteni, még a nagy sztrájk idején sem, volt olyan szemtelen, hogy a saját életét élje, a saját emlékeit őrizze, s szertekiáltsa őket az utcákon."154

A regény nyilvánvalóvá teszi, hogy a város emlékezet tekintetében valójában két város, melynek lakói különböző emlékezeti hagyományokat ápolnak. A regényben a gyilkosság szemtanúja az angol geológus, aki a szénmedence ásványairól készülő tanulmányához végzett terepmunka közben pillantja meg az elkövetőt a tett színhelyén, és le is leplezi a republikánus baráti körben, ezért a polgármester kiutasítja a városból és az országból. A gyilkos törvényszolga a halálos ágyán meg akarja gyónni szörnyü bünét, de a család

\footnotetext{
152 AFV 133. 0.

153 MCSL Entrevista amb l'oncle Joaquim del Patriciet.

${ }^{154}$ AFV 129. 0.
} 
megrémül, s egy törölközővel betömi a száját, nehogy kitudódjon a dolog, a bünös így elnémítva agonizál a pokol tüzétől rettegve. Megannyi nemtelen, becstelen, erőszakos részlet, melyek az elkövető oldalt erkölcsileg alacsonyrendűnek mutatja, a Blanco legendát a kor társadalmi, politikai kontextusába helyezve értelmezi, és felnagyítja a munkásvezető alakját. Az ő halála mártírhalálként élt tovább a közösség emlékezetében, mert sehol máshol nem élhetett tovább. Ugyanígy mártír az a körülbelül nyolcvan elesett vagy eltünt köztársasági halott is, akiknek neve a városháza kapujára szögezett listán szerepelt, akiknek nem lehetett síremléket állítani, s akikről nem lehetett megemlékezni sem. A „csak kettő” jobboldali halott egyedül azt bizonyítja, hogy a városnak sikerült megőriznie józanságát a polgárháború hátországi vérengzései közepette. Említésük a regényben olyannyira nem hangsúlyos, hogy az az érzésünk, maga az író is szívesen megfeledkezne róluk. Az identitásképző közösségi emlékezet - csakúgy, mint az egyéni emlékezetek - arról beszél, arra építkezik, ami szép, becsületes, tiszta és példaértékü. A gyilkosság, ha - mint mondják jogos erkölcsi alapja volt is, nem lehet példaértékü. Ezt jelzi a mindössze két félmondatnyi terjedelem, mely a város emlékezetregényében e két halálnak jut.

\subsection{Mequinensa emlékezete a spanyolországi emlékezetháború kontextusában}

A halottakról való megemlékezés a spanyolországi emlékezetháború neuralgikus pontja, mert akik a diktatúra évei alatt gyászolhattak és emlékezhettek hitük és szokásaik szerint, azok sérelmesnek érzik, hogy a másik oldal, aki az emlékezet segítségével próbálja exhumálni halottait, nem objektív. Josep Benet katalán politikus, történész és kiadó szavaival szólva, a Franco által elkövetett sok bün legnagyobbika a Caudillo háború utáni politikája volt. ${ }^{155} \mathrm{Az}$, hogy „nem a béke jött el [...], hanem a győzelem”. ${ }^{156}$ Ugyanezt fogalmazta meg fentebb az öreg bányász, Joaquim del Patriciet.

Franco nagyon határozott emlékezetpolitikát folytatott a legyőzöttekkel szemben, emlékezetüknek még az írmagját is kiirtotta. Birtokba vette az időt és a teret egyaránt, hiszen az utcák, közterek, épületek az új mitológia történelmi-politikai eseményei és személyiségei nyomán kapták nevüket. Az egyházi rituálék, a mártírokra való emlékezés szintén a keresztes háborúnak titulált katonai felkelés győzelmének emlékezetét állandósította és ünnepelte csakúgy, mint a katonai parádék és megemlékezések. A saragossai Nuestra Señora

\footnotetext{
${ }^{155}$ Idézi Bernecker, Walther L., „Luchas de memorias” en la España del siglo XX in Josefina Cuesta (dir.), Memorias historicas de España (siglo XX) Fundación Francisco Largo Caballero, Madrid, 2008. 40.o.

${ }^{156}$ Fernán-Gómez, Fernando, Las bicicletas son para el verano, Madrid, Espasa Calpe, 1994, 206. 0.
} 
del Pilar Székesegyházat a Spanyol Faj templomává avatták, melybe nem tartoztak bele a köztársaságiak és az ateisták, hiszen „akik nem azonosulnak Spanyolország katolikus ethoszával, nem azonosulhatnak magával Spanyolországgal sem”. ${ }^{157} \mathrm{Az}$ országban mindenütt felállították a „Caídos por Dios y por España”, (Elestek Istenért és a Hazáért) emlékműveket, s a templomok falán kőbe vésett listákon jelezték azoknak a nevét, akik Franco oldalán harcolva vesztették életüket, mint ahogy ezt történt Mequinensában is 1940 szeptemberében. ${ }^{158}$ Politikai vallást csináltak az elesett hősök kultuszából, amit a Valle de los Caídos templomának és kultuszhelyének koncepciója példáz. A másik Spanyolország, amelyet a damnatio memoriae sújtott, nem temethette el halottait, nem kapott munkát, egészen a hatvanas évekig szigorú és kegyetlen politikai megtorlás és elnyomás áldozata volt. Ennek a korszaknak az emlékezete csakis egyoldalúan a győztesek emlékezete volt, melyben a polgárháború a nemzetközi kommunizmus felett aratott fényes spanyol győzelemként tündökölt.

A Franco halála után a demokratikus átmenet szellemében, 1977-ben fogant Amnesztia törvény, kiszabadította ugyan a rendszer börtöneiből a politikai elítélteket, de a megbékélés jegyében, büntetlenséget biztosított az elnyomó rendszer nevében cselekvő üldözőknek és rabtartóknak. A spanyol demokratikus átmenetben nem volt jelen az a törekvés, hogy büntetőjogi felelősséget állapítson meg az emberi jogok korábbi megsértése miatt. ${ }^{159} \mathrm{Ez}$ elsősorban a spanyol polgárháború és a Franco korszak fájdalmas tapasztalatának tudható be, amelynek következtében az átmenetben résztvevő nemzedékek a békés reformok útján történő politikai átalakulás mellett döntöttek. A demokratikus átmenet és a szocialista kormányzás évei a békés rendszerváltás érdekében eltemették a köztársaságpárti emlékezetet, mely korábban a tiltás később pedig a „sebek felszaggatásának” veszélyét elhárítandó, továbbra is kimondatlan és kibeszéletlen maradt. ${ }^{160}$

A történészek körében a spanyol polgárháború, mint Spanyolország történelmének meghatározó és megkerülhetetlen eseménye természetesen nagy figyelmet kapott, és az irodalmi alkotásoknak is máig az egyik leggyakoribb témája. Ezek a szakmai és müvészeti körök azonban nem hatották át a társadalom egészét, és a spanyol társadalomban nem

\footnotetext{
${ }^{157}$ Az Acción Española korporatív , katolikus folyóirat és platform alapgondolata, melyhez Franco tábornok is tartozott. Idézi Anderle, Spanyolország története, 126-7. o.

${ }^{158}$ Estruga, J. (dir.), 300. o.

${ }^{159}$ Ysàs, Pere, „El antifranquismo y la democracia”, in Ricard Vinyes (dir.), El estado y la memoria, Gobierno y ciudadanos frente a los traumas de la historia, Barcelona, RBA, 2009, 406. 0.

${ }^{160}$ Ezt nevezik metaforikusan hallgatás paktumnak, ami a valóságban nem köttetett meg, de a kifejezés igen érzékletesen vall arról, hogy milyen árat fizettek a spanyolok a békés átmenetért, melyre úgy is utalnak, hogy az átmenet paktumot kötött a múltról.
} 
alakult ki olyan össztársadalmi megegyezés, amely a múltképet átalakította volna. Ebben bizonyára nagy szerepe van a Franco rendszer hosszúra nyúlt évei alatt müködő propagandagépezetnek is, melynek eredményeképp a spanyol lakosság csak részleges és torz képpel rendelkezik a háborúról, s ezt tovább is örökíti. ${ }^{161}$ A „harc a demokráciáért” típusú emlékezetnek nem volt akkora tere a politikában és a közéletben, hogy az aznari politikai érában, a „második átmenet” idején megakadályozza például a revizionista (nem akadémikus) történelmi művek óriási sikerét (Pío Moa, César Vidal) a 2000-es években. A közgondolkodás nem alakult át, megtartotta alapvető kétpólusosságát. Máig érvényesek Antonio Machado ezzel kapcsolatban megfogalmazott sorai: „Kicsi spanyol, ki születsz e világra, a Jóisten vigyázzon rád, mert szívedet jéggé dermeszti az egyik vagy a másik Spanyolország”. 162

Mikor Moncadát a mequinensai köztársasági emlékezetet feldolgozó második regénye kapcsán az író-újságíró riporter burkoltan manicheizmussal vádolja, ő így válaszol: „...nem kell semlegesnek lennem, és nem is akarok különösképpen az lenni, mert az a francóista társadalom volt manicheista, amelyben éltünk, abban a társadalomban mondták meg nekünk, hogy kik a jók és kik a rosszak. Már épp ideje volt, hogy az akkori rosszak is elmondják végre a maguk történeteit, nem?” ${ }^{163}$ Az Alexandria című irodalmi müsor riportere, Màrius Serra a spanyol történelemről kérdezi az írót, s Moncada úgy látja, hogy: „Olyan Spanyolország történelmet írtak, föleg a Franco korszak negyven évéről, amilyet csak akartak, ami egyáltalán nem hasonlított ahhoz, ami valójában történt [...], s elhazudták az összes őket nem érdeklő témát, mint Katalónia, vagy a Franja de Ponent történelmét.”164

Moncada Mequinensájában a különböző emlékezethagyományok örököseinek egymással szembeállított emlékei egyértelműen éreztetik a két fő vonal (republikánus baloldal konzervatív jobboldal) különbségét. Nem találkozunk azonban a regény lapjain - és egyik

\footnotetext{
${ }^{161}$ Reig Tapia, Alberto, „Mitos, contra-mitos y justificacions de la Guerra Civil Española” in Josefina Cuesta (dir), i.m., 86-110. o.

162 Machado, Antonio, Campos de Castilla (1907-1917) http://www.cervantesvirtual.com/obra/campos-decastilla-1907-1917/, letöltés 2017. aug. 28. Ugyanezt a két ország elméletet fogalmazza meg irodalmi formában Manuel Azaña dráma formában megírt politikai víziója, La velada en Benicarló (Benicarlói virrasztás), vagy Juan Benet, Herrumbrozas lanzas (Rozsdás lándzsák) címủ alkotásai.

${ }^{163}$ MCSL digitalizált adatok. Kronológiai jelzet nélküli cikkek:Vicién Mañé, Enrique, Astérix en Mequinensa. Trébede.

${ }^{164}$ Televisió de Catalunya, „Alexandria amb Jesús Moncada”. Az interjú 2004 február 25-én készült az Atheneu Barcelonèsben. https://www.youtube.com/watch?v=yKCcYn1pC3g, letöltés 2017. nov. 7. Ebben az interjúban Moncada utal a „kormány tervére”, (José María Aznar második PP kormánya) ami szerinte a régi állapotokhoz, vagyis a francóizmus történeti narratívájához való visszatérést tüzi ki célul, pedig épphogy elkezdhettek beszélni a történelem más verzióiról.
} 
Moncada müben sem - nemzeti alapon elkülönülö, katalán - spanyol szembeállásra vagy elkülönülésére alapozó emlékezeti hagyományokkal.

A folyók városa egyértelműen a köztársaságpárti emlékezet vonalát őrzi egy addig ismeretlen, franjai, kisvárosi, folyami hajós és bányász miliőben. Moncada azt a történelmet írja meg, amelyröl nem beszéltek, mert a „nem Spanyolország” története volt, s egy nagyközönség számára érthetetlen nyelven hagyományozódott, így kimaradt a kor minden szocializációs és indoktrinációs sémájából. Az ő hőseiről, az egyszerü, vidéki munkásemberekröl és mártírjaikról nem szóltak se történelmi, se irodalmi müvek. A Franja soha nem hallatta még a hangját, olyannyira, hogy a pánkatalán gondolat atyja, a valenciai irodalmár-esszéista Joan Fuster 1988-ban megjelent katalán irodalomtörténetében a Franja nem is szerepel, pedig Fuster az, aki ugyanebben a munkában Vicens Vivest a Principátus központúság vádjával illeti. ${ }^{165}$ A Franja „történelmének” megírására Jesús Moncada tette meg az első lépést a maga területén, az irodalomban, s nem kívánt az egész terület krónikása lenni, csakis saját szülővárosáé, amelyet különleges módon ismert, mert oda tartozott. A regény hiánypótló mü, egy teljesen ismeretlen terület és társadalmi osztály hangját szólaltatja meg, s ráadásul katalánul, amire ez volt az első példa. Moncada büszkén említi a korábban idézett Alexandria interjúban, hogy amikor 1981-ben megjelent az első novelláskötete, mindenki csodálkozott, hogy egy franjai író jelentkezik, s azon méginkább, hogy katalánul ír. Attól az időponttól kezdve azonban nem volt olyan franjai író, aki ne katalánul írt volna. ${ }^{166}$

\section{Gazdaság, társadalom és ideológia Mequinensában a regény tükrében}

\subsection{Az eröszak}

A szájhagyományban terjedő Blanco történetből ismert Fostigueres polgármestert a Mequinensából kapott információk alapján sikerült azonosítanom a monográfiában szereplő José Moré Matienzo gazdag kereskedő személyével ${ }^{167}$, akit a mequinensaiak kiszolgáltattak

\footnotetext{
${ }^{165}$ Fuster, Joan, Literatura catalana contemporània, Barcelona, Curial, 1988, 417. o.

${ }^{166}$ Arturo Quintana, Hèctor Moret, Mercè Ibarz, Francesc Serès, stb. L. még Moret, Héctor, Breu diccionari d'escriptura i escriptors contemporanis en català a l'Aragó, 2008. www.raco.cat/index.php/ Beceroles/article/download/.../326966, letöltés 2016. okt. 13.

${ }^{167}$ Hèctor Moret költő, nyelvész szintén mequinensai bányászcsaládból származik, ezt a történetet a családi legendáriumból ismerte, s szerette volna megírni is. Ö árulta el nekem, hogy Blanco asztúriai volt. Andrés Coso magánleveleiben szintén elmesélte a Blanco történetet, mint a családjukban tovább öröklődő, fontos legendát.
} 
az anarchista különítménynek. A Fostigueres ragadványnév, melynek jelentése „korbácsos”. Arra a kérdésemre, hogy miért nem szerepel Moré Matienzo neve Mequinensa polgármestereinek listáján, Hèctor Moret, és Andrés Coso is azt válaszolta, hogy a kacikáknak nem kellett hivatalos felhatalmazás ahhoz, hogy a város ügyeinek intézésében teljhatalmat gyakoroljanak. ${ }^{168}$ Moré Matienzo tehát nem volt a város polgármestere, hanem a háttérből irányította a hivatalban levő tisztségviselők döntéseit, mint a Restauráció korában játszódó Estremida memòria kacikája, majd 60 évvel korábban.

A regényben Moré Matienzo, Romaguera polgármester alakját ölti, akinek politikai, ideológiai beállítódását az író a következőképp jellemzi: „A társadalmi rend alapja a föld. Romaguera olyannyira megvetette a bányászatot, hogy a birtokain nem engedélyezte újabb lignittelepek feltárását...”169; „Ki lesz képes megállítani a munkásokat, ha rögtön az elején le nem törik az elbizakodottságukat? Meg kell értetni a csőcselékkel, hogy hálával tartoznak a fizetésért, amit kapnak...”170 Ezek a szavak az első világháború idején soha nem látott gazdasági fellendülés következményeit ostorozzák egy születésnapi vacsorán a Torres házban. A Primo de Rivera diktatúra idején polgármesterré választott Romaguerának már a mequinensai bányászok sztrájkjával is szembe kell néznie. Fia, aki osztotta apja nézeteit, Madridban ügyvédnek készült, s a regényben ő a gyilkosságra felbujtó alak, amiért a város emlékezetében gyülöletes figuraként maradt meg. „Mindig kijött a sodrából, valahányszor munkásmegmozdulásokról érkezett hír valahonnan, s azon a véleményen volt, hogy kemény kézzel, kíméletlenül el kell fojtani ezeket a kezdeményezéseket, mielőtt olyan katasztrófához vezetnek, mint Oroszországban, ahol a proletártömegek - »Istentelen, tetves népség, akasztófára való mind!« - megfosztották trónjától a cárt, és bevezették a kommunizmust [...] meg kell szabadulni a söpredéktől. Szocialisták, bolsevikok, anarchisták, republikánusok, zsákba velük, és egy jó nagy kővel együtt süllyedjenek az Ebro fenekére.” ${ }^{171} \mathrm{Ez}$ a szemlélet mintegy előrevetíti a regényben a Romaguera-fiú által javasolt megoldást, amely „félénk tiltakozást váltott ki” az erőszaktól irtózó gazdag gyár-, bánya- és földtulajdonos Torres úrból, özvegy Sallerasné, a Torresek nagy gazdasági riválisa pedig, „az urak közt egyedül, nyíltan ellenezte az idegen meggyilkolását”. ${ }^{172}$

\footnotetext{
168 Uo.

169 AFV 49. o.

${ }^{170}$ AFV 52. 0.

${ }^{171}$ AFV 103. o.

${ }^{172}$ AFV 131. o.
} 
A Spanyolország történelmét tanulmányozó történészek felhívják a figyelmet a spanyol politikai élet két jellegzetességére, az erőszakra és a türelmetlenségre. ${ }^{173}$ Anderle Ádám azt emeli ki, hogy a spanyol politikai tradíció nem ismerte a demokratikus megoldási technikákat, és „természetesen” alkalmazza az erőszakos módszereket. García-González megállapítja, hogy a 19. századtól a tábornokok a pártok természetes vezetőinek tartják magukat, ami a politikai kultúra hiányával és a polgári hatalom gyengeségével magyarázható. ${ }^{174}$ Unamuno nagyon találó mondatát idézi Pierre Vilar: „Az önkényuralom a spanyol nép számára természetes rendszer, melyet fönt pronunciamentóval, lent pedig anarchiával mérsékelnek.”175 A regényben ábrázolt gyilkosság szintén ezt a türelmetlen, apró lépéseket, engedményeket, tárgyalásokat, kompromisszumokat nem ismerő erőszakpolitizálást mutatja be, nyelvezetében szinte klisészerü fordulatokat alkalmazva. Ezzel Moncada arra utal, hogy ezek valószínűleg gyakran hangoztatott, jól ismert érvek voltak. A korszakban általános Szovjet-Oroszország fenyegető képével való példálózás a két ország hasonló társadalmi szerkezetére alapozott. Mint Vilar írja, Lenin Spanyolországban látta a második forradalom országát, s 1917-től a diktatúráig a szovjet forradalom vagy mint követendő példa, vagy mint visszautasítandó veszély szerepelt a spanyolországi közvélekedésben. $^{176}$

A regény a sztrájkot 1925 -re teszi ${ }^{177}$, a diktatúra idejére, amikor a munkások „nem voltak hajlandók felvenni a munkát, amíg fel nem emelik a bérüket és nem biztosítanak jobb munkakörülményeket. Csatlakoztak hozzájuk a hajósok is. A vitorlások nem futottak ki: a kikötőben vesztegeltek üresen, vagy szénnel megrakottan, a tulajdonosok és a munkások tárgyalásainak eredményét várva, amelyekben azonban nem mutatkozott haladás.»178 A történelmi monográfia tanúsága szerint „ebben az időszakban nincsenek adatok semmiféle munkaügyi konfliktusról vagy sztrájkról a szénmedencében” ${ }^{179}$, erre azonban a regényben ábrázolt erőteljes jelenetek (munkabeszüntetés, a város két részre szakad, a gazdagok rettegése, követelések, harc a csendőrökkel), rácáfolnak. Moncada sztrájkok iránti

\footnotetext{
173 Anderle Ádám, Spanyolország története, Budapest, Móra Ferenc Kiadó, 1992. 120-121. o.

${ }^{174}$ García de Cortázar-González Vesga, i.m. 318. o.

175 Vilar, 71. o.

176 Uo. 86. o.

177 Ennek ellentmondó adat a MCSL Oncle Calafat, oncle Patriciet, tiet Vidallet, Manolo Jordi interjúk a sztrájkot 1923-ra teszik: a nép tüntetett, a polgármester, Xorrús pedig megkérte őket, hogy oszoljanak fel, mert a diktatúra közegében semmit sem érhetnek el, öt pedig kompromittálják. A tömeg feloszlott, de a sztrájk folytatódott, s akkor kivezényelték ellenük a csendőrosztagokat Faióból. A regényben ábrázolt motívumok arra utalnak, hogy valószínüleg ugyanarról a sztrájkról van szó, mint a regényben, vagy több sztrájk is volt, amelyeket az író egy eseménybe sürítve ábrázol.

178 AFV 103. 0.

${ }^{179}$ Estruga, J. (dir), 242. o.
} 
érdeklődését mutatja az egyik interjú átirata végén található jegyzet: „A háború utáni bányászsztrájkok kérdésének bővebb kidolgozása. Kit vertek meg a csendőrök?" 180 A konkrét kérdés arra utal, hogy a sztrájk ténye közismert volt. A jegyzet szövegében a posguerra szó található, tehát a kérdés a polgárháború utáni időszakra vonatkozik, de a Moncada által lejegyzett szóbeli emlékezet arról tanúskodik, hogy Mequinensának korábban is volt sztrájkhagyománya, s hogy a több családi emlékezetben - a regény szerint pedig a város egész plebejus emlékezetében - máig megőrződött politikai indokú gyilkosság valóban bekövetkezett. A regény egy két hónapig tartó sztrájk kontextusába helyezi az eseményt, ami szélesebb társadalmi-politikai megvilágításba helyezi, s a pistolerók korszakában bevett gyakorlattal rokonítja ${ }^{181}$, amikor a patronátus úgy próbálta elejét venni a további konfliktusoknak, hogy a felforgató eszmék képviselőit, terjesztőit meggyilkoltatta. A munkásosztály tömegeinek politikán kívül rekedése, és gazdasági problémáinak, munkaügyi követeléseinek megoldatlansága súlyos következményekkel járt az ország további sorsa szempontjából. Ez vezetett a pistolerók korszakán át a diktatúrához már 1923ban is, amikor a burzsoázia (föként a katalán) a tömegektől való félelmében támogatta Primo de Rivera tábornok katonai államcsínyét. Ugyanezek a politikában nem bízó, türelmetlenné vált tömegek robbantották ki a társadalmi forradalmat a II. Köztársaság idején. ${ }^{182}$ A regény szerint az 1925-ös követelések között béremelés és a jobb munkakörülmények kivívása szerepelt, s a sztrájk „két hónapnyi harc után összeomlott”. A mequinensai bányatulajdonos burzsoáziának ${ }^{183}$ csak egyetlen tagja ellenezte, hogy behívják a csendőröket, és a munkásvezető likvidálásával oldják meg a helyzetet, s ő volt az egyetlen, aki törödött a zavargásokban megsebesült bányászokkal, akikhez orvost hívatott, s az ellátásukat ő fizette. ${ }^{184} \mathrm{~A}$ tárgyalásokról is őriz egy jelenetet a regény, mely szintén kiválóan illusztrálja a demokratikus kultúra hiányát. Romaguera polgármester fia, a gyilkosság kitervelője, a Városháza előtti zürzavarban, „amikor a sztrájkolók képviselői megpróbáltak

\footnotetext{
${ }^{180}$ MCSL Entrevista amb Quico.

${ }^{181}$ Az Ateneu Enciclopèdic Popular munkás önmüvelö egyesület alapítóit, Francesc Layret ügyvéd-politikust 1920-ban, Salvador Seguí anarchoszindikalista vezetőt 1923-ban gyilkolták meg.

${ }^{182}$ Joan Fuster a nyelvvédő katalán burzsoázia politikai viselkedését a 20 . század elején úgy jellemzi, hogy az a forradalmi tendenciáktól való félelmében mindig a saját osztályérdekei mögé sorolta a nacionalizmus célkitüzéseit, melyek érdekében a saját katalán munkástömegeivel kellett volna összefogni. A Lliga politikusai minden alkalommal, 1909-ben, 1917-ben, 1923-ban és 1934-ben, a rabaissairék követelései idején is a központi hatalommal kötött szövetséget a munkásosztály ellenében. Fuster, Joan, Literatura catalana contemporània, Barcelona, Curial, 1988. 325. o. Ugyanezt a munkásoktól való félelmet hangsúlyozza Rafael Vidiella a PSUC (Partit Socialista Unificat de Catalunya) (1936-1997) magyarországi száműzetésben élt egyik vezetője. L. Roig, Montserrat, Rafael Vidiella, l'aventura de la revolució, Barcelona, Laia, 1974. 46. o.

${ }^{183}$ A szénmedence legfontosabb bányáit ábrázoló térképen 42 bánya szerepel. Marcuello Calvín, i.m., 244. o.

${ }^{184}$ AFV 118. o. A regény hálás ezért az attitüdért, de kiemeli, mennyire nem szokványos.
} 
bejutni, hogy tárgyalhassanak a polgármesternél összegyült urakkal, pofon ütötte az öt rendreutasító Arnau Terrert (a munkások vezetőjét). A város emlékeiben úgy élt az úrfi, amint a munkásvezetővel való összetüzést követően, a csendőrség védelméből gyalázza a „vörös csürhének” titulált tüntetőket.” 185 A Romaguera-típusú, tradicionális értékekhez ragaszkodó, régi nemesi földbirtokos réteg nem foglalkozott az iparból nyerhető javakkal, a közigazgatás gépezetében igyekezett elhelyezkedni, elzárkózott a fejlődéstől, de ragaszkodott a politikai hatalomhoz. Ennek sáncaiba nem volt hajlandó beengedni a feudális függésböl kiszakadt, társadalmi-politikai képviselet csatornáit kereső dolgozó tömeget, amelynek tagjait nem tartotta önmagához mérhetőnek, se a „törvény előtti egyenlőség”, sem pedig a keresztény „Isten előtt mindenki egyenlő” elv alapján. E politikai életet irányító kiváltságos réteg elvei addig voltak igazolhatók, amíg a dolgozók müveletlen, és politika iránt közönyös tömegek, s ezért vált a regénybeli Arnau likvidálandó ősellenséggé, mert „ő ültette el a munkások fejében a követelések jogosságának gondolatát, és ő szervezte meg az ellenállás pénztárát.”186

\section{2. Írás-olvasás, müveltség Mequinensában}

A mequinensai munkástársadalom müveltségi szintjére egy folyami hajózás történetét felölelő cikk, és a mequinensai öregekkel készített Moncada interjúk vetnek fényt, valamint az író visszaemlékezései családjára, ahol elmondja, hogy mindkét nagymamája analfabéta volt. A hajózásról szóló cikk leírja, hogy aki hajósnak készült, az gyerekkorában már a legénységben szolgált, iskolába se járt, s korán belecsöppent a nehéz férfimunkába. ${ }^{187}$ Mariano Sanjuán (sz. 1904) hajóskapitány Moncadának fogalmazott életrajzában azt írja, hogy 12 évesen kezdett dolgozni hajósinasként „,erős és durva emberek közt”, ${ }^{\text {,188 }}$, Raiet bácsi (sz. 1904), a hajóács pedig elárulja, 14 évesen vette át balesetet szenvedett édesapja mühelyének irányítását, ahol 12 ember dolgozott. ${ }^{189}$ A regény egyik főszereplője, Nelson (sz. 1900) tizennégy éves, mikor édesapja halála után hajósinas lesz. A születési dátumok mutatják, hogy a 20 század elején született nemzedéknek nemigen jutott ideje a tanulásra. Mequinensában létezett elemi iskola, itt végezte tanulmányait az 1878-as születésű María

\footnotetext{
185 AFV 139. o.

${ }^{186}$ AFV 106. o.

187 1992-11-15 Presència - El llagut o l'origen del camí de sirga, Jordi Gamero.

${ }^{188}$ MCSL Carta de Mariano Sanjuán Sagarra.

${ }^{189}$ MCSL Entrevista amb el vell Raiet.
} 
Quintana Ferragut ${ }^{190}$, aki a Primo de Rivera diktatúra idején fontos pozíciót töltött be az állami oktatásügyi hivatalban, s összeköttetései révén elérte, hogy 1927-ben példaértéküen szép és modern iskola épüljön a városban. ${ }^{191}$

A regény több helyen is utal a nép írástudatlanságára: „Jaume de Torres úr egyszerüen a meggazdagodás régi receptje szerint cselekedett, amikor pénzt kölcsönzött Nicanor feleségének, aki a három gyerekkel magára maradt, amikor a férje a polgárháború után meghalt Franciaországban, majd a felhalmozódott adósságok és kamatok fejében elvette tölük a házat. Hogyan szedte össze vagyonát a város gazdagjainak többsége? A rossz termés, a betegségek és az adósságokkal súlyosbított nyomor éveiben megjelentek a fortélyosan fogalmazott jogi iratok, amelyekre az írástudatlan nép csak egy keresztet rajzolt.” ${ }^{192}$ Az író tehát az analfabétizmust egyértelmüen a nyomor egyik okának és egyben következményének is tartja, s Arnau Terrer pozitív hős figurájában az olyan munkás önmüvelő egyesületek állít emléket, mint a korábban hivatkozott Ateneu Popular Barcelonès.

Moncada kutatásai próbálták kideríteni, hogy Mequinensában milyen újságokat olvastak az emberek, a családi levéltárban erről egy géppel írott összefoglaló tanúskodik, melyhez az író kézzel csatolt kiegészítéseket. ${ }^{193}$ Ebből az derül ki, hogy a sajtótermékek egy része Barcelonából érkezett a fabarai vasútállomásra vonattal: La Vanguardia, El Socialista, La Noche, és a sport hetilap, az As, valamint a La Estampa (1928-38), La Traca, L’Esquella de la Torratxa, és a Patufet. Külön jelöli, hogy nagy népszerűségnek örvendett a Solidaridad Obrera, az U.G.T. lapja, Madridból érkezett az $A B C$ - a megjegyzés szerint nagyon kevés példány -, a Blanco y Negro (1891-1939) és a Mundo Gràfico (1911-1938). Saragossából érkezett az El Heraldo de Aragón (1895-) - jelzés: jobboldali lap -, a La Voz de Aragón (1925-35) - jelzés: baloldali lap -, és az El Noticiero - jelzés: nagyon kevés. Lejegyzi még, hogy a lapok a kávéházakba és a boltokba érkeznek, az emberek e két helyen olvassák őket, s a boltosok csomagolóanyagként használják az aktualitását vesztett újságot. A Moncada életrajzból tudjuk, hogy az író édesapjának is boltja volt, s ebben a kiskereskedelmi egységben ismerkedett Moncada már gyerekkorában a külvilág híreivel, legendáival, mert a bolt emberek és információk találkahelye volt. Egyes sajtótermékek mellett feltüntettem a megjelenési periódust jelző évszámokat, ami alapján arra kell következtetnem, hogy

\footnotetext{
${ }^{190}$ Marcuello Calvín, 355-9. o.

${ }^{191}$ Estruga, J. (dir.), 254-5. o. Ez a tény megjelenik a regényben is, kiemelve az összeköttetések fontosságát: „rövid fellendülés, amelyet egy a városból Madridba elszármazott hölgynek a Primo de Rivera-féle diktatúra minisztereivel ápolt jó kapcsolatának köszönhettek. Ekkor épült a híd az Ebrón, az iskola épületegyüttese, és akkor húzták fel a kikötő mentén futó falat is.” AFV 125. o.

192 AFV 209. o.

193 MCSL Cròniques dels oficis föcím alatt Què llegeixen els mequinensans?
} 
Moncada adatai a polgárháború előtti évekre vonatkoznak. A Barcelonából és Valenciából érkező katalán nyelvű sajtótermékek ${ }^{194}$, s köztük a híres gyermekújság, a Patufet ${ }^{195}$, kiadása a katalán nyelv tiltásával egyértelmüen megszűnt a Franco-korszakban. Moncada jegyzetei arra utalnak, hogy ez a népnevelő célzatú, katalanista gyereklap a köztársasági időkben a Principátuson túlra is eljutott.

Ugyanakkor felmerült bennem, hogy egy regényterv vázlatát tartom a kezemben - a kontextus ezt nem erősíti, hiszen a lapok felsorolása helyi mesterségek szociografikus leírása között található -, mivel az általam ismert mequinensaiak mind azt hangsúlyozták, hogy nem tudtak írni-olvasni katalánul, amit Moncada életrajza is megerősít. Igaz, hogy a szatírikus hetilapok nyelvezete nem a magas irodalmi színvonalat képviseli, de ezeknek a lapoknak a szerzőgárdája a polgárháború előtti katalán irodalom legnagyobb alakjaiból állt, és főként a Patufet, nemzeti irodalmi alapozó célzattal készült. Ha tehát ezeket a lapokat olvasták, nehéz elképzelni, hogy ne maradt volna egyetlen példány sem a későbbi nemzedékekre, bár a diktatúra idején ezeket a szülők nyilván elrejtették. ${ }^{196}$ A mequinensaiak olvasási szokásairól és műveltségéről Moncadának első kézből származó információi voltak a háború utáni időszakra vonatkozóan, hiszen olvasni szerető fiatalemberként rara avis-nak számított a kultúraellenes Franco korszakban csakúgy, mint saját könyvtárral rendelkező kiskereskedő édesapja. Az író polgárháború előtti időszakra irányuló érdeklődését jelzi a következő jegyzet: „Feltételezem, hogy a városka különböző pártjainak is megvoltak a maguk lapjai. Erről információt kell keresni." ${ }^{197}$ A feljegyzések között talált felsorolásból az derül ki, hogy a polgárháború előtt a mequinensaiak többségében Barcelonából érkező újságokat olvastak, ami annak a tükrében is furcsa, hogy ma, a nyelvi tudatosodás és a Franjáért folyó „kulturális harc” idején a Mequinensában olvasott lapok (12 spanyol, 5 katalán sajtótermék) többségükben Madridból és Saragossából érkeznek, nem pedig Barcelonából

\footnotetext{
${ }^{194}$ A L’Esquella de la Torratxa 1872-1939 katalanista, republikánus és antiklerikális szatírikus hetilap volt, a katalán irodalmi élet fontos személyiségeivel a szerzőgárdájában („Tísner” Avellí Artís Gener, Pere Calders, Serafí Pitarra, Prudenci Bertrana, Santiago Rusiñol, Rovira i Virgili). A La Traca szintén egy szatírikus újság volt, melyet Valenciában adtak ki 1884-től spanyolul és valenciaiul, többszöri betiltásokkal, s újrakezdésekkel. Szerkesztöjét, Vicent Miquel Carcellert, a lap utolsó korszakának népfrontpolitikához hủ hangneme és harcos antiklerikalizmusa miatt, Valencia elfoglalása után Franco kivégeztette.

${ }^{195}$ Castellanos, Jordi, En Patufet, cent anys: la revista i el seu impacte, L'Abadia de Montserrat, 2004. L. Lexikon 13.

${ }^{196}$ Rosa María Moncada, az író húga azt állítja, hogy családi könyvtárukban csak spanyol nyelvü könyvek voltak, Andrés Coso, a történeti monográfia szerzője a Franco diktatúra idejéből a következö lapokra emlékszik: El Heraldo de Aragón, ami nekik járt, az ABC, az Amanecer, és a sportújságok: As, Marca, Zaragoza Deportiva, Barça, Lean, Dícen. Az általa ismert újságok közül egy sem volt katalán nyelvü, és mindegyik jobboldali volt.

${ }^{197}$ L. 193. lábjegyzet.
} 
és Lleidából. ${ }^{198}$ Ezen adatok alapján inkább azt valószínűsítem, hogy a jegyzetek egy regénytervhez készültek, s azt mutatják, milyen kutatómunkát végzett az író a korszak sajtójáról.

A mequinensaiakat a 20-as években írni-olvasni tanító Arnau Terrer fikcionális alakjának megformálása a kollektív emlékezetben megőrzött tényeken alapul, melyeket az író annyiban változtatott meg, hogy az asztúriai Blancóból barcelonai munkásvezért csinált, akit a sötétben a sztrájk zürzavarában osonó cselédlány a helybeliekétől markánsan eltérő kiejtéséből azonosít. Ezzel a korábban már vázolt regénybeli teret nem tágítja tovább, hanem Barcelonához kapcsolja a betü és a kultúra általi haladás eszméjét, s a politikai tudatosodás forrásául Katalóniát jelöli meg. A feljegyzések közt talált sajtótermékek listája is Barcelona felé mutat, méghozzá a katalanizmus jeles folyóiratai felé, bár a regényekben végül ezekből nem jelenik meg semmi. Moncada döntését feltehetően a saját életútján szerzett tapasztalatai, az általa, s a legtöbb franjai intellektuel által bejárt pálya befolyásolta.

\subsection{A bányászsztrájk irodalmi kronológiája}

A történeti irodalom Primo de Rivera diktatúrájának pozitív vonásaként emeli ki, hogy sikerült drasztikusan csökkenteni az első világháború következtében kialakult áremelkedések és áruhiány nyomán az országot 1917-től elborító sztrájkok számát. A forradalmi sztrájkok csúcsidőszakában, 1920-1921 között, a sztrájkokban résztvevők száma 240 000-re, a diktátor által teremtett társadalmi béke korszakában, 1926-ban, számuk alig 20 000-re tehető. ${ }^{199}$ A mequinensai bányászat összesített adatait tekintve azt látjuk, hogy 1919-ben alig csökkent a kitermelt rossz minőségű lignit mennyisége ${ }^{200}$, melyre a bizonytalan, háború utáni évek ipara még nagy mértékben támaszkodott. A kitermelés táblázatokban kimutatott mennyisége csak 1926-tól jelez folyamatos csökkenést. A sztrájkot regénybeli időzítése a diktatúra ritka sztrájkjai közé sorolja. Mint a visszaemlékező mequinensaiak tanúsítják, valóban létezett egy nem mequinensai munkásvezér, akit az urak a sztrájk felelőseként

\footnotetext{
${ }^{198}$ Mit olvasnak ma a mequinensaiak? Andrés Coso közlése alapján Madridból érkezik: ABC, la Razón, El Mundo, El País, Marca és AS (e két utóbbi sportújságok). Saragossából: El Heraldo de Aragon és Periódico de Aragón.Lleidából: La Mañana, el Segre (spanyol) és Segre (katalán). Barcelonából: Ara (katalán), La Vanguardia (spanyol), La Vanguardia (katalán); El Periódico (spanyol) el Periódico (katalán); L'Esport és Mundo Deportivo. A helytörténész szerint sokkal többen olvasnak spanyol nyelven, az arány szerinte $90 \%$ $10 \%$ a spanyol javára.

${ }^{199}$ García de Cortázar-González 391. o.

${ }^{200}$ Marcuello Calvín, 260-1. o.
} 
kezeltek, s eltettek láb alól. Ez egyrészt arra is utal, hogy Mequinensában dolgoztak még vendégmunkások, tehát a termelés nem csökkenhetett olyan drasztikusan, ahogyan Moncada a compiègne-i német-francia fegyverszüneti egyezmény következményét láttatja. „A város bányáiban kitermelt szén iránti kereslet, mely addig kielégíthetetlennek tünt, hirtelen megcsappant. A bányák kikötői egykettőre megteltek az ipar által visszautasított lignittel [...] Először a hamiskártyások szedték a sátorfájukat [...] Öket a vendégmunkások követték, akiket segédmunkásként alkalmaztak a bányákban. Egyre-másra zártak be a kávéházak és az üzletek.”201 A fikció eltúlozva emeli ki a mequinensai bányák e jellegzetes tulajdonságát, hogy háború idején megsokszorozódik a termelés, majd a virágzást óhatatlanul követi a válság, ami jelzi az európai konjunktúrától való erős függést, és a belső ipar gyengeségét. A kronológia nem pontos, de a felrajzolt ív jelzi a változás irányát, mint egy jó karikatúra, amely a jellegzetes vonás kiemelésével az alapmotívum ábrázolását fontosabb helyre sorolja, mint az anatómiai pontosságot. Egy öreg bányász, Moncada által feljegyzett summás összértékelése, hogy „a mequinensai bányák háborús bányák”202, adhatta az ötletet Moncadának, hogy városka fejlődésének pulzáló ritmusát ebbe a képletbe tömörítse. A regénybeli idő alakítása az író kompetenciájába tartozik, aki megteheti, hogy azt a kiemelés és a kinagyítás céljainak rendelje alá. A történelemben a kronológia megsértése főbenjáró véteknek számít, hiszen a történész okokat, motivációkat keres a természettudományos kauzalitás modelljei alapján, s ennek lényegi alkotóeleme az események egymás utánisága a mérhető időben. Az író, aki nem Kronosz zord uralma alatt alkot, más sebességre állíthatja ezt a folyton egyformán múló időt, s egy kimerevített pillanathoz kapcsolva ábrázolhat minden lényegi és fontos jelentést. A fikció igazságának értékéből ez nem von le semmit, hiszen az csakis akkor sérülne, ha a valóságreferenciának durván ellentmondó dolgokat állítana. A valóságról azonban ebben az esetben nem maradt fenn más adat, mint ami a regényíró által feldolgozott szájhagyomány közvetítésében jut tudomásunkra, Mequinensa bányászsztrájkjai kérdésében ez a regény az egyetlen forrásunk. A hagyatékban fennmaradt interjúk a diktatúra idején 1923-ban zajlott sztrájkról beszélnek, ezért úgy gondolom, hogy a valóságreferencia kritériumát a feldolgozás nem sérti.

\footnotetext{
${ }^{201}$ AFV 73. o.

${ }^{202}$ MCSL Entrevista amb l’oncle Joaquim del Patriciet bányász (1892-).
} 


\subsection{A társadalmi szakadék}

Moncada az első világháború okozta fellendülés és az 1925-ben kibontakozó sztrájk tükrében ábrázolt társadalmi különbségek rajzával egy fontos társadalomlélektani fordulópontot regisztrál. A történelem színpadán megjelenik egy új réteg, s az ókonzervatív gondolkodás, mely ennek az emancipálódási törekvéseit addig nem volt hajlandó figyelembe venni, most kénytelen lesz számolni vele. S nem csak az iparfejlődés teremtette munkástömegekkel, hanem a tudomány és a technika fejlődése nyomán épülő új világgal, mely alapjaiban kérdőjelezi meg az övét. ${ }^{203}$

A folyók városa szerzője, a nép írástudó fia a Romaguera-szerű szereplőket nem tudja szimpátiával láttatni, ideológiájukban semmiféle pozitív vonást nem villant fel. Ez arra utal, hogy óriási szakadék létezhetett e társadalmi réteg és a nép között, mely feltevést a regény több ponton is igazolja. A sztrájk leírásakor látjuk, amint a sztrájkolók egyik ellenőrzési pontján áthaladó autóban ül Carlota de Torres, akit csak az ablaküveg választ el a munkások kényelmetlenül rászegeződő tekintetétől, akikhez addig még sosem került fizikailag ennyire közel. „Mindig távoli, különös lényeknek tekintette őket. A látogatóba érkező, városi barátnőinek, akikkel együtt járt az apácák által vezetett bentlakásos iskolába, úgy mutogatta őket, mint valami ritka állatfajt.” ${ }^{204}$ „Az ő világa és a között a másik világ között mindig volt egy védőháló, és a valóság a háló túloldalán maradt." ${ }^{205}$ Moncada ezzel azt a modern gondolkodásban már nehezen elfogadható távolságot ábrázolja, amely a 20-as évek vidéki aragón társadalmában ember és ember között létezett ${ }^{206}$, s amelynek megváltozása a küszöbön állt. Az engedelmes és tudatlan tömeg arcot ölt, és megszólal. Európában a társadalmi-politikai helyzet mindenütt a robbanásig feszült az első világháború után, Spanyolországban is bizonytalanná vált a politikai helyzet, amit a nagy sztrájkhullámok jeleztek. Ekkorra „a bá-

\footnotetext{
${ }^{203}$ A régi típusú arisztokrácia letűnését más nagyszerủ regény is megörökíti a katalán irodalomban: Villalonga, Llorenç, Mallorcai udvarház, Budapest, Európa Kiadó, 1982. A szerző maga is az anakronikussá vált arisztokrácia képviselője, így az általa ábrázolt Toni gróf - Lampedusa Gattopardo-jának katalán-mallorcai változata - rokonszenves, felvilágosult voltaire-iánus figura. Villalonga úgy gondolkodik a „népről”, hogy azt a „leghelyesebb a kerítésen túlról szeretni” idézi Joan Fuster, Literatura catalana contemporània, 275. o.

204 AFV 104. 0.

205 AFV 105. 0.

${ }^{206}$ Ugyanezt a társadalomlélektani pillanatot tükrözi a magyar irodalomban Kosztolányi Édes Anna címủ regénye, melyben az urak, a cselédet nem emberként, hanem egy teljesen más értéken kezelik egy olyan korban, amikor az alsó társadalmi osztályok az ezredéves beidegződések miatt még alázatosak, betartják a régi formákat, de már lázadnak ellene. L. Moviszter doktor beszélgetését az úri társasággal „A piskótáról, az irgalomról és az egyenlöségröl” címü fejezetben.
} 
nyászok már nem névtelen árnyak voltak, hanem nagyon is eleven, fenyegető sokaság, amely nem átallotta eltorlaszolni Carlota de Torres kocsijának útját.”207

Moncada egy öreg istállómester szájába adja ennek a sokaságnak a gondolatait az emberi méltóságról és a társadalmi különbségekről. Az öreg közli Nelsonnal, hogy gazdája, özvegy Sallerasné utasítására, fel kell vennie a hajójára Francesc Romaguerát, aki 1931-ben, a köztársasági időszak kezdetén Madridba akar visszautazni a faiói vasútállomásról. Az ügyvéd csomagjait egy szolgalegény cipeli, és vigyázza az indulásig. „Mért nem használod ki az alkalmat és fojtod a folyóba, Nelson? [...] Intézd el a legénykét is, ezek a seggnyalók nem érdemelnek jobbat. A gazdájuk egyetlen pillantására vagy böffentésére képesek kerékbe törni magukat [...] Szerencsétlenek! Az úr egy évben egyszer odanyújtja nekik a cigarettatárcáját, hogy sodorjanak maguknak egyet, s ettől aztán egyből elfelejtik micsoda nyomorúságban élnek.” ${ }^{208}$ Moncada jegyzeteiben találtam egy önmagának írott figyelmeztetést: „Nem szabad elfeledkeznem a cselédekről, akik a házaknál dolgoztak. Szinte intézménynek számítottak.”209 Mequinensa társadalmában egészen a régi város lerombolásáig jelen volt ez a réteg, amely a szociálisan érzékeny író figyelmét bizonyára anakronizmusánál fogva ragadta meg. A modern nagyvárosban élő, művelt író számára ez a középkori alávetettség státuszát elfogadó réteg az elmaradottság és a feudális formák vidéki túlélésének példája. Moncada a munkásöntudat büszkeségével tekint erre a társadalmi csoportra, nem kiszolgáltatottságukon sajnálkozik, hanem a szolgalelküségüket kárhoztatja. A regény végigkíséri Carlota de Torres cselédlányának, Carmelának a sorsát is, aki a bátyját óvni igyekszik a sztrájkoktól, munkásszerveződésektől, mert úgy jobban fizetett állást kaphatna a bányában, s őszinte odaadással szolgálja gazdáját, annak a hetvenes évek elején bekövetkezett haláláig, mert meg sem fordul a fejében, hogy a dolgok ezer éves rendje megváltoztatható volna. A cselédség emellett a leggazdagabb városi pletyka, babona és legenda forrás, akikkel Carlota de Torres-nek gyermekkorában tilos beszélgetnie. Ö azonban szájtátva hallgatta a cselédek történeteit, például a Fürge nevű lisztszállító vitorlás katasztrófájáról és a kapitány hazajáró lelkéről szólót, s „,szerette volna tisztázni, vajon a bolygó lelkű kapitány megitta-e valaha az apja, Jaume de Torres úr kávéját vagy likőrjét" is. ${ }^{210}$ Moncada ebben a jelenetben is kiválóan érzékelteti a társadalmi osztályok közti áthatolhatatlan távolságot, s annak a cselédség általi rendületlen tiszteletben tartását, hiszen a cselédlány válasza a következő: „Már megbocsásson kisasz-

\footnotetext{
${ }^{207}$ AFV 105. o.

${ }^{208}$ AFV 136. 0.

${ }^{209}$ MCSL Cròniques dels oficis/Notes.

${ }^{210}$ AFV 25. o.
} 
szony, de elment az esze? Hogy juthat egyáltalán eszébe [...], hogy egy szegény ember, legyen bár olyan kitünő kormányos, mint Ibars, akár haló poraiban is odáig merészkedjék, hogy betegye a lábát a Kormánykerék Kaszinóba, az urak kávéházába?” 211

\subsection{A kaszinó}

A kávéház 114-szer, a kaszinó pedig 33-szor jelenik meg a regényben, s a főszereplők, a pozitív emberi, erkölcsi példát adó figurák a Móló Kávéház törzsközönségéhez tartoznak. A kaszinóba csak a város urai járhattak, a tagságra nemesi cím, vagyon, vagy műveltségi cenzus jogosított. A regény az ezekhez a közösségi terekhez tartozó társadalmi konvenciók bemutatásával jellemzi a kisváros rétegződését.

Az író alteregójának, a patikusnak, miután elvégezte tanulmányait és 1945-ben visszatér Mequinensába „a Kormánykerék Kaszinó asztaltársaságához illett volna csatlakoznia, egyrészt társadalmi rangjánál, másrészt újdonsült, diplomás gyógyszerészi titulusánál fogva.”212 Ő azonban apjától örökölt szabadelvűsége miatt inkább a Móló Kávéházat választotta. „A fötörzset azonnal befogadta a Kormánykerék Kaszinó, ahol a bányászok egyre szervezettebb és erőteljesebb követeléseitől nyugtalan úri közönség az ő egyenruhás, bajszos, pökhendi alakjában látta a rend védelmének biztosítékát.”213

A regény, ugyanúgy, mint a helytörténeti monográfia, ${ }^{214}$ a Primo de Rivera diktatúra időszakához köti a csendőrőrs létesítését a városban. De míg az utóbbi a modernizáció folyamatának részeként mutatja be, a regény ironizáló hangneme egyértelmüvé teszi, hogy a városka az elnyomás eszközeinek modernizálását látta benne: „már nem is kellett a városból kérni a csapatokat, mert a nagy sztrájk óta helyben is jól felszerelt, állandó csendőrőrs létesült.”215 Moncada egy nagyon hatásos képben írja le a csendőrőrs városba költözését, melynek alaptörténete szerepel a hagyaték jegyzetei között: „El nem tudod képzelni, milyen hatással volt rám, hogy megint ott látom őket: apácák, papok és csendőrök együtt az utcán. Mintha nem evilági látomás lett volna, egy déjà $v u$, ami most megismétlődik: rémisztő volt.”216 Moncada jelképes értelmet tulajdonított a visszaemlékezésnek, s hatására egy kiváló, festői jelenetet komponált, mely az apácák távozásával együtt ábrázolja a csendőrök az-

\footnotetext{
${ }^{211}$ Uo.

${ }^{212}$ AFV 238. o.

213 AFV 130. o.

${ }^{214}$ Estruga, J. (dir.), 244-258. o.

${ }^{215}$ AFV 129. 0.

${ }^{216}$ MCSL Cròniques dels oficis/Notes.
} 
zal párhuzamosan zajló megérkezését: „A két dolog egybeesését senki sem tekintette véletlennek [...] aprólékosan tárgyalták a váltás szimbolikájának értelmét: csuha helyett egyenruha, kereszt helyett fegyverek, apácafátyol helyett háromszögkalap, vajon mit jelenthet mindez?”217 A regény nyelvén az idejétmúlt rendszer két alappilérét, az Egyházat és a Hadsereget.

Természetesen Mequinensa plébánosa is a Kormánykerék Kaszinó németbarát közegében issza konyakját, s a kaszinó törzsközönségéhez tartozott a II. Köztársaság kikiáltásával leváltott korábbi polgármester, Sadurní Romaguera is, aki „állandó szópárbajt folytatott a város fiatalabbik orvosával meg a többi republikánus érzelmü taggal, akik végül ki is koptak az urak törzshelyéről.” ${ }^{218}$ A regény terében a kaszinó-kávéház szembeállítása mutatja a társadalom végzetes polarizáltságát, a mérsékelt vagy jobboldali köztársasági opció kivitelezhetetlenségét, a szélsőségek felerősödését, mely végül a polgárháborúhoz vezetett.

A Kormánykerék Kaszinó tagja volt von Müller úr is, aki „a Romaguerák közvetítésével nagy birtokot vásárolt az Ebro partján. Az idegen nagy teljesítményü rádióadót és meteorológiai megfigyelőállomást állított fel a földjén." ${ }^{219}$ A Móló Kávéházban ezt a figurát az „undorító náci” jelzővel illetik. A vízerőmüvekkel kapcsolatos fejezetben láttuk, hogy a flix-i vegyikombinát német érdekeltségbe tartozott, ez valószínüsíti, hogy a terület ismert, vagy kívánatos célpont lehetett német befektetők számára. A rádióadó és a megfigyelőállomás telepítése viszont azt jelzi, hogy a közelgő II. világháború stratégiai érdekei is szerepet játszhattak a terület iránti német érdeklődésben.

A kaszinó tehát a konzervatív és németbarát gondolkodás híveit gyüjtötte egybe. Tagjai a városi arisztokrácia és a vidéki társadalom egyházi és rendfenntartói közegének képviselői közül kerültek ki. A regény jelzi, hogy ez a közeg a köztársasági és liberális gondolkodás mérsékelt formáit még a nemesektől és a diplomásoktól sem tolerálta.

A folyók városában megjelenő úri társadalom igen sokszínű, de tagjait az író mindvégig kíméletlen gúnnyal és ironikus távolságtartással ábrázolja. Az első világháború például hatalmas fellendülést okozott a mequinensai lignitbányászatnak, s ennek haszonélvezőit elsősorban a kaszinó törzstagjai között kell keresnünk. „Alighogy elkezdődött az öldöklés, Barcelonából máris folyamatosan érkeztek a szénrendelések [...] lignithegyekkel kellett táplálni az ipart, amelynek a háború hihetetlen lendületet adott [...] (a) bányák teljes gőzzel kezdtek dolgozni [...] másutt pedig újakat nyitottak [...] Munkáskéz kellett a bányákba, a folyóra,

\footnotetext{
217 AFV 151. 0.

${ }^{218}$ AFV 140. 0.

${ }^{219}$ AFV 140. 0.
} 
mindenüvé. Idegenek özöne jött munkát keresni [...].”220 Moncada ezt a sémát kétszer írja le a regényben, az első, majd a második világháború idején, amikor ismét mutatkoztak „a jól ismert történet forgatókönyvének jelei”, virágzó időszakot teremtve a helyi, rossz minőségü lignitet termelő bányák számára. A Kormánykerék Kaszinó ,gondterhelt hadvezérei” az első világháború idején azon töprengenek, vajon hogyan lehetne örökre fenntartani ezt a számukra oly nagy hasznot jelentő nemzetközi konfliktust. A mélyen hívő Adelina de Camps aszszony az ügy érdekében, „minden délután letérdepelt magántulajdonú imazsámolyára [...] és ájtatosan imádkozott a vérfürdő folytatásáért.”221 Moncada nem kíméli a „szent aszszonyt”, akinek a templomból való elmaradásán a plébános sokat szomorkodik a háború után. Ez a motívum a hamis ájtatosság jelzésén túl kiemeli az egyház, és az általa visszahódított liberális burzsoázia szövetségét is, akik harcostársakká lettek az egyre fenyegetőbb munkásmozgalmi szerveződések és követelések árnyékában. Az egyház megbocsájtja a polgárságnak javai kisajátítását, és mint a történész fogalmaz „megáldja a gazdagságát”222, s válik így a liberális kapitalizmus hathatós ideológiai támaszává, s a társadalmi különbségek szentesítőjévé.

A mequinensai vagyonos réteg gazdagságának forrásairól is sok információt találunk a regényben. Az egyik, az írástudatlanság kontextusában már említett „fortélyosan fogalmazott jogi iratok” módszere, valójában azt jelentette, hogy a nem létező bankrendszer helyett város gazdagjai töltötték be a bankárok szerepét, uzsorakölcsönöket adtak, s mások nyomorát vagy felelőtlenségét kihasználva gyarapították vagyonukat. A regény elején több oldalon át dicsekvő Jaume de Torres úr gőgös monológjából megtudhatjuk, hogy a családi vagyon alapját a bányák, a hajók és az édesgyökérkivonat gyár adja, s a többi vagyonos ábrázolásánál is ugyanezt a képletet találjuk a földeken és az ingatlanvagyonon túl. A város két édesgyökérkivonat gyára ${ }^{223}$ közül Moncada csak az egyiket, a város leggazdagabb családjának (Justribó-Fornos) kezében levőt ábrázolja a regényben, mint a főszereplő Torres i Camps családét ${ }^{224}$, a másikat, amelyik mentora és jóbarátja, Edmon Vallès családjának

\footnotetext{
${ }^{220}$ AFV 48. o.

${ }^{221}$ AFV 65. o.

${ }^{222}$ García de Cortázar-González Vesga 378-9. o.

${ }^{223}$ Marcuello Calvín, 164. o. L. Mellékletek. Képek, térképek, 8. Édesgyökérkivonat-gyár.

${ }^{224} \mathrm{Az}$ adatok történeti hüségével kapcsolatos anekdota, hogy amikor meghalt az a gazdag hölgy, akiröl az író Carlota de Torres figuráját mintázta, az írónak többen kondoleáltak a temetésén, mintha ő is közeli hozzátartozóját veszítette volna el. A Justribó-Fornos család Andrés Coso állítása szerint pert is akart indítani az író ellen, mert Carlotát házasságtörőnek ábrázolta, ami a mélyen vallásos családra nézve óriási sértést jelentett. Moncada természetesen nem élő embereket ábrázolt, hanem sok különféle figurából gyúrta össze alakjait, a kisvárosi gondolkodás logikája azonban óhatatlanul konkrét személyeknek akarta megfeleltetni őket. Edmon Vallès figurája Aleix de Segarra bohém alakjában köszön vissza.
} 
(Vallès-Perdrix) tulajdonában volt, azt nem. A 60-70 asszonyt foglalkoztató édesgyökérkivonat-gyárakat egyetlen gyár képébe sürítve rajzolja meg, mint a patriarchális kisüzemek mintapéldáját, mely a kisváros helyi iparát már a 19. század végén is jellemezte.

A kaszinó tagjai voltak az elszegényedett urak is, akik a regény tanúsága alapján sokkal többen voltak, mint a sikeres vállalkozásokba fektető, gazdagságukat gyarapítani képes családok leszármazottai. Moncada ezt a réteget is gúnnyal és idegenkedéssel ábrázolja, s több novellában is megörökíti a rájuk jellemző „ősi nemesi vonást”: „Hogy munka nélkül megélhessenek, előbb-utóbb elkótyavetyélték a birtokaikat, s hagyták, hogy lassacskán mindenükből kiforgassák őket. Néhányan beköltöztek a városba, eltékozolták, amijük még volt, majd üres zsebbel tértek vissza.” ${ }^{225}$ Moncada nem becsüli az általuk választott életmódot: „Belőlük lett aztán a sok kaszinótöltelék, savanyú hárpia és gyertyafaló szentfazék.”226 A regény az ő esetükben az író egyik nagyapjára, a matrackészítőre is támaszkodik, mint különleges információforrásra, ugyanis „amikor már nem maradt se festmény, se bútor, se régi faszobor, se fegyver, amit a régiségkereskedőkhöz [...] vihettek volna, akkor a büszke úri nép (titokban) túladott a derékalj gyapjúján.” ${ }^{227}$ A társadalmi rang a nemesi címmel ugyanakkor megmarad, s vele együtt a kaszinótagság, valamint a gazdagok lakomáin való részvétel joga. Moncada pecsétes ingmellben, molyrágta cilinderben és krónikus éhséggel ábrázolja az elszegényedett, munkát nem vállaló, ám régi, pazarló életmódját fenntartani kívánó nemeseket, akik közül Aitona bárójának nagy gondot okozott a rágás, mert egy „dörzsölt” fogorvos addig nem volt hajlandó pótolni hiányzó őrlőfogait, amíg felhalmozódott tartozásait ki nem egyenlíti.

Amikor 1970-től a városka házait kiürítik, majd lerombolják, sok díszes palotáról kiderül, hogy a termeiben rejtőző feltételezett gazdagságból nem maradt semmi. Sàssola báró utolsó vagyontárgya, egy csodálatos velencei tükör kapcsán fény derül a titokra, hogy honnan származott az egykori gazdagság, a tükör ugyanis ott volt a szobában, amikor a báró a plébános jelenlétében haldoklott, s megőrizte az agónia képét. „Az arisztokrata szenvedéseit nem enyhítette a vérfagyasztó gyónás után kapott feloldozás [...] A tükörből homályos alakok léptek elő, rettentő büzt árasztva [...] azok a rémült rabszolgák, akiket kíméletlenül az Atlanti-óceánba löktek, amikor járvány tört ki a hajófenékben összezsúfolt feketék közt. Megjöttek, hogy jelen legyenek az egykori rabszolgakereskedő távozásánál, akinek a gazdagsága emberkereskedelemből származott, nem pedig dohány- és cukornádültetvényekből,

\footnotetext{
${ }^{225}$ AFV 19. o.

${ }^{226}$ Uo.

${ }^{227}$ AFV 20. o.
} 
ahogy mindig is állította.”228 Innen származott a nemesi cím is, melyet IV. Károly ajándékozott a Sàssolának, aki hatalmas vagyonra, s egy elszegényedett barcelonai arisztokrata feleségre tett szert. A plébános csak annyit mond: „Példás keresztényként halt meg”, amivel nem hazudott, hiszen a báró formálisan teljesítette gyónási kötelezettségét. Nem kevésbé dicstelen, bár erkölcsileg kétségtelenül magasabb rendü a Camps dinasztia alapítójának története, aki cipész volt, „és azzal csinálta meg a szerencséjét, hogy teherbe ejtette egy franciabarát dúsgazdag özvegyét, aki a Napóleon ellen vívott háború után védelemre szorult.”229 Ezekből a példákból látjuk, hogy Moncada nem kíméli a Kormánykerék Kaszinó törzsközönségét, akiket a pénz, a hatalom és a jó erkölcsök máza mögötti romlottság jellemez, s „dicső” múltjukat is megkérdőjelezi. Az ősök arcképcsarnoka, mely a nemesi otthonok kötelező tartozékaként megjeleníti a hatalom és gazdagság folytonosságát, s ezáltal jogosságát, szintén gúny tárgyává válik, melyből hiányzik a valódi nagyság: „mogorva férfiak, bamba gyermekek és füzőbe gyömöszölt dámák rémisztő kísértethada sorakozott a szinte már felismerhetetlenségig elsötétedett festményeken.” A vagyonok eredetének és felhalmozásának erkölcsileg igen megkérdőjelezhető volta, és a nemesi státuszszimbólum, mely az ellenkezőjét igyekszik bizonyítani a fennálló társadalmi különbségek igazolására, egyértelmüen mutatja, mennyire idejétmúlt és képmutató értékrendnek tartja ezt az író.

\subsection{A Kávéház $z^{230}$}

A mequinensai úri társadalom gyüjtőhelyének plebejus párja a Móló Kávéház. Moncada maga is ehhez hasonló kávéházakban gyüjtötte történeteit, ahol a regény pozitív hőseinek törzshelye található. A helyi társadalom különböző rétegei a kisváros hírfórumának tartott kávéházi törzsközönségekhez tartozás alapján alkottak csoportokat, amelyeket az író az 1950-ben elhunyt Jaume de Torres úr temetési menetéhez való csatlakozásuk közben mutat

\footnotetext{
${ }^{228}$ A katalán kereskedők részvétele a rabszolga-kereskedelemben a kevéssé tárgyalt témák közé tartozik, nem a katalán történelem fényes lapjai közé. Regénybeli megjelenítése: Jordi Tomas író, antropológus nevéhez füződik: El mar dels traïdors, Barcelona, Proa, 2013. A katalán vállalkozások viszonylag későn indultak, mivel az Amerikával való közvetlen kereskedést csak III. Károly engedélyezte számukra, 1778-ban. Ezt követően sokan vettek részt az Újvilággal való kereskedésben, és Katalónia iparosodásának pénzügyi forrásait is sok esetben szolgáltatta rabszolga kereskedelemből származó vagyon. http://www.vilaweb.cat/ noticia/4096073/20130317/trafic-desclaus-vaixells-catalans-aventura-literaria.html, letöltés 2017. júl. 15.

${ }^{229}$ AFV 277. o. A franciabarát figura szerepeltetése egy másik történelmi mítosz egységén üt sebet, miszerint a „nemeslelkü aragónok” (L. II. fejezet/Mequinensa száz éve) egy emberként harcoltak a betolakodó ellen. A francia érzelmüek a felvilágosodás és a racionalizmus eszméinek a hatalom gyakorlatába való átplántálását várták az új monarchiától, ám a francia érdekeknek jobban megfelelt volna az annektált területek félgyarmati kizsákmányolása. A katalán történelemben visszatérő motívumként jelentkezett a spanyol abszolutista centralizmusból a francia függésbe menekülés (Pau Claris 1640, I. világháború katalán önkéntesek).

${ }^{230}$ L. Mellékletek. Képek, térképek, 9. Kávéház
} 
be: „A férfiak sokaságában a város minden társadalmi rétege képviseltette magát, kivéve az urakat, akik a gyászoló családdal tartottak. A Móló Kávéház, az Evezős Taverna és a Békához címzett Kávéház elsősorban bányászokat, hajósokat és mesterembereket delegált, a parasztok legnagyobbrészt a Földmüves Kávézó vendégei közül kerültek ki, míg az iparban, a közigazgatásban és a kereskedelemben dolgozók a Kastély Bár, más néven a Föníciaiak Tanyája csoportját alkották. A fiatalok társadalmi hovatartozásuktól függetlenül a Sport Kávézóból érkeztek, a nyugdíjasok zöme pedig Benjamí kocsmájának küszöbén álldogálva várta, hogy odaérjen a menet.”231 Mesteri tablókép az 50-es évek Spanyolországának egy vidéki, kisvárosi szegletéről, mely kompozícióba rendezve mutatja be a békeidők szakmai csoportjai által formált kávéházi közösségeket, s a temetés mindenki számára kötelező jellegét.

A nemesi emlékezet a felmenők vonala mentén több századot is vissza tud menni az időben, a köznép sorsát, történeteit azonban nem őrzik sem családi levéltárak, sem pedig ágasbogas családfák vagy festmények sora. Moncada a mequinensai hajós, bányász, mesterember sorsok sémáját egyetlen kerek történetben sommázza a regény elején, az első ház lerombolásakor (1970) eltemetett Pasqual Serafí sorsában, aki „említésre méltó események tekintetében igen szegényes életet élt. Korosztályának legtöbb tagjához hasonlóan viszonylag fiatalon bányász lett, megnősült, gyermekei születtek, harcolt a háborúban (a köztársaságiak oldalán), és a vereség után visszatért a városba, hogy tovább bányássza a lignitet egészen a nyugdíjazásáig, három évvel és hat nappal azelőtt, hogy megállt a szíve.”232 Ez a mondat jól érzékelteti a hagyományos társadalomban a mequinensai fiatalok előtt nyíló lehetőségek szük körét, a történelem által megszabott sorsok kiszolgáltatottságát és hasonlóságát. Ennek a társadalmi rétegnek az életében az említésre méltó események a háborúk, felkelések, sztrájkok, melyek emlékét és történeteit őrzik és továbbadják.

A regényben megjelenő legkorábbi csata a Marokkó földjén a spanyol befolyás megerősítéséért vívott tetuáni csata, melyet II. Izabella királynő csapatai vívtak IV. Mohamed marokkói szultán csapatai ellen. Az 1496-tól spanyol birtokban levő Melilla és az 1580-ban a portugáloktól megszerzett Ceuta jelentős spanyol telepes lakossággal rendelkezett. Ezek hátországának biztosítására a spanyolok igyekeztek befolyási övezetükbe vonni a környező területeket az Algéria felől több befolyásra törő franciákkal és a helyi berber törzsekkel szemben. E törekvés jegyében O'Donnell tábornok 1860 februárjában megszállta Tetuánt, fogalmaz a történész. ${ }^{233}$ A Prim tábornok katalán „önkéntesei” között harcoló, az 1840-es

\footnotetext{
${ }^{231}$ AFV 229-230. o.

${ }^{232}$ AFV 29. o.

${ }^{233}$ Harsányi Iván, Spanyol dilemmák-spanyol megoldások a 19-20. század útvesztőjében, Budapest, Pannónia
} 
születésű mequinensai, Arquimedes Quintana újra meg újra elmeséli a csata történetét a Móló Kávéház törzsközönségének. Ő másképp fogalmaz: „Undorító vérfürdő volt az egész.”234 $\mathrm{S}$ az ellenséggel kapcsolatban még azt is hangoztatja, hogy „Az a szerencsétlen legalább a sajátját védte, bennünket meg azért küldtek oda, hogy megvédjük az olyan emberek pénzeszsákját, mint a Campsok, a Salleresek, a Romaguerák meg a Torresek.”235 Az ágyútöltelék szerepét betöltő katonák szemében nem csillognak „hazafias könnyek”, s nem mondanak lángoló beszédeket, mint a városi elöljárók, az „Afrika rabigában sínylődő, ellenséges földjére” ${ }^{236}$ induló katonák búcsúztatóján. Harsányi Iván: A spanyol nemzettudat és Marokkó című cikkében szintén kiemeli a birodalmi és patrióta retorikát, mely igazolni hivatott a marokkói területekért folytatott harcokat. A kubai flottakatasztrófa után ez volt az utolsó terület, ahol Spanyolország a birodalmi nagyság álmait kergethette. E törekvések mögött azonban a marokkói érdekeltségű befektetők és szállítók, valamint a katonai kaszt érdekei álltak. ${ }^{237}$ Moncada is leszámol a hazáért halt dicső halál hősi mítoszával, amikor Arquimedes elmeséli, hogyan szállították a sebesülése után egy hordágyon egy levágott fejjel együtt, amelynek vonásaiban felismerte földijét, Camps tábornokot, akinek a teste soha nem is kerül elö.

A tetuáni csata történetének elbeszélése kiemeli a katalán önkéntesek szerepét, és megörökíti Prim tábornok, a reusi hadfi alakját. Prim tábornok fontos szereplője a spanyol történelemnek, hiszen ő az, aki Serrano tábornokkal és Topete admirálissal együtt a Dicsőséges forradalom (1868) egyik vezéralakja. II. Izabella Franciaországba menekülése után Serrano tábornok, a régens őt nevezte ki a spanyol kormány élére. Személyében ezt a pozíciót először töltötte be egy katalán. Ezt a tényt erősen hangsúlyozza Katalónia történetírója Ferran Soldevila, akit Amadeo király jelölése és lemondása kapcsán jobban foglalkoztat Prim szerepe, mint a királyé. ${ }^{238}$ A tábornok személye - tehetséges katona, okos diplomata, katalán patrióta, meggyőződéses liberális, spanyol egységben és alkotmányos monarchiában gondolkodó becsületes, egyenes politikus - példakép a spanyol haladó gondolkodás számára, Katalóniában pedig a nemzeti erények megtestesítője. Halálának körülményeit

\footnotetext{
könyvek, 2006, 26. o.

${ }^{234}$ AFV 36. o.

${ }^{235} \mathrm{Uo}$

${ }^{236}$ AFV 33. o.

${ }^{237}$ Harsányi Iván, Spanyol dilemmák, 21-41. o.

238 Soldevila, Ferran, Síntesis de historia de Cataluña, Barcelona Destino, 1978 282-292. o. Érdekes megfigyelni a motívumot, amely a katalán harci erényeket dicsőíti, hiszen Spanyolországon belül harci erényeket inkább a kasztíliai nép képzetéhez szokás kötni. Ebben a katalán történelmet a spanyollal homologálni kívánó törekvést vélek felfedezni. http://www.ccma.cat/tv3/alacarta/Sense-ficcio/Prim-anatomiadun-general/video/5325273/, letöltés 2015. máj. 10. L. Joan Prim melléklet Lexikon 14.
} 
máig vizsgálják. ${ }^{239}$ A regény kiemeli a tábornok alakját, mert a marokkói veterán elbeszélése nyomán megelevenedő tetuáni csata a kávéház legendáriumához tartozik, s a törzstagok az egyik márványasztal lapjának repedését a liberális ideált képviselő tábornok kardcsapásának tulajdonítják. ${ }^{240}$

Marokkó még egyszer feltünik a regényben a Tragikus Hét 1909 júliusi eseményeivel kapcsolatban. A mequinensaiak, „Barcelona szellemiségétől áthatva megakadályozták, hogy bevonultassák a városból frissen besorozott három legényt, akiknek a spanyol érdekeket kellett volna védeni Marokkóban, a Rif környéki bányáknál.”241 A történészek a Tragikus Hét eseményei kapcsán kiemelik, hogy a politikai döntéshozásból kizárt tömeg felháborodását és a spontán szerveződő tömegtüntetéseket az váltotta ki, hogy a kormány az 1903 óta tartalékos állományba helyezett korosztályokat hívta be, a madridi és a barcelonai körzetböl. Közülük sokan, fóként a barcelonai körzethez tartozó valenciai, aragóniai és katalóniai tartalékosai családos emberek voltak, így a döntés éhezésre, nyomorra ítélte ezeket a munkáscsaládokat. A sztrájkok, összecsapások, templomégetések és dúlások júliusi eseményeit ezeknek a tartalékosoknak a családtagjai indították el azzal, hogy megpróbálták megakadályozni a behajózást. A Tragikus Hét a társadalmi igazságtalanságok nyomán kirobbanó tömegmozgalmak emblematikus eseménye, amikor a nép irracionális dühe a hatalommal összefonódott egyház ellen fordul a társadalmi átalakulásra váró Spanyolországban.

A Maura kormány példás megtorlással válaszolt az eseményekre, és az ügyben tizenhét halálos ítéletet hoztak, melyek áldozatai közt ott találjuk Ferrer i Guàrdiát ${ }^{242}$, a nagy nemzetközi tekintélynek örvendő barcelonai anarchista pedagógust, akinek ítélete ellen Európa szerte nagy tömegtüntetéseken tiltakoztak a munkások. Moncada a regényben kiemeli, hogy ez a nemzetközi felháborodás vezetett a Maura kormány bukásához, s a regény mequinensai vádlottait (a legszimpatikusabb szereplők köréből) is ezért bocsátják végül szabadon. ${ }^{243}$

A Mequinensa történetét feldolgozó monográfiák nem említik a barcelonaihoz hasonló tiltakozás tényét, melyet hivatalos iratok sem támasztanak alá, s nem találtam ide vonatkozó

\footnotetext{
${ }^{239}$ Cònsul, Arnau, El general Prim, előszó: „L’Enigmàtica mort del general Prim”, Núvol, 2014. április 23. https://www.nuvol.com/noticies/lenigmatica-mort-del-general-prim/, letöltés 2017. szept. 18. http://www.ara.cat/media/TVE-sendinsa-lassassinat-general-Prim _0 1267073296.html, letöltés 2017. szept. 18. Pérez Abellán, Francisco, kriminológus Matar a Prim című könyvét ismerteti 2014 február 19 http://www.ccma.cat/tv3/alacarta/els-matins/com-va-morir-el-general-prim/video/4911252/, letöltés 2017. szept. 18.

240 AFV 34. 0.

${ }^{241}$ AFV 37. 0.

${ }^{242}$ Ferrer i Guàrdiának az egyszerü emberek iskoláztatása érdekében tett erőfeszítéseit ma is nagyra becsülik http://www.ferrerguardia.org/, letöltés 2017. szept. 16. L. melléklet Lexikon 15. http://uhu.es/cine.educacion/ figuraspedagogia/0 ferrerguardia.htm, letöltés 2017. szept. 16.

${ }^{243}$ AFV 38. 0.
} 
utalást a családi levéltárban és az interjúkban sem. Figyelmet érdemel azonban az a jelenet, amely leírja, hogyan fogadják a mequinensai asszonyok a csendőrökkel megrakott vitorlást, mely a zendülés, és tömeggyülés résztvevőinek megbüntetésére érkezik Mequinensába: éljenzik őket, így próbálják meglágyítani a szívüket. ${ }^{244}$ A meglepődött csendőrosztag azonban végzi munkáját, és két vitorlás hagyja el a várost foglyokkal telezsúfolva. A mequinensai nők lélekjelenlétéről és bátorságáról több történet is tanúskodik (anarchisták elleni fellépés, és az épülő víztározó falánál észlelt szivárgások elleni tüntetés csak nők és gyerekek részvételével). A Tragikus Hét egyik jellegzetessége is az volt, hogy a mozgósításban főszerepet játszottak az asszonyok és a gyermekek, s az elrendelt hadiállapot során a kirendelt katonák sok esetben nők és gyermekek ellen vívták csatájukat. ${ }^{245}$ Moncada talán ezen analógia alapján rajzolta meg a baljós történelmi eseményt, mely elörevetítette a polgárháborús idők tragédiáját: szocialisták, anarchisták, katalán köztársaságpártiak egyetértettek abban, hogy tiltakozni kell a háborús besorozások ellen, de az eseményeket végül nem irányította senki, s a tömeg dühe a szokásos forgatókönyv szerint a háborút támogató egyház ellen fordult. ${ }^{246}$ A Tragikus Héten 61 kolostort, templomot és egyházi iskolát égettek fel, köztük a Sagrada Família Gaudí által tervezett és addigra már megépített iskoláit. A megtorlás kemény volt és könyörtelen, a rendet helyreállították, a problémát nem orvosolták, s az 1909-es barcelonai események mélyen beleírták magukat a katalán történelembe, irodalomba, müvészetbe. ${ }^{247}$

Hilari Raguer egyháztörténész az egyház polgárháborús szerepvállalásáról írott könyvében azt állítja, hogy a La Veu de Catalunyában 1909 decemberében az eseményekkel kapcsolatban megjelent Joan Maragall cikk ${ }^{248} 30$ évvel később ugyanolyan aktuális volt, mint a Tragikus Hét után. Ebben a cikkben a költő, Gaudí jó barátja egy lerombolt, megszentségtelenített, felégetett templomban tartott misét ír le, s azt mondja, ilyen misén még sosem vett részt, vagyis talán még sosem vett részt igazi misén. Elképzeli, hogy a pap behívja az utcán járókat, hiszen már nincs kapu, ami bezárja a misét a védett falak közé, mert a felkelők kitépték a helyéből, mikor lerombolták a templomot, ami nekik épült, a szegényeknek, elnyomottaknak, remény nélkül maradottaknak. Maragall úgy érzi, az üldözöttségben mutat-

\footnotetext{
${ }^{244}$ AFV 37. o.

${ }^{245}$ Alcoberro, A. i.m., 170. o.

${ }^{246}$ Rafael Vidiella a nők tüntetésének nevezi az 1909-es eseményeket, s a tömeg templomok ellen fordult dühét nem vallásellenességgel magyarázza, hanem azzal, hogy a nép az egyház társadalomban elfoglalt helye miatt támadt a templomokra. Mint mondja, ma már (1970-es évek) nem fordulna ellene, mert ma a papok már a munkások pártját fogják. Roig, Montserrat, Rafael Vidiella, 34. o.

247 Az eseményeket a La ciutat cremada, az 1976-ban parádés szereposztással készült (Joan Manuel Serrat, Montserrat Roig, Joan Revetós) igen ritka katalán filmek egyike is megörökíti.

${ }^{248}$ Maragall i Gorina, Joan, Elogi de la paraula i altres assaigs, Barcelona: Edicions 62 i La Caixa, 1981.
} 
kozik meg Krisztus igazi arca, s azt kéri, ne építsék újra a vastag falakat, ne zárják be a hitet, a vigaszt a megerősített kapuk mögé, hisz nem az fogja megvédelmezni az egyházat. ${ }^{249}$ Raguer e vonulat alátámasztására idézi még Romanones gróf 1944-ben kiadott breviáriumát, amelyben a gróf a következőképp fogalmaz: „Amikor látom, hogy nap mint nap egyre több kolostor épül, és a keresztény egyszerüség helyett mindenütt hivalkodó pompa uralkodik, elfog a félelem, mert eszembe jut a múlt.”250 A Moncada regényben a Tragikus Hét megjelenítése szintén előrevetíti a polgárháború tragédiájának árnyát.

\subsection{A kávéházi emlékezet}

A folyók városában a Tragikus Hét mintájára szerveződő mequinensai események egyik főkolomposának tartott, és letartóztatott szereplö Arquimedes Quintana. A tetuáni veterán, a folyó legjobb kapitánya, aki az első világháborús fellendülés idején a város mulatójában esténként kikiáltja a köztársaságot, 1931. április 14-én hal meg egy Mequinensába tartó vitorláson. Az ö élettörténetéből a regényben kiemelt történeti események (Tetuán, Tragikus Hét, öszvérrel vontatás bevezetése, bányászsztrájk, Arnau Terrer meggyilkolása, 1931. ápr. 14.) alkotják a spanyolországi hosszú 19. század problémáinak, változásainak kisvárosi és alulnézeti vetületét: a szegények sorozása - a megfizethetetlen quinta -, és feláldozása a birodalmi ábrándok hamis illúziójának oltárán, egyházi oktatás, müvelődés monopóliuma, a politikába be nem engedett tömeg lefojtott dühe, a technikai fejlődés, a szociális igazságtalanságok, a köztársaság varázsszava. A legendás hajóskapitány már nem hallja meg a köztársaság kikiáltásának hírét, melyre egész életében várt, s halálának időpontja előrevetíti az ideál halálát is.

Arquimedes kulcsfontosságú szereplő, hiszen, apja helyett apja az elárvult főszereplőnek, Nelsonnak, aki tőle tanulja a hajósok mesterségét, az erkölcsi tartást, a folyó földrajzát és az ország történelmét. Nelson élete és emlékezete elér az új-Mequinensáig, Arquimedes emlékezete pedig a tetuáni csatáig. Ők alkotják a fent jelzett események mentén a város plebejus emlékezetének láncát.

Az öreg emlékezeténél régebbre nyúló esemény kettő található a regényben, mindkettő tárgyakhoz kötődik. Az egyik egy pompás réz látcsőhöz, melyet a patikus egyik őse zsákmányolt egy Suchet csapataival érkező francia tiszttől, és egy ágyú, mely szintén

\footnotetext{
${ }^{249}$ Raguer, Hilari, La pólvora y el incienso, La Iglesia Española y la Guerra Civil Española (1936-1939), Barcelona, Ediciones Península, 2001. 390-2. o.

${ }^{250}$ Uo. 393. o.
} 
a Napóleoni háborúk ereklyéje, s története felidézi a karlista háborúkat és Cabrera ${ }^{251}$ tábornok alakját is.

A házak lerombolás előtti kiürítése során elökerülő ágyú az általános pusztulás közepette már nem kelt érdeklődést, mint ahogy az sem tünik fel a zöldségesnek, hogy a Campells ház kiürítésekor megszerzett sárga, irka-firkával teli lapok, melyekbe a babot csomagolta, Goya rézkarcai. Az 1970-es városban ezt egyedül a patikus, az író alteregója ismeri fel, aki mindent megtesz, hogy a szemétből kimentse az értékes műveket. ${ }^{252}$ A gazdag, úri rétegeket nem érdekli a kultúra, a szegények nem ismerik. A város általános pusztulása közepette a muzeális értékü tárgyak, mủalkotások értéke az otthonukat vesztő emberek tragédiája mellett relativizálódik. A patikus, a müvelt, bohém kergeti egyedül ezeket a lapokat, ő érzi egyedül fontosnak a széphez, a magasztoshoz való ragaszkodást, mely a hétköznapokból felemel, és szintén folytonosságot biztosít az időben, mert hozzáköt egy hagyományhoz: Goya a festészethez, az eszperpentóhoz, és Aragóniához. ${ }^{253}$

A patikus emlékezetének polgárháború elötti vonulatát Aleix de Segarra, az úri családból származó festő képviseli. Ők alkotják a kávéház művelt, bohém emlékezeti vonulatát, mely kritikát gyakorol a zárt vidéki közösség mítoszképző mechanizmusai felett. A két vonulat egymáshoz való viszonyát jól érzékelteti Nelson töprengése, aki 1936-ban elemezni igyekszik a marokkói katonai lázadás teremtette helyzetet, és a köztársasági időszakban a várost ért csalódásokat, melyek közül a legnagyobb és legfájdalmasabb az asztúriai bányászsztrájk letörése volt. Úgy gondolja, hogy a Népfront februári választási győzelme visszaadta az embereknek a reményt: „A város újra teli volt bizakodással: a szocialisták a Móló Kávéházban ${ }^{254}$, a köztársaságpárti baloldal a Centrálban, a kommunisták a Városfal Kávézóban, majdnem szemközt az Angolna fogadóval, amely az anarchisták találkozóhelyéül szolgált,

\footnotetext{
${ }^{251}$ L. melléklet Lexikon 19.

${ }^{252}$ Erre a motívumra rímel Moncadának a Montaner i Simón Kiadóvállalatnál végzett első munkája, amivel Pere Calders megbízta. Calders szerette volna a pénzgondokkal küzdő, nagy múltú kiadó művészi hagyatékát újra összegyüjteni, mert az eredeti Zola leveleket, és Gustave Doré metszeteket el kellett adni. Moncada feladata volt katalogizálni azt, ami még maradt, s ezek közt több Goya rézkarcot is leltárba vett. Egy interjúban meséli el, hogy a páncélszekrényben található két eredeti Don Quijote kiadás közül - a kiadó facsimile kiadásához - az egyik eltünt, vagyis a müvészet értékét ez esetben felismerték.

${ }^{253}$ Az eszperpentó, a groteszknek ez a jellegzetesen spanyol megnyilatkozási formája Valle -Inclán találmánya, múveinek senki mással össze nem téveszthető nézőpontja és ábrázolási metodikája. A múfaj atyjaként a müvész Goyát jelöli meg, aki a kortárs Spanyolország állapotát láttatta különleges ábrázolásain. Goya grafikai munkássága (rézkarcai, rajzai, akvatintái) a spanyol müvészettörténetben előzmény nélküliek, s Picasso és Dalí feltünéséig páratlannak tekinthetők. E művek nem megrendelésre készültek. Az eszperpentó a századfordulón még igen gyakran látható vásári torztükrök mintájára groteszk deformációként tükrözi vissza a valóságot, a „politikai és az esztétikai tudat fúziója”. L. Matuz János doktori disszertáció Valle-Inclán és a groteszk, Színház és Filmmüvészeti Egyetem 2005-2008.

${ }^{254}$ Mint a történeti monográfia adatai mutatják, (Jesús Moncada fejezet 186. lábjegyzet) Mequinensában a szocialisták voltak többségben.
} 
mindenki egyformán hitte, hogy nemsokára learathatják e győzelem gyümölcseit. Nelsonnak azonban valami azt súgta, hogy a dolgok nem ilyen egyszerủek [...] Hol az igazság, ha a világ problémáit megoldani igyekvők ellentétei úgy elmérgesednek, hogy a közös ellenséget feledve egymás torkának ugranak? [...] Valóban meg lehet változtatni a dolgokat? [...] Oroszország messze van, és isten tudja mi igaz abból, amit a propaganda hirdet. Néha arra gondolt, jó volna elbeszélgetni Aleix de Segarrával ezekről a kérdésekről, amelyek sehogy sem fértek a fejébe, de végül sose merte megkérdezni felölük [...] A müvész jelenlétében zavarban volt.” ${ }^{255}$ Ez a hajóskapitány kétségeit tükröző leírás jól jellemzi az egyszerü emberek többségének kételyeit, tanácstalanságát, a politikai káoszt és bizonytalanságot, s azt a tiszteletet, melyet művelt, világlátott földijük iránt éreztek, akitől magyarázatra számíthattak.

Fontos motívum még ebben a töprengésben, hogy az asztúriai bányászsztrájk letörése, mint a legszomorúbb esemény jelenik meg Nelson értékelésében. A Mequinensa monográfia adataiból láttuk, hogy Mequinensa városvezetősége 1934. november 7-i ülésén elítélte az asztúriai és katalóniai eseményeket, üdvözölte a kormány és a hadsereg által alkalmazott intézkedéseket, sőt pénzügyi segítséget is megszavazott támogatásukra. Az asztúriai események megítélése levéltári dokumentumok alapján vagy a regény által feldolgozott városi emlékezet alapján, két különböző eredményt hoz. A monográfia a hiteles történeti dokumentumok alapján a valószínüleg köztársasági jobboldali vezetőség álláspontját, míg Moncada a város plebejus emlékezetét örökíti meg. A monográfia szerzője kommentálja az összes, városvezetőség által tárgyalt eseményt, amelyről levéltári adat fennmaradt, de mivel kevés az anyag, az ábrázolás töredékes marad. A levéltár nem örökíti meg a plebejus emlékezetet, mert nem feladata, és talán tudomása sincs róla. Moncadának van ugyan tudomása a városvezetőség állásfoglalásáról, de mint a plebejus emlékezeti közösség része, városportréjában nem örökíti meg. Az általa szelektált témák (asztúriai sztrájk, katalán autonómia statútum elutasítása) jelzik, hogy mivel nem ért egyet.

Az idézetben politikai állásfoglalás alapján szerveződött kávéházi törzsközönségek felsorolása mutatja, hogy a mequinensai közvélemény élénken reagált a politikai eseményekre, melyek átrendezték a békeidők grémiumokhoz tartozás szerinti közösségeit. A megosztottság, és a köztársasági oldal pártjai közti egyet nem értés fennmaradt a mequinensai öregek emlékezetében is. Joaquim del Patriciet így fogalmazott: „Hogyan is győzhettünk

${ }^{255}$ AFV 142-4. o. 
volna? Hisz mindenki más zászlót lengetett.” ${ }^{\text {256 }}$ Nelson töprengése is a baloldal széttöredezettségét hangsúlyozza, ami a Tragikus Hét eseményeit is jellemezte, s végig megmaradt a baloldalon békeidőben, majd amikor a fegyvereké lett a szó, tragédiához vezetett.

Ugyanez a baloldali széttöredezettség megjelenik még egyszer a regényben, de akkor már egy eszperpentóra jellemző, végletekig kikarikírozott jelenetben, amikor 1950-ben Jaume de Torres végtelenül hosszú temetési menetében már ott lépkedett a diktatúra akkorra már szervezetten müködő ellenzéke (a bányákban, elsősorban kommunista irányítással). Elterjedt a hír, hogy veszett kutyát láttak az egyik sarkon, mire a tömegben kitört a pánik. „A pap, a gyászoló család, az úri nép nagy része, négy kommunista, egy szocialista és három anarchista a városi börtönben lelt búvóhelyre [...] A véletlenszerü találkozó [...] a város politikai erőinek a Franco-korszak alatti első gyülésének nevezhető, ahol a távíróhelyiségben megbúvó trockistákon kívül minden erő képviseltette magát.” ${ }^{257}$ Ez a keserűen vicces ábrázolás is kiemeli, hogy a diktatúra színfalai mögött bujkáló baloldali ellenzék bár létezik, de továbbra is megosztott.

\subsection{Mequinensa és az egyház}

A spanyol és a katalán regényirodalom bővelkedik az egyházat kritikusan ábrázoló regényekben $^{258}$, s Moncada minden regénye is ebbe a vonulatba tartozik. A vele készült interjúkban is következetesen antiklerikális nézeteket vall: „Úgy gondolom, hogy az egyháznak nincs semmi köze a korai kereszténységhez, amely valóban keresztény lehetett. Jézust becsapták, megcsalták azok, akik azt állítják, hogy az ő üzenetének közvetítői.” ${ }^{259}$ Moncada kedvenc írói és regényei közé tartozik Nikosz Kazantzakisz, Akinek meg kell halnia címü

\footnotetext{
${ }^{256}$ MCSL Entrevista amb l’oncle Joaquim del Patriciet.

${ }^{257}$ AFV 233. o. A jelenet ábrázolásmódja felidézi a gyilkos pincér képét, aki eljön Spanyolországba, hogy meggyilkolja Francót csak azért, hogy véget vessen a dél-amerikai csendes kávéház nyugalmát feldúló emigráns köztársaságiak különböző csoportjai közt dúló állandó vitának, melyek megkeserítik dolgos hétköznapjait. L. Max Aub, La verdadera historia de la muerte de Francisco Franco https://littera.wikispaces.com/aub muerte francisco franco, letöltés 2017. nov. 8.

${ }^{258}$ L. melléklet Lexikon 16.

259 1998-12-25 El Punt - El nom i el personatge no tenen res a veure, Carina Filella. Moncada Egyházzal kapcsolatos véleményéről 1. még: 1992-02-10 El Observador - Podría escribir cien mil novelas con Mequinenza. como escenario, Santiago del Rey; 1999-11-24 Regió7 - Sempre he refusat el localisme, Josep Gras a francói kor egyházának evangéliumi tanítással ellentétes szerepéről, a hatalommal való összefonódásról; 2000-01-02 Lectura - Entrevista a Jesús Moncada, Anna Sàez. Ez utóbbiban Moncada elmondja, hogy nevetségesnek és falsnak találja a Püspöki Konferencia általi bocsánatkérést, mivel az egyház attitüdje közben nem változik. Galileiért bocsánatot kérnek, de az élet szentsége elleni véteknek tartják, és tiltják, hogy a háborúban megerőszakolt koszovói nők elvetessék a magzatot.
} 
mủve ${ }^{260}$, mely hasonlóképp a megmerevedett és saját érdekeinek védelmére berendezkedett egyházat állítja szembe a hit követelményeinek személyes felvállalásával, mely az élet minden napján újra feladat, s ami nem engedi meg a falak mögé zárkózást. A folyók városában szintén nem találunk egyetlen szimpatikus, hitéhez hü, mélyen gondolkodó papot vagy egyházi személyt sem. A regény elején a torkos plébánost kinevezik kanonokká a lleidai székesegyházba, s helyére egy „kemény, inkvizítor-szigorú, könyörtelen csontváz” érkezik, hogy aztán őt váltsa Ambròs atya, aki egészen a város lerombolásáig gondoskodik a hívők lelki táplálékáról. A polgárháború előtti időszakról az író idilli képet közvetít a helyi parókia és a Vértanú Szüzek Szalonja (Torres i Camps ház) viszonyáról, „amely olyan évszázados szekuláris hagyományokból táplálkozott, mint a csokoládé piskótával, a hajók megáldása valamint a túlvilági üdvözülésért és az evilági büntetlenségért felajánlott misék és alamizsnák.”261 A bien pensant, elégedett polgári kényelem vallása ez, egy az adok-kapok, kalmárszellemü, külső formák betartására ügyelő gyakorlat, melynek társadalmi tere az úri szalonok világa. Azé a korszaké, amikor az egyház a holtkézi birtokok eltörlése és áruba bocsátása (Mendizábal 1836) után mégis kiegyezett a liberális hatalommal, és a Vatikánnal megkötött konkordátum értelmében (1851) állami kötelezettség lett az Egyház finanszírozása, ami azt jelentette, hogy az egyszerủ spanyol állampolgárok adója tartotta fenn az egyházat, s az egyház újra a hatalom szövetségese lett. ${ }^{262}$ A regényben ez a békés szövetség Franco győzelme után kiegészült egy harcos elemmel is: a Torres i Camps-ok a templomban található családi oltárra helyezték a tetuáni csatában elhunyt hős Camps tábornok kardját. ${ }^{263}$ Ezzel a valószínüleg fiktív elemmel Moncada a Francóval önként szövetséget kötött egyház ${ }^{264}$ és a keresztes hadjárat ideológiájának védelmébe helyezett vagyonok összhangját emeli ki. A kard története ugyanakkor a köréje épített hősi mitológia deheroizálására szolgál, hiszen a harci ereklyéjét a családi ház vitrinéből a cselédek a szárnyasok kivégzéséhez szokták ki-

\footnotetext{
${ }^{260}$ Kazantzakisz, Nikosz, Akinek meg kell halnia, Budapest, Európa, 1973.

${ }^{261}$ AFV 224. o.

${ }^{262}$ L. Vicens Vives, i.m. 140. o.

263 A motívumot az író talán abból a valós történelmi eseményböl kölcsönözte, amikor Francisco Franco a polgárháborúban aratott győzelem tiszteletére rendezett katonai felvonulás után a Santa Bárbara templomban Goma kardinális elé helyezte győzhetetlen (a kor frazeológiájában gyakran használt jelző Francóra az Invicto) kardját, jelezvén, hogy Isten szolgájaként cselekedett, az Ö ellenségeitől védte meg az Igazságot, a spanyol egyházi hierarchia feje pedig megáldja. http://hispanismo.org/historia-y-antropologia/9076-franco-ofrendo-suespada-invicta-dios.html, letöltés 2017. aug. 29.

${ }^{264}$ Hilari Raguer hangsúlyozza az egyház polgárháborús szerepvállalásával kapcsolatban az önkéntes és azonnali csatlakozást a lázadókhoz, s korábban a köztársaság iránti ellenszenvet. Raguer, H. i.m. 50-61. o. Franco az állam laicizálása miatt az egyházra visszaszállt invesztitúra jogot visszakövetelte, s 1939. június 7én megállapodott erről a Szentszékkel, ami szigorú, államfői kontrollt tett lehetővé az egyház fölött. L. Harsányi Iván - Ormos Mária, Franco - Mussolini, Budapest, Pannonica, 2001. 257. o.
} 
csempészni, s innen kerül a templomi oltárra. Az író ezzel jelzi a hadi dicsőségre alapozó, közösségformáló mítosz nevetségessé válását a modernizálódó világban.

A regény elején a Torres i Camps család az első világháború okozta ipari fellendülésért érzett hálája jeléül nagy összegü adományokat juttat az egyháznak. A háborút követő válság idején azonban ezek elmaradnak, s a plébánosnak be kell érnie olyan sovány juttatásokkal, mint például annak a mórnak a lelki üdvéért mondatott mise ára, akit Arquimedes Quintana a tetuáni csatában megölt. A kapitány minden évben adott egy összeget erre a célra, amit a pap elfogadott ugyan, de lelkiismereti kételyei miatt (egy hitetlen republikánus kéri egy muzulmán lelki üdvéért) a misét sosem mondta el. ${ }^{265}$ Ezzel Moncada finoman jelzi, hogy a hitetlen republikánusok nem durva lelkü csőcselék, hanem az élet szentségét, a lélek halhatatlanságát tisztelő, lelkiismeretes emberek, akik elött a formák pompája és a hatalom fegyverei mögé bújó egyház nem képes kinyitni kapuit.

A spanyol társadalom megosztottsága a katolikus vallás mentén nyilvánvaló a Franco korszakban, melynek hivatalos ideológiája a katonai és a vallási erények dicsőítésén, Menéndez Pelayo és Ramiro de Maeztu gondolatain alapult. Ebben a gondolati rendszerben a spanyol nemzeti jellegnek alapvető alkotóeleme a katolikus hit, mely a birodalmat egykor naggyá tette, a Los heterodoxos españoles ${ }^{266}$ ebből a nemzetből ki vannak zárva. Ezt a megosztottságot tükrözték a már említett Caídos por Dios y por España” emlékmüvek, valamint a temetők, amelyekben az 1882. május 19-i királyi rendelet értelmében, minden 600 főnél nagyobb településen létesíteni kellett egy külön bejáratból nyíló, nem katolikusok számára fenntartott részt. ${ }^{267}$

Moncada a regényben egy igen mozgalmas korszakban ábrázolja a városi temetőt, mikor a halottak két csoportját egymástól elválasztó falat a II. Köztársaság kikiáltása után a politikához egyáltalán nem értő, Bakunyin de Planes kőmüves, a polgármester parancsára lebontja. ${ }^{268}$ A müvelet végeztével, mikor a protestánsok, megkereszteletlen gyermekek öngyilkosok és ateisták számára kijelölt helyet, már nem választja el fal a többi halottól, a kőműves szemét elfutja a könny, mert megpillantja apja sírkövét. „Az öreg anarchista Bakunyinon kívül nemzett még egy Germinalt, egy Felicitatot és egy Perfectet, de nem akart egyházi rí-

\footnotetext{
${ }^{265}$ AFV 74. o.

${ }^{266}$ Marcelino Menéndez Pelayo, Los heterodoxos españoles www.cervantesvirtual.com/servlet/SirveObras/ 01361608688915504422802/p0000001.htm\#I_1_, letöltés 2018. ápr. 30.

${ }^{267}$ Nistal, Mikel, Legislación funeraria y cementerial española http://www.ingeba.org/lurralde/ lurranet/lur19/19nistal/19nistal.htm, letöltés 2017 jan. 20.

${ }^{268}$ A köztársasági törvényhozás 1932. január 30-án adta ki a temetők rendjét szabályozó törvényt. L. Raguer, H. i.m. 51. o. A temetőkben a nem katolikus halottak elkülönítésének kötelezettségét a Franco korszak után az 1978-as alkotmány szünteti meg.
} 
tus szerint megházasodni, ezért amikor 1928-ban meghalt, a plébános nem engedte, hogy a szent földbe temessék.” ${ }^{269}$ A kőművesnek a Franco rendszer kezdetén, vissza kellett építenie a falat, ami újra megjelölte és elkülönítette őt az élők városában, amelynek a temetőbeli sírok a transzcendentális jelképei. Bakunyint a neve is megjelöli, hiszen „egy ilyen gyanús nevű embertől szinte elvárják, hogy felforgató tevékenységet végezzen.”270 A névadás merészsége nem csak a regényíró fantáziájának szüleménye, hiszen Mequinensa híres szülötteinek egyike Tomás-Germinal Gracia Ibars, a spanyol anarchizmus egyik legtermékenyebb írója ${ }^{271}$, tehát valóban létezett forradalmi szimbolikájú névadás a városban.

A regényben Ambròs atya alakja karikatúraként jelenik meg, ő a Franco hatalmának legitimitását igazoló egyház képviselője. A polgárháború utáni években sehogy sem fér a fejébe egy dolog: „Megharcolták a háborút, a keresztes hadjáratot, Isten nevében még az írmagját is kiirtották a köztársaságiaknak, vörösöknek, szabadkőműveseknek és szeparatistáknak [...], és az égi áldás helyett lám, mit kapnak cserébe: tartós szárazságot. A mezők elsivatagosodtak annak ellenére, hogy országszerte körmeneteken könyörögtek az esőért. Ezzel szemben [...], a republikánus Franciaországban, Voltaire és Rousseau hazájában, amely tömve van számüzöttekkel, ateistákkal és könnyüvérü nőkkel [...] úgy esett, mintha dézsából öntenék, és nem volt szükség egyetlen nyavalyás körmenetre sem.”272 Az esőért könyörgő körmenetek valóban részei voltak a polgárháború utáni aszályos évek mindennapjainak, a regény maró gúnnyal, a mágikus és az adok-kapok gondolkodás keverékeképp ábrázolja ezt az idejétmúlt gyakorlatot a modern víztározó-építkezések századában.

A kávéházi törzsközönség csúfondáros hangnemben tárgyalja a városi üdvtörténet különböző korszakait. A csodák korában „éjjel a város védőszentjének régi oltárán maguktól kigyulladtak a lámpácskák, és a plébános üzenetként értelmezte a jelenséget [...]: a vértanú szent új oltárt kívánt magának, mert valószínűleg zavarta, hogy a régi büzlik a köztársasági gázolajtól.”273 Moncada leírja, hogy „a republikánusok garázsnak használták a templomot, miután kidobálták belőle az oltárokat, a szentképeket és minden egyéb díszt, és még a háború kezdetén elégették, vagy az Ebróba hajigálták őket.”274 A regény egyik jelenetében Nelson hazafelé hajózva a marokkói lázadás aznap reggel hallott hírein gondolkodik, mikor matrózai meglátják a folyón lefelé úszó szenteket. Kihalásszák a vízből, s egy folyósziget

\footnotetext{
${ }^{269}$ AFV 179. о.

${ }^{270}$ AFV 178. 0.

271 Tomás-Germinal Gracia Ibars(1919-1991) l. Lexikon 23.

${ }^{272}$ AFV 245. 0.

${ }^{273}$ AFV 225. 0.

${ }^{274}$ AFV 183. o. L. MCSL Joaquima de la Faiona története.
} 
legmagasabban levő részére helyezik őket egymás mellé. „Olyanok, mint a halottak, ugye, Nelson? - suttogta Joanet, akit kissé megdöbbentett a kiterítve fekvő szobrok látványa."275 A pap személyével és retorikájával szemben maró gúnnyal és távolságtartó iróniával operáló szerző hangja érezhetően megváltozik, amikor az értelmetlen pusztítás, rombolás eredményével találkozik. Ezt mutatja az a kegyeleti gesztus is, amellyel a matrózok kihúzzák a szobrokat a vízből, s „rendben” lefektetik őket a sziget egy olyan pontján, ahol nem érheti őket víz. A jelenet az elszabadult pokol sejtetésére szolgál, ami után súlyos csönd burkolja be a hazafelé igyekvő, rossz sejtésekkel teli legénységet.

A Móló Kávéház asztaltársasága által csodák korának ${ }^{276}$ nevezett, sugalmazott időszakban a nem hívő, bünös Spanyolországnak kellett megfizetnie az okozott kárt, amit országos szinten a legjobban a Valle de los Caídos hatalmas sziklatemploma jelképez, mely 1940 és 1959 között épült, 20000 ember, javarészt politikai foglyok ingyen munkájával ${ }^{277}$, miközben az ország éhezett. Juan Pablo Fusi részletesen ismerteti, milyen hatalmas építkezésekbe kezdett a rendszer, amely csak Barcelonában 72 templomot építtetett 1945 és 59 között. ${ }^{278}$ Ez óriási anyagi áldozatot jelentett az autarkia körülményei között, de nem teremtett több hívőt. Nem csoda, hogy az erőszakos, államilag támogatott újra-evangelizáció megijesztette a korábban már idézett Romanones grófot. A korai Franco-korszak evangelizációjának mequinensai változatát megtaláljuk a regényben: „,a plébános elhatározta, hogy újra kidíszíti a még mindig csupasz falú templomot [...] kinyilatkoztatta, hogy a szobrokat és a díszeket az ateista vörösöknek kell megfizetniük [...], akik a háború kezdetén elégették vagy a folyóba dobálták öket’[...] javasolta, hogy a munkások béréből vonják le a [...] szükséges összegeket. [...] Attól kezdve szobrok és képek hosszú sora érkezett a városba, pompás ünnepségek keretében [...] a csendőrség is hozzájárult, kiráncigálva törzshelyéről a kávéházak ellenszegülő népét, hogy csatlakoztassa őket a díszmenetekhez." ${ }^{279}$ A leírás alapján érthető, hogy a penitencia nem váltotta ki a bányászok és hajósok megtérését, de nyilván nem is ez volt a célja. A mequinensai öregek interjúiban szereplő motívumokat Moncada mind felhasználta a regényben a tisztitótüz évtizedének nevezett korszak jellemzésére: „a köztársaság idején kötött polgári házasságokat meg kellett újíttatni az egyházzal, tiltották a káromkodást és a szemérmetlen öltözködést, és e szabályok betartását a csendőrség mindig készségesen ellenőrizte. A fegyveres közeg engesztelhetetlen vezetője nem volt más, mint Ambròs atya

\footnotetext{
${ }^{275}$ AFV 147. 0.

${ }^{276}$ MCSL Entrevista amb l'oncle Joaquim del Patriciet. Ö említi, hogy Josep atya mindig csodákról beszélt.

${ }^{277}$ Fusi, J. P. i.m. 108. o.

${ }^{278}$ Uo. 106. o.

${ }^{279}$ AFV 221. 0.
} 
[...] (a papi föveg és a csendőrcsákó egymással behelyettesíthető fejfedő), s ő vezette azokat a hajtóvadászatokat is [...] amelyek, ha partizánok nem akadtak, azok ellen a bünösök ellen irányultak, akik vasárnap vagy az anyaszentegyház által más, ünnepnek nyilvánított napon dolgozni mertek."280

Moncada nem kíméli a papok erkölcsét sem, s abban is a képmutatást rója fel a legnagyobb hibaként. Ennek egyik példája, mikor a lleidai kanonok közerkölcsöt sértő magatartásért feljelenti a teherbe esett örömlányt, akihez maga is járt. A regény a képmutatás mellett a rendszer katolikus morálon alapuló tiltó rendelkezéseit láttatja groteszk színben (káromkodás tilalma a bányászvárosban, dresszkód ellenőrzése a csendőrök által), és gyakran kiemeli az egyház és a fegyveres erők szövetségét. ${ }^{281}$

A regényben ábrázolt egyházi személyekről általánosságban elmondható, hogy nevetséges, öntelt, szük látókörü figurák, akikből legföképpen a hit mélysége és a krisztusi szeretet hiányzik. Jellemzően ostoba, jelmondatokban, toposzokban gondolkodó tisztségviselők, a nemzetikatolikus egyház hivatalnokai. Nem képviselnek sem morális autoritást, sem lehetséges alternatívát a közeledésre. Ez jelentheti azt, hogy vidéken, és konkrétan Mequinensában nem volt jelen a reformpapság, mely az egyház II. Vatikáni Zsinat utáni fordulatát képviselte volna, vagy jelentheti azt is, hogy Moncada számára, neveltetésénél és kultúrájánál fogva a vallásnak vagy a vallásgyakorlásnak nem volt hitele és értéke. A környezetébe tartozó, általam ismert emberek köre ezt a második feltételezést erősíti.

A regényben egyetlen szó sem esik a mequinensaiak érdekeit védelmező papról, akiről a történeti monográfia utolsó fejezetének epilógusa, Az egyház szerepe és a régi Mequinensa utolsó házai címmel említést tesz, de az esetet nem magyarázza, nem értékeli. A város történelmét lejegyző szerző, Andrés Coso nem hagyhatta említés nélkül a több korabeli sajtóban is megjelent tudósításokat, melyek Eduardo Royo atyának a „gyengék védelmében” 1973-ban kezdeményezett ellenállásáról adtak hírt. Az eset értelmezésének hiánya arra utal, hogy a szerző szerint az ellenállás kronológiája önmagáért beszél, vagyis egyértelművé teszi, hogy túl későn jött. A monográfia lapjain azonban nem fejti ki véleményét, mely sok mequinensai véleményével egybecseng: az ellenállás, tárgyalások, sztrájk, szövetkezet alapítás 16 éve alatt a város lakói nem kaptak semmi támogatást a paptól, akinek 1973-ban tett hősi gesztusa inkább akadályozta, mint segítette a többség átköltözését. A rendelkezésemre álló adatok alapján nem tudok világos hipotézist felállítani a pap ellenálló akciójáról. Fontos

${ }^{280}$ AFV 225. o. és MCSL Entrevista amb l’oncle Joaquim del Patriciet.

${ }^{281}$ L. Mellékletek. Képek, térképek, 13. A harcoló egyház. 
és árulkodó tény azonban, hogy személye és tevékenysége teljesen hiányzik a regény lapjairól. Az eddigi elemzés egyértelmüvé tette, hogy Moncada a város plebejus emlékezetének őrzője, aki a szegények és a kiszolgáltatottak hangját közvetíti. Ha ő említést sem tesz a pap akciójáról, az azt jelenti, hogy megkérdőjelezi a gyengéket védő pap akciójának őszinteségét és közösség iránti elkötelezettségét, s nem érdemesíti arra, hogy megörökítse tettét. Ha a pap valóban a gyengék védelmében emelte is fel a szavát, Moncada Mequinensája ezt nem fogadta örömmel, valódi segítségként. Bár a II. Vatikáni Zsinat után lassan megváltozott az egyház néhány szektorának irányvonala, az elutasítást kiváltó nemzetikatolikus szocializáció után, a repressziót elszenvedő rétegek már nem tudnak visszafordulni az egyház felé. A fikció szabályai nem köteleznek a valóság maradéktalan megjelenítésére, az író úgy döntött, hogy kihagyja a város portréjából ezt az epizódot. Moncada hely- és emberismereten, kutatáson valamint általános müveltségen alapuló véleménye a vörös városról, visszaköszön a monográfia szerzőjének a városról alkotott véleményében. A folyók városát a mequinensaiak saját történelemkönyvükként olvassák, még ha városszerte ismert epizódok vagy figurák kérdésében eltérő véleményt fogalmaznak is meg. Ezt az epilógust azonban a Móló Kávéház törzsközönsége nem vitatja meg, mert tapasztalatteréböl hiányzik a gyengéket gyámolító egyház képe.

\section{Irodalmi halál}

Moncada azt állítja, hogy a valóság nagyon irodalmi ${ }^{282}$, ami azt jelentheti, hogy egy jól megalkotott, elmesélt történet valóságteremtő erővel bír, hiszen aki hallja, az hajlamos rá, hogy úgy is lássa, ahogyan elmesélték neki. A homo ludens, aki szavai által megkettőzi a világot, nemcsak él, gondolkodik és dolgozik benne, hanem képes létrehozni benne egy teret, ahol a gravitáció és a biológia törvényszerüségein túl egy sajátos játéktörvénynek engedelmeskedik. Ez a játszani vágyás és tudás együtt születik a gyerekekkel, s egyidős az emberi kultúrtörténettel. ${ }^{283}$

A poesis görög szó jelentése alkotás, játék. Huizinga a játékról írt müvében a költőknek igen összetett szerepet tulajdonít az ősi társadalmakban. A költő-látnok-varázsló szerepéből ágazik ki később a próféta, a jós, az író, a filozófus, a törvényhozó, a rétor vagy a

\footnotetext{
282 1999-05-02 El Periódico - La realidad es muy literaria, Entrevista, Antón Castro.

283 Mint Hugo Rahner fogalmaz: „a játszó ember legzseniálisabb gesztusai is csak esetlen utánzatai a logosznak, aki ősidőktől fogva az atya színe elött játszik". A Bölcsesség mondja a Bibliában: az atya, a világot teremtő Deus Ludens „gyönyörüsége voltam nap-nap után, színe előtt játszadoztam mindenkor.” (Péld 8:30). L. Rahner, Hugo, A játszó ember, Budapest, Kairosz Kiadó, 2013.
} 
mystagogos. ${ }^{284}$ A költészet fogalmát Moncada esetében alkotásként, a szavakkal való komoly játékként értelmezem. Laura Farré Badia, nyelvész az Estremida memòria címü regényről írott diplomadolgozatának végkövetkeztetése így hangzik: „Az (Moncada által) elmesélt dolgokat nyelvészeti szempontból csakis azon a módon lehet kifejezni, ahogyan ő teszi. Ha másképp mondaná, mást mondana.” ${ }^{285}$ Ez az állítás összecseng az író fent idézett kijelentésével, miszerint minden történetnek megvan a maga formája, amely által elmesélhető, s a történeteket úgy ronthatjuk el, ha nem találjuk meg ezt a formát. A költészet Jaques Roubaud definíciója szerint olyan autonóm nyelvjáték, amelyben forma és tartalom egymástól elválaszthatatlan, és semmi mással nem helyettesíthető, nem parafrazeálható, s jelentése sem hozzáférhető azon a módon, ahogyan a gondolkodás vagy a tudás, vagyis az epistémé fogalmába tartozó területeké. A francia matematikus-költő definíciója szerint a költészet a nyelv emlékezete, a bennünk beszélő világ, ami azt mondja, amit mondva mond, s nem az epistémé, hanem a doxa kategóriájába tartozik. ${ }^{286}$ Moncada maga sem volt hajlandó értelmezni a regényeit, hiszen amit el akart mondani, azt a hosszú alkotási folyamatban pontosra csiszolt poliedrikus mondatok, lírai monológok vagy ízes bányászkáromkodások formájában elmondta. Ha kiragadom a „bennünk beszélő világ” meghatározást, akkor mégis kísérletet tehetek rá, hogy a regény által megalkotott emlékezet képeit „lefordítsam”.

A folyók városában megrajzolt fikciós halálok az irodalmi mủvelet általi helyrehozatal (reparació) kiváló példái. Moncada a gazdag embereknek mindig jelentéktelen, dicstelen vagy méltatlan halált juttat: „Hipòlit de Móra úr se szó, se beszéd összecsuklott, mint egy beteg tyúk”. Camps tábornok tetuáni csatatéren megtalált levágott fejéhez a koporsóban egy kabil testét illesztik az egyenruha takarásában, mert a tábornokét sehol sem találták. ${ }^{287}$ Adelina Camps a polgárháború idején hal meg, mikor a Torres i Camps család Valladolidban várja az események végét, így nem kísérte a temetőbe a rangjához illő tömeg. A temetési menet hossza a város által kifejezett tisztelettel egyenes arányban áll, s ezt csakis Mequinensa tudta volna biztosítani Adelina asszony számára, aki azért imádkozott idegenben, hogy a város szokásai szerint mezítláb temessék el, mert rettegett attól, hogy cipő-

\footnotetext{
${ }^{284}$ Johan Huizinga, Homo Ludens, Szeged, Universum Kiadó, 1990.

${ }^{285}$ Farré Badia, Laura, Normativa i estil a Estremida memòria, de Jesús Moncada, Treball final del Màster en Assessorament Lingüístic, Gestió del Multilingüisme i Serveis Editorials, Universitat de Barcelona, Barcelona, 2014.

${ }^{286}$ Roubaud, Jaques, Költészet és emlékezet, Budapest, Typotex, 2007. 169-210. o.

${ }^{287}$ Az 1921-es nagy annuali katasztrófában, Abd el-Krim Rif köztársasága ellen a spanyol haderő 12-16 ezer katonát vesztett, és a hadműveletet vezető Silvestre tábornok holtteste sosem került elő. Az eseménynek igen nagy sajtója volt a félszigeten. L. Harsányi Iván, Spanyol dilemmák-spanyol megoldások a 19-20. század útvesztőjében, Budapest, Pannónia könyvek, 2006. 39. o.
} 
ben kelljen átmennie a túlvilágra. Férjét, Jaume de Torres urat 1950-ben temették Mequinensában. Tortosából hozattak rangjához illő koporsót, melynek felül kellett múlnia a kevéssel korábban eltemetett mozitulajdonosét. ${ }^{288}$ Az úri osztály esetében szóba sem jöhetett, hogy a helyi asztalosoknál rendeljenek koporsót. A pompás szertartás mégis vidám bacchanáliába torkollik, ami örök szégyenfoltot hagy a Torres i Camps család emlékezetének becsületén, hiszen a katolikus szokás szerinti, évente megtartandó gyászmise alkalmával a város népe újra meg újra felidézi a hanyatt-homlok menekülő temetési menet, és a tér közepén ledobott díszkoporsó képét. Carlota de Torres, a legdrágább koporsó megrendelöje, évröl-évre újra megszégyenül, a kávéházak népe pedig elégedetten nyugtázza, hogy ami csak velük, szegény ördögökkel szokott megtörténni, az ezúttal olyan valakivel történik, akit vagyona egész életében megvédett a megszégyenüléstől, megaláztatástól, s minden más, számára méltatlan helyzettől.

Az író ezzel a népmesébe illő fordulattal vesz elégtételt a város leggazdagabb emberén, s egyben újabb oldaláról mutatja meg a holtak emlékezetének fontosságát. Az a halál, amelyhez a szégyen bélyege tapad, évtizedekkel később is kísérti a hozzátartozókat. Hiába a gazdagságban és hatalomban leélt élet, a dicstelen és groteszk temetés ellehetetleníti a méltóságteljes megemlékezést, és mindig nevetésre készteti a kávéházak népét. Az emlékezet birtoklásáért folytatott harc tehát egy csöppet sem hiábavaló, hiszen az emlékezet élete legalább olyan hosszú, mint az emberé. Az emlékezet csatáját Carlota de Torres az apja életművét megkoronázó és a család hatalmát kifejező legpompásabb temetéssel kívánta megnyerni, ám az író keresztülhúzta a számítását.

Carlota de Torres halála szomorú, temetése pedig méltatlan társadalmi rangjához és az általa mindvégig tiszteletben tartott formákhoz, rajta azonban annyiban megkönyörül az író, hogy nem teszi nevetségessé. Carlota de Torres nem adja el bányáit, házait, földjeit a vízerőmű vállalatnak. Hiába mesterkedik az intéző, s a Madridban és Barcelonában élő gyerekei, az asszony érthetetlen ellenállást tanúsít. Szalonjának vendégei, a gazdag családok mind búcsút mondanak a napról-napra romosabb Mequinensának, s a bányákért, épületekért, kapott kárpótlásokkal zsebükben ki Tarragonába, ki Lleidába, ki Barcelonába költözik. ${ }^{289}$

\footnotetext{
${ }^{288}$ Moncada a novelláiban gyakran elemzi, s teszi gúny tárgyává a halál rítusait, mint társadalmi eseményt, és mint társadalmi rangjelzést. Az egyik interjúban elmeséli megfigyelését egy Mequinensával szomszédos település temetkezési szokásáról, ahol a koporsóvivők szivaroztak, miközben a halottat kivitték a temetőbe. A három napos virrasztás szokása miatt a hulla már erősen szaglott, mire eltemették, $\mathrm{s}$ a szivarfüst ezt hivatott kompenzálni. Idővel azonban a szivar márkája és nagysága vált a gyászolók elemzésének tárgyává, mint a halott tehetősségének jele. 1988-06-01 Lletra de Canvi - Entrevista amb Jesús Moncada, Josep Maria Ripoll.

${ }^{289}$ A Santa Agatòclia Lakásépítő Szövetkezet tagjai között nem találjuk a vagyonos réteg képviselöit. Egyedül Manuel Justribó Fornos, a nagyhatalmú család fekete báránya számára épült egy lakás új-Mequinensában, a
} 
Carlota patriarchális világát alapjaiban zúzza szét a vízerőmü vállalat, de mikor a madridi minisztériumban dolgozó testvéreihez fordul, azok azt tanácsolják, ne menjen szembe vele, hiszen a vállalat maga az állam, amit a polgárháború győzteseihez tartozó asszony végképp nem ért, hiszen akkor, „mi a fenének nyertük meg a háborút?” Számára ez azt jelentette, hogy a dolgok visszatérnek a régi kerékvágásba, és konzerválják a II. Köztársaság előtti hatalmi-társadalmi viszonyokat. Mikor végül Carlota beleegyezik a bányák eladásába, a vízerőmű vállalat irodájában zajló tranzakciót elviselhetetlen szégyenként éli meg: „megvárakoztatták [...] nem mérnökök fogadták, csak egy ügyvéd, aki nem méltóztatott észrevenni, hogy maga Carlota de Torres i Camps áll előtte [...] emlékeztette [...], hogy bár nem tulajdonosa többé a bányáknak, leszereltetheti a berendezéseket és hasznosíthatja, amit jónak lát, mivel a vízerőmü-vállalat számára semmiféle értéket sem képviselnek.”290 Carlota de Torrest a vállalatóriás által képviselt modern személytelenség és az ő élete, értékrendje, rangja iránti közömbösség végtelenül megalázza. Keresztül kell mennie ugyanazon a kálvárián, amin a város többi lakójának, akik ragaszkodnak a közösséghez. A maga módján Carlota de Torres is ragaszkodik: „El tudná bárki is képzelni a települést az ő családja nélkül? Ö sosem menne el innen, ahogy mások, nem lakna... egyetlen nagyvárosban sem, ahol senki sem ismeri a nevét [...] El tudná bárki is képzelni a Torres i Camps nevet ugyanazon a listán és ugyanazokkal a jogokkal, mint a boltosok, a parasztok [...] vagy ami még megalázóbb, az egykori hajósok vagy bányászok? Ő nem egyszerüen egy a helybeliek közül [...] Mi adott kenyeret ezeknek a nyomorultaknak, ha nem a Torresek gyára, birtokai és bányái? Kié volt sok ház, ahol bérlőként lakott az a tetves népség, amelyik most háztulajdonos akar lenni? Térden állva kellene könyörögniük, hogy válassza ki a számára legmegfelelöbb helyet. ${ }^{291}$ Carlota de Torres a fikció szerint újra megszégyenül, mert azt a választ kapja a lakásszövetkezetbe tömörült mequinensaiaktól, hogy „ha házat szeretne az új településen, csak olyan lehet, mint mindenki másé, és az övét is sorsolással fogják kiutalni. Ez a szabály, amit senki kedvéért sem rúgnak fel.”292

A regény ezzel a fikciós követeléssel José Moncadának, az író édesapjának állít emléket, aki a lakásszövetkezet elnökeként az új település felépítéséért felelősséget vállalt, $\mathrm{s}$ ha Carlota de Torres arroganciájával nem is, bizonyára több egyéni igénnyel és követeléssel kellett szembeszállnia a folyamat során. Mint arra már utaltunk, a lakástípus kiválasztása

többiek, mint ahogyan a regény leírja, mind nagyvárosokba költöztek. (Andrés Coso közlése).

290 AFV 261. 0.

291 AFV 277-9. 0.

292 AFV 279. 0. 
után a bizottság sorsolással utalta ki az egyes lakásokat, melynek céduláit José Moncada megőrizte, s a hagyatékában ma is megtalálhatók.

A regényben Carlota de Torres a bányák eladása után, de még minden más ingatlanvagyona tulajdonosaként úgy dönt, hogy nem mozdul a régi városból, de agyvérzést kap, s miközben élet és halál között lebeg, a gyerekei hamis aláírással, tanúkkal, elintézik az eladást. Meg akarta örizni birodalmát a dolgok régi rendje szerint, de mindenéből kiforgatva, tulajdon leszármazottai által méltatlanul becsapva hal meg, egyszerü, dísztelen fakoporsóban viszik a temetőbe, alig kíséri valaki utolsó útján, hiszen a város csupa rom, és csak leghüségesebb cselédje siratja. Carlota de Torres a régi város utolsó halottja. Vele együtt hal meg az ő kitüntetett helyét biztosító város, ami számára a személyi függéseken alapuló társadalmi hierarchia architektonikus leképezése.

Nelson és Carlota de Torres egyidősek, s mindkettőjük gyerekei a nagyvárosban keresik a boldogulást, egyiküket sem érdeklik se a folyók se, a bányák, se tulajdonosként, se dolgozóként, mint Nelson mondja, ,elvakította őket a nagyváros délibábja”, s Barcelonába költöztek, mint a legtöbben. Az új nemzedék társadalmi hovatartozásától függetlenül dönt inkább a nagyváros mellett. Moncada az öregek elégikus fájdalmával búcsúztatja a várost, de úgy vélem, nem véletlen, hogy Carlota de Torres ennek a régi városnak az utolsó, és mindenéből kiforgatott halottja. Hiába állt a polgárháború győzteseinek oldalán, irodalmi sorsa az lett, hogy a várossal együtt kellett meghalnia, s „alattvalóit nem temették melléje”. A város és az ENHER Dávid és Góliát harcából egy új város született, melyben mindenki tulajdonosa a házának. Nelson és a lányáék ide költöznek át. Nem győzelem, de folytatás, amelyből a modernizáció sodrásában a lelkek és tárgyak régi ura, Carlota de Torres, és az általa képviselt ideológia kimarad. Mintha az író azt akarná jelezni, hogy ezen ne bánkódjunk annyira. Ugyanakkor, a régi városhoz tartozó Carlota de Torres halála tragikus számunkra, mert cselszövés áldozataként, a gyerekei pénzéhségének kiszolgáltatva, tehetetlenül szenvedi el világának összeomlását. Tragikus figura, mert nincs helye ebben a gazdasági fellendülés, modernizáció és pénz igazgatta új világban, mellyel szemben az ő partiarchális, személyes kötődéseken alapuló kisvárosi világa iránt még szánalmat is érzünk, ám csak azért, mert életrehalálra kötődött a városához.

A város és az ősi mesterségek halálát a regényben a Neptunus, Nelson hajójának sorsa jelképezi. Valószínűleg ez volt az a gondolati mag, az öreg hajós utolsó útja, melyből az egész regény kinőtt. Ezt a hajót 1920 táján tették vízre, s első és utolsó kormányosa is Nelson volt, akinek élete egybefonódott a hajóval, a legénységgel, a folyóval, a várossal. A hajó 
a bányák kollektivizálásának idején Karl Marx nevét kapta. Legénységéből a kommunista matróz önként jelentkezett a frontra, az öszvérhajtót meg a másik matrózt pedig besorozták, végül pedig a hajót is rekvirálták a Saragossa ellen induló köztársasági offenzíva céljaira, mikor Gelsánál pontonhidat építettek a vitorlásokból. 1937-ben hatalmas árvíz zúdult le a folyón, amely elsodorta a pontonhidat, és a Marx Károly Mequinensától nem messze egy másik hajóval összeláncolva fennakadt a folyóparti fák közt, Nelsonék kiszabadították, rendbe hozták, s újra vízre tették. A mequinensai öregek interjúiban is megtaláljuk a nagy árvizet, s az elsodort hajókat, melyeket 15 napi kemény munkával szabadítanak ki a Magdalena folyószigetnél, ${ }^{293}$ de itt nem szerepel a motívum, hogy egy városba visszatért hajóról volna szó. A regény egyetlen fontos hajó képét rajzolja ki erős vonásokkal, ember és hajó szoros viszonyát kiemelve, mely így minden más hajónak, és egy egész korszaknak a portréját adja, s a kép nem esik darabokra. A Marx Károly az utolsó vitorlás, amely a város evakuálása idején, 1938. március 27-én, menekültekkel a fedélzetén elhagyja a várost. Nelson és matrózai kiteszik a menekülteket a morai állomáson, majd egy mellékágba kormányozzák a hajót, s ott elsüllyesztik, hogy megmentsék a pusztulástól. A hajó nélkül maradt kapitány a barcelonai Gràcia negyedben, aggódik a fronton harcoló fiáért, a szétszóródott családért, s az ebrói csata hadmüveleti területén rejtőző hajóért. 1939 nyarán, mikor Nelson újra munkába áll Mequinensában, kiemelik a holtágból özvegy Sallerasné hajóját, amely így az első polgárháború utáni szénszállító vitorlás lett Mequinensában. A holtág felé induló mentőakció örökre beleírta magát Nelson emlékezetébe: „A folyó közönyösen hömpölygött az üres lövészárkok csöndje, a rozsdamarta szögesdrótok, a romba dőlt házak, és a bombák szántotta földek között.”294 „Aznap délelőtt, amikor látta, hogy a hajó egy karcolás nélkül kerül felszínre, Nelson élete újra értelmet nyert, és a katasztrófa ellenére megint megtalálta helyét a világban.”295 „Öszvérek nélkül, az embereknek kellett felvontatniuk (a hajót), mint régen, a törmelékkel teli vagy a harcokban szinte megsemmisült vontatóúton.”296 A politikai rendszer változását a hajó új neve jelzi, mely ezúttal Kármel-hegyi Szúzanya néven bont vitorlát. Az árral szemben újra emberi erővel vontatott hajó, a szent és sérthetetlen vontatóút eltűnése jelzi, milyen erősen visszavetette a települést a háború a haladás útján, (felrobbantották a hidat is) innen kezdődött újra az építkezés. A családtagként szeretett hajó fedélzetén Nelson egészen a város lerombolásáig vitorlázik, s szállítja a szenet. Mikor munkaadója

\footnotetext{
${ }^{293}$ MCSL Entrevista amb l'Almirant; Entrevista amb Quico; 2a entrevista amb Quico. Az elbeszélők részt vettek a hajók kiszabadításában, s ide sorolják még Raietet, a hajóácsot, s másokat is névtelenül.

294 AFV 190. 0.

295 AFV 193. 0.

296 AFV 196. 0.
} 
meghal, s az örökös eladja a bányákat, Nelson még gondozza, vigyázza a kikötőben horgonyzó, használaton kívüli hajót. A regény utolsó képe a riba-rojai tározó zsilipjeinek lezárása előtti dühödt eső, s a felduzzadt Ebro, mely szétszórja és elpusztítja a hajótemető vitorlásait, köztük a Neptunusz-Marx Károly-Kármel-hegyi Szüzanyát is, mely „többé nem volt egyéb, mint halott, névtelen faváz.”297 . A regényben ábrázolt emberi idő tehát eltünik a civilizációk, a nagy struktúrák idejében, vitorlás helyett a vízerőmüvek korába érkeztünk, de Moncada szép halált ajándékoz a vitorlásnak. Nem a lassú, tétlen rothadás martalékává válik, hanem a folyó ereje ragadja el, semmisíti meg, melyen kormányosa segítségével korábban mindig sikerült úrrá lennie. A folyó kétszer elengedte zsákmányát, harmadszorra azonban végzett vele, de nem engedte át egy újabb ellenség, az idő és a feledés kezébe. Valójában ez magának a regénynek a csatája is, mely a természeti erők és a felhasználásukra tett emberi kísérletek léptékeit ábrázolja $A$ folyók városában, s letűnt korszakainak emlékképeit átmenti a regények örök idejébe.

${ }^{297}$ AFV 298. 0. 


\section{IV. Összefoglalás: történelem az irodalomban}

Mequinensa esetében a történelem és az irodalom közötti kapocs az emlékezet, hiszen, mint a korábbi fejezetekben láttuk, a történeti monográfia gyakran fordul a közösségi emlékezethez a hiányos levéltári adatok pótlására, Moncada müveinek forrása és sok esetben központi témája is a város közösségi emlékezete. Ennek a regényeken kívül a legérzékletesebb kifejeződése az Aragón Irodalmi Nagydíj átadó ünnepsége volt, amikor az író úgy beszélt Mequinensáról, mint a társszerzőjéről. ${ }^{1}$

\section{Sikeres katalán emlékezetregények az 1980-as években}

Spanyolországon belül több ideológiai és nemzeti alapon elkülönülő emlékezeti közösség él, Moncada tehát egy problematikus, élő, mozgásban lévő területet jelenít meg irodalmi alkotás formájában. Emlékezetregényeiben egy baloldali beállítottságú, nemzeti identitás tekintetében kettőséget mutató, aragóniai katalán munkásváros rajzát tárja elénk. Az emlékezetregények fogalma a spanyol irodalomtörténetben a polgárháború traumájának fikciós feldolgozásához kapcsolódó művekre utal, mely kategóriába $A$ folyók városa ugyan beilleszthető, hiszen az író kutatásai, és oral history formájában készített interjúinak fikcionalizált feldolgozása kiegészítő információval szolgál a város korabeli történetére vonatkozóan. A regény emléktérképe azonban egy sokkal hosszabb időtartamot ölel fel, középpontjában pedig egy újabb keletű tragédia áll, a régi-Mequinensa és az évezredes folyami kultúra drasztikus eltörlése a modern kor fejlődése által.

A folyók városa 1988-as megjelenésekor a kritika meglepetéssel állapította meg, hogy milyen hatalmas sikere $v^{2}{ }^{2}$ közönség és kritika körében egyaránt. A modernitás és a nagyváros dicséretét váró kritika számára igen meglepő volt az is, hogy az 1980-as évek nagy könyvsikereit egyértelműen a „rurális” irodalomnak bélyegzett alkotások könyvelhették el maguknak: Maria Barbal, Pedra de tartera (Kö a görgetegben), Emili Teixidor, Retrat d'un assasí d’ocells (Egy madárgyilkos arcképe),vagy Moncada Camí de sirga ${ }^{3}$ c. regénye, és

\footnotetext{
${ }^{1}$ 2005-04-19 Diario de Teruel - No importa en que lengua escribas sino lo que hagas con ella. El escritor catalanoparlante considera a Mequinenza coautora de su obra; Eva Ron.

2 1988-09-01 El Urogallo - El auge de la narración Escrito en catalán; 1991-11-14 El Observador - Ante el balance de una década, Josep Maria Ripoll.

3 1988-10-11 La Vanguardia - El camí de la normalitat. Premis; 1989-10-01 El Urogallo - El año de Jesús Moncada, Quim Aranda.
} 
Moncadát nemzedékének egyik legjobb írójaként emlegetik. ${ }^{4} \mathrm{Az}$ írói hagyatékban találtam egy Maria Barbal által írt, és Jesús Moncadának elküldött konferenciaközleményt, mely a Ribagorçana elnéptelenedésének az irodalomra gyakorolt hatásáról szól, s amelynek bevezető soraiban az írónő A folyók városa utolsó, Végső számüzetés címü fejezetéből idéz. Az előadás záró sorai az írónő Càmfora című regényének végszavát visszhangozzák: „ki vagyok én Barcelonában?”. ${ }^{5}$ Barbal nyilvánvalóvá teszi ebben az előadásában, hogy azok hangját szólaltatja meg, akik már csak az ő emlékezetében élnek, regényei a modernizáció következtében a vidékröl a nagyvárosba vándorolt, gyökerüket vesztett emberek, új irányt kereső fiatalok, és az emlékeikbe, az eltünt idők képeibe kapaszkodó öregek portréi.

A vidék kiürülése és nagyvárosokba vándorlása hosszú ideje elkezdődött folyamat Spanyolországban, melynek végpontjai a 60-as években Madrid, Barcelona, Bilbao vagy Európa fejlettebb vidékei. ${ }^{6}$ Ennek az elvándorlásnak a mértékét jól érzékeltetheti Aragónia 1982ben született Autonómia Statútuma, mely (Előzetes Cím 6. cikkely, 2. bekezdés b) pont) kimondja, hogy: az aragón politikai hatalom egyik fö feladata olyan rendelkezéseket hozni, amelyek megakadályozzák az aragónok elvándorlását (a szöveg az exodus kifejezést használja). ${ }^{7}$ Nem csak az ipar által felszívott munkaerő kerül azonban a nagyvárosokba, hanem a továbbtanuló, intellektuális horizontját szélesíteni akaró értelmiségi réteg is. Nekik köszönhetjük ezeket a méltán nagy sikernek örvendő, és a társadalomban nagy visszhangot keltő emlékezetregényeket. Barbal és Moncada sorsában ez a közös motívum, nyilvánvalóan erre utal a Moncadának ajándékba küldött Barbal szöveg is a regényekből vett idézetekkel. A téma aktualitását a regények sikere mutatja. A modern nagyvárosokba emigrált tömeg leszármazottai a múlthoz való kötődést nem a hagyományok fenntartá-

\footnotetext{
${ }^{4}$ 1991-05-27 El Temps - Entrevista a Miquel Martí i Pol, L’essencial es diu amb sencillesa; 1991-05-01 L'Alè - Entrevista amb Ferran Torrent, Mercè Biosca; 1991-06-08 Avui - Entrevista amb Xavier Folch i Pep Blay, David Castelló.

${ }^{5}$ MCSL Revista Ripacurtia, 2005 május 11. Maria Barbal.

${ }^{6}$ Alfaya, Javier, Crónica de los años perdidos, La España del tardofranquismo, Madrid, Temas de Hoy/Colección Historia Viva, 2003. Ernst Breisach meghatározása szerint Európában a vidéki lakosság ipari központokba vándorlása olyan léptékü volt, hogy azzal összehasonlítva a híres germán népvándorlás szinte semmiségnek tünt. Breisach, Ernst, Historiográfia, Osiris Kiadó, Budapest 2004. 277. o.

${ }^{7}$ http://noticias.juridicas.com/base_datos/Derogadas/r1-lo8-1982.tp.htm, letöltés 2015. márc. $15 . \quad$ Julio Llamazares, Lluvia amarilla (Sárga eső) című, 1988-ban megjelent regénye az oscai Pireneusok egy kis falujának utolsó lakosáról szól. Mercè Ibarz, La terra retirada (1993) című (riport)regénye a vidék és város kapcsolatát, a vidék ellehetetlenülését tárgyalja. Antonio Muñoz Molina, Beatus Ille (1986), és El jinete polaco (1991) című regényei szintén tekinthetők úgy is, mint a modernizáció sodrában hátramaradt andalúz kisváros, Mágina portréi. A vidék elnéptelenedésének problémája a mai napig fennáll a katalán-aragón határ mindkét oldalán. L. $\quad$ www.elpuntavui.cat/territori/article/6-urbanisme/1103144-la-despoblacio-amenaca-els-poblesrurals-i-de-muntanya.html, letöltés 2017. nov. 2. és https://www.eldiario.es/aragon/sociedad/Aragon-afrontadespoblacion-oportunidad-futuro_0_655484680.html, letöltés 2017. nov. 2.
} 
sán keresztül valósítják meg, hanem egy új közegben, a könyvben találnak rá szüleik emlékeire.

\section{Absztrakt történelmi téridő, versus érintettséget elöidéző irodalmi téridó}

Maurice Halbwachs, francia szociológus, a történelmi időt olyan mesterségesen kreált, absztrakt időnek tekinti, amely kioldódott az élet valódi, tér és idő tekintetében konkrét érintettségéböl. Paul Ricoeur meghatározása szerint a történelem azt próbálja elhitetni velünk, hogy létezik egy jelen és jövő vonatkozásaitól független történelmi érdek. A két gondolkodó különböző megfogalmazásba azt jelzi, hogy a történelmi tér és idő egy történettudomány által létrehozott viszonyrendszer, melynek szereplői már nem az emberi színjáték érzelmek, vágyak, bünök és gyötrelmek által irányított figurái, hanem csakis a történelmi mozgások, változások bemutatására hivatott alakok.

Ezzel szemben az emlékezet, mely látni engedi a tapasztalattér és az elváráshorizont kapcsolatát, alkalmas arra, hogy visszakapcsolja a történelemtudósok tárgyát az élethez. ${ }^{8}$ Ezt jelzi A folyók városában a Moncada által totális regénynek nevezett időkezelési technika, amely által a pusztulásra ítélt város tragédiájából indul ki és tér vissza minden elmesélt történet, emlékezetszál mentén. A folyók városa időszerkezetéről Moncada így nyilatkozott: ,a regény elvesztette volna az erejét és a hatásosságát, ha időrendi sorrendben építem fel a cselekményét”. ${ }^{9}$ Utaltunk rá, hogy a regény egy öreg hajós visszaemlékezéseiből nőtt ki, az emlékezés kiváltó oka pedig a halál, a pusztulás. „A folyók városa saját gyerekkorom és ifjúságom regénye is [...], mely eltünt, megsemmisült. [...] Ez a kollektív emlékezet az én generációmmal együtt el fog tűnni.” „Nem volt elegendő, hogy elmeséljem egy víztározó építés miatt elsüllyesztett település problémáját. Az egy halott és hideg mű lett volna. Nem szociológiai értekezést akartam írni.”11 A regényben alkalmazott flash back technika képes megmutatni a város halálának fájdalmát, egy közösséget önnön múltjával összekötni és érintettséget megvalósítani. Ezért ez a forma alkalmas arra, hogy a történelmi tények mellett elbeszélje és kifejezze a tragédiát is. Ugyanezt a célt szolgálja az olvasót a rombolás közepébe állító nyitómondat is. Ez a hangsúly teszi lehetővé az olvasó számára, hogy részese legyen a közösség összekapaszkodásának és a gyászának, vagyis a regény nemcsak tar-

\footnotetext{
${ }^{8}$ Paul Riceour, Emlékezet - felejtés - történelem, in Narratívák 3. A kultúra narratívái, Kijárat Kiadó 1999.

9 1996-06-01 Serra d'Or - Jesús Moncada novellar l'absència, Marta Nadal.

101988 04. 09. ABC Catalunya - Camí de sirga recupera la memoria colectiva de Mequinenza.

11 1988-04- 07 El País - „Destruir una vila és destruir una memòria”.
} 
talmában, de egész formájában a tragédia elmesélésére szolgál, amit a felidézett múlt napfényes és vidám képei még inkább kiemelnek. ${ }^{12}$ A regényben alkalmazott időkezelési technika másik sajátossága a tanító funkció, mert az ismert és az ismeretlen arányos adagolásával a helyi történelembe beleszövi az ország és a kontinens történelmét, így kap a helyi történelem európai beágyazottságot.

A Moncada regény megmutatja az emlékezet jelenhez kötöttségét, részrehajló, töredékes, szubjektív természetét, s felvállalja annak megmutatását is, hogy egy történet hány rétegböl, hány különböző emlékezetből áll össze. Ennek kihangsúlyozására szolgál például $A$ folyók városában a bányászsztrájk képének felidézése egyrészt Nelson, másrészt Carlota cselédjének emlékeiben, ahol ugyanabban a téridőben két különböző emlékezetet ábrázol. A regény terében nyilvánvalóan elkülönül a kávéház-kaszinó törzsközönségei által szimbolizált, az emlékek különböző országaiban élő két Spanyolország. Moncada a bevezető fejezetben felhívja a figyelmet a városi krónikák (a város népe által a pusztulásról alkotott narratíva) torzító hajlamára, ami által a város a Történelem színe előtt próbálja igazolni magát. Ezzel arra hívja fel a figyelmet, hogy a képzeletbeli „megrendelő”, a történelem ítélőszéke, milyen kívánatos cselekményesítési módba illeszti a történetet: tragédia, áldozati narratíva. A regényben sok helyen találkozunk a patikus józan magyarázataival és ironikus kommentárjaival is, melyek a mesés, népi legendaképző mechanizmusokat hivatottak leleplezni. ${ }^{13}$

A tudományos történetírás lapjaira csak a történelmi közösség szempontjából fontos események kerülnek $^{14}$, a regény ezzel szemben a hétköznapokat ábrázolja, melyek a maguk tipikusságában szintén törvényszerűek, Jesús Moncada Mequinensát jellemző szavaival: „Itt, titkár úr, az egyetlen hihető és elérhető örökkévalóság, az a hétköznapi élet.”15 A Moncada regények a megélt történelmet rajzolják elénk, amely a legtöbb ember osztályrésze, hiszen a nagybetűs történelem fó és mellékszereplői is kevesen vannak a

\footnotetext{
${ }^{12}$ Ugyanezt a technikát alkalmazza Ramon Sender, Requiem egy spanyol parasztért című regénye is, melyben a jelen fájdalmas pontjába, az igazságtalanul meggyilkolt malmos Paco halálának első évfordulójára mondatott miséhez tér mindig vissza a történet, melyben az író elmeséli a főhős életét és a gyilkossághoz vezető okokat. Az aragón vidék ábrázolásában ugyanazokat a pontokat emeli ki, mint Moncada: tudatlanság, politikai tájékozatlanság, egyház és hatalom szoros összefonódása, törvényes igazságszolgáltatás hiánya, erőszak.

${ }^{13}$ AFV 208-9. o. A szaxofonos hajóács állítja, hogy Carlota de Torres gyászruhájának feketeségét a Nicanor de Sansa ház lerombolásából származó por tette szürkésfehérré, ami valójában Nicanor síron túli bosszúja azért, mert Carlota apja az ő franciaországi számüzetésben bekövetkezett halála után, adósságok fejében elvette özvegyétől és három árvájától a házat. A patikus szerint a szélnek nincs erkölcsi érzéke, fényképes bizonyítékot is mutat a hajóácsnak, pedig legszívesebben elhinné, amit az mond.

${ }^{14}$ A klasszikus és konzervatív történetírásnak egészen a posztmodern korig tartó vonulata a hierarchia megörzésére törekedett azzal, hogy kijelölte, mi számít emlékezetre méltó történelmi ténynek. L. Lionell Gossman, „Anekdota és történelem” in Kisantal Tamás (szerk.), Narratívák 8. 217-249. o.

${ }^{15}$ Moncada, Jesús, Calaveres atònites, Barcelona, La Magrana, 1999. mottó.
} 
tömegekhez képest, akik figyelik, átélik, és csupán statisztálnak hozzá. Az egyszerü emberek történelmét inkább az irodalom rajzolja ki. Amikor a történelem próbálja rögzíteni az ő dokumentálásra érdemtelen sorsukat, akkor a statisztikai közgazdaságtan és a demográfia módszereinek és tudományos eszközeinek átvételével, a nagy átlagok megmutatása révén igyekszik ezt megtenni. Walter Benjamin, a nácizmus fenyegetése elől menekülő német-zsidó filozófus síremlékének feliratán, Portbouban a következő áll: „Sokkal fáradtságosabb munka tiszteletben tartani a névtelen lények emlékét, mint a híres emberekét. A történetírásnak fel kell vállalnia azok emlékének a megőrzését, akik nem képesek hallatni a hangjukat.”16 Ugyanezt a gondolatot közvetíti Miguel de Unamuno intrahistoria fogalma, mely úgy aránylik az historiához, mint a történelem nélküli emberek millióinak csöndes élete a az újságok tudósításaiban szereplő jelen történelmi pillanathoz. A baszk filozófus a mindennapi, örök munkát, a belső történelmet, a zátonyépítő korallok munkájához hasonlítja, ami a történelem kiemelkedő szigetecskéinek alapját képezi, s örökké jelen van. ${ }^{17}$ Ezt a névtelen, az évszakok és a munka örök ismétlődésében zajló életet Carlo Levi neorealista regénye - Moncada egyik kedvenc olvasmánya - mint a történelem nélküliség állapotát írja le. A regény címe Krisztus megállott Ebolinál ${ }^{18}$ szintén erre utal, s azt jelzi, hogy a keresztény civilizáció nem ért el Lucania eldugott falvaiba, ahol az embereknek nincs történelme, vallása, politikai tudata, létük célja a túlélés, amit a rezignáció biztosít. Az író felvállalja a történelem névtelenjei sorsának megörökítését, mint Danilo Kiš A holtak enciklopédiájában. ${ }^{19}$ A szerb író novellájának víziója szerint e nagy könyvben Isten minden teremtménye szerepel, kivéve a híres embereket, akiknek van történelmük, ezért már feljegyezték őket, míg az enciklopédiában jegyzett emberek névtelenül éltek a történelem árnyékában.

Jesús Moncada Mequinensa mítoszának főszereplői az időtlen rétegek hétköznapi figurái, akiknek az író rajzolja meg a történelmét. Különleges kronológiai technikájával és asszociatív képeivel a városka eseményeit történelmi tényekké alakítja, és bekapcsolja a katalánspanyol-európai összefüggések rendszerébe. Ennek épp azért van különleges jelentősége, mert a nemzeti és a nemzetközi történelem lapjaira ez a hely sosem került volna fel alanyi

\footnotetext{
${ }^{16}$ Idézi Riera, Carme, La mitad del alma, Madrid, Alfaguara, 2005. 213. o.

${ }^{17}$ Miguel de Unamuno, En torno a casticismo, 1895, idézi Csejtei Dezső, A spanyol egzisztencializmus története, Unamuno és Y Gasset filozófiájának fó kérdései, Budapest, Gondolat, 1986. 106-108. o.

${ }^{18}$ A regény eredetije Levi, Carlo, Cristo si è fermato a Eboli, mely magyarul Krisztus megállott Ebolinál (Kriterion) és Ahol a madár se jár (Szikra) címen is megjelent. Az általam használt Edmon Vallès által készített katalán fordítás, Rosa Maria Moncada ajándéka: Levi, Carlo, Crist s’ha aturat a Ėboli, Barcelona, Vergara, 1964. 11-12. és 74-75. o.

${ }^{19}$ Kiš, Danilo, A holtak enciklopédiája, Budapest, Európa, 1990.
} 
jogon. Nézőpontja és történelme ábrázolásához egy speciális adottságú krónikásra volt szüksége, aki nem csak helyspecifikus adatokkal, hanem széleskörü európai müveltséggel is rendelkezett, s képes volt kirajzolni e vidéki kis közösség történelmének ívét, s ezáltal biztosítani identitása narratív megerősítését. A regényen keresztül Mequinensa sorsának történetét a kisvárosénál sokkal tágabb olvasótábor örökölte meg, s a 125000 eladott példány azt jelzi, hogy a mü nem csupán helytörténeti jelentőségü.

\section{A megteremtett táj}

A Mequinensa száz évének történetét felölelő regény, a Camí de sirga nagyon meglepő volt az olvasók számára, mert egy Spanyolországban, s azon belül Katalóniában is igen ritka folyami kikötö ${ }^{20}$ kultúrával rendelkező, ipari települést ábrázolt, amely addig hiányzott a katalánok szellemi térképéről. A Moncada müvei nyomán születő érdeklődés miatt fókuszba került terület ${ }^{21}$ igen hálás ezért, amit a nyugati katalán vagy aragóniai területek sajtójában található cikkek, interjúk sora bizonyít. Ezek kiemelik, hogy: „az Ebro nem tartozik a mítikus katalán tájak közé [...] nem vagyunk se müvelt barcelonaiak, se germán gyökerekkel rendelkező pireneusiak, s nem hordozzuk a sós tenger görög kultúráját sem. Igazság szerint, jóformán nem is létezünk”. ${ }^{22}$ A katalán olvasók körében ezt a mellőzöttséget $A$ folyók városa megjelenése szüntette meg. A regény mítikus mélységet és szépséget kölcsönzött e tájnak, s így az Pla l’Empordajához, Vilallonga Mallorcajához, Rodoreda Barcelonájához hasonlóan beépült a szélesebb köztudatba, mivel a narráció valóságteremtő képességgel bír. A Moncada életmü kiteljesedésével született meg, s vált irodalmi közkinccsé a Mequinensamítosz. ${ }^{23}$ Moncada számára is hatalmas meglepetés volt, hogy az olvasók csak A folyók városa megjelenése után, a regény által teremtett világnak köszönhetően fedezték fel, hogy az

\footnotetext{
${ }^{20}$ Bilbaót és Sevillát tartják Spanyolországi két nagy folyami kikötőjének. Mivel Spanyolországban a folyók vízhozama évszakonként igen változó, ez nem teszi lehető az egész éven át tartó hajózhatásukat.

${ }^{21}$ Chauvell, Josep-Anton, „La literatura a la Franja de Ponent”, in Fronteres, territoris, mites, 3er Encontre de creadors, Lleida, 18-19-20 d'abril de 2001, Guerrero, Manuel - Pont, Jaume (dir.), Ajuntament de Lleida i Pagès Editor, 2001, 159-162. o. A szerző úgy határozza meg a területet a katalán irodalmon belül, mint a periféria perifériáját.

22 2003-09-01 Árnica - Revista del consell Cultural de les Valls d'Aneu, Andreu Carranza.

23 1989-02-01 Serra d'Or 351 - Aproximación a la obra de Jesús Moncada, Mercè Biosca; 1989-05-29 El Temps - Jesús Moncada Després de Camí de sirga. Entrevista, David Castillo; 1992-03-28 Avui - Jesús Moncada ressegueix un camí enigmàtic amb un complex final, Isidor Cònsul; 1995-09-01 Tresmall - Terres de l’Ebre Entre el desig i la realitat Conversa amb Jesús Moncada, Pilar Romera i Emili Rosales; El mite de Mequinensa, Carme Abril.
} 
Ebro átfolyik Katalónián. ${ }^{24}$ A világról alkotott képzetünk tapasztalatainkon túl irodalmi és történeti szövegekből, s a kultúra egyéb, általunk elsajátított megjelenési formáiból áll. A megtörtént dolgok káoszából kimetszett irodalmi Mequinensa az ország értelmiségi rétegének tudását, érvkészletét gyarapította, és hivatkozási ponttá vált, például a vízerőmü építkezések, a vidék elnéptelenedése, Mequinensa helytörténete vagy a katalán irodalmi nyelv kapcsán. Jesús Moncada regényei nélkül ez a terület továbbra is teljesen ismeretlen volna a müvelt köztudat számára, s a Mequinensával foglalkozó helytörténeti munkák megjelenési idejéből az valószínüsíthető, hogy a helytörténészek érdeklődését is a regények, és azok sikere keltette fel saját településük iránt.

\section{A szemtanú irodalmi emlékezethelyet alkot}

Jesús Moncada ifjú- és fiatal felnőtt korában tapasztalta meg a városát elpusztító mequinensai építkezések (1957-73) okozta félelmet, bizonytalanságot, az otthontalanságtól való szorongást. Szemtanúként, a helyhez ezerszálú szeretettel kötődő tanúságtévőként írja le a folyamatot, kiemelve ezzel Mequinensát a sokszáz, sorsában osztozó település közül: „Végigkövettem a tizenhárom évig tartó folyamatot, és láttam, amikor lerombolták az első házat. A folyók városa lapjain nem csak erre koncentrálok, hogy a könyv ne legyen egy elviselhetetlen rémálom.” ${ }^{25}$ A regény tehát alkotójának irodalmi formában megkomponált tanúvallomása. Paul Ricoeur számára a tanú kulcsfigura a történelemben, hiszen ő a hitelesítő kapocs a jelen és a múlt közt, akinek emlékezete maga a történelem tárgya, ami „nem a múlt és nem az idő, hanem az időben létező ember". ${ }^{26}$

A történetírás konvenciói nem teszik lehetővé, hogy a történelem népek és milliók sorsát meghatározó eseményeket humoros formában ábrázoljon. Az irodalmi tanúságtétel azonban a megjelenítési módok szélesebb tárházából válogathat, mert belülről teremti meg a regény világát, és élhet a történelem elszenvedőinek nagyszerü fegyverével, a humorral. A humor nem egyenlő a komolytalansággal, hanem valóban fegyver, amelynek segítségével a történelem cselekvő erőinek kitett, makro szinten cselekvésképtelen, hétköznapi ember kialakíthat magának egy saját, magasabb szabadságfokú játékteret, amelyen belül kinevetheti az életét megnyomorító hatalmakat. Az egyetlen emlékezetregény formában megszületett iro-

${ }^{24}$ 1995-09-01 Tresmall - Terres de l'Ebre Entre el desig i la realitat Conversa amb Jesús Moncada, Pilar Romera i Emili Rosales.

${ }^{25}$ 1988-06-20 Avui - Jesús Moncada en el camí de la vida, Anna Cabeza.

${ }^{26}$ Ricoeur, Paul, La mémoire, l’histoire, l’oublie, Paris, Éditions du Seuil, 2000, 214. o. 
dalmi tanúságtétel, amely párhuzamba állítható A folyók városával, az Julio Llamazares, Distintas formas de mirar el agua (A víz szemlélésének különbözö módjai) címü regénye. Ezt olvasva nem lehetünk eléggé hálásak Moncadának, hogy általa nem a város temetésén, hanem a torán vehetünk részt, ahol ott van ugyan a halál torokszorító pillanata, de a felidézett boldog múlt, a méltón megőrzött emlék feloldást ad, amit nagyban elősegít a humor böven áradó ereje. Moncada képes egyensúlyt teremteni a gyász és a nevetés között a regényeiben, s az általa humorral megörökített tények egy sajátos civil bosszúként, rendszerkritikaként értelmezhetők a Franco rendszer durvaságával, műveletlenségével, igazságtalanságával és álszentségével szemben.

A fikciós formában megírt történet-tanúságtétel irodalmi emlékezethelyet alkot, mely képes megőrizni az egyedin túl az általánosat, vagyis Mequinensa pusztulásának regénye őrzi és ápolja a többi hasonló sorsra jutott település emlékét is. Művészi értékeinek köszönhetően fontos láncszem a hagyományok továbbörökítésében. Az ősi mesterségek, a folyók, és a város megszüntek létezni, de emlékezetüket az író méltósággal áttelepítette irodalmi létformájába, ahonnan újra megtermékenyítő erőként képesek hatni az olvasók és más alkotók közt. A cikkek, kritikák és olvasói levelek tanúsága szerint a Mequinensa mítosz nemcsak a mequinensai vagy a víztározó-építkezések által érintettek számára nyújt alternatív irodalmi emlékezetet, hanem minden ebrói, belső katalóniai, emigrációs szindróma által érintett vagy a köztársasági emlékezetet hordozó olvasó számára is.

\section{Történelmi megértés azonosulás útján, az egyedi és az általános viszonya}

A Poétika IX. könyvében Arisztotelész szükségesnek látta, hogy a „szavak művészetén” belül megkülönböztesse egymástól a történelmet és az irodalmat: „az egyik megtörtént eseményeket mond el, a másik pedig olyanokat, amelyek megtörténhetnének. Ezért filozofikusabb és mélyebb a költészet a történetírásnál, mert a költészet inkább az általánosat, a történelem pedig az egyedi eseteket mondja el.” ${ }^{27}$ A poesis (alkotás, játék) lényegfelmutatás, önmegmutatás, míg a historia (kutatás) adatok, tények, egyedi események koherens sorba rendezése, melynek telosa az „ahogy valójában történt” megmutatása. Paul Ricoeur meghatározásában a történeti és a fiktív beszámoló közti különbség alapvetően az olvasókkal kötött megállapodásban keresendő, mely szerint a történeti beszámoló az, amelyről az olvasó azt feltételezi, hogy megfelel a múlt tényeinek, ez azonban nem egy valóságos,

\footnotetext{
${ }^{27}$ Arisztotelész, Poétika IX. könyv, Szeged, Lazi Könyvkiadó, 2004. 24-25. o.
} 
hanem egy egyezményes alapon elfogadott megfelelés. ${ }^{28}$ A fikció nemcsak tényeket tartalmaz, hanem szereplők, terek és történetek által megjelenített érzelmi és morális ítéleteket is, és igazságkritériuma akkor teljesül, ha harmonizál az olvasó ítéletével, s nem mond ellent durván a valóságreferenciának. Moncada is a tényekből indul ki: „A regény valódi történelmi eseményeken alapul, de az, ahogyan látjuk ezeket az eseményeket, már az irodalmi fikció területe.”, vagy „Feltétlenül el akartam kerülni, hogy szereplőim valódi személyekkel legyenek azonosíthatók”. ${ }^{29}$ Vagy másutt: „Ha egy település száz évét akarjuk elmesélni, a történelmi eseményeknek nyilván nagy jelentőségük van. Engem azonban nem azért érdekelnek ezek az események, amiért a nagybetüs történészeket, hanem azért mert hatással vannak a szereplőim életére [...] Végül is, a regény központi témája az ember.”30 Ezért a „megtörténhetett volna” típusú fikciós tények is fontos mondanivalót közvetítenek a város közösségének politikai, ideológiai beállítottságára vonatkozóan. Az Estremida memòria záróképében elpusztul a mequinensai temető közepén álló, hivalkodó, hatalmat sugárzó mauzóleum, amelyet a kacika családja építtetett. 1938-ban egy becsapódó köztársasági lövedék rombolja le. A temetőnek, és a sírok elhelyezkedésének fontos, jelképes értelme van, mint azt A folyók városa Carlota de Torres temetési temetési menetének ábrázolásakor leírja „elindult felfelé, a temető irányába, ahol földi maradványai a főtéri ház megfelelőjéből, a családi kriptából elnökölhetnek a csend városa felett”. ${ }^{31}$ A regény terében a síremlék a kacika hatalmát és a városka társadalmát kettéválasztó óriási társadalmi szakadékot jelképezte. Pusztulása a regény végén csakúgy, mint Jaume de Torres úr pompás temetésének megszégyenítő bohózatba fordulása $A$ folyók városában, az író fikciós elégtétele a valóságon. Az Estremida memòria nem arról tudósít, hogy hol állt pontosan, mikor és hogyan pusztult el a mauzóleum, melyet valóban ledönthetett volna egy köztársasági lövedék, hanem arról, hogy az író által képviselt plebejus emlékezet gyülöletes intézménynek tartotta a kacikizmust. A regény lehetőséget ad az olvasóknak, hogy átérezzék a kacika hatalma előtti kiszolgáltatottságot, tehetetlenséget, s elégtételt kapjanak, amikor a fikciós emlékezeti térben elpusztul hatalmának jelképe.

A nem történeti-kritikai megjelenítés ellenére azonban a katalán sajtóban a Moncada regényekkel kapcsolatban gyakran találtam olyan kijelentéseket, hogy „Ha valaki Mequinensa

\footnotetext{
${ }^{28}$ Paul Ricoeur, i.m. 366.o.

29 1988-06-01 Lletra de Canvi - Entrevista amb Jesús Moncada, Josep Maria Ripoll.

30 1988-06-01 Llibrería 122 - Entrevista a Jesús Moncada, alquimista del temps, Joan Peña.

${ }^{31}$ AFV 297. o. L. Mellékletek. Képek, térképek. 10. Fénykép a városról a temetőből a Camí de sirga borítóján. 
történelmét ismerni akarja, feltétlenül olvasnia kell A folyók városát”32, vagy „A La galeria de les estàtues egyike azoknak a regényeknek, amelyek minden történelmi vagy szociológiai értekezésnél jobban képesek voltak összefoglalni egy egész korszak ellentmondásos valóságát.” 33

A Moncada regények ezt a hatást az által érik el, hogy egy korábban meg nem jelenített helyi történelemnek adnak hangot, melynek nemcsak a föszereplői és tényei voltak korábban ismeretlenek, hanem az a gondolati, ideológiai hagyomány is, amelyet ábrázol, s amelyben az emberek a maguk történetére ismerhetnek. Ezt a felismerést megkönnyíti az irodalmi forma is, amely lehetővé teszi, hogy az olvasók résztvevőkké váljanak, s személyes igazságérzetükhöz és történelmi tapasztalatukhoz kössék a regény történetét. Ezért tudnak a jó irodalmi művek katarzist előidézni az olvasóban, ami az érzelmi kötődést kizáró tudományos történeti munkák olvasása közben nem ragadja el őket. Erre utal Nietzsche is 1873-ban született történelemkritikájában: „Morálisan kifejezve: a fenségest nem sikerül immár megtartanotok... Mert a müvészet messzire szökik, ha tetteitek fölé nyomban a történelem sátortetőjét feszítitek. Aki ott akar rögtön megérteni, kiszámítani, felfogni, ahol hosszan tartó megrendültségben kellene az érthetetlent fenségesként őriznie”. ${ }^{34}$ A nietzschei kritika a „tudomány és művészet között” álló történelemtudománynak a tudomány útjára való áttérését, s az abból adódó veszteséget rögzíti. Ennek pótlására, a történelem tudománnyá válásának nyereségei - széles távlatok, rendszer, sine ira et studio ábrázolásmód - mellett ajánlott a korszakkal kapcsolatos irodalom ismerete, mely a kor belső, érzelmi és morális emlékezete. Egy jó regény valójában az örök emberi dráma megfogalmazása egy bizonyos kor és hely nyelvén. Egy különleges formájú, müvészi kalauz, mely lehetővé teszi, hogy a szereplőkkel való azonosulás révén szerezzünk ismereteket, s hogy a történelem tárgyát könnyebben a magunkénak érezhessük.

A Moncada regények önmagukon túlmutató jellege teszi lehetővé, hogy korokon átívelő társadalomkritika hangjait halljuk ki belölük, hiszen, mint Moncada nyilatkozta, az író valamiképpen mindig saját életét írja meg. Az író társadalmi érzékenységének ékes bizonyítéka, hogy a regényei épp azokat a motívumokat járják körül Mequinensa mikrokozmoszában, amelyek a spanyol társadalomfejlődés regényben ábrázolt korszakának kóros jelenségei. A Mequinensa mítosz fontos alkotóeleme a húszas években meggyilkolt bá-

\footnotetext{
32 1988-04-19 El Punt Diari de Girona - Sirgant tartera, Jordi Vendrell.

33 2005-06-18 La Vanguardia - Moncada, Anton M. Espadaler.

${ }^{34}$ Nietzsche, Friedrich, A történelem hasznáról és káráról, Budapest, Akadémiai Kiadó, 1989, 54. o.
} 
nyászvezér alakja, aki ezáltal ennek a gondolati vonalnak a mártírjává, fő vonatkoztatási pontjává válik. Moncada az ő regénybeli történetén keresztül értelmezi a spanyol politikai élet jellegzetességeit: vidéki nyomor, politikai gyilkosságokban megnyilvánuló erőszak, közrendi problémaként kezelt politikai konfliktusok, társadalmi szakadék, tudás és müveltség hiánya az alsóbb néposztályok körében, s ebből fakadó teljes politikai tájékozatlanság, az igazságszolgáltatás politikától való függése, egyház és állam szoros szövetsége, az emlékezetpolitika hiányosságai, a csendőrség, a fegyveres erők túlhatalma. A bányászvezér meggyilkolása a magyarázat a regényben a polgárháború egyik véres helyi eseményére is, amit a helytörténeti monográfia adatai is megerösítenek oral history közlésekre hivatkozva. A regény azonban csak mellékesen említi a polgárháború idején történt, dokumentált politikai gyilkosságot, mint a köztársasági emlékezet mítizált mártírfigurája melléktörténetét. Az interjúkban szereplő bányászvezér az asztúriai Blanco, a regényben Arnau Terrer néven szerepel. Mivel ő az, aki írni-olvasni tanítja az egyszerü munkásokat, s a sztrájk okozta zavargások bünbakjaként gyilkolják meg, úgy vélem, a névadás tisztelgés a híres, katalán anarchista pedagógus, Francesc Ferrer i Guàrdia emléke előtt (Ferrer-Terrer). Ferrer i Guàrdiának szintén az okozta a vesztét, hogy az általa alapított iskolákkal és kiadókkal kívánta felszámolni a nép tudatlanságból fakadó történelmi hátrányát. Igazságtalan mártírhalálának történelmi tényét szintén kiemeli a regény. Moncada a fikció által párhuzamot von a mequinensai orvgyilkosság és a barcelonai kivégzés között.

\section{Mequinensa kollektív emlékezete, mint irodalmi mítosz és identitásképzö tényezö}

A Moncada által felgyüjtött és irodalmi formába öntött szóbeli emlékezettel kapcsolatban az egyik cikkíró épp azt a kérdést teszi fel, ami engem a kutatásra indított: „Moncada életműve ösztönzőleg hat-e az emlékezet rögzítésének munkájára, s a történészek tesznek-e erőfeszítéseket ezen a téren?”35 Az életmü kritikai értékelése során konkrétan felmerült történelem és irodalom kapcsolata is: „A történelmet az irodalomtól a stílus különbözteti meg. S a jó regények esetében a fikció majdnem mindig több valóságot tartalmaz, mint a történelem. De legalábbis nehezen találhatnánk olyan történelemkönyvet, amelyböl többet megtudhatnánk Mequinensa városáról, mint ebből a könyvből.”36 Aki egyszer ily módon „beköltözött” a városba, az bizonyára igazat ad a cikkírónak. Moncada azt vallja, hogy a

\footnotetext{
${ }^{35}$ Uo.

36 1988-03-24 El País - Vida perdurable. Camí de sirga, Dolors Oller.
} 
„totális regény” 37 megírására törekszik, egy elveszett világot akar belesűríteni egy koherens irodalmi modellbe, hiszen mint egy másik interjúban vallja, „sosem vagyunk csak a jelen [...] (ennek) dolgait rengeteg múltbéli esemény határozza meg, ami mélységet ad ennek a jelennek, s nemcsak a mienknek, mert valójában a múlt hálójának egy pontja vagyunk”. ${ }^{38}$ Ez a moncadai elképzelés az emlékezet müködéséről teljesen egybecseng a Maurice Halbwachs által az 1920-as évek végén ${ }^{39}$ kidolgozott fogalommal, melynek értelmében a kollektív emlékezet nem az egyéni emlékezetek összessége, hanem eleve társadalmilag strukturálódik. Létezik egy személytelen emlékezési folyamat, melyben az egyes ember különböző vallási, társadalmi, rokoni kapcsolódásai, vagy gazdasági, érzelmi érdekei mentén vesz részt. Saját múltunk felidézéséhez gyakran van szükségünk mások emlékeire, azaz egy társadalmi keretre, hiszen soha nem egyedül emlékezünk. Amikor eltűnik egy életmód, egy szakma, egy társadalmi osztály, azzal a történelemből kiesik az ő emlékezetvonaluk. Moncada regényei egy korábban még nem ábrázolt hely, kor, mesterség és életmód képét őrzik. Erről a közösség emlékezetének krónikása így vall: „Az emlékezet asszociációk révén müködik, amikor kezded gyüjteni a saját emlékeidet, rájössz, hogy másokét is gyüjtöd, s kezd kialakulni egy háló, ami egy egész közösség emlékezetét fonja egybe.” ${ }^{40}$ Mequinensa asszociációs emlékezeti hálójának felgöngyölítését $A$ folyók városa című regénnyel kezdi meg az író, s e munkát további regényei is folytatják. A regény recepciójának elemzése egyértelmüen azt mutatja, hogy az általa közvetített múltkép szerepet játszik Mequinensa emlékeinek artikulásában, identitásának kialakításában. Úgy vélem, hogy a mequinensaiak számára a Moncada regények vonatkoztatási pontot, identitásforrást, és érvkészletet is jelentenek. Ezt bizonyítja például a családi levéltárban talált két levél. Az 1988. április 20-i keltezésű levelet Magda Godià, a frissen alakult Asociación de la mujer mequinenzana elnöke írta Moncadának, akit tájékoztat, hogy a nőegylet célja a kultúra felvirágoztatása a településen, s meghívja előadónak. Az 1999. december 15-i levélben P. Agué, az Associació „La Dona” nevében már katalánul köszöni meg Jesús Moncada irántuk tanúsított figyelmét. ${ }^{41} \mathrm{~S}$ ezt jelzi a városi múzeumban az író személyének szentelt nagy tér, s a város által

\footnotetext{
37 1989-10-22 El Día de Aragón - Imán- Sólo soy un contador de historias, Anton Castro.

38 1992-02-13 El País, Quaderns - Jesús Moncada de Mequinenza a Torrelloba, Xavier Moret.

${ }^{39}$ Maurice Halbwach, Les cadres sociaux de la mémoire 1925 http://classiques.uqac.ca/classiques/

Halbwachs_maurice/cadres_soc memoire/cadres_sociaux_memoire.pdf, letöltés 2017. márc. 6. La mémoire collective 1950 posztumus kiadás, http://classiques.uqac.ca/classiques/Halbwachs maurice/memoire collective/memoire_collective.pdf, letöltés 2017. márc. 6.

40 1989-05-29 El Temps - Jesús Moncada. Després de Camí de sirga, David Castillo.

${ }^{41}$ MCSL 3. Baráti levelek, olvasói gratulációk, vélemények, felkérések, meghívók, köszönetek. A nőegylet neve a város honlapján spanyolul szerepel. Magda Godià, az alapító ma Mequinensa polgármestere, kérdésem-
} 
alapított, 2018-ban először meghirdetendő Primer Premio de Investigación „Jesús Moncada”. tudományos pályázat. Szülővárosán túl az egész Franja, a katalán viszonylatban a marginálisnak számító, Lleida központú Belső-Katalónia, sőt Aragónia is ${ }^{42}$ fontos intellektuális képviselőjeként tekint az íróra. Egyes települések érdemként tekintenek arra, hogy szerepelnek a Moncada regények lapjain, s ezáltal irodalmi vonatkozást, vagyis kitüntetettséget nyernek. ${ }^{43}$ Az író halálakor Antoni Sabaté Ibars, a Katalán Kulturális Minisztérium nevében kondoleált az író édesanyjának, s kifejezte szomorúságát minden ebrói identitással bíró ember nevében, akik számára az irodalmi érdemeken, és díjakon túl óriási érzelmi jelentőséggel bír a Jesús Moncada által megelevenített univerzum, mely - mint fogalmaz - világlátásuk alapjává vált, ezért Ebro-parti emberként elsőként kell elismerniük és megköszönniük a Jesús Moncada által nekik adott szavakat és történeteket. ${ }^{44}$

A Moncada életmü jelentőségét Katalónia viszonylatában jól mutatja Jordi Pujol levele az íróhoz, melyben jelzi, nagyon boldog, hogy a katalán irodalom egyre szélesebb körben válik ismertté a világban. ${ }^{45}$ A világirodalom élvonalába kerülés fontosságára utaltunk már a lehetséges katalán Nobel-díj kapcsán született cikkek tárgyalásánál. Ez szintén azt jelzi, hogy a jeles irodalmi alkotások hivatkozási pontot jelentenek, és fontos identitásmegerősítő tényezők egy állam nélküli kis nemzet számára.

re elmesélte, milyen nehézségekbe ütközött a Moncada szövegek eredeti nyelven történő felolvasása a mequinensai asszonyok önművelö egyesületében. Ezért elöször a spanyol fordítással kezdtek, de ma már katalánul olvassák és tolmácsolják a müveket.

${ }^{42}$ MCSL Digitalizált adatok, Kronológiai jelzet nélküli adatok Discurso de la Consejera de la Cultura del Gobierno de Aragón, Eva Almunia en la entrega del Premio de las Letras Aragonesas 2004.

43 Serrano Dolader, Alberto, „Caspe literario: Memoria Estremecida, de Jesús Moncada”, El Agitador, 201506-10 www.bajoaragonesa.org/elagitador/caspe-literario-memoria-estremecida-de-jesus-moncada/ (2017-1124). Érdekes megfigyelni a caspi lokálpatrióta vonásokat, hogy a cikk írója azt emeli ki, hogy a regényben Casp mint a nagyobb, városiasabb jellegü település valamint azt, hogy a nagy tiszteletnek örvendő caspi törvényszéki orvos nevét, a spanyol fordításban spanyolra kellett volna változtatni, nem pedig meghagyni a katalánul.

${ }^{44}$ MCSL 3. Baráti levelek, olvasói gratulációk, vélemények, felkérések, meghívók, köszönetek 2005. november 4-i levél, írta Antoni Sabaté Ibars director del Serveis Territorials Generalitat de Catalunya Departament de Cultura.

${ }^{45}$ MCSL uo. 2000. január 8-i keltezésű levél Jordi Pujoltól, Katalónia akkori politikai vezetőjétől Jesús Moncadának. 


\section{Kisnemzeti irodalom és nemzeti identitás Spanyolországban}

A katalán irodalmi kultúra számára fájó pont, hogy Spanyolországban nem kezelik egyenrangúként a többi nemzeti irodalommal, melyeknek méltóságot és rangot kölcsönöz az, hogy egy állam biztosítja megbecsültségük politikai alapját, intézményrendszerüket, folytonosságukat és fennmaradásukat. Spanyolországon belül a perifériák irodalmának megítélése a spanyol közgondolkodásban valamiképpen az alkotmány második cikkelyével $^{46}$ áll összhangban, amely szerint a spanyol egy és oszthatatlan nemzet, amelyen belül elismerik és garantálják az országot alkotó kisnemzetek (nacionalidades) és régiók autonómiáját. Ezzel egy jogi rangsort állítanak fel, melyben a kisnemzeteket magában foglaló nemzet áll a legmagasabb szinten. A kisnemzetek megnevezés ugyan utal arra, hogy történelmi egységekről van szó, ám mivel az alkotmány autonómiájukat egy szintre helyezi a régiók autonómiájával, így a történelmi és a területi egységek közti különbség némileg elmosódik. ${ }^{47}$ Létezik tehát egy spanyol nemzet, amely egy és oszthatatlan, de mégis plurális, hiszen magában foglalja a kisnemzeteket is, melyek irodalma a központ felöl tekintve nem egyenrangú a spanyol irodalom alkotásaival, mert nem nemzeti szintü, hanem provinciális, periférikus, vagyis kevésbé érdekes és értékes. Erre enged következtetni az államnyelv meghatározása is az alkotmányban, mely úgy fogalmaz, hogy „a kasztíliai az állam hivatalos spanyol nyelve”. ${ }^{48}$ A többi spanyol nyelv azonban, melyek az ország védendő kulturális örökségét alkotják, nem jelennek meg olyan hangsúlyosan sem a közvéleményformálók által hangoztatott gondolatokban, sem a kormány nyelvpolitikájában. ${ }^{49}$ Ezek inkább a régi, a központosító, homogeneizációra törekvő beidegződések fennmaradását tükrözik az alkotmány pluralitást biztosító keretei ellenére. Ezt támasztja alá a Moncada munkásságával kapcsolatos riportokban szereplő rengeteg, nyelvre vonatkozó kérdés, melyekből kiviláglik a többségi nemzet értetlensége azzal a ténnyel kapcsolatban, hogy valaki katalánul akar alkotni, mert erre nem úgy tekintenek, mint a kulturális gazdagság forrására, hanem inkább úgy, mint egy már meghaladott szintre való visszalépésre. A

\footnotetext{
${ }^{46}$ Artículo 2. de la Constitución 1978 https://www.boe.es/diario boe/txt.php?id=BOE-A-1978-31229, letöltés 2017. nov. 24. L. melléklet Lexikon 20.

${ }^{47}$ Szilágyi István, Európa és a hispán világ, Veszprémi Egyetemi Kiadó, Veszprém 1998. 113-145. o. és Mira, Joan Francesc, Crítica de la nació pura, sobre els símbols, les fronteres i altres assaigs impetiosos, València, Eliseu Climent Editor, 1985.

${ }^{48}$ Artículo 3. de la Constitución Española. http://sepam.dipcas.es/files/pwm-Normativa lenguas oficiales_es.pdf, letöltés 2017. nov. 24. L. melléklet Lexikon 20.

${ }^{49}$ A nyelvek hierarchiájáról L. Moncada életmü recepciója német nyelvterületen témában írott cikket: Quintana, Artur i Font i Sigrid Schmidt von der Twer, „La recepció germanica de l’obra de Jesús Moncada”, in Cròniques del cerç i la garbinada, Lleida: Ajuntament de Lleida; Pagès Editors, 2006, 93-98. o.
} 
többségi Spanyolország Werth törvénnyel reagál a katalán kultúra és nyelv erősödésére, melynek a miniszter által nyíltan hangoztatott célja többek között a katalánok „visszaspanyolosítása” ${ }^{50}$ Szociolingvisztikai szempontból egy világnyelvnek, mely 21 ország hivatalos államnyelve, s világszerte kb. 400 millió beszélővel rendelkezik (a második vagy harmadik a világ legbeszéltebb nyelveinek rangsorában a kínai és az angol után) nincs miért félnie attól, hogy a Katalán Autonómiában használata háttérbe szorul. Alapvető demográfiai fölénye, az általa kínált kulturális és kommunikációs lehetőségek eleve biztosítják számára az elsőbbséget Katalónia területén is. Aki csak a törvényi szabályozást tekinti, és nem ismeri a Països Catalans valóságos nyelvi helyzetét, úgy vélheti, hogy a spanyol nyelv szorul védelemre Katalóniában, holott a törvényi szabályozások ellenére, a tartomány őshonos nyelvének, a katalánnak a helyzete veszélyeztetettebb, épp a demográfiai és szociolingvisztikai tényezők miatt. Analóg példaként Írországot említeném, ahol a kétnyelvű alkotmány Nemzet fejezetének 8. cikkelye rendelkezik az ország hivatalos nyelvének kérdésében. ${ }^{51}$ Annak ellenére, hogy az alkotmány szerint az ország első hivatalos nyelve az ír gaelic, beszélőinek száma igen alacsony, tanulása, megtartása egy csoportidentitás kifejező jele, de önmagában nem elegendő az országon belüli tágabb kommunikáció fenntartásához, sem pedig az érvényesüléshez.

A Països Catalans területei közül egyedül Katalóniában sikerült stabilizálni a nyelv helyzetét. Valenciában, Észak-Katalóniában a nyelv a kihalás szélére jutott, ami fenyegető árnyként vetül a Principátus katalán anyanyelvü lakosságára. A kis nyelvek beszélőinek ezzel a kérdéssel kapcsolatos véleménye alapvetően eltér a nagy nyelvek beszélőinek percepciójától. A kasztíliai spanyol anyanyelvüek értetlenül szemlélik, és túlzottnak érzik a katalán, mint másik spanyol nyelv védelmére hozott törvényi intézkedéseket. A kis nyelvek beszélői és alkotói azonban úgy látják, őket a pozitív diszkrimináció segíthetné hozzá a megmaradáshoz. Ennek fontos eleme lenne a nagyobb ismertség, ám sajnálattal állapítják meg, hogy az államnak ez nem fontos, intézményi szinten nem jelenik meg célkitűzésként. ${ }^{52}$ A katalán alkotók véleménye szerint Spanyolország nem vallja magáénak természetes

\footnotetext{
${ }^{50}$ El interés del Gobierno es „españolizar a los alumnos catalanes” con el fin de que „se sientan tan orgullosos de ser españoles como catalanes.” (A kormány célja a „katalán diákok spanyolosítása”, hogy legalább „annyira büszkék legyenek spanyolságukra, mint katalánságukra”.) http://www.abc.es/espana/20150625/abci-wert-frases-201506252227.html, letöltés 2017. nov.27.

${ }^{51}$ https://www.constitution.ie/Documents/Bhunreacht_na_hEireann_web.pdf, letöltés 2017. nov. 27.

52 www.cazarabet.com/conversacon/fichas/moncada.htm, letöltés 2017. nov. 25. Beszélgetés Chusé Aragüésszel, az aragóniai többnyelvű kiadó, a Prames vezetőjével Jesús Moncadáról, a spanyol könyvkiadásról és a kisnyelvek helyzetéről.
} 
módon a kisnemzetek nyelveit, kultúráit, mint azt az alkotmány preambuluma lefekteti. ${ }^{53}$ A többnyelvü, többkultúrájú ország fövárosában, Madridban egyetlen könyvesbolt szerepelteti kínálatában a „többi spanyol nyelv” irodalmát, ${ }^{54} \mathrm{~s}$ a Moncada mü spanyolországi recepciója is azt a hipotézist támasztja alá, hogy a perifériák más spanyol nyelven születő irodalma nem kap figyelmet a központban. ${ }^{55}$

A Franja katalán anyanyelvü településeinek 2017-18-as nyelvi és irodalmi fejlesztő programját az aragón kormány oktatásügyi hivatala „Jesús Moncada program” néven ${ }^{56}$ indította, ami azt jelzi, hogy a Moncada életmü fontos, szimbólumértékü helyet foglal el a terület lakosságának kulturális identitásában. Ez a program - mely az autonómia másik kisebbségi nyelvén, aragónul is elindult - a katalánnal kapcsolatban politikai természetü ellenérzéseket vált ki Aragóniában, amiről az ABC Aragón 2017 szeptember 26-i cikke tanúskodik. ${ }^{57}$ Ebben a cikk szerzője arról tudósít, hogy a PANHC (Nem Beszélünk Katalánul Aragón Platform) ${ }^{58}$ kifogásolja, hogy egy függetlenségpárti katalán nevét kapja a program, aki a szélsőbaloldali PSAN aktivistája volt, s aki úgy határozta meg önmagát, mint „mequinensai katalánt”. Emellett, az anyanyelvi oktatás programját egyértelmúen úgy állítja be, mint a katalán függetlenségpártiak annexiós törekvését. Ennek az érvelésnek része az is, hogy a cikk a franjai katalánt „chapurreau”-nak nevezi, s úgy állítja be, mintha csak a katalán politikai törekvések igyekeznének ezt az „aragón nyelvi változatot” a katalán normáihoz igazítani. A dolgozatomban igyekeztem hangsúlyozni, mennyire nem kívánta

\footnotetext{
${ }^{53}$ Preambulo www.lamoncloa.gob.es/documents/constitucion_es1.pdf, letöltés 2017. nov. 27. L. melléklet Lexikon 20.

54 www.cazarabet.com/conversacon/fichas/moncada.htm, letöltés 2017. nov. 25.

55 1996-03-09 El Periódico de Aragón - No existe tradición de narraciones cortas, M.Á.R. A cikk írója szerint A folyók városa az első olyan katalánból fordított regény, mely sok és jó kritikát kapott, ám spanyolországi terjesztésére nem fordítottak gondot, hiszen a katalánból fordított szerzőkkel mindig ugyanaz a helyzet: irodalmon kívüli okokból kifolyólag nem lehet őket jól eladni. 2004-11-27 El País (Babelia) - Bífidos y activos, Sergi Pàmies. A spanyolra fordított katalán irodalommal kapcsolatban azt mondja, hogy közepes vagy nem túl sikeres a spanyol piacon, ami alól kivételt képeznek Quim Monzó művei, Jesús Moncada, Camino de sirga és Miquel de Palol El jardín de los siete crepúsculos címü regényei.

56 Jesús Moncada program indul https://finestro.wordpress.com/2017/03/20/programa-jesus-moncada-20172018/ letöltés 2017. jún. 12.

${ }^{57}$ http://www.abc.es/espana/aragon/abci-denuncian-aragon-utiliza-como-referente-educativo-independentistacatalan-201709260924_noticia.html, letöltés 2017. nov. 27.

${ }^{58}$ Plataforma Aragonesa No Hablamos Catalán (PANHC) https://nohablamoscatalan. wordpress.com/page/5/, letöltés 2017. dec. 1. Ez az aragón civil egyesület jó példája az aragón társadalom bizonyos rétegeiben továbbélő, politikai szinten is aktiválható, zsigeri antikatalanizmusra. A jelenleg érvényben lévő aragóniai nyelvtörvényt 2013. május 9-én szavazta meg az Aragón Parlament, ennek értelmében a franjai katalán neve LAPAO. www.boa.aragon.es/cgi-bin/EBOA/BRSCGI?CMD= VERDOC\&BASE=BOLE\&PIECE $=$ BOLE\&DOCS=1-28\&DOCR=1\&SEC=FIRMA\&RNG= 200\&SEPARADOR=\&\&PUBL=20130524, letöltés 2017. dec. 1. L. melléklet Lexikon 20.
} 
Jesús Moncada politikai platformok vagy zászlók mellett elkötelezni magát. ${ }^{59}$ Bár valóban a PSAN aktivistája volt, ez csak néhány hónapig tartott, a párt illegális müködése idején, Franco halála előtt. Már elismert íróként határozottan elutasította a politikai ügyekben való állásfoglalást. A „mequinensai katalán” definíció a sors által neki rendelt és a választott haza közti kettősségre, a mindkettőhöz tartozásra utal, és semmiképpen sem rejt annexiós vagy birodalmi gondolatokat. Moncada egy 2004-ben készült interjúban ${ }^{60}$ beszél a diákkorában és ifjúsága idején Saragossában megtapasztalt zsigeri antikatalanizmusról, ami a mai napig létezik Aragóniában annak ellenére, hogy már megjelent egy kisebbségben lévő aragón vélekedés is, mely nem elutasító a franjai katalánnal kapcsolatban. Mint mondja, korábban nem harcos katalanistaként háborodott fel ezen, hanem a gyerek ösztönös igazságérzetével, mert úgy érezte, senkinek sincs joga megtiltani neki, hogy az anyanyelvén beszéljen. A Franja katalán anyanyelvű lakosai számára a katalán identitás vállalása csak akkor válik lehetővé, ha átköltöznek a szomszédos tartományba, mint tette Jesús Moncada, aki Barcelonába költözött, s a katalán irodalmi standardot elsajátítva, annak hagyományába helyezkedve, azt a franjai katalánnal gazdagítva, a kortárs katalán irodalom egyik legnagyobb jelentőségü müvét hozta létre. A „mequinensai katalán” mint önmeghatározás, és a katalán nyelven megírt mítikus aragóniai szülőföld azonban jelzik a fennmaradó kettősséget. Az írót, aki kizárólag a művészi alkotás eszközeivel kívánta kifejezni gondolatait, és soha nem vállalt semmiféle közéleti szerepet, a jelen politikai csatározásiban igaztalanul úgy állítják be, mintha a Franja politikai elszakadását tüzte volna ki irodalmi alkotómunkájának végcéljaként. ${ }^{61}$ Ez a „Nem beszélünk katalánul Aragón Platform” által benyújtott tiltakozás a franjai katalánok Jesús Moncada nevével jelzett anyanyelvi oktatási programja ellen, jól tükrözi az alkotmánya által többnyelvű és többkultúrájú országként meghatározott Spanyolhon régi beidegződéseit és félelmét a pluralitástól.

Érdekes megfigyelni a Jesús Moncada mű hatását az aragón nyelvi kisebbség értelmiségi körében. Az alig 10 ezer beszélővel rendelkező nyelv irodalmárai fontosnak érezték, hogy

\footnotetext{
${ }^{59}$ Különös adalék ehhez a Moncada hagyatékban talált dráma paródia MCSL Obra teatral titulada El Capellà punit, o L'Enciclopèdia en doina. L. melléklet Lexikon 21.

60 2004-02-01 l'Avenç - La memòria d'un món negat, Josep M. Muñoz.

${ }^{61}$ Egyedül azokra a felkérésekre mondott igent, amikor iskolákba hívták, hogy a gyerekeknek beszéljen a müvein keresztül az irodalomról. Egy anekdota megörökíti, hogy visszautasította a katalán irodalompolitika által adományozott, a „hónap írója címet”, ami népszerüsítő kampányok és médiaszereplések sorát jelentette volna. L. 2003-12-25 El País - El món de Jesús Moncada (sobre Cabòries estivals), Xavier Moret; Másutt kijelentette, hogy nem pályáz meg nagy anyagi jutalommal járó irodalmi díjakat, mióta van kiadója, s véleménye szerint a szubvencióknak arra kéne szolgálniuk, hogy az iskolákban új olvasónemzedékeket neveljenek ki, valamint arra, hogy a világirodalmat katalán fordításban ismertessék meg a diákokkal. Enrique Vicién Mañé, Astérix en Mequinenza, Jesús Moncada, un aragonés que escribe en catalán, Trébede.
} 
lefordítsák A folyók városát aragónra, melynek belső irodalmi termése igen csekély. ${ }^{62} \mathrm{~A}$ szintén aragóniai kisebbségi nyelven, katalánul született regény nyelvi komplexitása és magas irodalmi színvonala azt bizonyította, hogy az aragón spanyol nyelv pontosan ugyananynyira alkalmas bonyolult nyelvi és müvészi valóságok kifejezésére, mint a kasztíliai spanyol nyelv, mely a tartományban a magaskultúra egyetlen képviselője. A regény aragón fordítása, ez a gazdaságilag egyáltalán nem rentábilis vállalkozás így méltóságot kölcsönzött e kihalófélben levő nyelvnek. ${ }^{63}$ A folyók városa írója számára ugyanakkor nagy megtiszteltetést jelentett, hiszen Chusé Aragüés ebbe a különleges aragón nyelvű sorozatba csakis a világirodalom legnagyobbjainak a fordítását válogatta bele. ${ }^{64}$ Ez egyrészt azt mutatja, hogy Aragóniában a kétnyelvű nyelvi kisebbségek irodalmár képviselői kölcsönös figyelemmel és megértéssel fordulnak egymás felé, másrészt pedig azt, hogy mennyire fontos számukra saját kultúrájuk, identitásuk, örökségük megbecsülése. ${ }^{65}$ Nem véletlenül használja a cikk írója a méltóság szót, amely igazolja szemében az aragón fordítás létjogosultságát, hiszen egy nyelv Gutenberg galaxisban elfoglalt helye képes méltóságot kölcsönözni e nyelv beszélőinek azáltal, hogy eloszlat egy tévhitet, melyet a diglosszia hosszú ideje tartó állapota konzervált a kisnemzeti nyelvek beszélői körében: a xapurreo alacsonyabbrendűségének sokat sulykolt tételét. Az állam nélküli nyelvek nem örvendenek akkora nemzetközi tekintélynek, s nem élvezik azt az intézményi védelmet, amit egy hasonló számú beszélővel rendelkező államalkotó nép nyelve. Vicens Vives ezt a Notícia de Cataluña című könyvében a következő szomorú megállapítással fejezi ki: „Nem voltunk elég erősek ahhoz, hogy saját történelmet írjunk magunknak, ez a mi nagy kollektív tragédiánk.”66

Moncada nem politikai eszközökkel és csatatéren folytatott küzdelmet, hanem a nyelv várát védte, az irodalom eszközeivel, békés országépítőként. Ennek ékes bizonyítéka a regények által tükrözött nyelvi valóság. A katalán szó mindössze háromszor jelenik meg $A$ folyók városa szövegében, abból kétszer a tetuáni csatában hőse, Prim tábornok katalán önkénteseinek jelölésére, egyszer pedig az ismeretség és közelség magasabb fokának jelzésére: „amikor már elég jól beszélt katalánul, miszter Wilson megvallotta”. A település nyelvi rea-

62 2004-01-08 La Vanguardia - Camí de sirga al aragonés, Mario Sasot.

63 2004-02-08 La Mañana - Camín de sirga en aragonés, Francesc Guillaumet (fordította Chusé Aragüés, Gara d'Edizions).

64 2004-05-21 La Veu de l'Ebre - Camín de sirga, Esteve Betrià.

65 Acín, Ramón, „La recepció de Moncada i la seva obra a l'Aragó”, in Cròniques del Cerç i la garbinada, Recepció i projecció de l’obra de Jesús Moncada, Lleida, , Pagès Editors, 2006. 85-93. o. Ezt támasztja alá az a tény is, hogy a katalán számára legkedvezőbb törvényi hátteret biztosító 2009-es aragóniai nyelvtörvény előkészítése idején az aragón kormány feje a szocialista Marcelino Iglesias (1999-2011) volt, aki az aragóniai Pireneusok egy kis, a katalán nyelvü falujából, Bonansából származik.

${ }^{66}$ Vicens Vives, Jaume, Noticias de Cataluña, Barcelona, Destino, 1980, 19. o. 
litására még egyetlen apró utalást találunk, amikor az 1945-ben a városba érkező katonatiszt kérdésére „a patikus bizonytalan spanyolsággal” válaszol. Moncada semmilyen módon nem törekszik rá, hogy a kétnyelvűség állapotát vagy a franjai mindennapokat jellemző diglosszia helyzetét érzékeltesse a regényben. Számára a katalán a választott nyelvi haza, melyen belül nem kívánja a különböző nyelvek használatával érzékeltetni a sokszínű kulturális világot, mint teszi azt például a spanyolul író, s a katalánt nyelvi dekorációként alkalmazó Manuel Vázquez Montalbán a barcelonai valóságot ábrázoló népszerủ Carvalho regényeiben, vagy Joan Sales, akinek katalán nyelven írott, Incerta glòria címủ regényében a falusi emberek aragón tájnyelven szólalnak meg. ${ }^{67}$ Moncada a választott nyelvi univerzumon belül a legteljesebb költői szabadsággal ír, s nem érzi szükségét, hogy a történetek világán belül más, direkt nyelvi eszközöket megragadva építsen valóságot, s a nyelvi egység szétesésével fenyegető technikával jelezze, ki beszél spanyolul, ki katalánul, ki dialektusban. Az, hogy a katalán irodalom esetében ez a nyelvi-hitelességi kérdés egyáltalán felmerülhet, nem irodalmi, hanem szociolingvisztikai problémát jelez, ami a nagyvárosokban kikerülhetetlen valóság. ${ }^{68}$ A moncadai alkotói hozzáállás Antoni Gaudí szavait juttatja eszembe, aki szintén kizárólag a saját eszközeivel dolgozott a hazájáért, s a Sagrada Família építkezése közben a következőképp nyilatkozott: „Én a saját területemen dolgozom Katalóniáért, a templomát akarom felépíteni, mert a templom a legméltóbb arra, hogy egy népet képviseljen”. ${ }^{69}$ Jesús Moncada is „csak” a saját területén dolgozott, ${ }^{70} \mathrm{~s}$, hogy sikerrel járt, megerősíti egy kritikus nyilatkozata is, aki szerint „Moncada többet tett a katalán irodalomért, mint bármelyik kampány.” ${ }^{71}$ „Az irodalom a feledés elleni küzdelem” jelentette ki Josep Pla, a l’Empordà par excellence írója irodalom és emlékezet szoros kapcsolatát hangsúlyozva, ami a katalán irodalom esetében a nyelvi és irodalmi jelentésen túl történelmi jelentőséget is hordoz. ${ }^{72}$ Moncada regényeinek nyelvi bravúrja ugyanazzal a technikával müködik, mint az író kronológiai rendszere. Arányosan tartalmaz ismeretlen, különleges és elfeledett szava-

\footnotetext{
${ }^{67}$ A Franja településein az állami fizetéssel, kinevezéssel dolgozók mind spanyol nyelvüek (orvos, tanár). Egy anekdota tanúsága alapján egy franjai településre orvosi tanulmányai elvégzése után visszakerült fiatal orvoshoz a rendelőben a szülőhelye polgárai spanyolul szólnak, vagyis a posztjának kijáró nyelven.

${ }^{68}$ 2003-02-16 Segre - El català desafina, Anna Sáez. A cikkíró szerint leggazdagabb, legszebb katalán nyelvet Baltasar Porcel és Jesús Moncada müveiben találjuk. Miquel de Palol írót idézi, aki szerint egyre szegényebb a nyelv, Barcelonában nem születik semmi új, hiszen ott csak az emberek 30\%-a beszél katalánul. Moncada a kommunikációs és informatikai forradalom nyelvegyszerüsítő hatása előtti nyelvből táplálkozott. Szülővárosában a víztározók építéséig nem volt bevándorlás, s a közösség egésze ugyanazon nyelvi hazában élt.

${ }^{69}$ Puig i Tàrrech, Armand, Gaudí és a Sagrada, Budapest, Typotex, 2013. 184. 0.

${ }^{70}$ 1999-10-30 Segre - Jesús Moncada i la dinamita, Ferran Sáez Mateu.

${ }^{71}$ 2005-06-14 El Periódico de Catalunya - Moncada ha fet més per la literatura catalana que qualsevol campanya, Ernest Folch

${ }^{72}$ Josep Pla L. melléklet Lexikon 22.
} 
kat, szóképeket, nyelvi fordulatokat, melyek azonban a kontextusból mindig értelmezhetők. Így tanít, s építi vissza a müvelt köztudatba a nyelvi emlékezet elveszett elemeit, melynek legékesebb példája a camí de sirga kifejezés története.

Jesús Moncada lerombolandó szülőházához írt búcsúversét olvasva az a gondolat kísért, hogy a vers olvasható úgy is, mintha az ő nyelvi otthonáról, a katalánról szólna, még ha nem is annak szánta. Ez a dolgozatom mottójául választott vers álljon itt újra befejezésképp, ezúttal a katalánra, mint nyelvi hazára vonatkozóan. „Annak, aki jön, hogy lerombolja (írják fel a házunk ajtajára) Rombold le, ha ezt kell tenned,/ de ne üzz csúfot belöle/Amit te habarcsnak és kőnek vélsz/ az régi idők fájó burka /Ahol te csak a csendet hallod/ ott hozzánk a régi szavak szólnak." 73

${ }^{73}$ MCSL „Al que vingui a enderrocar” kezdetü vers. 


\title{
Felhasznált források
}

\section{Moncada Családi Levéltár anyaga}

\author{
Jesús Moncada Estruga (1941-2005)
}

A levéltár anyaga kézzel vagy géppel írott, a hagyaték kezelője még nem klasszifikálta, amikor 2012 szeptemberoktóberében és 2013 májusában megtekinthettem.

1. Jesús Moncada jegyzetei, vázlatai, versei, az általa készített interjúk a helyi öregekkel

- Jesús Moncada: Al que vingui a enderrocar-la; Consell per a ben morir (kiadatlan versek).

- Calendari perpetu 1801 - 2000 (öröknaptár).

- Severiana i Aleix Segarra viatge a BCN a l’Exposició de 1888 (Regényvázlat)

- Detalls (részletek): foglalkozások (vándorárusok, ételek, betegségek, balesetek, ruházat, gyerekjátékok, babonák,vándormuzsikusok romanços de cec/de fil i canya (kifejezést alkalmazni).

- Kézzel rajzolt térkép a Mequinensa központú világról folyók, városok, utak, vasút, guardamontes.

- Idees sobre la novel.la de la Guerra del Francés (assasinat polític, novella policíaca) Ötletek a függetlenségi háborúk korában játszódó regényhez, pl: la Revolució Francesa te repercussió a Espanya durant l'adolescencia del protagonista stb.

- Viatges mequinensans alcím:Cròniques amb llum d'estiu vacances a M. (història, records, lectures, anècdotes, personatges (70 témagondolat/javaslat.).

- Arnau de Roda genealógia a regényfigura adatainak, családfájának kidolgozása.

- Segarra család családfája.

- „Cançoner” mequinensà (dalok, rigmusok gyüjteménye).

- Notes - anècdotes mequinensanes, imatges de pagesos vells, d'una vella assesinada/presumida, l'enfonsament de les antigues cases fortes 
- Relación de motes (Apodos) de Mequinenza con su vocabulario de adjectivos originales y nombres comunes de cosas. Denominación de fincas o partidas (nevek, helynevek, csúfnevek).

- Mario Arbiol, Sitio de Mequinenza en la Guerra de la Independencia (helytörténészi leírás Mequinensa ostromáról 1808-1810).

- Contes barcelonins (28 téma).

Cròniques dels oficis (mesterségek):

- Els pastors

- Què llegeixen els mequinensans (premsa, publicacions, bars, partits)

- Els pastissers

- Els pagesos

- Els ferrers

- El blat de llossar (ferrers o pagesos)

- Els pescadors

- Els amoranos

Altres cròniques (történelmi események):

- Cròniques mequinensanes

- Crònica republicana

- Cròniques de Guerra

- 18 Juliol

- 27-28 Març 1938

Històries per a recordar (anekdoták):

- El vell del horta de les vaques (el colera, nota final: buscar informació sobre aquesta epidemia)

- Història del anarquiste Silvestre

- Història de un enterramorts

- L'enterrament de l'oncle Bertran (el primer pel civil)

- Història de les 50000 pessetes

- Història del bidet 
- Història de la bomba

- Història del Patriciet

- Història de Joaquima la Faiona captaire de Mequinensa

- Història dels llaguters (primera passada (any '14)

- Història del noi del Barberet (quinta del biberon)

- Com era el café del Racó

- Com era el café d’Alejandro

- Com era el café L’Agricola

- Història del sergent de la Guardia Civil

- Història de quan Hermes anava a Lleida

- Històries del riu (cobles)

- 24 maig 1931

- 21 juny de 1931

- 15 nov. 1931

- 29 nov. 1931

- 15 maig 1932 telèfon

- 15 maig 1932 oposició a l’Estatut Català

- 5 juny 1932 ferrocarils

- 7 Gener 1933

- 4 Febrer 1933

- 25 Febrer 1933

- 4 Març 1933

- 1 Abril 1933

- 3 Maig 1933

- 7 Juny 1933

Entrevistes Interjúk (60-as években készültek)

- Entrevista amb el vell Raiet (feta a la seva fusteria l'estiu de l'any que vaig anar a $\mathrm{Bcn})$

- Cronica del tio Rayet, calafate y musico (1889-) en castellano

- Entrevista amb l’oncle Joaquim del Patriciet bányász (1892-) El Jardí; La guerra i la posguerra 
- Entrevista amb l’Almirant hajóskapitány (1899-) veszélyes folyószakaszok, hajók mérete, teherkapacitása, távolságok, tartozékok, elnevezések, öszvérrel vontatás ’15, gőzhajó, kifejezések stb.

- Entrevista amb Garin hajós (1920-) folyó, útvonalak, települések, kifejezések, Tortosa bordélyai, rais-faúsztatók, Segre-Tremp; Ebre-l’Arboleda de Saragossa, guerra, maquis

- Entrevista amb Quico hajóskapitány (apja szül: 1893, csempészet, hajózás, útvonalak, teherszállítás, polgárháború, hajórekvirálás, pontonhíd, hb. utáni szénszállítás, Mariano Canero szolgálatában, hajóácsok hb. után, veszélyes folyóhelyek, evakuálás, ’37-es nagy árvíz

- 2a entrevista amb Quico éjszakai hajóút, vonatot megelözték, megfeneklés, téli-nyári szállítmány, alvás, öszvérrel vontatás ’18-’20, tortosai katedrálisban imádkozni, piac

- Entrevista amb Jorget a folyószúkületeknél a gőzhajó nem jól ment, hajóácsok, az első öszvér sirgador, a vontatóút és a parasztok, Tortosától a deltáig csak rendszámmal mehettek

- Carta de Mariano Sanjuán Sagarra (63 éves) Mequinensáról és az életéről 1967 júniusában

- Oncle Calafat, oncle Patriciet, tiet Vidallet, Manolo Jordi

- Obra teatral titulada El Capellà punit o L'Enciclopèdia en doina Drama líric en tres acte i sis quadres. Ez a mü az Enciclopèdia Catalana szerkesztőségében töltött évek, a politikai beavatkozás miatt (Max Cahner és az Edicions 62 helyett Jordi Pujol i la banca) botrányba és elbocsátásokba fulladt lelkes katalanista tudós-müvész vállalkozás paródiája. (Barcelona, 1974) A Nagy Katalán Enciklopédia és a Nagy Països Catalans álmok kifigurázása.

- Nyelvtani útmutató a katalán helyesírás gyakori buktatóit javításához, a hátoldalán a szerző rajzai

- Regénytervezet: Severiana i Aleix Segarra viatge a BCN a l’Exposició de 1888 (transformacions de BCN, pla Sarda, Severiana, aki müvészlélek, lelkesedik a művészeti, építészeti remekekért, Guillem de Segarra sógorával vitatkozik a bcn-i átalakulásokról, megtudjuk, hogy Guillem de Segarra részvényes a La Carbonífera de l’Ebre S.A-ban, mely céget Josep Fontanals közjegyző előtt jegyezték be 1880. febr. 27-én. Birtokai jó részét eladta, már ami maradt apja bukott vállalkozása után, amely az Ebro hajózhatóvá tételét célozta. A folyó történetét a Segarra család történetén át 
mutathatná meg. Severiana egy patronat és anarchisták közti lövöldözésben veszti életét. Bcn-ban találkoznak Amèliával, lleidai bányász közben munkásvezető lett, ez megmutathatja az érme/a város szépségének másik oldalát, Muntaner y Simón, szereplők születési évek, családfa).

\section{Díjak, kitüntetések, gratulációk}

- 1989. február 20. Joan Cuscó i Aymamí president de la Fundació Amics de les Arts i de les Lletres de Sabadell gratulál Jesús Moncadának, mert az ő irodalmi munkásságának, és különösképp a nagy sikerü Camí de sirga-nak ítélte az Alapítvány a nagydíját.

- 1989. április 10. Eliseu Climent Edicions del País Valencià, S.A. gratulál Jesús Moncadának a Crítica díjának elnyeréséért, melyet a Camí de irga-ért kapott,.

- 1989. május 5. Oriol Pi de Cabanyes az Institució de les Lletres Catalanes nevében értesíti, hogy a Svéd Akadémia kérésére a katalán kormány több más katalán íróéval együtt Moncada müveit is elküldte a Nobel Könyvtárba.

- 1997. december 12. Isabel-Clara Simó és Magdalena Oliver Departament de Cultura Institució de les Lletres Catalanes részéről gatulálnak Jesús Moncadának az Estremida memòriáért kapott Creixells díjhoz (Ateneu Barcelonès, honorífic).

- 1998. február 18. Josep Massot i Muntaner közli Jesús Moncadával, hogy elnyerte a Premis Crítica „Serra d’Or” de Literatura i Assaig -t az Estremida memOria című regényéért, és gratulál

- 1999. március 12. Carles Duarte, Departament de Presidencia értesíti Jesús Moncadát, hogy Jordi Pujol a Camí de sirga gallego nyelvű változatát ajándékozta Sant Jordi alkalmával a politika és a kultúra fontos személyiségeinek.

- 2001. június 18. Javier Lamban Montañes Diputación de Zaragoza távirata, melyben közli, hogy a Saragossa Provincia Önkormányzata Jesús Moncadának ítélte a Portugáliai Szent Izabella díjat, az általa adható legmagasabb kitüntetést.

- 2001. szeptember 12. Jaume Pérez Montaner Junta Directiva de l’Associació d’Escriptors en Llengua Catalana (Katalán Írószövetség) gratulációt küld Jesús Moncadának a Generalitat de Catalunya által Jesús Moncadának ítélt Szent György kereszt, a legmagasabb katalán, állami kitüntetés elnyeréséért. 
- 2001 november 16. Antoni Llevot i Lloret Ajuntament de Lleida Kulturális Osztály gratulál a Szent György Kereszt elnyeréséért.

- 2001 december 3. Josep A. Duran i Lleida president de l’Unió Democràtica de Catalunya a Comité del Govern nevében gratulál Jesús Moncadának a Szent György Kereszt elnyeréséért.

- 2001 sense data Antoni Morell, andorrai ügyvéd gratulál a Szent György Kereszt elnyeréséért.

- 2002 január 7. Enric Alvarez i Vila de la Junta Directiva de l’Orfeó Català nevében gratulál Jesús Moncadának a Szent György Kereszt elnyeréséért, melyet méltóan ítéltek neki Katalóniának tett kimagasló kulturális szolgálatáért.

- 2004 december 13 Jordi Estruga magánlevélben gratulál az Aragón Irodalmi Nagydíjért (kifogás 25 fordítás, Aragónia megörökítése, ahelyett, hogy irodalmi minősége miatt, mellyel nyíltan feltárt egy társadalmi igazságtalanságot).

- 2001 október 17. Jordi Úbeda i Bauló president de Gremi d’Editors de Catalunya gratulál a katalán kormány által adományozott Szent György Kereszt elnyeréséért

- 2005 április 22. Ricard Fornesa i Ribó president Caixa d’Estalvis i Pensions de Barcelona gratulál a Lletras Aragonesas (Aragón Irodalmi nagydíj) elnyeréséért.

- 2005 január 10. A de l’Associació d’Escriptors en Llengua Catalana felkéri, mint tagot, hogy szavazzon a Jaume Fuster díj jelöltjére, melyet ő maga már elnyert.

- 2005 június 14. Jordi Pujol magánlevélben kondoleál Jesús Moncada édesanyjának Maria Estrugának: „Vosté ha perdut el seu fill estimat però a Catalunya hem perdut un dels més distingits i indiscutiblement millors escriptors en llengua catalana dels últims anys...em va colpir especialment el seu cèlebre „Camí de sirga”.

\section{Baráti levelek, olvasói gratulációk, vélemények, felkérések, meghívók, köszönetek}

- 1967 szeptember 12 Rosa Maria Moncada levele Mequinensából (sp) Örvend a család, hogy végleg a kiadóban fog dolgozni. Szeretne ő is Barcelonába menni

- 1968 június 26. Glòria T’adjunto l’opinió literaria del Sr. Joan Oliver (pere Quart) (llivertat, savíem) zsüritag szerint a katalán elbeszélés érdekes, jó stílusú, a sp. versek utánérzések, kat-ul kéne írnia 
- 1969. július 2. Guillem Frontera (író, újságíró, katalanista Palma de Mallorca) Jesús Moncadának a „Montaner y Simón”-ba megköszöni Jesús Moncadának az ő problémái iránt tanúsított figyelmét, s kéri, értesítse, ha munka van kilátában.

- 1969. augusztus Guillem Frontera érdeklődik, talált-e ’Amic Montcada’ neki munkát, s felvázolja terveit egy írószövetkezetröl, mely megakadályozná az írók kizsákmányolását (magáról: somiatruita)

- 1981. sense data Històries de la mà esquerra könyvbemutatóra meghívó a Cornella de Llobregat-i Llibreria Can Pi-be. A népszerü könyvet bemutatja Ignasi Riera.

- 1985. szeptember 10. Miquel i Carme Castanys megköszönik, hogy ellentétben a 'lletraferit' tudós nyelvészekkel Jesús Moncada prózája az egyszerü emberek beszédének frissességét őrzi, akiknek nincs fonetikai üldözési mániájuk, mint a katalán jövőjét fenyegető cinturó industrial (ipari agglomeráció) szorításában élő barcelonaiaknak.

- 1988. április 20. Magda Godià presidenta de la Asociación de la mujer Mequinenzana nevében ír levelet, bejelentve, hogy megalakult kulturális egyesületük, melynek célja „culturizar a la mujer ya que en nuestro pueblo la tendencia general sea quizá dar mas importancia al aspecto económico que al cultural”. Meghívják Jesús Moncadát előadónak.

- 1988 sense data Anton Castro aragóniai újságró, dramaturg (gallego, Dirigió los suplementos culturales Imán, en El Día de Aragón, y Rayuela y La Cultura en El Periódico de Aragón, en los que fue responsable de su sección de cultura. Dirige desde 2001 el suplemento Artes y Letras del periódico Heraldo de Aragón), katalán klasszikusokat eredetiben olvas, értékeli, gratulál a Camí de sirga sikeréhez.

- 1990. január 1. Pere Calders Estimat Moncada, BUÉK a Calders-Artís család nevében.

- 1990. április 22. A Príncipe de Astúrias y de Gerona meghívja Jesús Moncadát a Pedralbes Palotában tartandó fogadásra.

- 1990. május 26. Pierre Audureau Mequinensa tetvérvárosából lefordította az Històries de la mà esquerra-t.

- 1992 sense data Anton Castro a Jesús Moncada narrador homérico y sentimental a Galeria de les estàtues-t méltatja” Jesús Moncada világa és újraalkotod a világot” kifejezések. 
- 1994. október 24. Maria Victòria Maduell és Xavier Vidal i Duch olvasók és rajongók elküldenek Jesús Moncadának egy dokumentumot (ezt nem találtam, csak a leírását) az egyik mequinensai bányával kapcsolatban., mert úgy gondolják, örömet szerezhetnek vele az írónak.

- 1995. március 9. Kjell Johansson a svéd fordító konzultál Jesús Moncadával a kérdéses megoldásokról, találkozni szeretne az íróval, 1954-ben járt először Bcnban, nem beszél és ír kat-ul, csak olvas.

- 1999. december 15. P. Agué presidenta de la Associació „La Dona” nevében már katalánul megköszöni Jesús Moncada irántuk tanúsított figyelmét, az elküldött cikkeket, gratulálnak a Calaveres atònites sikeréhez, amit már felolvastak.

- 1999. december 24. Toni Martinez professzor de Mequinensa, elnézést kér, az első levél, amit katalánul ír hosszú évek óta, hallani fogsz az Aiguabarreig lapról.

- 2000. január 8. Jordi Pujol, el President de Catalunya tudatja Jesús Moncadával, hogy egy jóbarátja, Ko Tazawa felesége fordítja a Camí de sirgát - ami neki is nagyon tetszett - japánra. Boldog, hogy a katalán regény mindenhova eljut a világon. Elküldte nekik a Calaveres atònites-t is. BUÉK, nagy tisztelöje JP.

- 2000. április 5. Alexandre Lloreda Saleta olvasói levél, melyben megköszöni a könyvélményeket, nagy klasszikusokhoz hasonlítja, s kéri, írjon még.

- 2000. május 30. Eulàlia Sin (Girona) olvasói levél, várja a következő könyvet, elment megnézni Mequinensát, nagy szomorúság, hogy semmi sincs már belőle.

- 2001. november 24. egy zaragozai barát jó humorral, kivárja a 6025-öt, mikor Jesús Moncada. Nobelt kap, hogy hallja, mit mond az átvételkor frakkban.

- 2003. augusztus 26. Carles -Jordi Guardiola bocsánatkérő levele, amiért Jesús Moncada arra kényszerült, hogy elhagyja a Magrana-t. Elismeri, hogy nem figyeltek eléggé a Moncada-müre. „,...hisz te sokkal inkább a Magrana vagy, mint bárki más... hajlandó vagyok megfizetni az árát, hogy továbbra is így legyen.”

- 2003. november 15. Juan Antonio Resina Navas A GE-t a polgárháborúról írott legjobb könyvnek tartja, Cervantes is a valóságra alapozta mủvét.

- 2004. december 1. Equip de professors a barcelonai szaléziánus Szent József Gimnázium tanári kara meghívja Jesús Moncadát az iskolában rendezendő XIII. Jocs Florals irodalmi ünnepre, nagy megtiszteltetésnek vennék, ha elfogadná.

- 2004. december 8. „kivándorolt” franjai barátok Igualadából. Furcsa év volt a Franja-ban, csak várjuk a nyelvtörvényt, mely nem készül el soha, csak egyesüle- 
tek alakulnak, a dolog nem tart egy irányba, mint minden országnál, hogy megszünjön a katalán anyanyelvűek kisebbségi érzése és az „autoodi”. Örül, hogy Jesús Moncada megkapta az Aragón Irodalmi Nagydíjat.

- 2005. március 4. Club de lectura Xirgú València Köszönjük, hogy megteremtette számunkra ezt a tájat. Az Ebro és vidéke nagyon közel áll azóta a szívükhöz, részükké vált, köszönik.

- 2005. április 8. Kjell Johansson baráti levele, melyben megköszöni az Ed. 62 kiadásában megjelent, s neki elküldött könyveket (Cabòries estivals és Camí de sirga új kiadás)

- 2005. április 23. Carlo Forcadell Alvarez a Zaragozai Egyetem Legújabb Kori Történeti tanszékének tanára felkéri Jesús Moncadát, hogy írjon egy készülő kiadványba arról, hogy milyen háborús pusztítások voltak Mequinenza vagy az Ebró alsó folyása melletti régió területén.

- 2005. május 3. Eva Almunia Badía Consejera de Educación, Cultura y Deporte Gobierno de Aragón (aragón kultuszminiszter) felkéri Jesús Moncadát, hogy küldjön anyagot a kiadványhoz, melyet az aragón kormány készül szerkeszteni spanyol és külföldi írók műveiből, akik Aragónt ábrázolják. 20-30 szerző, 60 Euró/fö.

- 2005. május 10. Jesús Cirac Febas Caspban könyvbemutató, cikk a Memoria Estremecida-ról a Comarcaban

- 2005, május 11. Maria Barbal elküldi Jesús Moncadának egy előadását, mely a Ribagorçana elnéptelenedésének az irodalomra gyakorolt hatásáról szól (revista Ripacurtia) Konferencia: Arenys de Noguera 3 juliol 2004. Az előadás bevezető sorai idézet a Camí de sirga utolsó fejezetéből Exili ense retorn (Végső számüzetés) és a saját Càmfora -ból (végszó: ki ő BCN-ban?)

- 2005. november 4. Antoni Sabaté Ibars director del Serveis Territorials Generalitat de Catalunya Departament de Cultura kondoleál Jesús Moncada édesanyjának

- Acte d’Homenatge meghívó.

- 2005. sense data Magda Godià Mequinensa polgármesterének kézzel és spanyolul írt három oldalas levele, melyben jobbulást kíván, bátorítja, és az egész közösség aggodalmát fejezi ki. 
- Dátum nélkül M. Carmen García i Jarque directora de risc d’Institut Català de Finances, dedikálást kér, én állítottam meg a metróban, megjöttek a megrendelt könyveim

- Vicién Mañé, Enrique, „Astérix en Mequinenza, Jesús Moncada, un aragonés que escribe en catalán”, Trébede

\section{Az Estremida memòria címü regény eredeti dokumentumai}

- Causa de Val Comuna, camino de Mequinenza - a caspi bíróság aktái közt talált eredeti kézzel írott dokumentum

- Causa de Val Comuna, camino de Mequinenza - a caspi bíróság aktái közt talált eredeti gépelt átirata

- Diario de Zaragoza 1877. augusztus 26. Az újság igazgatóját értesíti R.G. (valószínüleg a caspi tudósító) a hírekről. Megtámadták és megölték az adószedőt, csendőrt , hordárt, elmenekültek a pénzzel. A még élő csendőrt kórházba szállították.

- Egy piros pecséttel és számozással ellátott jegyzői dokumentum: NIHIL PRIUS FIDE Colegios Notariales de España, protocolo, 28 mayo de 1862 H0274811

- Diario de Zaragoza 1877. augusztus 31. Tudósítás Caspból aug. 29. További információk a mequinenzai bűntényről. Elfogták az elkövetőket. Bekísérés közben Antonio Borbon Soler, aki M-ban városi csendőrként dolgozott, menekülni próbált, lelőtték. Azt beszélik, hogy M-ban nagy felzúdulás volt a bünösök ellen: „Al llegar a esta ciudad, el pueblo en masa los esperaba indignados por sus fechorias..” Az újságíró szerint „el crimen no ha de quedar impune”

- Diario de Zaragoza 1877. nov. 27 Numero 331. pag. 2. Tudósít, hogy előző nap negyed kilenckor kivégezték a rablógyilkosokat

- Numero 332 pag. 1. nov. 28. A tudósítás Caspból érkezik nov. 26-án, utolsó hírek a kivégzésről, hogy a kedves olvasók ne mulasszanak el egy részletet se. Leírja az emberek reakcióját, rengetegen eljöttek a kivégzésre, Teixidót csak a kislánya ríkatta meg, az anyja oly szívettépően sírt, hogy az emberek meghatódtak, érthetetlen, hogy egy gyilkost hogy lehet így siratni. Mellékeli a fotót a halálraítéltekről, három nappal a haláluk előtt készült, és nagy keletje van, José Alcaine fényképésznél kapható. végül a nevek, korok, stb.

- Dokumentumok gépelt verzióban: 
1. 1876. dec. 13. a kormányzóhoz folyamodik a kastélyban állomásozó csendőrőrség vezetője a lőporraktárral kapcsolatban, a rongyos zászlóval, a kapitány lábsérülésével kapcs-ban majd nov. 27-i írásban tudósít a kivégzésről, megköszöni az erősítést, s jelenti, hogy a kivégzésre Fragából érkezett egység, és a halálraítélteket Caspból felkísérő csendőrök visszatértek szolgálati posztjaikra

2. 1878 jan. 20-i doc. A helyőrség vezetője arra kér engedélyt a Capitán Generaltól, hogy az 1875-ben kapott, a karlisták Ebrón való átkelését jelezni hivatott világítóbombákat (20db) felhasználhassák a király házasságkötését megünnepelendö, különben haszontalanul lejár a szavatosságuk.

\section{José Moncada Moncada archívuma}

- Újságkivágások az épülő vízierőmüről és Mequinensa elsüllyesztéséről, a lakosok által létrehozott lakásszövetkezetről, a szövetkezet dokumentumai. Az újságkivágásokon sok esetben nem látszik, hogy melyik napilapban jelentek meg, de több kézzel írt jegyzetet a megjelenés idejéről.

- 1958. szeptember 8. Távirat, melyben a Gobernador Civil azonnali hatállyal meneszti José Moncada Moncadát a polgármesteri tisztségből.

- 1965. El Noticiero 20. o. Castillo Genzor, Adolfo, „Sigilografia y Heraldica Municipal, Escudos de los pueblos, villas y ciudades de Aragón, Armas de la villa de Mequinenza."

- 1973. 02. 19. Cartas a „Aragon /exprés” Puntualizaciones de la Cooperativa de viviendas de Mequinenza, carta del presidente de la cooperativa, José Moncada al director de „Aragon /exprés.”

- 1976. 12. 17. Avui Països Catalans melléklet: Ll. Sole Sabaris, Les terres desmembrades del Principat.

- 1981. 05. 05. Disolución de la cooperativa de Viviendas Santa Agatoclia.

- Sorsolócédulák, melyek kiosztották a típustervek alapján készült lakásokat a tulajdonosok között. 


\section{Moncada Családi Levéltár digitalizált anyaga}

Újságcikkek, kiadványok, közlemények, beszédek, hirdetmények, végrendelet

1970-12-20 El Correo Catalan - Cuando los nombres se repiten

1971-02-01 Bases del premi Joan de Santamaría

1971-03-01 Serra d'Or - Crònica del darrer rom - Escriptors joves, Jesús Moncada

1971-05-26 Premi Joan de Santamaría

1971-05-26 El Correo Catalán - La 'Ma esquerra' de Jesús Moncada

1971-05-26 El Noticiero Universal - Premio Joan de Santamaría

1971-05-26 La Vanguardia Española - Premi Joan de Santamaría

1971-05-27 Brugues - Premio Joan de Santamaría

1971-05-27 Diario de Barcelona - Jesús Moncada premi Santamaría

1971-05-27 Tele-eXpres - El premio es la única forma posible por ahora, Josep M. Soria

1971-10-02 El Correo Catalán - Penya Santamaría comienza el curso

1971-10-28 La Vanguardia Española - Novedades editoriales en perspectiva. Històries

de la mà esquerra

1975-06-07 Tele-eXpres - Nueva sala de exposiciones en Begur

1975-06-13 Tele-eXpres - Sala en Begur

1975-06-14 Tele-eXpres - Nueva galería de arte en Begur

1975-06-17 Restaurant Bienservida

1976-01-03 Darreres notícies sobre el diari Avui

1976-01-08 La Vanguardia - Comunicació del diari Avui

1977-04-29 Tele-eXpres - Exposición Picasso.

1977-12-01 Exposició d'olis de Jesús Moncada

1978-12-12 Crónica de Mataró - Pinturas de Jesús Moncada

1978-12-15 El Maresme - Els forats de Jesús Moncada

1982-08-20 Arada - Riada. Jesús Moncada Butlletí de I'Associació de Veins

Castellbisbal 20 d'agost del 1983

1982-10-15 El Món - Propostes per la narrativa catalana actual, Francesc Parcerisas 1984-06-14 La Vanguardia - Donde paces. más que de donde naces 1985-04-04 Nagyvilág - Jesús Moncada 'Galaxis Joe' 1985-04-16 Avui - Novetats. El Café de la Granota 1985-04-16 El Correo Catalán - El café de la Granota - Novela aplazada 1985-04-21 Avui - Novedad El Café de la Granota 1985-04-23 El País - De tot i més en la novel.la, Pilar Rahola 
1985-05-04 El Periódico - El Café de la Granota, Emili Teixidor 1985-05-26 El País - Ocupeu una cadira al café de la Granota, Estanislau Vidal-Folch 1985-06-15 El Periódico - Un exótico café, Ignasi Riera 1985-10-13 El País - L'escriptor i el seu paisatge. Cabòries estivals 1986-06-01 Via Fora - Com acabar amb els poetes, Ferran Torrent - Setge i destrucció de Sedaví Jesús Moncada 1987 - Para escribir sobre BCN debería volver a Mequinenza, Nuestro fin de mundo Jesús Moncada escriptor 1987-01-01 Diari de Lleida - Fecha estimada - Els nous escriptors - Jesús Moncada, Marc Soler 1987-01-01 Información de Alicante - Fecha estimada - Cien títulos 1987-02-02 El Temps -núm 137 Una reacció ferotge. Crítica por Jesús Moncada 1987-04-26 Avui - Guardeu-vos de somiar genives esdentegades 1987-04-27 El Temps - Un esbòs amb cavalls, Jesús Moncada 1988-01-01 Fecha estimada - Les bateliers de l'ebre Ed. Seuil, Bernard Lesfarges 1988-02-01 Resso de Ponent - Guardeu-vos de caure en mans de periodistes afeccionades, Mercè Biosca 1988-02-14 Avui - Camí de sirga 1988-03-03 Avui - Jesús Moncada debuta com a novel.lista - Condemnat a l'èxit 1988-03-11 La Vanguardia - El Café de la Granota 1988-03-17 Diario de Barcelona - La Marrana esgota existéncies en pocs dies. Camí de sirga

1988-03-17 Segre - Pasatiempos - Las siete diferencias 1988-03-24 El País - Vida perdurable. Camí de sirga, Dolors Oller 1988-03-28 El Temps - Dalí i Moncada, Ramon Barnils 1988-03-28 El Temps - Quadern de treball, Víctor Ripoll 1988-03-29 Diari de Barcelona - Mequinensa al costat de les grans obres. Camí de sirga, Pere Marcet 1988-03-31 La Vanguardia - La primera novel.la de Jesús Moncada 1988-04-01 Batecs - El llibre. Camí de sirga, F.R. 1988-04-01 Pel i ploma - Setze jutgen 1988-04-07 El País - Jesús Moncada 'Destruir una vila és destruir una memòria', T. D. 1988-04-09 ABC Catalunya- Camí de sirga recupera la memoria colectiva de

Mequinenza. Entrevista, Adela Farré 1988-04-17 Avui - Camí de sirga. Una novel.la esplèndida, Isidor Cònsul 1988-04-18 El Temps - Parets. camins i l'aigua, Estanislau Vidal-Folch 
1988-04-19 Punt Diari de Girona - Sirgant tartera, Jordi Vendrell 1988-04-20 Punt Diari - Aires de Mequinensa, Emmanuel Cuyàs 1988-04-24 El País - Flores y papeles. Camí de sirga. Novedad y clásico el mismo día, Joan Barril 1988-04-25 El Temps - Portada 1988-05-01 Lletra de Canvi - Una novel.la rescalfada. Camí de sirga, Xavier Lloveras 1988-05-03 La Vanguardia - Teixidors de testimonis (apòcrifs), Ignasi Riera 1988-05-23 Setze - Baluard inútil, Jesús Moncada 1988-06-01 Lletra de Canvi - Entrevista amb Jesús Moncada, Josep Maria Ripoll 1988-06-01 Llibrería 122 (Gremi de llibreters) - Entrevista a Jesús Moncada, alquimista del temps, Joan Peña 1988-06-20 Avui - Jesús Moncada en el camí de la vida, Anna Cabeza 1988-06-28 El Periódico - Mnemosina, Montserrat Roig 1988-07-10 La Mañana - Jesús Moncada. la literatura de Mequinensa, Cristina Segura 1988-07-25 El Temps - Uf ! Quines vacances, J. Prats/C Gámez 1988-08-08 El Temps - El món perdut de Jesús Moncada, Xulio Ricardo Trigo 1988-09-01 El Urogallo - El auge de la narración 1988-10-01 Ateneu -núm 16 4rt trimestre Desprès del Creixells, Jesús Moncada 1988-10-01 Ateneu - núm 16 4rt trimestre El premi Creixells - Desprès del Creixells 1988-10-01 Reseña - Camí de sirga. Brillantez abigarrada, Antonio Blanch 1988-10-11 La Vanguardia - El camí de la normalitat. Premis, Robert Saladrigas 1988-11-01 El Boscater Negre - Petita història de un jersei gris Homenatje a Josep Soler

Vidal, Jesús Moncada 1988-12-13 Diari de Barcelona - Camí de sirga guanya el Creixells de novela 1988-12-13 El País - Camí de sirga obtiene el premio Creixells 1988-12-13 El Periódico - Jesús Moncada obtiene el premio Creixells de novela 1988-12-13 La Vanguardia - Jesús Moncada obtiene el premio Creixells por Camí de sirga 1988-12-13 Segre - Camí de sirga gana el premio Creixells 1989-01-09 El Temps - Premi Creixells 1989-02-01 Serra d'Or - Aproximación a la obra de Jesús Moncada., Mercè Biosca 1989-02-11 Avui - Premis Ciutat de Barcelona 1988. Ningú és forà a Barcelona 1989-02-11 La Vanguardia - Premios Ciutat de Barcelona 1989-02-14 Jesús Moncada L'Art d'un escriptor de café, Caricatura, Ignasi Riera 1989-03-01 Diari de Barcelona - Fecha estimada - Solidaris per decret, Ignasi Riera 1989-03-01 Serra d'Or - Premis crítica. Anuncio de los premios 
1989-03-02 La Mañana - Premio literario para Moncada en Sabadell 1989-03-03 Segre - Jesús Moncada galardonado en Sabadell 1989-03-22 Bitllet d'anada - (periòdic independent de la Mediterrània) Jesús Moncada a la Sedeta 1989-04-09 Avui - Moncada i Gimferrer guanyen el Premio Nacional de la Crítica

guardons honorífics para cada nacionalidad del estado, Avel.lí Artís 1989-04-09 Diari de Barcelona - Moncada y Gimferrer guanyen els premis de la Crítica Literària, Francisco Acedo 1989-04-09 El País - Galardonados con el premio de la crítica. Buscando los mejores 1989-04-09 Heraldo de Aragón - Los premios de la crítica literaria 1989-04-09 La Vanguardia - Gimferrer y Moncada premios de la crítica en catalán,

Francisco Acedo

1989-04-11 Avui - Els crítics de Serra d'Or també voten per Moncada 1989-04-11 El Día de Aragón - El triunfo de Camí de sirga, Antón Castro 1989-04-11 La Vanguardia - La crítica catalana premia a Jesús Moncada y Gimferrer 1989-04-12 El Dia de Aragón - El pueblo inundado de Mequinenza 1989-04-18 Diari de Barcelona - L'any del retrobament d'un paradís perdut, Pere Marcet 1989-04-21 Avui - Jesús Moncada i Mequinensa. Entrevista 1989-04-21 La Veu de l'Anoia - Els ulls de Pep Albanell Francesc Rossell i Farré 1989-04-21 La Veu de l'Anoia - Jesús Moncada camí de premis, Francesc Rossell i Farré 1989-05-27 El País - Finalistas Premio Nacional de literatura 1989. Ministerio de Cultura 1989-05-29 El Temps - Jesús Moncada. Després de Camí de sirga. Entrevista, David Castillo 1989-06-19 El Temps - L'exit assolit per Camí de Sirga 1989-07-01 Serra d'Or - Josep Albanell habla de la coherencia de estilo de Jesús Moncada 1989-07-23 El davantal de Pere Calders, El forat i la banya, Pere Calders 1989-09-18 Abc - Publicación de Camino de sirga 1989-09-23 Abc - Camino de sirga, Joaquín Marco 1989-09-28 Heraldo de Aragón - Jesús Moncada. La alquimia de los recuerdos, Ramón Acín 1989-10-01 El Urogallo - El año de Jesús Moncada, Quim Aranda 1989-10-08 El País - Los poderes del relato, José Antonio Ugalde 1989-10-15 El País - Sugerencias. Camino de sirga 1989-10-22 El Día de Aragón - Imán - Sólo soy un contador de historias, Anton Castro 
1989-10-26 La Comarca - Camí de sirga. La recreació d'un món amb nom propi, Hèctor

Moret

1989-11-01 Leer - 25 libros para leer en Noviembre

1989-11-09 El Día de Aragón - Los senderos se bifurcan en Mequinenza

1989-11-16 Diario16 - Un camino prometedor, Arturo Ramoneda

1989-11-26 El Punt - El mite de l'Ebre, Miquel Pairolí

1989-12-01 Catalan Review $N^{\circ} 2$ - El libro que ha causado más impacto es Camí de Sirga 1989-12-02 Inventario - Camino de Sirga

1989-12-09 Diario16 - Moncada. La novela rural, Carles Mengual

1990-01-01 Lletra de canvi - Entrevista amb, Pere Calders

1990-05-19 Diari de Barcelona - Bona nit, novel.la, Jaume Creus

1990-05-25 Diari de Vilanova - Entrevista a Jesús Moncada, Estger Casas

1990-05-28 El Temps - Solució al criptograma de Marius Serra

1990-06-01 L'Illa - №2 Alzira Un bon moment per a la novel.la, Isidor Cònsul

1990-06-12 La Vanguardia - La narrativa del balón. Inventario.

1990-08-18 Avui - Enquesta del Pen Club - La funció filològica del IEC

1990-08-27 El Temps - On anirà l'aigua de l'Ebre

1990-10-01 Serra d'Or - Una generació sense fantasmes, Emili Bayo i Xavier Macià 1990-10-06 Avui - El grau de compromís dels escriptors amb la normativa, Ricard Fité 1990-10-08 El Periódico - La feria de Frankfurt ....

1990-11-03 Avui - Les tardors, Montserrat Roig

1991-01-01 Els Marges - Al marge. Rurales y urbanos, Víctor Martinez Gil

1991-02-11 El Temps - Colaboración.

1991-02-24 Segre - Jesús Moncada i la memòria, Josep S. Oms

1991-05-01 L'Alè - Entrevista amb Ferran Torrent, Mercè Biosca

1991-05-27 El Temps - Entrevista a Miquel Martí i Pol L’essencial es diu amb sencillesa 1991-05-30 La Vanguardia - Broch. Las letras catalanas de los 90, Rosa Maria Piñol 1991-06-08 Avui - Entrevista amb Xavier Folch, Pep Blay i David Castillo 1991-06-08 Avui - Volem menuts - Sabates vermelles, Jaume Subirana 1991-06-18 La Vanguardia - Traducción al neerlandés de Camí de Sirga 1991-06-19 El Periódico - La literatura catalana ha alcanzado la normalidad, Jaume

Fabre

1991-06-22 Avui - Entrevista a Carles Jordi Guardiola, Pep Blay i David Castillo 1991-09-18 La Vanguardia - Jesús Moncada entrega al editor su segunda novela 1991-10-02 Avui - La bona salut de la literatura 1991-10-09 El País - El fin de la resistencia. Encuesta Enric Bou 
1991-10-31 El Periódico - Moncada vuelve con otra novela 1991-11-06 Avui - La galeria de les estàtues sortirá el pròxim febrer 1991-11-07 Diari de Barcelona - Nova novel.la de Jesús Moncada 1991-11-14 El Observador - Ante el balance de una década, Josep Maria Ripoll 1991-11-17 Avui - A la vora de Yves Montand, Josep Ma Espinàs 1991-11-25 El Temps - Jesús Moncada ja té títol per a la seva pròxima novel.la 1991-12-03 Heraldo de Aragón - Un mequinenzano escritor de un río y de sus gentes, Mario Sasot

1991-12-03 Invitación a la lectura 15 - Jesús Moncada - Un camino prometedor, Arturo

Ramoneda; Sólo soy un contador de historias, Anton Castro; Guía didáctica de

Camino de sirga, Simeón Martín Rubio, Herminio Lafoz Rabaza, Luís Fernando

Giménez Marco

1991-12-06 La Vanguardia - Jesús Moncada crea un nuevo universo literario en La

Galeria de les estàtues, Mario Sasot

1991-12-11 Avui - Una revista eslovaca dedica un apartat a la narrativa catalana actual 1991-12-12 El Periódico - La revelación del premio Sèsamo 1991-12-14 Avui - De la República a les Lletres, Oriol Izquierdo 1991-12-23 El Temps - Edicions de la Magrana, quinze anys, Neus Aiguadé 1992-01-13 El Temps - Què li han portat els reis?

1992-01-30 Diari de Barcelona -Opinió- Jesús Moncada dels pinzells a la ploma 1992-01-30 Diari de Barcelona - Jesús Moncada recrea la postguerra amb mots amables,

Carles Singla

1992-02-01 Diari de Barcelona - Asos a la màniga

1992-02-05 La Vanguardia - Camí de sirga se editará en inglés

1992-02-10 El Observador - Podría escribir cien mil novelas con Mequinenza como escenario, Santiago del Rey

1992-02-13 Avui - L’última novel.a de Jesús Moncada recrea la postguerra en una ciutat de l’Ebre Galeria de les estàtues es posará a la venda dilluns que ve, Carme Giró 1992-02-13 El País - Quaderns- Jesús Moncada de Mequinenza a Torrelloba, Xavier Moret 1992-02-14 Diari de Barcelona - No m'interesso gens a mi mateix com a personatge, Carles Singla 1992-02-16 Avui - Golden Kim, Ramon Solsona 1992-02-16 Diari d'Andorra - La Galería de les estàtues apareix demà, Ignasi P. Roda 1992-02-19 El Observador - Con Camí de sirga el país descubrió que tenía un gran río 1992-02-19 El Periódico - Torrelloba no es Zaragoza. Entrevista, A. Ribas 
1992-02-20 El Observador - Los fantasmas de Jesús Moncada - Clasificaciones

equívocas, Josep Maria Ripoll

1992-02-21 Diari de Barcelona - Més a prop de la novel.la total. La Galería, Xulio

Ricardo Trigo

1992-02-21 El Triangle - No més enjòlit que vaig de bòlit, Joaquim Soler i Ferret 1992-02-21 Revista de Badalona - La galeria de les estàtues, Albert Ibañez Domènec 1992-02-24 El Temps - Moncada contraataca. Entrevista, Assumpció Maresma 1992-02-27 La Vanguardia - La seducción de Moncada, Josep Maria Soria 1992-03-04 El Periódico - Peldaños que llevan a lo más alto. Guia de lectura, Oriol

Castanys 1992-03-06 Diari de Lleida - Guia de lectura de les novel.les de Moncada, Jordi Úbeda 1992-03-06 La Vanguardia - El triunfo por condena. La galeria de les estàtues, Oriol

Izquierdo

1992-03-06 La Vanguardia - Ranking de ventas

1992-03-12 El País - De Rimini a Palerm. La galería de les estátues Josep Maria

Fonarellas

1992-03-14 Avui - L'últim llibre de Jesús Moncada porta ja tres edicions i sortirà en

castellà Carme Giró

1992-03-17 Diari de Lleida - La galeria de les estàtues esgotat en només 15 dies 1992-03-22 Segre - La galería de les estátues

1992-03-28 Avui - Jesús Moncada ressegueix un camí enigmàtic amb un complex final

Isidor Cònsul

1992-03-29 Segre - Jesús Moncada. El mite de Mequinensa, Isidor Cònsul 1992-03-29 Segre - La teoria del 'Pulvises', Ramon Macià Fornos 1992-04-01 La Lluna - Dos apunts sobre el mòn editorial català, Jaume Vallcorba 1992-04-04 Segre - Doce escritores actuales de Lleida reunidos en un libro 1992-04-24 La Vanguardia - Moncada y Mendoza los más vendidos de Sant Jordi, Rosa

Maria Piñol, Ignacio Vidal-Folch

1992-05-01 Revista de Catalunya - Guia de lectura. La galeria de les estàtues, Neus

Torres

1992-05-05 Tirant lo Blanc $N^{\circ} 5$ - Entre el talent i l'ofici. Les noveles de Jesús Moncada,

Emili Bayo

1992-05-10 Regió7 - L'última lectura de Pere Calders

1992-05-15 Diari de Barcelona - Moncada ho intenta a Franca publicació de Les

bateliers de l'Ebre

1992-05-17 La Croix l'Événement - Barcelone hors les murs 
1992-05-22 Diari de Barcelona - Moncada exporta a Holanda 1992-05-25 El Nou 9 - Jesús Moncada comenta La galeria de les estàtues, F.F.A. 1992-05-31 Centre France - Polyphonie des souvenirs, D.M. 1992-06-03 L'Express - Une sardane dans les ruines, Paul Jean Franceschini 1992-06-07 Segre - Qué escriuen les dones, Andreu Loncà 1992-06-17 El Periódico - Monzó y Moncada a lo Maastricht 1992-07-01 Nuit Blanche - Jesús Moncada écrivain par entêtement, Anik Lapointe 1992-07-01 Nuit Blanche - La nouvelle modernité catalane, Anik Lapointe et Louis

Jolicreur

1992-07-03 Diari de Mallorca - El passat present, Lluís Colòm 1992-07-06 El Temps - Calders a Calders, J.C.

1992-07-08 L'Humanité - Un talent tumultueux, Jean-ClaudeLebrun 1992-08-05 La Vanguardia - Records de un riu enfurit i calmós, Jesús Moncada 1992-08-07 Segre - Portugal publica Camí de sirga de Jesús Moncada 1992-09-01 El Mirall - La galería de les estàtues. Una sátira de la dictadura, Pere

Rosselló Bover 1992-09-03 El Temps - De la geografía a la història, Manel Ollé 1992-10-29 El País - L'equació de la literatura en català, Anna Dionís 1992-11-01 Llibres - La mort omnipresent, Pere Martí i Bertran 1992-11-15 Presència - El llagut o l'origen del camí de sirga, Jordi Gamero 1993-01-28 Heraldo de Aragón - La ciudad innombrable, Mario Sasot 1993-04-23 El País - Els millors d'araSant Jordi '93 Camí de sirga novel.la més votada 1993-04-23 El País - Entrevista y fotos, Xavier Moret 1993-11-25 Segre - Jesús Moncada hace un retrato esperpéntico de la BCN de los 50, E.R.

1993-12-02 Heraldo de Aragón - De Mequinenza a Zaragoza, Ramon Acín 1993-12-02 Traducción al castellano de La Galería de las estatuas, Trinidad de LeónSotelo 1993-12-03 El Periódico - Esperemos que la DGA renueve el premio en catalán, José Bada 1993-12-09 Heraldo de Aragón - No pretendo retratar el vicio ni el pecado, Mario Sasot 1993-12-20 El Siglo - Inmortal Torrelloba, Luís Carandell 1994-01-02 El Periódico - Mequinenza ya no existe y no volverá a existir, Miguel Á Royo

1994-03-31 El Periódico - Fábulas de Moncada uno de los grandes nombres de las letras hispanicas, Jesús Duce 
1994-04-11 El Temps - Els 13 escriptors catalans més traduïts

1994-05-09 Avui - Mequinensa retroba las seves arrels islàmiques, Ignasi Aragay 1994-08-01 The European - Rich view from the banks of the Ebro, Euan Cameron 1994-09-07 El Periódico - Moncada en inglés 1994-09-08 Avui - Es molt bo que hi hagi una projecció exterior dels llibres, Carme Giró 1995-02-18 Segre - Elegia per Tiurana, Andreu Loncà 1995-02-21 La Mañana - Pep Albanell elogia la calidad literaria de la obra de J.M i

Maria Barbal, Marina Pujol 1995-02-21 Segre - La 'huella literaria' de Lleida en una antología, Anna Sáez 1995-02-27 El Temps - Les històries de Jesús Moncada, Víctor Ripoll 1995-03-16 Memória de desaparicions, Marga Moreno 1995-05-01 Berlin - Festa Catalana 1995 Jesús Moncada i Barbal en el programa 1995-05-28 Francesc Puértolas - Berlín reportatje de la Festa Catalana 1995-05-30 Efe Catalunya - Berlin acogera muestra cultura catalana 1995-05-31 ABC - Fiesta catalana en Berlín 1995-05-31 Avui - Festa catalana a Berlín 1995-05-31 Diario de Tarragona - Berlín 1995-05-31 El País (1ª Edición) - Berlín 1995-05-31 Segre - Literatura leridana en Berlín 1995-06-01 Diario de Terrassa - Berlín 1995-06-01 El Punt (Girona) - Mostra de cultura catalana a Berlín 1995-06-09 Die Tages Zeitung 1995-06-12 El Temps - Festa de la cultura catalana a Berlín 1995-06-14 Der Tages Spiegel 1995-06-18 Avui - EIs autors catalans tenen una gran rebuda a Berlín, Eva L. Ontiveros 1995-09-01 Tresmall - Terres de l’Ebre, Entre el desig i la realitat, Conversa amb Jesús

Moncada, Pilar Romera i Emili Rosales; El mite de Mequinensa, Carme Abril 1995-09-11 El Periódico - Segre y Ebre poder de agua, Sergi Ramis 1995-12-05 La Vanguardia - Para ganar el Nobel mejor no ir a Estocolmo, Margarita Rivière 1995-12-18 El Temps - Jesús Moncada, Ramón Barnils 1995-12-24 Heraldo de Aragón - El fin de la Mequinenza vieja me afectó mucho, Genoveva Crespo. 1996-02-22 Heraldo de Aragón - Cuatro novedades aragonesas, Ramon Acín 1996-03-08 Jesús Moncada. El relato no es un entrenamiento para la novela, M.G. 
1996-03-09 El Periódico de Aragón - No existe tradición de narraciones cortas M.Á.R.

Zaragoza

1996-04-04 El Periódico de Aragón - La prosa de un embaucador, Antón Castro

1996-04-15 El Periódico - El libro cumple años

1996-04-18 Avui - Edicions de la Magrana estrena local

1996-04-21 Segre - La Lleida del S. XXI a debate. A.S. Lleida

1996-06-01 Serra d'Or - Jesús Moncada novel.lar l'absència, Marta Nadal

1996-06-15 La Vanguardia - La Magrana tomó la calle, Rosa Maria Piñol

1997-02-01 Pressedienst S. Fischer Verlag - Jesús Moncada. Alemán

1997-02-15 La Vanguardia - El Semáforo - Índice

1997-02-16 Avui - Al.legat contra la pena de mort - El mite continúa, Jordi Guardiola 1997-02-16 El País - No he escrito una novela histórica. Estremida memoria, Xavier

Moret

1997-02-28 ABC - Reos del agua, Víctor Batallé

1997-03-02 Segre - Estremida memòria. Quin novel.lot, Andreu Loncà

1997-05-01 Descobrir Catalunya - Temps amunt, Jesús Moncada

1997-09-01 Revista de Catalunya - Guia de lectura - Estremida memòria, Jordi Malé i

Pegueroles

1997-10-01 Regió7 - Sempre he estat un narrador nat - Drama i ironia, Josep Gras

1997-10-10 La Fura - Una novel.la per a la memòria literària, Pere Martí i Bertran

1997-11-01 Círculo de Lectores - Estremida memòria

1997-12-12 Avui - Premio Creixells por Extremida Memòria, Beatriz Cabezas

1997-12-12 El País - Premio Creixells por Extremida Memòria

1997-12-12 La Mañana - Estremida memòria es la mejor del año

1997-12-12 Segre - Jesús Moncada premi Creixells a Estremida memòria

1997-12-14 Tradueixen al francès i al castellà Estremida memòria

1997-12-24 Segre - Isidor Cònsul critica el poc suport institucional...

1997-12-25 Avui - Oferta literaria nadalenca tarragonina

1998-02-15 Escola Montessori - Palau - Girona Col.loqui amb Jesús Moncada

1998-03-01 Ateneu - Nota al peu de la fosca, Jesús Moncada

1998-04-03 Segre - Jesús Moncada guanya el premi de la crítica Serra d'Or de novel.la

(contes La gran novel.la sobre BCN)

1998-04-25 La Mañana - El premio Humbert Torres recala ex-aequo en Jesús Moncada

y Felip Vendrell

1998-04-25 Segre - Guardons per a l'ultim llibre de Jesús Moncada (i premi ilerdenc per una obra en aranès) 
1998-04-26 Segre - La ciutat de la memòria, Andreu Loncà

1998-06-11 Segre - L'Obra de Moncada, en japonés.

1998-06-28 El País - Camí de sirga traducida al japonés

1998-07-01 Lletra de Canvi - Estremida Memòria, Sandrine Ribes

1998-07-04 El País Babelia - Camí de sirga traducida al japonés

1998-11-01 Cercle de lectors( Botlletí informatiu publicitari)

1998-11-19 Segre - Pura dinamita, Vidal Vidal

1998-12-25 El Punt - El nom i el personatge no tenen res a veure, Carina Filella

1999-03-13 Autorenlesung mit Jesús Moncada

1999-04-15 Avui -Una joventut que cremava Joan Josep Isern sobre Mas, finalista de St

Jordi - A la manera de Cabré o Moncada...

1999-05-02 El Periódico - La realidad es muy literaria - Entrevista, Antón Castro

1999-08-31 El temps - Moncada generacional, Víctor Ripoll

1999-09-03 El Periódico - La tardor abans del final (de secle), Oscar López

1999-09-24 Heraldo de Aragón - Un regreso al relato y a Mequinenza, Mario Sasot

1999-09-27 El País - Mequinenza en la memoria, Xavier Moret

1999-09-29 El Triangle P.22 - Moncada, ara en castellá

1999-10-01 Els Marges - Ressenyes. Calaveres atònites, Pau Vidal

1999-10-01 La Cabana - Calaveres atònites, Fina Font Ruana

1999-10-02 ABC - Mequinenza 1887, Ana Rodríguez Fisher

1999-10-02 - Fecha aprox - Artesà del llenguatge, Pep Martí

1999-10-02 L’Illa (Revista de lletres núm 23) - Sobre la universalitat dels localismes,

Joan Olivares

1999-10-14 El País - Aragó mira la Franja Elección M.Iglesias, Concha Monserrat

1999-10-14 El País - La Mequinensa de Jesús Moncada, Xavier Moret

1999-10-22 Avui - Els contes que semblen més fantàstics són els més reals, Jordi

Capdevila

1999-10-22 Heraldo de Aragón - .Memoria e historia, Ramon Acín

1999-10-22 La Vanguardia - Calaveres atònites, Rosa Maria Piñol

1999-10-22 La Vanguardia - Crónicas de un pueblo, Julià Guillamon

1999-10-23 Segre - Agenda

1999-10-24 Presència - Calaveres Atónites, Pere Puig

1999-10-26 Avui - Guardias civils i republicans pixen de la mateixa manera

1999-10-26 Segre - No faig literatura convencional entrevista

1999-10-28 El País - Anècdotes que fan història, Anton M. Espadaler

1999-10-30 Segre - Jesús Moncada i la dinamita, Ferran Sáez Mateu 
1999-10-31 Presència - Calaveres Atónites

1999-11-04 Avui - Parla Mequinensa

1999-11-04 Avui - L’hereu de Ramon Muntaner, Jordi Llavina

1999-11-05 El Periódico - Programación C33 Avisa'ns quan arribi el 2000

1999-11-06 Sur (Suplemento) - Piezas de tiempo. Extremecida memoria, Antonio

Garrido

1999-11-13 La Razón - El territorio de la novela. Extremecida Memoria, Jesús Ferrer Solà

1999-11-14 Lectura - Prodigi narratiu, Andreu Loncà

1999-11-15 El Temps - L'humor amera el meu darrer llibre. Calaveres atonites, Lluís

Bonada

1999-11-17 Diari de Girona - Calaveres atonites, Carles Duarte

1999-11-24 Regió7 - Sempre he refusat el localisme, Josep Gras

1999-11-26 l'Ebre - Calaveres atonites, Esteve Betrià

1999-11-28 Diari d'Andorra - Retorn a Mequinensa, Oriol Malló

1999-12-01 Galera 12 - Llibreria Gaudí - Reus

1999-12-05 Presència - Una crònica distorsionada, Ponç Puigdevall

1999-12-09 Segre - Atònites i rialleres, Vidal Vidal

1999-12-10 Segre - Calaveres atònites per l'exit, Anna Sáez

1999-12-26 La Mañana (Revista) - Jesús Moncada escriptor de culte, Xavi Manau

1999-12-30 La Mañana - Moncada trae sus Calveres Atònites a Ponent, Marta Grau

2000-03-13 Aiguabarreig - Entrevista amb Jesús Moncada

2000-01-02 Lectura - Entrevista a Jesús Moncada, Anna Sàez

2000-01-16 Cuadernos - Els personatges són part de mi, Vicent Usó i Mezquita

2000-02-01 Lectures - Tria personal, Josep M. Ripoll

2000-02-11 El Periódico - Ránking ventas libros

2000-02-11 La Fura - Jesús Moncada La ironía feta art, Pere Martí i Bertran

2000-02-11 La Marxa - El règim franquista era grotesc, Esther Pasqual

2000-02-28 Avui - Borbón, Joan Oliver

2000-03-02 El País - Collita del 99, Xavier Bru de Sala

2000-03-06 El País - Una dedicatoria por favor, Jordi Puntí

2000-03-16 El Punt de Girona - L'Home de Mequinensa, Ramon Estéban

2000-03-20 Jesús Moncada a la biblioteca Francesc Pujols - Martorell

2000-03-27 El 9 Nou - Jesús Moncada i l'humor, Joaquim Vinyes

2000-05-01 Públic - Jesús Moncada desde Mequinensa amb humor

2000-05-01 Serra d'Or - La Mequinenza de Jesús Moncada, Ana Rodríguez Fisher 
2000-10-08 El Periódico - Autodefinit. Passatemps

2000-10-27 Avui - Moncada al 'cafè de la Virreina'

2000-12-15 El Periódico - Sentència literària aclaridora - Espinàs

2001-02-01 Avui - Els escriptors catalans premien Jesús Moncada i Victor Mora

2001-03-01 L'independent - Preparo la meva primera novel.la ambientada en BCN

2001-04-01 Lateral - El origen de las especies, Jesús Moncada

2001-04-01 Serra d'or - Encuesta literatura catalana S.XX

2001-04-08 El Periódico de Aragón - El Ebro

2001-04-20 El Periódico - El pintor que escribe, Jaume Fabre

2001-04-23 El Periódico - Avui només firmaré llibres a casa, Ramon Marcano

2001-05-01 El 855 - Jesús Moncada. La ironia feta art

2001-06-15 El Mundo - Escritores. Foto de Jesús Moncada en el Ateneu de Barcelona. 7

edición, Quique García

2001-06-16 El Periódico de Aragón - Los premios de Santa Isabel rinden un homenaje al

periodismo Jesús Moncada de la narrativa

2001-06-16 Heraldo de Aragón - Medalla de Santa Isabel

2001-07-01 Temps de Franja - Jesús Moncada medalla de Santa Isabel de Portugal 2001

Mario Sasot

2001-07-09 Temps de Franja - Llengua catalana. Premi Isabel de Portugal

2001-09-01 L'Hiperbòlic - Entrevista

2001-09-07 Presència - Els autors de la temporada de tardor

2001-09-13 Avui - Moncada entre els guardonats amb la Creu de Sant Jordi

2001-09-13 El País - Jesús Moncada Creu de Sant Jordi

2001-09-13 El País - Jugant fora de casa Isabel Obiols la literatura catalana traduida

2001-09-13 La Mañana - La Creu de Sant Jordi recala en cuatro insignes leridanos,

Andrés Rodriguez

2001-09-30 Segre - Jesús Moncada. El novel.lista més traduït, Andreu Loncà

2001-10-01 L'Illa - Creu de Sant Jordi a Jesús Moncada (Carme Riera Premi Nacional de

LitCat)

2001-10-01 L'Illa - La recreació de la natura, Vicent Borràs

2001-10-04 Segre - Jesús Moncada finalista del premi Femina a França per Estremida

memòria en trad.

2001-11-06 La Vanguardia - Todos los cuentos de Moncada ed. Magrana

2001-11-07 Segre - Jesús Moncada recopila les narracions curtes a 'Contes'

2001-11-08 El País - Quadern. Entrevista, Pau Vidal

2001-11-08 El País - Caricaturisme civilitzat, Ponç Puigdevall 
2001-11-11 Entregan la Creu de Sant Jordi a cuatro ponentins, Toni Alcántara 2001-11-11 La Mañana - El Goverm distingue a cuatro ponentins.

2001-11-11 Segre - Entrega de la Creu de Sant Jordi a cuatro ponentins, Toni Alcántara 2001-11-12 Avui - 20 anys de contes de Jesús Moncada, Ada Castells 2001-11-12 El Triangle - El mèrit del contista, Pep Martí 2001-11-13 La Mañana - El Gobern honra la lletres de Ponent 2001-11-23 La Vanguardia - Carne de café, Julià Guillamon 2001-12-01 Temps de Franja - Jesús Moncada Escriptor de l'any, Hèctor Moret 2001-12-08 El Periódico - El valor del caràcter que marca, Josep María Espinàs 2002-01-01 La pizarre litèraire - A travers la mémoire, Jaques Fressard 2002-01-03 l'Humanité - Rèvoltes en Catalogne, Juan Marey 2002-01-18 Presència - Jesús Moncada. Entrevista, Xavier Cortadellas 2002-02-01 El Periódico - Andamio de Mequinenza, Vicenç Pagès Jordà 2002-02-01 El Periódico - Bastida de Mequinensa, Vicenç Pagès Jordà 2002-02-04 La Vanguardia - Jesús Moncada, Joan Maria Pujals 2002-02-07 Avui - La gran novella de Mequinenza - Contes, Jordi Carrión 2002-02-26 Avui - Cognoms Borbón, Joan Oliver 2002-02-26 El Temps - L'inabastable univers d'un poble diminut, Arantxa Bea 2002-04-07 Avui - L'escriptor apassionat - Ser escriptor ha estat sempre la gran passió de

la meva vida; El conte de Mequinensa, Xavier Moret 2002-05-01 Gran Enciclopedia de España - Moncada Estruga, Jesús 2002-05-05 Avui - Anuncio del Dominical 2002-05-19 Segre - Literatura in-ponent, Anna Sáez 2002-11-17 Segre - Al seu aire. 2003-01-09 Segre - Jesús Moncada se solidaritza amb els pescadors gallegs amb un relat A.S.M. 2003-02-02 La Mañana - Mequinensa sempre ha estat d'esquerres, Francesc Guillaumet 2003-02-07 La Mañana - Camí de Sirga traducido al aragonés Gara d’Edizions,

Francesc Guillaumet 2003-02-16 Segre - El català desafina, Anna Sáez 2003-02-23 ABC Catalunya - Mi próxima novela transcurre en Barcelona, Sergi Doria 2003-03-02 Segre - El pare, Andreu Loncà 2003-03-07 Cicle xerrades literàries - LÁmetlla del Vallès 2003-03-26 La Vanguardia - Vichy catalán, Josep María Espinàs 2003-04-17 La Vanguardia - Jesús Moncada publica un libro de artículos, Mario Sasot 2003-04-18 La veu de l'Ebre - A la recerca de l'Ebre desaparegut 
2003-04-19 Segre - Jesús Moncada publica el primer libro de no ficción

2003-04-24 Segre - Escriptors de ponent de ponent, Vidal Vidal

2003-04-28 El País - Sin novedad en el fondo, Imma Monsó

2003-05-01 Heraldo de Aragón - Libro de la semana. Cabòries Estivals, Lluís Rajadel

2003-05-01 Temps de Franja - Jesús Moncada a Tamarit, Marià Alvarez

2003-05-05 Diari de Sabadell - M'interessen les repercussions individuals de la història 2003-06-06 La Veu de l'Ebre - Tinc tots els llibres de Jesús Moncada,

2003-07-01 Rolde - La recepción aragonesa de la obra de Jesús Moncada, Hèctor Moret 2003-09-01 Árnica - Revista del consell Cultural de les Valls d'Aneu.n58, Andreu

Carranza Fort

2003-09-01 La Narrativa española contemporánea vista desde Suecia, Kjell Johansson 2003-10-17 La Veu de l'Ebre - Geografía d'un imaginari

2003-10-24 La Mañana - Nosaltres els andorrans del sud, Joan Argilés Ciscart

2003-11-01 Temps de Franja - Projecte d'animació cultural a les escoles de la Franja 2003-11-08 Avui - Jesús Moncada canvia d'editorial després de 22 anys, Jordi Capdevila 2003-11-08 El País - Jesús Moncada ficha por Edicions 62 tras 22 años en La Magrana,

R.M.

2003-11-08 El Periódico - Jesús Moncada canvia d'editorial i esdevé estrella d'Edicions

62, M. Eugenia Ibañez

2003-11-08 La Vanguardia - Jesús Moncada ficha por Edicions 62 tras 22 años en La

Magrana, Rosa Maria Piñol

2003-11-08 Segre - Jesús Moncada canvia d'editorial després de 22 anys, R. Banyeres

2003-11-30 Segre - El anuncio de que Moncada deja la Magrana, Anna Sáez

2003-11-30 Segre - Me gustaría fichar a María Barbal

2003-12-01 El Cercle Literari. (Publicidad)

2003-12-01 Temps de Franja - Escriptors franjolins, A. Coso

2003-12-09 La Mañana - Traducido al húngaro y al esloveno 15-ena, Francesc

Guillaumet

2003-12-23 El Periódico - Autors catalans amb difusió forana

2003-12-25 El País - El món de Jesús Moncada (sobre Cabòries estivals), Xavier Moret 2004-01-01 Books in Catalán Guadalajara un clàssic: Camí de sirga, Associació dEditors

en llengua catalana

2004-01-02 Beletrina - Entrevista könyvvásár szlovén, Simona Škrabec

2004-01-08 La Vanguardia - Camí de sirga al aragonés, Mario Sasot

2004-01-09 Segre - Tradueixen a l'aragonès Camí de Sirga

2004-01-13 Segre - El Moncada més insòlit, Anna Sáez 
2004-02-01 Avui (Suplement Diumenge) - Treballar amb Pere Calders no era mai

avorrit, Xènia Bussé

2004-02-01 l'Avenç - La memoria d'un món negat, Josep M. Muñoz

2004-02-04 El Punt - L'Any del llibre 2005 centrará, Andreu Barnils

2004-02-08 La Mañana - Camín de sirga en aragonés, Francesc Guillaumet

2004-02-21 El País - Palabrotas. Isoacrónimo, Empar Moliner

2004-02-25 La Mañana - Jesús Moncada habla de su obra en 'Alexandria'

2004-03-02 Segre - Reestrena de Camí de sirga, Anna Sáez

2004-03-04 El País - Geografía de Jesús Moncada, Jordi Puntí

2004-03-04 El Periódico - Edicions 62 reedita Camí de sirga, Eugènia Ibañez

2004-03-04 El Punt - Jesús Moncada repren Camí de sirga amb Edicions 62 V. Gaillard

2004-03-04 Internet Avui - Jesús Moncada aplega els seus dotze articles de premsa, Jordi

Capdevila

2004-03-04 Internet El Temps (Valencia) - Jesús Moncada publica els seus artlcles

periodìstics, Ll.B.

2004-03-04 La Vanguardia - El mito de Mequinenza Rosa Maria Piñol

2004-03-04 Segre - Camí de sirga arriba als 125.000 exemplars 25. edició

2004-03-05 Presència - Dossier La Franja de Ponent Bressol de destacats autors C.

Artigues

2004-03-07 La Vanguardia - La Mequinensa de Jesús Moncada fotók és a Crònica del darrer rom

2004-03-14 Segre - Autors traduits. Jesús Moncada polvoritza records

2004-03-26 El Periódico - 25 anys d'un clàssic. Camí de Sirga

2004-04-18 Segre - Lectura - Viure al peu de la lletra

2004-04-23 Internet Diari de Girona - Suplemento sobre Cabòries estivals

2004-04-23 La Veu de l'Ebre - Benvolgut senyor lector...

2004-05-02 Segre - A l'altra galàxia Gutengerg no hi ha impremta ni paper

2004-05-04 Intrenet La Vanguardia - Cabòries estivals

2004-05-13 El Periodico Libros Calaveres Atònites - retrato generacional

2004-05-20 Internet Avui Cultura aparició de tres reculls de contes

2004-05-21 La Veu de l'Ebre - Camín de sirga, Esteve Betrià

2004-06-17 Heraldo de Aragón - El orfebre de la prosa Cabòries estivals, Mario Sàsot

2004-10-01 Tríptico - Edicions 62

2004-10-14 Avui - Pàmias, El repòs de la literatura, Vicenç Llorca

2004-11-01 La crónica del Bajo Cinca - Soy un escritor de fuego lento, J. Casas

2004-11-18 El Periódico Llibres - Estremida memòria 
2004-11-23 Gobierno de Aragón - Jesús Moncada premio de las letras aragonesas 2004 2004-11-24 El Periódico de Aragón - Afabilidad, Mariano Gistaín

2004-11-24 El Periódico de Zaragoza - Jesús Moncada, Premio de las Letras

Aragonesas

2004-11-24 Heraldo de Aragón(2) - El fabulador de l’Ebro, Antón Castro

2004-11-24 Heraldo de Aragón - Todavía sueño con mi casa natal que se tragó el

pantano; Valle-Inclán, Lampedusa y Chejov, José Luís Solanilla

2004-11-24 La Mañana Jesús Moncada, Premio de las Letras Aragonesas

2004-11-24 Segre - J, Premio de las Letras Aragonesas

2004-11-25 Avui - Jesús Moncada, Premi de les Lletres Aragoneses

2004-11-25 Diario del Alto Aragón - Fraga Soy un escritor de fuego lento, Jaime Casas

2004-11-25 El Periódico de Aragón - Notícia del premi

2004-11-25 La Mañana - Moncada, Premio de las Letras Aragonesas 2004 La DGA

distigue por primera vez un autor en catalán, Francesc Guillaumet

2004-11-25 La Vanguardia - Jesús Moncada, premio de las Letras Aragonesas, Mario

Sasot

2004-11-27 El País (Babelia) - Bífidos y activos, Sergi Pàmies; Voces sin denominación

de origen, Ponç Puigdevall; La conquista del mercado, Rosa Mora; Mequinensa como lugar literario, Xavier Moret

2004-11-28 La Mañana - Viatge a Mequinensa Jesús Moncada, Xavier Moret; Apunt

crític Un premi merescut, Antonio Ibañez Izquierdo

2004-12-03 La Veu de l'Ebre Tortosa - Jesús Moncada. Premi de les lletres aragoneses 2004-12-06 Ajuntament de Mequinensa. Noticias Internet Notícia del premi aragonès 2004-12-15 Segre - Insten la DGA a protegir el català a la Franja, Maite Monné 2005-01-01 Temps de Franja - Jornada sobre la Franja a la universitat de Lleida, Marta

Canales

2005-01-01 Temps de Franja - La Franja de Ponent, aquesta gran desconeguda, Anna

Porquet i Botey; Anys i planys, Francesc Ricart

2005-02-03 Heraldo de Aragón - 30 años de narradores de aquí, Felix Romeo

2005-02-03 Heraldo de Aragón - Los autores que leyó y lee Aragón desde la democracia

Moncada, Labordeta, Mainer, Lalana

2005-02-03 Heraldo de Aragón - Los escritores mas votados. El jurado

2005-03-15 Internet - Associació d'escriptors - Retrats de Jesús Moncada, X.Moret

2005-03-22 El Punt - Bricall proposa un Consell de les Arts independent

2005-04-18 El Periódico - Jesús Moncada recibe en Teruel el Premio de las letras

Aragonesas 
2005-04-19 Diario de Teruel - Moncada recibe el premio de las letras aragonesas El autor escribe en lengua catalana

2005-04-19 Diario de Teruel - No importa en que lengua escribas sino lo que hagas con ella. El escritor catalanoparlante considera a Mequinenza coautora de su obra; Eva Ron

2005-04-19 Heraldo de Aragón - Jesús Moncada premio a una obra surcada por las aguas del Ebro, Leonor Franco

2005-04-19 Segre - Moncada rep el premi de les lletres aragoneses 2005-04-21 La Vanguardia - Aragón da su mayor galardón literario a Jesús Moncada, Mario Sasot 2005-04-29 La Comarca - Jesús Moncada. Azar y memoría, Jesús Cirac Febas 2005-05-05 Avui - Sant Jordi dels manifestos, Emili Teixidor 2005-05-15 Internet - Mequinensa i el Nobel en català, Carles Terès Bellès 2005-05-18 Discurso de la Consejera de la Cultura del Gobierno de Aragón, Eva

Almunia en la entrega del Premio de las Letras Aragonesas 2004.

2005-05-19 Diario del Alto Aragón - Jesús Moncada recibe la distinción de Aragón a su 'mundo literario' 2005-06-01 Club Excursionista de Gràcia Butlletí social - Crònica de llibres 2005-06-01 Els Marges - Camí de Sirga que no es pot recórrer a peu, Simona Skrabec 2005-06-01 Serra d'Or - Sis notes a partir de una lectura mequinensana de l'obra de Jesús Moncada, Héctor Moret 2005-06-01 Temps de Franja - Qui es qui a les lletres catalanes. Premi de les lletres aragoneses, Moncada rep el Premi de les Lletres Aragoneses a Terol, a companyat per cent mequinensans, Mario Sasot 2005-06-13 Europa press - Resumen Muere Jesús Moncada 2005-06-13 Jesús Moncada, des de Mequinensa, Guillem Chacón i Cabas 2005-06-13 Periódico electrónico de Corazonistas - Fallece Jesús Moncada. 2005-06-13 Segre - Internet - Mor l'escriptor Jesús Moncada 2005-06-14 20 Minuts - Mor l'autor Jesús Moncada 2005-06-14 ABC - Jesús Moncada murió ayer en la BCN que lo empujó a la literatura 2005-06-14 Avui - Els consells de l'Avui 2005-06-14 Avui - Creador del mite de Mequinensa különszám Mor Jesús Moncada; La voluntad de la perfecció, Carles-Jordi Guardiola; Un mestre de la memoria.del traç i de l'humor, Joan Triadú; Faulkner, García Márquez, Juan Benet, Jesús Moncada, Isidor Cònsul; Dol de la cultura catalana Redacció Barcelona; Des de la Franja, 
Guillem Chacón; El primer escriptor en català guardonat a l’Aragó Redacció Saragossa

2005-06-14 Ayuntamiento de Fraga - Fallece el escritor de Mequinenza Jesús Moncada. 2005-06-14 Diari de Balears - Mequinensa i les lletres catalanes es queden sense

l'escriptor Jesús Moncada

2005-06-14 Diario del Alto Aragón - Fallece - El consejo de Mequinenza le nombrará

Hijo predilecto Jaime Casas. Carrera con numerosos reconocimientos

2005-06-14 El Mundo de Catalunya - Fallece Jesús Moncada. El creador del mito de

Mequinensa, Rafael Vallbona

2005-06-14 El Mundo.es - Obituarios Jesús Moncada, autor aragonés que escribía en catalán

2005-06-14 El País - Fallece Jesús Moncada, el gran escritor del Ebro, Fallece Jesús

Moncada, cronista del Ebro, Xavier Moret; Un clásico en vida, Xavier Moret; La

magia de la memoria, Pau Vidal; La otra Mequinenza, Jordi Puntí; Cocodrilo de agua

dulce, Sergi Pàmies; Lamento por la pérdida de un autor „clásico” y „discreto,

Redacción BCN

2005-06-14 El Periódico - Fallece a los 63 años el escritor aragonés Jesús Moncada. Sin

sirga en el camino, José Antonio Labordeta; Hijo predilecto de su pueblo

2005-06-14 El Periódico Internet - Luto en las Letras catalanes, M. Eugenia Ibañez 2005-06-14 El Periódico de Catalunya - Mor Jesús Moncada. Sense sirga al camí,

Labordeta; Mequinensa plora, Moncada ha fet més per la literatura catalana que qualsevol campanya, Ernest Folch

2005-06-14 El Periódico de Aragón - Esquelas

2005-06-14 El Punt - Mor I'escriptor Jesús Moncada, catalá de Mequinensa; Mor Jesús

Moncada, la veu de Mequinensa, Valèria Gaillard; Estremida memòria”, relat d'una densa història moral, Toni Sala

2005-06-14 Heraldo de Aragón - Murió el narrador Jesús Moncada Anton Castro; Un

escritor aragonés Santiago Paniagua

2005-06-14 Heraldo de Castellón - Murió el narrador Jesús Moncada, Anton Castro 2005-06-14 Internet Alemán - Chronist des Ebro

2005-06-14 Internet - Elegía por Jesús Moncada, AntonCastro

2005-06-14 La Mañana - Noticia y homenaje, Jordi Rull; Moncada; Mequinenza in su

memoria literaria; Jesús Moncada, el novelista de Mequinenza muere a los 63 años, F.

Guillaumet; Vallverdú destaca que „escribía desde casa para describir un universo”;

Retorn a Mequinensa 
2005-06-14 La Razón - Muere a lo 63 años Jesús Moncada, escritor aragonés en lengua catalana, V Fernández; Las letras pierden a Jesús Moncada que mostró su Aragón natal en clave mágica, Víctor Fernández

2005-06-14 La Vanguardia - Jesús Moncada cruza el río. Un vacío que intriga y fascina; Aragón ha reconocido la obra de Moncada, escrita íntegramente en lengua catalana; Un vacío que intriga y fascina, Julià Guillamon; En las tierras de frontera, Mercé Ibarz;

2005-06-14 Metro Directe - Mor l'escriptor Jesús Moncada 2005-06-14 Qué - Adiós a Jesús Moncada 2005-06-14 Segre - Noticia y Homenaje. Mor Jesús Moncada, i les lletres catalanes perden el eu escriptor més tradüit; Un del escriptors en català més tradüits; Aragó lamenta la seua pèrdua; La literatura d’un home senzill, Mercè Biosca; L’últim camí de sirga, R.B.

2005-06-14 VilaWeb Lletres - Del món petit de Mequinensa a la literatura de valor universal

2005-06-15 ABC - Cenizas de calendario, Julio José Ordovás 2005-06-15 Avui - El llegat de Jesús Moncada. Jesús Moncada. Jesús Moncada. Jesús

Moncada, Isabel Clara Simó; Jesús Moncada, Maria de la Pau Janer; El llegat de Jesús Moncada Vinyet Panyella; Les cendres de Jesús Moncada s’escamparan per Mequinensa 2005-06-15 Ayuntamiento de Fraga - Mequinenza nombra a Jesús Moncada hijo predilecto 2005-06-15 El País - Prohombres. Rosa Cullell; Familiares. amigos y lectores velan los restos de Jesús Moncada

2005-06-15 El Periódico - Moncada s'acomiada amb discreció (Rous foto i paraules), M. Eugenia Ibáñez 2005-06-15 El Periódico - Moncada se despide con discreción, M.E. Ibáñez; Las lecturas de Jesús Moncada 2005-06-15 El Punt - L'escriptor descansara a la casa on va néixer. que no va quedar coberta pel pantà 2005-06-15 Heraldo de Aragón - Jesús Moncada dejó dispuesto que sus cenizas e epazan por Mequinenza 2005-06-15 Heraldo.es. - Emotiva despedida a Jesús Moncada en Mequinenza (no, en el tanatorio de les Corts, Maragall, Godia, Bargalló, escriptors aragoneses, 2 autocars de Mequinensa) 
2005-06-15 La mañana - El mite de Mequinensa Jesús Moncada, Mercè Biosca;

Mequinensa declara hijo 'adoptivo' de la población a Jesús Moncada, Francesc

Guillamet

2005-06-15 Noticies Mequinensa - Jesús Moncada fill predilecte dels Mequinensans,

Pleno Extraordinario de la Corporación Municipal de Mequinensa

2005-06-15 Noticies Mequinensa - Jesús Moncada. Su historia

2005-06-15 Segre - Jesús Moncada vuelve al Edén, Anna Sáez; Mequinensa hace

predilecto a su hijo, José Díaz

2005-06-15 Yahoo - Unas 400 personas despiden al escritor Jesús Moncada en

Barcelona

2005-06-16 Avui - Que hi feu aquí - Només sòc un escriptor, Ada Castells

2005-06-16 Avui(2) - Bustia Jesús Moncada, Meritxell Nus i Gallart

2005-06-16 Diari de Tarragona - Emotiva despedida a Jesús Moncada

2005-06-16 El Mundo - Emotivo adiós al ecritor Jesús Moncada

2005-06-16 El País - Amigos, familiares y escritores despiden a Jesús Moncada, Israel

Punzano

2005-06-16 El País (Quadern) - Última sirga, Homenatge a Jesús Moncada; Afluents,

Agustí Fancelli; Un paseig per Mequinensa; Xavier Moret; Pilans i parets mestres,

Francesc Serès; Elègia i commoció, Ponç Puigdevall; Comprar temps, Jordi Puntí;

Mala comanda, Pau Vidal; Com un riu llarg i tranquil, Imma Monsó; Rèquiem, Sergi

Pàmies

2005-06-16 El Periódico - Un emotivo acto laico, M. Eugenia Ibáñez

2005-06-16 El Periódico (Cat.) - Un emotiu acte laic, M. Eugenia Ibáñez

2005-06-16 El Periódico (Libros) - Qué quiere? - Libros, contesté, Eva Melús

2005-06-16 El Periódico (Libros) (Cat.) - Què vol? Llibres, E. Melús

2005-06-16 El Periódico de Aragón - Luto compartido por un literato universal, R. M.

2005-06-16 El Punt - L'adéu al navegant sense llagut, Marius Serra

2005-06-16 Heraldo de Aragón(1) - Mequinenza viaja a BCN para despedir a Jesús

Moncada

2005-06-16 Heraldo de Aragón(2) - El fabulador inmortal de Mequinenza; Jesús

Moncada, Cocodrilos y calaveras, Félix Romeo

2005-06-16 Internet Esloveno.

2005-06-16 La Mañana - Emotiva despedida en BCN a Jesús Moncada

2005-06-16 La Vanguardia - Mequinenza en Barcelona, Rosa Maria Piñol

2005-06-16 Segre(1) - A Jesús Moncada, Francesc Blanc

2005-06-16 Segre(2) - Emotivo último adiós a Jesús Moncada 
2005-06-17 Avui - Sobre la inqüestionable valua del'obra de JesúsMoncada: Calaveres atònites, Sebastià Alzamora

2005-06-17 El Periódico - La voz de un río y su mundo, Josep Maria Espinàs 2005-06-17 La Mañana - Jesús Moncada ya tiene una calle (Lleida), D. Torrado 2005-06-17 L'Independent - Mor Jesús Moncada, veí de Gràcia, Meritxell Díaz; Carta

d'una veina a un escriptor, Aurora Moreno

2005-06-17 L'Independent (2) - Escriptor, llengua, país

2005-06-17 Presència - En la mort d'un gran autor, Miquel Riera

2005-06-17 Segre - Carrers per a Jesús Moncada i ..., Jesús Albert Villaró; De Porto a la

Seu, per Mequinensa, Vidal Vidal

2005-06-17 Segre - Ponentades homenajea a Moncada, R. Banyeres

2005-06-18 Avui - La Franja creará un guardó a la memòria de Jesús Moncada, Joan Tort 2005-06-18 La Vanguardia - Moncada, Anton M. Espadaler

2005-06-19 Avui - Cartas al director, M. Pilar Febas

2005-06-19 El Punt - Jesús Moncada, un clàssic viu, Ramon Monton

2005-06-19 El Punt(2) - Mequinensa de Moncada, Manuel Cuyàs

2005-06-19 La Mañana - Adéu a Moncada, Francesc Guillamet

2005-06-20 El Punt - Entrevista a Feliu Formosa - Cita a Jesús Moncada, Valèria

Gaillard

2005-06-20 Internet Diari Avui - Que hi feu aquí. Només sóc un escriptor, Ada Castells 2005-06-21 El Temps - La Franja perd el seu referent, Anna Sáez

2005-06-21 El Temps(2) - Homenatge a Jesús Moncada, Martí Mancilla Muntada; ERC, estatut, Salvador Cot

2005-06-21 El Temps(3) - Moncada i el silenci, F. Marc Álvaro

2005-06-21 La Vanguardia Digital - Mequinenza en Barcelona, Rosa Ma Piñol

2005-06-21 La Vanguardia Digital(2) - Jesús Moncada, Antón Mª Espadaler

2005-06-21 La Vanguardia Digital(3) - Jesús Moncada, Oriol Pi de Cabanyes

2005-06-21 Segre - Era un gran autor que va convertir Mequinensa en un lloc universal

2005-06-22 Segre - La Universitat Catalana d'Estiu recordará a Jesús Moncada

2005-06-23 Avui - Algunes coses que s'han escrit i dit de l'escriptor de Mequinensa,

Ferran Sáez Mateu

2005-06-23 El 3 de vuit - Adéu Jesús, Pere Martí i Bertran

2005-06-23 El Periódico (Libros) - Territorio Moncada. Viaje al escernario y a la

memoria literaria del autor de 'Camí de sirga'; El autor que tiró siempre de la sirga entrevista amb Carles-Jordi Guardiola, Eva Melús; Tierna Arcadia irònica, Vicenç Pagès Jordà; El Macondo del Ebro, Maria Jesús Ibáñez; Negro carbón y flores en el 
camposanto; Un dialecto que es lengua literaria; Del 'llaüt' y las gruesas sirgas a la pesca deportiva; Los títulos, el único secreto; La gran enciclopedia viviente; Moncada en Liubiana, Ernest Folch

2005-06-23 La Voz del Bajo Cinca - Fallece Jesús Moncada; „En Mequinenza están mis raíces y venir aquí, me vivifica” 2005-06-24 Presència - Moncada. Un dels afluents més rics de I'Ebre, Emili Teixidor 2005-06-25 El País - El laúd del Ebro, Javier Goñi (amb la Samba) 2005-06-25 La Vanguardia - Jesús Moncada, Oriol Pi de Cabanyes 2005-06-26 Avui - La llengua de Jesús Moncada, M Pilar Febas 2005-06-26 Segre Lectura 3 - Adéu senyor Moncada, Andreu Lloncà 2005-06-28 Diari de Tarragona - De Moncada a Pedrals, Carles Duarte 2005-06-28 La Vanguardia - Moncada, Calders y Montaner i Simón 2005-06-29 La Vanguardia - Mequinenza, fracaso tropical, Julià Guillamon 2005-07-01 Butlletí Terra Alta - Recordant Jesús Moncada 2005-07-01 Temps de Franja - A reveure Jesús, Màrio Sasot 2005-07-06 El Periódico de Aragón - Zaragoza rinde homenaje a Jesús Moncada 2005-07-06 Noticies Mequinensa - Mequinenza le dirá adiós a Jesús Moncada en la

Antigua Mequinenza 2005-07-07 Emotivo homenaje al escritor Jesús Moncada en Zaragoza 2005-07-07 Heraldo de Aragón - Jesús Moncada era uno de los nuestros. Homenaje en

Zaragoza

2005-07-08 L'Independent - A la memòria històrica de Jesús Moncada 2005-07-09 Ayuntamiento de Meqiunenza - Cenizas

2005-07-10 Heraldo de Aragón - Último adiós a Jesús Moncada a Mequinenza donde su

madre esparció sus cenizas, José Díaz 2005-07-10 Heraldo de Aragón - Último adiós a Jesús Moncada 2005-07-10 Internet - Elegía por Jesús Moncada con comentarios, AntonCastro 2005-07-10 La Mañana - Las cenizas de Jesús Moncada que noveló Mequinenza ya descansan en el corazón de Mequinenza, F.G. (600-an kísérték) 2005-07-10 La Mañana - Mequinenza recibe las cenizas de Moncada 2005-07-10 Segre - La mare de Jesús Moncada escampa les cendres, José Díaz 2005-07-11 Mikado - Libros de Jesús Moncada en península 2005-07-13 La Vanguardia - Moncada, más que ejemplar, Xavier Bru de Sala 2005-07-15 La veu de l'Ebre - Portada 2005-07-15 La veu de l'Ebre - Monográfic De Mequinensa al món; Dissabte 16 van escampar les cendres de Jesús Moncada al poble, M. G. Castellà; Cultura prepara un 
homenatge de nivell a Jesús Moncada per al mes de setembre, Redacció; Tornar a casa, Hèctor Moret; Jesús Moncada - Entrevista a Santiago Arbiol, amic intim, M. Castellà; Entrevista a Magda Gòdia, Montse G. Castellà; Entrevista a la Rosa Maria Moncada; Entrevista al Carles-Jordi Guardiola; Entrevista a l’Ernest Folch; La humanitat elegant, Montse G. Castellà; Estremides paraules atònites, Els diaris més destacats del país homenatgen l'escriptor català de Mequinensa més universal recull i resum del que es va escriure sobre ell a la premsa; Profeta a casa seua; L’esport nacional del poble; Llista de premis i guardons

2005-07-28 La Mañana - La muerte de Jesús Moncada dispara la venta de sus novelas en Lleida Francesc Guillamet

2005-07-29 Segre -Jesús Moncada trobador a l'ombra, Olga Sánchez i Centeno 2005-07-29 L'Independent - Homenatge a Jesús Moncada. Nom de la plaça, Neus Nogué i Jordi Matas 2005-08-14 Segre - Abacus compta amb una taula exclusiva de les obres de Jesús Moncada 2005-08-14 Segre - Moncada en el record dels lectors 2005-08-17 La Vanguardia - Ranking de ventas Camí de sirga, Dona justa de Márai 2005-08-20 La Mañana - La Universitat Catalana d'estiu homenajea a Jesús Moncada 2005-08-21 El Periódico - La universidad de Prada recuerda a Jesús Moncada 2005-08-21 La Vanguardia - La Magrana no prevé editar la obra inacabada de Jesús Moncada, Xavier Aldekoa 2005-08-21 Segre - Un gran autor que va convertir Mequinensa en un lloc universal, R. B. 2005-08-21 Avui - Prada homenatja l'escriptor de Mequinensa 2005-08-23 El Periódico - La novela pòstuma de Jesús Moncada no serà publicada, M.

Eugenia Ibáñez 2005-08-24 Segre - La família de Jesús Moncada decideix no publicar l'obra inacabada 2005-08-28 Segre - El temor al punt final, A. S. M. 2005-09-01 Diploma Hijo adoptivo de Mequinenza 2005-09-10 El Periódico de Aragón - Mequinenza rinde un emotivo homenaje a Jesús

Moncada, Daniel Montserrat Mequinenza 2005-09-10 Heraldo de Aragón - Jesús Moncada halla en una Mequinenza estremecida una casa para siempre Homenaje hijo predilecto e inauguraciones 2005-09-10 Segre - Mequinensa ret homenatge al seu fill predilecte Jesús Moncada 2005-10-27 Avui - Moncada 'in concert,' Enric Vila 2005-10-27 Diari de Tarragona - La cultura catalana retrat homenatge a Jesús Moncada 
2005-10-27 El Punt - Memòria estremida, Valèria Gaillard

2005-10-28 El Punt - El Museu d'Art M de Tarragona exposará l'obra pictòrica de Jesús

Moncada, Carina Filella

2005-10-29 Diari de Tarragona - Tarragona recorda Jesús Moncada programa

Recuperem la paraula amb Tirant lo Blanc, lectura de Camí de sirga intellectual,

polítics

2005-11-01 Avui - Les Terres de l'Ebre recordaran l'obra de Jesús Moncada, Joaquim

Vilarnau

2005-11-01 Franja de Ponent - Jo sòc un català de Mequinensa, Auca de la Franja 2005-11-01 L'escletxa - Jesús Moncada El camí de la Franja, Francesc Ricart 2005-11-01 Públics - Recuperem la paraula amb Camí de sirga 2005-11-04 El Punt - Exposició i homenatges a l'escriptor Jesús Moncada, Gustau Morei 2005-11-05 El Punt - L'univers pictòric de Jesús Moncada exposició a Tarragona,

Natàlia Borbonès

2005-11-06 Diari de Tarragona - Homenatjant Jesús Moncada, Joan Aregio Navarro 2005-11-06 El Punt - La Diputació de Tarragona homenatja Jesús Moncada 2005-11-11 Diari de Tarragona - Segunda jornada de la lectura de Camí de sirga 2005-11-22 La Mañana - La Institució Cultural de la Franja premia al museo diocesà de

Lleida unitat musaistica, obispado de Lleida respectuosa amb la identitat de la Franja 2005-11-22 Segre - Lleida ret dos homenatges a Jesús Moncada el mateix dia 2005-11-23 La Mañana - Agenda Conferencia „Moncada a través de les seves lletres” 2005-11-23 La Mañana - El IEI y el consell de l'estudiantat rinden homenaje a Jesús Moncada, F.G. 2005-11-23 Segre - Agenda L’IEI recorda l'escriptor Jesús Moncada 2005-11-24 La Mañana - El IEI debate sobre la creación del novelista Jesús Moncada 2005-11-24 Segre - L'obra de Jesús Moncada supera la d'autors més mediàtics 2005-12-07 La Vanguardia - Concurso Què és una sirga?

2005-12-11 Lectura - Jesús Moncada, fantasmagories de la memòria, Josep Miquel

Garcia

2005-12-11 Segre - Alexandria sense accent lleidatà, J.B.

2005-12-24 Felicitació de Nadal Ajuntament de Mequinensa amb cita de Camí de sirga 2005-12-24 Felicitació de Nadal Llengua Nacional 2005-12-30 Passejada literària per la vila de Gràcia 2008-09-27 La Mañana - L'Aigua obra teatral a base de obraJesús Moncada dirigit per

Xicu Masó 2008-10-23 La Mañana - Mequinenza acogerá un encuentro de traductores 


\section{Kronológiai jelzet nélküli cikkek a digitalizált adattár sorrendjét követve}

Ajoblanco 61 - Quince prosistas catalanes que merece la pena leer, Vicenç Pagès i Jordà Anagrama edita a Todó y a Moncada en castellano

Avui - Mequinensa llueix sota l’aigua. Calaveres atònites, Bernat Salvà

Calders y la fotografía

Camino de sirga. Un elefante blanco sale de los cajones vacíos, Horaci Viola

Diario16 - Casi una epopeya - La galería de las estatuas, Santos Alonso

Exposició, Lectura i Conferència (Sandrine Ribes) Jesús Moncada pinzell i ploma 2006. 02. 6-17.

El alquimista Jesús Moncada. Traducción del Conde de Montecristo. El desierto avanza, Anton Castro

El terròs - Ebre amunt pel camí de sirga

En esta tierra - Mequinenza de Bajo-Aragon ahora

Jesús Moncada presenta Estremida memòria en Lleida, Albert Andreu

Jesús Moncada. La força de la narració, Joan Josep Isern

La galeria de les estàtues será la pròxima novella de Jesús Moncada

La nueva España - Retrato de multitud - La galería de las estatuas, C. G. E.

La tertulia, Ignasi Riera

L'Illa - La novella negra en català, Víctor Mansanet

Lo Raier - Camí de sirga de Jesús Moncada. proposta de lectura, Eva Aubarell Solduga

Los surcos de la memoria - La galería de las estatuas, Javier Goñi

Manarions - IX trovada d'escriptors al Pirineu

Moncada multifuncional

No hago novela rural, Rosa Maria Piñol

Novelles i novellistes. Balanç del segon semestre 1981, Ignasi Riera

Pujol admite los progresos del Ministerio de Cultura

Relatos - Historias de la mano izquierda

Serra d'Or - La crida de Serra d'Or als escriptors joves, Crónica del darrer rom

Testamento Jesús Moncada. Jesús Moncada végrendelete. Kelt. 1995. június 28.

Un Pueblo de humos y nieblas - Traducción al castellano de Historias de la mano izquierda, Javier Goñi

Una pàgina de novella són quatre dies de treball, F. Burget Ardiaca

Discurso de la Consejera de la Cultura del Gobierno de Aragón, Eva Almunia en la entrega del Premio de las Letras Aragonesas 2004. 2005. ápr. 18. 


\section{Felhasznált irodalom}

\section{Bibliográfia}

Acín, Ramón (dir.), Jesús Moncada, Su universo literario, Zaragoza, Gobierno de Aragón, Ayuntamiento de Mequinenza, 2005.

Aguilar Fernández, Paloma, „La evocación de la guerra y del franquismo en la política, la cultura y la sociedad españolas”, in Santos, Julià (dir.), Memoria de la Guerra Civil y del Franquismo, Madrid, Taurus Historia, Fundación Pablo Iglesias, 2006. 279319. o.

Alcoberro, Agustí, 100 històries clau de la Història de Catalunya, Valls, Cossetània Edicions, 2015.

Alcoberro, Agustí, Arxiu de ficcions, Barcelona, Cruïlla, 1991.

Alfaya, Javier, Crónica de los años perdidos, La España del tardofranquismo, Madrid, Ediciones Temas de Hoy, 2003.

Amat-Piniella, Joaquim, K.L. Reich, Barcelona, Edicions 62, 2006.

Anderle Ádám, Spanyol mozaik, Pécs, Kronosz Kiadó, 2016.

Anderle Ádám, „Spanyol törvény a történelmi emlékezetről”, in Anderle Ádám, Történelmi minták és utak, Esszék Spanyolországról és Latin-Amerikáról, Szeged, Szegedi Tudományegyetem „Hispán világ története” PhD-program gondozásában, 2009.

Anderle Ádám, Spanyolország története, Budapest, Móra Ferenc Kiadó 1992.

Anderle Ádám, Megosztott Hispánia, Budapest, Kossuth Kiadó 1985.

Aragüés, Chusé a Prames Kiadó vezetője Moncadáról www.cazarabet.com/ conversacon/fichas/moncada.htm, letöltés 2017. nov. 25.

Arbó, Sebastià Juan, Terres de l’Ebre, Barcelona, Edicions 62 i La Caixa, 1980.

Arisztotelész, Poétika, Szeged, Lazi Könyvkiadó, 2004.

Arnau Segarra, Pilar (dir), Identitat, Literatura i Llengua, Actes de la secció literAriade XIX-é Colloqui Germano-Català, Barcelona, Publicacions d’Abadía de Montserrat, 2006.

Aróstegui, Julio, „Memorias, historias y confrontaciones. Los conceptos del debate” in Josefina Cuesta (dir), Memorias históricas de España, Madrid, Fundación Largo Caballero, 2007. 
Aróstegui, Julio, „Traumas colectivos y memorias generacionales” in Godicheau, François - Aróstegui Sánchez, Julio (dir.), Guerra civil, mito y memoria, Madrid, Marcial Pons, Ediciones de Historia, 2006. 57-95. o.

Aróstegui, Julio, „Retos de la Memoria y trabajos de la historia”, Pasado y Memoria. Revista de la historia contemporánea, 2004. Núm. 3. 15-36. o.

Assman, Aleida, Rossz közérzet az emlékezetkultúrában, Budapest, Múlt és Jövő Kiadó, 2016.

Assmann, Aleida, „Beszélgetés a holtakkal: a szöveg, mint a kulturális emlékezet médiuma”, in Kisantal Tamás (szerk.), Narratívák 8. 146-160. o.

Assmann, Jan, A kulturális emlékezet, Budapest, Atlantisz Könyvkiadó, 2013.

Augustinus, Aurelianus, Vallomások, Budapest, Gondolat 1987.

Aub, Max, La verdadera historia de la muerte de Francisco Franco https://littera.wikispaces.com/aub_muerte_francisco_franco, letöltés 2017. nov. 8.

Bada Panillo, José R., El debat del català a l’Aragó (1983-1987), Calaceit, La Gabella, Associació Cultural de Matarranya, Centre d’Estudis de Baix Cinca, 1990.

Balaña i Abadía, Pere, Les arrels islàmiques de Mequinensa, Barcelona, Rafael Dalmau, Editor, 1994.

Balcells, Albert, Els llocs de memòria dels catalans, Barcelona, Proa, 2008.

Balcells, Albert, La història de Catalunya a debat, Barcelona, Curial, 1994.

Balcells, Albert, Cataluña contemporánea II. 1900-1939, Barcelona, Siglo XXI. Editores, 1974.

Barceló, Miquel -de Riquer, Borja - Ucelay Da Cal, Enrique, „Sobre la historiografia catalana”, Avenç 1981. Núm. 50. 68-73. o.

Barceló, Miquel - Casassas, Jordi - Garrabou, Ramon - Izard, Miquel - de Riquer, Borja - Serra, Eva - Termes, Josep - Ucelay Da Cal, Enrique, „Debat sobre la tasca del'historiador avui”, Avenç, 1984. Núm. 67. 70-76. o. https://app.box.com/s/ cqz2xjt63y4rhp93gpif, letöltés 2017. okt. 11.

Bargalló Valls, Josep, Què fem a Frankfurt? 2007 http://es.slideshare.net/ JosepBargallo/que-fem-fkt-catala, 2015. okt. 11.

Barbal, Maria, Pedra de tartera, Barcelona, La Magrana, de Butxaca, 2007.

Bartlett, F. C., Az emlékezés, Budapest, Gondolat, 1985.

Baylac-Ferrer, Alà, Catalunya Nord, Societat i identitat, Perpinyà, Edicions Trabucaire, 2009. 
Bayo, Emili - Biosca, Mercè, Guia de lectura de Jesús Moncada, Barcelona, La Magrana, 1992.

Bécsy Tamás, Mi a dráma?, Budapest, Akadémiai Kiadó, 1987.

Benguerel, Xavier, Els fugitius, Barcelona, Barcanova, Biblioteca didàctica de literatura catalana, 1990.

Bernanos, Georges, Les grands cimitières sous la lune, Paris, Librerie Plon, 1938.

Bernecker, Walter L., „Luchas de memorias” en la España del siglo XX., in Josefina Cuesta (dir.), Memorias históricas de España, Madrid, Fundación Largo Caballero, 2007. 38-58. 0.

Bezsonoff, Joan Daniel, Les amnèsies de Déu, Barcelona, Empúries Narrativa, 2005.

Biosca i Llahí, Marc, Jesús Moncada, mosaic de vida, Lleida, Pagès Editors, 2017.

Biosca, Mercè - Cornadó, M. Pau - Morvay, Károly, Aportacions de Jesús Moncada a la fraseologia catalana, vol. I., Lleida, Pagès Editors, 2015.

Biosca, Mercè, Dibuixos i caricatures de Jesús Moncada, Lleida, Pagès Editors, 2011.

Biosca, Mercè, „El riu de la memòria”, in Acín, Ramón (dir.), Jesús Moncada, Su universo literario, Zaragoza, Gobierno de Aragón, Ayuntamiento de Mequinenza, 2005. 27-39. o.

Biosca, Mercè - Cornadó, M. Pau, „Jesús Moncada: el riu de la memòria”, in Escriptors d'avui. Perfils literaris, Lleida, Ajuntament de Lleida, 1992. 45 -51. o.

Blázquez, Mariano - Fernández, Gabino - Tarquis, Pedro, Reseña histórico-social del protestantismo español www.elolivo.net/HISTORIA/Resena\%20historico-social\%20del\%20 Protestantismo\%20Espanol-Blazquez.pdf, letöltés 2017. dec. 2.

Bloch, Marc, A történész mestersége. Történetelméleti írások, Budapest, Osiris, 1996.

Breisach, Ernst, Historiográfia, Budapest, Osiris, 2004.

Broch, Àlex - Calafat,Francesc - Izquierdo, Oriol - Lluró, Josep M. - Sala-Valldaura, Josep M., 70-80-90 Literatura, València, Quaderns Tres i Quatre, 1992.

Cabré, Jaume, Én vétkem, Budapest, Libri, 2014.

Cabré, Jaume, Les veus del Pamano, Barcelona, Edicions Proa, 2009.

Cabré, Jaume, Junoy barát és a hangok halála, Budapest, Európa, 2009.

Cabré, Jaume, L’ombra de l'eunuch, Barcelona, Proa, 1996.

Calders, Pere, Aquí descansa Nevares, Institut Ramon Llull, 36 Festival Internacional Cervantino, Cataluña invitada de honor, 2008.

Calders, Pere, Unitats de хос, Barcelona, Observador, 1991. 
Carbó, Ferran - Simbor, Vicent, Literatura catalana del siglo XX., Madrid, Editorial Sintesis, 2005.

Carpentier, Alejo, Irodalom és politikai tudat Latin-Amerikában, Budapest, Gondolat, 1979.

Carrasco, Jesús, Kegyetlen idő, Budapest, Magvető, 2013.

Castellanos, Jordi, „En Patufet, cent anys: la revista i el seu impacte”, L'Abadia de Montserrat, 2004. 80. o. https://books.google.cat/books?id=Ja5lf-tv8sgC\&pg=PA80\&dq $=$ Ramon+Folch $+\mathrm{i}+$ Camarasa $+1973+$ patufet\&hl=ca\&sa=X\&ei=8yO3UrjWNeO70QWyp YGoDw\#v=onepage\&q=Ramon\%20Folch\%20i\%20Camarasa\%201973\%20patufet\&f=f alse, letöltés 2017. nov. 7.

Castellet, Josep María, Qüestions de la literatura, política i societat, Barcelona, Edicions 62, 1975.

Castells, Manuel, Az identitás hatalma, Budapest, Gondolat Kiadó, 2005.

Castro, Luís, Héroes y caídos, Políticas de la memoria en la España contemporánea, Madrid, Los libros de la Catarata, 2008.

Cela, Camilo José La Colmena, Barcelona, Club Bruguera, 1982.

Cela, Camilo José, Pasqual Duarte családja, Budapest, Európa Kiadó, 1976.

Cercas, Javier, Szalamiszi katonák, Budapest, Európa Kiadó, 2013.

Chartier, Roger, „A világ mint reprezentáció”, in Kisantal Tamás (szerk.), Narratívák 8. Elbeszélés, Kultúra, történelem, Budapest, Kijárat Kiadó, 2009. 35-55. o.

Chauvell, Josep-Anton, „La literatura a la Franja de Ponent”, in Guerrero, ManuelPont, Jaume (dir.), Fronteres, territoris, mites, 3er Encontre de creadors, Lleida, 18-1920 d'abril de 2001, Ajuntament de Lleida i Pagès Editor, 2001.

Chavarría, Joan - Dolç, Jordi - Pont, Màrius, „La Mequinensa de Jesús Moncada”, in El gust per la lectura, Barcelona, Generalitat de Catalunya, Departament d'Ensenyament, Seminari 2000-2001.

Cirac Febas, Jesús, „Jesús Moncada y el manuscrito encontrado en Caspe” http://www.bajoaragonesa.org/elagitador/jesus-moncada-y-el-manuscrito-encontrado-encaspe/, 2017. dec. 5.

Comas, Antoni, Antologia de la literatura catalana, Barcelona, Andros, 1985.

Comas Cabistany, Manolo, Memorias, Mequinensa,'Coses del Poble’ 2007. 
Cònsul, Arnau, El general Prim, Barcelona, La Mansarda, 2014. „L’Enigmàtica mort del general Prim” Núvol 2014 április 23. https://www.nuvol.com/noticies/lenigmaticamort-del-general-prim/, 2017. szept. 18.

Coses del Poble Grupo de Investigación, Mequinenza 1877: La Causa de Vall Comuna, Mequinenza, 1999.

Coses del Poble Grupo de Investigación, Estiu ardent. Acción del alto de los Auts, Huesca, 1996.

Coso, Andrés, magánlevelek

Costa, Joaquín, Colectivismo Agrario en España, Madrid, Biblioteca J. Costa, 1911. http://www.saber.es/web/biblioteca/libros/colectivismo-agrario-en-espana/colectivismoagrario-en-espana.php?idLibro=28, letöltés 2017. máj. 10.

Crameri, Kathryn (dir.), Jesús Moncada, Where the rivers meet, Nottingham, Five Leaves Publications, 2011.

Cubero, Carlos - Estruga, Batiste, Mequinenza „Lo Poble” El triste final de un pasado, la esperanza de un futuro 1956-73, Zaragoza, Diputación de Zaragoza, 2016.

Cuesta, Josefina (dir), Memorias históricas de España, Madrid, Fundación Largo Caballero, 2007.

Cuesta, Josefina, „Memorias persistentes en España”, in Josefina Cuesta (dir), Memorias históricas de España, Madrid, Fundación Largo Caballero, 2007. 390-412. 0.

Csejtei Dezső, A spanyol egzisztencializmus története, Budapest, Gondolat, 1986.

Csikós Zsuzsanna, „A spanyol polgárháború traumája a kortárs spanyol szépprózában” Mediterrán Világ, 2017/39-40. 78-89. 0.

Csikós Zsuzsanna, „A kortárs spanyol regény”, Tiszatáj, 70. évf. 3. sz. 2016. március. 5-22. o.

Dávidházi Péter, „Epika és történetírás közös forrásvidékén”, in Dávidházi Péter (szerk.), A narratív identitás kérdései a társadalomtudományokban, Budapest-Szeged, Gondolat Kiadói Kör-Pompeji, 2003.

Delibes, Miguel, Patkányok, Leányfalu, Patak Könyvek, 2008.

Delibes, Miguel, Los santos inocentes, Barcelona, Planeta, 2001.

Domańska, Ewa, Encounters. Philosophy of History after postmodernism, Charlottesville and London, University Press of Virginia, 1998.

Eco, Umberto, Az értelmezés határai, Budapest Európa Kiadó, 2013. 
Egido León, Ángeles (dir.), Memoria de la Segunda República. Mito y Realidad, Madrid, Biblioteca Nueva, 2006.

Ellwood, Sheelag, Franco, Budapest, Akadémiai Kiadó, 1997.

Escudero Alday, Rafael, „Los tribunales españoles ante la memoria histórica: el caso de Miguel Hernández” http://hispanianova.rediris.es/11/ensayos/11e001.pdf, letöltés 2015. jan. 7.

Espluga Josep (dir.), Com embolicar la Franja amb una fulla de pi, Calaceit, Quaderns del Cingle, 2008.

Espluga, Josep - Moret, Hèctor, „Sobre la Transició a la Llitera (1976-1979): el tímid despertament de la identitat sociocultural d'una comarca perifèrica”, in Espluga, Josep (dir.), Com embolicar la Franja amb una fulla de pi, Calaceit, Quaderns del Cingle, 2008. 55-79. 0.

Espluga, Josep, „La imatge de l’altre: aragonesos i catalans fronterers que s’observen mútuament”, in Ripacurtia, 2003. Núm. 1. Dossier, Identitat Ribagorçana, 47-61. o.

Espluga, Josep, Planeta Franja, El trencaclosques del català a l’Aragó, Lleida, Pagès Editors, 2005.

Espriu, Salvador, La pell de brau. www.epdlp.com/texto.php?id2=486, letöltés 2017. dec. 11.

Estruga Estruga, Jordi (dir.), Mequinenza a través de la historia, Mequinenza, Ayuntamiento de Mequinenza, 2010.

Fabre, Jaume, Quienes somos los Catalanes... y porque así somos pedimos la autonomia, Barcelona, Edición Epidauro, Colección ¿Quienes somos?, 1979.

Falcones, Ildefonso, La catedral del mar, Barcelona, Grijalbo, 2006.

Faluba Kálmán (szerk.), A Gondviselés szeszélye, Mai katalán elbeszélők, Budapest, Íbisz Kiadó, 1998.

Farré Badia, Laura, Normativa i estil a Estremida memòria, de Jesús Moncada, Treball final del Màster en Assessorament Lingüístic, Gestió del Multilingüisme i Serveis Editorials, Universitat de Barcelona, Barcelona, 2014.

Fay, Brian, „Unconventional History”, History and Theory, 2002/41. 1-6. o. https://www.jstor.org/stable/3590664, letöltés 2017. nov. 27.

Fernán-Gómez, Fernando, Las bicicletas son para el verano, Madrid, Espasa Calpe, 1994.

Ferres, Antonio, A legyőzöttek, Kossuth, Budapest, 1965. 
Ferwagner Péter Ákos, „Történelem és politika; emlékezetpolitika”, Mediterrán Világ 2017. 39-40, 5-20. o.

Fusi, Juan Pablo (dir), España. Autonomías, Madrid, Espasa Calpe, 1989.

Fusi, Juan Pablo, Un siglo de España, La cultura, Madrid, Marcial Pons, 1999

Fuster, Joan, Nosaltres, els valencians, Barcelona, Edicions 62, 1994.

Fuster, Joan, Literatura catalana contemporània, Barcelona, Curial, 1988.

Gadamer, Hans-Georg, Igazság és módszer, Budapest, Gondolat Kiadó 1984.

García Márquez, Gabriel, Száz év magány, Budapest, Szépirodalmi Könyvkiadó, 1984.

García de Cortázar - González Vesga, Spanyolország története, Budapest, Osiris Kiadó, 2001.

Gelléri Gábor, „Az emlékezet fenomenológiától az emlékezetpolitikáig. Paul Ricoeur új könyvéröl”, in Korall, 2001 Ösz-Tél. 253-263. o. http://epa.oszk.hu/00400/ 00414/00004/pdf/12recenziok.pdf, letöltés 2017. ápr. 11.

Godicheau, François -Aróstegui Sánchez, Julio (dir.), Guerra civil, mito y memoria, Madrid, Marcial Pons, Ediciones de Historia, 2006.

Gómez López-Quiñones, Antonio, La guerra persistente, Memoria, violencia y utopía: representaciones contemporáneas de la guerra civil española, Madrid, Iberoamericana Vervuert, 2006.

Gonzàlez Vilalta, Arnau, La nació imaginada Els fonaments dels Països Catalans, Barcelona, Editorial Afers, 2006.

Gossman, Lionell, „Anekdota és történelem”, in Kisantal Tamás (szerk.), Narratívák 8. Elbeszélés, Kultúra, történelem, Budapest, Kijárat Kiadó, 2009. 217-249. o.

Goytisolo, Juan, Hordalék, Budapest Európa Kiadó, 1962.

Goytisolo, Juan, Problemas de la novela, Barcelona, Seix Barral, 1959.

Gregori Soldevila, Carme, „Metaficció irònica a Estremida memòria” https://www.uv.es/ironialitcat/metaficcio_ironica_moncada.pdf, letöltés 2017. nov. 27.

Gregori Soldevila, Carme, „Identitat, memòria, literatura: les novelles de Carme Riera”, https://www.academia.edu/34997261/18_Gregori-Soldevila.pdf, letöltés 2017. dec. 6.

Guardiola, Carles Jordi, Ofici d'editar, Barcelona, Edicions de la Magrana, 1996.

Guerrero, Manuel - Pont, Jaume (dir.), Fronteres, territoris, mites, Lleida, Ajuntament de Lleida i Pagès Editor, 2001. 
Guillamon, Julià, „Un coro de voces en el fondo del pantano”, La Vanguardia 1997. február 21. https://traces.uab.cat/search? $\operatorname{ln=ca\& sc=1\& p=estremida+memoria+jesus+}$ moncada\&f=\&action_search=Cerca\&c=tracesref\&c=tracesbib, letöltés 2017. nov. 24.

Gyáni Gábor, „A történetírás fogalmi alapjairól”, in Bódy Zsombor - Ö. Kovács József, Bevezetés a társadalomtörténetbe, Budapest, Osiris, 2006. www.tankonyvtar.hu/ hu/tartalom/tamop425/2011 0001520 bevezetes a tarsadalomtortenetbe/ch03s05.html, letöltés 2018. ápr. 2.

Gyáni Gábor, „Történelem és regény: a történelmi regény” http://www.lib.jgytf.uszeged.hu/folyoiratok/tiszataj/04-04/gyani.pdf, letöltés 2017. ápr. 6.

Gyáni Gábor, „Identitás, emlékezés, lokalitás”, 2000, 2008/6. ketezer.hu/2008/06/ identitas-emlekezes-lokalitas/, letöltés 2017. dec. 12.

Gyáni Gábor, Emlékezés, emlékezet és a történelem elbeszélése, Budapest, Napvilág, 2000.

Harsányi Iván, A félperifériáról a centrum felé, Pécs, Publikon Kiadó, 2011.

Harsányi Iván, „Manuel Azaña literátor, a harcoló Spanyol Köztársaság elnöke”, in A félperifériáról a centrum felé, Pécs, Publikon Kiadó, 2011. 109-119. 0.

Harsányi Iván, „Az elrabolt füzetek” http://www.c3.hu/ klio/klio992/klio119.html, letöltés 2017. aug. 12.

Harsányi Iván, Spanyol dilemmák, spanyol megoldások, Budapest, Pannónia könyvek, 2006.

Harsányi Iván, Franco, in Ormos Mária - Harsányi Iván, Mussolini - Franco, Budapest, Pannonica, 2001. 183-383. o.

Herzberger, David K., Narrating the Past, Fiction and Historiography in Postwar Spain, Durham and London, Duke University Press, 1995.

Huizinga, Johan, Hogyan határozza meg a történelem a jelent? Válogatott írások (1915-1943), Budapest, Typotex, 2015.

Huizinga, Johan, Homo Ludens, Universum Kiadó, Szeged, 1990.

Ibarz, Mercè, La tierra retirada, Barcelona, Editorial minúscula, 2009.

Iglesias Gallart, Xavier, Cadaqués i el patriotisme planià kéziratban.

Izquierdo, José María, „Maquis: Guerrilla antifranquista. Un tema en la literatura de la memoria española” https://www.uv.es/cerverab/Izquierdo.pdf, letöltés 2018. ápr. 18. 
Izquierdo, José Maria Memoria y literatura en la narrativa española contemporanea https://gupea.ub.gu.se/bitstream/2077/3226/1/anales_3-4_izquierdo.pdf, letöltés 2017. nov. 28.

Izquierdo, Oriol, Figuracions de l'imaginari https://www.vilaweb.cat/media/imatges/ AREES/biblioteca/1991/1/1_6.html, 2017. nov. 12.

Jackson, Gabriel, „Fascismo y comunismo en la historia de la república española”, in Egido León, Ángeles (dir.), Memoria de la Segunda República. Mito y Realidad, Madrid, Biblioteca Nueva, 2006. 35-63. o.

Jünke, Claudia, „Pasarán los años y olvidaremos todo, La guerra civil española como lugar de memoria en la novela y el cine actuales en España”, in Ulrich Winter (dir.) Lugares de memoria de la guerra civil y el franquismo Representaciones literarias y visuales, Madrid: Iberoamericana, Frankfurt: Vervuert, La Casa de la Riqueza Estudios de Cultura de España, 9. 2006, 101-131. o.

Katona Eszter, „Egy elfelejtett tragédia: spanyolok a mauthauseni lágerben”, http://old.szinhaz.net/pdf/drama/KatonaEszter Egy\%20elfejtett\%20tragedia.pdf, letöltés 2017. márc. 12.

Kavafís, Konstantinos, Versek https://www.researchgate.net/publication/283487014 Nuestro_Cavafis_El_nostre_Kavafis 63, letöltés 2017. júl. 21.

Kellner, Hans, „A Valóság legmélyebb tisztelete”, in Kisantal Tamás (szerk.), Tudomány és müvészet között. A modern történelemelmélet problémái, Budapest, L’Harmattan, 2003. 211-232. o.

King, Stewart, „Un problema de identidad? La cultura catalana de expresión castellana”, in Stewart King (dir.), Estudios de literatura, teatro y cine, Kassel, Edition Reichenberger, 2005, 1-15. o.

Kiš, Danilo, A holtak enciklopédiája, Budapest, Európa, 1990.

Kisantal Tamás, „Az irodalmi alkotás mint történelmi szöveg”, in Tiszatáj, LVIII. évf. 11. sz, 2004. november. http://epa.niif.hu/00700/00713/00159/pdf/tiszataj_EPA00713_ 200411 075-101.pdf, letöltés 2017. ápr. 12.

Kisantal Tamás (szerk.), Narratívák 8. Elbeszélés, Kultúra, történelem, Budapest, Kijárat Kiadó, 2009.

Kosztolányi Dezső, Édes Anna, Budapest, Osiris Milleneumi Könyvtár, 2000.

Kulin Katalin - Belia György (szerk.), Interjú! Nagy Írók Mühelyében, Budapest, Európa Könyvkiadó Modern Könyvtár, 1965. 
„L’Aragó catalonòfon entre el Primer Congrés (1906) i el Segon (1986)”, Estudis Baleàrics 82/83 Separata, Institut d’Estudis Baleàrics, 1986.

La divisió territorial de Catalunya, Barcelona, Generalitat de Catalunya, 1937. facsimile 1977.

Laforet, Carmen, A semmi, Leányfalu, Patak Könyvek, 2006.

Lara Ródenas, Manuel José de, Contrareforma y bien morir. El discurso y la representación de la muerte en la Huelva del Barroco. Huelva, Diputación Provincial de Huelva, 2001. 23. o.

Larraz, Fernando, „La Guerra civil en la última ficción narrativa espanyola”, in $L a$ Guerra Civil, Studia Historica. Historia Contemporánea, vol. 32., Universidad de Salamanca, 2014. 345-356. o.

László János, Történelem, elbeszélés, identitás, Magyar Tudomány, 2003/1 www.matud.iif.hu/03jan/laszlo2.html, letöltés 2016. nov. 1.

Lera, José, El País 1999. január 10. „40 años de la tragedia de Ribadelago en la que murieron 144 personas” https:/elpais.com/diario/1999/01/10/espana/915922818 850215.html, letöltés 2017. ápr. 6.

Levi, Carlo, Crist s’ha aturat a Èboli, Barcelona, Editorial Vergara, 1964.

Llamazares, Julio, Distintas formas de mirar el agua, Barcelona, Pinguin Random House, 2016.

Llamazares, Julio, Sárga eső, Budapest, Európa Kiadó, 2000.

Llamazares, Julio, Luna de lobos, Barcelona, Seix Barral, 1985.

Llanas, Manuel, L’edició a Catalunya: el segle XX (1939-1975), Barcelona, Gremi d'Editors de Catalunya, 2006.

Llanas, Manuel - Chumillas, Jordi, Edicions Magrana (1976-2000) Política, Literatura i escola, Barcelona, Publicacions de l’Abadia de Montserrat, 2012.

Lluís, Joan-Lluís, Conversa amb el meu gos sobre la França i els francesos, Barcelona, La Magrana, 2011.

López Facal, Ramón, „La nación ocultada”, in Pérez Garzón, Juan Sisinio (dir.), La gestión de la memoria, La Historia de España al servicio del poder, Barcelona, Crítica, 2000. 111-161. o.

López Villaverde, Ángel Luis, „La cultura de la memoria. Nuevo Balance bibliográfico”, in La Guerra Civil. Studia Historica. Historia Contemporánea, vol. 32. Universidad de Salamanca, 2014. 263-283. o. 
Luczak, Barbara, Espacio y memoria, Barcelona en la novela catalana contemporánea, Poznań, Uniwersytet im. Adama Mickiewicza w Poznaniu, Seria Filologia Romańska, 2011.

Lukács György , A történelmi regény, Budapest, Magvető, 1977.

Mainer, José-Carlos, Tramas, libros, nombres, Para entender la literatura española 1944-2000, Barcelona, Editorial Anagrama, 2004.

Maragall i Gorina, Joan, Elogi de la paraula i altres assaigs, Barcelona: Edicions 62 i La Caixa, 1981.

Marcuello Calvín, José Ramón, Siempre Mequinenza, Mequinenza, Ayuntamiento de Mequinenza, 2007.

Marías, Javier, A szívem fehér, Budapest, Európa, 1998.

Margarit, Joan, Pregó Les Festes de la Mercè 2010, Barcelona, nyitóbeszéd https://es.slideshare.net/silviamartinez/preg-de-la-merc-2001-margarit, letöltés 2016. szept. 14.

Marsé, Juan, Utolsó délutánok Teresával, Budapest, Magvető, 2008.

Marsé, Juan, Gyíkfarkak, Budapest, Magvető, 2005.

Massot i Muntaner, Josep, Tres escriptors davant la Guerra Civil, George Bernanos, Joan Estelrich, Llorenç Villalonga, Barcelona, Publicacions d’Abadía de Montserrat, 1998.

Matute, Ana María, El río, Barcelona, Ediciones Destino, 1998.

Mayorga, Juan, El cartógrafo, http://muestrateatro.com/archivos/22Cartografo.pdf, letöltés 2017. dec. 7.

Mea Culpa színtársulat Jesús Moncada novelláin alapuló pedagógiai programja www.meaculpa-teatre.cat/wp-content/uploads/2014/10/Dossier-pedagògic.pdf, letöltés 2017. dec. 11.

Mendoza, Eduardo, La ciudad de los prodigios, Barcelona, Seix Barral, Biblioteca Breve, 1986.

Mequinensa: vila, aigua i gent. Mequinenza: villa, agua y gentes Fotografías de Josep Moncada Moncada y Jesús Moncada Estruga, Aragón, Prames, 2013.

Mink, Louis O., History and fiction as Modes of Comprehension, https://www.scribd.com/document/218585088/History-and-Fiction-as-Modes-of-

Comprehension, letöltés 2016. okt. 2.

Mira, Joan Francesc, „Népek és országhatárok”, in Magyar Lettre, 2006 ősz, 44-49. o. 
Mira, Joan Francesc, Els treballs perduts, Barcelona, Proa, 2005.

Mira, Joan Francesc, Purgatori, Barcelona, Proa, 2003.

Mira, Joan Francesc, Sobre la nació dels valencians, València, Tres i Quatre, Eliseu Climent, Editor, 1997.

Mira, Joan Francesc, Crítica de la nació pura, sobre els símbols, les fronteres i altres assaigs impetiosos, València, Eliseu Climent Editor, 1985.

Mitja Ferenc, "Secret World War Two mass graves in Slovenia", in Jambrek, Peter, Crimes Committed by Totalitarian Regimes, Ljubljana: Slovenian Presidency of the Council of the European Union, 2008.

Molas, Joaquim, Lectures crítiques, Barcelona, Edicions 62, 1975.

Moncada, Jesús, El café de la granota, Cinc relats, Adaptació d’Elisenda Galobardes i Tuneu, Català fàcil 18, Barcelona, Eumo Editorial, Publicacions i Edicions de la Universitat de Barcelona, 2012.

Moncada, Jesús, Cabòries estivals i altres proses volanderes, Calaceit-Fraga, Quaderns de les Cadolles, 2003.

Moncada, Jesús, Calaveres atònites, Barcelona, La Magrana, 1999.

Moncada, Jesús, Estremida memòria, Barcelona, La Magrana, 1997.

Moncada, Jesús, La galeria de les estàtues, Barcelona, La Magrana, 1992.

Moncada, Jesús, Camí de sirga, Barcelona, La Magrana, 1988. (A folyók városa, Budapest, Íbisz Kiadó, 2004; 2. kiadás l’Harmattan Kiadó, 2013.)

Moncada, Jesús, El Cafè de la Granota, Barcelona: La Magrana, 1985.

Moncada, Jesús, Històries de la mà esquerra i altres narracions, Barcelona, La Magrana, 1981. (Balkézről jött történetek, Budapest, l’Harmattan Kiadó, 2012.)

Moncada, Jesús, Dante S. A. töredékes kéziratban

Mora, Victor, A barcelonai platánok, Budapest, Kozmosz könyvek, 1977.

Moreno, Rogelio, La farmacia del olvido, Barcelona, RBA, 2007.

Moret, Héctor, Breu diccionari d'escriptura i escriptors contemporanis en català a l’Aragó, 2008. www.raco.cat/index.php/Beceroles/article/download/.../326966, letöltés 2016. okt. 13.

Moret, Hèctor (dir.), Cròniques de la cerç i la garbinada, Recepció i projecció de l'obra de Jesús Moncada, URC 21. Lleida, Pagès Editors, Ajuntament de Lleida, 2006.

Moret, Hèctor, Indagacions sobre llengua i literatura catalanes a Aragó, Calaceit, Associació Cultural del Matarranya, Institut d’estudis del Baix Cinca, 1998. 
Moret, Hèctor, Aproximació a la toponímia rural de Mequinensa, 1994. http://ifc.dpz.es/recursos/publicaciones/19/13/10moret.pdf, letöltés 2016. júl. 10.

Moret, Hèctor, Lèxic de l’Aragó catalanòfon al Diccionari Aguiló i al Diccionari Català/Valencià/Balear, Alazet Revista de Filología, 5. sz. 1993. 91-126. o.

Moret, Xavier, Jesús Moncada, La passió per escriure, Retrats 7. Barcelona, Associació d’Escriptors en Llengua Catalana, 2005.

Mudrovcic, María Inés, Historia, narración y memoria, Madrid, AKAL, 2005.

Muñiz Sánchez, Jorge az 1962-es asztúriai bányászsztrájkról http://web.archive.org/ web/20120505122421/http://www.lavozdeasturias.es:80/suplementos/as-7/sacrificiolanzo-transicion_0_674332650.html, letöltés 2017. máj. 6.

Muñoz, Josep M., „La memòria d’un món negat”, in Ramón Acín (dir.), Jesús Moncada, Su universo literario, Zaragoza, Gobierno de Aragón, Ayuntamiento de Mequinenza, 2005.

Muñoz Molina, Antonio, El jinete polaco, Barcelona, Planeta, 1991.

Muñoz Molina, Antonio, Beatus ille, Barcelona, Seix Barral, 1986.

Nichols, William J., „La narración oral, La escritura y los Lieux de mémoire en el Lápiz de carpintero de Manuel Rivas”, in Ulrich Winter (dir.), Lugares de memoria de la guerra civil y el franquismo: Representaciones literarias y visuales, Madrid: Iberoamericana, Frankfurt: Vervuert, La Casa de la Riqueza Estudios de Cultura de España, 9. 2006. 155-177. o.

Nietzsche, Friedrich, A történelem hasznáról és káráról, Budapest, Akadémiai Kiadó, 1989.

Noiriel, Gérard, A történetírás „válsága” Elméletek, irányzatok és viták a történelemről tudománnyá válásától napjainkig, Budapest, Napvilág, 2001.

Nora, Pierre, Emlékezet és történelem között. Válogatott tanulmányok, Budapest, Napvilág Kiadó, 2010.

Nuckols, Anthony, El afecto cómo antidoto contra la privatización y despolitización de la memoria, Valencia, 2016. http://www.academia.edu/21284094/El afecto como_ant\%C3\%ADdoto_contra_la_privatizaci\%C3\%B3n_y_despolitizaci\%C3\%B3n_d e_la_memoria, letöltés 2017. jún. 4.

Onze de Frankfurt, a Alemanya, en català, Barcelona, Institut Ramon Llull, 2007.

Orja, Joan, Fahrenheit 212, Barcelona, Magrana, 1989. 
Palacios, Francisco az 1962-es asztúriai bányászsztrájkról http://www.lne.es/cuencas/ 2012/04/09/primavera-62/1225151.html, letöltés 2017. máj. 6.

Parcerisas, Francesc (dir.), Entre dos mons, Visions de la literatura catalana a l'inici del segle XX. 1906-2006, Un segle de modernitat literària, Barcelona, Generalitat de Catalunya, Institució de les Lletres Catalanes, 2008.

Perelló Capdevila, Joan, La navegació fluvial al riu Ebre http://wwwa.urv.cat/ ogovern/consellsocial/PSecundaria/DVD\%20Premis\%202007-

09/material/09cap08/09cap08.pdf, letöltés 2017. aug. 10.

Pérez Galdós, Benito, Zaragoza ostroma, Budapest, Móra Ferenc Könyvkiadó, 1954.

Pérez Garzón, Juan Sisinio, „Conclusiones para el debate o epílogo sobre qué historia enseñar en España”, in Pérez Garzón, Juan Sisinio (dir.), La gestión de la memoria La historia de España al servicio del poder, Barcelona, Crítica, 2000. 221-231. o.

Pi de Cabanyes, Oriol - Graells, Guillem - Jordi, La generació literària dels 70, 25 escriptors nascuts entre 1939-1949, Barcelona, Institució de les Lletres Catalanes, 2004.

Pinilla Navarro, Vicente (dir.), Gestión y usos del agua en la cuenca del Ebro en el siglo XX., Zaragoza, Prensas Universitarias de Zaragoza, 2008.

Platón, „Phaidrosz” in Platón, Összes művei II. kötet, Budapest, Európa, 1984. 711809. 0.

Porcel, Baltasar, A vaddisznó szíve, Budapest, Palimpszeszt Alapítvány, 2004.

Porcel, Baltasar, Cavalls cap a la fosca, Barcelona, Edicions 62, 1975.

Preston, Paul, „Franco y la segunda república, de general mimado a golpista”, in Egido León, Ángeles (dir.), Memoria de la Segunda República. Mito y Realidad, Madrid, Biblioteca Nueva, 2006. 85-117. o.

Puig i Tàrrech, Armand, Gaudí és a Sagrada, Budapest, Typotex, 2013.

Puigvert, Antoni, „Envenenar la llengua de Moncada”, La Vanguardia 2013 máj. 13. http://www.caffereggio.net/2013/05/13/envenenar-la-lengua-de-moncada-de-antonipuigverd-en-la-vanguardia/, letöltés 2013. jún. 12.

Quintana, Artur, (dir.), Epistolari de Desideri Lombarte (1981-89), Calaceit, Lo Trill (8), Associació Cultural de Matarranya, 2002.

Quintana, Artur i Font - Schmidt von der Twer, Sigrid, „La recepció germanica de l’obra de Jesús Moncada”, in Moret, Hèctor (dir.), Cròniques de la cerç i la garbinada, Recepció i projecció de l'obra de Jesús Moncada, URC 21. Lleida, Pagès Editors, Ajuntament de Lleida, 2006. 93-98. o. 
Quintana, Artur i Font, Panorama de la literatura contemporània catalana a l'Aragó, Institut d'Estudis Catalans - Consello d'a Fabla Aragonesa, 119-145. o. http://aillc.espais.iec.cat/files/2017/11/2017_08.pdf, letöltés 2017 dec.30.

Raguer, Hilari, „La »cuestión religiosa« en la Segunda República”, in Egido León, Ángeles (dir.), Memoria de la Segunda República. Mito y Realidad, Madrid, Biblioteca Nueva, 2006. 177-197. o.

Raguer, Hilari, La pólvora y el incienso, La Iglesia Española y la Guerra Civil Española (1936-1939), Barcelona, Ediciones Península, 2001.

Raguer, Hilari, Divendres de passió, vida i mort de Manuel Carrasco i Formiguera, Barcelona, Publicacions de l’Abadia de Montserrat, 1992.

Rahner, Hugo, A játszó ember, Budapest, Kairosz, 2013.

Rákai Orsolya - Z. Kovács Zoltán (szerk.), A narratív identitás kérdései a társadalomtudományokban, Budapest-Szeged, Gondolat Kiadói Kör-Pompeji, 2003.

Reig Tapia, Alberto, „Mitos, contra-mitos y justificacions de la Guerra Civil Española”, in Cuesta, Josefina, (dir), Memorias históricas de España, Madrid, Fundación Largo Caballero, 2007. 86-110. o.

Ricoeur, Paul, - Sorin Antochi, „Emlékezés, történelem, megbocsátás”, 2000, XV. évf. 2003/11-12. november-december, 5-13. o.

Ricoeur, Paul, La mémoire, l’histoire, l'oublie, Paris, Éditions du Seuil, 2000.

Ricoeur, Paul, „Emlékezet - felejtés - történelem”, in Narratívák 3. A kultúra narratívái, Budapest, Kijárat Kiadó 1999. 51-69. o.

Riera, Carme, La mitad del alma, Madrid, Alfaguara, 2005.

Risques, Manuel, „Dictadura i rebellió militar, 1936-1968”, in Sobrequés, Jaume (dir.), Les presons de Franco, Barcelona, Museu d’Història de Catalunya, 2004.

Rivière Gómez, Aurora, „Envejecimiento del presente y dramatización del pasado. Una aproximación a las síntesis históricas de las Comunidades Autónomas españolas (19751995)”, in Pérez Garzón, Juan Sisinio (dir.), La gestión de la memoria La historia de España al servicio del poder, Barcelona, Crítica, 2000. 161-215. o.

Rodoreda, Mercè, A Diamant tér, Európa, 1978.

Rodoreda Mercè, Törött tükör, Budapest, L’Harmattan, 2014.

Rodríguez López, Sofía, „Los secretos de la memoria.guerra civil, franquismo y fuentes orales en Almería”, Pasado y Memoria. Revista de Historia Contemporánea, 2008. Núm. 7. 263-283. o. 
Roig, Montserrat, Els Catalans als camps nazis, Barcelona, Edicions 62, 1977.

Roig, Montserrat, Rafael Vidiella, l'aventura de la revolució, Barcelona, Laia, 1974.

Roubaud, Jaques, Költészet és emlékezet, Budapest, Typotex, 2007.

Rubio Velasco, Albert, „Atentado anarquista en el Liceu”, La Vanguardia, http://www.lavanguardia.com/hemeroteca/20131107/54392762387/liceu-bombaatentado-anarquismo-santiago-salvador.html, letöltés 2017 aug. 28.

Ruiz Zafón, Carlos, La sombra del viento, Barcelona, Planeta, 2005.

Sainz Borgo, Karina, „Volverás a Vegamián, Llamazares rescata el pueblo que Benet sepultó bajo un pantano” http://www.vozpopuli.com/cultura/Literatura-Novelas-FiccionNovela-Julio_Llamazares-Vegamian_0_779922050.html; http://elpais.com/diario/2007/06/24/eps/1182665761 850215.html, letöltés 2017. ápr. 4.

Salvador Maldonado, Dolores, A cuencai gyilkosság, Budapest, Magvető, 1983.

Salabert, Miguel de, Belsö számüzetés, Budapest, Kossuth, 1963.

Sales, Joan, Incerta Glòria, Barcelona, Club Editor, 1969.

Santoja Gómez-Agero, Gonzalo, „El afán de leer y la conquista de la cultura”, in Egido León, Ángeles (dir.), Memoria de la Segunda República. Mito y Realidad, Madrid, Biblioteca Nueva, 2006. 215-231. o.

Santos, Julià (dir.), Memoria de la Guerra Civil y del Franquismo, Madrid, Taurus Historia, Fundación Pablo Iglesias, 2006.

Sasot Escuer, Mario (dir.), Així s’escriu a la Franja (Antologia i guia didàctica d'autors de l'Aragó catalanòfon), Zaragoza, Gobierno de Aragon, Departamento de Educación y Cultura, 1992.

Sasot Escuer, Mario, „Jesús Moncada, A la recerca de la infància segrestada”, in Sasot Escuer, Mario (dir.), Així s'escriu a la Franja Antologia i guia didàctica d'autors de l'Aragó catalanòfon, Zaragoza, Gobierno de Aragon, Departamento de Educación y Cultura, 1992.

Scagliola, A., „Cambio en las políticas públicas de la memoria en Cataluña: El pasado como problema” Entelequia, Revista interdisciplinar, 2008. http://www.eumed.net/ entelequia/pdf/2008/e07a18.pdf, letöltés 2014. nov. 10.

Sender, Ramon J., Requiem egy spanyol parasztért, Budapest, Európa, 1983.

Serés, Francesc, Els ventres de la terra, Barcelona, Columna, 2000. 
Serrano Dolader, Alberto, „Caspe literario: Memoria Estremecida, de Jesús Moncada”, El Agitador, 2015. június 10. www.bajoaragonesa.org/elagitador/caspeliterario-memoria-estremecida-de-jesus-moncada/, letöltés 2017. nov. 24.)

Sistac, Ramon, Menú de degustació, Opcions nutrícies sobre la cuina de la llengua, Calaceit, Iniciativa Cultural de la Franja, Quaderns del cingle, 2009.

Sistac, Ramon, „Territori, llengua i identitat en l’obra de Jesús Moncada”, in Moret, Hèctor (dir), Cròniques de la cerç i la garbinada, Recepció i projecció de l'obra de Jesús Moncada, URC 21. Lleida, Pagès Editors, 2006. 64-69. o.

Sobrequés, Jaume (dir.), Les presons de Franco, Barcelona, Museu d'Història de Catalunya, 2004.

Solà, Joan, Plantem cara, Barcelona, RBA Libros, 2009.

Soldevila, Ferran, Síntesis de historia de Cataluña, Barcelona, Destino, 1978.

Solé i Sabater, Josep María - Villaroya, Joan, Cronología de la repressió de la Ilengua i la cultura catalanes 1936-1975, Barcelona, Curial, La Mata de Jonc, 1993.

Szélpál Lívia, „A történelem jövője: Bevezetés egy nem hagyományos történetírás (unconventional history) elméletébe”, Aetas, 135-146. o. http://acta.bibl.u-szeged.hu/ 41312/1/aetas 2007001 135-146.pdf, letöltés 2018. ápr. 15.

Szerb Antal, A világirodalom története, Budapest, Magvető Kiadó, 1989.

Szilágyi István, Európa és a hispán világ, Veszprém, Veszprémi Egyetemi Kiadó, 1998.

Tamames, Ramón, La república, La era de Franco, Madrid, Alianza Editorial Alfaguara, 1986.

Todorov, Tzvetan, A rossz emlékezete, a jó kísértése, Budapest, Napvilág Kiadó, 2005.

Teixidor, Emili, Retrat d'un assasí d'ocells, Barcelona, Proa, 1988.

Tengelyi László, „A történelmi tapasztalat védelmében. Paul Ricoeur vitája Hayden White-tal”, http://real.mtak.hu/34197/1/Tengelyi Laszlo A tortenelmi tapasztalat vedelmeben u.p df, letöltés 2018. ápr. 17.

T. Horvat, Marian, „A szent Inkvizíció, mítosz és valóság” http://web.axelero.hu/ kesz/jel/03 01/mitosz.html, letöltés 2017. júl. 12. 
Tomas, Jordi, El mar dels traïdors, Barcelona, Proa, 2013. http://www.vilaweb. cat/noticia/4096073/20130317/trafic-desclaus-vaixells-catalans-aventura-literaria.html, letöltés 2017. júl. 15.

Tomasi di Lampedusa, Giuseppe, A párduc, Budapest, Magyar könyvklub, 1997.

Tormo Benavent, David, „La restauración y la Dictadura de Primo Rivera, República, Guerra Civil y Franquismo”, in Estruga Estruga, Jordi (dir), Mequinenza a través de la historia, Mequinenza, Ayuntamiento de Mequinenza, 2010. 195-301. o.

Tort i Donada, Joan - Tobaruela i Martínez, Pere, „Interjú Victoriano Muñoz Oms vízmérnökkel” http://www.ub.edu/geocrit/b3w-339.htm, letöltés 2017. ápr. 2.

Treglown, Jeremy, Franco's Crypt: Spanish Culture and Memory Since 1936, Farrar, Straus and Giroux, 2013.

Treserres, Joan Manuel, „Catalunya i la mundialització, Llengua i cultura: nous reptes”, in Albareda i Salvadó, Joaquim (dir.), Catalunya, Nació d’Europa, Barcelona, Enciclopèdia Catalana, 2014. 222-235. 0.

Triadú, Joan, La novella catalana de postguerra, Barcelona, Edicions 62, Llibres a l’abast, 1982.

Vallverdú, Francesc, „La meva experiència a Edicions 62”, A Barcelonai Autonóm Egyetem „Fordítás és Cenzúra” című konferenciájának nyitóbeszéde Jornades sobre „Traducció i censura”, Càtedra Jordi Arbonès, UAB, 17/18 octubre 2012.

Vallverdú, Francesc, El fet lingüístic com a fet social, Barcelona, Edicions 62, 1980.

Vallverdú, Francesc, L’Escriptor català i el problema de la llengua, Barcelona, Edicions 62 Llibres a l'abast, 1968.

Vázquez Montalbán, Manuel, Déltengerek, Budapest, Zrínyi Katonai Kiadó, 1982.

Vázquez Montalbán, Manuel, A menedzser magányossága, Budapest, Zrínyi Katonai Kiadó, 1985.

Vicens Vives, Jaume Aproximación a la historia de España, Barcelona, Editorial Vicens-Vives, 1990.

Vicens Vives, Jaume, Noticia de Cataluña, Barcelona, Destino, 1954.

Vila Foruny, Jordi, El nacionalisme català, aportacions a un debat, Barcelona, Barcanova, 1992.

Villalonga, Llorenç, Mallorcai udvarház, Budapest, Európa Kiadó, 1982.

Vilar, Pierre, Spanyolország története, Gondolat, Budapest, 1984. 
Vinyes, Ricard, „L’univers penitenciari en el franquisme”, in Sobrequés, Jaume (dir.), Les presons de Franco, Barcelona, Museu d'Història de Catalunya, 2004. 28-44. o.

Vinyes, Ricard (dir.), El estado y la memoria: gobiernos y ciudadanos frente a los traumas de la historia, Barcelona, RBA, 2009.

Voltes Bou, Pedro, Nueva historia de España, Barcelona, Plaza \&Janes, 1989.

Weinrich, Harald, Léthé. A felejtés müvészete és kritikája, Budapest, Atlantisz Könyvkiadó, 2002.

White, Hayden, Metahistory: The Historical Imagination in Nineteenth Century Europe, Johns Hopkins University Press, 1973.

White, Hayden, A történelem terhe, Budapest, Osiris Kiadó, 1997.

Winter, Ulrich, „La memoria compleja. Guerra Civil y dictadura en la novela española desde 1975”, in Josefina Cuesta (dir), Memorias históricas de España, Madrid, Fundación Largo Caballero, 2007. 172-186. o.

Winter, Ulrich, (dir.) Lugares de memoria de la guerra civil y el franquismo. Representaciones literarias y visuales, Madrid: Iberoamericana, Frankfurt: Vervuert, La Casa de la Riqueza Estudios de Cultura de España, 9. 2006.

Ysàs, Pere, „El antifranquismo y la democracia”, in Ricard Vinyes (dir.), El estado y la memoria, Gobierno y ciudadanos frente a los traumas de la historia, Barcelona, RBA, 2009.

Zapater, Ismael, La Ribera Baix del Cinca: una comarca frontera, Fraga, Institut d’Estudis del Baix Cinca, Instituto de Estudios Altoaragonesos, la Gabella, 1992.

Zelei Dávid, „A Katalán Atlantisz”, Élet és Irodalom, LVII. évf. 22. sz. 2013. május 31.

Zuriaga, María José Esteban, Curas contestatarios en el campo aragonés durante el tardofranquismo,

http://www.academia.edu/12466061/Curas contestatarios en el campo aragon\%C3\%A 9s_durante_el_tardofranquismo, letöltés 2017. máj. 8.

20é aniversari AELC, Institució de les Lletres Catalanes, Generalitat de Catalunya, 1996. 


\section{A szerző témához kapcsolódó publikációi}

'Mort a Mequinensa,' in Catalanística a Hongria 1971/72-2011/12. Budapest, Universitat Eötvös Loránd de Budapest, 2013. 149-155. o.

Katalán függetlenség 2014? A katalán nacionalizmus történetéhez I., Új Egyenlitő, 2013/2-3. 49-57. o.

Katalán függetlenség 2014? A katalán nacionalizmus történetéhez II., Új Egyenlitő, 2013/július, 42-50. o.

Jaume Vicens Vives, AETAS 2013/1 28. évf. 148-160. o.

La història, creadora de mites, Acta Hispanica, Tomus, XVIII, Szeged, 2013. 131139. 0 .

The Catalan Church and the Independence Qüestions de la vida cristiana, 2014.

Christians Associated for Democracy in Europe (CADE) http://principium journal.com/hu/?cat=5 : http://www.amazon.com/Principium-Christianity-Democracy-

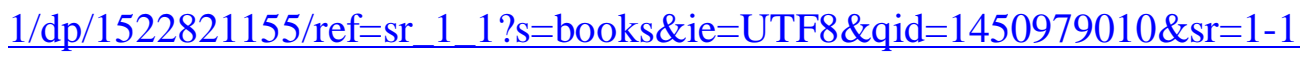

Aragónia és Katalónia között, Öt Kontinens, 2014. 271-282. o.

Függetlenség, állam, nyelv Katalónia különös esete. Létünk, 2015/2. 117-128. o.

Törvénybe foglalt emlékezet . Létünk, 2015/2. 129-145. o.

A hegedủ példája (Jaume Cabré, Én vétkem) Nagyvilág, 2015/4 április, 458-461. o.

Kisebbségi kérdések az Európai Unióban. Szerbia és az Európai Unió. Magyar Nyelvű jogi-tudományos tanácskozás a csatlakozás jogi és nyelvi aspektusairól, Palics, Magyar Nemzeti Tanács, 2015. június 5-6., Hét Nap, 2015. március 23. http://hetnap.rs/cikk/ Kisebbsegi-kerdesek-az-Europai-Unioban-22223.html

La larga transición del libro en catalán, in Berta Tibor, Csikós Zsuzsanna, Jancsó Katalin, Katona Eszter, Lénárt András, Praefort Veronika (dir.), Transiciones: De la dictadura a la democracia, Szeged, SZTE BTK Hispanisztika Tanszék; SZTE BTK Amerika-közi Tanulmányok Kutatóközpont, 2016. 324-335 o.

Regénybe zárt emlékezet - Jesús Moncada: Szoborgaléria, Mediterrán Világ, 39-40. 2017. 90-105. o.

La memòria estremida de Jesús Moncada, in Estudis de llengua i literatura catalanes/LXXI. Homenatge a Kálmán Faluba, I. vol. Barcelona, Publicacions de l’Abadia de Montserrat, 2017. 137-155. o. 


\section{Folyóirat-, újság- és online cikkek, weboldalak}

AELC Associació d'Escriptors en Llengua Catalana https://www.escriptors.cat/, letöltés 2017. jún. 10.

AELLC Associació d'Editors en Llengua Catalana http://editors.cat/lassociacio/qui-som/, letöltés 2017. jún. 17.

Aragónia 1982-es Autonómia statútumának nyelvvel kapcsolatos rendelkezései:

http://noticias.juridicas.com/base_datos/Admin/lo5-2007.tp.html\#a7, letöltés 2017. jan.

17.

Aragón népdalok, melyek az elárasztott településeket siratják https://www.letras.com/laronda-de-boltaa/457977/; https://www.letras.com/la-ronda-de-boltaa/457978/, letöltés 2017. ápr. 10.

Aragón nyelvtörvény 2013 május Boletín Oficial del Gobierno de Aragon www.boa.aragon.es/cgi-bin/EBOA/BRSCGI?CMD=VERDOC\&BASE= BOLE \&PIECE $=$ BOLE $\& D O C S=128 \& D O C R=1 \&$ SEC $=$ FIRMA $\& R N G=200 \&$ SEPARA

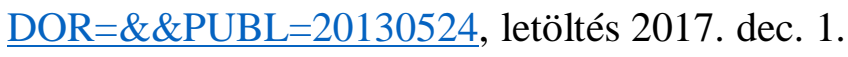

Azaña, Manuel http://www.enciclopedia.cat/EC-GEC-0006389.xml, letöltés 2017. aug. 30.

A vízienergia története Spanyolországban http://www.energiaysociedad.es/manenergia/1-2historia-de-la-electricidad-en-espana/, letöltés 2017. ápr. 3.

Balzac, Honoré de http://enciklopedia.fazekas.hu/palyakep/vilag/Balzac.htm, letöltés 2017. júl. 20.

Cabrera i Grinyó, Ramón y la segunda guerra carlista dels Matiners www.legitimistadigital.com, letöltés 2017. jún. 11.; www.zumalakarregimuseo.eus, letöltés 2017. jún. 11.

Cantero Cuadrado, Pedro Saragossa érseke http://www.enciclopediaaragonesa.com/voz.asp?voz id=3071\&voz id origen=4220, letöltés 2017. ápr. 7.

Consejo General del Poder Judicial által készített felmérés 2000-ből www.poderjudicial.es/stfls/cgpj/.../ENCUESTAS/...851 7EXT2000 1.0.0.pdf, letöltés 2017. aug. 1.

Constitución Española 1978 https://www.boe.es/diario boe/txt.php?id=BOE-A-1978-31229, letöltés 2017. nov. 24. 
Constitution of Ireland

https://www.constitution.ie/Documents/Bhunreacht_na_hEireann_web.pdf, letöltés 2017. nov. 27.

Costa, Joaquín, El problema de la ignorancia del derecho y sus relaciones: el status individual, el referéndum y la costrumbre, székfoglaló beszéd a Moráltudományok Királyi Akadémiájára való belépésekor. \%. http://e-archivo.uc3m.es/bitstream/handle/ 10016/2708/TEMA\%202.pdf;jsessionid=EBAA4596FA9DE7AFA080B415707223AF?s equence $=1$, letöltés 2017. ápr. 7.

Diccionari català-valencià-balear de Alcover Moll (Institut d'Estudis Catalans) http://alcover.iec.cat/, letöltés 2017. okt. 5.

Espais literaris Jesús Moncada www.jesusmoncada.cat/?page_id=5, letöltés 2017. dec. 7. Españoles en los campos nazis http://www.lavanguardia.com/internacional/20160508/401639794161/espanoles-en-loscampos-nazis.html, letöltés 2016. dec. 12.

EULP 2013 A Katalán Kormány nyelvhasználattal kapcsolatos statisztikai felmérése http://www20.gencat.cat/docs/Llengcat/Documents/Publicacions/Altres/Arxius/EULP20 13 fullet.pdf, letöltés 2017. febr. 13.

Euromosaik statisztikai felmérése http://www.uoc.edu/euromosaic/web/document/catala/ca/i4/i4.html, letöltés 2015. okt. 5

Exhumálások https://lamemoriaviva.wordpress.com/2009/01/30/consulta-listados-dequeralt-sole/, letöltés 2017. aug. 31.

https://aricomemoriaaragonesa.wordpress.com/2010/09/26/\%C2\%BFdonde-esta-mi-abuelo/, letöltés 2017. aug. 31.

https://es.answers.yahoo.com/question/index?qid=20080907091216AAHkvKL, letöltés 2017. aug. 31.

https://www.meneame.net/m/actualidad/c/21356942, letöltés 2017. aug. 31.

Fayón, El embalse de discordia https://www.youtube.com/watch?v=1JAUqxUU7Gg, letöltés 2017. máj. 10.

Foment de Pietat Catalana http://www.enciclopedia.cat/EC-GEC-0015608.xml, letöltés 2017. júl. 13.

Fundación de Francisco Franco weboldala http://www.fnff.es/Obra_senera_de_Franco_embalses_regadios_colonizacion_y_repobla cion forestal Parte 11113 c.htm, letöltés 2017. ápr. 4. 
Global Water Risk Assessment http://www.wri.org/our-work/project/aqueduct, letöltés 2017. ápr. 5.

Guardiola, Carles-Jordi http://www.vilaweb.cat/noticies/carles-jordi-guardiola-carles-ribaactua-com-a-pal-de-paller-vertebrador-daquesta-generacio-destrossada-per-la-guerracivil-i-lexili/, letöltés 2017. júl. 20. interjú a Magrana Kiadó volt igazgatójával, Carles Riba életmüvéröl

Guillem Nicolau Irodalmi Díj Aragónia http://masdebringue.wordpress.com/2013/01/16/descovocats-els-premis-guillem-nicolaui-arnal-cavero/, letöltés 2016. febr. 17.

Halbwachs, Maurice, Les cadres sociaux de la mémoire 1925 http://classiques.uqac.ca/classiques/Halbwachs_maurice/cadres_soc_memoire/cadres_soc iaux memoire.pdf, letöltés 2017. márc. 6.

Halbwachs, Maurice, La mémoire collective 1950 posztumusz kiadás http://classiques.uqac.ca/classiques/Halbwachs maurice/memoire collective/memoire c ollective.pdf, letöltés 2017. márc. 6.

Hernández, Miguel https://elpais.com/elpais/2011/02/16/actualidad/1297847848 850215.html, letöltés 2017. nov. 19.

Immersió Linguística módszerehttp://www.vilaweb.cat/noticia/4176888/20140306/immersio-linguistica-modeldexit.html, letöltés 2014. dec. 3.

INI Instituto Nacional de Industria http://www.enciclopediaaragonesa.com/voz.asp?voz id=7148, letöltés 2017. ápr. 2.

Írország alkotmánya https://www.constitution.ie/Documents/Bhunreacht na hEireann web.pdf, letöltés 2017. nov. 27.

„Jesús Moncada program” az aragóniai anyanyelvi katalán oktatáshoz https://finestro.wordpress.com/2017/03/20/programa-jesus-moncada-2017-2018/, letöltés 2017. jún. 12.

Jesús Moncada a katalán függetlenség posthumus bajnoka http://www.abc.es/espana/aragon/abci-denuncian-aragon-utiliza-como-referenteeducativo-independentista-catalan-201709260924_noticia.html, letöltés 2017. nov. 27. 
Joffre, Joseph tábornok http://www.historyofwar.org/articles/people joffre.html, letöltés 2017. szept. 23. és https://www.racocatala.cat/forums/fil/189857/militar-catala-mesimportant-historia-va-ser?pag=1, letöltés 2017. szept. 23.

Katalán Irodalmi Intézet honlapja: http://www.lletrescatalanes.cat/ca/patrimoniliterari/exposicions/item/294-800-anys-de-literatura-catalana, letöltés 2017. ápr. 6.

Katonasírok www.karpataljalap.net, letöltés 2017. aug. 31.

La conquista de Carrascal del Chimillas https://www.youtube.com/watch?v=ZpOqxCbH2Xs, letöltés 2017. aug. 30.

Literatura de fil i canya http://www.laxarxa.com/actualitat/cultura-ixarxes/noticia/romancos-literatura-de-fil-i-canya, letöltés 2016. júl. 11.

La Batalla de Tetuán http://www.museunacional.cat/es/colleccio/la-batalla-de-tetuan/mariafortuny/010695-000, letöltés 2017. aug. 1.

Llei de jurisdiccions http://www.enciclopedia.cat/EC-GEC-0035149.xml, letöltés 2016. okt. 17.

Katalán autonómia statútumok összehasonlító elemzése http://blocs.xtec.cat/historia2nbat/files/2013/02/estatut-1932-1931-BLOG.pdf , letöltés 2017. márc. 21.

„La Canadiense” dokumentumfilm a TV3 archívumából http://www.rtve.es/alacarta/videos/otros-documentales/otros-documentales-granaventura-canadiense-canadiense-nacimiento-sueno/4021758/, letöltés 2017. ápr. 4.

Llamazares, Julio a víztározókról http://www.vozpopuli.com/cultura/Literatura-NovelasFiccion-Novela-Julio Llamazares-Vegamian 0 779922050.html, letöltés 2017. ápr. 5.

Liceu de Barcelona bombamerénylet http://www.ccma.cat/324/el-centre-de-colleccions-delmuhba-un-viatge-per-la-historia-de-barcelona/noticia/2672726/, letöltés 2017. aug. 28.

Los pantanos de Franco http://foros.periodistadigital.com/viewtopic.php?t=37198; , letöltés 2017. ápr. 4.

Maragall i Gorina, Joan, La ciutat de la perdó, http://www.xtec.cat/ jrovira6/restau21/maragall.htm, letöltés 2017. júl. 13.

Marimon, Sílvia, 'Els Catalans als camps nazis' torna a les llibreries, https://www.ara.cat/cultura/catalans-camps-nazis-torna-llibreries_0_1862 813822.html, letöltés 2017. nov. 7.

Mea Culpa színtársulat El darrer dia del Cafè de la Granota https://vimeo.com/153133635, letöltés 2017. dec. 5. 
Memorial Democràtic

http://memorialdemocratic.gencat.cat/ca/detalls/Noticia/20140915_Pablo-de-Greiff, letöltés 2015. jan. 7 .

Memòria Històrica http://www.memoriahistorica.org.es/joomla/index.php/quienes-somos, letöltés 2017. szept. 10.

Memòria Històrica finanszírozási problémák http://www.eldiario.es/sociedad/Segundoenterramiento-Memoria-historica０ 110239847.html, letöltés 2017. szept. 10.

Mequinensa http://www.mequinenza.com/historia, letöltés 2017. máj. 10.

Mequinensa-Lleida távolság http://www.distanciasentreciudades.com/distancia-lerida-amequinenza, letöltés 2017. aug. 10.

Mequinensa lakossága http://www.enciclopediaaragonesa.com/voz.asp?voz id=8740\&voz id origen=1775, letöltés 2017. aug. 2.

Mequinenzai Nyilatkozat https://www.elnacional.cat/es/efemerides/marc-pons-declaracionmequinensa-catalan-aragon 134967 102.html, letöltés 2017 jún. 25.

Muñiz Sánchez, Jorge az 1962-es asztúriai bányászsztrájkról http://web.archive.org/web/20120505122421/http://www.lavozdeasturias.es:80/suplemen tos/as-7/sacrificio-lanzo-transicion 0 674332650.html, letöltés 2017. máj. 6.

Muñoz Molina, Antonio, „Desmemorias”, El País, https://elpais.com/diario/2008/09/06/babelia/1220657954_850215.html, 2015. szept. 16.

Països Catalans ábrázolások térképen http://blocs.mesvilaweb.cat/vicent/?p=268581, letöltés 2017. júl. 20.

Partit Socialista d'Alliberament Nacional dels Països Catalans weblapja https://www.psan.cat/, letöltés 2017. jún. 3.

Pérez Abellán, Francisco, kriminológus Matar a Prim című könyvét ismerteti 2014. február 19. http://www.ccma.cat/tv3/alacarta/els-matins/com-va-morir-el-generalprim/video/4911252/, letöltés 2017. szept. 18.

„Pilar” kultusz http://www.enciclopediaaragonesa.com/voz.asp?voz id=10191\&tipo busqueda=1\&nombre=Pilar\&categoria id= \&subcategoria_id=\&conImagenes=\#Punto_3, letöltés 2017. aug. 12.

Plataforma Aragonesa No Hablamos Catalán (PANHC) https://nohablamoscatalan.wordpress.com/page/5/, letöltés 2017. dec. 1.

Puig Antich, Salvador, http://www.amnistiacatalunya.org/edu/es/historia/pm-espana.html, letöltés 2017. júl. 11. 
http://elpais.com/diario/1978/08/25/espana/272844004 850215.html, letöltés 2017. júl. 11.; http://noticias.juridicas.com/base_datos/Penal/lo11-1995.html, letöltés 2017. júl. 11.

Quico Sabaté 1980. Colectivo Penta. Documental sobre el guerrillero catalán https://www.youtube.com/watch?v=Dqne1wyftPY, letöltés 2017. ápr. 18.

Real, Neus, Els catalans als camps nazis, http://www.visat.cat/traduccions-literaturacatalana/cat/articles/59/11/0/2/0/neus-real.html, letöltés 2017. nov. 7.

Rengel, Carmen, 10 años de la Ley de Memoria Histórica: ni verdad, ni justícia, ni reparación https://www.huffingtonpost.es/2017/12/26/10-anos-de-la-ley-de-memoriahistorica-ni-verdad-ni-justicia-ni-reparacion a 23316863/, letöltés 2017. dec. 30.

Ribadelago katasztrófája http://www.elmundo.es/elmundo/2009/01/02/castillayleon/1230902542.html, letöltés 2017. ápr. 6.

Ripoll, Cayetano, az inkvizíció utolsó kivégzése Spanyolországban http://www.elespanol.com/cultura/20160729/143736258 0.html, letöltés 2017. júl. 12.

Royo Tejedor, Eduardo http://www.enciclopedia-aragonesa.com/voz.asp?voz id=4220, letöltés 2017. máj. 8.

Saragossa bazilikája a „Pilar” http://www.basilicadelpilar.es/inicio.htm, letöltés 2017. aug. 12.

„Se funda la Canadiense” http://www.lavanguardia.com/hemeroteca/19110912/54214299775/se-funda-lacanadiense.html, letöltés 2017. ápr. 3.

Serra d’Or folyóirat weblapja http://www.pamsa.cat/pamsa/revista/sdo.html, letöltés 2017. ápr. 12. http://www.lluisvives.com/hemeroteca/serrador/, letöltés 2017. ápr. 12.

Sirga_Kortárs Zenei Fesztivál Tortosa http://www.sirga-festival.com/, letöltés 2017. aug. 10.

Sistema de Información sobre el Agua http://hispagua.cedex.es/datos/energia\# ENERGIA ESPA\%C3\%91A, letöltés 2017. ápr. 4.

Spanyol Alkotmány https://www.boe.es/diario_boe/txt.php?id=BOE-A-1978-31229, letöltés 2017. nov. 24.

Spanyol Alkotmány nyelvekről rendelkező szakasza http://sepam.dipcas.es/files/pwmNormativa_lenguas_oficiales_es.pdf, letöltés 2017. nov. 24.

Spanyol Alkotmány Preambulum www.lamoncloa.gob.es/documents/constitucion es1.pdf, letöltés 2017. nov. 27. 
Spanyolország 10 legnagyobb vízierőmüve http://elperiodicodelaenergia.com/las-10mayores-centrales-hidroelectricas-de-espana/, letöltés 2017. ápr. 2.

Sztrájk Baszkföldön, Bilbaóban 1966-ban http://www.abc.es/20120328/archivo/abcibandas-huelga-franquismo-echevarri-201203271431.html, letöltés 2017. máj. 6.

Sztrájktörvény Spanyolországban http://losojosdehipatia.com.es/cultura/historia/brevehistoria-del-derecho-de-huelga-en-espana/, letöltés 2017. máj. 6.

Tormo, David és Sánchez Cervelló, Josep sobre els fets de Vilalba dels Arcs del 21 de juliol de 1936, durant la Guerra Civil www.alfatara.com/?p=5206, letöltés 2017. aug. 10.

Toulouse a franciaországi köztársasági emigráció központja http://www.tour.toulouserepublicana.com/ca/, letöltés 2017. aug. 30.

Történelmi emlékezet törvénye http://www.boe.es/boe/dias/2007/12/27/pdfs/A5341053416.pdf, letöltés 2017. aug. 31.

Vergara Kiadó Isard sorozat https://negritasycursivas.wordpress.com/2014/10/17/lacoleccion-que-mimaba-a-los-traductores-isard-1962-1971/, letöltés 2017. máj. 14.

Vízenergia felhasználás http://www.vizinform.hu/pic/kepek/vizenergia.pdf, letöltés 2017. ápr. 5.

Víztározók és vízierőművek építése Spanyolországban http://foros.periodistadigital.com/viewtopic.php?t=37198, letöltés 2017. ápr. 4.

Víztározókkal kapcsolatos müszaki, gazdasági adatok http://www.embalses.net/pantano133-porma-juan-benet.html, letöltés 2017. ápr. 5.

Víztározók mélyére süllyesztett települések http://www.traveler.es/viajes/alnatural/articulos/lo-que-el-embalse-se-llevo-pueblos-espanoles-sumergidos-bajo-elagua/6189; http://pueblos-desiertos.blogspot.hu/2016/11/aceredo-orense.html, letöltés 2017. ápr. 5.

https://pueblosdelolvido.wordpress.com/2016/01/17/trago-de-noguera-lleida/, letöltés 2017. ápr. 4.

https://es.wikipedia.org/wiki/Embalse_de_Ria\%C3\%B1o, letöltés 2017. ápr. 4. http://www.turismoreinodeleon.com/embalses/pueblos-anegados/, letöltés 2017. ápr. 4. http://www.traveler.es/viajes/al-natural/articulos/lo-que-el-embalse-se-llevo-pueblosespanoles-sumergidos-bajo-el-agua/6189, letöltés 2017. ápr. 5.

Wert törvény célja http://www.abc.es/espana/20150625/abci-wert-frases201506252227.html, letöltés 2017. nov. 27. 


\section{Mellékletek}

\section{Lexikon}

\section{Kis Katalán Kultúrtörténet Jesús Moncada nyomában}

1. Miquel Labordeta Subías (Saragossa, 1921-Saragossa, 1969) szürrealista költő, világpolgár, a saragossai Niké müvészi asztaltársaság tagja, az Oficina Poetica Internacional alapítója. Édesapja, a kiváló pedagógus és latinista halála után 1953-ban vette át a Colegio Santo Tomás intézményének vezetését. Tanítványaival iskolai kirándulásokat szervezett az ország megismerésére, irodalmi folyóiratot müködtetett a diákok számára, Samprasarana néven, költészeti felolvasóesteket rendezett, és irodalmi pályázatokat hirdetett, ami a korszakban egyedülállónak számított. Első verseskötetének 1948-as megjelenése óta Aragónia öt tartja legnagyobb költőjének.

2. Juan Antonio Labordeta Subías (Saragossa, 1935-Saragossa, 2010) a leghíresebb aragón cantautor (költő dalszerző), aki az aragón regionalista szellemiség felélesztésének is egyik fontos kulcsfigurája, az Andalán című újság főszerkesztője, a demokratikus Spanyolország parlamentjének aragón nemzeti képviselője. Szabadságot, demokráciát hirdető dalait országszerte énekelték, s éneklik még ma is Spanyolországban.

3. Edmon Vallès i Perdrix (Mequinensa, 1920-Barcelona, 1980) katalán-francia intellektuel, író, fordító, történész, szocialista aktivista, szervező. A polgárháborúban a lleva de biberó-ban harcolt, majd ezt követően rövid ideig családja franciaországi ágának otthonában talált menedéket. Innen 1944-ben visszaköltözött Barcelonába. Újságíróként a La Vanguardia, a TeleExprés, az Avui az El Correo Catalán és a Serra d’Or munkatársa. 1968ban társaival megalapítja az Historia y Vida címü folyóiratot, és szocialista - katalanista földalatti tevékenységet végez. Fordítóként legjelesebb munkája az olasz neorealista próza kitűnő művének, Carlo Levi, Crist s’ha aturat a Èboli című regényének katalán változata, és az ő nevéhez füződik az Història Gràfica de la Catalunya contemporània címü hat kötetes munka ötlete és szövege, ami a 20. századi Katalónia képekben ábrázolt története.

4. A Montaner y Simón Kiadóvállalat Spanyolország egyik legelső és legjelentősebb kiadóvállalata, mely 1861-1981 között müködött, s kiváló példája a müvészet és a technikai haladás házasításának. Magas művészi színvonalú, híres kiadványaik például a modernista építész, Lluís Domènech i Montaner által szerkesztett: Historia general del arte. A kiadó föként luxuskivitelü enciklopédiái közt találjuk a Biblioteca universal ilustrada, 
Diccionario enciclopédico hispano-americano de ciencias, artes y literatura, vagy a Geografía universal címủ opus magnumokat. Második korszakának (1952-1981) jelentős, híres munkatársai közt tartják számon Pere Calders, Jesús Moncada és Josep Soler Vidal személyét. A kiadóvállalat egykori székhelye egyike Barcelona leghíresebb modernista épületeinek, ma itt müködik az Antoni Tàpies Alapítvány.

5. Unión Tipográfica Editorial Hispano América kiadót 1938-ban alapította a korábban Kubában dolgozó, galíciai származású González Porto, könyvügynök. Az UTEHA részletre vásárolható, igényes, müvészi kivitelezésủ enciklopédiáival írta bele magát a kiadótörténetbe. A polgárháború pusztítása, az állandósult papírhiány és a háború utáni cenzúra okozta nehézségek a dél-amerikai spanyol nyelvü könyvkiadásnak kedveztek, s föként Argentínában és Mexikóban alakultak nagyon fontos kiadók, amelyek sok, az irodalom szférájához tartozó köztársaságpárti menekültnek adtak munkát.

6. Pere Calders (Barcelona, 1912- Barcelona, 1994) katalán író, grafikus, a katalán irodalom egyik legolvasottabb, ironikus hangvételű szerzője, aki a 30-as években grafikusként kezdett dolgozni az Avui, valamint az Esquella de la Torratxa (szatírikus, antiklerikális, katalanista hetilap) folyóiratoknál. A polgárháború elött publikálta első novelláit El primer arlequí, és kisregényét La glòria del doctor Larén címmel. Önkéntesként vonult be a republikánus hadseregbe 1937-ben, s térképészként dolgozott az aragóniai fronton. A polgárháború fontos irodalmi dokumentumának számít a frontélményeit megörökítő, Unitats de Xoc című napló-regénye, mely Carles Riba előszavával jelent meg 1938-ban. A háború végén a köztársasági menekülteknek kialakított gyüjtőtáborba került a franciaországi Prats de Mollóban (Észak Katalónia). Innen megszökött és sikerült eljutnia Mexikóba, ahol az UTEHA Könyvkiadónál dolgozott illusztrátorként, közben pedig katalánul és spanyolul írt és publikált (Cròniques de la veritat oculta, La gent de l'alta vall, Aquí descansa Navares, stb.).

7. Josep Soler i Vidal (Barcelona, 1908-Gavà, 1999). A Katalán Komunista Párt (PCC) egyik alapító tagja (1926), aki Francesc Macià testőre volt a Katalán Köztársaság kikiáltásakor, a polgárháború alatt pedig a gavà-i városvezetőségben kultúráért és oktatásügyért felelős képviselőtestületi tagként dolgozott. A polgárháború után mexikói számüzetésben élt, ahol irodalmi és politikai szervezői tevékenységet végzett. Innen 1965-ben hazatért, és Barcelonában, a Montaner y Simón Kiadó vállalatnál dolgozott. 1968-ban belépett a pánkatalán eszméket hirdető PSAN-ba (Partit Socialista d’Alliberament Nacional). Róla szól Moncada Història d'un jersey gris c. elbeszélése, melyben a zárkózott és szótlan szerkesztő egy nagylelkű gesztusát örökíti meg. A hideg, huzatos padlástéri szerkesztőségben a téli hónapok 
igencsak próbára tették az ifjú Moncadát, akinek nem volt pénze meleg ruhára. Egyik reggel egy becsomagolt, szürke pulóvert talált az asztalán. A mindig komoly, visszafogott Soler Vidal (akinek a családja Mexikóban maradt), a kérdezősködésre csak annyit mondott, majd ha lesz pénze, megadhatja az árát.

8. Idézet a „A spanyol hazafiság katekizmusa” c. mű egyik dialógusából: „Beszélnek Spanyolországban más nyelvet a kasztíliain kívül?”, válasz: „Azt lehet mondani, hogy Spanyolországban kizárólag a kasztíliait beszélik, bár ezen kívül [...] néhány tanyán a baszkot is beszélik, mely nyelvi-filológiai szegénysége miatt a dialektus szerepét tudja csak betölteni.” Újabb kérdés: „És melyek a Spanyolországban beszélt fő dialaktusok?” válasz: „Spanyolországban 4 fő nyelvjárást beszélnek: a katalánt, a valenciait, a mallorcait és a gallegót.” Ez az iskolai tankönyvekben használatos, indoktrinációs célzattal született párbeszéd nyelvészeti szempontból egyáltalán nem állja meg a helyét, mert dialektusként kezeli a nyelvtudomány által külön ibero-román nyelvnek tekintett katalánt, s mert a katalán, a valenciai és a mallorcai egy és ugyanaz újlatin nyelv. Ezeknek a nyelveknek politikai egység híján sosem volt közös nevük, ám nagy múltú, és a középkorban igen jelentős irodalmuk igen, amely a 19. századi Renaixença mozgalom után és a közös nyelvi norma megteremtésével a 20. századra újra fejlődésnek indult.

9. Joseph Joffre (1852-1931) a marne-i győző, az I. világháború tábornoka, majd marsall, s később az Egyesült Államokban tárgyaló francia bizottság vezetője. Az 1659-es Pireneusi békekötés során Franciaországhoz csatolt észak-katalóniai Ribesaltes-ből, szőlőműves családból származott, s a történetek tanúsága szerint a szülőföldjéről származó katonákkal katalánul beszélt. 1920-ban a katalán kulturális, nyelvvédő mozgalom barcelonai bizottsága a Barcelonai Jocs Florals elnökévé választotta.

10. Salvador Espriu (Santa Coloma de Farners, 1913-Barcelona, 1985) katalán költő, drámaíró a polgárháború előtti 1936-os nemzedék tagja, aki Josep Plaval együtt a katalán próza megújítójaként tart számon az irodalomtörténet. Ikonikus verse, A bika bőre (La pell de brau), a Franco alatti katalán kulturális ellenállás irodalmi szimbóluma. „Néha szükséges, és elkerülhetetlen, hogy meghaljon valaki a közösségért, de sosem kell meghalnia egy egész közösségnek egyetlen emberért, erre mindig emlékezz, Szefárád.” Ebben a versben a katalán költő saját nyelvi, kulturális közösségének megmaradásáért emeli fel a hangját, az általa áhított sokszínü, sok kultúrájú és nyelvü Spanyolországon belül, ahol a különböző nyelvü népek megértik egymást. Espriu az áldozathozatal szükségtelenségére figyelmeztet, $\mathrm{s}$ azt sugallja, hogy a katalánoknak nem kell beolvadniuk azért, mert a diktátor szerint a köz- 
jó, azaz az Egységes, Nagy és Szabad Spanyolország érdeke azt kívánja, hogy a katalánoknak hősi áldozatot hozva, tünjenek el a történelem süllyesztőjében. A központi hatalom egységesítésre törekvő, birodalmi irányítási koncepciója és a katalán kisebbség federatív, nagyobb helyi szabadság hagyományára épülő modellje a 19. század óta problémaforrás a spanyol történelemben.

11. Mauthausen A köztársasági menekültek legnagyobb része Mauthausenbe került, ők voltak a tábor első lakói, mely az ő munkájukkal épült fel. Egyikük, Francesc Boix fotós, a Nürnbergi per egyik koronatanúja, akinek a koncentrációs táborban készített, szerencsésen kicsempészett és megőrzött képei perdöntő bizonyítékként szolgáltak a vádlottak ellen. Az ő történetét dolgozza fel a kortárs spanyol dráma két nagyszerü alkotója Laia Ripoll és Mariano Llorente, A kék háromszög (El triángulo azúl), címü 2014-es darabja, mely magyarul is olvasható http://szinhaz.net/wp-content/uploads/2016/07/A-kek-haromszog.pdf. Katalóniában és egész Spanyolországban is az első, emlékezetet őrző egyesület az Amical de Mauthausen, amely 1962-ben alakult, de a legalizálására indított többszöri kísérletek ellenére csak 1978-ban tett szert teljes körü jogi elismerésre. A katalán irodalom egyik igen fontos alkotása, Joaquim Amat-Piniella, K. L. Reich, címü regénye, mely a szerző mauthauseni rabságát dolgozza fel, 1963-ban jelent meg. A manresai író segítségével indul neki nagyszabású vállalkozásának Montserrat Roig, akinek az Els catalans als camps nazis című dokumentumkötete először tette ismertté a katalán közvélemény számára a köztársasági deportáltak történetét. A könyv 1977-ben jelent meg Josep Benet történész-politikus előszavával, aki sokban segített a német és francia forrásokat felhasználó írónőnek az úttörő vállalkozásban. A könyv nagy siker lett, tizenegy kiadást ért meg, utoljára 2017-ben jelent meg újra. Hiánypótló mű volt, mint Roig írja a bevezetőben „A náci haláltáborok republikánus áldozatai mintha nem is léteztek volna. [...] A spanyol állam 1974-ig nem állított ki egyetlen halotti bizonyítványt sem, ahol a halál helyeként Mauthausent jelölte volna meg.” A demokratikus átmenet idején megjelent könyv segítette elő az Amical de Mauthausen egyesület legalizálását, s érdekes adalék, hogy - mint a cím is jelzi: Katalánok a náci haláltáborokban - a függelék külön sorolja fel a katalán áldozatokat és külön a Spanyolország más tájairól származókat, vagyis az emlékezés terében is külön rajzolódik ki Katalónia.

12. Manolo Comas Cabistany 1913-ban született Mequinensában, anarchista elkötelezettséggel harcolta végig a polgárháborút, majd végigjárta Franco Spanyolországának több börtönét. A mequinensai helytörténészekből álló, Coses del Poble nevü csoport, 2007-ben, 
94 éves korában adta ki, kevéssel korábban írt emlékiratait. Az ebben található történetek közül több megtalálható a Moncada regényekben.

13. Patufet A gyermekfolyóirat első korszaka 1904-1938-ig tartott, és óriási szerepet játszott a katalán gyerekek normatív helyesírásra oktatásában, főleg a diktatúra időszakától, mely 1923-ban betiltotta az intézményekben és az oktatásban a katalán nyelv használatát. Az újító pedagógiai szemléletü, a katalanista középrétegek szemléletét tükröző lapot Aureli Capmany, a Foment Autonomista Català tagja alapította, s a korai időszakban a katalán kultúra olyan meghatározó személyiségeit mondhatta munkatársainak, mint Carles Aribau, Antoni Gaudí, Jacint Verdaguer, Josep Anselm Clavé, Joan Maragall, Àngel Guimerà vagy Narcís Oller. Josep Carner, a noucentista költőfejedelem szintén közremüködött Pepet C. írói álnéven, s a lap szerkesztője majd igazgatója Jaume Folch i Torres író volt. A polgárháború utáni tiltást követően a lap 1968-ban jelent meg újra, akkor már jóval kevesebb sikerrel, mert a háború előtti idők hangján szóló tartalom nem fogta meg az új nemzedéket. Leginkább a nagyszülők szubvenciója tartotta fenn 1973-ig, amikor végleg megszünt.

14. Joan Prim i Prats (Reus, 1814-Madrid, 1870) politikai karrierjének felívelését a történetírás egyrészt a Tetuánnál, a katalán önkéntesek élén vakmerő hadvezérként játszott szerepének, másrészt pedig Miksa császár mexikói kalandjából államfői bölcsességre valló kihátrálásának tulajdonítja. A romantikus katalán történész, Ferran Soldevila Katalónia történetében jelzi azt is, hogy a tetuáni győzelem milyen reakciót váltott ki a katalán közvéleményben: 1. nagy összegü adományok, 2. katalán és spanyol nyelvü háborús-patrióta irodalom, 3. Barcelona provincia küldöttgyülése által finanszírozott Marià Fortuny festmény, 4. Anselm Clavé kórusának fellépése, 5. háborús krónikák a katalán önkéntesek dicső haditetteinek megörökítésére, melyek közül a leghíresebbet, az afrikai hadműveletekben önkéntesként és újságíróként résztvevő Pedro Antonio de Alarcón, Diario de un testigo de la guerra de África címü, folytatásokban közölt, majd később könyv formában is kiadott naplóját említi. Prim tábornok személye napjainkban is foglalkoztatja mind a spanyol, mind pedig a katalán közvéleményt. A Basílica de Nuestra Señora de Atocha bazilikában (később Panteón Nacional de Hombres Ilustres - Híres Emberek Nemzeti Panteonja) nyugvó, bebalzsamozott holttestére 1964-ben a szülővárosa, a katalóniai Reus nyújtott be igényt. Hosszas huzavonát követően a holttest végül 1971-ben, katonai repülőgépen érkezett Reusba, a reptérről nyolclovas hintó vitte a koporsót a város temetőjében épült Prim Mauzóleumba, s a temetési menetben a családtagokon túl a hadsereg minden fegyverneme 
is képviseltette magát. 2010-ben a mauzóleum és a múmia restaurálása során több orvosi csoport végzett vizsgálatokat a halál okának, körülményeinek vizsgálatokat a halál okának kiderítésére, s ezek egymásnak ellentmondó következtetésekre jutottak. Vélhetően szimbolikus jelentőséget tulajdoníthatunk az 1971-es (demokratikus átalakulás iránti fokozódó igény) és a 2010-es (erőteljes katalán függetlenségi törekvések kezdete) exhumálásoknak, s a tábornok személye iránt újjáébredő érdeklődésnek. A katalán televízió által a Prim bicentenárium alkalmából 2014-ben készített portré a tábornok katonai és politikai képességeit Napóleonéhoz hasonlítja, s utal rá, hogy meggyilkolásának oka is ez lehetett. A liberális és korszerü monarchia ugyanis, melynek létrehozásán fáradozott, sok érdekbe ütközött, ezek képviselői pedig ezzel a politikai gyilkossággal próbálták elejét venni egy Napóleon-típusú államcsínynek. A film azt sugallja, hogy a tehetséges tábornoknak nem engedték meg, hogy megváltoztassa a spanyol történelem irányát. Mindez persze csak hipotézis, de igen sokatmondó párhuzamba állítható azokkal a katalán törekvésekkel, melyet új irányt próbálnak adni Spanyolország történelmének.

15. Francesc Ferrer i Guàrdia (Alella, 1859- Barcelona, 1909) nemzetközi hírü anarchista pedagógus, szabadkőmüves, eszperantista, aki 1901-ben létrehozta az országban egyedülálló Escola Moderna intézményét. Ez a hagyományos oktatást minden tekintetben megreformálta, szabadgondolkodó, racionalista és pozitivista elveken alapuló, különböző társadalmi osztályok, és lányok-fiúk együttes oktatását megvalósító, s büntetést nem alkalmazó rendszer volt, mely kinyitotta az iskolát a munka világa, és a természet szépségének megtapasztalása felé. Ferrer i Guàrdia kiadót is müködtetett, mely sorra adta ki a kor modern tudományos és filozófiai szerzőit spanyol fordításban. Abban a Spanyolországban, ahol az oktatásban mindenütt az egyház monopóliumát találjuk, és a krausista elveken nyugvó reformgondolkodást is csak a felsőoktatásban képviselte, elitista jelleggel az Institución Libre de Enseñanza, az Escola Moderna elemi osztályok szintjén indított reformja forradalmi tettnek bizonyult, ami szellemi szerzőjét megjelölte a hatóságok szemében. Ezért tették meg őt a lázadás bünbakjának. Ehhez hivatkozási alapot szolgáltatott, hogy már korábban is letartóztatták, mint Mateu Morral, a XIII. Alfonz elleni 1906-ban elkövetett sikertelen bombamerénylet végrehajtójának egykori tanárát és mentorát.

\section{Egyházkritika a kortárs katalán spanyol regényirodalomban}

Ramon J. Sender, Requiem egy spanyol parasztért, Budapest, Európa, 1983; Victor Mora, A barcelonai platánok, Budapest, Kozmosz könyvek, 1977; Miguel de Salabert, Belső számüzetés, Kossuth, Budapest 1963. Ennek a regénynek a magyar fordítása a „L’exil 
intérieur”, Paris Juillard 1961-es kiadás alapján készült. Antonio Ferres, A legyőzöttek Kossuth, Budapest 1965. Ez a fordítás a Giangiacomo Feltrinelli Editore, Milano, 1962-es kiadásából készült. Juan Goytisolo, Hordalék, Európa Budapest 1962, ennek a magyar fordításhoz szolgáló eredetije La resaca, Club del libro español, 1958 Párizs. Ezek a könyvek megírásuk idején hazájukban nem jelenhettek meg. A szocialista országokban nyilván örömmel fordítottak emigráns spanyol irodalmat, melynek egyházképe megegyezett a keleti blokkban a hatalom által propagált egyházképpel. Különleges példa az egyházkritika témára Joan Sales, Incerta Glòria, Club dels novelistes, Barcelona, 1971 (első kiadás Párizs, 1956) című nagyszerü regénye, mely egy mélyen hívő ember szempontjából dolgozza fel a polgárháború és a francói korszak témáját. A regény egyik főhőse pap, a polgárháború alatt a szemináriumból állt be a republikánusokhoz, a háború után egy kis faluban szolgál, az 50-es években Barcelonában egy szegénynegyed papja, s az 1966. május 11-i papi tiltakozás egyik résztvevője. A katalán papok a katedrálisban azt prédikálják, hogy tisztelni és szeretni kell mindenkit, nem gyülölni a másikat. Petíciójukban arra kérik „,rendőr testvéreiket”, hogy ne bántalmazzák „egyetemista és munkás testvéreiket”, mert azzal bünt követnek el. Az ember Isten képmására teremtetett, ezért tiszteletet érdemel, a kínvallatás bün. A regény egy meggyötört, kétségekkel teli, megtérő anarchistákat is megkeresztelő jezsuita pap személyében rajzolja meg a keresztényi szeretet elfogadó, megbocsátó, béke felé vezető útját. Jaume Cabré, a kortárs katalán irodalom egyik legkiemelkedőbb, nemzetközileg is elismert, és sok nyelvre lefordított sikeres írójának három müvében is (Fra Junoy és a hangok halála, A Pamano zúgása, és az Én vétkem) központi fö motívumként találjuk az egyház hitelességének és a hatalomhoz való viszonyának kritikáját. Jesús Moncadának minden regényében és rengeteg novellájában szerepel az egyházkritika, mely igen gyakran az egyházi személyek álságos, nem keresztényi vonásainak maró humor általi kíméletlen kifigurázásában ölt testet.

17. Lluís Companys i Micó (Tarròs, 1882-Barcelona, 1940) Katalónia második elnöke Francesc Macià halála után (1934-1939). A köztársaságpárti katalán kormányfő a polgárháború idején, a vereség után Franciaországba menekült, ahol a Gestapo elfogta, majd kiadta Francónak, aki 1940. október 15-én a Monjuïc hegyén kivégeztette. Halálának évfordulóján sírját a mindenkori katalán kormányfő a kivégzés hajnali időpontjában koszorúzza meg.

18. Manuel Carrasco i Formiguera (Barcelona, 1890- Burgos, 1938). Katalán köztársaságpárti jobboldali politikus, akit még a háború alatt végeztek ki annak ellenére, hogy mély és meggyőződéses katolikus volt. Az 1932-es katalán statútum spanyol országgyülés- 
ben való vitáján ő volt az egyetlen képviselő, aki a módosított statútumot nem szavazta meg, mert úgy vélte, hogy a katalán parlament által jóváhagyott, és referendummal megerősített statútumot az összspanyol parlamentnek nincs joga módosítva beiktatni.

19. Ramón Cabrera i Grinyó (Tortosa, 1806- Wentworth, UK, 1877) kiemelkedő karlista tábornok, a második karlista háború hőse, aki a Maestrat tigrise nevet érdemelte ki haditettei jutalmául. (A történelmi Maestrat a katalán-aragón-valenciai határon helyezkedik el, ezt a területet kapták meg a templomosok a mórok hódoltatásában való segédkezésükért az aragón királytól, IV. Ramon Berenguer-tól). Eszméi a progresszív karlista szárny vezetőjévé tették, akiknek eszméi között még a régi Aragón Korona területeinek független állammá alakulása is szerepelt. A tábornok 1875-ben már nem vállalta a harmadik karlista háború vezetői tisztét, és felesküdött XII. Alfonz hűségére, de soha nem tért haza Angliából, ahol 1877 májusában halt meg.

\section{A katalán nyelv az alkotmányos szabályozás tükrében}

Artículo 2. La Constitución se fundamenta en la indisoluble unidad de la Nación española, patria común e indivisible de todos los españoles, y reconoce y garantiza el derecho a la autonomía de las nacionalidades y regiones que la integran y la solidaridad entre todas ellas.

2. cikkely: Az alkotmány alapja a spanyol nemzet megbonthatatlan egysége, mely minden spanyol közös és oszthatatlan hazája, és elismeri, s garantálja az őt alkotó nemzetiségek és régiók számára az autonómia jogát, valamint a közöttük levő szolidaritást.

Artículo 3 1. La Constitución Española El castellano es la lengua española oficial del Estado. Todos los españoles tienen el deber de conocerla y el derecho a usarla. 2. Las demás lenguas españolas serán también oficiales en las respectivas Comunidades Autónomas de acuerdo con sus Estatutos. 3. La riqueza de las distintas modalidades lingüísticas de España es un patrimonio cultural que será objeto de especial respeto y protección.

Spanyol Alkotmány 3. cikkely: 1. Az állam hivatalos spanyol nyelve a kasztíliai. Minden spanyolnak kötelessége ismerni, és jogában áll használni. 2. A többi spanyol nyelv szintén hivatalos azokban az autonóm közösségekben, melyek statútuma ezt szabályként rögzíti. 3. Spanyolország különböző nyelvi modalitásainak gazdagsága kulturális örökségünk része, mely különös tiszteletben és védelemben részesül.

Preambulo La Constitución Española „Proteger a todos los españoles y pueblos de España en el ejercicio de los derechos humanos, sus culturas y tradiciones, lenguas e instituciones.” 
A Spanyol Alkotmány preambuluma így fogalmaz: Biztosítjuk minden spanyol és Spanyolország minden népe számára, hogy gyakorolhassa alapvető emberi jogait, s megőrizhesse kultúráját, hagyományait, nyelvét és intézményeit.”

Érdekes megfigyelni, hogy a preambulum az egyéni emberi jogok biztosításán túl a „népek” jogairól, azaz közösségi jogokról is beszél.

LAPAO. „Además del castellano, lengua utilizada en toda la Comunidad Autónoma, a los efectos de esta Ley existen en Aragón: a) Una zona de utilización histórica predominante de la lengua aragonesa propia de las áreas pirenaica y prepirenaica de la Comunidad Autónoma, con sus modalidades lingüísticas; b) Una zona de utilización histórica predominante de la lengua aragonesa propia del área oriental de la Comunidad Autónoma, con sus modalidades lingüísticas.

LAPAO: A kasztíliain kívül, melyet az egész autonóm közösség területén használnak, e törvény meghatározása szerint létezik még Aragóniában: a) Egy olyan terület, ahol történelmileg túlnyomórészt az autonóm közösség pireneusi és előpireneusi területeinek saját aragóniai nyelvét és annak nyelvi modalitásait beszélik; b) Egy olyan terület, ahol történelmileg túlnyomórészt az autonóm közösség keleti területeinek saját aragóniai nyelvét és annak nyelvi modalitásait beszélik.

A cirkalmas, jogi megfogalmazás a) pontja írja le az aragón, a b) pont pedig a katalán nyelvet.

21. La Gran Enciclopèdia Catalana a Capella punit c. Moncada paródia tükrében

El Capellà punit o L’Enciclopèdia en doina, Jesús Moncada egy kiadatlan, valószínüleg csak önmaga vagy munkatársai szórakoztatására szánt paródia, amelyben Moncada kifigurázza a politika szolgálatába állított tudós, katalanista vállalkozást, a Nagy Katalán Enciklopédiát (és a Nagy Països Catalans álmokat), melynek első csapatában maga is közremüködött. A Max Cahner és Jordi Carbonell vezetésével indult nagy volumenü intellektuális vállalkozás első szerzőgárdáját 1972-ben elbocsátották, a finanszírozást, s egyben a vállalkozás irányítását is az Edicions 62 helyett a Banca Catalana biztosította Jordi Pujol közvetítésének köszönhetően. A hatékonyság érdekében a vállalkozás vezetőjét, Jordi Carbonellt, a katalán kultúra központi jelentőségű szervező alakját is menesztették, s egy kvázi politikai biztost neveztek ki a helyére Joan Carreras i Martí személyében, aki a darab címében szereplö, és igen ellenszenvesnek ábrázolt pap.

22. Josep Pla (Palafrugell, 1897-Mas Pla de Llofriu, 1981) a legnépszerübb, legolvasottabb és legtermékenyebb katalán író (45 kötet, több mint 20000 oldal), aki hatalmas olvasó- 
tábort szerzett a katalán irodalomnak. A polgárháború előtt a Francesc Cambó által vezetett Lliga Regionalista katalanistái közé tartozik. A háború alatt Franciaországban élt, és a Lliga politikusa, Josep Bertran Musitu által müködtetett francóista hírszerzéssel állt kapcsolatban. A polgárháború után visszavonult a barcelonai irodalmi körökből, s szülőföldjén l'Empordàban gazdálkodó életet élt és írt, amint lehetett, katalánul. Írói életművének óriási történeti és morális jelentősége van, hiszen megőrizte egy fél évszázad katalán kollektív emlékezetét. Cadaqués címü, 1947-ben már katalánul megjelent könyve a Dalí nyomán a hírnév felé induló tengerparti városka történeti és földrajzi bemutatása. A könyv előszava jelzi az író szándékát, ami a polgárháború utáni, a katalán kultúra eltörlésére irányuló politika kontextusában kap értelmet: „Egy kultúra kerítésén belül létezik egy homályos, ámde feltétlenül elvégezendő feladat, a folytatásé. Ez a könyv nem más, mint annak a folytatása, ami előttünk történt, azzal a céllal, hogy aki utánunk következik, dolgozni tudjon”. Pla nem csak annyiban folytatója a katalán kultúrának, hogy tollát az észak katalóniai kis közösségek életének katalán nyelvü megörökítésének szentelte. Cadaqués lokális történetét helyi forrásokra hivatkozva írja meg, de a mü valójában Katalónia történelmét rajzolja elénk, amelyben a hangsúlyok eltolódnak, és kiemelik Hódító Jakab katalán uralkodó dicsőségét, de csökkentik a spanyol történetírásban kiemelt jelentőségü lepantói győzelemét, és textuális egyezést is találunk Ferran Soldevila, Història de Catalunya c. müvével. Pla helytörténetbe rejtett katalán patriotizmusára Xavier Iglesias Gallart, Cadaqués i el patriotisme planià kiváló, publikálatlan tanulmánya hívta fel a figyelmemet, melyet írója nagylelkűen rendelkezésemre bocsátott.

23. Tomás-Germinal Gracia Ibars írói nevén, Víctor García (Barcelona, 1919Montpellier, 1991). A család Mequinensába költözött, ahol Víctor García a gyermekkorát töltötte. Már tizenkét évesen a CNT ifjúsági tagozatának volt tagja, a polgárháborúban az aragóniai fronton megsebesült, Franco győzelme után Franciaországba menekült, ahol koncentrációs táborba került, s 1944-ben Dachauba deportálták. Sikerült azonban megszöknie a marhavagonból, s kijutnia Dél-Amerikába, ahol sikeres vállalkozást alapított, s a kontinensen utazva terjesztette az anarchizmus tanait, amivel kiérdemelte „az anarchizmus Marco Polója” nevet. Víctor García néven írta cikkeit, könyveit, tanulmányait az anarchizmusról, például: Bakunin hoy, El anarchismo japonés, Utopías y anarchismo, stb. Marcuello Calvín monográfiájában a híres mequinensaiak panteonjának tagja, l. 361-5. o. 
24. INI Instituto Nacional de Industria - Nemzeti Ipari Intézet

A nyolcvanas évekig Spanyolország legnagyobb és legfontosabb vállalkozói csoportosulását alkotta, mely 1995-ben szűnt meg. Élén Franco jóbarátja, a szintén ferroli születésű tengerészeti mérnök, Juan Antonio Suanzes (1891-1977) állt 1963-ig. Az INI kezdeményezésére létrejött állami nagyvállalatok főként a vas-, acél-és alumíniumipari, valamint vegyipari és villamosipari létesítmények voltak. 
Képek, térképek
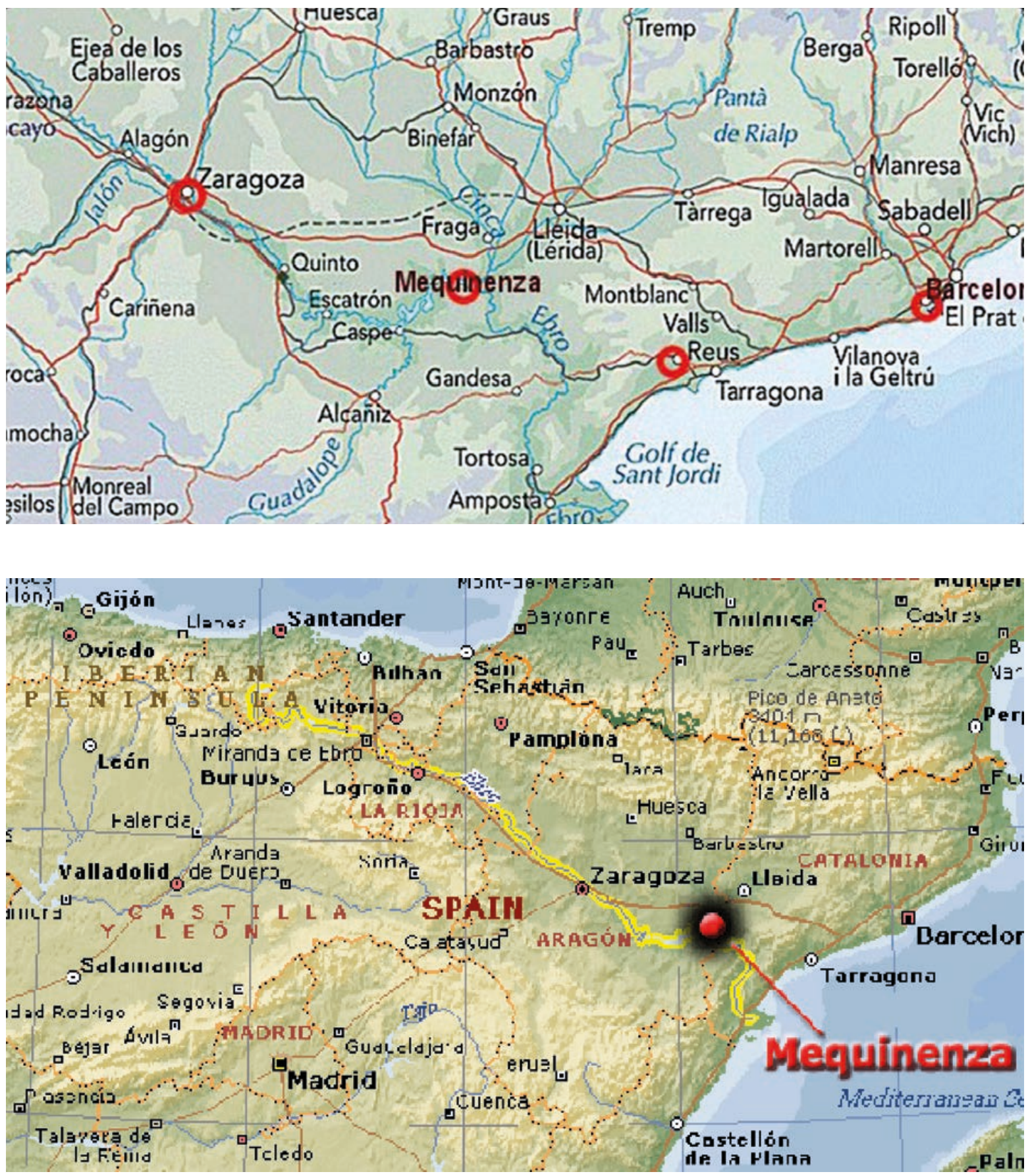

1. Térképek 


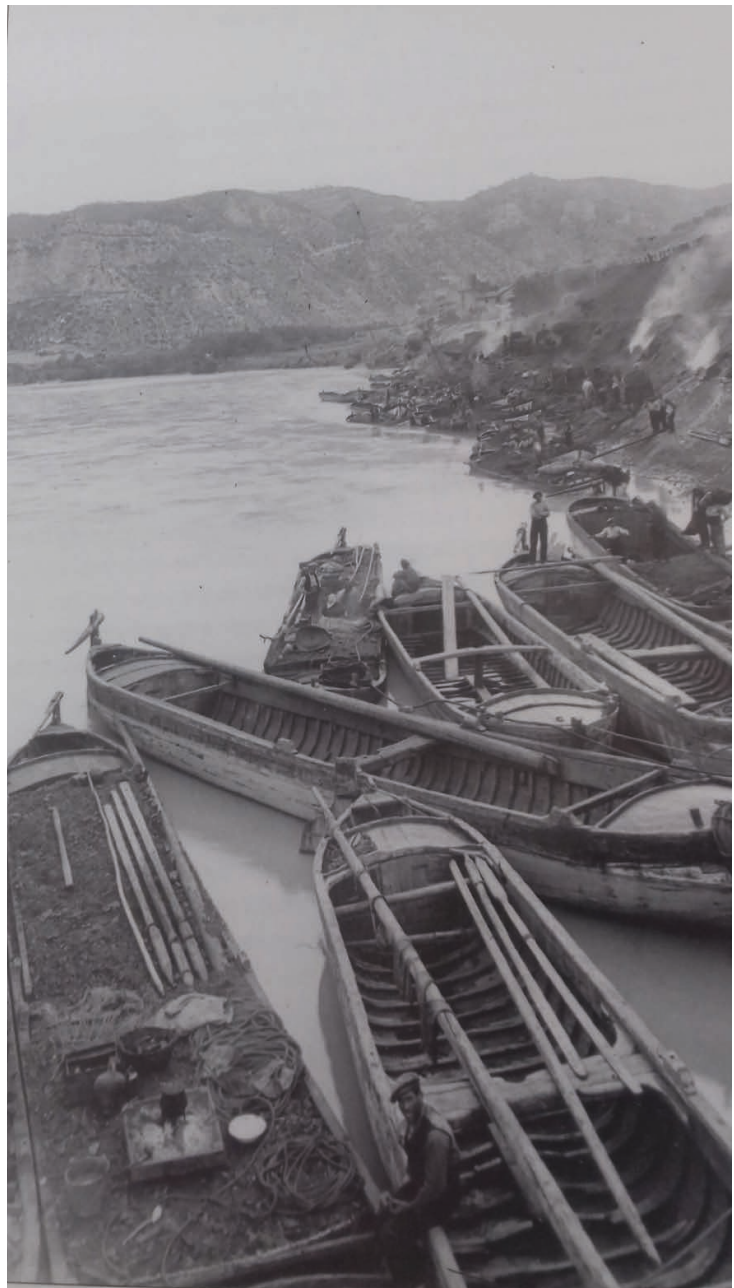

2. Szénszállító hajók

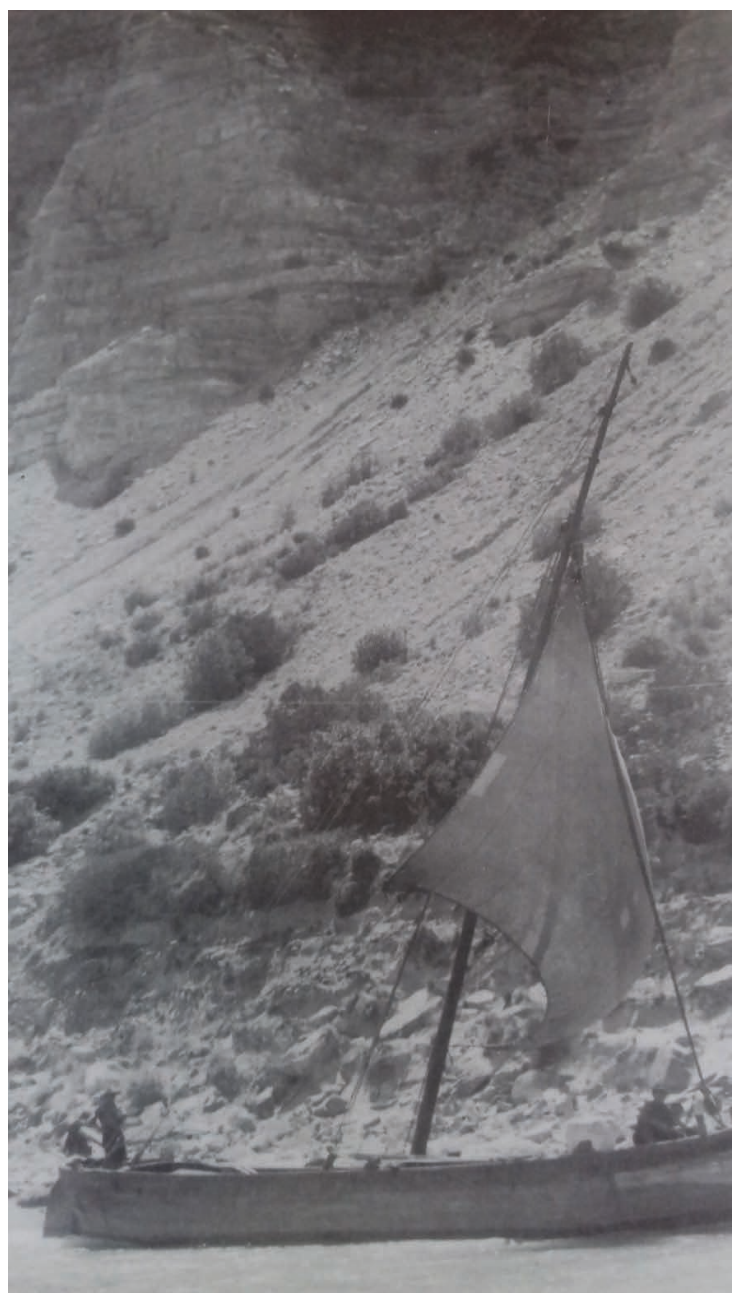

3. Latin vitorla

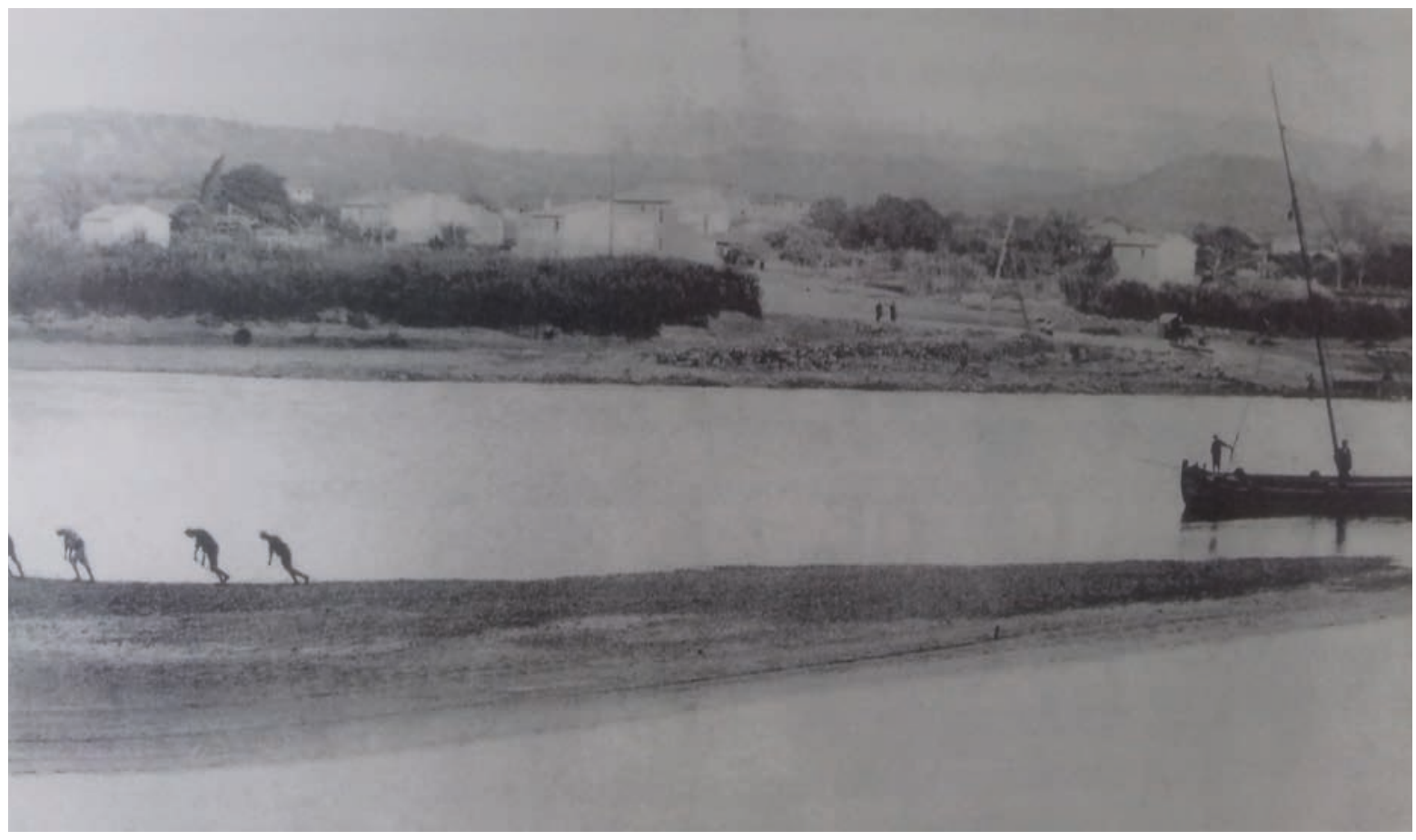

4. Vontatás - Camí de sirga 


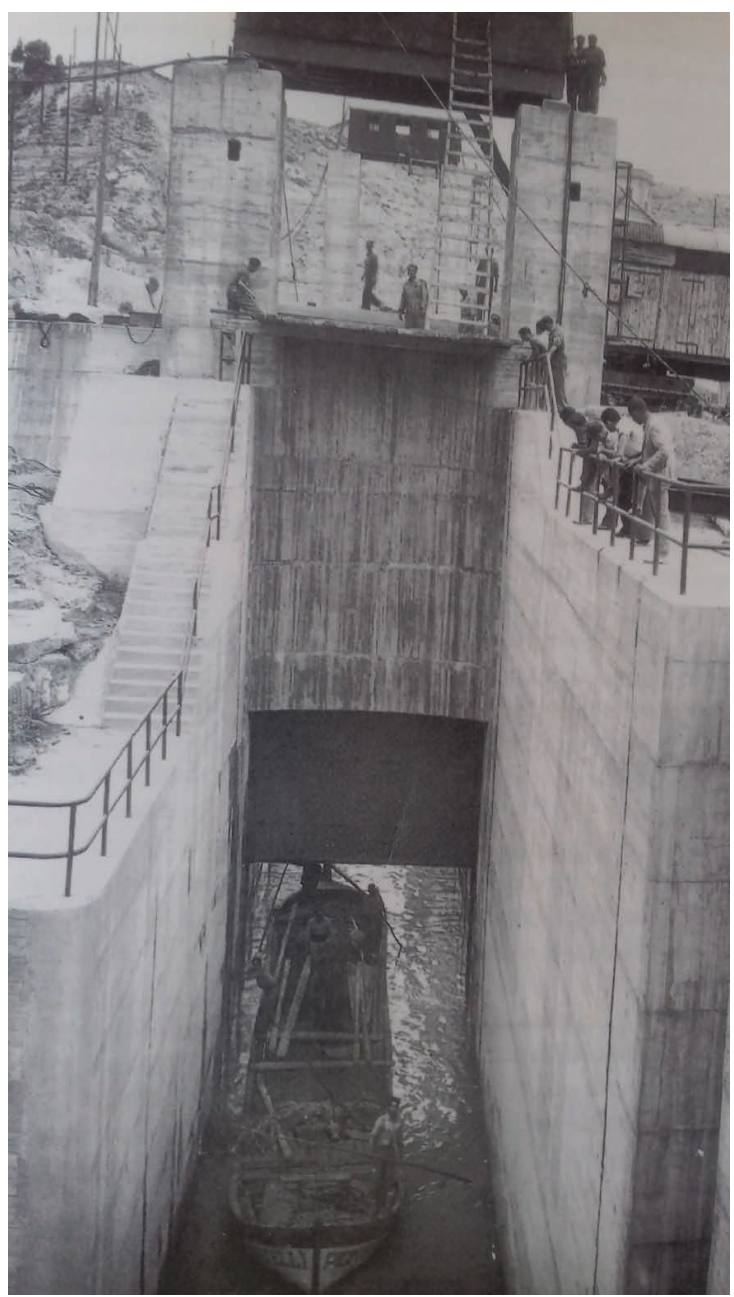

5. Zsilipelés

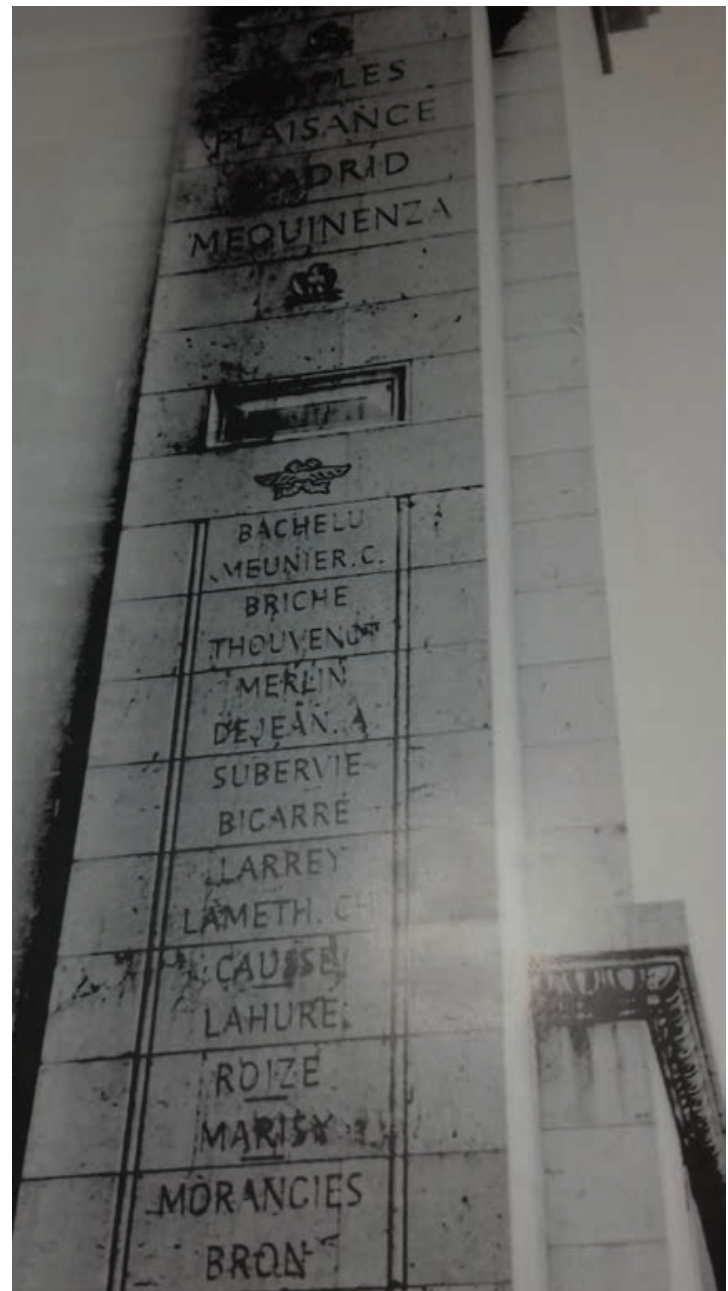

6. Mequinenza felirat a diadalíven Párizsban

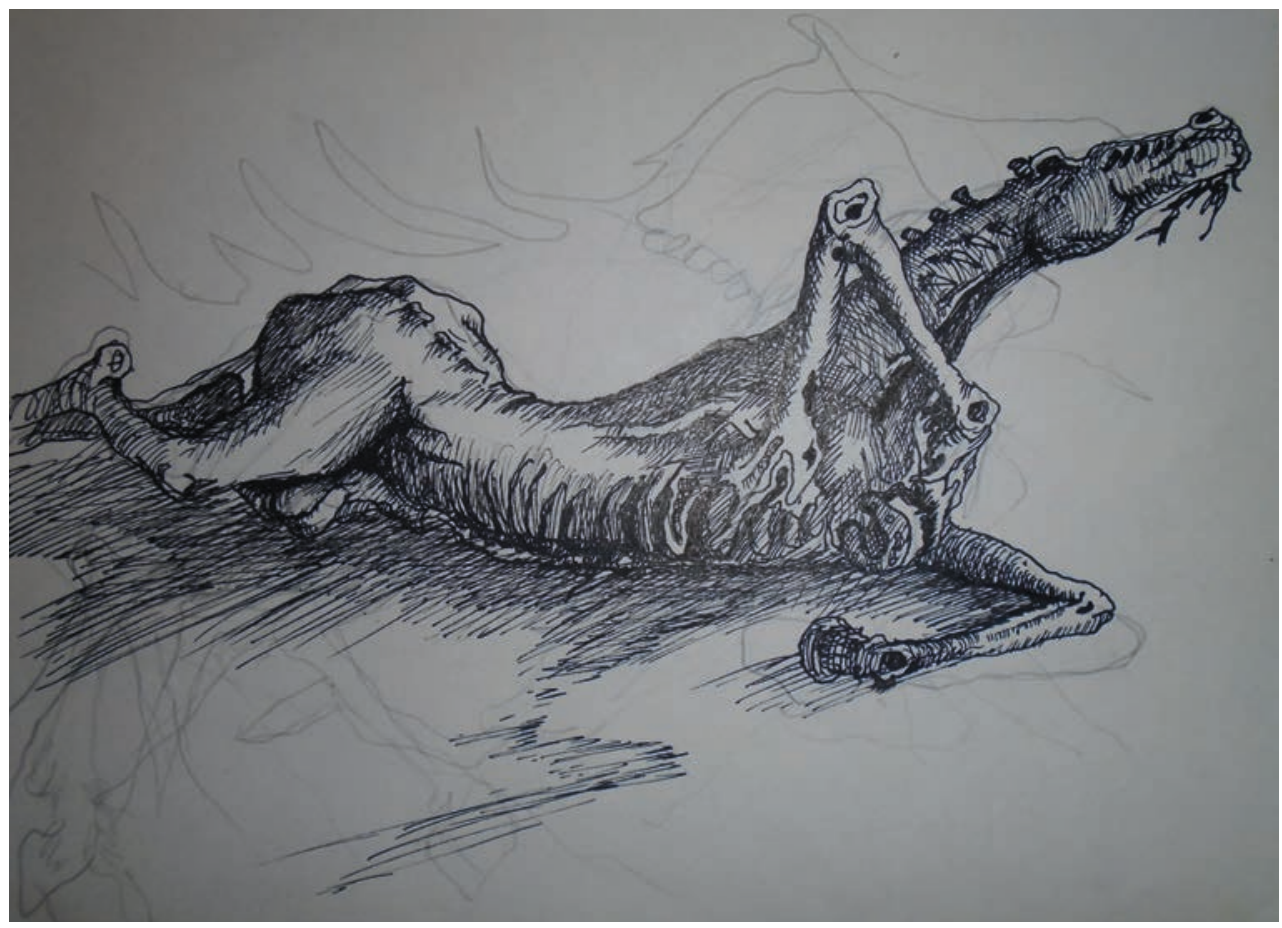

7. Cavall mort sencer 


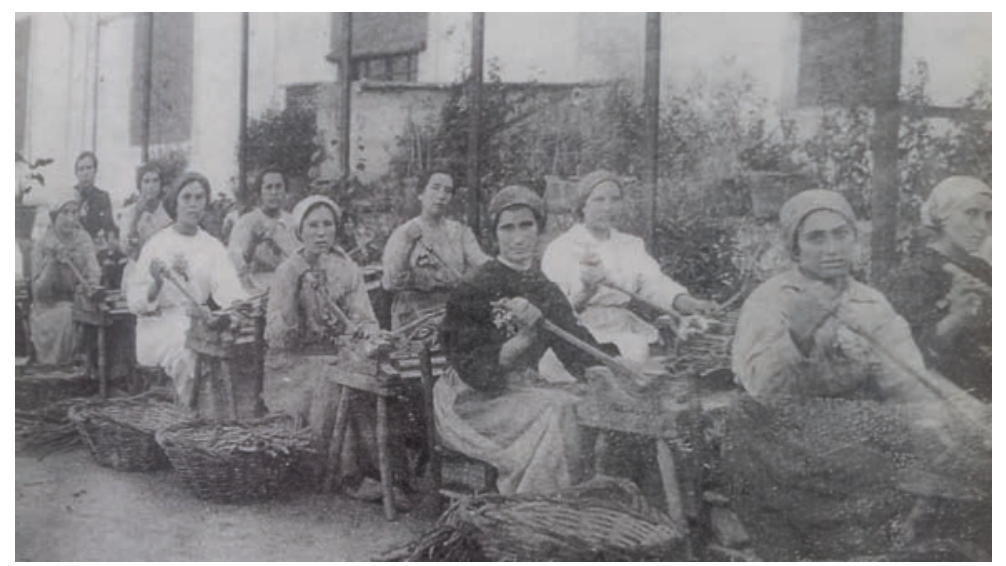

8. Édesgyökérkivonat-gyár

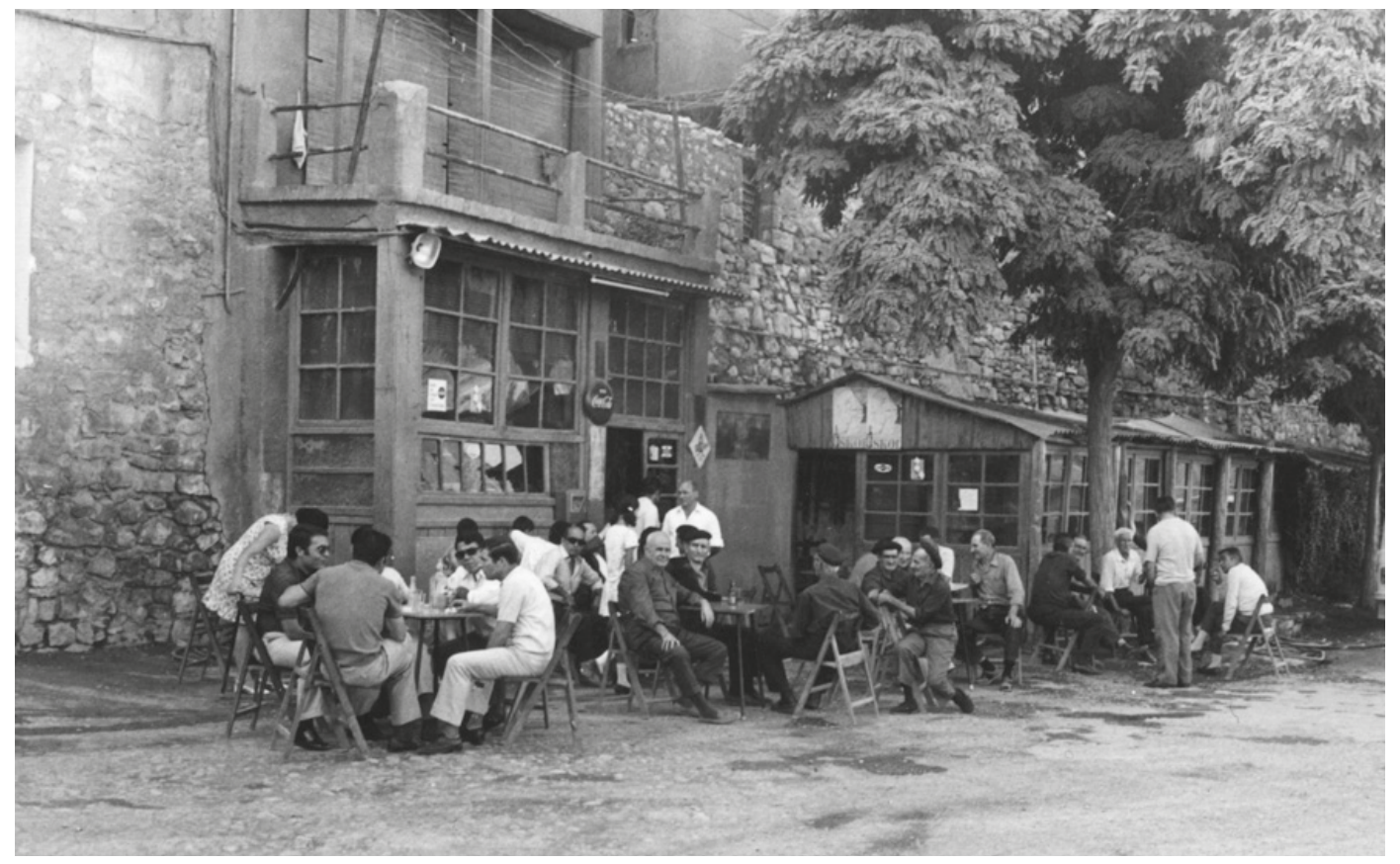

9. Kávéház

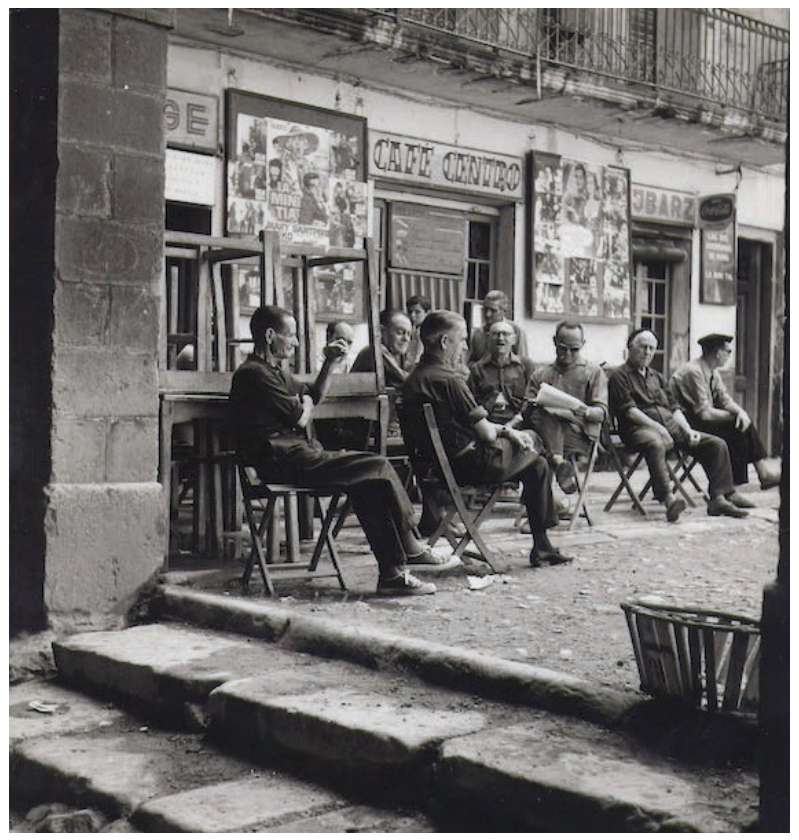


Jesús Moncada

\section{CAMÍ DE SIRGA}

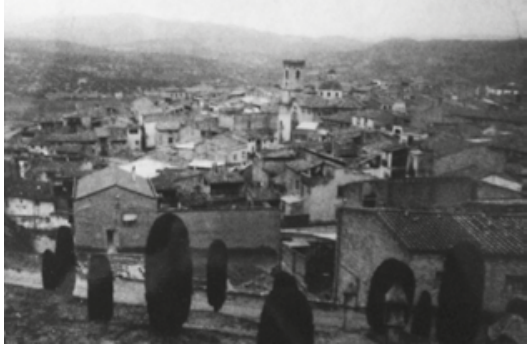

10. Fénykép a városról a temetőből a Camí de sirga borítón

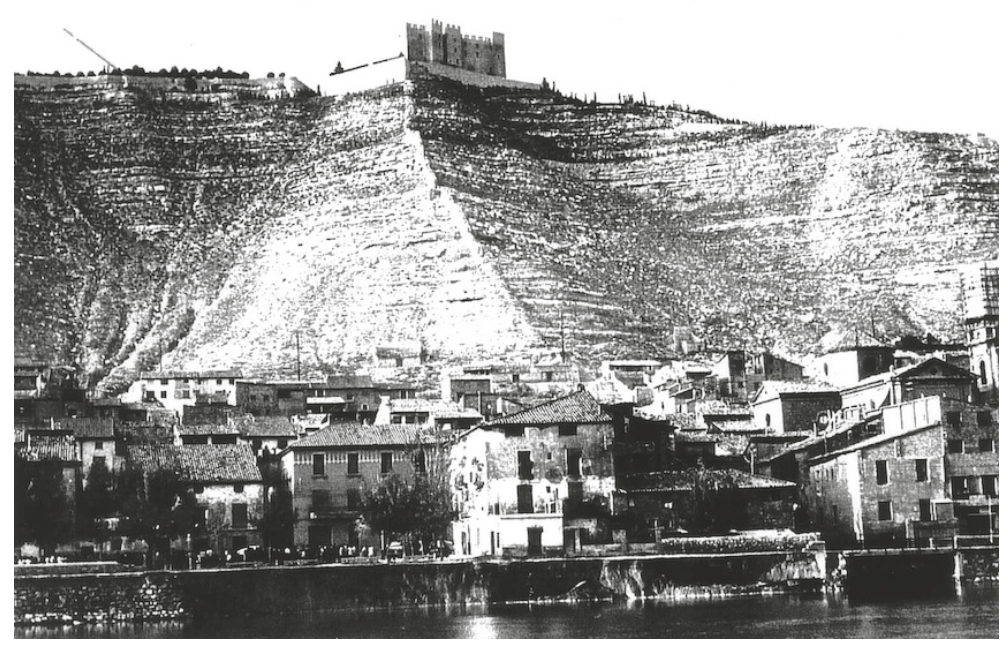

11. A folyók városa

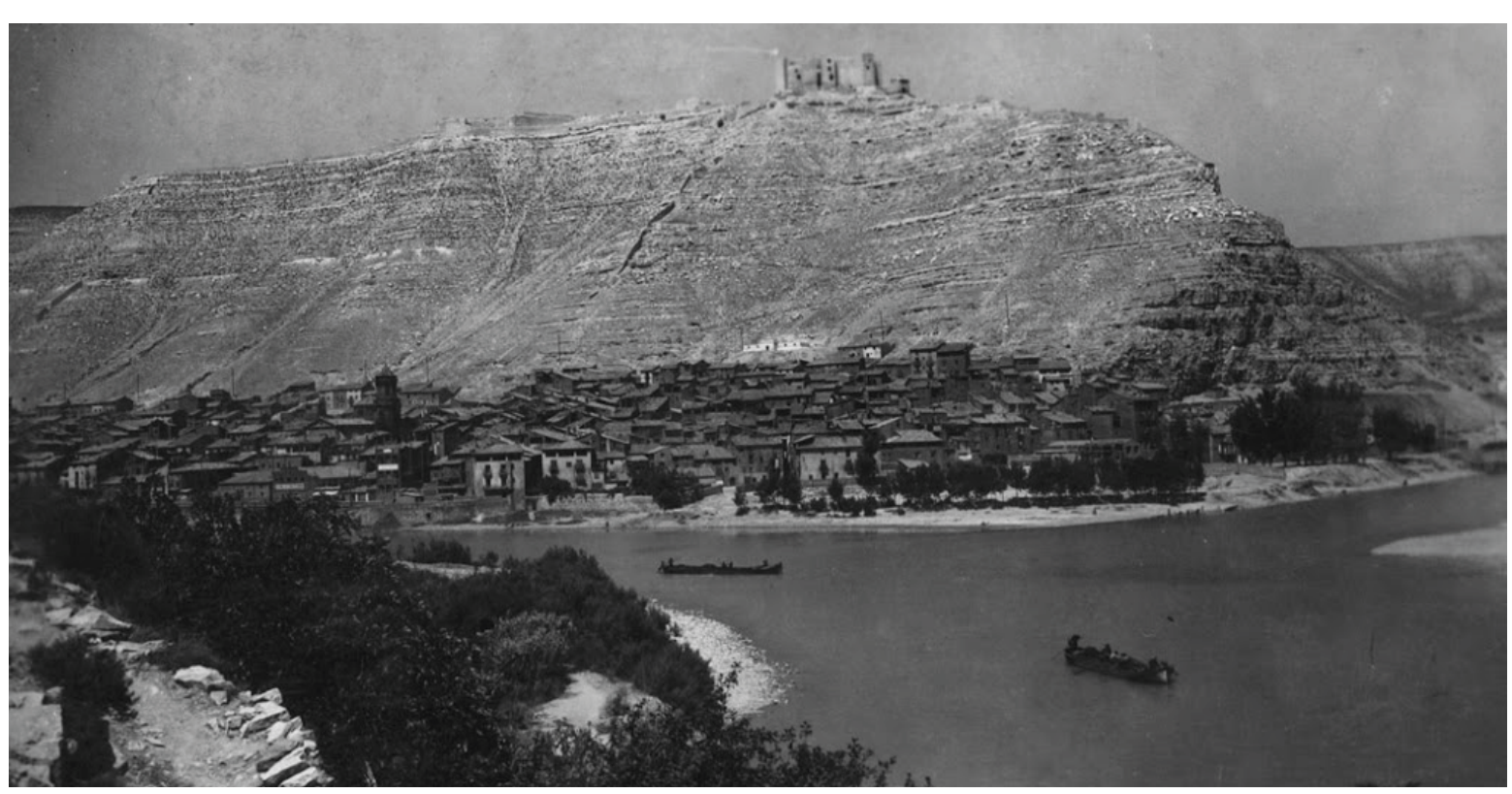

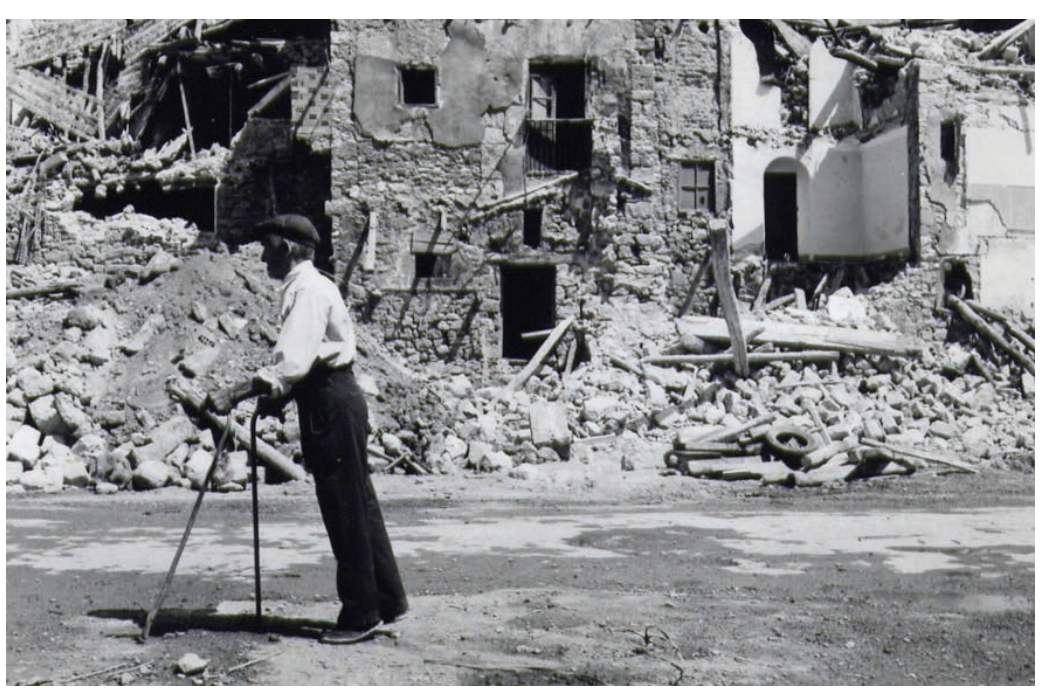

12. Az érem másik oldala 


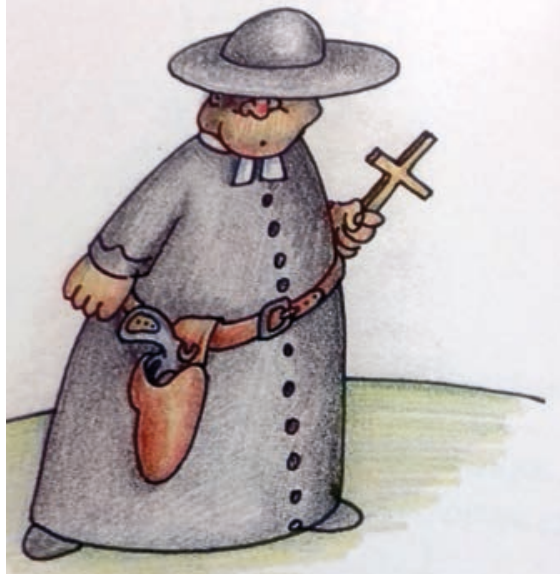

A LA MERCÈ, LECTORSI=MATRTIR DE LA PETúlTima REDACCiOD' AOUESTA GALERTR...

(BASIRICA DE TORRELLOBA, 16/2). fun

13. A harcoló egyház
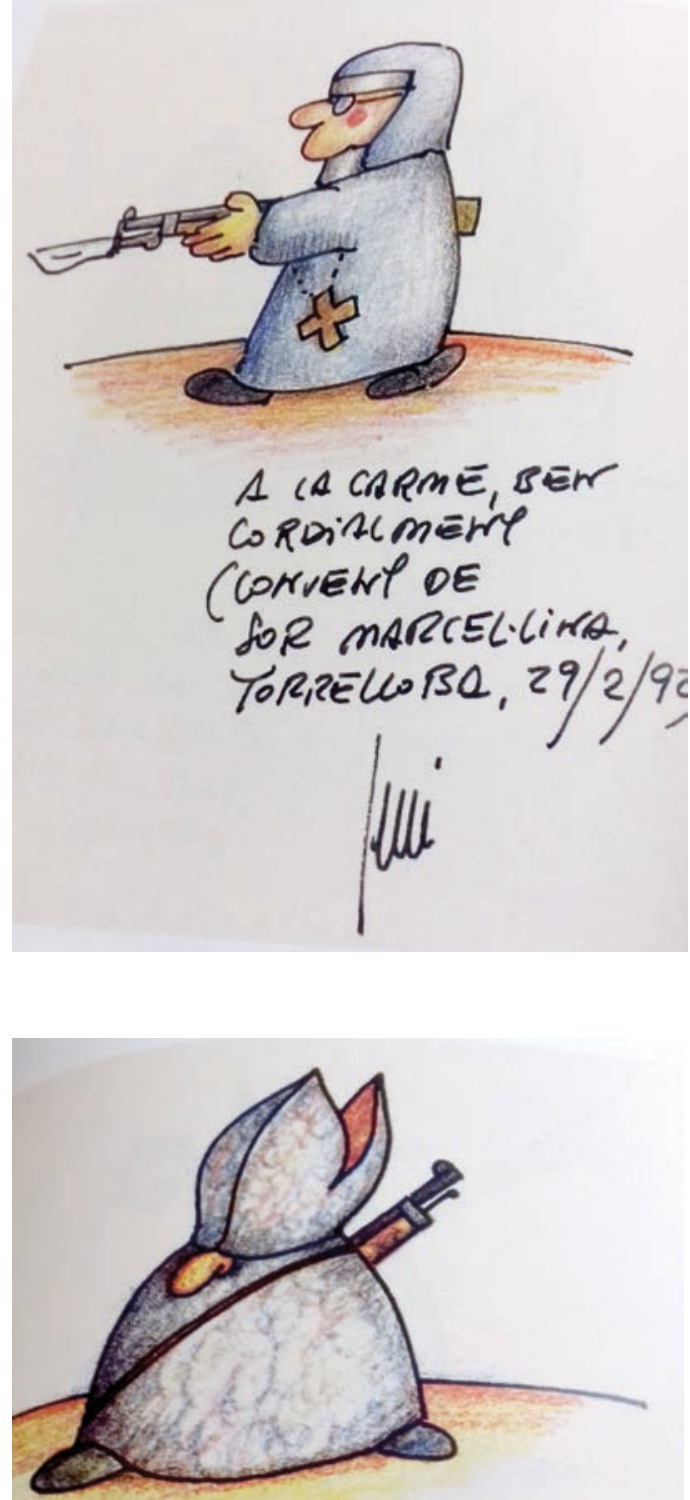

A LO TERESO, DEJ OE L'DRQVUE RIS.30Y OE TORRECLOBA.. UNA DBRA SAOA lini 